Andrews University

Digital Commons @ Andrews University

Dissertations

Graduate Research

2017

\title{
Toward A Priestly Christology: A Hermeneutical Study Of Christ's Priesthood
}

Adriani Milli Rodrigues

Andrews University, adriani@andrews.edu

Follow this and additional works at: https://digitalcommons.andrews.edu/dissertations

Part of the Biblical Studies Commons, and the Religious Thought, Theology and Philosophy of Religion Commons

\section{Recommended Citation}

Rodrigues, Adriani Milli, "Toward A Priestly Christology: A Hermeneutical Study Of Christ's Priesthood" (2017). Dissertations. 1631.

https://digitalcommons.andrews.edu/dissertations/1631

https://dx.doi.org/10.32597/dissertations/1631

This Dissertation is brought to you for free and open access by the Graduate Research at Digital Commons @ Andrews University. It has been accepted for inclusion in Dissertations by an authorized administrator of Digital Commons@ Andrews University. For more information, please contact repository@andrews.edu. 


\section{ABSTRACT \\ TOWARD A PRIESTLY CHRISTOLOGY: A HERMENEUTICAL STUDY OF CHRIST'S PRIESTHOOD}

by

Adriani Milli Rodrigues

Adviser: Fernando Canale 


\title{
ABSTRACT OF GRADUATE RESEARCH
}

Dissertation

\author{
Andrews University
}

Seventh-day Adventist Theological Seminary

\section{Title: TOWARD A PRIESTLY CHRISTOLOGY: A HERMENEUTICAL STUDY OF CHRIST'S PRIESTHOOD}

Name of researcher: Adriani Milli Rodrigues

Name and degree of faculty chair: Fernando Canale, Ph.D.

Date completed: June 2017

\section{Problem}

There is a disagreement between three theological models (sacramental, functional, and ontological) of interpretation about Christ's priesthood. One clear aspect of this disagreement is the existence of different views on the relationship between sacrifice and heavenly mediation in the priesthood of Christ. These conflicting views reveal that Christian theology does not have a consensus about the nature of the priestly work of the ascended Christ, including the conception of how Christ mediates salvation through his priesthood. This problematic situation raises the question whether there is a way to resolve this conflict of interpretations. 


\section{Method}

The present study hermeneutically deconstructs these models of Christ's priesthood to articulate a constructive proposal of an alternative model as a suggestion for the resolution of the conflict of interpretations regarding this doctrine. This deconstruction seeks to uncover the logic of each interpretation of Christ's priesthood from the perspective of the macro-hermeneutical principles of reality or ontological presuppositions assumed in that interpretation. Such perspective indicates how these presuppositions inform and impact an interpretation or theory about the priesthood of Christ. This deconstruction involves three steps in this dissertation: (1) a systematic outline of the interpretations of Christ's priesthood; (2) a description of the understanding of the macro-hermeneutical principles of reality assumed in each interpretation depicted in the first step and an indication of the implications for the doctrine of Christ's priesthood; and (3) a transition to the construction of an alternative model derived from an interaction with Hebrews, including its pointers to the interpretation of macrohermeneutical principles of reality, and the implications for the doctrine of Christ's priesthood.

\section{Results}

With regard to the macro-hermeneutical principles of reality in the sacramental, functional, and ontological models, the research shows that divinity is a reality defined by non-sequentiality (understood as, or at least logically close to, a timeless-spaceless being), the humanity of Christ is a spatio-temporal instrument of the divine nonsequential reality, and heaven is understood as, or logically close to, a timeless-spaceless environment. When the sacramental, functional, and ontological interpretations of the 
priesthood of Christ are read from the perspective of these macro-hermeneutical principles of reality, the results below are generated.

In the sacramental model, the priesthood of Christ refers to a Christological picture that is soteriologically concrete in spatio-temporal instruments that convey and actualize the timeless-spaceless reality of the new creation in human beings.

In the functional model, the priesthood of Christ is described in a Christological language that involves sequentiality of functions (earthly cross and heavenly intercession), but it is soteriologically concrete in spatio-temporal instruments that convey/actualize the timeless-spaceless reality of the new creation in human beings.

In the ontological model, the priesthood of Christ portrays a Christology that reveals, by means of spatio-temporal instruments, in our spatio-temporal world the soteriological reality of new creation that is already concrete in God.

However, on the basis of a systematic reading of Christ's priesthood in the epistle to the Hebrews, the research suggests an alternative view, namely, the historical model. This reading finds pointers to a different interpretation of macro-hermeneutical principles of reality, where the divine reality, the humanity of Christ, and heaven are spatiotemporal realities. In contrast to the other models, as they hold a distinct interpretation of macro-hermeneutical principles, the historical model strongly emphasizes a heavenly priesthood and intentionally interprets Christ's priesthood as spatio-temporal. This means that Christ performs a sequential official activity in heaven, in which God is involved in the soteriological process of forgiving and transforming human beings.

\section{Conclusions}

The main contention of this study is that the historical model constitutes a viable 
alternative that points to a way out of the conflicting systematic interpretations of the doctrine of Christ's priesthood. This conclusion is unpacked in the following arguments.

First, the basic problem of the sacramental model lies on the interpretation of the macro-hermeneutical principles of reality, as it conceptualizes the divine reality and realm in terms of timelessness-spacelessness. By assuming a spatio-temporal view of divine reality, the historical model necessarily (in terms of internal consistency) outlines a different conception of the priesthood of Christ in comparison with the sacramental model.

Second, in contrast to the internal coherence of the sacramental model, the chief weakness of the functional model is the lack of consistency between its notion of the priesthood of Christ and its interpretation or assumptions regarding the macrohermeneutical principles of reality. While the picture of Christ's priesthood in this model seems to imply a spatio-temporal view of reality, its interpretation of the principles of reality is aligned with a timeless-spaceless perspective of divine reality. In this way, the important idea of sequential actions and events in the functional model is obscured by a timeless-spaceless understanding of divine reality. With this situation in mind, the historical model stipulates that a consistent understanding of Christ's priesthood characterized by sequential actions and events requires an interpretation of the macrohermeneutical principles of reality that presupposes spatio-temporality in the notion of divine reality.

Third, the major problem of the ontological model is that it did not modify in a substantial way the timeless-spaceless view of reality assumed by the sacramental and functional models. While this model is more internally coherent than the functional 
model, the interpretation of Christ's priesthood in the ontological model does not seem consistent with the picture of this priesthood in Hebrews, according to the interpretation of the historical model.

Fourth, the consistency of the historical model is basically described by a focus on an official heavenly priesthood in Hebrews that implies, for instance, a real appearance before God and a real activity of intercession in the heavenly sanctuary that is supported by a spatio-temporal view of divine realm and reality. These activities allow an actual sequential interaction between what takes place on earth (e.g., human prayer) and what happens in heaven (e.g., Christ's intercession). 


\title{
Andrews University
}

Seventh-day Adventist Theological Seminary

\section{TOWARD A PRIESTLY CHRISTOLOGY: A HERMENEUTICAL STUDY OF CHRIST'S PRIESTHOOD}

\author{
A Dissertation \\ Presented in Partial Fulfillment \\ of the Requirements for the Degree \\ Doctor of Philosophy
}

by

Adriani Milli Rodrigues

June 2017 
(C) Copyright by Adriani Milli Rodrigues 2017 All Rights Reserved 


\title{
TOWARD A PRIESTLY CHRISTOLOGY: A HERMENEUTICAL STUDY OF CHRIST'S PRIESTHOOD
}

\author{
A dissertation \\ presented in partial fulfillment \\ of the requirements for the degree \\ Doctor of Philosophy
}

by

Adriani Milli Rodrigues

APPROVAL BY THE COMMITTEE:

Faculty Adviser,

Fernando L. Canale

Emeritus Prof. of Theology and Philosophy

Martin Hanna

Associate Prof. of Historical Theology

Richard M. Davidson

Professor of Old Testament Interpretation

Felix Cortez

Associate Prof. of New Testament

Marc Cortez

Associate Prof. of Theology

Wheaton College
Director of Ph.D. / Th.D. Program

Thomas Shepherd

Dean, SDA Theological Seminary

Jiř́i Moskala 


\section{TABLE OF CONTENTS}

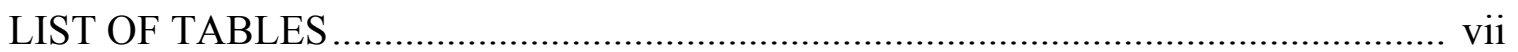

LIST OF ABBREVIATIONS....................................................................................

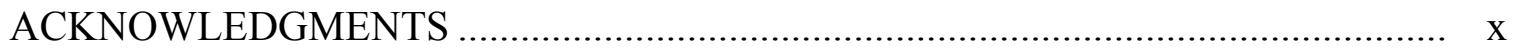

Chapter

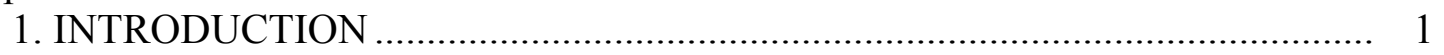

Background of the Problem......................................................................... 1

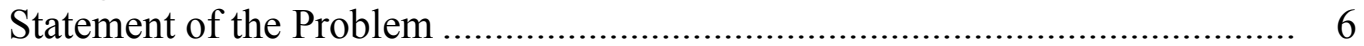

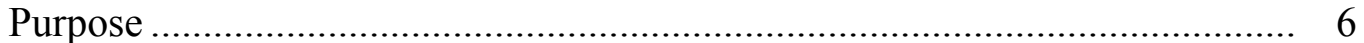

Justification.................................................................................... 7

Scope and Delimitations ............................................................................ 9

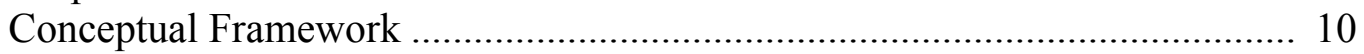

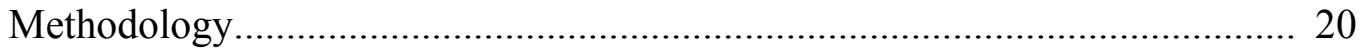

2. A DESCRIPTION OF THEOLOGICAL MODELS OF CHRIST'S

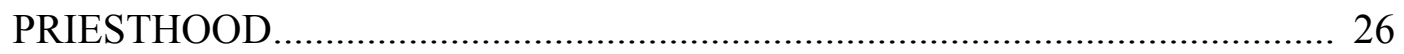

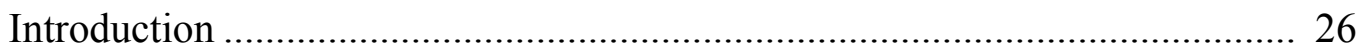

The Sacramental Model.............................................................................. 30

The Need for Christ's Priesthood............................................................ 31

The Agent of the Priesthood...................................................................... 38

The Actions of the Priest .......................................................................... 44

The Goal of the Priesthood..................................................................... 56

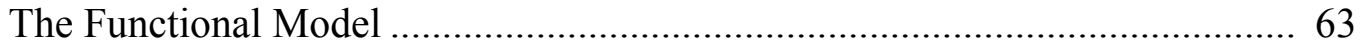

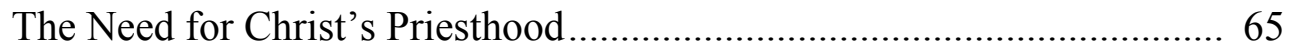

The Agent of the Priesthood................................................................... 71

The Actions of the Priest ......................................................................... 76

The Goal of the Priesthood.................................................................. 85

The Ontological Model............................................................................. 91

The Need for Christ's Priesthood........................................................... 92

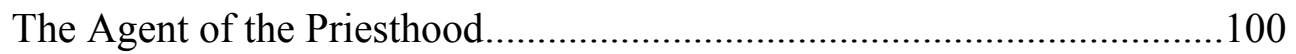

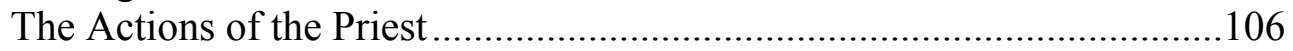




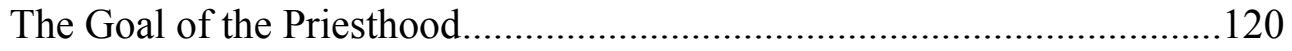

A Brief Comparison of the Models ................................................................129

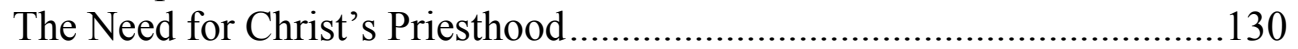

The Agent of the Priesthood........................................................................132

The Actions of the Priest.........................................................................135

The Goal of the Priesthood....................................................................139

\section{A STUDY OF MACRO-HERMENEUTICAL PRINCIPLES OF REALITY}

IN THE MODELS OF CHRIST'S PRIESTHOOD ............................................142

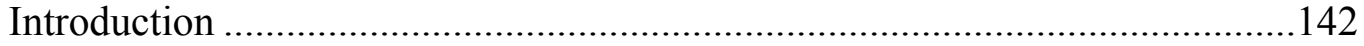

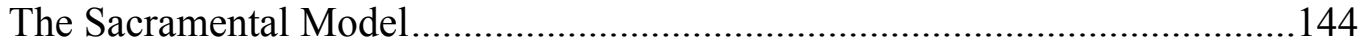

Divinity: Christ and the Concept of Divine Nature....................................144

Humanity: Christ and the Concept of Human Nature ................................154

Cosmology: Christ, Heaven, and Earth .....................................................161

Implications for Christ's Priesthood ……………………….....................171

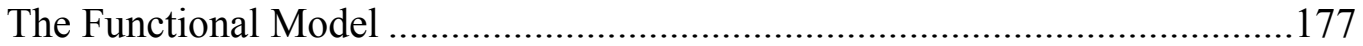

Divinity: Christ and the Concept of Divine Nature...................................177

Humanity: Christ and the Concept of Human Nature .................................186

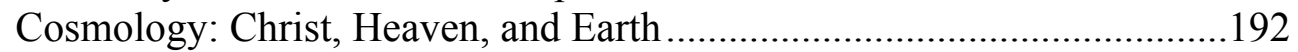

Implications for Christ's Priesthood .....................................................203

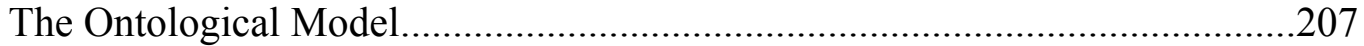

Divinity: Christ and the Concept of Divine Nature...................................207

Humanity: Christ and the Concept of Human Nature .................................222

Cosmology: Christ, Heaven, and Earth .....................................................233

Implications for Christ's Priesthood ……………………........................251

A Brief Comparison of the Models ................................................................257

Divinity: Christ and the Concept of Divine Nature....................................257

Humanity: Christ and the Concept of Human Nature .................................259

Cosmology: Christ, Heaven, and Earth .....................................................260

Implications for Christ's Priesthood ......................................................262

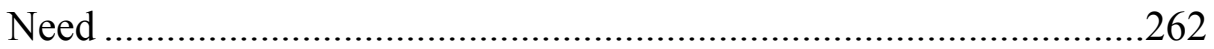

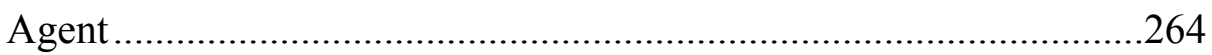

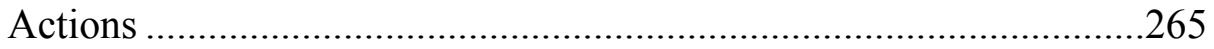

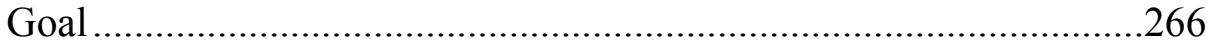

4. THE HISTORICAL MODEL: AN ALTERNATIVE SYSTEMATIC ARTICULATION OF CHRIST'S PRIESTHOOD BASED ON HEBREWS .....272

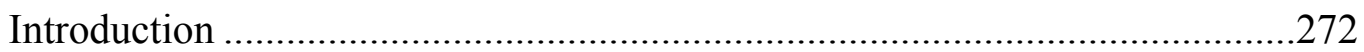

The Priesthood of Christ: Components of His Priesthood .................................2275

The Need for Christ's Priesthood.............................................................227

The Relationship of Sinful Human Beings with God .........................278

Sin and Human Beings......................................................................282

Sin and Creation at a Cosmic Level..................................................287 


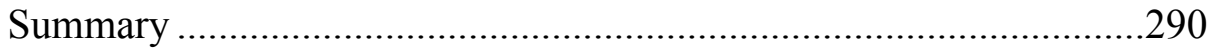

The Agent of the Priesthood......................................................................291

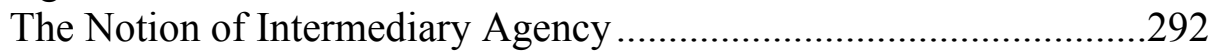

Christ's Humanity as a Pre-requisite ...............................................294

The Notion of Priestly Appointment..................................................295

The Beginning of the Priestly Appointment ……………..................300

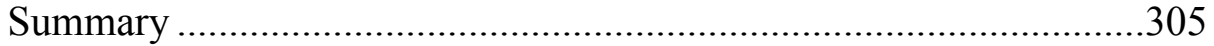

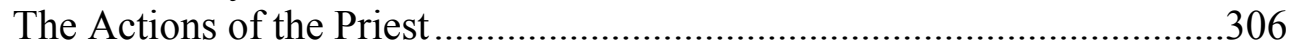

The Heavenly Offering of His Earthly Sacrifice.................................307

Ongoing Salvific Mediation..............................................................315

Intercession for Forgiveness...........................................................315

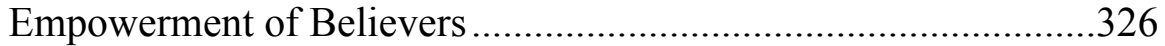

Eschatological Judgment and Salvation.............................................329

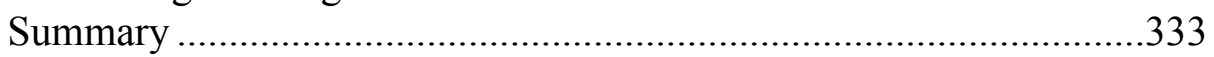

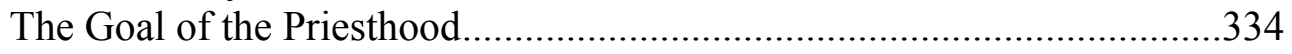

Better/New Covenant and Goal ......................................................335

Stages in the Fulfillment of the Goal ...............................................339

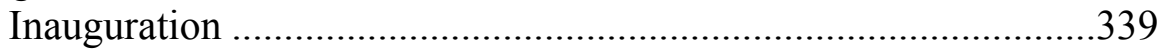

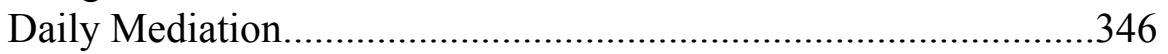

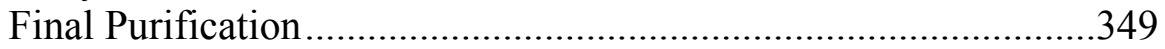

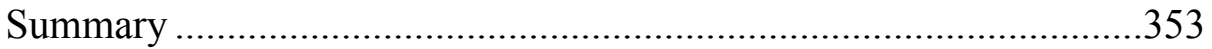

The Priesthood of Christ: Hermeneutical Principles of Reality ..........................354

Divinity: Christ and the Concept of Divine Nature.....................................356

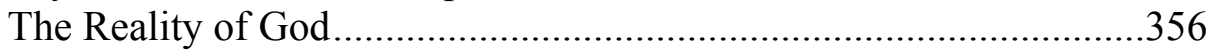

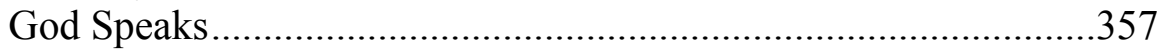

God Reacts to Human Actions ........................................................360

God Reacts to Christ's Sacrifice .....................................................362

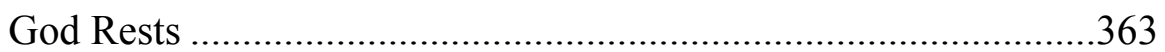

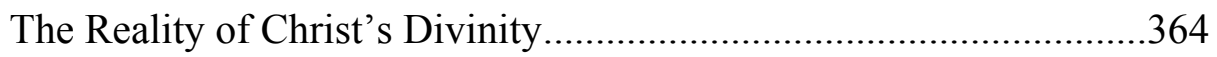

Divine Temporal Sameness.........................................................364

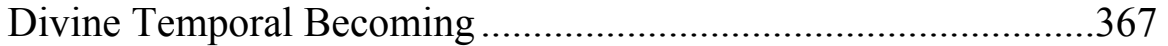

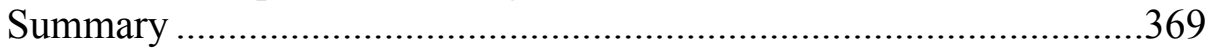

Humanity: Christ and the Concept of Human Nature ..................................371

General Anthropology: Human Nature Grounded in the Body ...........372

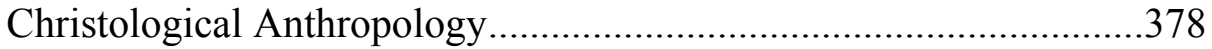

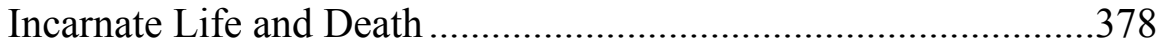

Incarnate Life and the Heavenly Priesthood ..................................384

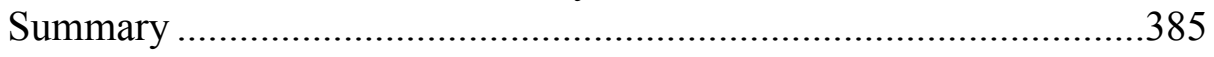

Cosmology: Christ, Heaven, and Earth .........................................................386

Framework: A Cosmological Eschatology ……………...................38

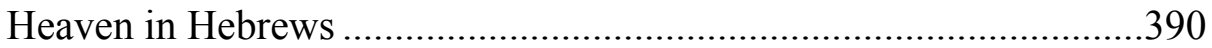

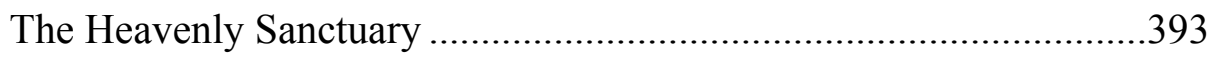

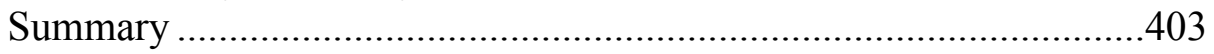

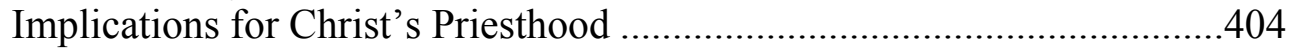

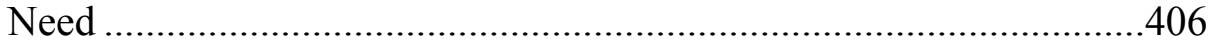

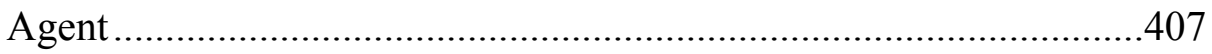




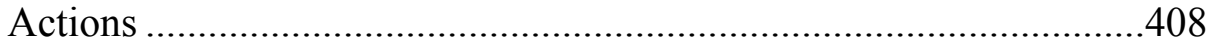

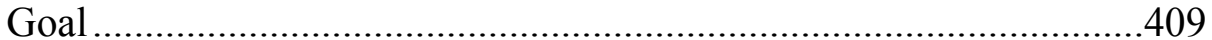

Potential Challenges to These Implications .......................................409

5. A BRIEF COMPARISON OF THE MODELS.................................................413

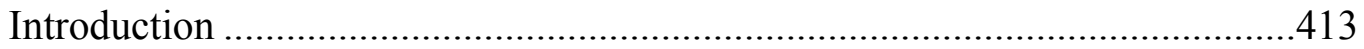

The Priesthood of Christ ..............................................................................413

The Need for Christ's Priesthood ...............................................................413

The Agent of the Priesthood....................................................................... 416

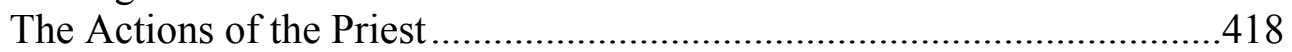

The Goal of the Priesthood....................................................................422

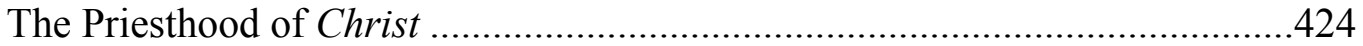

Divinity: Christ and the Concept of Divine Nature.....................................424

Humanity: Christ and the Concept of Human Nature .................................426

Cosmology: Christ, Heaven, and Earth ...................................................427

Implications for Christ's Priesthood ………............................................428

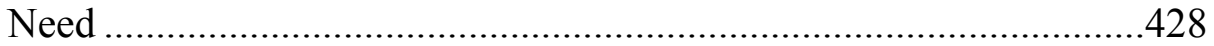

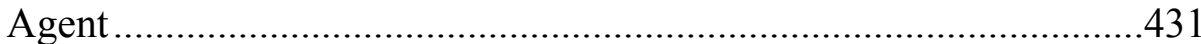

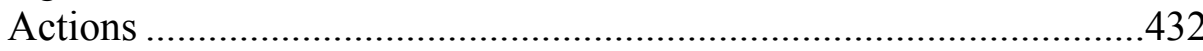

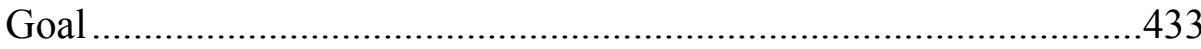

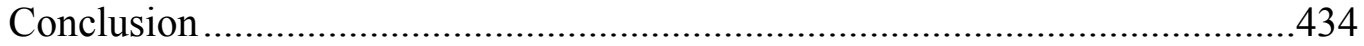

6. SUMMARY, CONCLUSION, AND RECOMMENDATIONS...........................438

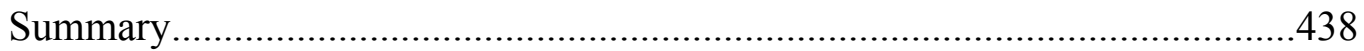

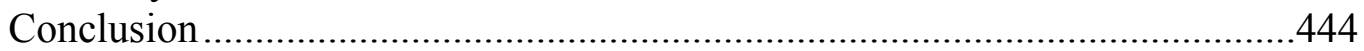

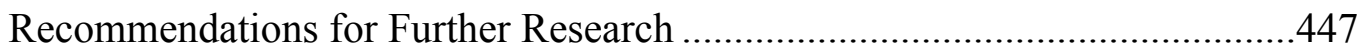

Appendix

A. REFERENCES AND ALLUSIONS TO CHRIST'S PRIESTHOOD IN THE CONTEXT OF THE STRUCTURE OF HEBREWS

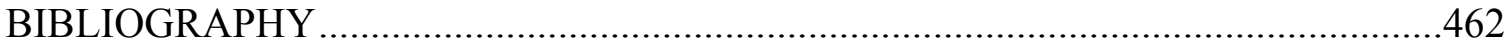




\section{LIST OF TABLES}

1. The need for CP (sacramental, functional, and ontological models) ..................131

2. The agent of CP (sacramental, functional, and ontological models) ..................133

3. The actions of CP (sacramental, functional, and ontological models) ...............136

4. The goal of CP (sacramental, functional, and ontological models) ....................140

5. Divinity (sacramental, functional, and ontological models) ............................257

6. Humanity (sacramental, functional, and ontological models) ..........................259

7. Cosmology (sacramental, functional, and ontological models).........................261

8. Implications for CP (sacramental, functional, and ontological models).............263

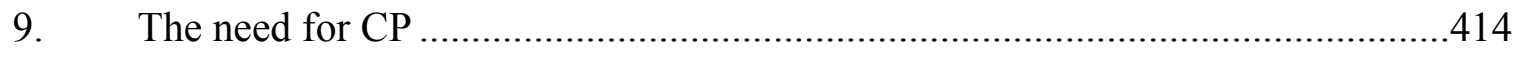

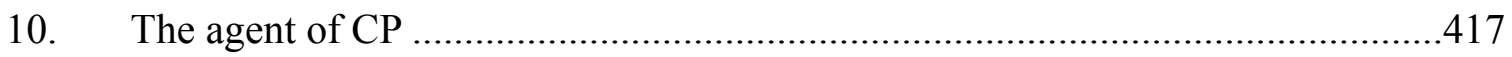

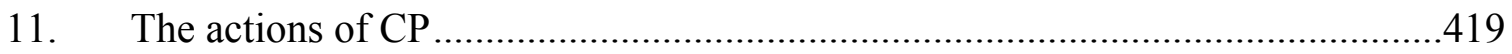

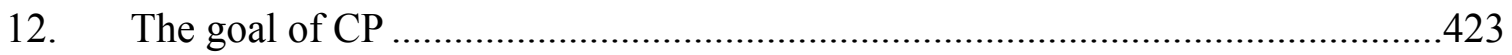

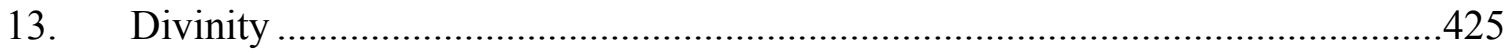

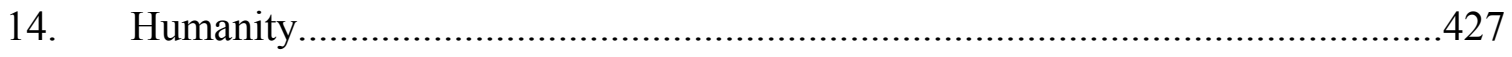

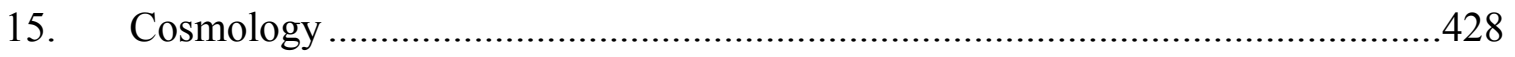

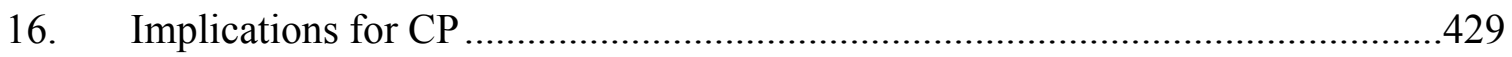

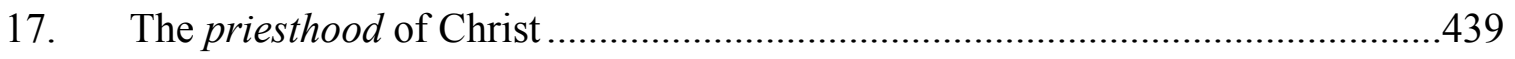

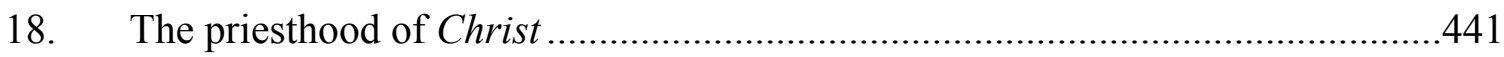




\section{LIST OF ABBREVIATIONS}

AUSS $\quad$ Andrews University Seminary Studies

$\mathrm{AB}$

Anchor Bible

BDAG Bauer, W., F. W. Danker, W. F. Arndt, and F. W. Gingrich. Greek-English Lexicon of the New Testament and Other Early Christian Literature. 3d ed. Chicago, 2000

CBC John Calvin, Calvin's Bible Commentaries

CD $\quad$ Karl Barth, Church Dogmatics

CDT Gerald O'Collins and E. G. Farrugia, Concise Dictionary of Theology

CP Christ's Priesthood

EDNT Exegetical Dictionary of the New Testament. Edited by Horst Robert Balz and Gerhard Schneider. ET. Grand Rapids, 1990-1993

ESV English Standard Version

HALOT Koehler, L., Walter Baumgartner, and J. J. Stamm, The Hebrew and Aramaic Lexicon of the Old Testament. Translated and edited under the supervision of M. E. J. Richardson. 4 vols. Leiden, 1994-2000

ICR John Calvin, Institutes of the Christian Religion

JOP Gerald O'Collins and Michael Keenan Jones, Jesus Our Priest

LEH A Greek-English Lexicon of the Septuagint. Rev. ed. Edited by Johan Lust, Erik Eynikel, and Katrin Hauspie. Stuttgart, 2003

L\&N Greek-English Lexicon of the New Testament: Based on Semantic

Domains. Edited by J. P. Louw and E. A. Nida. 2nd ed. New York, 1989

LXX Septuagint

LW Martin Luther, Luther's Works

MT Masoretic Text 


\begin{tabular}{|c|c|}
\hline NASB & New American Standard Bible (1995 Update) \\
\hline NAC & New American Commentary \\
\hline NET & New English Translation \\
\hline NICNT & New International Commentary on the New Testament \\
\hline NIGTC & New International Greek Testament Commentary \\
\hline NIV & New International Version \\
\hline NJB & New Jerusalem Bible \\
\hline NJPS & $\begin{array}{l}\text { Tanakh: The Holy Scriptures: The New JPS Translation according to the } \\
\text { Traditional Hebrew Text }\end{array}$ \\
\hline NRSV & New Revised Standard Version Bible \\
\hline NT & New Testament \\
\hline NTL & The New Testament Library \\
\hline $\mathrm{OT}$ & Old Testament \\
\hline PNTC & Pillar New Testament Commentary \\
\hline RSV & Revised Standard Version of the Bible \\
\hline$S C G$ & Thomas Aquinas, Summa Contra Gentiles \\
\hline$S T$ & Thomas Aquinas, Summa Theologiae \\
\hline$T D N T$ & $\begin{array}{l}\text { Theological Dictionary of the New Testament. Edited by G. Kittel and G. } \\
\text { Friedrich. Translated by G. W. Bromiley. } 10 \text { vols. Grand Rapids, 1964- } \\
1976\end{array}$ \\
\hline $\mathrm{UBS}^{5}$ & The Greek New Testament, United Bible Societies, $5^{\text {th }}$ ed. \\
\hline$W A$ & Martin Luther, Weimarer Ausgabe \\
\hline WBC & Word Biblical Commentary \\
\hline YLT & Young's Literal Translation \\
\hline
\end{tabular}




\section{ACKNOWLEDGMENTS}

Writing a dissertation on the priesthood of Christ is a remarkable spiritual and intellectual journey. I am thankful to God for the profund learning experience that I had

during this academic journey. I pray that my work will attract minds to the deep meaning of Christ's mediatorial priesthood.

Special gratitude is extended to my committee members. Thank you, Dr.

Fernando Canale, the chair of my dissertation committee, for giving tremendous support and providing conceptual clarity to my work. You really taught me how to think systematically and hermeneutically. Thank you, Dr. Martin Hanna, for your careful reading of my drafts, which gave more precision to my language. Thank you, Dr. Richard Davidson, for supporting me with your expertise and stimulating questions that improved the quality of the research. I am thankful to the internal examiner Dr. Felix Cortez, who was very helpful as a Hebrews scholar in the defense. Special gratitude to Dr. Marc Cortez, from Wheaton College, who graciously served as the external examiner and provided excellent feedback on the approach of my dissertation.

I would like to acknowledge Dr. Bruce L. McCormack for his insightful suggestions during my time as a student in the Doctoral Research Scholars Program at Princeton Theological Seminary, in the spring 2015 semester.

I am deeply indebted to the financial support that I received from the Adventist University of Sao Paulo (UNASP) throughout my doctoral studies at Andrews 
University. I am personally thankful to Dr. Amin Rodor and Pr. Paulo Martini for their vision and support. I am also grateful to Dr. Emilson dos Reis and Dr. Reinaldo Siqueira for their words of encouragement.

Finally, I would like to thank my wonderful wife Ellen for her loving wisdom, patience, and companionship. The relationship with our beautiful 2-year-old daughter Sarah has been a foretaste of the joy to be experienced in the new creation mediated by the priesthood of Christ. 


\section{CHAPTER 1}

\section{INTRODUCTION}

\section{Background of the Problem}

\section{As a central aspect of Christian soteriology, Christ's priesthood (CP) is}

foundational for a proper understanding of His work. ${ }^{1}$ Based on the fact that the book of "Hebrews contains the only detailed Christology of the High Priest in the New

Testament,"2 Oscar Cullmann argues in his classic New Testament Christology that “Hebrews' development of the High Priest concept offers a full Christology" that “includes all the three fundamental aspects of Jesus' work": ${ }^{3}$ (1) "his once-for-all earthly

\footnotetext{
${ }^{1}$ Donald Hagner points out the biblical connection between Christology and soteriology, particularly in Christ's priesthood. "Christology in Hebrews, as throughout the New Testament, consists in the identity of Jesus bound together with what he does. Very simply, it is because of who Christ is that he can do what he does. The unique emphases of the christology of Hebrews can be best appreciated by examining this connection between the person and work of Christ." Donald A. Hagner, "The Son of God as Unique High Priest: The Christology of the Epistle to the Hebrews," in Contours of Christology in the New Testament, ed. Richard N. Longenecker (Grand Rapids, MI: Eerdmans, 2005), 248.

${ }^{2}$ Oscar Cullmann, The Christology of the New Testament, trans. Shirley C. Guthrie and Charles A. M. Hall (Philadelphia: Westminster, 1959), 104. George Ladd claims that the priesthood of Christ is "the central theme in the Christology of Hebrews." George Eldon Ladd, A Theology of the New Testament, rev. ed. (Grand Rapids, MI: Eerdmans, 1993), 625. For further information about the centrality of Christ's priesthood in the Epistle to the Hebrews, see Hagner, "The Son of God as Unique High Priest," 247-266; Albert Vanhoye, Our Priest Is Christ: The Doctrine of the Epistle to the Hebrews (Rome: Pontifical Biblical Institute, 1977); Joy D. Tetley, "The Priesthood of Christ as the Controlling Theme of the Epistle to the Hebrews," (Ph.D. dissertation, University of Durham, UK, 2008).

${ }^{3}$ Cullmann, The Christology of the New Testament, 103. Cullmann recognizes that "this concept does not especially take into account the work of the pre-existent Christ. But, besides the bold reference in 1.10 to Christ as the Creator of earth and heaven," he highlights that the book of Hebrews "especially emphasizes another Christological title, 'Son of God' which refers precisely to Jesus' pre-existence.” Ibid. For further information about the connection between the Christological concepts of Son of God and High Priest in the book of Hebrews, see Hagner, "The Son of God as Unique High Priest," 247-266.
} 
work"; ${ }^{4}$ (2) "his present work as the exalted Lord"; 5 and (3) "his future work as the one coming again." However, Cullmann notes that this third aspect "is only mentioned and not fully developed.",

Overall, the most systematic treatments of the doctrine of the priesthood of Christ tend to focus on the two first aspects pointed by Cullmann, which roughly correspond respectively to the notions of atonement and mediation. Among the different views of Christ's priesthood in Christian theology, ${ }^{8}$ three main theological models ${ }^{9}$ may be distinguished. ${ }^{10}$ In fact, one of the chief dissimilarities between them is the way in which they integrate the atoning sacrifice of Christ and His heavenly mediation. Broadly speaking, the first model sacramentally identifies Christ's sacrifice with His mediation

${ }^{4}$ Cullmann, The Christology of the New Testament, 103-104. This aspect is mainly related to the once-for-all sacrifice of Christ on the cross (Heb 7:27; 10:10).

${ }^{5}$ Ibid., 104.

${ }^{6}$ Ibid.

${ }^{7}$ Ibid. Cullmann affirms that this aspect is mentioned in Heb 9:28 and represents "the eschatological side" of Christ's priesthood, pointing to "the 'second' coming of Jesus." Ibid., 103.

${ }^{8}$ For useful information about patristic interpretations of the concept of Christ as priest and mediator, especially in the context of the book of Hebrews, see Gerald O'Collins and Michael Keenan Jones, Jesus Our Priest: A Christian Approach to the Priesthood of Christ (Oxford; New York: Oxford University Press, 2010), 69-104; Michael Keenan Jones, Toward a Christology of Christ the High Priest (Rome: Gregorian University Press, 2006), 63-126; Jon M. Robertson, Christ as Mediator: A Study of the Theologies of Eusebius of Caesarea, Marcellus of Ancrya, and Athanasius of Alexandria (Oxford; New York: Oxford University Press, 2007); Rowan A. Greer, The Captain of Our Salvation: A Study in the Patristic Exegesis of Hebrews (Tübingen: Mohr, 1973).

${ }^{9}$ In the present study, "the concept of 'model' refers to the specific way in which a theological doctrine is articulated in its essential features." It means that models are "ideal, simplified, and schematic, accounts of a much more complex reality." Fernando Luis Canale, Back to Revelation-Inspiration: Searching for the Cognitive Foundation of Christian Theology in a Postmodern World (Lanham, MD; Oxford: University Press of America, 2001), 76.

${ }^{10}$ As far as the doctrine of Christ's priesthood is concerned, the present study could not find a significant taxonomy of the different interpretations of this doctrine in Christian theology from a systematic perspective. It means that the classification and labels provided below represent an attempt to systematize broadly the main theological views of the priesthood of Christ. 
(sacramental priesthood); while the second affirms that Christ's sacrifice and His heavenly mediation are connected, but they are distinct and sequential activities (functional ${ }^{11}$ priesthood); and the third model argues that His sacrifice and mediation are ontologically merged in Christ's own being (ontological priesthood).

More specifically, the model labeled in this study as sacramental priesthood is particularly defended by traditional Catholic theology. For Thomas Aquinas, the sacraments administered by the church are derived and flow from Christ's priesthood. ${ }^{12}$ In this sense, Gerald O'Collins highlights that, as the eternal high priest, "the risen Christ exercises his saving mission as primary" and invisible "minister of all the sacraments."13 According to that perspective, the priesthood of Christ is principally connected with the idea of sacrifice in the sacrament of the eucharist. ${ }^{14}$ Aquinas assumes that Christ's sacrifice essentially means the achievement of His priestly work, ${ }^{15}$ and His sacramental sacrifice ${ }^{16}$ takes place in the eucharist by virtue of the alleged reality of

\footnotetext{
${ }^{11}$ The term functional, in this context, conveys the idea that Christ performs specific and distinct priestly functions.

${ }^{12} S T$ 3.63.3.

${ }^{13} J O P, 212$. Elsewhere Collins declares that "the eternal High Priest incessantly acts as the primary, invisible minister in the preaching and sacramental life of the Church.” Ibid., 267.

${ }^{14}$ According to Aquinas, the eucharist is the most important of the seven sacraments because of two main reasons: (1) it contains Christ substantially, the source of grace, whereas the other sacraments are merely instruments of Christ's grace; (2) the eucharist is the end and consummation of all the other sacraments. ST 3.65.3; 3.63.6.

${ }^{15}$ Aquinas presumes that "the priesthood of Christ was made manifest most of all in His passion and death." ST 3.22.5. All English quotations of ST are taken from Thomas Aquinas, Summa Theologica, trans. Fathers of the English Dominican Province, 5 vols., The Master Christian Library Ver. 5.0 [CD Rom] (Albany, OR: AGES Software, 1997).

${ }^{16}$ The sacramental sacrifice is not different from the sacrifice on the cross. ST 3.22.3.2. In regard to the relationship between the sacrifice on the cross and the sacramental sacrifice in the eucharist (the sacrifice of the mass), Ludwig Ott explains that the latter is a "relative sacrifice," and "it is essentially linked" to the former. This relative sacrifice "in no way detracts from the Sacrifice of the Cross. The
} 
transubstantiation. ${ }^{17}$ In this way, Christ's mediation is sacramentally identified with the eucharistic sacrifice, ${ }^{18}$ because such mediation occurs in the sense that humans receive the fruits of Christ's priestly sacrifice through the eucharistic elements. ${ }^{19}$

On the other hand, the model named functional priesthood is mainly related to classical Protestant theology, as expounded by figures such as Martin Luther and John Calvin. ${ }^{20}$ In contrast to the sacramental model, the functional priesthood rejects the idea of sacramental sacrifice in the church and its connection with Christ's mediation of

Sacrifice of the Mass draws its whole power from the Sacrifice of the Cross, whose fruits applies to individual men." Furthermore, they are different only in "the nature and mode of the offering ... [whereas] on the Cross the sacrificial gift was offered in a bloody manner by a real separation of the body and blood (immolatio realis), in the Holy Mass it is offered in an unbloody manner by a mystical separation of the body and blood (immolatio mystica)." Ludwig Ott, Fundamentals of Catholic Dogma (Rockford, IL: Tan Books, 1974), 407-408. As O'Collins and Jones indicate, eucharist is a sacramental, not a historical sacrifice. JOP, 290.

${ }^{17}$ ST 3.75.4. The Council of Trent (1551) defined transubstantiation as follows: "By the consecration of the bread and of the wine, a conversion is made of the whole substance of the bread into the substance of the body of Christ our Lord, and of the whole substance of the wine into the substance of His blood." The Council of Trent: The Canons and Decrees of the Sacred and Ecumenical Council of Trent, ed. J. Waterworth (London: Dolman, 1848), 77. For further information about the concept of transubstantiation, see Engelbert Gutwenger, "Transubstantiation," Encyclopedia of Theology: The Concise Sacramentum Mundi, ed. Karl Rahner (New York: Crossroad, 1982), 1751-1755; Joseph Pohle, "The Real Presence of Christ in the Eucharist," The Catholic Encyclopedia, vol. 5 (New York: Robert Aplleton, 1909), http://www.newadvent.org/cathen/05573a.htm (accessed 30 December, 2016); Stephen L. Brock, "St. Thomas and the Eucharistic Conversion," The Thomist 65, no. 4 (2001): 529-565; Joseph Pohle and Arthur Preuss, The Sacraments: A Dogmatic Treatise, 4 vols. (St. Louis, MO: B. Herder, 1917), 2:25.

${ }^{18}$ According to Ott, in the "sacrifice of the mass, Christ's sacrifice on the cross is made present, its memory is celebrated, and its saving power is applied." Ott, Fundamentals of Catholic Dogma, 407.

${ }^{19}$ ST 3.79.1; 3.22.6. In short, the "eucharist provides a sacramental means of entry into the offering and fruits of Christ's priestly sacrifice." JOP, 108.

${ }^{20}$ The discussion about the priesthood of Christ has been particularly fruitful in Calvinist circles. See Efion E Evans, "The Puritan Concept of Divine Intercession," in Puritan Papers, Volume Two: 19601962, ed. J.I. Packer (Phillipsburg, NJ; Kingsburg, CA: Presbyterian and Reformed; The den Dulk Christian Foundation, 2001), 187-205; Howard Griffith, "High Priest in Heaven: The Intercession of the Exalted Christ in Reformed Theology; Analysis and Critique," (Ph.D. dissertation, Westminster Theological Seminary, 2004); Graham Redding, Prayer and the Priesthood of Christ in the Reformed Tradition (Edinburgh; New York: T\&T Clark, 2005); Arthur J. Tait, The Heavenly Session of Our Lord: An Introduction to the History of the Doctrine (London: R. Scott, 1912). Overall, these studies highlight the names of John Owen, John Murray, and William Milligan. 
salvific grace. ${ }^{21}$ Rather, the Reformers emphatically affirm that Christ's death on the cross is the once-for-all sacrifice, which means that this sacrifice is full, perfect, and sufficient, and therefore is not to be repeated in any form. ${ }^{22}$ Based on this unique sacrifice Christ performs His subsequent work as mediator before the Father in heaven. In this context, the priesthood of Christ encompasses two inseparable but distinct and sequential functions or aspects, namely, the earthly sacrifice and the heavenly intercession. ${ }^{23}$

Finally, the model identified as ontological priesthood is basically adopted by some strands of modern theology, as in the case of Karl Barth and Thomas Torrance. Unlike the previous model, this position emphasizes that Christ's salvific mediation is not related to something that He does, but to something that He has in His being. To put differently, the priestly mediation of Christ is understood ontologically, not in terms of functions or activities performed in heaven. ${ }^{24}$ Because Barth and Torrance maintain that

\footnotetext{
${ }^{21}$ Luther affirms that Christ did not ordain the sacrament of the eucharist in terms of sacrifice, since the sacrifice was once performed by the true high priest on the cross. $L W, 13: 313$ (Commentary on Psalm 110, 1535). See also ibid., 36:36-40 (The Babylonian Captivity of the Church). According to Paul Althaus, the idea of sacrifice in the community of the church is understood in the light of the concept of the priesthood of all believers. "For Luther, Christ's priesthood and the Christian's priesthood belong together, as reconciling faith in Christ and the community of saints together constitute the nature of the church. In the final analysis, the Christian's priestly sacrifice is nothing else than Christ's own sacrifice. For the life of Christians is Christ's life. All sacrifice through which the community exists is an offering with and in Christ in that one sacrifice which took place once but is yet everywhere present, which cannot be repeated but lives on in the reality of the community." Paul Althaus, The Theology of Martin Luther, trans. R. C. Schultz (Philadelphia: Fortress, 1966), 315. For Calvin's statements against the idea of sacrifice of the mass, see ICR 2.15.6; 4.18.

${ }^{22}$ See ICR 4.18.3; $L W, 13: 320$.

${ }^{23}$ See ICR 4.6.2; $L W, 13: 315,320-321$.

${ }^{24}$ Barth criticizes any "distinction between the restoration of fellowship between God and man accomplished once and for all in Jesus Christ" (sacrifice) "and the 'continual' mediation of it" (heavenly mediation). $C D$ IV/1, 285. All quotations of $C D$ are taken from Karl Barth, Church Dogmatics, ed. G. W. Bromiley and T. F. Torrance, 14 vols. (Peabody, MA: Hendrickson, 2010). According to Torrance, "looked at from the side of God, the whole work of salvation is accomplished in the Son." Thomas F. Torrance, Atonement: The Person and Work of Christ (Milton Keynes, UK; Colorado Springs, CO; Downers Grove, IL: Paternoster; IVP Academic, 2009), 174. For Barth, the continuous mediation of the ascended Christ
} 
incarnation and sacrifice took place in the being of Christ, the atonement is a complete and ontological reality in Him. ${ }^{25}$ Thus, the complete salvific reality that is already present in Christ's being needs to be revealed to believers.

\section{Statement of the Problem}

There is an evident disagreement between the three theological models mentioned above (sacramental, functional, and ontological) concerning Christ's priesthood. One clear aspect of this disagreement is the existence of different views on the relationship between sacrifice and heavenly mediation in the priesthood of Christ. These conflicting views reveal that Christian theology does not have a consensus about the nature of the priestly work of the ascended Christ, including the conception of how Christ mediates salvation through his priesthood. This problematic situation raises the question whether there is a way to resolve this conflict of interpretations.

\section{Purpose}

The purpose of this dissertation is to deconstruct hermeneutically ${ }^{26}$ conflicting

needs to be interpreted according to His timeless being, which means that all His earthly experience is present in His being. "He not only did represent us, He does represent us. He not only did bear the sin of the world, He does bear it. He not only has reconciled the world with God, but as the One who has done this, He is its eternal Reconciler, active and at work once and for all. He not only went the way from Jordan to Golgotha, but He still goes it, again and again." $C D$ IV/1, 313.

${ }^{25}$ In Torrance's words, "the judgement of the judge" took place "within his own person." Torrance, Atonement, 124. In this sense, Barth mentions that "Jesus Christ is the atonement." CD IV/1, 34. For Kevin Vanhoozer, this view implies that "the efficacy of the atoning act is internal, not external, to God's own being." Kevin J. Vanhoozer, "Atonement," in Mapping Modern Theology: A Thematic and Historical Introduction, ed. Kelly M. Kapic and Bruce L. McCormack (Grand Rapids, MI: Baker Academic, 2012), 24.

${ }^{26}$ For a proper explanation of the concept of hermeneutical deconstruction or adopted in this study, see Conceptual Framework below. For a detailed description of the application of this deconstruction in this study, see Methodology below. 
models of Christ's priesthood in order to articulate a constructive proposal of an

alternative model as a suggestion for the resolution of the conflict of interpretations

regarding this doctrine.

\title{
Justification
}

Many scholars have argued that by assuming a Greek notion of being Christian

theology has traditionally interpreted the doctrine of God guided by non-biblical

presuppositions, ${ }^{27}$ particularly, from a timeless perspective. ${ }^{28}$ If "theological

hermeneutics recognizes that our doctrine of God affects the way we interpret the

Scriptures," 29 and if Christian "doctrine reflects the nature of God," 30 the concept of a

\begin{abstract}
${ }^{27}$ See Anthony C. Thiselton, The Hermeneutics of Doctrine (Grand Rapids, MI: Eerdmans, 2007), 39-40; Jean-Luc Marion, God without Being: Hors-Texte, trans. Thomas A. Carlson (Chicago: University of Chicago Press, 1995); Stanley J. Grenz, The Named God and the Question of Being: A Trinitarian TheoOntology (Louisville: Westminster John Knox Press, 2005), 15-89.

${ }^{28}$ See Fernando Luis Canale, A Criticism of Theological Reason: Time and Timelessness as Primordial Presuppositions, Andrews University Seminary Doctoral Dissertation Series 10 (Berrien Springs, MI: Andrews University Press, 1987); Fernando Luis Canale, Basic Elements of Christian Theology: Scripture Replacing Tradition (Berrien Springs, MI: Andrews University Lithothec, 2005); Gregory A. Boyd, God of the Possible: A Biblical Introduction to the Open View of God (Grand Rapids, MI: Baker, 2000), 17; Clark H. Pinnock, Most Moved Mover: A Theology of God's Openness, Didsbury Lectures (Carlisle, UK; Grand Rapids, MI: Paternoster Press; Baker Academic, 2001), 7. Many scholars have discussed the relationship between God and time, from different standpoints. See William Lane Craig, Time and Eternity: Exploring God's Relationship to Time (Wheaton, IL: Crossway, 2001); Garrett J. DeWeese, God and the Nature of Time, Ashgate Philosophy of Religion Series (Aldershot, UK; Burlington, VT: Ashgate, 2004); Gregory E. Ganssle, ed., God and Time: Four Views (Cumbria, UK: Paternoster, 2001); Gregory E. Ganssle and David M. Woodruff, eds., God and Time: Essays on the Divine Nature (Oxford; New York: Oxford University Press, 2002); William Hasker, God, Time, and Knowledge, Cornell Studies in the Philosophy of Religion (Ithaca, NY; London: Cornell University Press, 1998); Paul Helm, Eternal God: A Study of God without Time (Oxford; New York: Oxford University Press, 2010); William J. Hill, Search for the Absent God: Tradition and Modernity in Religious Understanding (New York: Crossroad, 1992); Eunsoo Kim, Time, Eternity, and the Trinity: A Trinitarian Analogical Understanding of Time and Eternity (Eugene, OR: Wipf and Stock, 2010); Brian Leftow, Time and Eternity, Cornell Studies in the Philosophy of Religion (Ithaca, NY: Cornell University Press, 1991); John J. O’Donnell, Trinity and Temporality: The Christian Doctrine of God in the Light of Process Theology and the Theology of Hope, Oxford Theological Monographs (Oxford; New York: Oxford University Press, 1983); Alan G. Padgett, God, Eternity, and the Nature of Time (New York: St. Martin's Press, 1992); Nelson Pike, God and Timelessness, Studies in Ethics and the Philosophy of Religion (London: Routledge and K. Paul, 1970).
\end{abstract}

${ }^{29}$ Kevin J. Vanhoozer, First Theology: God, Scripture and Hermeneutics (Downers Grove, IL; 
timeless God in Christian theology should affect the understanding of the doctrine of Christ's priesthood. Recently, scholars have debated the impact of the timeless notion of God on Christology. ${ }^{31}$ Even though this discussion may reveal significant implications for the priestly work of Christ, the debate is mainly focused on the earthly ministry of the incarnate Christ and does not address the condition of the ascended Christ and his heavenly work as a priest. In this sense, this dissertation may reveal if the timeless presupposition plays a role in the understanding of Christ's priesthood in Christian theology.

Furthermore, some theologians have concluded that there is a scarcity of attentive theological reflection upon the connection between Christ's priesthood and soteriology, ${ }^{32}$

Leicester, England: InterVarsity; Apollos, 2002), 10.

${ }^{30}$ Thiselton, The Hermeneutics of Doctrine, 63.

${ }^{31}$ See Brian Leftow, “A Timeless God Incarnate," in The Incarnation: An Interdisciplinary Symposium on the Incarnation of the Son of God, ed. Daniel Kendall, Stephen T. Davis, and Gerald O'Collins (Oxford: Oxford University Press, 2002), 273-299; Thomas D. Senor, "Incarnation, Timelessness, and Leibniz's Law Problems," in God and Time: Essays on the Divine Nature, ed. Gregory E. Ganssle and David M. Woodruff (Oxford; New York: Oxford University Press, 2002), 220-235; Thomas D. Senor, "Incarnation and Timelessness," Faith and Philosophy 7, no. 2 (1990): 149-164; Douglas K. Blount, "On the Incarnation of a Timeless God," in God and Time: Essays on the Divine Nature, ed. Gregory E. Ganssle and David M. Woodruff (Oxford; New York: Oxford University Press, 2002), 236248; Eleonore Stump and Norman Kretzmann, "Eternity," The Journal of Philosophy 78, no. 8 (1981): 451453; Pike, God and Timelessness, 172-173; Paul Helm, "Divine Timeless Eternity," in God and Time: Four Views, ed. Gregory E. Ganssle (Cumbria, UK: Paternoster, 2001), 33, 54-55; Nicholas Wolterstorff, "Unqualified Divine Temporality," in God and Time: Four Views, ed. Gregory E. Ganssle (Cumbria, UK: Paternoster, 2001), 209-210; DeWeese, God and the Nature of Time, 232-234; Gerald O'Collins, Christology: A Biblical, Historical, and Systematic Study of Jesus, 2 ed. (Oxford; New York: Oxford Univesity Press, 2009), 249.

${ }^{32}$ See Louis Berkhof, Systematic Theology (Grand Rapids, MI: Eerdmans, 1976), 401; Jones, Toward a Christology of Christ the High Priest, 10; O'Collins and Jones, Jesus Our Priest, v. As Jones indicates, even though "notable theologians and biblical scholars of the twentieth century have presented their own various studies of Christ, ... rarely do they approach Christ through the prism of his priesthood. Salvation, redemption, and mediation are constant themes running through Christology but there is often a hesitation, a moment's reluctance to call him a priest, or if the title is mentioned at all, it often seems to be in passing, as a taken-for-granted throw-away term." Jones, Toward a Christology of Christ the High Priest, 10. 
including in evangelical circles. ${ }^{33}$ In this context, the present study may uncover hermeneutical reasons why systematic theologians in general have not properly developed the role of the priesthood of Christ in soteriology, particularly if the timeless presupposition does play a role in their understanding of Christ's priestly work.

\section{Scope and Delimitations}

The present study is restricted to three existing models ${ }^{34}$ of Christ's priesthood, which are identified as sacramental priesthood, functional priesthood, and ontological priesthood. The analysis of these models will be essentially limited to specific representatives. The selection of representatives is based on two criteria: (1) significance of the representative for Christian theology, particularly in the area of systematic theology; (2) the representative provides an explicit, detailed, and systematic description of the priesthood of Christ. Therefore, the criteria derive primarily from the perspective of systematic theology (structure of ideas), and not from the standpoint of historical theology (development of ideas). On this basis, the following representatives have been selected for each model: (1) Sacramental priesthood-Thomas Aquinas and Gerald O’Collins; ${ }^{35}$ (2) Functional priesthood-Martin Luther and John Calvin; ${ }^{36}$ (3)

\footnotetext{
${ }^{33}$ Berkhof, Systematic Theology, 401-402.
}

${ }^{34}$ David Tracy defends the importance of using models in theology. "A widely accepted dictum in contemporary theology is the need to develop certain basic models or types for understanding the specific task of the contemporary theologian." David Tracy, Blessed Rage for Order: The New Pluralism in Theology (Chicago: University of Chicago Press, 1996), 22. For a specific definition of the concept of models in the present study, see footnote 9 above.

${ }^{35}$ Aquinas is arguably the most important systematic theologian in classical Roman Catholic tradition. He also provides the most systematic description of the priesthood of Christ in this tradition. In this same tradition, O'Collins is the most important systematician who provides a systematic portrayal of this doctrine in the twentieth-first century. Writing from the perspective of Vatican II, O'Collins implies that Aquinas' understanding of Christ's priesthood is still foundational for Roman Catholic tradition. 
Ontological priesthood-Karl Barth and Thomas Torrance. ${ }^{37}$

After the hermeneutical deconstruction of these three models, in the interaction with Scripture for the articulation of an alternative model, the scriptural corpus will be delimited to the Epistle to the Hebrews as the focus of the study. Because of the systematic focus of the research, this dissertation will not engage in the analysis of the way the representatives of the sacramental, functional, and ontological models interpret Hebrews for their conceptualization of Christ's priesthood. Rather, the research will privilege sources in which the representatives present more systematic expositions, and note their references to Hebrews when they are conceptually important to inform specific points of the model.

Furthermore, at the outset, the study does not provide an exact definition of the concept and scope of Christ's priestly work. The present research will use the definitions indicated by the models as the starting point for the reflection on the concept and scope of Christ's priesthood.

\section{Conceptual Framework}

A significant notion for the development of this hermeneutical analysis is the concept of theological deconstruction. The explanation of this concept in the present section reveals the basic assumptions of this dissertation, which include the notions of Hellenization of Christian doctrine, onto-theo-logy and theo-onto-logy, macrohermeneutical principles, time and timelessness. All these notions are employed from a

\footnotetext{
${ }^{36}$ Luther and Calvin are the most significant names in classical Protestantism.

${ }^{37}$ Barth and Torrance are the most important theologians in modern Protestantism who discuss the priesthood of Christ from a systematic perspective.
} 
hermeneutical standpoint.

Two points are important for an adequate understanding of the concept of theological deconstruction, namely, the need and nature of this deconstruction. By using the term onto-theo-logy scholars have indicated that Greek ontology has traditionally been the metaphysical ground of Christian theology. ${ }^{38}$ This has been caused by the Hellenization of Christian doctrine. Studies on the historical development of doctrine in Christian theology indicate an assimilation of Greek metaphysical conceptions in the explanation of biblical material, promoted chiefly by "the expansion of Christianity into a Hellenistic milieu in the first centuries of its history. ${ }^{, 39}$ As Gunton indicates, in the context of the idea of Hellenization of theology, the historical development of Christian doctrines is generally interpreted in three ways: (1) the presence of Greek elements in Christian doctrines represented a clear distortion of the original faith (Adolf von Harnack); (2) the use of Greek categories in the development of doctrine basically unfolded "what was already implicit in the original faith" (J. H. Newman); and (3) the development of Christian doctrine involved an ambivalent rejection and assimilation of Hellenism (Jaroslav Pelikan). ${ }^{40}$ My perspective on Hellenization in this dissertation

${ }^{38}$ See Martin Heidegger, "The onto-Theo-Logical Constitution of Metaphysics," in Identity and Difference (Chicago: University of Chicago Press, 2002); Iain D. Thomson, Heidegger on Ontotheology: Technology and the Politics of Education (Cambridge; New York: Cambridge University Press, 2005), 743; Marion, God Without Being, 35-38; Grenz, The Named God and the Question of Being, 15-130; Canale, A Criticism of Theological Reason, 19-284; Brian D. Ingraffia, Postmodern Theory and Biblical Theology: Vanquishing God's Shadow (Cambridge; New York: Cambridge University Press, 1995), 119.

${ }^{39}$ Alister E. McGrath, The Genesis of Doctrine: A Study in the Foundations of Doctrinal Criticism (Oxford, UK; Cambridge, MA: Blackwell, 1990), 4.

${ }^{40}$ Colin E. Gunton, "Historical and Systematic Theology," in The Cambridge Companion to Christian Doctrine, ed. Colin E. Gunton (Cambridge: Cambridge University Press, 2004), 5. Pelikan highlights that "the accusation" of Hellenization "recurred in the attacks of the Reformers on medieval scholasticism, but it was in modern times that the idea of dogma as the hellenization of Christianity became 
follows this third option of ambivalent rejection and assimilation. ${ }^{41}$

However, the problem of assimilation is not a simple one, since it has taken place at the level of hermeneutics. As Alister McGrath points out, in the context of "the expansion of Christianity into a Hellenistic milieu in the first century, . . . the move from the repetition or reiteration of scripture to doctrinal exposition through an already existing language [Greek] and conceptual framework [Hellenism], inevitably carried with it the demand for an engagement with the view, or range of views, of reality already associated with that language and conceptual framework." 42 As a result, "the data of scripture and the Christian tradition were thus interpreted in the light of presuppositions, within a hermeneutical framework, alien to their sources."43 Therefore, McGrath emphasizes that the problem of Hellenization is essentially hermeneutical, as Christian doctrine tends to be interpreted through presuppositions of a Greek view of reality.

The problem of Hellenization calls for a deconstruction of the ontotheological

a widely circulated explanation of the development of early Christian doctrine. Taken as it stands, 'hellenization' is too simplistic and unqualified a term for the process that issued in orthodox Christian doctrine. Nevertheless, it is true that in its language and sometimes in its ideas orthodox Christian doctrine still bears the marks of its struggle to understand and overcome pagan thought, so that what later generations of the church (including those generations that were themselves ignorant of antiquity) inherited in the dogma of the church included more than a little of Greek philosophy as well." Taking the example of the early apologists "as the interpreters of the church to the Gentile world," Pelikan argues that "their attitude toward ancient culture is contradictory." Jaroslav Pelikan, The Emergence of the Catholic Tradition (100-600), The Christian Tradition: A History of the Development of Doctrine (Chicago: University of Chicago Press, 1971), 45 (italics mine).

${ }^{41}$ As McGrath points out, "we fail to do justice to the pressures confronting early-Christian thinkers if we represent them as simply incorporating pre-existing philosophical or civil views of the divine attributes." Similar to the experience of the early-Christian thinkers, "there is a temptation for every generation of theologians to bring a cluster of inherited metaphysical commitments as self-evident, requiring no further justification, to the task of theology. McGrath, The Genesis of Doctrine, 5.

$$
\begin{aligned}
& { }^{42} \text { Ibid., } 4 . \\
& { }^{43} \text { Ibid., } 5 .
\end{aligned}
$$


structure of Christian theology ${ }^{44}$ and a replacement of onto-theo-logy by theo-onto-logy. ${ }^{45}$

The type of deconstruction adopted in this study intends to prepare the way for an

alternative theological construction ${ }^{46}$ that interacts with the Scripture as the ground for

Christian theology. Considering that the main problem of Helenization for Christian

doctrine is hermeneutical, the deconstruction of ontotheology also needs to be

hermeneutical. Furthermore, the "principles that guide theological interpretation and

construction" $" 47$ are found at the hermeneutical level. In other words, from a

hermeneutical standpoint it is possible to observe and evaluate how theological models

have been structured. Studies on hermeneutics indicate two helpful concepts for the

understanding of the cognitive process involved in the construction of a theological

model by a theologian: (1) the fusion of horizons and (2) the spiral movement of

induction and deduction. Christian theologians usually construct theological models

based on their reading and interpretation of Scriptures, and this process of interpreting

${ }^{44}$ See David R. Griffin, "Reconstructive Theology," in The Cambridge Companion to Postmodern Theology, ed. Kevin J. Vanhoozer (Cambridge; New York: Cambridge University Press, 2003), 102;

Fernando Luis Canale, "Deconstructing Evangelical Theology?," AUSS 44, no. 1 (2006): 95-130; Ingraffia, Postmodern Theory and Biblical Theology, 167-224.

${ }^{45}$ See Grenz, The Named God and the Question of Being, 90-373; Canale, A Criticism of Theological Reason, 285-387. The term theo-onto-logy suggests an ontology defined by God's selfdisclosure in Scripture.

${ }^{46}$ According to Griffin, there are two types of postmodern deconstruction: deconstructive/eliminative and constructive/revisionary. The former attempts to overcome the modern worldview through the deconstruction or elimination of the ingredients necessary for a worldview, and is mainly associated to Derrida's work. Conversely, the latter aims to deconstruct the modern worldview "not by eliminating the possibility of worldview as such, but by constructing a postmodern worldview through a revision of modern premises and traditional concepts." David R. Griffin, "Introduction to Suny Series in Constructive Postmodern Thought," in Founders of Constructive Postmodern Philosophy: Peirce, James, Bergson, Whitehead, and Hartshorne, ed. David Ray Griffin (Albany: State University of New York Press, 1993), viii. Therefore, the theological deconstruction to be used in the present study assumes a constructive perspective.

${ }^{47}$ Fernando Luis Canale, "Evolution, Theology, and Method: Part 3 Evolution and Adventist Theology," AUSS 42, no. 1 (2004): 10. 
biblical data is characterized by a fusion of horizons, which refers to the horizon of the text and the horizon of the interpreter. This fusion "does not allow the interpreter to speak of an original meaning of the work without acknowledging that, in understanding it, the interpreter's own meaning enters in as well. ${ }^{, 48}$ To put it differently, hermeneutics is not only about texts that are read, but also about the mind of the reader, because interpretation "takes place when [these] two sets of horizons are brought into relation to each other."

The horizon of the interpreter encompasses the pre-understanding that he or she brings to the text, which is defined as "the initial application of a tentative working assumption to set the understanding going and on its journey toward a fuller appreciation of all that this might entail." ${ }^{50}$ As the "understanding begins to move and to grow, we may discover that certain aspects of our preliminary understanding need to be corrected while other aspects seem to be proving their value.. ${ }^{51}$ Therefore, the relationship between the horizon of the text and the pre-understanding of the reader is not a matter of warfare involving "nonnegotiable fixed presuppositions. ${ }^{, 52}$ Rather, "preliminary understanding and responsible journeys into fuller understanding leave room for renegotiation, reshaping, and correction in the light of subsequent wrestling with the parts and the

\footnotetext{
${ }^{48}$ Hans-Georg Gadamer, Truth and Method, trans. Joel Weinsheimer and Donald G. Marshall (London; New York: Continuum, 2004), 578. In the context of biblical interpretation, Karl Barth indicates that "exegesis is always a combination of taking and giving, of reading out and reading in." $C D \mathrm{I} / 1,106$.

${ }^{49}$ Anthony C. Thiselton, The Two Horizons: New Testament Hermeneutics and Philosophical Description (Carlisle, UK; Grands Rapids, MI: Paternoster; Eerdmans, 1993), 103. 15.

${ }^{50}$ Anthony C. Thiselton, Hermeneutics: An Introduction (Grand Rapids, MI: Eerdmans, 2009), 13, ${ }^{51}$ Ibid.
} 
whole." 53

The process of understanding, described by the reshaping of presuppositions through the interactions between the parts and the whole, is properly explained by Grant Osborne in terms of a spiral movement of induction and deduction. ${ }^{54}$ In the process of construction of theological models, theologians spirally move using inductive and deductive reasoning. Inductively, they move from observations of specific texts in Scripture (the parts) to the composition of broad theories or concepts (the whole). Deductively, they apply "hermeneutical principles and previously formed theological decisions [the whole] to the text itself [the parts]." ${ }^{, 55}$ In other words, the inductive movement recognizes the horizon of the text, and the deductive movement acknowledges the horizon of the interpreter. Ideally, the theologian needs to work constantly in this spiral movement "to refine the model on the basis of an increased understanding of the data." ${ }^{56}$ In this ideal situation, the horizon of the interpreter is gradually shaped by the horizon of the text, that is, the pre-understanding and presuppositions of the theologian are progressively informed by the biblical data. However, considering that theology is a fallible "process of human reflection upon the revelation of God," 57 in practice the spiral

\footnotetext{
${ }^{52}$ Ibid.
}

${ }^{53}$ Ibid.

${ }^{54}$ Similarly, Bernard Lonergan argues that the process of understanding is "a self-correcting process of learning that spirals into the meaning of the whole by using each new part to fill out and qualify and correct the understanding reached in reading the earlier parts." Bernard J. F. Lonergan, Method in Theology (Toronto: University of Toronto Press, 1990), 159.

${ }^{55}$ Grant R. Osborne, The Hermeneutical Spiral: A Comprehensive Introduction to Biblical Interpretation (Downers Grove, IL: InterVarsity, 1991), 298.

${ }^{56}$ Ibid.

${ }^{57}$ Karl Rahner, Theology, Anthropology, Christology, trans. David Bourke, Theological 
theological movement tends to stop. In this sense, the work of theological deconstruction is always necessary to keep Christian theology moving in a growing understanding of God's revelation in Scripture. ${ }^{58}$

Even though Osborne correctly highlights that the presuppositions that theologians bring for the construction of a theological model or system need to be shaped by the biblical data, he seems to discuss these presuppositions basically at the level of the influence of theological traditions. ${ }^{59}$ Although this is a legitimate discussion, it is not able to properly grasp the philosophical influence of onto-theology (mentioned above) that stands behind and inform those theological traditions. As Millard Erickson points out, "our interpretation of the Bible is affected by our philosophical presuppositions." ${ }^{60}$ These presuppositions are at the level of the macro-hermeneutical principles, which guide theologians in the interpretation of biblical texts and in the construction of theological models and systems.

There are three levels of hermeneutical principles according to the nature of

Investigations 13 (New York Seabury, 1975), 61.

${ }^{58}$ While affirming that theology is a "fallible human work," Barth emphasizes the "human task of criticizing and revising its speech about God." In fact, he thinks that the existence of theology is justified by its task of humbly guiding the talk of the church about God. $C D \mathrm{I} / 1,3-4$.

59 "We do not simply move from the Bible to theological assertions, and those assertions are not automatic reproductions of biblical truths. Rather, all decisions are filtered through a network of tradition and preunderstanding, which itself exerts tremendous influence upon our interpretations and choices. To this extent each decision we make is provisional and we must establish a continual dialogue between tradition and biblical text in the spiral upward to truth." The understanding of presuppositions in terms of theological tradition is also evident when he emphasizes the need of a conscious reconstruction of our preunderstanding: "If we desire an honest re-examination of the issue, we must define carefully where we and our tradition stand on the doctrine before beginning the study. ... Unless these are brought to the surface they will dominate and skew the research, for it is natural to want the evidence to corroborate rather than challenge our presuppositions." Osborne, The Hermeneutical Spiral, 308, 315 (italics mine).

${ }^{60}$ Millard J. Erickson, Truth or Consequences: The Promise and Perils of Postmodernism (Downers Grove, IL: InterVarsity, 2001), 326. 
theological interpretation: micro-hermeneutics (biblical/textual principles of interpretation), meso-hermeneutics (theological/doctrinal principles of interpretation), and macro-hermeneutics (the most inclusive ontological, epistemological, and articulation principles of interpretation) ${ }^{61}$ This distinction on the levels of hermeneutical principles means that the influence of theological traditions, as Osborne's emphasizes, occurs at the level of meso-hermeneutics, while the influence of philosophical presuppositions behind the theological traditions, as Erickson highlights, takes place at the level of macro-hermeneutics.

One of the main presuppositions at the macro-hermeneutical level is the principle of reality (ontology), which includes the interpretation of the reality of God, human beings, and the world. ${ }^{62}$ Basically, the principle of reality permeates the understanding of any theological issue. According to Fernando Canale, the notions of time or timelessness function as primordial presuppositions that condition the macro-hermeneutical principles. ${ }^{63}$ Under the influence of Greek ontology on Christian theology, God and heavenly realities have been conceived timelessly, which affects the macro-hermeneutical principles of reality (interpretations about the reality of God, humans, and the world) and,

${ }^{61}$ Canale, "Evolution, Theology, and Method: Part 3," 21.

${ }^{62}$ Ibid., 10. Christoph Schwobel stresses the need for constructing an ontology based on these three principles of reality (God, humans, and the world), more specifically, taking into account "the interactions of God with particular human beings in a world of particular characteristics." In this way, the biblical "descriptions of the interaction between God, human beings, and the world" needs to be taken "seriously in an ontological sense." In other words, "who God is, how God and what God is, becomes clear from the relationships he establishes, maintains, and restores with his creatures. And consequently, who, how, and what a human being is become clear from the way God relates to human beings and invites them to relate to their God, to one another, and to their world. A relational view of reality is therefore an exercise in descriptive biblical metaphysics which hopes to avoid the risks of subjecting the biblical witnesses to a prior metaphysical scheme." Christoph Schwobel, "Recovering Human Dignity," in God and Human Dignity, ed. R. Kendall Soulen and Linda Woodhead (Grand Rapids, MI: Eerdmans, 2006), 48. 
thus, distorts the interpretation of the biblical doctrines. ${ }^{64}$ Canale explains that the notion of timelessness refers to "the absence of time and space" and he specifies a minimal definition of a timeless reality by focusing on the concept of non-sequentiality, where there is no experience of "the flow from past to present and future," $" 65$ that is, there is no before and/or after. Conversely, time is minimally defined as sequentiality, implying "past-present-future flow," 66 before and after. Furthermore, time is not conceived as "a thing" or a "container," but it "co-appears with things," being "relative to reality." "67 From this standpoint, God's temporality is infinite and analogical, meaning that it is His own nature that determines His experience of temporality, and not a previous definition of time as thing that dictates God experience with time. ${ }^{68}$ It should be noted that this perspective on time and timelessness, particularly this idea of God's temporality, is not necessarily identical to the affirmation of divine temporality in the scholarly literature on

${ }^{63}$ Canale, A Criticism of Theological Reason.

${ }^{64}$ Canale summarizes this historical process in the following way: "First, the most universal and all-inclusive of all hermeneutical principles is the concept of Being. Second, Parmenides originated the classical tradition that interprets Being from a timeless horizon. Third, when Plato and Aristotle decided to build their ontologies from the timeless horizon suggested by Parmenides, Western philosophy fixed the macro-hermeneutical direction from which classical and modern philosophies and theologies would be constructed. Fourth, classical Christian theology sealed its intellectual destiny when Justin Martyr (implicitly) and Origen and Augustine (explicitly) interpreted God and human nature as nontemporal and nonhistorical from within the Platonic ontological tradition." Canale, "Deconstructing Evangelical Theology?" 115.

${ }^{65}$ Fernando Luis Canale, The Cognitive Principle of Christian Theology: A Hermeneutical Study of the Revelation and Inspiration of the Bible (Berrien Springs, MI: Andrews University Lithothec, 2005), 93.

${ }^{66}$ Ibid., 251.

${ }^{67}$ Ibid., 250-252. Canale points out that "time can be of limited or unlimited duration depending on which reality it is describing. A limited being will experience time as of limited duration; a limitless being will experience time as endless. Out understanding of time must be relative to whatever reality in which it coappears." Ibid., 252.

${ }^{68}$ Ibid., 252-253. 
this topic. $^{69}$

The idea that the study of God's nature in Scripture is necessary for the understanding of His temporality constitutes the basis for the development of a theoontology. Indeed, Erickson seems to provide a general perspective for this type of development, as he affirms the necessity of using "the Bible to formulate our presuppositions, thus avoiding the problem of distortion from external presuppositions."70 Erickson proposes a construction of philosophical presuppositions (macro-hermeneutical principles) through a spiral process of biblical study:

Since the Bible is to supply our philosophical conceptions, but our discerning of those within the Bible is itself affected by our antecedent philosophy . . . a series of incremental changes will be necessary. We should seek to discern whether the Bible gives us a metaphysic, then check against it our own conceptions, correcting them to fit, then repeating the exegesis, again matching the results to our philosophy, and continuing in this process. ${ }^{71}$

In summary, the theological deconstruction to be developed in this study is an analysis of the macro-hermeneutical principles of reality upon which theological models have been constructed. The final goal of this deconstruction is to observe whether these hermeneutical principles are informed by the Hellenization of doctrine. If the answer is positive, the deconstruction prepares the way for an alternative model to be articulated from an interaction with Scripture. My next step is to show how this conceptual framework is methodologically applied to the study of the doctrine of Christ's priesthood.

\footnotetext{
${ }^{69}$ References to the literature on this topic are indicated in foonotes 28 and 31 above.

${ }^{70}$ Erickson, Truth or Consequences, 327.

${ }^{71}$ Ibid.
} 


\section{Methodology}

The deconstruction of conflicting interpretations about the doctrine of the priesthood of $\mathrm{Christ}^{72}$ in the present study constitutes an attempt to uncover the logic of each interpretation of Christ's priesthood from the perspective of the macrohermeneutical principles of reality or ontological presuppositions assumed in that interpretation. ${ }^{73}$ This perspective reveals how these presuppositions inform and impact an interpretation or theory about the priesthood of Christ.

This deconstruction involves three steps in this dissertation: (1) a systematic outline of the interpretations of Christ's priesthood; (2) a description of the understanding of the macro-hermeneutical principles of reality assumed in each interpretation depicted in the first step and an indication of the implications for the doctrine of Christ's priesthood; and (3) a transition to the construction of an alternative model derived from an interaction with Hebrews, including its pointers to the interpretation of macrohermeneutical principles of reality, and the implications for the doctrine of Christ's priesthood.

In the first step, the interpretations to be outlined correspond to three models. As mentioned above, they are labeled sacramental, functional, and ontological models. The

\footnotetext{
${ }^{72}$ For examples of similar use of deconstruction in the hermeneutical study of doctrines, particularly on the doctrines of God, revelation and inspiration, creation, and the nearness of the second coming of Christ, see Canale, Basic Elements of Christian Theology; Canale, Back to RevelationInspiration; Marcos Blanco, "Atemporalidad, Omnisciencia Y Providence Divinas: Podemos Adelantar La Segunda Venida?" DavarLogos 2, no. 2 (2003): 153-165. For an example of this use of deconstruction in the hermeneutical study of exegetical methodology, see Klaus Popa, "Method, Data and Hermeneutical Presuppositions: A Limited Analysis of the Relation between Method, Data and Hermeneutical Presuppositions in Rhetorical Criticism, Rhetorical Critical School, Narrative Criticism and Text Linguistics" (MA thesis, Vrije Universiteit, Amsterdam, 2007).

${ }^{73}$ Henceforth, the terms 'macro-hermeneutical principles of reality' and 'ontological presuppositions' will be used interchangeably.
} 
focus on models of interpretation instead of on the ideas of individual interpreters reveals three important interest of the present research: (1) the interest on an interpretive paradigm of Christ's priesthood; (2) the use of models as a heuristic tool for the conceptualization of this priesthood; and (3) the preparation for the second step, leading to the study of macro-hermeneutical principles of reality that undergird the models. First, even though individual interpreters provide the concepts for the description of the model, my main interest is not on their individual ideas but on how the reading of two theologians in the model reveal a broad paradigm for the interpretation of Christ's priesthood that is even able to accommodate specific differences between these theologians. Second, since I will describe a model of interpretation and not merely a theologian, I will not follow the sequence of arguments that one theologian offers for his understanding of the priesthood of Christ. Rather, the sequence and organization of the description of the models will be guided by formal components of Christ's priesthood that should be present in any interpretation of the reality of this priesthood. As it will be explained in the introduction of the second chapter, the four components selected derive from a preliminary phenomenological reading of Hebrews: need, agent, actions, and goal. The use of these components intentionally privileges the hermeneutical focus on systematic interpretation of an issue, and not merely on what one author thinks, since a common formal structure of a topic provides a better condition for comparing different ways of interpreting or understanding the priesthood of Christ. In this way, the use of these formal components facilitates a systematic conceptualization about Christ's priesthood in which the description and comparison of models function as a heuristic tool that gives insight to ways of systematic thinking about this priesthood. In other words, the 
study of models will help us think about conceptual possibilities regarding the doctrine of Christ's priesthood. Third, the description of the interpretation of each component in the different models selected in this study prepares the way for the study of macrohermeneutical principles of reality that undergird the models, providing the necessary information about the interpretation of the doctrine for the analysis of the ontological presuppositions that inform or modify that interpretation, which is the next step to be undertaken in this dissertation.

In the second step of the dissertation, I will uncover the interpretation of the macro-hermeneutical principles of reality assumed in each model. As it will be explained in the introduction of the third chapter, similar to the phenomenological reading of the previous step, the formal macro-hermeneutical principles of reality derive from a preliminary phenomenological reading of Hebrews: divinity, humanity, and cosmology. In this way, I will describe the interpretation of each principle existent in the three models, and then delineate their implications for the logic of the interpretation of Christ's priesthood in each model. The comparison of the conflicting interpretations in the models will justify the articulation of an alternative model.

While the first and second steps operate in the internal conceptualization and coherence of each model, the third step provides an alternative model (namely, the historical model) derived from an interaction with Hebrews (the main biblical book that deals with this priesthood, where we find the grounding data from which all models construct their interpretations about the priesthood of Christ), ${ }^{74}$ to be compared with the

\footnotetext{
${ }^{74}$ In his discussion about high priestly Christology, Johnsson points out that "Hebrews is unique among the NT writings for its presentation of this motif. Elsewhere we find, at most, hints, such as in
} 
models described in the previous steps. This alternative model is a constructive proposal suggested as a way out of the conflicting interpretations of Christ's priesthood in the existing models. The same formal components and principles used in the previous steps are used in the third step. To provide the material interpretation each compoment and each principle I read Hebrews phenomenologically. ${ }^{75}$ In this way, I attempt to find out whether the description of Christ's priesthood in the book of Hebrews seems to imply a structure of the reality of His priesthood and point to ontological presuppositions necessary for a proper understanding of the biblical thinking about this reality. ${ }^{76}$

Romans 8:34 or 1 John 2:2, or allusive imagery as in Revelation, chapters 1, 4, and 5. In Hebrews, however, Jesus as high priest is a dominant idea, and the book works it out in great detail." William G. Johnsson, "Hebrews: An Overview," in Issues in the Book of Hebrews, ed. Frank B. Holbrook (Silver Spring, MD: Biblical Research Institute, 1989), 21.

${ }^{75}$ Canale indicates three essential features of a phenomenological reading of the Bible: (1) It "applies a scientific, philosophical, theological, and doctrinal epoché [which means suspension of judgment]. In other words, as the text is analyzed in search of its meaning, every prior existent theory is 'suspended' or 'bracketed out.' Yet epoché is not ignorance of those theories. Phenomenological epoché can be applied in its fullness only when all the involved theories are properly understood, otherwise they will not be suspended but rather ignored or, worse, applied unconsciously." (2) It "works and is grounded on the 'things themselves,' which in our particular case are the meaning of the text itself as it is." (3) It “presents its results not by 'constructing,' 'building up,' or 'proving' its assertions and statements, but rather by 'describing' or 'showing' what has been heard or seen while the exegete catches at least some glimpses of what is being thought in the text." Canale, A Criticism of Theological Reason, 296-297. See his phenomenological reading of Exod 3:14-15 on pages 321-348. Considering the three levels of hermeneutical principles mentioned on pages 15-16 (micro-hermeneutics, meso-hermeneutics, and macrohermeneutics), the application of the epoché in this study occurs mainly at the level of macro-hermeneutics, which means that the there is no intentional suspension of presuppositions at the level of the textual or linguistic principles of interpretation of the Bible (micro-hermeneutics). Moreover, I intend to suspend the presuppositions at the level of macro-hermeneutics as much as possible, but I also recognize the necessity of further studies giving continuity to the movement of the hermeneutical spiral, since our preunderstanding (or presuppositions) needs to be increasingly shaped by the biblical text.

${ }^{76}$ This endeavor is similar to McCormack's stipulation that the biblical text implies an ontology that is able to explain how what is mentioned in the biblical narrative actually takes place. See Bruce L. McCormack, "With Loud Cries and Tears': The Humanity of the Son in the Epistle to the Hebrews," in The Epistle to the Hebrews and Christian Theology, ed. Richard Bauckham, Daniel R. Driver, Trevor A. Hart, and Nathan MacDonald (Grand Rapids, MI: Eerdmans, 2009), 55, 59, 66. Several scholars have discussed the significance of the study of ontology in the Bible. Langdom Gilkey argues that "biblical theology must take cosmology and ontology more seriously," because Christian theology "desperately" needs "a biblical ontology that will put intelligible and credible meanings into our analogical categories of divine deeds and of divine self-manifestation through events." B. Gilkey Langdon, "Cosmology, Ontology, and the Travail of Biblical Language," The Journal of Religion 41, no. 3 (1961): 203. Similarly, Paul 
At this point, I need to clarify what is methodologically called deconstruction in this dissertation, since the two first steps also involve a great deal of systematic construction. For instance, in these steps I provide the formal structure (from my reading of Hebrews) to be interpreted by the models, which means that I formally describe the models differently from the way the representatives of each model explain the priesthood of Christ. In other words, I put concepts together in a way that the representatives did not do, as I delineate the logic of the model as an interpretive paradigm. However, the use of the term deconstruction is justified by the fact that I am not merely constructing a theory or interpretation, but uncovering a logic implied in the data provided by the representatives of the models (in the case of the sacramental, functional, and ontological models). In the process of uncovering a logic from the data, I need to think about it, draw conceptual connections, implications, and eventually provide a systematic organization of ideas that will probably state more than what is simply said in the data, but that attempts to be faithful to the logic implied by the data.

Hanson questions, "Why should biblical theology shy away from questions of ontology when Israelite religion assumes an historical ontology that sets it apart from the mythopoeic worldviews of surrounding cultures?” Paul D. Hanson, “A New Challenge to Biblical Theology,” Journal of the American Academy of Religion 67, no. 2 (1999): 449. In the same vein, Douglas Hall firmly believes in a biblical ontology: "the question is not whether biblical theology will or will not discuss ontology but what ontology it assumes. There is, I believe, a biblical ontology — or, better stated, an ontology that is native to the tradition of Jerusalem. . . Christian thinkers throughout the ages have been extremely negligent in delineating the conception of being or ontology that belongs to the tradition of Jerusalem. . . That tradition, however, did not approach the question of being or reality explicitly - that is, as a direct subject of detached or specific inquiry. Jerusalem (as contemporary Jewish theologian-philosophers like Martin Buber and Abraham Heschel have shown) did and does have a theory of reality, but it is implicit and indirect - and above all it is not abstract, which is the reason why it could not be treated in an isolated way." Douglas John Hall, Professing the Faith: Christian Theology in a North American Context (Minneapolis: Fortress, 1996), 302. Canale seems to agree with Hall: even though "we do not find in Scripture a technically developed ontology ... Scripture includes specific and detailed interpretations about the beings of God, humans, the world, and the whole." Therefore, through these significant interpretations it is possible to "use biblical teachings to define our macro-hermeneutical presuppositions." Canale, "Deconstructing Evangelical Theology?" 117. 
With this clarification in mind, I can now indicate that the first, second, and third steps depicted above correspond respectively to chapters two, three, and four. The fifth chapter will provide a brief comparison of the models described in this dissertation.

Finally, the sixth chapter will present a summary, conclusion, and recommendations. 


\section{CHAPTER 2}

\section{A DESCRIPTION OF THEOLOGICAL MODELS OF CHRIST'S PRIESTHOOD}

\section{Introduction}

The first step of the hermeneutical study of Christ's priesthood, as proposed in the present dissertation, is the description of models of this priesthood in systematic theology. In the previous chapter, I indicated that the three theological views of the priesthood of Christ to be initially explored in this research would be labeled as sacramental, functional, and ontological models. Therefore, this second chapter intends to describe these three theological models of Christ's priesthood. Overall, the purpose of this description is to gain a general overview of the discussion from a systematic perspective, and also prepare the ground for the study of the macro-hermeneutical presuppositions that undergird each model, which is the task of the next chapter.

In order to facilitate the description and comparison of these models, it is necessary to outline the general structure of Christ's priesthood (formal level of description) that each model interprets in a concrete way (material level of description). I will use this structure as the pattern to describe and compare each model. ${ }^{1}$ Once I define this general structure, I will be able to describe each theological model of the priesthood

\footnotetext{
${ }^{1}$ A similar strategy used to study theological models of the doctrine of revelation-inspiration is found in Canale, Back to Revelation-Inspiration.
} 
of Christ by showing how each model interprets (material aspect) each element of the structure (formal aspect).

I recognize that a careless description of the general structure of Christ's priesthood at this point may jeopardize the further steps and conclusions of the present research, especially if categories alien to the materials to be studied are introduced in the process. To avoid this danger as much as possible, I attempt to proceed with caution on this point regarding (1) the selection of its source and (2) the definition of its nature. With regard to the selection of the source, Christian theology has no basis for an explicit doctrine of the priesthood of Christ without the NT book of Hebrews. ${ }^{2}$ Hence, any reflection on this priesthood needs to start with Hebrews. ${ }^{3}$ In the context of the present research, this assumption is confirmed by the fact that the models to be described below generally draw their reflections primarily from the book of Hebrews. Second, the formal structure of Christ's priesthood suggested in this study is essentially an outline of the basic components involved in the general concept of this priesthood, which must be present in any possible interpretation of this issue. ${ }^{4}$ Thus, the present attempt to delineate

\footnotetext{
2 This statement takes into account that Hebrews is the only book in Scripture that explicitly refers

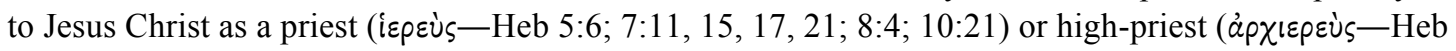
$2: 17 ; 3: 1 ; 4: 14-15 ; 5: 5,10 ; 6: 20 ; 7: 26 ; 8: 1,3 ; 9: 11)$. While different theological schools of thought in Christianity may dispute the principle of Sola Scriptura, and even offer distinct definitions of this principle, it is my understanding that no one of these schools will consciously advance a Christian doctrine that has no legitimate basis in Scripture. I am not arguing that any doctrine advanced by these schools is necessarily biblical. Rather, I am affirming that these schools normally want to be consistent with Scripture in their doctrines.

${ }^{3}$ I agree with Gerald O'Collins that, whereas the book of Hebrews is the main source of information about Christ's priesthood in the Bible, the background of the OT and the NT needs to be considered for a proper understanding of His priesthood. See $J O P, 1,240$. It is in this sense that I suggest that Hebrews is the starting point for a theology of the priesthood of Christ.

${ }^{4}$ The formal structure of Christ's priesthood that I suggest in this study may be proved limited and perhaps provisional. While the suggested structure provides an initial framework necessary to start this study, this structure remains open to further improvement and correction that can be advanced by a better
} 
the implied structure of Christ's priesthood from the picture of this priesthood in

Hebrews is regarded as a minimal formal description that is going to be used as a

conceptual tool to organize the material description of the theological models.

With these considerations in mind, it is possible to affirm that Christ's priesthood

can be formally described in terms of (1) an agent who performs specific (2)

functions/actions that are (3) needed to deal with a situation in order to (4) accomplish a

particular goal. ${ }^{5}$ Arguably, this formal description may potentially outline the general

structure of any type of priesthood, ${ }^{6}$ and seems to be consistent with the picture of the

understanding that is generated in the progression of the study. More specifically, if the present study shows that all the models have given serious thought to each component of the structure suggested here, this structure will be confirmed. If this does not happen, then the suggested structure should be modified or replaced.

${ }^{5}$ By using this minimal formal description to initiate the study of the doctrine of the priesthood of Christ, I assume that the focus of studies in systematic theology goes beyond a mere summary of the biblical teaching on a particular topic, as Wayne Grudem seems to define the task of systematic theology. See Wayne Grudem, Systematic Theology: An Introduction to Biblical Doctrine (Leicester, England; Grand Rapids, MI: InterVarsity; Zondervan, 1994), 21, 23. Rather, my assumption is that the focus of systematic theology is on the conceptualization of the realities, pictures, or notions described or implied in the biblical text. The understanding of systematic theology in terms of conceptualization of reality is affirmed by Fernando Luis Canale, "Is There Room for Systematics in Adventism?" Journal of the Adventist Theological Society 12, no. 2 (2001): 121-122; John Webster, Introduction to The Oxford Handbook of Systematic Theology (Oxford: Oxford University Press, 2009), 1; Wolfhart Pannenberg, An Introduction to Systematic Theology (Grand Rapids, MI: Eerdmans, 1991), 18; Walter Kasper, Jesus the Christ, new ed. (London; New York: T\&T Clark, 2011), 9. In this sense, the minimal formal description that I suggest is an attempt to initiate a conceptualization of the priesthood of Christ.

${ }^{6}$ This potential formal openness to other types of priesthood is particularly important because the book of Hebrews compares Christ's priesthood with both the Aaronic priesthood (Heb 5:1-5; 7:11, 13, 2324, 27-28; 8:3-4; 9:6-7, 11-14, 23-25; 10:11-12) and Melchizedek's priesthood (Heb 5:6, 10; 6:20; 7:1-3, $11,15,17,21)$. Dealing with the priestly cult in the Hebrew Bible, Philip Jenson utilizes four categories (spatial, personal, ritual, and temporal dimensions) to provide a systematic description of the priestly cult. Jenson believes that his categories, which in my view are elaborated from a perspective of the realities involved in the cult, constitute a more suitable framework for the understanding of the priestly cult than an organization "by word, formula or theme." Also, he clearly distinguishes his approach from a historical, literary, and redactional research. Philip Peter Jenson, Graded Holiness: A Key to the Priestly Conception of the World, Journal for the Study of the Old Testament Supplement Series, vol. 106 (Sheffield, England: Sheffield Academic Press, 1992), 32-34. Similarly, Frank Gorman adopts the categories of space, time, and status in order to explore the conceptual framework of the priestly cult. He argues that his research contrasts with the majority of studies on this topic, which are "primarily text-oriented" as they emphasize more "the analysis of texts than ritual." For him, "there have been very few attempts to analyze and understand the conceptual, ideological, or theological framework of the Priestly cult embodied in these 
priesthood of Christ in the book of Hebrews. ${ }^{7}$ In this way, the material description of the

texts." Frank H. Gorman Jr., The Ideology of Ritual: Space, Time, and Status in the Priestly Theology, Journal for the Study of the Old Testament Supplement Series, vol. 91 (Sheffield, England: Sheffield Academic Press, 1990), 7. My general formal structure of the priesthood of Christ, which may serve systematic studies of other types of priesthood, is close to the approach adopted by Jenson and Gorman in their study of the priestly cult, in the sense that this structure attempts to work with categories that describe the priesthood as a reality (need, agent, actions, and goal) in order to better understand its conceptual framework. As far as I know, the majority of biblical studies on priesthood are more concerned with textual and historical aspects, rather than a systematic conceptualization of priesthood. For examples of these types of studies, see Gary A. Anderson and Saul M. Olyan, Priesthood and Cult in Ancient Israel, Journal for the Study of the Old Testament Supplement Series (Sheffield, England: Sheffield Academic Press, 1991); Joseph L. Angel, Otherworldly and Eschatological Priesthood in the Dead Sea Scrolls, Studies on the Texts of the Desert of Judah (Leiden; Boston: Brill, 2010); Joseph Blenkinsopp, Sage, Priest, Prophet: Religious and Intellectual Leadership in Ancient Israel, Library of Ancient Israel (Louisville, KY: Westminster John Knox Press, 1995); Aelred Cody, A History of the Old Testament Priesthood (Rome: Pontifical Biblical Institute, 1969); Martha Himmelfarb, A Kingdom of Priests: Ancestry and Merit in Ancient Judaism, Jewish Culture and Contexts (Philadelphia: University of Pennsylvania Press, 2006); Mark Leuchter, Levites and Priests in History and Tradition, Ancient Israel and Its Literature (Atlanta: Society of Biblical Literature, 2011); Deborah W. Rooke, Zadok's Heirs: The Role and Development of the High Priesthood in Ancient Israel, Oxford Theological Monographs (Oxford: Oxford University Press, 2012); James C. VanderKam, From Joshua to Caiaphas: High Priests after the Exile (Minneapolis: Fortress Press, 2004). Comparative studies and biblical theologies on the priesthood attempt to provide a more systematic account of this theme. See, for instance, E. O. James, The Nature and Function of Priesthood: A Comparative and Anthropological Study (London: Thames and Hudson, 1955); Leopold Sabourin, Priesthood: A Comparative Study (Leinden: Brill, 1973); Albert Vanhoye, Old Testament Priests and the New Priest: According to the New Testament, trans. J. Bernard Orchard, Studies in Scripture (Petersham, MA: St. Bede's Publications, 1986); Richard D. Nelson, Raising up a Faithful Priest: Community and Priesthood in Biblical Theology (Louisville, KY: Westminster John Knox Press, 1993). However, in my opinion, they are not able to provide a systematic conceptual framework of the priesthood, as Jenson and Gorman do with the theme of the priestly cult, because these comparative studies and biblical theologies tend to organize the description of the priesthood in topics of discussion (sometimes emphasizing the functions of a priest), instead of working with categories that describe its reality. It seems to me that Schenck's treatment of the cosmology and the eschatology of Hebrews would have the potential to develop the framework that I propose here, as he attempts to explore Hebrews from the perspective of time and space, if his focus on time and space were not merely rhetorical, but ontological. As he indicates, his study provides "a systematic picture of Hebrews' narrative and rhetorical worlds." Kenneth L. Schenck, Cosmology and Eschatology in Hebrews: The Setting of the Sacrifice, ed. John M. Court, Society for New Testament Studies (Cambridge: Cambridge University Press, 2007), 183.

${ }^{7}$ Even though the formal description suggested here should not include at this point a precise definition of its categories (agent, actions, need, goal), as this definition constitutes the material description of each model, I briefly indicate how these broad categories can be generally found in the exposition of the priesthood of Christ in the book of Hebrews: (1) Agent - the incarnate Christ (2:17), who is the ascended Son of God (4:14; 7:28); (2) Actions - offering of sacrifice (7:27; 8:3; 9:14, 26-27; 10:12), continual intercession $(7: 25)$, ministry in the heavenly sanctuary $(8: 2,5 ; 9: 11,24)$, mediation of a better/new covenant $(8: 6 ; 9: 15)$; (3) Need -human sins $(2: 17 ; 9: 7,26,28 ; 10: 2,4,11-12 ; 13: 11)$ and weaknesses $(4: 15 ; 5: 2)$; (3) Goal-human perfection $(7: 11 ; 10: 1,14)$ and sanctification $(9: 13 ; 10: 10,14 ; 13: 11)$, access to God $(4: 15 ; 7: 25 ; 10: 19)$, eternal salvation $(5: 9 ; 7: 25 ; 9: 15,28)$. I have intentionally provided a loose, perfunctory, and non-comprehensive characterization of these formal categories because this characterization will receive a more precise and in depth interpretation in the material description of the models. At the same time, I attempted to show in this characterization that these categories can be derived 
theological models of Christ's priesthood selected for this study (sacramental, functional, ontological) is organized on the basis of the following components dictated by the formal structure of Christ's priesthood indicated above: (1) Need, (2) Agent, (3) Actions, and (4) Goal. ${ }^{8}$ The first model to be described is the sacramental model.

\section{The Sacramental Model}

The model outlined below is labeled sacramental because a crucial conception in the understanding of Christ's priesthood in this model is that Christ's priestly mediation is performed through spatio-temporal instruments that convey divine (spaceless-timeless) realities to human beings. According to this label, the emphasis of this model seems to be on the medium of the priesthood. I will unpack this conception in my treatment of the sacramental model both here in this chapter and in the next chapter. The representatives selected for this model are the medieval theologian Thomas Aquinas ${ }^{9}(1225-1274)$ and

from the book of Hebrews, which means that they are not arbitrary. Likewise, as indicated in my comment on the previous footnote regarding studies that attempt to systematize the priesthood, scholars who analyze the priesthood of Christ in the book of Hebrews tend to be more interested in textual and historical aspects. Therefore, they usually do not work with categories that systematically describe Christ's priesthood as a reality, as I do in the present study. See, for example, Eric F. Mason, 'You Are a Priest Forever': Second Temple Jewish Messianism and the Priestly Christology of the Epistle to the Hebrews, Studies on the Texts of the Desert of Judah (Leiden; Boston: Brill, 2008); R. J. McKelvey, Pioneer and Priest: Jesus Christ in the Epistle to the Hebrews (Eugene, OR: Pickwick Publications, 2013); Nelson, Raising up a Faithful Priest, 141-154; Sabourin, Priesthood, 178-211; Jerome Smith, A Priest Forever: A Study of Typology and Eschatology in Hebrews (London; Sydney: Sheed \& Ward, 1969), 66-136; Vanhoye; Vanhoye, Old Testament Priests and the New Priest, 61-235; Albert Vanhoye, A Different Priest: The Letter to the Hebrews, Series Rhetorica Semitica (Miami, FL: Convivium Press, 2011); John M. Scholer, Proleptic Priests: Priesthood in the Epistle to the Hebrews, Journal for the Study of the New Testament Supplement Series, vol. 49 (Sheffield: Sheffield Academic Press, 1991), 82-90.

\footnotetext{
${ }^{8}$ I have changed the order between need and agent indicated in the previous paragraph and in the previous footnote. The reason for placing the need as the first component is that it provides the explanatory context for the agent performing actions.

${ }^{9}$ ST III, q. 22 is the most detailed description of Christ's priesthood in Aquinas. Concisely, q. 22 defines Christ as the mediator (article 1), discusses the notions of sacrifice (article 2), the effects (articles 3 and 4) and the eternity (article 5) of His priesthood, and compare it with other priesthoods (article 6). According to Scheller, the six articles reflect the four Aristotelian causes and the Platonic-Augustinian
} 
the modern Jesuit theologian Gerald O'Collins ${ }^{10}$ (1931-). I will explore the way they

interpret each aspect or component of the formal structure of Christ's priesthood.

\section{The Need for Christ's Priesthood}

The need for the priesthood of Christ in the sacramental model is explained by a distance between God and human beings that requires a priestly mediation. This distance is partially related to an original limitation of creatures (ontological distance), but is mostly associated with sin (moral distance). The ideas of ontological and moral distance are better understood in the context of a teleological movement of creation toward God, which implies an evolutionary dynamics in creation.

In the framework of this teleological movement, the idea of ontological distance is not a problem that appeared in creation, but an intended characteristic of original creation. From an anthropological perspective, Aquinas highlights that before sin "man was happy in paradise, but not with that perfect happiness to which he was destined,

exemplary cause. Emil Justus Scheller, Das Priestertum Christi Im Anschluss an Den Hl. Thomas Von Aquin: Vom Mysterium Des Mittlers in Seinem Opfer Und Unsere Anteilnahme (Paderborn: Schöningh, 1934), 213, 215. For a comprehensive study of the priesthood of Christ in Aquinas, see ibid., 180-282. Even though Scheller's book is arguably the best study of this subject, other useful works could be mentioned: Jean-Pierre Torrell, Christ and Spirituality in St. Thomas Aquinas, Thomistic Ressourcement Series (Washington: Catholic University of America Press, 2011), 127-163; Matthew Levering, Christ and the Catholic Priesthood: Ecclesial Hierarchy and the Pattern of the Trinity (Mundelein, IL: Hillenbrand, 2010), 86-119; Matthew Levering, "Christ the Priest: An Exploration of Summa Theologiae III, Question 22," The Thomist 71, no. 3 (2007): 379-417; Jones, Toward a Christology of Christ the High Priest, 126158; Thomas Marschler, "Das Hohepriestertum Jesu Christi Nach Dem H1. Thomas Von Aquin," Doctor Angelicus 3 (2003): 143-163; Denis Chardonnens, "Eternité Du Sacerdoce Du Christ Et Effet

Eschatologique De L'eucharistie,” Revue Thomiste 107, no. 1 (1999): 159-180; Martin Morard, "Sacerdoce Du Christ Et Sacerdoce Des Chrétiens Dans Le Commentaire Des Psaumes De Saint Thomas d'Aquin," Revue Thomiste 107, no. 1 (1999): 119-142; D. Mastroserio, "La Natura Del Sacerdocio Di Cristo Nel Pensiero Dei Tomisti," Sapienza 16 (1963): 337-372; Gérard Remy, "Sacerdoce Et Médiation Chez Saint Thomas," Revue Thomiste 99, no. 1 (1999): 101-118.

${ }^{10}$ The main discussion of $\mathrm{O}^{\prime}$ Collins on the priesthood of Christ appears in JOP. 
which consists in the vision of the Divine Essence." $" 11$ Hence, human beings are destined to a better condition than the initial condition of their creation, which suggests that perfect human beings in original creation are incomplete. From a cosmological perspective, O'Collins adopts a unified view of creation and redemption in which the latter is not a mere restoration of the former, but a continuation of it. ${ }^{12}$ If redemption is a continuation of creation (not a restoration), the implication is that original creation needs to be improved. Therefore, both the anthropological and the cosmological perspectives assume an intended incompleteness in original creation that justifies a teleological movement of creation toward God as the key to completeness or wholeness.

In this context, sin is a problem that appears in creation and negatively accentuates the ontological distance between God and human beings. As a deliberate disobedience of God's will, ${ }^{13}$ the sin of the first human beings resulted in "the loss of

${ }^{11}$ ST I, q. 94, a. 1, ad 1. Aquinas claims that Adam "was midway between our knowledge in the present" sinful "state, and the knowledge we shall have in heaven, when we see God through His Essence." ST I, q. 94, a. 1. In contrast to human knowledge after sin, "the first man was not impeded by exterior things from a clear and steady contemplation of the intelligible effects." Ibid. O'Collins also contrasts human beings in the perfect creation with their future destiny, as he compares their natural condition with their supernatural destiny: "The order of grace has existed right from the beginning, in that God has freely called all men and women to the supernatural destiny of eternal life." CDT, 3 ed. (2013), s.v. "nature."

${ }^{12}$ For the Jesuit theologian, "creation and redemption as two distinguishable but interconnected moments in God's one saving plan for all humanity and the whole cosmos." Thus, redemption is not "a mere restoration of the order of creation," but a "continuity in the newness, above all through the one plan of God and the one figure of the creative Word who is also the Redeemer." Gerald O'Collins, Jesus Our Redeemer: A Christian Approach to Salvation (Oxford; New York: Oxford University Press, 2007$), 35$. O’Collins wants to follow Ireneaus' "unified vision of creation and redemption." Ibid., 37.

${ }^{13}$ According to Aquinas, "two things concur in the nature of sin, viz. the voluntary act, and its inordinateness, which consists in departing from God's law.” ST IIa, q. 72, a 1. Similarly, O’Collins defines sin as "any thought, word, or deed that deliberately disobeys God's will and in some way rejects the divine goodness and love." CDT, 3 ed. (2013), s.v. "sin.” For O'Collins' and Aquinas' discussions on sin, see respectively Jesus Our Redeemer, 43-62 and ST IIa, q. 71-89; Thomas Aquinas, On Evil, trans. Richard J. Regan (Oxford; New York: Oxford University Press, 2003). 
grace and wounding of nature"14 (original sin) in humanity. From an anthropological standpoint, as Aquinas points out, this means a disorder of the soul that promotes attention to material or sensible things. The loss of divine grace (original justice), which ordered human nature in a way that "the body was subjected to the soul" and "the soul remained subject to God,"15 caused a disorder (wounding of nature) in which the lower parts of human nature are not subject to the higher anymore. ${ }^{16}$ Considering that the lower parts focus on material things while the higher focus on intellectual/spiritual realities, the disorder of the soul means that human beings are actually "distracted by and occupied

${ }^{14} C D T, 3$ ed. (2013), s.v. "original sin." For Aquinas, "original sin denotes the privation of original justice" and "the inordinate disposition of the parts of the soul." ST 2a, q. 82, a. 1, ad 1. Commenting on original justice, O'Collins indicates that "the graced state of the first human beings before they fell into sin" was "interpreted for centuries as a historical period of time." However, he avoids this historical interpretation by suggesting that "this original righteousness is better understood to be a way of speaking of our goodness as created and sanctified by God (Gen 1:26-31)." CDT, 3 ed. (2013), s.v. "original justice." The Jesuit theologian argues that Adam's story has been traditionally understood as "an initial period of perfection in creation and an original innocence that ended with a 'one-point' event, the fall of Adam and Eve into sin." Yet, this "story need not be interpreted as necessarily entailing the first human couple (monogenism) spoiling a state of primordial happiness by one spectacular sin. It could also apply to a number of original human beings (polygenism), who, right from the start of their existence, through sin drifted away from what God intended for them." O'Collins, Jesus Our Redeemer, 51-52.

${ }^{15}$ ST IIa, q. 81, a. 5, ad 2. Roughly speaking, Aquinas stipulates that the good of human nature was originally threefold: (1) "the powers of the soul," (2) "inclination to virtue," and (3) "the gift of original justice." Sin entirely destroyed the third aspect and diminished the second, but did not impact the first. ST IIa, q. 85, a. 1. As a divine gift to human nature (ST IIa, q. 83, a. 2, ad 2), original justice provided order to the powers of the soul, in the sense that "the reason had perfect hold over the lower parts of the soul, while reason itself was perfected by God, and was subject to Him." Because sin destroyed the gift of original justice, the powers of the soul, although intact, lost "their proper order, whereby they are naturally directed to virtue." ST IIa, q. 85, a. 3.

${ }^{16}$ ST I, q. 94, a. 1. The distinction between lower and higher is evident in Aquinas' statement that "the irascible and concupiscible powers" are supposed to obey "the higher part, in which are the intellect or reason, and the will." ST I, q. 81, a. 3. The disorder effected by original sin impacts "the lower parts of the soul" and "the body itself." ST IIa, q. 81, a. 3, ad 1. In Aquinas, "the soul's parts are its various capacities or powers." Robert Pasnau, Thomas Aquinas on Human Nature: A Philosophical Study of Summa Theologiae 1a, 75-89 (Cambridge, UK; New York: Cambridge University Press, 2002), 145. In his classification of the powers of the soul according to its operations, Aquinas indicates that the more the power/part has an operation related to corporeality (the body), the lower the power/part is. ST I, q. 78 , a. 1. 
with sensible things, ${ }^{\prime \prime}$ and thereby not subject to God, ${ }^{18}$ who is an intellectual/spiritual being. Therefore, the basic problem of sin is that, by focusing only on inferior material things, human beings do not follow the order of things that leads them to intellectual/spiritual realities (teleology). ${ }^{19}$ This same point about sin being a disorder that impedes the teleological movement toward God is implied in the cosmological perspective of sin, as emphasized by O'Collins. Both human beings and the world are under the bondage and corruption of evil, which hinders the communion between human beings and God. Furthermore, sinful humans are self-alienated from God. ${ }^{20}$ In this situation, they cannot reach the goal of their existence (teleology), namely, communion with God. $^{21}$

${ }^{17}$ ST I, q. 94, a. 1.

${ }^{18}$ ST IIa, q. 82, a. 1, ad 1; IIa, q. 82, a. 2. For Aquinas, "inordinate movements of the sensitive appetite cannot help occurring since the lower appetite is not subject to reason, so likewise, since man's reason is not entirely subject to God." $S T$ IIa, q. 109, a. 8. The medieval theologian explains that "the whole order of original justice consists in man's will being subject to God: which subjection, first and chiefly, was in the will, whose function it is to move all the other parts to the end, ... so that the will being turned away from God, all the other powers of the soul become inordinate. Accordingly the privation of original justice, whereby the will was made subject to God, is the formal element in original sin; while every other disorder of the soul's powers, is a kind of material element in respect of original sin." ST IIa, q. 82, a. 3.

${ }^{19}$ This idea is vividly portrayed in Aquinas' definition of "mortal sin," where "the soul is so disordered by sin as to turn away from its last end, viz. God.” ST IIa, q. 72, a. 5. He maintains that there is an "order of ends" in which "man must be directed to the last end by the motion of the first mover." ST IIa, q. 109, a. 6. Indeed, "all movements, both corporeal and spiritual, are reduced to the simple First Mover, Who is God ... this motion is according to the plan of His providence." ST IIa, q. 109, a. 1.

${ }^{20} \mathrm{O}$ 'Collins provides a threefold definition of sin: bondage, corruption, and self-alienation. The bondage of the power of the devil and death destroys humanity and the world, and hinders the communion between human beings and God. This bondage refers to the human "drive to possessions, success, and power" (idolatry), "compulsions and addictions" ("inner demons"), and "various economic, social, and political forces" ("organized evil . . embedded in the structures of society"). With regard to corruption, "sin degrades and defiles human beings and corrupts their environment." O'Collins, Jesus Our Redeemer, 58-60. This corruption refers to the "breakdowns in relations with God, our neighbour, and the created world," and shows that "the moral order, damaged by sin, needs to be reordered and purified." JOP 263. Finally, sin is "self-alienation or estrangement from God and others," which clearly entails an attitude of distance from God. O'Collins, Jesus Our Redeemer, 60.

${ }^{21}$ O'Collins defines "human existence" as "a lifelong pilgrimage towards God, the fullness of 
As a disorder that distances human beings from God, hindering their teleological movement toward Him, sin needs to be addressed by the mediatorial priesthood of Christ. ${ }^{22}$ However, two main questions arise from this understanding of the need for Christ's priesthood: (1) Is the priesthood necessary only to eliminate the hindering of the teleological movement, or does it actually produce that movement? (2) Does the mediatorial priesthood deal only with human beings, promoting their movement toward God, or does it also deal with God? The first question assumes the following logic: If Christ's priesthood addresses the sin problem (moral distance), His priesthood is not needed for the teleological movement itself (ontological distance), since this movement per se is unrelated to sin. Consequently, full communion with God would be achieved through the teleological movement, and not through the priesthood of Christ. This provoking logic may be answered by the anthropological and cosmological perspectives of the sacramental model. From an anthropological perspective, divine grace was always necessary for the teleological movement of perfect (without sin) human beings. ${ }^{23}$ However, in terms of grace, human nature is impacted by sin on two grounds, namely, it

being and final goal of all." O'Collins, Jesus Our Redeemer, 28. For him, creation has a teleology. In his words, "creation has only one history, which finds in God its source and goal." Ibid.

${ }^{22}$ Both O'Collins and Aquinas maintain that the effects of sin are eliminated by Christ's priesthood. Considering that the Jesuit theologian defines sin basically as bondage, corruption, and selfalienation (see footnote 20 above), the priesthood of Christ effects redemption by delivering from the bondage of evil, purifying from the defilement or corruption of sin, and annulling the human estrangement from God. JOP, 262. In this way, teleologically speaking, the mediation of Christ "ensures that the divine project for humankind and the world reaches its goal." O'Collins, Jesus Our Redeemer, 62. For Aquinas, the effects of sin are essentially the stain of sin and the debt of punishment (see $S T$ IIa, q. 87, a. 6; q. 109, a. 7) and these effects are eliminated by the priesthood of Christ (see ST III, q. 22, a. 3).

${ }^{23}$ Aquinas points out that perfect human nature needed "a gratuitous strength superadded to natural strength for one reason, viz. in order to do and wish supernatural good.” ST IIa, q. 109, a. 2. 
has a greater need of grace ${ }^{24}$ and a different way of receiving it. On this second ground, the attention to material things in the sinful condition requires that grace (spiritual reality) be mediated through material instruments. ${ }^{25}$ As I will explain later, this type of mediation is a central feature of Christ's priesthood in the sacramental model, which means that His priesthood is necessary for the human reception of grace needed for both the ontological and moral distance. Furthermore, according to a cosmological perspective, a unified view of creation and redemption is based on the belief that Christ is the mediator of both creation and redemption, ${ }^{26}$ which means that His priesthood is a continuation of the mediation in creation. ${ }^{27}$ This conception appears to imply that Christ's mediation in creation was related to the ontological distance, while the priesthood adds to His

${ }^{24}$ Sinful human beings need grace not only for the ontological distance, but also for the moral disunity. For Aquinas, perfect human nature needed grace for one reason (see footnote above), while corrupt human nature needs it for two reasons: "in order to be healed" and "to carry out" meritorious "works of supernatural virtue." ST IIa, q. 109, a. 2. Therefore, the corrupt nature adds one more reason for grace, namely, healing from sin. See the idea of grace healing the soul in q. 109, a. 9; q. 111, a. 3. A. N. Williams argues that, in contrast to the Augustinian notion that grace is needed only in the human fallen state, Aquinas emphasizes that grace is always necessary for creatures to attain their end, even without the fall. Actually, "the fall only adds another dimension to an ever-present need." A. N. Williams, The Ground of Union: Deification in Aquinas and Palamas (New York: Oxford University Press, 1999), $79,84$.

25 This notion is evident in Aquinas' comparison between the human reception of grace before and after sin. Before sin, human beings did not need sacraments to receive grace, because they could obtain it "in a spiritual and invisible manner." Thus, there was no need of "sensible signs" (sacraments). ST III, q. 61 , a. 2, ad 1. Conversely, after sin, human beings "subjected" themselves by their "affections to corporeal things." Thus, God has provided human beings "with a spiritual medicine" (grace) "by means of certain corporeal signs" (sacraments), "for if man were offered spiritual things without a veil, his mind being taken up with the material world would be unable to apply itself to them." ST III, q. 61, a. 1.

${ }^{26}$ O'Collins assumes a "coupling of redemption and creation with the mediation of Christ." This means that "creation and the story of salvation were united in the Son of God from all eternity." In other words, "the NT brings together the order of redemption and that of creation by understanding creation, and not merely redemption, to have occurred through the mediation of the Son of God." O'Collins, Jesus Our Redeemer, 33-35.

${ }^{27} \mathrm{O}$ 'Collins indicates that "mediation is a broader category than priesthood. All priests are mediators, but not all mediators are priests." JOP, 120. For explicit statements that Christ's priesthood is a mediation, see ibid., 80, 265, 269. The point here is that the priesthood of Christ is part, actually a new phase, of the His broad work of mediation (creation-redemption). This point will be further elaborated below in the discussion of the agent of the priesthood. 
mediation the dealing with the moral distance $(\sin )$. What seems clear from these

anthropological and cosmological explanations is that the priesthood of Christ relates to

the ontological distance as an instrument of grace.

The second question inquires if Christ's mediatorial priesthood is one-sided, working exclusively with sinful human beings and their movement toward God, or twosided, which includes also a work before God. Apparently, the sacramental model can accommodate both perspectives. In a two-sided mediation, as it can be seen in Aquinas, the priesthood of Christ cleanses human beings from sin and satisfies/appeases God with regard to their $\sin .{ }^{28}$ Conversely, in a one-sided mediation, as defended by O'Collins, Christ's priesthood addresses only human beings. God is not supposed to be satisfied/appeased. ${ }^{29}$ In the next chapter, I will analyze from a macro-hermeneutical

${ }^{28}$ His priesthood cleanses/expiates the stain of sin by grace, turning the human heart to God, and satisfies God (divine aspect), removing the human debt of punishment. ST III, q. 22, a. 3. The divine satisfaction is accomplished inasmuch as Christ's passion "takes away sin by which men became God's enemies" and constitutes a "sacrifice to appease [placetur] God." ST III, q. 49, a. 4. Original Latin terms indicated in brackets for Aquinas' works were taken from http://www.dhspriory.org/thomas (accessed 29 December 2016), a website from the Dominican House of Studies.

${ }^{29} \mathrm{O}$ 'Collins rejects any notion of God's wrath and propitiation. He argues that reconciliation is not about reestablishing "friendly relations between personal agents but as Christ making 'all things' conform to the divine plan." O'Collins, Jesus Our Redeemer, 14. There is no human debt of punishment or divine satisfaction. In fact, the Jesuit theologian criticizes the penal substitutionary view of atonement, which in his understanding was promoted by Aquinas, claiming that this view portrays an angry God appeased by the punishment of an innocent person. JOP, 256. For further information, see ibid., 105-119. Strongly disagreeing with O'Collins, Nieuwenhoves argues that Aquinas did not contribute to penal substitution and propitiation of divine anger. Rather, he points out that "Aquinas, like Anselm, understands satisfaction in terms of purification and penance," which "excludes" the notion of "punishment." Rik Van Nieuwenhove, “"Bearing the Marks of Christ's Passion': Aquinas' Soteriology," in The Theology of Thomas Aquinas, ed. Rik Van Nieuwenhove and Joseph Wawrykow (Notre Dame, IN: University of Notre Dame Press, 2005), 289-290. Levering's comments on the priesthood of Christ in Aquinas also affirm a satisfaction without the notion of penal substitution. See Levering, Christ and the Catholic Priesthood, 112-115. For other studies on atonement in Aquinas, see Eleonore Stump, Aquinas, Arguments of the Philosophers (London; New York: Routledge, 2003), 427-454; Adam J. Johnson, “A Fuller Account: The Role of 'Fittingness' in Thomas Aquinas' Development of the Doctrine of the Atonement," International Journal of Systematic Theology 12, no. 3 (2010): 302-318; Brandon Peterson, "Paving the Way? Penalty and Atonement in Thomas Aquinas's Soteriology," International Journal of Systematic Theology 15, no. 3 (2013): 265-283. 
standpoint whether the sacramental model really allows the accommodation of both twosided and one-sided types of mediation.

In summary, the solution for the sin problem requires the mediatorial priesthood of Christ. More specifically, sin causes a disorder that distances human beings from God by hindering their teleological movement toward Him. Christ's priesthood is intended to solve the hindering/sin problem, and deals instrumentally with the ontological distance implied by the teleological movement. Also, the solution provided by His priesthood for the sin problem may demand a two-sided (involving God and human beings) or a onesided (only human beings) mediation. In the third chapter I will analyze the viability of these two types of mediation in the sacramental model. For now, I will describe the next component of the priesthood of Christ, namely, the agent.

\section{The Agent of the Priesthood}

The agent of the priesthood or the priest in the sacramental model is obviously identified as Christ. The key feature of the agent in this model is His human nature, which indicates that the incarnation is necessary for Him to be a priest. ${ }^{30}$ In fact, this model holds that Christ's priesthood started with His incarnation. ${ }^{31}$ This conception has

\footnotetext{
${ }^{30}$ Aquinas points out that "Christ was a priest, not as God, but as man, yet one and the same was both priest and God." ST III, q. 22, a. 3, ad 1. Similarly, O'Collins defines Christ's priesthood in terms of His humanity by stating that Christ's incarnation is the association of "divine sonship and a human priesthood." JOP, 49. Hence, for the Jesuit theologian, Christ's "humanity was essential to his priesthood." $J O P, 242$. He indicates that this idea can be found in Chrysostom, Augustine, Aquinas, Calvin, Newman, and Torrance. Ibid., 242. For additional historical information regarding the priesthood of Christ, from the church fathers to Vatican II, see ibid., 68-236.

${ }^{31}$ According to O'Collins, Christ became a high priest "when he took the human condition." JOP, 241. Referring to the Council of Ephesus (AD 431), Aquinas maintains that the priesthood of Christ started in the incarnation: Christ became high priest when He became man. ST III, q. 22, a. 3, ad 1. For helpful studies on Aquinas' Christology, see Eleonore Stump, "Aquinas' Metaphysics of the Incarnation," in The Incarnation: An Interdisciplinary Symposium on the Incarnation of the Son of God, ed. Stephen T. Davis,
} 
implications for the scope of Christ's priesthood and the nature of His mediation. In terms of scope, this priesthood includes everything that Christ is and does since His incarnation. As O'Collins emphasizes, the priesthood of Christ encompasses His entire human life, including His public ministry (teachings and miracles). ${ }^{32}$

With regard to the nature of His priestly mediation, Christ's humanity mediates the divine presence in creation (cosmological perspective) and divine grace to human beings (anthropological perspective). In both cases, Christ's human nature mediates divine salvation in the sense that His corporeality provides a contact of the divine with the physical world and material human beings. According to the cosmological perspective expounded by O'Collins, the incarnation "brought a new stage in" Christ's "revealing and saving presence. This event put" Him "in a material solidarity with all human beings and their world." 33 This means that the incarnation inaugurates a new

Daniel Kendall, and Gerald O'Collins (Oxford; New York: Oxford University Press, 2002), 197-218; Joseph Wawrykow, "Hypostatic Union," in The Theology of Thomas Aquinas, ed. Rik Van Nieuwenhove and Joseph Wawrykow (Notre Dame, IN: University of Notre Dame Press, 2005), 222-251; Édouard-Henri Wéber, Le Christ Selon Saint Thomas d'Aquin, Jésus Et Jésus-Christ (Paris: Desclée, 1988); Thomas G. Weinandy, "Aquinas: God Is Man: The Marvel of the Incarnation," in Aquinas on Doctrine: A Critical Introduction, ed. Thomas G. Weinandy, Daniel A. Keating, and John Yocum (London; New York: T\&T Clark International, 2004), 67-89; Brian Davies, The Thought of Thomas Aquinas (New York: Oxford University Press, 1993), 297-319; Michael Gorman, "Incarnation," in The Oxford Handbook of Aquinas, ed. Brian Davies and Eleonore Stump (Oxford; New York: Oxford University Press, 2011), 428-435.

${ }^{32}$ The Jesuit theologian affirms that, in Hebrews $(5: 7 ; 7: 26 ; 10: 5-7)$, Christ's priesthood comprises His entire human life. JOP, 242. This means that although Christ's "death, resurrection, and glorification" are decisive priestly moments, Christ's life and public ministry are not "a mere prelude to the real exercise of His priesthood." Ibid. He points out that Origen and Luther viewed Christ's public ministry as a priestly ministry. Ibid., 244.

${ }^{33}$ O'Collins, Christology, 345; italics mine. The Jesuit theologian understands "soteriology as the multiform ways . . . in which Christ's presence (or God's unique, foundational presence in /to Christ) mediated and mediates itself to human beings and their world, so as to communicate revelation and redemption." Ibid., 344. Reflecting on John 4, he argues that, as "the new priestly Mediator between God and human beings," Christ "is the new place of the divine presence." JOP, 25. Hence, O'Collins associates Christ's priesthood with His mediation of the divine presence. Indeed, the presence of Christ, conceived in terms of the universal scope of His mediation, is part of the "primary interpretative key" of O'Collins' systematic Christology. O’Collins, Christology, x, 15. 
phase of His mediation in creation-redemption, ${ }^{34}$ a phase characterized by material mediation, as Christ enters "into a kind of physical contact with the material universe" by means of His human body. ${ }^{35}$ Through this physical contact, the "personal presence in the world of the Son of God" initiates a process of transformation/divinization of the "whole human race and the whole created order." 36 This mediation of Christ through His physicality is an intended part of His whole creative-salvific mediation. More specifically, "the creation of the world and humankind provided the possibility for the Son of God to assume a human nature." 37 The intentionality of the existence of this material/human nature of Christ in a material creation is observed in the idea that salvation is "effected through a very long process of creation, incarnation, and final consummation." 38 On the basis of the premise that Christ's priesthood initiated in His incarnation, in the cosmological perspective, His priesthood corresponds to the intended human phase of Christ's creative-salvific mediation, which provides a material mediation of the divine presence for the transformation of creation.

\footnotetext{
34 This statement is based on three lines of evidence in O'Collins: (1) he understands mediation as a broad category that may include priesthood ("mediation is a broader category than priesthood. All priests are mediators, but not all mediators are priests." JOP, 120); (2) he affirms a large scope of Christ's mediation as including creation and redemption (Christ is "mediator of creation and redemption." O'Collins, Christology, 317); (3) he maintains that Christ's priestly mediation initiates with His incarnation (this point is emphasized at the beginning of the discussion of the Agent of the Priesthood above). These lines of evidence imply that Christ's priesthood is the human phase of His mediation.

${ }^{35}$ O'Collins, Jesus Our Redeemer, 85. He maintains that "our bodies insert us into the material world. We become part of the cosmos and the cosmos part of us . . our life is constituted by a dynamic process of constant circulation between our bodies and our material environment.” Ibid., 84.

${ }^{36}$ Ibid., 85. O'Collins argues that the incarnation initiates the process of "conformation of all things to the plan of God," as Christ united Himself "with the whole created world." Ibid., 15.

37 Ibid., 35 .

${ }^{38}$ Ibid., 28. O'Collins assumes that "creation is there "for the sake of redemption," since "the mystery of love that was creation reached its climax at redemption, with both creation and redemption coming through the same agent." O'Collins, Christology, 307.
} 
In the anthropological perspective elaborated by Aquinas, the association of

Christ's priestly mediation and His humanity assumes that the latter is the mean between

God (one extreme) and sinful human beings (the other extreme). ${ }^{39}$ As a mean, Christ's

humanity is the material instrument by which salvific divine activities are performed. ${ }^{40}$ In

fact, this instrumental mediation of Christ's humanity is appropriate to the sinful

condition of human beings. In agreement with what was mentioned above in the

discussion of the need for Christ's priesthood, “on deserting God” sinful human beings

"had stooped to corporeal things," which made "necessary that God should take flesh,

and by corporeal things should afford" humanity "the remedy of salvation." 41 In this way,

the humanity of Christ is a material instrument that channels a divine strength or force

(grace) to the souls of concrete human beings. ${ }^{42}$ Assuming that the human locus of grace

${ }^{39}$ For Aquinas, "as man," Christ "is distant both from God, by nature, and from man by dignity of both grace and glory. Again, it belongs to Him, as man, to unite men to God." ST III, q. 26, a. 2; italics mine. Hence, the man Christ as priest is a mean that unites the extremes. In his words, "the office of a mediator is to join together and unite those between whom he mediates," the "extremes are united in the mean [medio]." ST III, q. 26, a. 1. A mean is distant from both extremes, but it unites them "by communicating to one that which belongs to the other." ST III, q. 26, a. 2. As a mean between God and human beings, "Christ had beatitude in common with God" and "mortality in common with men," so that He could die to reconcile human beings with God and also confer beatitude on humankind. ST III, q. 26, a. 1, ad 2. According to Scheller, the notions that the extremes are united in the mediator/mean and that the extremes are different from the mediator/mean are derived from Aristotelian metaphysics. Scheller, Das Priestertum Christi im Anschluss an den hl. Thomas von Aquin, 261.

${ }^{40}$ Aquinas affirms that "the humanity of Christ is the instrument of the Godhead." ST III, q. 7, a. 1, ad 3. In Latin, "humanitas Christi est instrumentum divinitatis." This is not "an inanimate instrument, which nowise acts, but is merely acted upon; but an instrument animated by a rational soul, which is so acted upon as to act." Ibid.

${ }^{41}$ ST III, q. 1, a. 3, ad 1.

${ }^{42}$ For the purpose of this discussion, Aquinas believes that grace is a superadded strength (ST IIa, q. 109, a. 5) or "higher force" (ST IIa, q. 109, a. 2) given by God to heal the corrupted human nature and to carry out meritorious works of supernatural virtue. The medieval theologian explains that divine grace can be defined in two ways, namely, as "the movement of the soul" (God moves the human soul "to know or will or do something"), and as "habitual gift" that "is infused by God into the soul." ST IIa, q. 110, a. 2. The discussion of the reasons why the corrupt human nature needs grace (grace as superadded strength and higher force) refers to grace as habitual gift. See ST IIa, q. 109, a. 2, ad 1. For helpful information on Aquinas' conception of grace, see Davies, The Thought of Thomas Aquinas, 262-273; Wawrykow, 
is the soul, ${ }^{43}$ the humanity of Christ "receives the greatest outpouring" of divine grace in His soul, because His human nature is closely united to the divine nature (hypostatical union). ${ }^{44}$ Whereas Christ as God is the source of grace, Christ as man gives it "instrumentally," "inasmuch as His manhood is the instrument of His Godhead.",45 According to this view, the mediatorial instrumentality of Christ's humanity in relation to His divinity is analogous to the instrumentality of the human body in relation to the soul. ${ }^{46}$ This correspondence between Christ's humanity (instrument) and divinity, and the human body (instrument) and soul indicates the following logical sequence: Christ's divinity, His humanity, human body, and human soul. More specifically, Christ's divinity is the source of grace, which is instrumentally bestowed through His humanity on concrete human beings, who receive this grace "secondarily and instrumentally" through their bodies and, then, divine grace reaches their souls. ${ }^{47}$ In this anthropological view,

“Grace," 192-221.

${ }^{43}$ ST III, q. 7, a. 11.

${ }^{44}$ ST III, q. 7, a. 9. This statement connects the twofold grace that is in Christ: (1) "the grace of union," as His humanity is "personally united to the Son of God;" and (2) the "habitual grace" which is "in the soul of Christ." ST III, q. 7, a. 11. For Aquinas, in Christ, "the grace of union precedes, in thought," not in time, "habitual grace." $S T$ III, q. 7, a. 13. The medieval theologian believes that the reason why Christ, being divine, needed an habitual grace created in His soul is the acknowledgment of His genuine humanity: "because it is necessary to admit a human operation, distinct from the Divine operation, . . . it was necessary for Him to have habitual grace, whereby this operation might be perfect in Him." ST III, q. 7, a. 1, ad 2. For further justifications of habitual grace in Christ, see $S T$ III, q. 7, a. 1.

${ }^{45}$ ST III, q. 8, a. 1 , ad 1.

46 "Inasmuch as the soul is its motor, the body serves the soul instrumentally. Therefore ... the manhood of Christ had the power of 'influence,' inasmuch as it is united to the Word of God." ST III, q. 8, a. 2. Aquinas argues that the humanity of Christ cleanses (ST III, q. 31, a. 1; q. 14, a. 4, ad 1) and perfects (ST III, q. 1, a. 6; q. 2, a. 11) human nature, brings human beings to the end of beatitude (the vision of God) (ST III, q. 9, a. 2), and bestows upon humankind the full participation of the divinity (ST III, q. 1, a. 2).

${ }^{47}$ As an instrument of the soul, the body receives grace "secondarily and instrumentally." ST III, q. 8 , a. 2 , ad 1 . See also q. 8 , a. 2 ; q. 8 , a. 4 , ad 1 . 
Christ as priest is "the head of all" and "the fount of all grace," 48 which implies that He bestows through His humanity the grace that overflows in Him on others. ${ }^{49}$ This is a key aspect of His mediation as priest. ${ }^{50}$

In summary, Christ's humanity is His central feature as priest (the agent of the priesthood), meaning that the incarnation is not only necessary but also the starting point of His priesthood. In terms of scope, this implies that Christ's priesthood encompasses His entire human life, including His public ministry. With regard to the nature of His mediation as priest, Christ's human nature mediates divine salvation as His corporeality provides a contact of the divine with the physical world and material human beings. From a cosmological standpoint, Christ's priesthood corresponds to an intended human phase of His whole creative-salvific mediation, which provides a material mediation of the divine presence for the transformation of creation. According to an anthropological perspective, Christ's divinity bestows grace through the material instrumentality of His humanity upon concrete human beings, who receive this grace in their soul through the material instrumentality of their bodies.

${ }^{48}$ ST III, q. 22, a. 1, ad 3. In his explanation of the grace of Christ, Aquinas explores "the grace of Christ as an individual man" and "the grace of Christ as He is the head of the church." ST III, q. 7 and q. 8 , respectively. In these sections, "the end of grace is the union of the rational creature with God" (q. 7, a. 12; see also q. 7, a. 1, ad 1)

${ }^{49}$ ST III, q. 7, a. 5. In the list of reasons for calling Christ the head of the church, all the arguments center on the idea of grace: (1) "on account of" Christ's "nearness to God His grace is the highest and first, though not in time, since all have received grace on account of His grace"; (2) "He had perfection as regards the fulness of all graces"; (3) "He has the power of bestowing grace on all the members of the Church." ST III, q. 8, a. 1.

50 'For Christ, as man, is the 'Mediator of God and men,' as is written, 1 Timothy 2:5; and hence it behooved Him to have grace which would overflow upon others, according to John 1:16." ST III, q. 7, a. 1. The medieval theologian points out that whereas the sin of Adam, the head of humanity in Creation, is transmitted by fleshly generation, "the merit of Christ, who has been appointed by God to be the head of all men in regard to grace, extends to all His members" (ST III, q. 19, a. 4, ad 1) through "spiritual regeneration," when "we are incorporated with Christ" by baptism (ST III, q. 19, a. 4, ad 3). 


\section{The Actions of the Priest}

In the sacramental model, the actions of Christ the priest are under a broad concept of sacrifice, ${ }^{51}$ which is conceived as invisible/internal (a personal disposition) and visible/external (a concrete offering). In the context of Christ's priesthood, the invisible sacrifice encompasses His entire life and the visible sacrifice is defined by the shedding of His blood on the cross, which is followed by the consummation of His sacrifice. This consummation seems to combine visible and invisible aspects of sacrifice, as it includes Christ's heavenly intercession and the sacrament of the eucharist.

Therefore, the actions of Christ in His priesthood can be generally classified in the following way: (1) His invisible/internal sacrifice, (2) His visible bloody sacrifice, and (3) His consummation of the sacrifice. In the discussion below, I will clarify how these types of priestly actions are understood in the sacramental model.

The notion of Christ's invisible sacrifice assumes a distinction of invisible and visible sacrifice. The former is an internal disposition or self-offering to God, ${ }^{52}$ while the latter is an external expression or "a sacrament, that is a sacred sign, of the invisible

\footnotetext{
${ }^{51}$ Scheller argues that, for Aquinas, while the concept of a mediator priest refers to the person of Christ, the notion of a sacrificial priest concerns the office or work of Christ. Scheller, Das Priestertum Christi im Anschluss an den hl. Thomas von Aquin, 218. For helpful studies on the work of Christ and salvation in Aquinas, see Bernard Catão, Salut Et Rédemption Chez Saint S. Thomas d'Aquin: L'acte Sauveur Du Christ (Paris: Aubier, 1965); Davies, The Thought of Thomas Aquinas, 320-344; Matthew Levering, Christ's Fulfillment of Torah and Temple: Salvation According to Thomas Aquinas (Notre Dame, IN: University of Notre Dame Press, 2002); Romanus Cessario, "Aquinas on Christian Salvation," in Aquinas on Doctrine: A Critical Introduction, ed. Thomas G. Weinandy, Daniel A. Keating, and John Yocum (London; New York: T\&T Clark International, 2004), 117-137; Nieuwenhove, "'Bearing the Marks of Christ's Passion'," 436-447; Rick Van Nieuwenhove, "The Saving Work of Christ," in The Oxford Handbook of Aquinas, ed. Brian Davies and Eleonore Stump (Oxford; New York: Oxford University Press, 2011), 277-302.

${ }^{52}$ Aquinas stipulates that "whatever is offered to God in order to raise man's spirit to Him, may be called a sacrifice." ST III, q. 22, a. 2.
} 
sacrifice. ${ }^{, 53}$ In other words, sacrifice is an internal disposition accompanied by an external aspect. ${ }^{54}$ As O'Collins points out, “whatever Christ did by way of external sacrifice symbolized and expressed his interior self-giving to the Father." ${ }^{, 55}$ Reflecting on Christ's priesthood, Aquinas highlights His offering of the sacrifice (visible sacrifice) and the devotion with which He endured the passion (invisible sacrifice). ${ }^{56}$ The conception of invisible and visible sacrifice implies that Christ's visible offering of the sacrifice was a sacrament or a materialization of His invisible devotion. In his emphasis on the invisible sacrifice, the medieval theologian claims that "Christ obtained a result from His passion, not as by virtue of the sacrifice [visible], which is offered by way of satisfaction, but by the very devotion [invisible] with which out of charity He humbly endured the passion." Thus, sacrifice is primarily invisible (spiritual) and understood as a self-offering or devotion. For O'Collins, Christ's sacrifice must be viewed in terms of love and selfgiving and, therefore, it refers not only to His death on the cross but also to His entire

${ }^{53}$ Ibid. In this explanation, Aquinas quotes Augustine (De Civ. Dei x, 5).

${ }^{54} \mathrm{O}$ 'Collins argues that this conception is largely based on the following notions: (1) in the OT, "external rituals were worthless without . . the corresponding interior dispositions, and . . compassionate behavior" (see e.g., Pss 40:6-8; 51:17-19; Hos 6:6; Mic 6:6-8); (2) in the NT, Paul employs "the terminology of sacrifice in both a cultic (e.g., 1 Cor. 5:7) and a non-cultic way" (e.g., Rom 12:1); (3) for Augustine, "the external sacrificial gift must symbolize the inner, invisible sacrifice"; (4) "Aquinas endorsed a broad, non-cultic account of sacrifice . . . and a more cultic reading of sacrifice." JOP, 253-254.

${ }^{55}$ Ibid., 256. For O'Collins, this can be seen in the fact that Christ "had come to do God's will (Heb. 10:7, 9)." Ibid. According to Aquinas, "the outward sacrifice" that someone "offers is a sign of the inner sacrifice whereby he offers himself to God." ST III, q. 82, a. 4.

${ }^{56}$ ST III, q. 22, a. 4, ad 2.

${ }^{57}$ Ibid. The "passion was most acceptable to God, as coming from charity." ST III, q. 48, a. 3. Matthew Levering comments that, for Aquinas, "the fundamental 'offering"” of Christ's "human life ... is the active offering that he makes spiritually out of love, not the more 'passive' submission of his flesh to the nails of the Roman soldiers." Levering, Christ and the Catholic Priesthood, 106. 
life. ${ }^{58}$ Christ's life is a sacrifice of self-giving to God and others. In this perspective, Christ's teaching, miracles, and the last supper are priestly actions. ${ }^{59}$ For the Jesuit theologian, the latter is the climax of Christ's internal sacrifice (His life of service for others), as He committed Himself to a self-sacrificing death in the last supper. ${ }^{60}$

The premise that sacrifice is an invisible self-offering accompanied by a visible expression or sacrament has implications for Christ's visible sacrifice on the cross. One implication drawn by $\mathrm{O}^{\prime}$ Collins is that sacrifice, as a self-offering, is a gift to God, ${ }^{61}$ not a punishment. This means that it is not true that Christ "bore 'the sins of the world' and was . . under divine judgment 'as the object of the anger of God" " on the cross. ${ }^{62}$ Thus,

${ }^{58}$ Regarding the first idea, the Jesuit theologian agrees with Aquinas that the death of Christ was a sacrifice only because He suffered "out of love." JOP, 257. In the second idea, Christ's "whole life was a continual free gift of himself (or sacrifice) to God and others." Hence, it is a "mistake to limit Christ's sacrificial performance to his death and exaltation." Ibid., 256. In Hebrews, a "priestly self-offering characterized his entire human existence (10:5-7)." Ibid., 50.

${ }^{59}$ This broad notion of sacrifice is compatible to O'Collins' broad notion of Christ's priesthood. Both sacrifice and priesthood encompass His entire life. In this sense, Christ's public teaching and preaching as part of His priesthood which is supported, in O'Collins' view, by the teaching function of the priests in the OT and by Paul's understanding of his preaching work as a priestly or liturgical ministry (Rom 15:16). Ibid., 244. The Jesuit theologian stipulates that Christ' healings and the Last Supper were significant priestly activities of His public ministry. His argument is that Christ's proclamation and teaching were inseparable from His healings in the Gospels, and that "during his ministry and at its end, Jesus nourishes people in a 'double' and priestly way," namely, through His teachings and in the institution of the eucharist. JOP, 244-245. O'Collins quotes the document "Decree on the Ministry and Life of Priests" (Presbyterorum Ordinis 18) of the Second Vatican Council: “"Christians draw nourishment through the Word of God from the double table of holy Scripture and the Eucharist." Following this view, he claims that Jesus fed the people "with his teaching and shared his presence with them by joining them for meals." Actually, "what he does in feeding people on both occasions" (the feeding of five thousand in Mark 6:30-44 and of four thousand hungry people in Mark 8:1-10) "foreshadows the Last Supper and the institution of the Eucharist." Hence, "during his ministry and at its end, Jesus nourishes people in a 'double' and priestly way." Ibid.

60 "at the Last Supper, when instituting the Eucharist as a sacrificial meal, Jesus committed himself through a cultic, priestly act to his self-sacrificing death.” Ibid., 250. See also ibid., 261. Regarding "Christ's priestly self-offering at the Last Supper," the Jesuit theologian stipulates that "the Last Supper integrated into his mission a final act of service." Ibid., 261, 258.

${ }^{61}$ Ibid., 256.

${ }^{62}$ O'Collins, Jesus Our Redeemer, 147. See ibid., 152. Commenting on Lev 16, O'Collins points out that "transferring sins from human beings to an animal comes across as a spectacular gesture but seems 
the cross is about Christ giving His life to God, and not about Him receiving human sins and then suffering the punishment of the divine wrath. A second and more significant implication is that the crucifixion constitutes a visible expression or sacrament that accompanies an invisible self-offering (the essence of the sacrifice). Following this perspective, the crucifixion is the visible expression of Christ's commitment in the last supper (invisible sacrifice). In this sense, the Jesuit theologian declares that "Christ's priestly self-offering at the Last Supper was consummated in the sacrifice of Calvary., For Aquinas, as the crucifixion is related to Christ's corporeality, ${ }^{64}$ the experience of the cross was an instrument used by God. In his words, “inasmuch as Christ's flesh, wherein He endured the Passion, is the instrument of the Godhead, so that His sufferings and actions operate with Divine power for expelling sin." ${ }^{, 65}$ This notion of expelling sin or purification seems to interpret the crucifixion in terms of the sacrament of penance. ${ }^{66}$

quite incompatible with the nature of sin as a breakdown in a personal relationship with God." Actually, "Hebrews was to use the imagery of Yom Kippur to express the meaning of redemption, but emphasized that Christ, having died once and for all for our sins, expiated them and so made the whole ceremony of Yom Kippur superfluous (Heb. 9: 1-10: 18).” Ibid., 152.

${ }^{63} \mathrm{JOP}, 261$. O'Collins argues that the last supper and the crucifixion are "defining moments in the narrative of Christ's priesthood." Ibid., 241.

64 The passion belongs to Christ "in respect of His human nature.” ST III, q. 64, a. 3.

${ }^{65}$ ST III, q. 49, a. 1. "Christ's Passion, although corporeal, has yet a spiritual effect from the Godhead united." Ibid. Aquinas acknowledges that the passion of Christ is "the cause of justification" as "an instrument," and "not as the principal cause." Ibid. The following quotations confirm this perspective of the passion: "Christ's actions and sufferings operate instrumentally in virtue of His Godhead for the salvation of men." q. 48, a. 6; "Although Christ did not suffer as God, nevertheless His flesh is the instrument of the Godhead; and hence it is that His Passion has a kind of Divine Power of casting out sin." q. 49, a. 1, ad 1; "Although Christ's Passion is corporeal, still it derives a kind of spiritual energy [virtutem] from the Godhead, to which the flesh is united as an instrument: and according to this power Christ's Passion is the cause of the forgiveness of sins." q. 49, a. 1, ad 2.

${ }^{66}$ In his discussion of the saving work of Christ in Aquinas, Van Nieuwenhove emphasizes that the medieval theologian connects "the satisfaction Christ makes on the Cross" with "the sacrament of penance." Nieuwenhove, "The Saving Work of Christ," 439. See also Davies, The Thought of Thomas Aquinas, 328, 335. Nieuwenhove's conclusion is based on Aquinas' understanding that one of the three 
Furthermore, from a broader perspective, considering that sin is a disorder in which material things distract human beings, ${ }^{67}$ the crucifixion or Christ's human suffering is a decisive material instrument used by God to bring their attention to spiritual realities. ${ }^{68}$ As a visible sacrifice, the crucifixion, besides its connection with penance, functions as a sacrament ${ }^{69}$ in two senses: (1) as a sign or visible expression of Christ's devotion to God

elements of the sacrament of penance is satisfaction (the paying of the penalty owed). See SCG IV.72.4. For Nieuwenhove, it is the element of satisfaction that makes the crucifixion a penitential act. Other important aspects of the sacrament of penance higlighted by Aquinas that appear to be related to Christ's crucifixtion are: penance is a "sacramental remedy by which sins are washed away" (SCG IV.72.1), and this spiritual cure proceeds both "from something internal and from something external" (SCG IV.72.3), which seems to include both an invisible and visible sacrifice. All English quotations of $S C G$ are taken from Thomas Aquinas, Summa Contra Gentiles, ed. Joseph Kenny, trans. James F. Anderson Anton C. Pegis, Vernon J. Bourke, and Charles J. O’Neil (New York: Hanover House, 1955-1957), available at http://dhspriory.org/thomas/ContraGentiles.htm (accessed 29 December 2016), a website from the Dominican House of Studies.

${ }^{67}$ See section above about the need for Christ's priesthood.

${ }^{68}$ For the medieval theologian, Christ's passion or crucifixion was not necessary to earn salvific merits, but to secure the effects of the merits that He already had. "From the beginning of His conception Christ merited our eternal salvation; but on our side there were some obstacles, whereby we were hindered from securing the effect of His preceding merits: consequently, in order to remove such hindrances, 'it was necessary for Christ to suffer." ST III, q. 48, a. 1, ad 2. See also ad 3. To put it more sharply, the crucifixion was necessary to remove the hindrances of human beings so that Christ's preceding merits could have a salvific effect in human beings. The crucifixion "has a special effect" (q. 48, a. 1, ad 3) on human beings, not necessarily more merit for their salvation. Overall, Aquinas seems to spell out the effect of removing human hindrances in the following way: through Christ's passion human beings (1) know "how much God loves" them and are "thereby stirred to love Him in return"; (2) are "all the more bound to refrain from sin"; (3) are motivated to charity, by which "we procure pardon of our sins"; (4) have "an example of obedience, humility, constancy, justice, and the other virtues . . . which are requisite for man's salvation." ST III, q. 46, a. 3; q. 49, a. 1. These impacts of Christ's passion on human beings are consistent with the idea highlighted above that sinful human beings "stooped to corporeal things" and God had to inhabit flesh in order to save them through corporeal things (q. 1, a. 3, ad 1). On the basis of this idea, the hindrances of human beings seem to be related to their sole attention to corporeal things, which makes them unable to appreciate and receive divine (immaterial) salvation. Therefore, Christ's crucifixion, as a corporeal reality, removes the hindrances of human beings by bringing their attention and desire for divine and spiritual realities, which are described in the three points above.

${ }^{69}$ In fact, Aquinas uses the language of sacrament in reference to the cross. "Death on the cross was also appropriate as a sacrament. Christ wished to make clear by His death that we ought so to die in our carnal life that our spirit might be raised to higher things." Thomas Aquinas, Compendium of Theology 1.228. Quotation taken from the translation by Cyril Vollert (St. Louis \& London: B. Herder Book, 1947), available at http://www.dhspriory.org/thomas/english/Compendium.htm (accessed 30 December 2016), a website from the Dominican House of Studies. According to Nieuwenhove, "by adopting the notion of the humanity of Christ as the instrument of his divinity Aquinas can argue that every aspect of Christ's life, death, and resurrection has a sacramental meaning and power." Nieuwenhove, "The Saving Work of 
(invisible sacrifice) and (2) as a material instrument of divine salvific action that brings human attention to spiritual realities, which are communicated to human beings in the consummation of the sacrifice. ${ }^{70}$

In the consummation of Christ's sacrifice, human beings concretely receive the effect of the divine salvific action. ${ }^{71}$ Because Christ ascended to heaven, this consummation encompasses the heavenly and earthly realms. ${ }^{72}$ His heavenly intercession has its counterpart particularly in the earthly eucharist. In heaven, Christ's intercession

Christ," 438.

${ }^{70}$ As a divine salvific action, Christ's passion is "a kind of universal cause of the forgiveness of sins" that "needs to be applied to each individual for the cleansing of personal sins" through the "sacraments." ST III, q. 49, a. 1, ad 4. See also ad 3. This idea of universal cause and personal application assumes that Christ is the head and humans beings in the church are members of the body. See q. 49, a. 1 .

${ }^{71}$ Aquinas distinguishes the visible bloody sacrifice from its consummation by using the Latin words oblation and consummatio. For him, the priestly office consists of two parts: (1) "the offering [oblatio] of the sacrifice" and (2) "the consummation [consummatio] of the sacrifice." In the second part, "those for whom the sacrifice is offered . . . obtain the end of the sacrifice." ST III, q. 22, a. 5. According to this perspective, the bloody "offering [oblatio] made by Christ" was prefigured by the animal sacrifices of the levitical priesthood, while the consummation or the "partaking [participatio] thereof" was foreshadowed by the non-bloody offering of bread and wine in Melchizedek's priesthood. ST III, q. 22, a. 6 , ad 2. The levitical priesthood foreshadowed "the shedding of blood," whereas in the priesthood of Melchizedek there "was no blood-shedding." Ibid. "In the New Law the true sacrifice of Christ is presented to the faithful under the form of bread and wine." ST III, q. 22, a. 6, ad 2. Aquinas associates Christ's priesthood with Melchizedek by quoting especially Heb 7 (see q. 31, a. 8) and Ps 109:4 (see q. 63, a. 5). For Melchizedek's offering of bread and wine, he quotes Gen 14:18 (see q. 61, a. 3, ad 3). O'Collins employs the language of consummation of Christ's sacrifice assuming that "through the Spirit the heavenly consummation of Christ's sacrifice continues for all eternity.” JOP, 266. See also ibid., 271.

${ }^{72}$ In his remarks about the "consummation of Christ's sacrifice," Aquinas connects the heavenly aspect of this consummation with Christ's ascension to heaven. In his words, such consummation "was foreshadowed in this, that the high-priest of the Old Law, once a year, entered into the Holy of Holies with the blood of a he-goat and a calf, as laid down, Leviticus 16:11, and yet he offered up the he-goat and calf not within the Holy of Holies, but without. In like manner Christ entered into the Holy of Holies - that is, into heaven - and prepared the way for us, that we might enter by the virtue of His blood, which He shed for us on earth.” ST III, q. 22, a. 5. Commenting on this statement in an editorial note, Colman E. O'Neill argues that "Thomas is concerned to exclude the idea of a heavenly sacrifice in the sense of a visible offering of a victim. However, the interior element of Calvary ... does remain. ... Such a permanence in heaven of the interior sacrifice of Christ, in union with his mystical body, is precisely the consummation of Calvary. The Mass gives sacramental expression, during the time of the earthly Church, to this interior sacrifice of all those who belong to Christ." Thomas Aquinas and Colman E. O'Neill, The One Mediator (3a.15-26): Latin Text, English Translation, Introduction, Notes, Appendices and Glossary, Summa Theologiae (London: Blackfriars, 1965), 153na. 
before God means that He offers Himself to the Father through the Spirit (O'Collins), ${ }^{73}$ and that He presents His humanity to the Father (Aquinas).$^{74}$ In accordance to the idea of invisible sacrifice, the notion of intercessory self-offering is conceived as an eternal sacrifice in heaven. ${ }^{75}$ Arguably, the basic difference between O'Collins and Aquinas on the concept of heavenly intercession refers to the propitiation of the Father. For the medieval theologian, the presentation of Christ's humanity aims at causing the Father to have mercy on human beings, ${ }^{76}$ whereas the Jesuit theologian does not mention the Father's mercy in this context. For O'Collins, Christ's heavenly mediation is part of His work of bringing to completion the fulfillment of the divine promises, ${ }^{77}$ which takes place as blessings to the world, ${ }^{78}$ and does not refer to a propitiation of divine wrath. ${ }^{79}$

\footnotetext{
73 "The priesthood of Christ continues forever, since he eternally intercedes for the world and blesses the world, offers himself through the Holy Spirit to the Father." JOP, 265. This conclusion is based on the picture of the Lamb who was slain facing the presence of God forever in the heavenly liturgy in Revelation, and on the notion of the Spirit offering the sacrifice of Christ to the Father in Heb 9:14. See ibid., 265-266. O'Collins emphasizes that "at all stages (incarnation, ministry, death, and risen glory) the priesthood of Christ is essentially Trinitarian.” Ibid., 270.

${ }^{74}$ As the OT high-priest "entered the holy place [sanctuarium] to stand before God for the people, so also Christ entered heaven 'to make intercession [ad interpellandum] for us." For Aquinas, "the very showing [repraesentatio] of Himself in the human nature which He took with Him to heaven is a pleading [interpellatio] for us so that for the very reason that God so exalted human nature in Christ, He may take pity [misereatur] on them for whom the Son of God took human nature." ST III, q. 57, a. 6.

${ }^{75}$ For O'Collins, "the heavenly consummation of Christ's sacrifice continues for all eternity."JOP, 266. The Jesuit theologian does not firmly differentiate the categories of sacrifice and intercession, as the former may include the latter. "Sacrifice can include other such features as adoration, praise, thanksgiving, and intercession." O'Collins, Christology, 304; italics mine. The identification of heavenly intercession and sacrifice is clearly perceived in the following statement, "Eternally interceding now for those still to be brought to completion through the fulfilment of the divine promises, Christ the High Priest presents forever on their behalf to the Father his sacrificial self-offering." JOP, 262; italics mine.

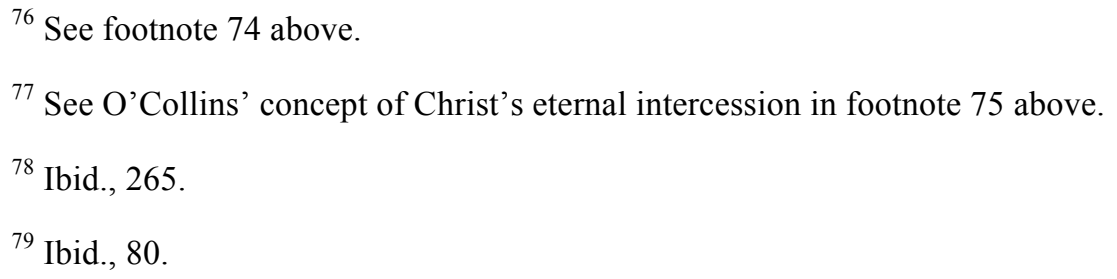


The consummation of Christ's sacrifice in heaven finds its counterpart on earth through the Holy Spirit, who makes the benefits of the sacrifice available to human beings. The Jesuit theologian affirms that Christ, the ascended priest, "continues to pour out the Holy Spirit upon the Church and the world," and this means that "the Spirit universalizes the priestly work of Jesus.. ${ }^{, 0}$ Through the Spirit, the main locus of Christ's priestly activity on earth is the church, where He is the "primary minister" of all "preaching and sacramental life." ${ }^{, 81}$ According to Aquinas, "the whole rite of the Christian religion is derived from Christ's priesthood, ${ }^{382}$ which implies that He acts through the sacraments of the church to apply the power of His sacrifice to human beings. ${ }^{83}$ Just as Christ's humanity was a material instrument of His divinity for the

${ }^{80}$ Ibid., 265-266. For O'Collins, the sending of the Spirit by the ascended Christ constitutes an aspect of His cosmic presence. See O'Collins, Jesus Our Redeemer, 226. In fact the Jesuit theologian seems to believe that, through the work of the Holy Spirit in the world, Christ mediates the redemption of all" as He "sows the seeds of truth in the minds of every human being." O'Collins, Christology, 325. Overall, O'Collins claims that "witnessing, giving new life, teaching the truth, and commissioning on the part of the Spirit are ongoing activities that involve a constant sending by the eternal High Priest." JOP, 266. O'Collins adds, "Luke can move from cases of faithful guidance by the risen and ascended Lord (Acts 9:10-16; 18:9-10; 22:17-21) to cases of guidance by the Holy Spirit (Acts 8:29; 10:19; 16:6), without distinguishing clearly between them. He reports at least once guidance by 'the Spirit of Jesus' (Acts 16:7), in parallelism with 'the Holy Spirit' (Acts 16:6).” Ibid., 268.

${ }^{81}$ JOP, 265. Using the language of Vatican II (Lumens Gentium 8), O'Collins affirms that the church is the "visible organization" used by Christ to communicate "grace and truth" to human beings. O'Collins, Christology, 329. In this way, he considers that "the fullness of the means of salvation are to be found in the Church.” Ibid., 331.

${ }^{82}$ ST III, q. 63, a. 3. As Liam Walsh highlights, the medieval theologian identifies the activity of Christ as priest with the liturgical activity of the church. See Liam G. Walsh, "Liturgy in the Theology of St. Thomas," The Thomist 38, no. 3 (1974): 571.

${ }^{83}$ O'Collins affirms that Christ "ministers really, if under signs, in the whole sacramental system of the Church and beyond." O'Collins, Jesus Our Redeemer, 200-201. According to Aquinas, the salvific "power [virtus] of the Passion is applied to the living through the sacraments which make us like unto Christ's Passion." ST III, q. 52, a. 1, ad 2. Aquinas affirms that there are seven sacraments: baptism, confirmation, eucharist, penance, extreme unction, order (ordination), and matrimony. See $S T$ III, q. 65, a. 1. For helpful studies on sacraments in Aquinas, see Davies, The Thought of Thomas Aquinas, 345-376; Dominic Holz, "Sacraments," in The Oxford Handbook of Aquinas, ed. Brian Davies and Eleonore Stump (Oxford; New York: Oxford University Press, 2011), 448-457; Liam G. Walsh, "Sacraments," in The Theology of Thomas Aquinas, ed. Rik Van Nieuwenhove and Joseph Wawrykow (Notre Dame, IN: 
visible sacrifice on the cross, the sacraments are material instruments of the consummation of the sacrifice performed on earth by the ascended Christ. ${ }^{84}$ In fact, Christ as priest does not act only by means of the instrumentality of material objects (sacraments in general) but also through concrete human beings, the ordained priests of the church (the sacrament of holy orders), ${ }^{85}$ who act in Christ's person in the

University of Notre Dame Press, 2005), 326-364; John P. Yocum, "Sacraments in Aquinas," in Aquinas on Doctrine: A Critical Introduction, ed. Thomas G. Weinandy, Daniel A. Keating, and John Yocum (London; New York: T\&T Clark International, 2004), 159-181.

${ }^{84}$ Aquinas points out that "as in the person of Christ the humanity causes our salvation by grace, the Divine power being the principal agent, so likewise in the sacraments of the New Law, which are derived from Christ, grace is instrumentally caused by the sacraments, and principally by the power of the Holy Ghost working in the sacraments." ST IIa, q. 112, a. 1, ad 2. John Yocum formulates a Christological understanding of the sacraments in Aquinas: Christ, "the Word incarnate, in whom the Word of God is united to sensible flesh, and this union of word and sensible element is paralleled in the composition of the sacraments." Additionally, "the human being who is sanctified is also a composition of body and soul; and the sacraments are adapted to that condition, since the sacrament touches the body through the sensible element, and touches the soul through faith in the words." Yocum, "Sacraments in Aquinas," 166, 172.

${ }^{85}$ Aquinas explains that the two effects of the sacraments on human beings are grace and a character. See ST III, q. 62 and 63. The idea of the sacramental production of character, a "spiritual seal" given for a specific purpose (ST III, q. 63, a. 1, ad 1), is understood Christologically: "the character of Christ, to Whose character the faithful are likened [configurantur] by reason of the sacramental characters, which are nothing else than certain participations of Christ's Priesthood, flowing [derivatae] from Christ Himself." ST III, q. 63, a. 3. On the basis of Heb 1:3, Aquinas speaks of Christ having the character (figure, substance) of the Father. See ST III, q. 63, a. 1, ad 2. The character has two characteristics in human beings, it is eternal and instrumental. Because the priesthood of Christ is eternal, the "sanctification wrought by His Priesthood is perpetual," and therefore the character is an indelible mark imprinted in the soul. This perpetuity is not a result from the perfection of the human person (the instrument), "but from the perfection of Christ's priesthood" (the principal agent) — from the principal agent "the character flows like an instrumental power [instrumentalis virtus].” ST III, q. 63, a. 5. Considering that the purpose of a character is to receive or bestow divine gifts (ST III, q. 63, a. 3; see also q. 63, a. 2), there are two types of participation in the priesthood of Christ. While the sacraments of baptism and confirmation "confer the power to receive the other sacraments of the church" (receptive power), the sacrament of order confers the power to bestow sacraments on others (active power). ST III, q. 63, a. 6; see also q. 63, a. 2. Thus, believers participate in the priesthood of Christ by receiving the character as a receptive power through baptism (see ST III, q. 63, a. 5, ad 2), whereas priests receive the character as an active power by means of ordination (see ST III, q. 63, a. 6), which means that priests participate in Christ's priesthood as a special (active) kind of instrument. See ST III, q. 63, a. 2. Aquinas argues that a priest or "minister is of the nature of an instrument, since the action of both is applied to something extrinsic, while the interior effect is produced through the power of the principal agent, which is God." ST III, q. 64, a. 1. Similarly, O'Collins stipulates that the unique priesthood of Christ is "participated in, albeit differently, by all the baptized and by ordained ministers." JOP, 271. All the baptized share in the priesthood of Christ as they (1) offer "priestly sacrifices of praise and good works," (2) "express their priestly identity at the celebration of the Eucharist," (3) "become the means through which Christ blesses and sanctifies others," (4) offer themselves in the Holy Spirit as a living sacrifice to God and to intercede for the Church and the salvation of the whole world," and 
administration of the sacraments. ${ }^{86}$ Both sacramental objects and priests have the instrumental power to confer grace, as Christ's humanity does. Aquinas argues that the humanity of Christ is "a united instrument" due to the incarnation, while the sacraments and priests are "a separate instrument," and the grace conferred by the priest and the sacraments comes from "Christ's Godhead through His humanity." ${ }^{87}$ In accordance to the discussion above on the agent of the priesthood, this instrumental notion suggests the following logical sequence for the communication of grace from God to human beings: (1) Christ's divinity (principal agent), (2) Christ's humanity (united instrument), (3) ordained priests (separate instrument), (4) sacraments (separate instrument), (5) human body (the instrument of the soul), (6) human soul (the essence of a human being). The best example of this instrumental dynamics is the eucharist, which is the climax of the

(5) face afflictions and trials in the life of faith. Ibid., 273-279. However, through ordination, priests "share in a special way in the priesthood of Christ" (ibid., 281) and by acting "in the person of the invisible Christ" they "intercede for others as His visible representatives" (ibid., 286). The Jesuit theologian points out that Jesus "called and 'established' some of his disciples as priestly ministers who would share in a special way in his priesthood for the service of his community and the world." Even though He did that "during his ministry" and also "after his resurrection," the "defining moment in their being initiated into a priestly office" was the last supper. Ibid., 279-280.

${ }^{86}$ ST III, q. 22, a. 4. "The priests of the New Law" are "called mediators" insofar "as they are the ministers of the true Mediator by administering, in His stead, the saving sacraments to men." $S T$ III, q. 26, a. 1. For Aquinas, "Christ is the Head of all who pertain to the Church in every place and time and state; but all other men are called heads with reference to certain special places, as bishops of their Churches. Or with reference to a determined time as the Pope is the head of the whole Church." ST III, q. 8, a. 6. Likewise, O'Collins subscribes to the idea that the priests of the church are "visible signs of the invisible but dynamically present priesthood of Christ—sacraments of Christ." JOP, 286.

${ }^{87}$ ST III, q. 62, a. 5. While this text refers only to the sacraments, q. 64 , a. 3 discusses the same concept applying it both to the sacraments and to the ministers. According to Aquinas, because the humanity of Christ "is an instrument united to the Godhead in unity of Person, it has a certain headship and efficiency in regard to extrinsic instruments, which are the ministers of the Church and the sacraments." To put it differently, "Christ produces the inward sacramental effect, both as God and as man, but not in the same way." ST III, q. 64, a. 3. As God He works as the principal agent, while as man He works instrumentally, since God, and not man, is the principal agent "because God alone can enter the soul wherein the sacramental effect takes place." ST III, q. 64, a. 1. Yocum argues that, according to this perspective, the sacraments "are an extension of the effects of the incarnation. In the sacraments, God continues to act in and among human beings to life in Christ, and nourish, sustain and perfect that life in 
priestly act of the ascended Christ. ${ }^{88}$ In the eucharist, Christ, the invisible priest, acts through the instrumentality of the visible priest, ${ }^{89}$ and is particularly present through the instrumentality of the eucharistic elements (bread and wine), which are changed into His actual body and blood..$^{90}$ Because of the presence of Christ's real body and blood, the

conformity to Christ." Yocum, "Sacraments in Aquinas," 172.

${ }^{88}$ Considering that the sacraments, and actually all the liturgy of the church, are priestly acts of Christ (they derive from His priesthood), the eucharist is the climax of the priestly acts of the ascended Christ on earth because it is the apex of the sacraments and the liturgy of the church. For O'Collins, the eucharist is the center of the church's mediation of grace through preaching and sacraments. O'Collins, Christology, 332. According to Aquinas, the eucharist is the "greatest of all the sacraments." ST III, q. 65, a. 3. In his study of the eucharist in Aquinas, Levering highlights that "the Eucharist is the supreme act of Christ's priesthood: Christ as priest enables believers to share in his sacrifice, that is, to share in himself." Matthew Levering, "Aquinas on the Liturgy of the Eucharist," in Aquinas on Doctrine: A Critical Introduction, ed. Thomas G. Weinandy, Daniel A. Keating, and John Yocum (London; New York: T \& T Clark International, 2004), 191. For helpful studies on the eucharist in Aquinas, see ibid., 183-197; Brock, "St. Thomas and the Eucharistic Conversion," 529-565; Catherine Pickstock, "Thomas Aquinas and the Quest for the Eucharist," Modern Theology 15, no. 2 (1999): 159-180.

${ }^{89} \mathrm{O}$ 'Collins indicates that "in the celebration of the Eucharist ordained priests are visible signs of the invisible Christ, Priest and Victim or Offerer and Offering." JOP, 289. For Aquinas, as the "intermediary between God and the people" who performs the priestly work of delivering "consecrated gifts to the people," the minister or priest is the appointed agent to effect "the consecration of Christ's body" in the eucharist, and he does that "as in the person of Christ." ST III, q. 82, a. 3. Also, the sacrament of order is particularly "ordained to the consecration of the Eucharist." ST III, q. 65, a. 3.

${ }^{90}$ Aquinas calls this change transubstantiation, a change of substance. Through the words of consecration pronounced by the priest, "the whole substance of the bread is changed into the whole substance of Christ's body, and the whole substance of the wine into the whole substance of Christ's blood." ST III, q. 75, a. 4. On the other hand, "the accidents of the bread and wine remain after the consecration." q. 75, a. 5. For further details about this concept, according to Aquinas, see q. 75-77. Based on the concept of transubstantiation, the medieval theologian stipulates that the eucharist is the "greatest of all the sacraments," especially because "it contains Christ Himself substantially," while "the other sacraments contain a certain instrumental power which is a share of Christ's power." ST III, q. 65, a. 3. O'Collins points out that "in its Constitution on the Sacred Liturgy of 1963, the Second Vatican Council did not use the term 'transubstantiation' and listed various ways through which Christ is vitally present in liturgical celebrations. This presence comes to its highpoint with the consecrated bread and wine upon the altar and his encounter with Christians in sacramental communion." Gerald O'Collins, Catholicism: A Very Short Introduction, Very Short Introductions (Oxford; New York: Oxford University Press, 2008), 77. The Jesuit theologian follows this conception, affirming four modes of Christ's presence in the eucharist according to Vatican II (see Sacrosanctum Concilium 7): “(1) 'in the person of his minister'; (2) 'in the Eucharistic species'; (3) 'in his word since it is he himself who speaks when the holy scriptures are read'; and (4) in the assembled faithful praying and singing together." JOP, 200. Even though he does not employ the term transubstantiation, O'Collins believes in the presence of Christ in the eucharistic elements, meaning that they are changed into His body and blood. "With the eucharistic invocation ... and the words of institution, the Spirit descends upon the gifts to change them and bring about the intense and real presence of Christ for the Church and the world." O'Collins, Christology, 336. In other words, the gifts are 
eucharist is regarded a sacrifice that represents His passion and communicates its effects to the participants, ${ }^{91}$ allowing them to partake of the eternal effects of the sacrifice from Christ Himself. Hence, as the consummation of Christ's sacrifice, the eucharist is a sacrifice and a sacrament (an instrument that conveys the benefits of the sacrifice). ${ }^{92}$

Overall, O'Collins suggests a correspondence between "the permanent sacrifice in heaven with the Eucharistic sacrifice on earth," $" 93$ which implies that the continuous "offering of the eucharist" expresses "visibly the permanent priesthood of Christ that was expressed invisibly in his interceding constantly for all at the right hand of the Father." 94

changed "into the body and blood of Christ for the spiritual profit of those who receive them." O'Collins, Jesus Our Redeemer, 203.

${ }^{91}$ ST III, q. 79, a. 1. See also q. 83, a. 1. Aquinas states that the eucharist "benefits recipients by way both of sacrament and of sacrifice, because it is offered for all who partake of it." ST III, q. 79, a. 7. For the medieval theologian, "the sacrifice offered every day in the Church is not distinct from that which Christ Himself offered, but is a commemoration thereof." ST III, q. 22, a. 3, ad 2. O'Collins offers the following arguments for the eucharist as a sacrificial meal: (1) "the Last Supper integrated into" Christ's "mission a final act of service"; (2) "by the time of Jesus the festival of the Passover had long been given a sacrificial significance," which means that "to claim that Jesus (and his companions at the Last Supper) did something sacrificial would not have appeared strange talk in first-century Judaism"; (3) "through the words and gestures of the 'institution narrative' (Mark 14:22-4 parr.; 1 Cor. 11:23-5), Jesus offered a covenant sacrifice - a cultic, priestly act that he wished to be continued as a central practice in the community which he had gathered"; (4) "in the discourse on the Bread of Life, John's Gospel provides its own precious commentary on what Jesus' institution of the Eucharist intended." JOP, 258-260.

92 These two meanings of the eucharist are indicated by Aquinas in the following way: the eucharist "is both a sacrifice and a sacrament. It has the nature of a sacrifice inasmuch as it is offered up; and it has the nature of a sacrament inasmuch as it is received. And therefore it has the effect of a sacrament in the recipient, and the effect of a sacrifice in the offerer." ST III, q. 79, a. 5.

93 JOP, 199. On this point, O’Collins seems to agree with Jean-Jacques Olier (1608-1657) from the French School of spirituality. See ibid., 265-266.

94 Ibid., 66. O'Collins emphasizes that, "by connecting the bread and wine offered by Melchizedek with the eternal priesthood of Christ, Cyprian and others supported the permanent, even daily, celebration of the Eucharist." Furthermore, they promoted "that those who presided at the Eucharist shared in the one high priesthood of Christ that Hebrews presented." Ibid. The Jesuit theologian also highlights that Augustine initiated the notion of "Christ's permanent, (invisible) priestly activity . . in the daily [sacramental] life of the Church." This "priestly activity moves beyond what Paul (Rom. 8:34) and Hebrews $(7: 25 ; 9: 24)$ say about the High Priest's permanent intercession at the right hand of God on behalf of human beings. One might interpret Augustine's view of Christ's active presence in the administration of all the sacraments as developing and applying what Hebrews said about human beings 'approaching God' through the High Priest.” Ibid., 96. These statements suggest that Cyprian, Augustine and other church 
In summary, Christ's priestly actions are understood in terms of sacrifice, which is an invisible devotion or self-offering (primary) accompanied by a visible expression or sacrament (secondary). Since Christ's entire life is a self-offering to God, all His life is a sacrifice and, thus, all His actions are priestly actions. The sacramental model emphasizes two events as highly significant visible expressions of Christ's self-offering to God. The crucifixion is the climactic materialization of His earthly decisive devotion in the last supper, and the eucharist is the visible earthly expression of His invisible heavenly selfoffering (intercession) before the Father. In fact, both the crucifixion and the eucharist function as sacraments, not only as signs or visible expressions of Christ's self-offering, but also as material instruments of divine salvific action on earth that reaches concrete human beings. Through Christ's human suffering, human beings turn their attention to spiritual realities that are communicated to them especially in the eucharist, by means of concrete priests and eucharistic elements. Indeed, if crucifixion and eucharist function as sacraments of Christ's self-offering, the eucharist is not a repetition of the sacrifice on the cross, because both of them are expressions of His invisible sacrifice. Concisely, Christ's priestly action is an internal disposition that takes the form of visible actions, by means of material instruments, in order to reach concrete human beings.

\section{The Goal of the Priesthood}

Generally speaking, the goal of Christ's priesthood in the sacramental model is to lead human beings to God, who is the goal of all creation. In the description of this goal, I will clarify two important aspects of His priesthood: (1) how this goal is attained through 
Christ's priesthood, and (2) how the attainment of this goal is compatible with the idea that His priesthood is eternal. In fact, the description of the previous components of Christ's priesthood (need, agent, actions) already pointed to the goal of His priesthood. I have emphasized above that there is an ontological and moral distance between human beings and God (the need), implying that Christ's priestly mediation is meant to provide ontological and moral union. This union is understood in terms of participation. ${ }^{95}$ Actually, all creation participates in God since its beginning, in the sense that He is the source of its being and existence. ${ }^{96}$ However, creatures do not participate in God only as their source, but also as their goal. ${ }^{97}$ In other words, the participation existing in creation implies a teleological higher participation. ${ }^{98}$ Aquinas emphasizes that this teleological participation requires divine grace, because human beings need "to receive in addition

\footnotetext{
${ }^{95}$ In his study of deification in Aquinas, Williams points out that union and participation are interchangeable terms in the discussion of theosis. Williams, The Ground of Union, 52.

${ }^{96}$ According to O'Collins, "we cannot participate in the material universe, without participating in God, the inmost ground of all being." O'Collins, Jesus Our Redeemer, 256. Aquinas highlights that "all beings apart from God are not their own being, but are beings by participation." Thus, "all things which are diversified by the diverse participation of being, so as to be more or less perfect, are caused by one First Being, Who possesses being most perfectly." ST I, q. 44, a. 1. Commenting on Aquinas, Williams argues that "participation in divine life occurs initially not as the sanctifying work ... but in order for the creature to exist at all," which means that the participation implied in creation provides "the base for all other varieties or degrees of participation in divine being." Williams, The Ground of Union, 66.

${ }^{97}$ O'Collins highlights that God is the "source and goal" of all creation. This means that "human existence is a lifelong pilgrimage towards God." O'Collins, Jesus Our Redeemer, 28. Similarly, Aquinas affirms that God "is the last end of all." ST IIa.62.2. According to O'Neill, "the master-concept of the Summa" is that God "is the goal of man's life in life everlasting, God as he is the point to which all our universe is tending, whether unconsciously and in obedience to a law of development written into its being, or consciously and in freedom." Aquinas and O'Neill, The One Mediator, xxi.

${ }^{98}$ An important example of this concept of the image of God (imago Dei) in human beings. Aquinas' statement that "likeness is a kind of unity" (ST I, q. 93, a. 9) indicates that humans participate in God by creation. On the other hand, the teleological participation is highlighted by O'Collins when he points out that "final redemption will complete the being made in the image and likeness of God." O’Collins, Jesus Our Redeemer, 197.
} 
something supernatural to direct" them "to a supernatural end." 99 This divine aid includes the infusion of supernatural/theological virtues by God and implies a kind of participation in the divine nature. ${ }^{100}$ In this context, grace means God's self-communication, which lifts human beings to a higher participation in Him. ${ }^{101}$ The final goal of the teleological participation is the beatific vision of God experienced by human beings in heaven, ${ }^{102}$ which requires God's union with the human intellect. ${ }^{103}$ All this description of the

${ }^{99}$ ST IIa, q. 62, a. 3.

${ }^{100}$ Aquinas calls these virtues "theological virtues" (charity, faith, and hope). They "surpass the nature of man" (ST IIa, q. 62, a. 1, ad 1), "are infused in us by God," and "direct us aright to God." This reception of God's powerful aid is considered "a kind of participation of the Godhead" (2 Pet 1:4). ST IIa, q. 62 , a. 1 .

${ }^{101}$ O'Collins affirms that "all divine giving is self-giving." O'Collins, Jesus Our Redeemer, 197. Hence, grace is the "the self-communication of God" meant for "the deification of human life (2 Pet 1:4)," lifting "to a new and undeserved level the relationship of creature to creator, thereby transforming human nature ... and anticipating the future life of heaven." CDT, 3 ed. (2013), s.v. "grace." According to Aquinas, "faith, hope, and charity," the theological virtues, "are superhuman virtues: for they are virtues of man as sharing in the grace of God." ST IIa, q. 58, a. 3, ad 3. The medieval theologian explains that "the gift of grace surpasses every capability of created nature, since it is nothing short of a partaking of the Divine Nature." q. 112, a. 1. Commenting on Aquinas, Williams claims that grace is "not an entity distinct from God or an effect of God's working in us but the fact of God's indwelling, the name given to the sustenance that is God's own being." He adds, "although Thomas does not equate grace and God, he does not use the term grace as to distinguish it from divine being itself, shared with creatures." Williams, The Ground of Union, 84. Similarly, Rudi te Velde argues that "grace, according to Thomas, is the free gift of God himself to man by which man becomes united with God in knowledge and love. It is through the gift of grace that man achieves his ultimate perfection which consists in the vision of God." Rudi te Velde, "Deelgenoot Van De Goddelijke Natuur": Genade En Participatie Bij Thomas Van Aquino," Tijdschrift voor Filosofie 55, no. 4 (1993): 632.

102 O'Collins explains the "beatific vision" as the "immediate and fulfilling vision of God in heaven that will constitute the core of eternal happiness for the redeemed." $C D T, 3$ ed. (2013), s.v. "beatific vision." For him, 2 Pet 1:3-4 offers a "striking picture of grace as sharing in the very being or nature of God," and encourages "the notion of the ultimate happiness of the redeemed as seeing God "face to face."” O'Collins, Jesus Our Redeemer, 197. Aquinas claims that, in heaven, "glorified eyes will see God" (ST I, q. 12, a. 3, ad 2). In other words, "the blessed see the essence of God" (q. 12, a. 1), enjoying "Him as the ultimate fulfilment of desire" (q. 12, a. 7, ad 1). The medieval theologian believes that God can only be seen by human beings in the next life because in the present life their soul "has its being in corporeal matter" (human corporeal body), "hence naturally it knows only what has a form in matter." Therefore, "God cannot be seen in His essence by a mere human being, except he be separated from this mortal life." q. 12, a. 11. Based on this assumption, Aquinas concludes that "when Jacob says, 'I have seen God face to face,' this does not mean the Divine essence, but some figure representing God." q. 12, a. 11, ad 1.

${ }^{103}$ According to Aquinas, "those who see the divine essence see what they see in God ... by the divine essence itself united to their intellect." ST I, q. 12, a. 9. To put if differently, "created intellect cannot 
ontological union of human beings with God is related to Christ's priesthood.

Considering that "the ultimate goal of salvation" is "a totally fulfilling union with God

through Christ," ${ }^{104}$ the divine gifts that make human beings participants of the divine

nature are bestowed on them through Christ the priest. ${ }^{105}$ Through His priestly mediation

in heaven, "the blessed enjoy the vision of God.",106

As mentioned before, the priesthood of Christ brings about a moral union between

human beings and God. By addressing the sin/moral problem His priesthood can

ultimately generate the ontological union with God, ${ }^{107}$ as sin hinders the teleological

movement of human beings toward God. ${ }^{108}$ O'Collins highlights that "sin stops us from

responding to God's call and receiving the divine gifts" ${ }^{\prime 109}$ that lift human beings to a

see the essence of God, unless God by His grace unites Himself to the created intellect, as an object made intelligible to it." q. 12, a. 4. This union is conceived as "some kind of participated likeness of Him who is the first intellect". q. 12, a. 2. Furthermore, he explains this conception by indicating that "divine grace" is "added" to "raise up" or supernaturally increase the human "intellectual powers." q. 12, a. 5. In his study of Aquinas, Velde attempts to answer the following question, "How can man (as a finite intellect) be understood to attain his ultimate perfection of seeing God's infinite essence, if this vision is only connatural to an infinite intellect?" His answer implies that divine grace does not "perfect man in relation to his human nature." Rather the human act of seeing God is related "to the divine nature as participated in him by grace." Therefore, it is only "by receiving a participated likeness of God" that "the human intellect (and will)" is "capable of an act with respect to God himself." Velde, "Deelgenoot Van De Goddelijke Natuur," 632-633.

${ }^{104}$ O’Collins, Jesus Our Redeemer, 47.

105 Aquinas argues that a priest is "a mediator between God and the people" in the sense that the priest "bestows Divine things on the people." He emphasizes that Heb 5:1 depicts the priestly work as offering gifts. His conclusion is that "this is most befitting to Christ. For through Him are gifts bestowed on men, according to 2 Peter $1: 4$." ST III, q. 22, a. 1.

${ }^{106}$ JOP, 265.

${ }^{107}$ Commenting on Aquinas, O’Neill points out that, "through his human service to the Father," Christ "restores to the created image of God that inner dynamism which bears all creation towards its fulfillment in God." Aquinas and O'Neill, The One Mediator, xxii.

${ }^{108}$ See the section on the need for Christ's priesthood above.

${ }^{109}$ O’Collins, Jesus Our Redeemer, 47. 
higher participation in the divine nature. Aquinas argues that the human sinful condition requires that these divine gifts be mediated through material instruments. ${ }^{110}$ First, this condition explains the priestly mediatorial role of Christ's material human nature (the agent). Actually, the medieval theologian assumes that the incarnation was the most fitting way of healing human beings, highlighting that it enkindles the theological virtues (faith, hope, and charity) in them, and emphasizes that the humanity of Christ bestows on them a participation in God. ${ }^{111}$ Second, the human fallen condition indicates why His priestly action (essentially a self-offering) takes a visible form by means of material instruments (His suffering humanity on the cross, ${ }^{112}$ and His activity through ordained priests and the sacraments). ${ }^{113}$ Interestingly, the notion of Christ's sacrifice as an invisible self-offering out of charity ${ }^{114}$ is clarified by the idea that this is the most excellent of the theological virtues, ${ }^{115}$ and therefore the most important virtue for participation in God. ${ }^{116}$ Accordingly, what the material instruments of Christ's priestly action really mediate is a

${ }^{110}$ See the section on the need for Christ's priesthood above.

111 This statement describes in large measure the reasons that Aquinas presents for Christ's incarnation in ST III, q. 1, a. 2.

112 In his remarks on believers' "devotion by considering Christ's passion," Aquinas stipulates that "such is the weakness of the human mind that it needs a guiding hand, not only to the knowledge, but also to the love of Divine things by means of certain sensible objects known to us. Chief among these is the humanity of Christ," which is the main "incentive to devotion." ST IIb, q. 82, a. 3, ad 2.

${ }^{113}$ See section above about the actions of Christ's priesthood.

${ }^{114}$ See section above about the actions of Christ's priesthood.

${ }^{115}$ ST IIb, q. 23, a. 6.

${ }^{116}$ In his study of Aquinas, Williams argues that charity is "the most deifying" virtue. Williams, The Ground of Union, 159. The medieval theologian maintains that "charity attains God, it unites us to God.” ST IIb, q. 23, a. 3. Indeed, charity “is a participation of the Holy Ghost.” q. 23, a. 3, ad 3. 
participation in the divine nature. ${ }^{117}$ The notion of participation seems even to qualify the instruments for this mediation. ${ }^{118}$ Indeed, the eucharist offers a clear example of participation in the divine nature: as human beings partake of this sacrament through their bodies, they actually receive in their souls the divine Christ (idea of union, participation), who in His humanity is instrumentally present in the eucharistic elements. ${ }^{119}$

Overall, the idea that Christ's priesthood is basically a material mediation for a participation in the divine nature highlights the moral and ontological union promoted by His priesthood. While the material mediation of divine grace is required by the $\sin / \mathrm{moral}$ problem (Aquinas), a higher participation in the divine nature constitutes the ontological goal of creation. Nevertheless, this conception raises the following question regarding the eternity of Christ's priesthood, which is assumed in the sacramental model: Why is His priesthood eternal if the material mediation is required by the human fallen condition? Is the priesthood really necessary for the saved in heaven? A key point in this discussion is the priestly mediatorial role of Christ in the beatific vision of God. In the sacramental model, the blessed in heaven enjoy the vision of God through Christ's eternal priesthood.

\footnotetext{
${ }^{117}$ O'Collins points out that the sacraments have a "special role" in the life of grace, which is "the deification of human life (2 Pet 1:4)." CDT, 3 ed. (2013), s.v. "grace." Aquinas indicates that the sacraments cause grace, which "is nothing else than a participated likeness of the Divine Nature." ST III, q. 62, a. 1. In his study of deification in Aquinas, Williams claims that the sacraments are the "way in which the grace of the hypostatic union is communicated, to the end of a wider union of humanity with God." Williams, The Ground of Union, 92.

118 According to Aquinas, "the nearer any recipient is to an inflowing cause, the more does it partake of its influence." ST III, q. 7, a. 1. In the case of the humanity of Christ, it participates in His divine nature. See q. 9, a. 2, ad 1; q. 16, a. 5, ad 3; q. 59, a. 4, ad 3. Moreover, the ordained priests participate in Christ's priesthood. See footnote 85 above.

119 Aquinas assumes that "we communicate with Christ through" the eucharist, "because we partake of His flesh and Godhead ... through it." ST III, q. 73, a. 4. Moreover, through this sacrament human beings "may stand perfect . . . by union with God." q. 79, a. 1, ad 1. Commenting on Aquinas, Williams calls the eucharist the "locus of union with God." Williams, The Ground of Union, 93.
} 
Aquinas and O'Collins interpret the eternity of this priesthood with specific emphases, namely, eternity in terms of its eternal effects ${ }^{120}$ (Aquinas) and in terms of His eternal humanity ${ }^{121}$ (O'Collins). In the first emphasis, the vision of God is an eternal effect of the priesthood. The saved/blessed enjoy this vision in heaven as an eternal result of the benefits they received on earth through Christ's priestly material mediation. This material mediation is not necessary anymore because human beings return to their original condition before sin, in which the participation in the divine nature does not need to be mediated by material instruments. ${ }^{122}$ According to the second emphasis, the vision of God is mediated through Christ's eternal glorified humanity. This emphasis implies an eternal need of some kind of (glorified) material mediation. This perspective is aligned with the conception that the material mediation of Christ does not bring human beings to

\footnotetext{
120 "Although Christ's passion and death are not to be repeated, yet the virtue of that Victim" (sacrifice) "endures for ever." q. 22, a. 5, ad 2. This virtue or effect is understood by Aquinas as the end or consummation of Christ's sacrifice. Following this perspective, he argues that "the Saints who will be in heaven will not need any further expiation by the priesthood of Christ, but having [been] expiated, they will need consummation through Christ Himself, on Whom their glory depends." q. 22, a. 5, ad 1. Commenting Aquinas, Levering highlights, "because of what it achieves, Christ's priesthood endures forever," meaning that "it endures in its end or goal." More specifically, "when the goal is achieved, the action that brought about the goal is not lost, but instead shares in its completion or consummation." Hence, "eternal life belongs to Christ's priestly action as its goal, and in this sense Christ's priesthood endures everlastingly. Eternally, the consummation enjoyed by the saints in heaven depends upon Jesus Christ." Levering, "Christ the Priest," 394-395.

${ }^{121}$ In his remarks on the "ultimate destiny" of all human beings, O'Collins claims that they will share through Christ "in the divine life forever. In his glorified humanity he will remain the means by which the blessed know the Trinity and enjoy the fullness of salvation." O'Collins, Jesus Our Redeemer, 225. The Jesuit theologian adds, "In his glorified humanity Christ will remain eternally the Agent ... through whom human beings will . . enjoy divine life forever." JOP, 269.

${ }^{122}$ This conclusion is based on Aquinas' view that before sin, human beings did not need material instruments (sacraments) to receive grace. Rather, they could obtain it "in a spiritual and invisible manner." There was no need of "sensible signs" (sacraments). ST III, q. 61, a. 2, ad 1. In contrast to this conclusion, Paul O'Callaghan argues, based on some remarks about Aquinas, that "it is reasonable to suppose that the instrumental action of the humanity of Christ is in some way involved in the reception and maintenance of the perpetual vision of God." Paul O'Callaghan, Christ Our Hope: An Introduction to Eschatology (Washington, DC: Catholic University of America Press, 2011), 186. Even though I grant that this position can be articulated on the basis of some concepts offered by Aquinas, I find it difficult to affirm that this is
} 
a supposed original condition. ${ }^{123}$ Rather, this mediation is an intended characteristic of the participation of finite creatures in the infinite God. ${ }^{124}$

In summary, the goal of Christ's priesthood is to provide union, that is, the teleological participation of human beings in God. The divine Christ mediates this participation through material instruments. The material mediation achieves the final goal of participation in heaven as a result of its eternal effects (Aquinas) and as an intended characteristic of the eternal participation of creatures in God (O'Collins).

Having provided this general depiction of the priesthood of Christ in the sacramental model, I move to the description of this priesthood in the functional model.

\section{The Functional Model}

The model depicted in this section is labeled functional due to the fact that a prominent notion in the comprehension of Christ's priesthood in this model is that Christ's priestly work is performed in two distinct and sequential functions, namely, (earthly) sacrifice and (heavenly) intercession. The emphasis of this model seems to be

actually his position.

${ }^{123}$ O'Collins questions the idea of an original sinless condition of human beings to be recovered by redemption. In his interpretation of redemption in Paul he claims that "reconciliation means 'bringing hostility to an end' or 'uniting those who were formerly separated', and not necessarily 'causing to be friendly again' or 'bringing back into harmony'. In other words, this Pauline language does not necessarily suppose an original state of harmony that was ruptured." O'Collins, Jesus Our Redeemer, 12. In this way, the Jesuit theologian affirms that "redemption should not be taken as a divine rescue operation, mounted subsequently after an original plan of creation went astray." O’Collins, Christology, 211.

${ }^{124}$ This idea is compatible with the notion that redemption does not restore an original human condition in creation, but is a progressive "continuity in the newness . . . through the one plan of God." In this perspective of creation preparing the ground for redemption, "the creation of the world and humankind provided the possibility for the Son of God to assume a human nature." O'Collins, Jesus Our Redeemer, 35. This association of creation and incarnation seems to be different from Aquinas' association of sin and creation ("the work of the Incarnation was ordained by God as a remedy for sin; so that, had sin not existed, the Incarnation would not have been." ST III, q. 1, a. 3). These two notions of incarnation appear to imply two distinct conceptions of Christ's priestly material mediation, which is primarily characterized by the 
on the process of the priesthood. While proponents of the sacramental model could argue that these functions are also found in their model, defenders of the functional model would probably answer that these two functions are not distinguished enough in the sacramental model. I will unpack this crucial notion in my treatment of the functional model both here and in the next chapter. The representatives selected for the functional model are the German theologian Martin Luther ${ }^{125}$ (1483-1546) and the French theologian John Calvin ${ }^{126}$ (1509-1564). I will describe their interpretations of each

incarnation: one is meant to improve original creation (O'Collins) and the other to deal with sin (Aquinas).

${ }^{125}$ The texts in which Luther engages in an extensive discussion about priesthood and its relationship with Christ are his lectures on the book and Genesis (given from 1535 to 1545), and his commentaries on Psalm 110 (a series of eight sermons preached in 1535). For useful descriptions of the priesthood of Christ in Luther, see Jones, Toward a Christology of Christ the High Priest, 165-190; Alberto R. Timm, "The Priesthood of Christ According to Martin Luther," in Christ, Salvation, and the Eschaton: Essays in Honor of Hans K. LaRondelle, ed. Daniel Heinz, Jiri Moskala, and Peter M. van Bemmelen (Berrien Springs, MI: Seventh-Day Adventist Theological Seminary, 2009), 171-187; Alberto R. Timm, "El Sacerdocio De Cristo Y De Todos Los Creyentes Según Martín Lutero," Theologika 10, no. 1 (1995): 2-47. Overall, "a theological break or departure is sometimes discerned within Luther's scholarship between the 'early' Luther and the 'later' Luther. The idea is that the Reformer started with a view of the gospel that stressed spiritual warfare, the principalities and powers of the world against the authority and command of Christ, the overthrow of human strongholds by means of the exorcising power of God. The 'early' Luther also stressed a theology of glory, i.e., of victory. The 'later' Luther moved more into ideas like forensic forgiveness and justification, imputation and also economic theories of the Atonement." Paul F. M. Zahl, The First Christian: Universal Truth in the Teachings of Jesus (Grand Rapids, MI: Eerdmans, 2003), 26n14. Probably, "Ritschl was the first to study Luther and his work with an evolutionary lens, distinguishing the early Luther from the later Luther, and separating Luther from Melanchton and the later confessional and dogmatic writings." Mary Elizabeth Anderson, Gustaf Wingren and the Swedish Luther Renaissance, American University Studies 243 (New York: Peter Lang, 2006), 14. Overall, the break between the 'two Luthers' is placed at 1517-1518. Bernhard Lohse, Martin Luther: An Introduction to His Life and Work, trans. Robert C. Schultz (Philadelphia: Fortress, 1986), 144-145. Even though Lohse acknowledges that Luther's writings evidence "further development, precising, clarifying," and "shifts in accent," he indicates that "earlier and frequent attempts at sharply differentiating the 'young' and the 'old' Luther, at precisely dating the difference between them, a problem in and of itself, have in general been abandoned. On the whole, there is considerable consistency and continuity of views where Luther is concerned." Bernhard Lohse, Martin Luther's Theology: Its Historical and Systematic Development, trans. Roy A. Harrisville (Minneapolis: Fortress, 2011), 8. In the present dissertation, Luther's writings are studied from this perspective of continuity.

${ }^{126}$ Calvin's main discussion on the priesthood of Christ appears in ICR 12.15.6. For helpful introductions on this topic in Calvin, see Stephen Edmondson, Calvin's Christology (Cambridge; New York: Cambridge University Press, 2004), 89-114; Jones, Toward a Christology of Christ the High Priest, 190-217; Redding, Prayer and the Priesthood of Christ in the Reformed Tradition, 82-106; Robert A. Peterson, Calvin's Doctrine of the Atonement (Phillipsburg, NJ: Presbyterian and Reformed Publishing 
component of the formal structure of Christ's priesthood, starting with the need for His

priesthood.

\section{The Need for Christ's Priesthood}

The priesthood of Christ in the functional model is required by a sharp rupture in the personal relationship between human beings and God. ${ }^{127}$ This broken relationship is a consequence of human sin. ${ }^{128}$ Because of sin, an important aspect of such a rupture of is

Company, 1983), 54-60; Paul Van Buren, Christ in Our Place: The Substitutionary Character of Calvin's Doctrine of Reconciliation (Edinburgh: Oliver \& Boyd, 1957), 66-73, 89-91; John Frederick Jansen, Calvin's Doctrine of the Work of Christ (James Clarke \& Co.: London, 1956), 93-97; James B. Torrance, "The Vicarious Humanity and Priesthood of Christ in the Theology of John Calvin," in Calvinus Ecclesiae Doctor, ed. W. H. Neuser (Kampen, Netherlands: J. H. Kok, 1978), 69-84; Charles Partee, The Theology of John Calvin (Louisville; London: Westminster John Knox Press, 2008), 164-167. For a more recent and specific study on Christ's priesthood in Calvin, see John Christian Clark, "The Priestly Office of Jesus Christ in the Thought of John Calvin," (Ph.D. Dissertation, The University of Toronto, 2013).

${ }^{127}$ This focus on relation is particularly perceived in the Protestant relational understanding of divine grace in human beings, the solution for the problem of the broken relationship. Kathryn Tanner highlights the "Protestant preference for an account of the effects of grace that stresses the creature's changed relationship with God rather than the transformation of the creature's own powers," which is the emphasis of the sacramental model in the present dissertation. Kathryn Tanner, God and Creation in Christian Theology: Tyranny or Empowerment (Minneapolis, MN: Fortress Press, 2005), 103; italics mine. Luther privileges the category of relation over that of substance. In his words, "a Christian is not inwardly and essentially (instrinsece et formaliter) holy. Neither is holiness a category of substance but of relation (praedicamento substantiae sed relationsi); it is given freely in mercy, simply by confessing and acknowledging that God is merciful to sinner." WA 40/II: 354, 2-5 (comments on Ps 51:4, 1532). Translation taken from Oswald Bayer, Theology the Lutheran Way, trans. Jeffrey G. Silcock and Mark C. Mattes, Lutheran Quarterly Books (Grand Rapids, MI: Eerdmans, 2007), 249-250n420. Peter Wyatt sees the same emphasis in Calvin. He argues that "Calvin puts the matter in terms of relation rather than ontology, and he speaks of our need of a mediator rather than for (abstract) grace." Peter Wyatt, Jesus Christ and Creation in the Theology of John Calvin, Princeton Theological Monograph Series (Allison Park, PA: Pickwick Publications, 1996), 39. Gehard Ebeling sees in Luther a "relational ontology" that is in many ways opposed to Aristotelian "substance ontology." Gerhard Ebeling and Scott A. Celsor, "Luther's Understanding of Reality," Lutheran Quarterly 27, no. 1 (2013): 71. On the other hand, following the Finnish school of Luther interpretation, Antti Raunio rejects a "contradiction between substantial and relational ontology" in Luther. He stipulates that Luther "understood the terms 'substance' and 'relation' as Aristotelian categories," and that "a relational ontology as an alternative to substantial ontology is in fact a more or less a Kantian idea, which was developed further by Hegel." Antti Raunio, "The Human Being," in Engaging Luther: A (New) Theological Assessment, ed. Olli-Pekka Vainio (Eugene, OR: Wipf and Stock, 2010), 29.

${ }^{128}$ L'ubmoír Batka points out that, for Luther, "original sin is primarily a broken relationship with God that is deep-rooted in the human heart from the beginning of life." L'ubmoír Batka, "Luther's Teaching on Sin and Evil," in The Oxford Handbook of Martin Luther's Theology, ed. Robert Kolb, Irene Dingel, and L’ubmoír Batka (Oxford; New York: Oxford University Press, 2014), 242. 
God's reaction against sinful human beings. More specifically, sin causes God to react as

a wrathful judge that condemns sin and sinners. Indeed, sinful human beings are afraid of

God's judgment against them. ${ }^{129}$ As they are guilty before Him, not even their prayers

have access to God. This picture underlines their need for a priestly mediator. Through

his mediation, God can hear human prayers, and human beings can have their guilty

conscience quieted. ${ }^{130}$

This situation raises the question about the nature of sin, and why it leads to such

a personal rupture between God and human beings. In contrast to the sacramental model,

the basic understanding of $\sin$ in the functional model is not an anthropological disorder

${ }^{129}$ Luther emphasizes that Christ as "our priest" reconciles "God with us and quietened our conscience." $L W, 52: 280$ (sermon on Matthew 2:1-12, 1522). Furthermore, the fact that Christ "is our Priest," which means that God is not "angry with us" anymore, "is by far the sweetest and greatest comfort for consciences." $L W, 20: 71$ (Lectures on Zechariah, 1526). The German theologian seems to identify God's wrath with the condemnation of His law against human sin. In his words, human beings "are all under sin and God's wrath, and are condemned by the Law." LW, 24:342 (Sermons on the Gospel of St John [14-16], 1537). In fact, he speaks of the "wrath of the Law." In this context, there is a "terror of the conscience before the Law" or a "struggle of conscience" that "feels the wrath and judgment of God over the sin that the Law discloses and increases." LW, 26:324-325 (Lectures on Galatians [1-4], 1535). All quotations of $L W$ are taken from Martin Luther, Luther's Works, ed. J. Pelikan, H. Lehmann, and Hilton C. Oswald, American ed., 55 vols. (Saint Louis, MO; Philadelphia: Concordia; Fortress, 1955-1986).

Likewise, Calvin maintains that Adam's sin "provoked the wrath of God" "to inflict . . . fearful vengeance on the whole human race." ICR 2.1.4. For sinful human beings without a mediator, "no way and no access to God remain; nothing is left in his throne but wrath, judgment, and terror." Ibid., 3.20.19. The French theologian explains that sinful human "minds are first struck and overwhelmed by fear of God's wrath and by dread of eternal death." Ibid., 2.16.2. Indeed, "apart from Christ, God is . . hostile to us, and his hand is armed for our destruction." Ibid. Calvin adds, "God, who is the highest righteousness, cannot love the unrighteousness that he sees in us all. All of us, therefore, have in ourselves something deserving of God's hatred.” Ibid., 2.16.13. All quotations of ICR are taken from John Calvin, Institutes of the Christian Religion, ed. John T. McNeill, trans. Ford Lewis Battles, 2 vols. (Philadelphia: Westminster Press, 1960).

${ }^{130}$ In Calvin's words, without Christ "as our High Priest", "we or our prayers have no access to God." ICR 2.15.6. "No prayer is pleasing to God unless this Mediator sanctifies it." Ibid., 3.20.27. He adds, "no one can be helped by any prayers at all save when Christ intercedes." Ibid., 3.20.19. Similarly, Luther argues that "we cannot come before God with our prayers without" Christ the "Mediator." $L W, 24: 406$ (Sermons on the Gospel of St John [14-16], 1537). See also ibid., 24:397, 407; 8:277; 35:99-100. He argues that "without this Mediator no prayer is acceptable to God," and that Christ "presents their prayers before God, and they become acceptable and are heard for His sake." LW, 13:332, 334 (Commentary on Psalm $110,1535)$. 
caused by a lack of divine grace or original justice. ${ }^{131}$ Instead of a mere disorder that alienates human beings from God as their end, sin is essentially a personal attitude of a depraved human being against God as the sovereign ruler. ${ }^{132}$ This attitude is particularly defined as unbelief, which doubts and despises God's word, making Him a liar. ${ }^{133}$ In fact, Luther stipulates that God deals with human beings through His word in two ways, as

${ }^{131}$ For Calvin, "those who have defined original sin as the want of the original righteousness which we ought to have had, though they substantially comprehend the whole case, do not significantly enough express its power and energy. For our nature is not only utterly devoid of goodness, but so prolific in all kinds of evil, that it can never be idle." ICR 2.1.8. In this way, human nature is not only "wounded, but so corrupted, that mere cure is not sufficient. There must be a new nature." Ibid., 2.1.9. According to G.C. Berkouwer, for the Reformers, "sin is more than a 'defect in general' and is always an active, dynamic and destructive force. Thus sin ... was not a mera privatio. Rather, precisely as privation it was seen as a vitiositas, despoilment, or corruptio totalis." Berkouwer adds, "The carentia-idea, as used in Catholic theology, had come to mean the loss of the donum superadditum and was very different from the biblical corruptio totalis. Therefore that concept came to have a certain negative flavor. In the Reformers there remained a connection or identity between the privatio and corruptio while in Catholic theology these two were held apart." G. C. Berkouwer, Sin, Studies in Dogmatics (Grand Rapids, MI: Eerdmans, 1971), 259260. Oswald Bayer argues that, for Luther, "sin has a qualitative nature and is not simply deficit, as if something good is lacking, so that one minimizes the intensity of one's being." Oswald Bayer, Martin Luther's Theology: A Contemporary Interpretation (Grand Rapids, MI: Eerdmans, 2008), 180.

${ }^{132}$ Calvin speaks of human sin as a revolt "against the authority of God" (ICR 2.1.4) and Luther maintains that sin "would not be sin if it did not offend God" ( $L W, 14: 316$ [comments on Ps 2, 1519]). For the German theologian, "the real nature of $\sin$ " is that it is "an attack on God as God." Althaus, The Theology of Martin Luther, 169.

${ }^{133}$ In his remarks on the fall, Calvin defines the human revolt against God's authority especially in terms of "despising His word. Instead of hanging upon God's lips, Adam was "incredulous as to his word," doing the "very utmost to annihilate the whole glory of God." ICR 2.1.4. According to Luther, "there must first be in the heart faith or unbelief. Unbelief is the root, the sap, and the chief power of all sin." $L W$, 35:369 (Preface to the Epistle of St. Paul to the Romans, 1522). He explains that "unbelief is certainly the principal sin of mankind. It was the first sin committed in Paradise . . When Adam and Eve had God's Word, which they were obligated to believe and in which they also had God and life as long as they clung to it, they were tempted first of all, by unbelief toward this Word. . . First of all, the devil attacks their faith by telling them to give up this Word and not to regard it as God's Word. He is not interested primarily in the bite into the forbidden apple; it is his concern to lead them from faith, in which they were walking before God, into unbelief, from which disobedience and every other sin would necessarily follow as fruits." $L W, 24: 343$ (Sermons on the Gospel of St John [14-16], 1537). For the German theologian, unbelief in God's promise is the greatest "rebellion against God" because it makes "God a liar." $L W, 31: 350-351$ (The Freedom of a Christian, 1520). For further instances where Luther defines sin as unbelief, see $L W, 14: 84$; $35: 369 ; 24: 341,343-344 ; 31: 347,362$. Batka outlines the development of Luther's conception of sin in the following way: "Early in his lecturing career Luther understood the lack of belief as active resistance against the judgment of God," namely, "the law's judgment that a person is a sinner. . . From 1519, in light of his newly developed reformational teaching, his understanding of unbelief deepened. It became an active resistance against the gospel, blasphemy against Christ, a refusal of grace, an abomination of the promise." Batka, "Luther's Teaching on Sin and Evil," 242. 
they correspond to the two forms of His word, namely, gospel and law. ${ }^{134}$ In the first

case, God manifests His grace in the form of promise; in the second, He condemns

sinners in His righteous wrath. ${ }^{135}$ In this view, sin started as unbelief in God's word (an

attack on God's integrity), causing His wrath (condemnation of sinners), and the solution

\footnotetext{
${ }^{134}$ Luther divides "Christian doctrine into two parts, law and gospel," which means that "there are two things set before us in God's Word . . the wrath or the grace of God, sin or righteousness, death or life, hell or heaven." WA 39/I: 361, 1-6 (first disputation against the Antinomians, 1537). Translation taken from Lohse, Martin Luther's Theology, 268. He also affirms that "the words of God . . . mean both the law and the gospel, the law requiring works and the gospel faith." $L W, 33: 105$ (On the Bondage of the Will, 1525). Ebeling emphasizes that, in Luther, the "one Word of God is to be differentiated in its disclosure as law and gospel." Ebeling and Celsor, "Luther's Understanding of Reality," 66. See also Althaus, The Theology of Martin Luther, 251-265. Likewise, Calvin maintains a distinction between gospel and law, especially on the basis of Paul's discussion of the law as a curse. See ICR 2.9.4. However, there are some differences between Luther and Calvin regarding this distinction, which I indicate in the footnote below.

${ }^{135}$ For Luther, "sin is to be dealt with either according to the law, or according to the gospel." When treated "in terms of law alone, it is wrath and death, but if in terms of the gospel alone, it is grace and life." LW, 32:230 (Against Latomus, 1521). According to Ebeling, "as law, what the Word says is not merely given, but rather what it demands from humans and from one's actions. In the gospel God indeed gives his Word, but only his Word. In one case, a mere order, in the other, a mere promise." Ebeling and Celsor, "Luther's Understanding of Reality," 66. See also Althaus, The Theology of Martin Luther, 251265. Similarly, Calvin points out that the gospel refers to "all the promises by which God reconciles men to himself" (ICR 2.9.2), while the law is associated with the wrath of God, destruction of sinners, accusation, guilty conscience (2.7.7), despair (2.7.4), curse (2.7.3, 7), condemnation (2.7.4, 6, 8), and death (2.7.3). However, the French theologian argues that this aspect of the law is "experienced by sinners not yet regenerated" (2.7.7), which means that the contrast between gospel and law is not absolute. In fact, Calvin sees a positive role of the law for the regenerate "in whose hearts the Spirit of God already flourishes and reigns," as the law enables "them daily to learn with greater truth and certainty what that will of the Lord is." (2.7.12). In this case, Calvin stipulates that the promises of the gospel "occur throughout the law." (2.9.2). This positive role of the law in the believer is what the French theologian calls the "third use of the Law," which is "the principal use" of the law, "and more closely connected with its proper end." (2.7.12). Scholars generally indicate that the third use of the law adopted by Calvin is the main difference between Luther and him on the relationship of gospel and law. See, e.g., Edward A. Dowey, "Law in Luther and Calvin," Theology Today 41, no. 2 (1984): 148, 151, 153; Jesse Couenhoven, "Grace as Pardon and Power: Pictures of the Christian Life in Luther, Calvin, and Barth," Journal of Religious Ethics 28, no. 1 (2000): 69. Conversely, Althaus and Lohse claim that the concept of this third use, not the expression itself, is found in Luther. Althaus, The Theology of Martin Luther, 273; Lohse, Martin Luther's Theology, 275. In my opinion, the basic difference between Luther and Calvin on this point is that they disagree, at least, on what the main function of the law is. For Calvin, as highlighted above, the principal function of the law is its positive role in the life of believers (the third use). On the other hand, for Luther, the chief function of the law is its negative role. In his words, "the true function and the chief and proper use of the Law is to reveal to man his sin, blindness, misery, wickedness, ignorance, hate and contempt of God, death, hell, judgment, and the well-deserved wrath of God." Hence, "the proper and absolute use of the Law is to terrify," which means that "when the Law is being used correctly, it does nothing but reveal sin, work wrath, accuse, terrify, and reduce the minds of men to the point of despair. And that is as far as the Law goes." LW, 26:309-310, 312-313 (Lectures on Galatians [1-4], 1535).
} 
to this problem includes His word of promise or grace. This context suggests that divine grace is understood more as a declaration of acceptance or forgiveness than a power to regenerate sinful human beings, ${ }^{136}$ at least in terms of a logical priority. ${ }^{137}$ According to the discussion above, the broken personal ${ }^{138}$ relationship between God and human beings has a cause, the inward depraved condition of human beings in

\footnotetext{
${ }^{136}$ Luther understands grace as "mercy, the good will [favor] of God." He takes "grace in the proper sense of the favor of God-not a quality of the soul." LW, 32:227 (Against Latomus, 1521). Likewise, Calvin conceives gospel/grace in terms of divine "mercy and paternal favor." ICR 2.9.2.
}

${ }^{137}$ The distinction between grace as pardon and power is helpfully indicated by Couenhoven, who points out that, overall, "grace has been understood in two ways: as a declaration of acceptance and as a power that transforms." These two ways relate respectively to justification and sanctification. Couenhoven, "Grace as Pardon and Power," 63-64. The idea of a logical priority of grace as forgiveness over grace as regeneration matches the traditional protestant notion of a logical priority of forensic justification over transformative sanctification. I am aware that some scholars, especially those following the Finnish school of Luther research, reject this differentiation of justification and sanctification in Luther, because his view of justification includes forensic and transformational aspects. See, e.g., David S. Yeago, "Lutheran-Roman Catholic Consensus on Justification: The Theological Achievement of the Joint Declaration," Pro Ecclesia 7, no. 4 (1998): 452n7; Tuomo Mannermaa, "Justification and Theosis in Lutheran-Orthodox Perspective," in Union with Christ: The New Finnish Interpretation of Luther, ed. Carl E. Braaten and Robert W. Jenson (Grand Rapids, MI: Eerdmans, 1998), 38-39; Simo Peura, "Christ as Favor and Gift: The Challenge of Luther's Understanding of Justification," in Union with Christ: The New Finnish Interpretation of Luther, ed. Carl E. Braaten and Robert W. Jenson (Grand Rapids, MI: Eerdmans, 1998), 47-48. While a proper assessment of this contention goes beyond the scope of the present study, it is possible to avoid the criticism of such scholars in the affirmation of a priority of grace as forgiveness over grace as regeneration in the present study. Peura argues that, in Luther, "Christ on the one hand is the grace that is given to the sinner that protects him against the wrath of God (the forensic aspect), and on the other hand he is the gift that renews and makes the sinner righteous (the effective aspect)." Peura, "Christ as Favor and Gift," 48. Given the fact that Christ's priestly mediation in Luther focuses on protecting believers from the wrath of God, my contention is that there is a priority of grace as fogiveness (the forensic aspect) in the context of His priesthood. A similar defense can be formulated in regards to Calvin. According to Alister McGrath, Calvin understands justification and sanctification as simultaneous "effects of union with Christ." Alister E. McGrath, Iustitia Dei: A History of the Christian Doctrine of Justification, 3 ed. (Cambridge; New York: Cambridge University Press, 2005), 256. This simultaneity is also perceived in François Wendel's rejection of a chronological sequence in Calvin's conception of justification and sanctification. François Wendel, Calvin: Origins and Development of His Religious Thought, trans. Philip Mairet (New York: Harper and Row, 1963), 256, 259. However, my contention of the priority of grace as forgiveness is confirmed by Wendel's claim that Calvin advances "the doctrine of double justification; first, the justification of the sinner, and then the justification of the justified, or more correctly of their works." This means that "even after we have received the faith, our works are still contaminated by sin: nevertheless God does not impute them to us as sins but holds them acceptable." Wendel, Calvin, 260. In other words, in this life, there is an ongoing dependence of regeneration (the works of the justified person) on forgiveness (non-imputation).

${ }^{138}$ Luther emphasizes that "wrath and grace have to do with persons. He whom God receives in grace, He completely receives, and he whom He favors, He completely favors. On the other hand, He is angry at the whole of him with whom He is angry." LW, 32:228 (Against Latomus, 1521). 
which they attack God's integrity, ${ }^{139}$ and a result, namely, an offended God who inflicts

His wrath on them outwardly. This situation requires a priestly mediation, ${ }^{140}$ which has to

focus primarily on the result of the broken relationship, as this is the most urgent problem

to be solved. ${ }^{141}$ In other words, the primary target of this mediation is the offended God,

not the sinful condition of human beings. Christ the priest addresses mainly God's holy

and wrathful reaction against sinful humans, which judges and condemns them in their

unbelief against Him. ${ }^{142}$ This means that human beings can be regenerated only on the

\footnotetext{
${ }^{139}$ In Calvin's language, the human "corrupt nature is at enmity with the Divine law." ICR 2.7.7. He adds, "Perverted and corrupted in all the parts of our nature, we are . . corruption, deservedly condemned by God, to whom nothing is acceptable but righteousness, innocence, and purity." Ibid., 2.1.8. Similarly, Luther affirms that unbelief was "implanted in human nature since Adam," and that through the mediation of Christ "this sin inherited from Adam will no longer keep us under the wrath and condemnation of God." LW, 24:343 (Sermons on the Gospel of St John [14-16], 1537). Althaus explains that, for Luther, "the holy God, God cannot respond to man's sin in any other way than with enmity and wrath. ... Every sin insults and injures God for sin injures righteousness. Since God loves righteousness and himself is righteousness, sin strikes and injures him in his very being. In relationship to sin therefore God's righteousness necessarily expresses itself as wrath." In this sense, "the real nature of sin, as an attack on God as God," finds "a corresponding basis for God's wrath in his determination to remain God." Althaus, The Theology of Martin Luther, 169.

${ }^{140}$ Luther and Calvin speak of Christ's priesthood as a mediation. See $L W, 13: 315,290,23: 195$; 24:103, 295; 26:28; ICR 2.15.6; 2.12.4.

${ }^{141}$ The priority of the divine (offended God) over the human (sinful nature) aspect of the sin problem is evident in Calvin's understanding of original sin, which is defined as the "depravity of our nature, extending to all the parts of the soul, which first makes us obnoxious to the wrath of God, and then produces in us works which in Scripture are termed works of the flesh." ICR, 2.1.8. A similar emphasis is found in Luther. The German theologian stipulates that the "law reveals a twofold evil" in human beings, namely, the "inward . . corruption of nature" (inflicted by human beings themselves) and the "outward ... wrath, death, and being accursed" (inflicted by God). After introducing "us to sin" and overwhelming "us with the knowledge of it," the law is followed by the gospel, which announces "the righteousness and the grace of God." While the righteousness (identified as the divine gift of "faith in Christ"—an "inward good") "heals the corruption of nature" (the inward evil), the grace (identified as the mercy of God-an "outward good") removes the wrath (the outward evil). The priority of the outward grace/mercy that removes the divine wrath over the inward gift that restores human nature is evident in the statement that, in this life, "everything is forgiven through grace, but as yet not everything is healed through the gift." Because of the forgiveness of grace, the sin that still remains in forgiven human beings is treated "without wrath, without the law, dead sin, harmless sin, as long as one perseveres in grace and his gift." In this way, grace "produces peace of heart until finally a man is healed from his corruption." $L W, 32: 224,226-227,229$ (Against Latomus, 1521).

${ }^{142}$ In both Luther and Calvin, there is a strong emphasis on Christ as priest or mediator appeasing or propitiating God's wrath $(L W, 12: 67,75-76,85 ; 13: 319 ; 14: 25 ; 16: 231 ; 18: 418 ; 26: 232,324-325 ; 27: 11$;
} 
basis of the propitiation of God.

In summary, the need of restoration of the personal relationship between God and human beings, with a special focus on the divine reaction to human sin, provides the context for the understanding of the agent of the priesthood in the functional model.

\section{The Agent of the Priesthood}

As the agent of the priesthood, Christ is a mediator sent by God the Father. ${ }^{143}$

This means that the agent or priest is (1) sent by another person, and that He is (2)

characterized as a mediator. First, the idea that the agent of the priesthood is sent

highlights important information about the sender. While the priestly mediator is needed

to propitiate the wrath of God against human beings, it is God Himself who provides the

priest to propitiate His wrath. In other words, the agent of the priesthood is constituted as

a priestly mediator according to the plan of God. Second, the concept of mediation is

broader and includes the concept of priesthood, which implies that Christ is a priest as

part of His identity as a mediator. Calvin describes Christ the mediator in terms of His

threefold office as prophet, king, and priest. ${ }^{144}$ Similarly, Luther associates the roles of

28:140; 51:279-280; ICR 2.12.3-4; 2.15.6; 2.16.6; 3.11.9; 3.20.18; 4.18.13), invoking His favor on behalf of believers (ICR 2.15.6; 2.16.5; 4.18.13), so that their sins are not imputed to them $(L W, 13: 290 ; 27: 86$; $I C R$ 2.12.4). In their discussion of the priesthood of Christ, the German and the French theologians emphasize more the propitiation of God than the regeneration of believers.

${ }^{143}$ Luther underscores that "the Father Himself has introduced and given Him [Christ] to us as a Mediator and has also placed Him at His own right hand to remove all wrath, sin, and death from us." $L W$, 28:140 (Commentary on 1 Corinthians 15, 1534). See also ibid., 24:406-407. This is consistent with the idea that "a priest is a person whom God has ordained and commanded to mediate between God and men. That is to say, a priest comes from God." Ibid., 13:315 (Commentary on Psalm 110, 1535). For Calvin, "the office which" Christ "received from the Father consists of three parts. For he was appointed both Prophet, King, and Priest." ICR 2.15.1. Referring to Christ's sacrifice, the French theologian claims that the Christ as mediator was "destined in the eternal counsel of God to purge the pollution of man." Ibid., 2.12.4.

${ }^{144}$ For details about Christ's threefold mediatorial office in Calvin, see ICR 2.15. The French theologian considers that the "the title 'Christ' pertains to these three offices: for we know that under the 
Christ as king and priest. ${ }^{145}$ Therefore, the agent of the priesthood assumes other roles that relate to His activity as priest. In His role as king (Luther and Calvin), Christ rules in a spiritual kingdom (not visible). ${ }^{146}$ Calvin specifies that He is the head/governor and defender of the church, reigning through the Spirit, and will execute the final

law prophets as well as priests and kings were anointed with holy oil. Hence the illustrious name of 'Messiah' was also bestowed upon the promised Mediator." Ibid., 2.15.2. Calvin's Christology is more defined by the understanding of the threefold office of Christ as the mediator rather than by considerations about His person. Bruce McCormack points out that "Calvin never set forth a comprehensive account of Christology in the classical sense of a careful investigation into the ontological constitution of the Mediator." Rather, "it was the office of the Mediator that dominated Calvin's attention-the mediatorial activity of Christ that had brought salvation to the human race - and not (to his mind) more abstract question of the being of the Mediator." Bruce L. McCormack, For Us and Our Salvation: Incarnation and Atonement in the Reformed Tradition, Studies in Reformed Theology and History (Princeton: Princeton Theological Seminary, 1993), 6. See also Richard A. Muller, Christ and the Decree: Christology and Predestination in Reformed Theology from Calvin to Perkins (Durham, NC: The Labyrinth Press, 1986), 28, 33; Edmondson, Calvin's Christology, 5, 84, 220. For helpful information about Calvin's Christology, see Dawn DeVries, Jesus Christ in the Preaching of Calvin and Schleiermacher, Columbia Series in Reformed Theology (Louisville, KY: Westminster John Knox Press, 1996); Edmondson, Calvin's Christology; McCormack, For Us and Our Salvation, 6-9; Partee, The Theology of John Calvin, 142-158; Jill Raitt, "Calvin's Use of Persona," in Calvinus Ecclesiae Genevensis Custos: International Congress for Calvin Research (New York: Peter Lang, 1984), 273-287; Van Buren, Christ in our Place, 3-23; Von Johannes L. Witte, "Die Christologie Calvins," in Daskonzil Von Chalkedon: Geschichte Und Gegenwart, ed. Aloys Grillmeier and Heinrich Bacht (Wurzburg: Echter-Verlag, 1954), 3:487-529; Randall C. Zachman, The Assurance of Faith: Conscience in the Theology of Martin Luther and John Calvin (Minneapolis: Fortress Press, 1993), 159-187; E. David Willis, Calvin's Catholic Christology: The Function of the So-Called "Extra Calvinisticum", Studies in Medieval and Reformation Thought (Leiden: Brill, 1966).

${ }^{145}$ The concept of the priesthood of Christ in Luther is largely defined by his understanding of Christ as king and priest, and by the contrast between the priesthood of Christ and the priesthood of the Roman church. The German theologian connects the concept of priesthood and kingship with the birthright of primogeniture in the OT. He points out that the birthright involved a "twofold honor, that of priesthood and that of kingship." In this sense, the firstborn "was priest and lord over all the others and a type of Christ, the true and only first-born of God the Father and the Virgin Mary and true king and priest." $L W$, 31:353 (The Freedom of a Christian, 1520). For helpful studies on Luther's Christology, see Althaus, The Theology of Martin Luther, 179-198; Neal J. Anthony, Cross Narratives: Martin Luther's Christology and the Location of Redemption, Princeton Theological Monograph Series (Eugene, OR: Pickwick, 2010); Bayer, Martin Luther's Theology, 214-238; Marc Lienhard, Luther, Witness to Jesus Christ: Stages and Themes of the Reformer's Christology (Minneapolis: Augsburg, 1982); Lohse, Martin Luther's Theology, 219-231; Ian D. Kingston Siggins, Martin Luther's Doctrine of Christ, Yale Publications in Religion (Eugene, OR: Wipf and Stock, 2003); Vidar L. Haanes, "Christological Themes in Luther's Theology," Studia Theologica 61, no. 1 (2007): 21-46.

${ }^{146}$ According to Luther, Christ "will not only rule but will also bless . . . for not only royal authority but also a priesthood is dealt with, and the name and office of priest embrace the foremost benefits of Christ." LW, 4:177 (Lectures on Genesis, 1539-1540 [chapters 22-23]). For the idea that Christ's role as a king is spiritual and not-visible, see ibid., 5:20 (Lectures on Genesis, 1541 [chapter 26:1-8]). 
judgment. ${ }^{147}$ As a prophet (Calvin), Christ teaches doctrine and preaches the gospel. ${ }^{148}$

Furthermore, the idea that Christ's mediation is broader and includes His

priesthood derives from Calvin's understanding of the mediation of Christ before His

incarnation. This perspective assumes that Christ in His divinity is a mediator between

the Father and creatures since the beginning of creation, given the transcendent

unapproachable glory of the Father. ${ }^{149}$ In this sense, mediation is not only about "the

overcoming of a presupposed boundary" (created by sin) "between God [the Father] and

creation but about the proper way God and creation are related." ${ }^{150}$ According to this

view, the mediatorial priesthood of Christ appears to be a necessary extension of His

Calvin agrees that the His kingship has a spiritual nature, being related to a future life. See ICR 2.15.3.

${ }^{147}$ ICR 2.15.3-5. According to the idea that "the kingdom of Christ consists in the Spirit," Christ the king sends the gifts of the Spirit, and "enriches his people with all things necessary to the eternal salvation of their souls, and fortifies them with courage to stand unassailable by all the attacks of spiritual foes." In this way, He governs, cherishes, sustains us, keeps "us under his guardianship," gradually bringing "us to full communion with God." Ibid., 2.15.4-5. For Luther, in the spiritual church, Christ "rules as Priest or true pope through the office of the ministry and through the power of the Holy Spirit," communicating "His eternal and divine gifts" for "forgiveness of sins," and "His power and strength" for a "life of eternal righteousness." $L W, 13: 324$ (Commentary on Psalm 110, 1535).

${ }^{148}$ ICR 2.15.2.

${ }^{149}$ This emphasis is evident in his controversy against Stancaro on Christ as the mediator. Stancaro believed that Christ was not mediator between God and human beings in His divinity-because this would imply that His divinity is inferior to the Father's, but only in His humanity. In opposition to this view and referring to passages such as Col 1:15, Calvin argues that Christ is the mediator between the Father and His creatures since the beginning of creation, which underlines a mediatorial activity performed by Christ before His incarnation and, therefore, a mediation of Christ in His divinity. In this sense, the priestly work of the incarnate Christ was characterized by a mediation performed not only by His humanity but also by His divinity. For an introduction of this controversy and a translation of Calvin's reply to Stancaro, see Joseph N. Tylenda, "Christ the Mediator: Calvin Versus Stancaro," Calvin Theological Journal 7 (1972): 5-16; Joseph N. Tylenda, "The Controversy on Christ the Mediator: Calvin's Second Reply to Stancaro," Calvin Theological Journal 8 (1972): 131-157.

150 Julie Canlis, Calvin's Ladder: A Spiritual Theology of Ascent and Ascension (Grand Rapids, MI: Eerdmans, 2010), 66. For Calvin, "as the creative Word ... Christ is already and eternally the Mediator between creatures and their Creator." Wyatt, Jesus Christ and Creation in the Theology of John Calvin, 39. Calvin affirms that Adam, in his excellence, "approximated to the glory of his Maker" "by means of the only begotten Son." ICR 2.12.6. He adds, "Had man remained free from all taint, he was of too humble a condition to penetrate to God without a Mediator." Ibid., 2.12.1. 
mediatorial work in creation due to the sin problem. ${ }^{151}$ A significant implication of this notion for the interpretation of Christ as the agent of the priesthood is that His divinity is able to perform mediation. ${ }^{152}$ While this implication could potentially lead to the conclusion that the incarnation is unnecessary for His mediation, the idea is that the incarnation allows a new level of mediation in the context of sin. In this sense, Christ's humanity is not a mere instrument of the divine, but it adds a new type of mediation, a truly human mediation that is able to deal with sin.

In fact, the functional model holds that the incarnation of Christ is foundational for His mediatorial priesthood, ${ }^{153}$ and both His human and divine natures are essential to the priestly activity. Christ's humanity is necessary for Him to show obedience to the

\footnotetext{
${ }^{151}$ In his commentary on John 1:5, Calvin stipulates that "there are two distinct powers which belong to the Son of God: the first, which is manifested in the structure of the world and the order of nature; and the second, by which he renews and restores fallen nature." $C B C$, Commentary on the Gospel According to John. All quotations of $C B C$ are taken from John Calvin, Calvin's Bible Commentaries, The John Calvin Collection (Albany, OR: AGES Software, 1998). These two powers relate to the two types of mediatorial work performed by Christ. According to the French theologian, in His mediatorial work of creation, Christ was "appointed head of angels and men" in the "first ordering of creation." ICR 2.12.4. In this way, "the entire structure of the world" has its "beginning" in Christ. Ibid., 2.12.7. Since the beginning of creation the mediation of Christ provides unity between the creatures and God. The priestly work of Christ was necessary after the fall, adding a component of expiation to His mediation. Edmondson, Calvin's Christology, 144. See the translation of the arguments elaborated by Calvin in Tylenda, "Christ the Mediator," 12-13; Tylenda, "The Controversy on Christ the Mediator," 147.

${ }^{152}$ Accounts in which only the humanity of Christ mediates seem to imply that mediation is made possible to Christ through the instrumentality of His humanity. For Muller, Calvin's assertion that the divinity of Christ performs mediation is distinct from the "Christologies of Chalcedon and of the medieval scholastics," since for them "the work of mediation focuses upon the flesh which is assumed and not upon the eternal person who assumes it." While the medieval scholastics believed that Christ is mediator "according to his humanity," Calvin attributes His mediation to the "divine-human person rather than the flesh assumed by the divine person." Muller, Christ and the Decree, 33.

${ }^{153}$ In most cases, when Calvin speaks of Christ as the mediator, he refers to Christ's incarnate life. He argues that "from the time that Christ was manifested in the flesh, he has been called the Son of God, not only in that he was the eternal Word begotten before all ages from the Father, but because he took upon himself the person and office of the Mediator, that he might join us to God." ICR 1.13.24. He adds, "It was of the greatest importance for us that he who was to be our Mediator be both true God and true man," as this necessity "stemmed from a heavenly decree, on which men's salvation depended." Ibid., 2.12.1.
} 
Father in the human flesh, ${ }^{154}$ assume the sin of human beings, and offer Himself as a sacrifice at the cross. ${ }^{155}$ From the perspective delineated above regarding the need for Christ's priesthood, the obedience of the human Christ and His sacrifice propitiates the divine wrath against sinful human beings who are characterized by lack of faith. In other words, Christ propitiates the divine wrath as a human being. On the other hand, His divinity is required for the eternity ${ }^{156}$ and power ${ }^{157}$ of the priesthood. In short, "as God

\footnotetext{
${ }^{154}$ The idea of obedience is particularly emphasized by Calvin. As a result of disobedience, humanity became lost and in need of a mediated reconciliation with God. Then, the obedience of the incarnate Christ satisfied "God's judgment" and paid "the penalties for sin." ICR 2.16.5. "How has Christ abolished sin, banished the separation between us and God, and acquired righteousness to render God favorable and kindly toward us? . . He has achieved this for us by the whole course of his obedience." Ibid. Edmonson affirms that "the foundation of Christ's sacerdotal work, both as priest and as sacrifice, is his obedience." Edmondson, Calvin's Christology, 96. Based on this notion of obedience, Calvin concludes that the entire life of the incarnated Christ is significant for His earthly work of reconciliation: "From the time when he took on the form of a servant, he began to pay the price of liberation in order to redeem us." ICR 2.16.5. According to McCormack, the emphasis on Christ's obedience underlines His acquired righteousness. In his polemic against Osiander, who maintained that Christ justifies us with His "essential divine righteousness," Calvin argued that "the righteousness that is made ours in justification is the acquired righteousness of Christ, that is, that righteousness which the God-man acquired through the acts of obedience performed through His divine-human unity." In this sense, "the redemptive significance of the life of Christ is not made to consist in the cleansing of a diseased human nature," as a result of the contact of His human nature with the essential righteousness of His divinity, but "in the establishing if a divinehuman righteousness. It is the creation of a new humanity." McCormack, For Us and Our Salvation, 22-23.

${ }^{155}$ For Calvin, "our Lord came forth as true man and took the person and the name of Adam in order to take Adam's place in obeying the Father, to present our flesh as the price of satisfaction to God's righteous judgment, and, in the same flesh, to pay the penalty that we had deserved." ICR 2.12.3. "He offered as a sacrifice the flesh he received from us, that he might wipe out our guilt by his act of expiation and appease the Father's righteous wrath." Ibid. "The only reason given in Scripture that the Son of God willed to take our flesh, and accepted this commandment from the Father, is that he would be a sacrifice to appease the Father on our behalf." Ibid., 2.12.4. In short, Christ "assumed flesh" in order to "become a sacrifice and expiation to abolish our sins." Ibid. Likewise, Luther points out that Christ must have a human nature in order to be "our priest and mediator," especially in the sense that "as our High Priest He had to assume our sin and pay for it." $L W, 13: 323$ (Commentary on Psalm 110, 1535).

${ }^{156}$ Luther points out that Christ "must also be true God," since He "possesses in His person the quality of eternity," as "an eternal priest." Therefore, because "the true divine nature was in Him and His priestly office was eternally established, He could not remain in death or in the grave. He had to rise again and enter into another life, an eternal life, where He can function as our Priest forever in the presence of the Father." LW, 13:323-324 (Commentary on Psalm 110, 1535).

${ }^{157}$ According to Calvin, if Christ "had not been true God," He "could not cleanse our souls by his blood, nor appease his Father by his sacrifice, nor absolve us from guilt, nor, in sum, fulfill the office of priest, because the power of the flesh is unequal to so great a burden, yet it is certain that he carried out all these acts according to his human nature." ICR 3.11.9.
} 
only" Christ "could not suffer, and as man only could not overcome death."158

In summary, Christ as the agent of the priesthood is sent by the Father to be a

mediator. As a mediator, His role as priest is associated with the roles of king and

prophet. Moreover, the priestly mediation is an extension of His mediatorial work in

creation due to the sin problem, which means that the human and divine natures of the

incarnate Christ are involved in the activity of priestly mediation. While Christ's

humanity is necessary for His obedience and sacrifice that propitiate the divine wrath, His

divinity is essential for the eternity and power of the priesthood.

Having discussed the agent of the priesthood, I turn to the interpretation of the

priestly actions performed by this agent.

\section{The Actions of the Priest}

The actions or functions of the priest in the functional model are basically three, namely, (1) teaching/preaching the word of God, (2) offering His sacrifice, and (3) making intercession. ${ }^{159}$ According to Luther, Christ has performed the function of teaching/preaching God's word since His public ministry on earth. ${ }^{160}$ Even though Calvin

${ }^{158}$ ICR 2.12.3.

${ }^{159}$ Luther affirms that "a priest comes from God and brings us [1] His Word and doctrine; again, he presents himself to God to [2] sacrifice and [3] pray for us." LW, 13:315 (Commentary on Psalm 110, 1535). For Calvin, Christ's "priesthood consists not in [1] teaching only but in appeasing God, which Christ by his [2] death has accomplished, and in that [3] intercession which he now makes in his father's presence." ICR 4.6.2.

160 "This priestly office properly belongs to Christ and is completely derived from Him" because "He personally began the office of the public preaching of the Gospel." $L W, 13: 316-317$ (Commentary on Psalm 110,1535). Based on his traditional distinction between the law and the gospel, Luther argues that the purpose of preaching the law is to let people recognize their sin and plead for God's grace. In his words, "no one can repent and obtain forgiveness unless he knows his sin and feels God's wrath. For this reason Christ Himself, as well as the apostles, began by preaching repentance. Thereby they confirmed the preaching of the Law." However, the most important aspect of preaching is the presentation of the gospel. The true priestly office consists on preaching God's grace and the forgiveness of sins. Luther concludes 
ascribes this function to Christ's prophetic office, ${ }^{161}$ and tends to focus on the priestly

functions of sacrifice and intercession, ${ }^{162}$ he does relate the priesthood of Christ with His

teaching, ${ }^{163}$ which implies an overlap of the prophetic and priestly offices.

The second function of the priest refers to Christ's sacrifice on the cross, ${ }^{164} \mathrm{a}$

penal substitutionary sacrifice. ${ }^{165}$ For Calvin, the term sacrifice generally refers to

that "this office of preaching derives from Him who is Himself the High Priest; and the only content of its message is about Him." Ibid.

${ }^{161}$ See ICR 2.15.2.

${ }^{162}$ Commenting on 1 Tim 2:6, Calvin argues that "there is a necessary connection between the two things, the sacrifice of the death of Christ, and his continual intercession. (Romans 8:34.) These are the two parts of his priesthood; for, when Christ is called our priest, it is in this sense, that he once made atonement for our sins by his death, that he might reconcile us to God; and now having entered into the sanctuary of heaven, he appears in presence of the Father, in order to obtain grace for us, that we may be heard in his name. (Psalm 110:4; Hebrews 7:17)." CBC, Commentaries on the Epistles to Timothy, Titus, and Philemon. Thus, for Calvin, "the priestly office of Christ refers not only to what he accomplished at Calvary, where, by the sacrifice of his death he blotted out the guilt of humankind and made satisfaction for their sins (the High Priest was also the sacrifice), but also to what he continues to do as an everlasting Intercessor." Redding, Prayer and the Priesthood of Christ in the Reformed Tradition, 82.

${ }^{163}$ In his comments on Mal 2:6 and 2:9, respectively, Calvin argues that "the office of the priesthood and teaching" are two "inseparable" things, and that "there is no priesthood without doctrine or teaching, and no priest except he who faithfully performs his office as a teacher." $C B C$, Commentary on the Prophet Malachi. In his remarks on John 7:14, he points out that "Christ undertook the office of a teacher; and justly, because he was the great High Priest." $C B C$, Commentary on the Gospel According to John. Finally, commenting on Heb 7:12, the French theologian indicates that "Christ, being made a priest, was invested also with the authority of a legislator, that he might be the teacher and interpreter of the new covenant." $C B C$, The Commentaries on the Epistle of Paul the Apostle to the Hebrews. According to Jansen, "while Calvin never minimizes the teaching of Jesus or the importance of doctrine, he does not make of teaching a separate messianic work alongside of the two-fold work of redemption." In this sense, "the messianic work of redemption remains for Calvin a regal and reconciling work of king and priest," since "the prophetic or teaching office nowhere in Calvin assumes a separate messianic function." Jansen, Calvin's Doctrine of the Work of Christ, 102, 97, 99.

164 "Based on Heb 5:1, Luther indicates that the purpose of the divine appointment of a priest is to offer sacrifice for human sins, and that this function was fulfilled by Christ in His sacrifice on the altar of the cross." $L W, 13: 318-319$ (Commentary on Psalm 110, 1535). According to Calvin, as in the OT pattern of priesthood where the work of reconciliation demanded expiation through sacrifice, "we must begin from the death of Christ in order that the efficacy and benefit of his priesthood may reach us." ICR 2.15.6. Being "both priest and sacrifice," Christ "blotted out our own guilt and made satisfaction for our sins" by His death. Ibid. See also ibid., 4.14.21.

${ }^{165}$ Luther argues that Christ took "upon himself" the "guilt and sin" of human beings "as an innocent lamb," and "paid for us by his sufferings." LW, 37:362 (Confession Concerning Christ's Supper, 1528). Calvin highlights that Christ "was burdened with another's sin rather than his own." Accordingly, 
everything that is "offered to God." ${ }^{, 166}$ However, from a more specific perspective, there are two types of sacrifices: (1) the "sacrifice of propitiation or of expiation," which is a satisfaction for sin that redeems human guilt before God; and (2) the "sacrifice of praise and reverence" or the "sacrifice of thanksgiving," which represents "veneration and worship of God," 167 and includes supplications for God's favor, thanksgiving for blessings received, or "the exercise of simple piety." 168 According to this distinction, the death of Christ on the cross refers to the sacrifice of propitiation/expiation, "intended to appease God's wrath, to satisfy his judgment, and so to wash sins and cleanse them that the sinner, purged of their filth and restored to the purity of righteousness, may return into favor with God." ${ }^{169}$ As the sacrifice of Christ is identified exclusively with His death on the cross, sacrifice in the functional model is understood as a specific event. ${ }^{170}$

Finally, the third function of the priest refers to Christ's intercession. For Luther, this function was partially accomplished in Christ's intercessory prayer in John 17 and in His intercessory prayers on the cross. However, Christ's priestly intercession refers more directly to His ongoing office as mediator before God in heaven (Rom 8:34). ${ }^{171}$

\footnotetext{
"the guilt that held us liable for punishment has been transferred to the head of the Son of God." ICR 2.16.5.

${ }^{166}$ ICR 4.18.13.

167 Ibid.

${ }^{168}$ Ibid. Calvin affirms that "burnt offerings, libations, oblations, first fruits, and peace offerings" in the OT belonged to this second type of sacrifice. Ibid.

${ }^{169}$ Ibid.

${ }^{170}$ This perspective is clear in Luther's and Calvin's rejection of the Catholic identification of the eucharist with Christ's sacrifice. See $L W, 13: 313$; ICR 4.18.2; 4.19.28.

${ }^{171}$ LW, 13:320 (Commentary on Psalm 110, 1535). Luther argues that Isa 53:12 and Heb 5:7 speak about the intercessory function of Christ's priestly office. Ibid.
} 
According to Calvin, after Christ's resurrection and ascension, His priestly work of propitiation continues in heaven as He intercedes for human prayers. In his words, "we or our prayers have no access to God unless Christ, as our High Priest, having washed away our sins, sanctifies us and obtains for us that grace from which the uncleanness of our transgressions and vices debars us." ${ }^{172}$ The French theologian assumes that the biblical teaching of praying in the name of Jesus implies that the Father needs to be continuously ${ }^{173}$ appeased by the heavenly intercession of Christ before He receives the prayers of His people. ${ }^{174}$ Excluded from the divine presence, human beings need a mediator to appear before "God's dread majesty" so that their prayers may be heard. ${ }^{175}$ Luther summarizes the three priestly functions of Christ in the following way: first, in His preaching Christ "proclaims God's grace and promises us the forgiveness of

${ }^{172}$ ICR 2.15.6. Human prayers need to be cleansed by the blood of Christ. Otherwise, they are tainted and unclean. Ibid., 3.20.18. "No prayer is pleasing to God unless this Mediator sanctifies it." Ibid., 3.20.27. "By Christ's intercession are consecrated our prayers, which would otherwise have been unclean, so the apostle, enjoining us to offer a sacrifice of praise through Christ, warns us that our mouths are not clean enough to sing the praises of God's name until Christ's priesthood intercedes for us." Ibid., 3.20.28. The French theologian derives this notion from the fact that the OT priests should enter alone in the sanctuary bearing "the names of the tribes of Israel upon his shoulders and the same number of precious stones on his breastplate, but the people should stand afar off in the court, and there join their petitions with the priest." Ibid., 3.20.18.

${ }^{173}$ According to Calvin, passages such as 1 John 2:1; Rom 8:34; and 1 Tim 2:5 ascribe to Christ a continuous mediatorial work, instead of affirming a once for all intercession. Ibid., 3.20.20.

${ }^{174}$ Ibid., 3.20.18. "No one can be helped by any prayers at all save when Christ intercedes." Ibid., 3.20.19.

175 Ibid., 3.20.17-18. Luther also emphasizes that human prayers are heard by God only through Christ's mediation. The German theologian highlights that believers "do not base these prayers upon themselves nor upon their merit, but upon Christ the Mediator. He presents their prayers before God, and they become acceptable and are heard for His sake. LW, 13:334 (Commentary on Psalm 110, 1535). "Christ is our priest or minister in heaven before God." He "takes up our cause, presents us and our prayer and praise, and also offers himself for us in heaven" $L W, 35-99-100$ (A Treatise on the New Testament, that is, the Holy Mass, 1520). See also LW, 24:406; 35:78. 
our sins." ${ }^{176}$ Considering that the priest directs the conscience of human beings toward God and provides them with the interpretation of God's word and will, ${ }^{177}$ Christ is described as a "spiritual, internal priest" who "teaches us internally, in the heart.", Second, Christ "has made the true priestly sacrifice for us, which has the power of reconciling God and of removing our sin from us." ${ }^{179}$ Third, Christ "represents us before God with His intercessions in our behalf, so that we may continue in this reconciliation and grace and be preserved in it." 180

In their polemic against Roman Catholicism, Luther and Calvin oppose the idea of participation in Christ's activities of sacrifice and intercession, because they think such participation ultimately implies a replacement of His priesthood by an alleged mediation of human beings (priests and saints). ${ }^{181}$ Even though the German and the French theologians affirm the priesthood of believers, ${ }^{182}$ they distinguish it from Christ's

${ }^{176}$ LW, 13:321 (Commentary on Psalm 110, 1535).

${ }^{177}$ Ibid., 13:304.

${ }^{178}$ Ibid., 39:80 (On the Papacy in Rome Against the Most Celebrated Romanist in Leipzig, 1520).

${ }^{179}$ Ibid., 13:321 (Commentary on Psalm 110, 1535).

${ }^{180}$ Ibid.

${ }^{181}$ From Luther's perspective, the priesthood of Christ is perverted by the sacrifice of the mass and the belief in other mediators, which refer to the priestly functions of sacrifice and intercession. According to him, Christ did not institute the eucharist as a sacrifice, since the sacrifice was once performed by the true High Priest on the cross. Ibid., 13:313. However, for Luther, the medieval church created its own priesthood and sacrifice that silence, contradict, and ultimately replace Christ's priestly work and sacrifice. Ibid., 13:325. In this context, the mediation of Christ is replaced by the intercession of Mary and other saints. Ibid., 13:327. As a result of the human inability "to do sufficient penance and good works," and the consequent and constant fear of the wrath of Christ, the church "directed us further to the saints in heaven; these were supposed to be the mediators between us and Christ." Ibid., 13:326.

${ }^{182}$ For Luther, all Christians are priests through baptism. LW, 13:329 (Commentary on Psalm $110,1535)$. However, although the priestly office is common to all Christians, it does not eliminate the necessity of ministers, preachers, or pastors in the church. Nevertheless, this ministry is not a priestly work in the common sense of the work of a priest in the Scriptures. Ministers must be selected by the church from the body of Christians in the same way that officials are appointed in secular government. There are 
priesthood. Taking into account Calvin's distinction between the sacrifice of

propitiation/expiation and the sacrifice of praise/thanksgiving, the priesthood of believers

refers only to the second type of sacrifice, as the first type belongs exclusively to

Christ. ${ }^{183}$ And even their performance of the second type of sacrifice is only accepted by

the Father because of the priestly intercession of Christ on their behalf. ${ }^{184}$ In fact, the

French theologian concludes that when there is no distinction between the sacrifice

offered by believers (including especially ecclesiastical leaders/priests) and the sacrifice

offered by Christ and, therefore, the dependence of the former on the latter is disregarded,

the priesthood of Christ is ultimately usurped. Calvin argues that this situation takes place

when the eucharist is considered a sacrifice- the sacrifice of the mass, where priests

two reasons for the distinction between common priesthood and the ministry office, namely, the different gifts of the Spirit and the necessity of order in the church. Ibid., 13:331-334. For further information about Luther's understanding of the priesthood of all believers and of the Christian ministry, see Norman E. Nagel, "Luther and the Priesthood of All Believers," Concordia Theological Quarterly 61, no. 4 (1997): 277-298; Mark Rogers, "A Dangerous Idea? Martin Luther, E. Y. Mullins, and the Priesthood of All Believers," Westminster Theological Journal 72, no. 1 (2010): 119-134; Brian A. Gerrish, "Priesthood and Ministry in the Theology of Luther," Church History 34, no. 4 (1965): 404-422; Herman A. Preus, "Luther on the Universal Priesthood and the Office of the Ministry," Concordia Journal 5, no. 2 (1979): 55-62; Markus Wriedt, "Luther on Call and Ordination: A Look at Luther and the Ministry," Concordia Journal 28, no. 3 (2002): 254-269; James R. Jeffcoat, Jr., “Martin Luther’s Doctrine of Ministry,” (Ph.D.

dissertation, Drew University, 1989). For information on Calvin's notion, see John Richard Crawford, "Calvin and the Priesthood of All Believers," Scottish Journal of Theology 21, no. 2 (1968): 145-156.

${ }^{183}$ In Christ "we all are priests, but to offer praises and thanksgiving, in short, to offer ourselves and ours to God. It was his office alone to appease God and atone for sins by his offering." ICR 4.19.28. For Calvin, under the sacrifices of thanksgiving "are included all the duties of love," and "all our prayers, praises, thanksgivings, and whatever we do in the worship of God." Instead of seeking "forgiveness of sins, or with meriting righteousness," these sacrifices are "concerned solely with magnifying and exalting God." Calvin quotes on this regard Rom 12:1; Heb 13:16; and Phil 4:18, which generally highlight that "all the good works of believers are spiritual sacrifices." Ibid., 4.18.16. "From this office of sacrificing, all Christians are called a royal priesthood (1 Pet 2:9), because through Christ we offer that sacrifice of praise to God." Ibid., 4.18.17.

${ }^{184}$ Calvin highlights, "We do not appear with our gifts before God without an intercessor. The Mediator interceding for us is Christ, by whom we offer ourselves and what is ours to the Father." Ibid., 4.18.17. He is the high priest "who has entered the heavenly sanctuary and opens a way for us to enter. He is the altar upon which we lay our gifts, that whatever we venture to do, we may undertake in him. He it is, I say, that has made us a kingdom and priests unto the Father (Rev 1:6)." Ibid. 
pretend to perform the sacrifice of $\mathrm{Christ}^{185}$ and "intercede before God for the people.",186

Assuming a distinction of the priesthood of Christ and of believers, where the

latter is dependent on the former, Calvin argues that Christ's intercession enables

believers to participate in His priestly work. Indeed, Christ's ongoing intercession makes

"us as his companions in this great office. For we who are defiled in ourselves, yet are

priests in him, offer ourselves and our all to God, and freely enter the heavenly sanctuary

that the sacrifices of prayers and praise that we bring may be acceptable" to God. ${ }^{187}$

Hence, the priesthood of believers is a participation in Christ's priesthood in terms of

praise and prayers, particularly in intercessory prayers among believers. ${ }^{188}$ While

${ }^{185}$ For Calvin, the mass is a blasphemy against the eternal priesthood of Christ, and the priests who perform this pretended sacrifice are not successors, but substitutes of the heavenly Christ. "Those who sacrifice daily are required to appoint for their oblations priests whom they put in Christ's place as successors and vicars. By this substitution they not only deprive Christ of his honor, and snatch from him the prerogative of that eternal priesthood, but try to cast him down from the right hand of his Father, where he cannot sit immortal without at the same time remaining eternal priest." Ibid., 4.18.2. Calvin combats the idea that by offering bread and wine to Abraham (Gen 14:18) Melchizedek prefigured the sacrifice of the mass. Rather, he claims that "Melchizedek gave bread and wine to Abraham and his companions, to refresh them, wearied by their journey and battle. What has this to do with a sacrifice?" Ibid., 4.18.2.

${ }^{186}$ Ibid., 4.18.14. "All who call themselves priests to offer a sacrifice of expiation do wrong to Christ. Christ was appointed and consecrated priest according to the order of Melchizedek by the Father . . . without end, without successor. He once for all offered a sacrifice of eternal expiation and reconciliation; now, having also entered the sanctuary of heaven, he intercedes for us." Ibid., 4.19.28. Affirming Christ as the only "Pontiff and Priest of the New Testament, to whom all priesthood's have been transferred, and in whom they have been closed and terminated," Calvin denies the existence of priests in the church that by the oblation of the mass "intercede before God for the people and, having appeased God, obtain atonement for sins.” Ibid., 4.18.14.

${ }^{187}$ Ibid., 2.15.6. For Luther, the ascended Christ not only prays for us; He also grants us the power and freedom to pray directly to God, by bringing our prayers to God. LW, 13:321 (Commentary on Psalm $110,1535)$.

${ }^{188}$ Calvin explains that besides commending "himself to the prayers of believers," Christ, "the greatest and truest priest of the church," requests "that all members of Christ's body mutually pray for one another." In this way, "the mutual prayers for one another of all members yet laboring on earth rise to the Head [Christ], who has gone before them into heaven, in whom "is propitiation." ICR 3.20.20. In short, the intercession of believers in prayer depends entirely on the priestly intercession of Christ in heaven. "Christ does not by his intercession hinder us from pleading for one another by prayers in the church," provided that "all intercessions of the whole church" are directed "to that sole intercession," as "those intercessions are ... made in Christ's name." In this sense, "the saints still retain their intercessions, whereby they 
believers do not participate in Christ's propitiatory sacrifice, and somehow participate in

His intercession through their prayers (as long as their intercession is mediated by

Christ's intercession), they assume through the guidance of the Holy Spirit a more

instrumental participation in the function of teaching, which is actually understood as

Christ Himself preaching. ${ }^{189}$ More concretely, this priestly function is described as the

preaching of the gospel and the administration of the sacraments (particularly the Lord's

Supper) ${ }^{190}$ where the salvific benefits of Christ's sacrifice on the cross are communicated

commend one another's salvation to God," as long as they "depend solely upon Christ's intercession." ICR 3.20.19.

${ }^{189}$ According to Luther, although Christ "has ascended to heaven and no longer preaches on earth in person, He has not stopped speaking through the apostles and their successors; nor will He stop extending His Gospel farther and farther and powerfully working in it by means of the Holy Spirit. ... If He did not stir up our hearts and preserve them through the Holy Spirit, no man would believe the Gospel or remain faithful to it." $L W, 13: 324$ (Commentary on Psalm 110, 1535).

${ }^{190}$ For Luther, sacrament is a word of divine promise or testament which has material/visible signs attached to it. LW, 36:124 (The Babylonian Captivity of the Church, 1520). In this view, God adds some external sign to His word as a "memorial or remembrance of the promise, so that thereby we may serve him the more diligently and he may admonish us the more effectually." Ibid., 36:44. The remembrance provided by the sacrament "is nothing else than a preaching of the Word." Ibid., 40:22 (Concerning the Ministry, 1523). In this sense, Luther stipulates that "during the mass, we should do nothing with greater zeal ... than to set before our eyes, meditate upon, and ponder these words, these promises of Christ-for they truly constitute the mass itself - in order to exercise, nourish, increase, and strengthen our faith in them by this daily remembrance." Ibid., 36:41 (The Babylonian Captivity of the Church, 1520). For the German theologian, "the Eucharist was a visible Word of God," as he "interpreted the Eucharist in the new context of Word and faith rather than in the older context of sacrifice and priest." David C. Steinmetz, "Scripture and the Lord's Supper in Luther's Theology," Interpretation 37, no. 3 (1983): 255. In The Babylonian Captivity of the Church (1520), Luther expounds a critique of the theology and administration of the sacraments in the Roman church. For instance, he (1) denies the existence of seven sacraments $(L W, 36: 18)$ and affirms that there are only baptism and the Lord's Supper (36:124); he (2) rejects the thomistic notion of transubstantiation (36:29) and suggests that the body of Christ is "contained in every part" of the bread-without any distinction between substance and accidents, just like "in red-hot iron . . the two substances, fire and iron, are so mingled that every part is both iron and fire" (36:32); he (3) repudiates the view that "the mass is a good work and a sacrifice" (36:35) and argues that "what we call the mass is a promise of the forgiveness of sins made to us by God, and such a promise as has been confirmed by the death of the Son of God. For the only difference between a promise and a testament is that the testament involves the death of the one who makes it" (36:38). For additional information on Luther's understanding of the sacraments, see Wolfgang Simon, "Worship and the Eucharist in Luther Studies," Dialog: A Journal of Theology 47, no. 2 (2008): 143-156; Steinmetz, "Scripture and the Lord's Supper in Luther's Theology," 253-265; Althaus, The Theology of Martin Luther, 345-403; Lohse, Martin Luther's Theology, 298-313. 
or applied to believers. ${ }^{191}$ It is important to note that, according to Luther, "it is not the sacrament but faith in the sacrament that makes righteous." 192 This general picture suggests a correspondence between the application of the salvific benefits of Christ's sacrifice provided by the Spirit on earth (through word and sacrament) ${ }^{193}$ and the intercession of Christ in heaven. ${ }^{194}$ From the perspective of the need for Christ's

\footnotetext{
${ }^{191}$ Luther underscores that "teaching and praying" are "two priestly offices: to hear God speaking and to speak with God." In the context of teaching, "through the blessing, through preaching, and through the administration of the sacraments God descends and speaks with me." Ibid., 5:197 (Lectures on Genesis, 1542 [chap. 28:5]). For Calvin, the salvific benefits of Christ's sacrifice on the cross are communicated to human beings through the "the preaching of the gospel and the administration of the Sacred Supper." ICR 4.18.3 With regard to the Lord's Supper, Calvin maintains that "after Christ's sacrifice was accomplished," God "instituted" a "method ... to transmit to the believing folk the benefit of the sacrifice offered to himself by his Son. He has therefore given us a Table at which to feast, not an altar upon which to offer a victim; he has not consecrated priests to offer sacrifice, but ministers to distribute the sacred banquet." Ibid., 4.18.12. McCormack emphasizes that, for Calvin, the Holy Spirit effects union with Christ through the preached word and sacrament. McCormack, For Us and Our Salvation, 23. According to Kilian McDonnell, "Calvin did not consider the sacraments as a necessary means of salvation, and though union with Christ was not considered as dependent on the sacraments - as is also the case in Roman Catholicism - he did consider union with Christ as quite unthinkable apart from the sacraments. Union with Christ was not considered without reference to the Eucharist ... just as union with Christ was not considered without reference to faith." In this sense, "a comparison of Calvin's teaching on the union with Christ which takes place in faith through the power of the Holy Spirit, with the union with Christ which takes place in the Eucharist, also through the power of the Holy Spirit, will show how Calvin subsumed the eucharistic eating under the larger moment of faith, the perpetual eating." Kilian McDonnell, John Calvin, the Church and the Eucharist (Princeton: Princeton University Press, 1967), 179, 184-185.

${ }^{192}$ LW, 29:206-207 (Lectures on Hebrews, 1517-1518).

${ }^{193}$ The ontological meaning of this earthly application of benefits through word and sacrament will be explored in the next chapter in the section dealing with the Cosmology of the functional model.

${ }^{194}$ Luther affirms that Christ's intercessory prayer in heaven communicates the power and merit of His sacrifice to human beings, for the forgiveness of sins, righteousness, and eternal life, giving strength to believers so that they might overcome sin and the temptations of Satan, and preserving them in God's grace. $L W, 13: 320$ (Commentary on Psalm 110,1535). These benefits parallel what Luther calls "the significance or effect" of the Lord's Supper, which is the "fellowship of all the saints," where "all the spiritual possessions of Christ and his saints are shared with and become the common property of him who receives this sacrament." As a result, this sacrament has "the property of strengthening" and encouraging believers in the battle against sin, because they are assured by God through these material signs that they "are not fighting alone"; rather, "Christ and his saints intercede for us before God, so that this sin may not be charged to our account by God's strict judgment." Ibid., 35:50-53 (The Blessed Sacrament of the Holy and True Body of Christ, and the Brotherhoods, 1519). Commenting on 1 John 2:1, the French theologian argues that "Christ appears before God" in order to "exercise towards us the power and efficacy of his sacrifice," and that "the intercession of Christ is a continual application of his death for our salvation. That God then does not impute to us our sins, this comes to us, because he has regard to Christ as intercessor." $C B C$, Commentary on the First Epistle of John. If both the heavenly intercession of Christ and the earthly
} 
priesthood, described as God's wrath against human sin or disobedience/lack of faith, and the obedient humanity of His priesthood that undergoes a substitutionary sacrifice, this application of benefits seems to be understood in terms of the acquittal of guilt and the imputation or participation of human beings in the righteous obedience of Christ.

In short, the sacrifice of Christ was a past event at the cross, while His heavenly intercession and earthly teaching (through the Holy Spirit, and then through the preaching of the word and the sacraments/Lord's Supper) are present and ongoing activities performed by Christ since His ascension (obviously, the activity of intercession and teaching marked His public ministry). ${ }^{195}$ On the basis of the penal substitutionary sacrifice at the cross, the ascended Christ constantly propitiates the Father in His heavenly intercession and communicates blessings (acquittal of guilt and imputation or participation in His obedience) to believers through His earthly teaching.

\section{The Goal of the Priesthood}

According to the description above, the priesthood of Christ in the functional model is needed primarily because God's holy wrath condemns sinful human beings. As the priestly agent, Christ is the mediator sent by the Father. Calvin claims that $\mathrm{He}$ is the

Lord's Supper are understood in terms of application of salvation, then the parallel or identification between them is clearly affirmed. In his study of the eucharist in the theology of Calvin, Tylenda stipulates that, through the Lord's Supper, Christ "today applies the salvation which he once obtained for us by his expiation on the cross." Joseph N. Tylenda, "Eucharistic Sacrifice in Calvin's Theology," Theological Studies 37, no. 3 (1976): 466.

${ }^{195}$ Luther argues that "Christ is a spiritual, internal priest. He is seated in heaven and intercedes for us as a priest; he teaches us internally, in the heart." $L W, 39: 80$ (On the Papacy in Rome Against the Most Celebrated Romanist in Leipzig, 1520). The German theologian adds, "Nor does he only pray and intercede for us but he teaches us inwardly through the living instruction of his Spirit, thus performing the two real functions of a priest, of which the prayers and the preaching of human priests are visible types." Ibid., 31:354 (The Freedom of a Christian, 1520). 
mediator between God in His transcendent unapproachable glory and creation since the beginning of the world, meaning that Christ's priesthood is an added function to His mediatorial activity of creation and providence, which now includes a redemptive/propitiatory mediation. This new and necessary feature of Christ's mediation comprises the activities of sacrifice, intercession, and teaching. While the sacrifice and heavenly intercession propitiate the wrath of God, ${ }^{196}$ the spiritual (through the Spirit) teaching comforts the conscience of believers who feel condemned for their sins. ${ }^{197}$ In this context, the goal of Christ's priesthood can be discussed in two levels: (1) His mediation between God and sinful human beings, and (2) the contribution of the priesthood to Christ's broader mediation between God and creation. Regarding the first level, the goal of the priesthood of Christ is to provide salvation by grace. ${ }^{198}$ This goal

${ }^{196}$ Calvin points out that Christ, as an "advocate, took upon himself and suffered the punishment that, from God's righteous judgment, threatened all sinners; . . . he purged with his blood those evils which had rendered sinners hateful to God; that by this expiation he made satisfaction and sacrifice duly to God the Father; . . . as intercessor he has appeased God's wrath between us and God, and acquired righteousness to render God favorable and kindly toward us." ICR 2.16.2; italics mine. For Luther, even in His intercession before the Father, Christ "bears the iniquities of us all as if they were His own to make us coheirs with Him of all the good things of His Father and to reconcile us to His Father." $L W, 20: 71$

(Lectures on Zechariah, 1526).

${ }^{197}$ Luther associates the propitiation of God's wrath with the comfort offered by the priesthood of Christ to the conscience of believers. See $L W, 20: 71$ (Lectures on Zechariah, 1526). Actually, one of the main purposes of His priestly work is to comfort "those who have weaknesses, frailties, and sins, and who therefore possess a shy, burdened, and disturbed conscience." The priestly office of Christ "is all our comfort and hope, all that needs to be preached and believed for our salvation. Everyone who enshrines this in his heart and keeps it will have comfort and joy all his life. He will never be afraid. Here he learns that Christ, the Son of God, wants to be our Priest. This is not for one hour or for one day; nor is His Mass or priestly office of as brief duration as the private Mass of a popish priest. But He has been a Priest since the day He became the Christ and began to sacrifice His body. He continues to present His sacrifice to the Father, to plead for us without ceasing, until the end of the world." Ibid., 13:321, 325-326. Similarly, Calvin highlights that Christ's intercession gives assurance to believers, as they can have peace of mind and "trust in prayer." ICR 2.15.6.

${ }^{198}$ Luther emphasizes that the priesthood of Christ nullifies human works for salvation. The very existence of a priest that reconciles us to God through His sacrifice and intercession implies that human efforts cannot achieve this reconciliation. $L W, 13: 328$ (Commentary on Psalm 110, 1535). 
corresponds to the traditional Protestant understanding of justification and sanctification.

Luther points out that, in His ongoing heavenly intercession, Christ "is our representative and pronounces us righteous." "199 Because of His intercession, sin is not "reckoned to our account" (justification: grace as forgiveness) and He may "grant us the strength and power of the Holy Spirit to overcome sin" (sanctification: grace as power). ${ }^{200}$ Taking into account the need for Christ's priesthood, the idea of grace as forgiveness refers to the forensic acquittal of guilty human beings before a wrathful God, and the notion of grace as power is understood as the transformation of human beings, previously characterized by lack of faith, into obedient believers. However, this does not mean that original sin is removed from them, as believers can fall into disobedience. Therefore, there is a priority of the first aspect of Christ's intercession (grace as forgiveness) in the functional model,

${ }^{199}$ Ibid., 13:326.

${ }^{200}$ LW, 13:320 (Commentary on Psalm 110, 1535). Luther claims that the reason why Christ "ascended to heaven to sit at the right hand of God was to preserve us forever in God's grace through His intercessions and, further, to give us power and victory over the terrors of sin, Satan, and the temptations of the world and our flesh." Ibid. Scholarship in Luther studies has debated about the relationship of forensic justification and sanctification, and consequently about Luther's concept of justification. The so-called Mannermaa school at the University of Helsinki has fostered a new interpretation of Luther's view of justification. In contrast to the prevailing German school approach and the theology of the Lutheran confessions, this new interpretation claims that "Luther does not make a distinction between forensic and effective justification, but rather argues that justification includes both. In other words, in line with Catholic theology, justification means both declaring righteous and making righteous." Veli-Matti Kärkkäinen, "Justification," in Global Dictionary of Theology: A Resource for the Worldwide Church, ed. Veli-Matti Kärkkäinen William A. Dyrness, Juan F. Martinez, Simon Chan (Downers, IL; Nottingham, UK: InterVarsity, 2008), 449. See also Veli-Matti Kärkkäinen, "Deification View," in Justification: Five Views, ed. James K. Beilby and Paul R. Eddy (Downers Grove, IL: InterVarsity, 2011), 220-222; Scott H. Hendrix Günther Gassmann, Fortress Introduction to the Lutheran Confessions (Minneapolis: Fortress, 1999), 80; Tuomo Mannermaa, Christ Present in Faith: Luther's View of Justification (Minneapolis: Fortress, 2005). Another aspect of the debate is related to the fact that this new interpretation suggests that Luther's view of justification implies the notion of deification or theosis. See W.D. Persaud, "Lutheran Theology," in Global Dictionary of Theology: A Resource for the Worldwide Church, ed. Veli-Matti Kärkkäinen William A. Dyrness, Juan F. Martinez, Simon Chan (Downers Grove, IL; Nottingham, UK: InterVarsity, 2008), 512; Lohse, Martin Luther's Theology, 221. However, the discussion does not seem to take into account the concept of the priesthood of Christ and its relationship with the ideas of forensic justification and sanctification/effective justification. 
since justified and sanctified believers are still sinful human beings in this life, awaiting the eschatological transformation or perfection. ${ }^{201}$ This situation requires a constant priestly intercession that does not take sin completely away from believers, but changes the way their sin is treated by God, that is, "as non-existent and as expelled." ${ }^{202}$ In this sense, Luther's notion of simul justus et peccator implies a "movement from sin to righteousness that begins every moment anew and continues without end until death."203 Therefore, salvation is purely by the grace of God's forgiveness, and this is achieved on the basis of Christ's ongoing mediatorial priesthood. Indeed, this conception of salvation that highlights exclusively God's forgiveness, without any merit from human beings, is associated with the notion that Christ's mediatorial priesthood is a divine provision — the priestly mediator sent by the Father is the Son, who communicates salvation to human beings through the Spirit—for the salvation of believers, and magnifies "the glory of God's great generosity," which in Calvin's perspective is the final cause or goal of

201 According to his idea of simul justus et peccator, Luther claims that "everything is forgiven through grace, but as yet not everything is healed through the gift" of transformation. LW, 32:229 (Against Latomus, 1521). Likewise, Calvin claims that "there is always sin in the saints, until they are freed from their mortal frame, because depraved concupiscence resides in their flesh, and is at variance with rectitude." He explains, "In regenerating his people God indeed accomplishes this much for them; he destroys the dominion of sin, by supplying the agency of the Spirit, which enables them to come off victorious from the contest. Sin, however, though it ceases to reign, ceases not to dwell in them." ICR 3.3.10-11.

${ }^{202}$ LW, 32:229 (Against Latomus, 1521). In Luther's words, “As far as its nature is concerned, sin in no way differs from itself before grace and after grace; but it is indeed different in the way it is treated. It is now dealt with otherwise than before. How was it treated previously? In such a way that it was existent, known, and overwhelmed us; but now it is treated as non-existent and as expelled." It is important to note that, for Luther, this different treatment takes place "as long as one perseveres in grace and his gift" of transformation. Ibid. This means that the ongoing intercession of Christ is constantly forgiving and giving power. The only difference is that while the forgiveness is complete, the transformation produced by the power is not complete yet.

${ }^{203}$ Batka, "Luther's Teaching on Sin and Evil," 240. Quoting McGrath, Couenhoven argues that, "for Luther, the Christian life is repetition: 'ever to be justified anew'. In emphasizing the metaphor of journey, Calvin is more like Augustine, for whom the Christian life is 'ever to be made more and more righteous." Couenhoven, "Grace as Pardon and Power," 75 (italics mine). See McGrath, Iustitia Dei, 227. 
salvation. $^{204}$

The second level of the goal of Christ's priesthood in the functional model takes

into account the contribution of this priesthood to Christ's broader mediation between a

transcendent God in His glory and creation, a reflection stimulated by Calvin's

conception of the mediation of the divine Christ. More specifically, this reflection focuses

on how the priesthood of Christ is related to God's purposes for human beings in the

context of creation, and not only salvation. The French theologian stipulates that human

beings, either before or after sin, are supposed to receive "a better life" from Christ. ${ }^{205}$ If

human beings had not sinned they would receive it from Christ's divine mediation

between God and creation. However, due to sin, they can only receive it now from

Christ's divine-human priesthood. ${ }^{206}$ This understanding is similar to the teleological

${ }^{204}$ In Calvin's Trinitarian conception of the causes of salvation, "the efficient cause" is the love of the Father, "the material cause" is the obedience of the Son, "the instrumental cause" is the illumination of the Spirit - which is faith, and "the final cause" is "the glory of God's great generosity." ICR 3.14.21. This is the Trinitarian backfround for Calvin's understanding of the work of Christ. For helpful information on the work of Christ in Calvin, see J. Todd Billings, "John Calvin's Soteriology: On the Multifaceted 'Sum' of the Gospel," International Journal of Systematic Theology 11, no. 4 (2009): 428-447; Jansen, Calvin's Doctrine of the Work of Christ; McCormack, For Us and Our Salvation, 17-34; Richard A. Muller, Calvin and the Reformed Tradition: On the Work of Christ and the Order of Salvation (Grand Rapids, MI: Baker Academic, 2012); Partee, The Theology of John Calvin, 158-167; Peterson, Calvin's Doctrine of the Atonement; Van Buren, Christ in our Place.

${ }^{205} C B C$, Commentary on the Book of Genesis (comment on 3:19). In this comment on Gen 3:19, Calvin maintains that "the first man would have passed to a better life, had he remained upright; but there would have been no separation of the soul from the body, no corruption, no kind of destruction, and, in short, no violent change." Ibid. This statement indicates that human beings, both before and after sin, are supposed to pass to a better life. Such life seems to correspond to Calvin's description of human perfection in his remarks on Gen 2:7, where he argues that "the state of man was not perfected in the person of Adam; but it is a peculiar benefit conferred by Christ, that we may be renewed to a life which is celestial, whereas before the fall of Adam man's life was only earthly, seeing it had no firm and settled constancy." Ibid., 58. This statement conflates the condition of humanity before (Adam) and after ("we") sin, as in both cases human beings would receive perfection from Christ.

${ }^{206}$ Because "of the fall, the perfecting of human nature can occur in no other way than as the completion of Christ's redemptive work." Wyatt, Jesus Christ and Creation in the Theology of John Calvin, 40. In this sense, commenting on 1 Cor 15:45, Calvin claims that "Christ came to restore our nature from ruin, and raise it up to a better condition than ever." $C B C$, Commentary on the First Epistle to the 
perspective of the sacramental model. In fact, the better life or perfect human condition seems to refer to an incorporeal life characterized by constancy. ${ }^{207}$ This life is probably related to Calvin's notion that the mediation of Christ will have an end, namely, when redeemed human beings "shall openly behold God reigning in his majesty, and Christ's humanity will then no longer be interposed to keep us back from a closer view of God. ${ }^{208}$ To put it in another way, the mediation of the incarnate Christ will eschatologically give way to the enjoyment of "the immediate presence" of the "Godhead," when "we shall see God as he is." ${ }^{, 209}$ Therefore, in this second level of the goal of Christ's priesthood, His priestly work ultimately allows human beings to enjoy the immediate vision of God.

Corinthians.

${ }^{207}$ The idea of constancy derives from Calvin's affirmation that human beings will be "renewed to a life which is celestial, whereas before the fall of Adam man's life was only earthly, seeing it had no firm and settled constancy." $C B C$, Commentary on the Book of Genesis (comment on 2:7). There is a contrast here between earthly and celestial lives, which are differentiated by the implied notion that the latter is characterized by "firm and settled constancy." A possible further description of the celestial life is incorporeality or immateriality. This description is inferred from Calvin's assertion that, because "the prophets were unable to give a verbal description of that spiritual blessedness" of the eschatological kingdom of God, "they usually delineated it by corporeal objects" ICR 3.25.10. Arguing that, in Calvin, the "perfecting work would be necessary even without the fall" of human beings, Wyatt indicates that "the final goal of salvation includes the resurrection of transformed bodies as well as the gift of immortality to the soul." Wyatt, Jesus Christ and Creation in the Theology of John Calvin, 40.

${ }^{208} C B C$, Commentary on the First Epistle to the Corinthians (comment on 15:27). In this comment, Calvin points out that Christ will transfer the divine kingdom "from his humanity to his glorious divinity, because a way of approach will then be opened up, from which our infirmity now keeps us back." Ibid.

${ }^{209}$ ICR 2.14.3. In this section Calvin maintains that Christ is sitting "at the right hand of the Father ... only for a time, until we enjoy the immediate presence of his Godhead." He adds, "When, as partakers of the heavenly glory, we shall see God as he is, then Christ, having accomplished the office of Mediator, shall cease to be the vicegerent of the Father, and will be content with the glory which he possessed before the world was." This means that "God will then cease to be the head of Christ, and Christ's own Godhead will then shine forth of itself, whereas it is now in a manner veiled." Ibid. Wyatt comments, "In the consummation, the human nature of Christ will continue to exist in union with the divine nature of the eternal Son, but it will no longer exercise the functions of veiling, reconciling, or even ruling. The power and the glory which the human Christ once shared in the mediatorial ministry will revert to the divine nature alone." Wyatt, Jesus Christ and Creation in the Theology of John Calvin, 43. 
In summary, the goal of Christ's priesthood is to provide salvation by grace, which magnifies the glory of God for His great generosity, and ultimately leads believers to the eschatological immediate vision of God.

Having provided this overall description of Christ's priesthood in the functional model, I will turn to the discussion of His priesthood in the ontological model.

\section{The Ontological Model}

The model explored in this section is labeled ontological because a key idea in its account of Christ's priesthood is that He is the object, and not only the subject, of the priesthood. According to this label, the emphasis of this model seems to be on the object of the priesthood. Even though supporters of the sacramental and functional models could find ontological aspects of Christ's priesthood in their respective models, only in the ontological model is the person or being of Christ (even as God) the primary object of the priesthood (atonement). I will unpack this key idea in my treatment of the ontological model both in this chapter and in the next chapter. I must indicate at this point that because the conception of time is foundational for a complete picture of the ontological model, the priesthood of Christ in this model will come to a full view in the next chapter, which will directly address the notion of time. The representatives selected for the ontological model are the Swiss theologian Karl Barth ${ }^{210}$ (1886-1968) and the Scottish theologian Thomas F. Torrance ${ }^{211}$ (1913-2007). I will describe their interpretation of each

\footnotetext{
${ }^{210}$ Barth's main discussions on the priesthood of Christ in $C D$ appear in II/1, 156-159; IV/1, 135, 143-146, 274-283, 314-316. For general comments of this theme in Barth, see JOP 222-224.

${ }^{211}$ Torrance's main ideas about the priesthood of Christ are found in Torrance, Atonement, 61-96; Theology in Reconciliation: Essays Towards Evangelical and Catholic Unity in East and West (London: G. Chapman, 1975), 106-138; Royal Priesthood: A Theology of Ordained Ministry (Edinburgh: T\&T Clark,
} 
component of the formal structure of Christ's priesthood, starting with the need for His

priesthood.

\section{The Need for Christ's Priesthood}

The need for the priesthood of Christ in the ontological model seems to be built on the understanding of the functional model about this issue. ${ }^{212}$ The ontological model assumes a sharp rupture in the relationship between human beings and God as a consequence of $\sin$. According to the disruptive character of sin, humans are described as covenant breakers who have their humanity perverted and are under the condemnation or judgment of God, that is, under His wrath. ${ }^{213}$ Therefore, in line with the functional model and in contrast to some aspects of the sacramental model, sin is not merely an ontological/metaphysical distance between the Creator and His creatures or a lack of properties in the creatures that leads to an understanding of reconciliation as a

2003), 1-22; Space, Time and Resurrection (Edinburgh: Handsel Press, 1976), 112-118. For comments regarding his view of on this theme, see JOP, 224-229; Myk Habets, Theosis in the Theology of Thomas Torrance (Farnham, UK; Burlington, VT: Ashgate, 2009), 185-188; Griffith, "High Priest in Heaven," 221243.

212 This is certainly not surprising. The representatives of the functional model are classic Protestant theologians (Luther and Calvin), and the representatives of the ontological model are modern Protestant theologians (Barth and Torrance). For both models, human sin and God's wrath are key concepts in the discussion of the need for Christ's priesthood.

${ }^{213}$ Barth argues, "The sin and sins of man form the disruptive factor within creation which makes necessary the atonement." CD IV/1, 252. He mentions the "human covenant breaker" being "put to death" and the need of "Jesus Christ as the priestly Representative of all men." Ibid., 102; italics mine. Furthermore, the Swiss theologian emphasizes the "seriousness of God's wrath against sin." CD I/1, 410. Similarly, Torrance describes "human nature" as "determined and perverted by sin, and ... under the accusation and judgment of holy God." Thomas F. Torrance, Incarnation: The Person and Life of Christ (Downers Grove, IL: IVP Academic, 2008), 201. The Scottish theologian depicts sin as "repudiated fellowship with God," a "rupture in the relation between God and man," "disobedience and covenantbreaking," which is understood as the breaking of "the covenant of God with his creation" that "shattered the communion it entailed between God and his creatures." Ibid., 254, 39, 114. Torrance's conception of covenant as communion implies that the renewal of the covenant is in fact a renewal of the communion of human beings with God. This point will be elaborated below in the discussion of the goal of the priesthood. 
continuation of creation. ${ }^{214}$ Rather, $\sin$ is a destructive rebellion and alienation from

\title{
God. ${ }^{215}$ A rebellion in which human beings resist God's love, ${ }^{216}$ and an alienation
}

whereby humanity is untrue to his/her own nature, ${ }^{217}$ as human beings become

disconnected from the relationship that constitutes their own beings, namely, the

relationship with God. ${ }^{218}$

\begin{abstract}
${ }^{214}$ Barth accuses Schleiermacher for "weakening" the "seriousness" of "God's wrath against sin" by viewing sin as "a mere lack," and then "logically" concluding that "reconciliation ('redemption')" is "the crowning of creation." $C D \mathrm{I} / 1,410$. For Torrance, "Sin is utter separation from God . . . but the distance between God and man is not constituted by any metaphysical magnitude such as the infinite distance between the creator and the creature." Torrance, Incarnation, 247. The Scottish theologian explains that "what divides man from God is not the discrepancy between the finite and infinite ... although that discrepancy does become a real disjunction for us when it is infected by sin and guilt and enmity." Torrance, Space, Time and Resurrection, 73.
\end{abstract}

${ }^{215}$ Barth describes sin as "the source of our destruction." $C D$ IV/1, 254. See also ibid., 252-253. The Swiss theologian points out that "the very heart of the atonement is the overcoming of sin: sin in its character as the rebellion of man against God, and in its character as the ground of man's hopeless destiny in death." Ibid., 253. For Torrance's understanding of sin as alienation from God, see Incarnation, 247.

${ }^{216}$ Barth maintains that the wrath of God is part of the divine love. In fact, "when it is resisted His love works itself out as death-dealing wrath." $C D$ IV/1, 253; italics mine. The Swiss theologian associates the concepts of resistance and usurpation in his understanding of human sin. For him, "the fall of man is that he would not keep to the limits appointed for him in relation to God as a human creature. And man's being in sin is that he will not accept that he is the rebel against God that he is, that he will not see and acknowledge his usurpation for what it is, that he will not confess it and therefore his own fall, that he wants to explain and excuse and justify himself, to be in the right against God. If he ceased to do this, He would acknowledge that God is in the right against him, thus returning to the place which is proper to him as a creature in relation to God, and reversing the fall which consists in his usurpation. His unwillingness to repent is the constant renewal of his sin." Ibid., 258.

${ }^{217}$ According to Barth, "In sin, and therefore in disobedience, man . . is . . . untrue not only to God but also to his own nature" CD IV/1, 257. Likewise, in his discussion on sin Torrance maintains that "mankind has fallen from true humanity, from true human existence." Torrance, Atonement, 160. For the Scottish theologian, the locus of $\sin$ in human beings is the mind. In this sense, the distortion of true human nature takes place primordially in the mind. In his words, "It is in the human mind that sin is entrenched, and it is right there ... that we require to be cleansed by the blood of Christ and to be healed and reconciled to God." Ibid., 438. This focus on the mind derives from his understanding that there is no "body/soul or body/mind dualism" in biblical anthropology. Ibid. This perspective is similar to Barth's conception of biblical anthropology as "concrete monism," which contrasts with the soul/body "dualism of the Greek and traditional Christian doctrine." CD III/2, 393.

${ }^{218}$ Torrance considers the human "fellowship with God" as "the relation which constitutes the very being of humanity." Torrance, Incarnation, 254. From this perspective, sin is "a form of suicide. By rebelling against the creator and by asserting his or her independence, the creature is rebelling against the innermost relation which constitutes their very being as a creature, as a human being" Ibid., 247-248. Barth speaks of a "point of contact" between human beings and God lost because of sin. In his perspective, "man 
However, the differences between the ontological and the functional models, with regard to the comprehension of the rupture in the relationship between human beings and God, are at least two. One has to do with the historical initial cause of the rupture (sin) and the other is related to what the divine reaction (God's wrath) to this rupture entails. First, while the functional model interpreted the fall of Adam and Eve historically, the ontological model tends to view it existentially (non-historically), ${ }^{219}$ as theistic evolution emerged as a major influence in modern theology in general. ${ }^{220}$ In the functional model,

has completely lost the capacity for God," which implies that "the reconciliation of man with God in Christ also includes, or already begins with, the restitution of the lost point of contact." $C D \mathrm{I} / 1,238$.

${ }^{219}$ As Stanton Norman nicely summarizes, "Karl Barth argued for an existential interpretation of the account of Adam and Eve in the garden. He contended that the events of Genesis are to be understood as saga, not history. The fall of Adam describes the event that happens to all as each individual reenacts personally the events described in the garden. Adam is thus an existential symbol for every person and the fall a saga of the existential, sinful demise of all people. Sin originated in the fall, but the precise details of sin's origin transcend human comprehension." R. Stanton Norman, "Human Sinfulness," in A Theology for the Church, ed. Daniel L. Akin (Nashville, TN: B\&H Publishing Group, 2007), 442. Arguing that the genre of the Genesis account of creation is saga and not history (not "susceptible as such of historical proof"), Barth maintains that it is a mistake to understand the "being and existence of Adam" as "history, relating it either favourably or unfavourably to scientific paleontology, or to what we know with some historical certainty concerning the oldest and most primitive forms of life." According to this standpoint, the Swiss theologian interprets the fall as the divine statement of the pride of human beings. $C D$ IV/1, 508. Who is Adam for Barth? He is "the truth concerning us as it is known to God and told to us." Ibid., 511. Similarly, Torrance seems to understand the fall existentially, and not historically. In his words, "'the Fall"” is "man's estrangement from God resulting from his sin in seeking to make himself independent of him. Here there has opened up in man's existence a gulf of corruption and perdition which threatens to swallow him up, but that does not altogether happen. God refuses to be estranged from man or to forego his claim over him, and so he does not allow man to fall completely away from him, but continues to sustain him in being in his fallen condition as the creature which he had made to be 'good." Thomas F. Torrance, Divine and Contingent Order (Edinburgh: T\&T Clark, 1998), 123.

${ }^{220}$ In their account of science in modern theology, Robert Russell and Kirk Wetger-McNelly maintain that "Christian theologians have developed a diversity of positive responses to Darwin's theory of evolution over the past 140 years, which by and large assume that what science describes in terms of evolutionary biology is what theology sees as God's acting in the world. Simply put, evolution is God's way of creating life, a view frequently called 'theistic evolution." Robert John Russell and Kirk WegterMcNelly, "Science," in The Blackwell Companion to Modern Theology, ed. Gareth Jones (Malden, MA; Oxord, UK: Blackwell, 2004), 523. While the validity of such position is debatable, Russell and WetgerMcNelly correctly describe theistic evolution as a major influence in modern theology. Even though the ontological model does not seem to elaborate much on the notion of evolution, this notion can be identified in the writings of Barth and Torrance. In a letter to Christine Barth (Letter 181), Barth points out that "the creation story is a witness to the beginning . . . of all reality distinct from God . . in the form of a saga or poem. The theory of evolution is an attempt to explain the same reality . . in the form of a scientific 
the fall is the historical point when human beings began to rebel against God, causing His wrathful reaction. ${ }^{221}$ Conversely, the ontological model seems to follow the influence of theistic evolution in modern theology, an influence that regards the historical understanding of origins in classical Christian theology as pre-scientific (scientifically untenable). ${ }^{222}$ Indeed, instead of approaching hamartiology from the starting point of protology, the ontological model treats sin from the standpoint of Christology. ${ }^{223}$

explanation." Hence, "one's attitude to the creation story and the theory of evolution can take the form of an either/or only if one shuts oneself off completely either from faith in God's revelation or from the mind (or opportunity) for scientific understanding." Hinrich Stoevesandt and Jurgen Fangmeier, eds., Karl Barth: Letters, 1961-1968, trans. Geoffrey W. Bromiley (Edinburgh: T\&T Clark, 1981), 184. Habets indicates that a close reading of Torrance reveals that "he supports an evolutionary view of the cosmos, an expanding universe that resulted from some form of original Big Bang, along with a concomitant commitment to some form of theistic evolution." Habets, Theosis in the Theology of Thomas Torrance, 44. See, for example, Thomas F. Torrance, Preaching Christ Today: The Gospel and Scientific Thinking (Grand Rapids, MI: Eerdmans, 1994), 24; Torrance, Divine and Contingent Order, 122.

${ }^{221}$ Luther treats Gen 1-3 as "facts in their historical meaning, which is their real and true one." In fact, he criticizes Origen, Jerome and others who "depart from the historical account" in their allegorical treatment of these chapters. $L W, 1: 231$ (Lectures on Genesis, 1535 [chaps. 1-8:14]). For further information regarding Luther's understanding of the account creation and fall in Genesis as historical reality, see Theo Bell, "Man Is a Microcosmos: Adam and Eve in Luther's Lectures on Genesis (1535-1545)," Concordia Theological Quarterly 69, no. 2 (2005): 161-162. Examples of Calvin's reading the first chapters of Genesis from a literal/historical perspective are found in his comments on Gen 1:5 and 2:3 (literal days of creation); 3:1 (the serpent as non-allegorical); 5:1 (Adam and Eve were not born of previous creatures). See $C B C$, Commentary on Genesis.

${ }^{222}$ For recent examples of this posture in theistic evolution, in the particular context of original sin and Adam, see Daryl P. Domning and Monika Hellwig, Original Selfishness: Original Sin and Evil in the Light of Evolution (Aldershot, Hants, England ; Burlington, VT: Ashgate, 2006); Peter Enns, The Evolution of Adam: What the Bible Does and Doesn't Say About Human Origins (Grand Rapids, MI: Brazos Press, 2012).

${ }^{223}$ As Allen Jorgenson indicates, "Barth wants to develop a theological treatment of sin that begins at Christ and does not depend on a historical reading of the Adam story" Allen Jorgenson, "Karl Barth's Christological Treatment of Sin," Scottish Journal of Theology 54, no. 4 (2001): 458. See, for instance, Barth's treatment of sin in CD IV/1, 145-146. Likewise, Torrance treats evil and sin from the perspective of "a theology operating from a central point of reference in Christ." Torrance, Divine and Contingent Order, 117. In this view, "the incarnation, passion, and resurrection conjointly tell us that far from evil having to do only with human hearts and minds, it has become entrenched in the ontological depths of created existence." Ibid., 116. For helpful studies on sin in Barth, see Wolf Krötke, Sin and Nothingness in the Theology of Karl Barth, trans. Philip G. Ziegler and Christina-Maria Bammel (Princeton: Princeton Theological Seminary, 2005); William David Ellington, "Karl Barth's Doctrine of Sin in the Church Dogmatics, Vol. I/1-IV/3," (Ph.D. Dissertation, Boston University, 1965); Bruce A. Milne, "The Idea of Sin in Twentieth-Century Theology," Tyndale Bulletin 26 (1975): 5-15; John Webster, "The Firmest Grasp of the Real: Barth on Original Sin," Toronto Journal of Theology 4, no. 1 (1988): 19- 
Consequently, there was no time in history when human beings had a perfect relationship with the Creator that anteceded their rebellion against Him. ${ }^{224}$ A potential implication raised by the assumption that creation was characterized by sin since its beginning would be that God's wrath was always active against human beings. If His wrath was active since the beginning of creation, the need of Christ's salvific mediation that propitiates God's wrath appears to be required ultimately by the original reality of creation, and not by a historical subsequent human rebellion against God. To be sure, this is not the justification of the need for Christ's priesthood in the model, but the logical outcome of its methodological commitments seems to lead to this conclusion.

The second difference concerns the notion of divine wrath. ${ }^{225}$ Whereas the

29; Jorgenson, "Karl Barth's Christological Treatment of Sin," 439-462; Erin Kesterson Bowers, "In Opposition to God: The Doctrine of Sin in the Theologies of Friedrich Schleieramcher and Karl Barth," (Ph.D. Dissertation, Princeton Theological Seminary, 2013), 124-245; Matt Jenson, Gravity of Sin: Augustine, Luther, and Barth on Homo Incurvatus in Se (London; New York: T\&T Clark, 2006), 130-187; Ron Highfield, Barth and Rahner in Dialogue: Toward an Ecumenical Understanding of Sin and Evil, American University Studies Series VII (New York: Peter Lang, 1989).

${ }^{224}$ Barth's rejection of original sin as a historical fall implies that "there is no time prior to man's transgression: the life of man is transgression from the very first." Accordingly, "there never was a golden age. There is no point in looking back to one. The first man was immediately the first sinner." $C D$ IV/1, 508. Additionally, this rejection implies that there is no hereditary sin. See ibid., 500, 509.

${ }^{225}$ Barth views the wrath of God as a reaction of His love being resisted. The Swiss theologian wrote, "When it is resisted His love works itself out as death-dealing wrath." CD IV/1, 253. Similarly, for Torrance, the wrath of God is the negative aspect of the divine love that resists sin. "When men and women assert themselves against the Godness of God they are actually asserting themselves to be God, and so placing themselves in direct contradiction to the Godness of God. God resists sin in the full Godness of God - that is the meaning of the wrath of God. That is the negative aspect of his holiness and love ... God would abdicate from being God, would un-God himself, if he condoned sin." Torrance, Incarnation, 249. Therefore, both Barth and Torrance describe the divine wrath as God's resistance, that is, a divine negative reaction to a human attitude. Furthermore, they interpret the wrath of God as part of His love, and not as a divine attribute different from His love. This seems to be another important distinction between the functional and the ontological models, which is highlighted by the difference of Calvin and Barth regarding the relationship between divine wrath and divine love. According to McCormack, while in Calvin the wrath of God or His righteousness is distinct from (and even in contradiction with) His love and mercy, in Barth the wrath of God or His holiness/righteousness is part of His love. Hence, McCormack suggests that Barth attempts to remove the contradiction between divine wrath and divine love that is found in traditional theology. See McCormack, For Us and Our Salvation, 27-34. 
functional model, as described above, relates the wrath of God with a final condemnation and destruction of the non-elected, the ontological model views the divine wrath as a crucial step for the transformation of human beings and their reconciliation with God. ${ }^{226}$ In other words, while divine grace and wrath are two distinct attitudes of God towards human beings (which is compatible with the idea of two groups of people, the elect and the reprobate, as the respective recipients of grace and wrath) in the functional model, the ontological model views divine wrath as part of divine grace ${ }^{227}$ or its first step in God's dealings with $\sin$ (which is compatible with the idea that reprobation and election do not refer to two groups of people, but to a twofold divine salvific action). ${ }^{228}$ In the ontological model, sinful human beings must be completely destroyed in order to be

\footnotetext{
${ }^{226}$ In his criticism of Luther's distinction of law (divine holiness) and gospel (divine love), Barth argues that "in Scripture we do not find the Law alongside the Gospel but in the Gospel, and therefore the holiness of God is not side by side with but in His grace, and His wrath is not separate from but in His love." $C D$ II/1, 363. Following this idea of the divine wrath as part of God's grace and love, Torrance emphasizes that "God's judgement cannot be equated with annihilation," which means that the "wrath of God is a sign of hope, not of utter destruction." He adds, "God's wrath is really a part of atonement." Torrance, Incarnation, 249-250. Commenting on Barth's notion of divine wrath, Andrew Hay points out that, for the Swiss theologian, "the target at which the wrath of God is aimed, once it has annihilated every hindrance in its path, is the gracious restoration of fellowship. Thus, the wrath of God attends the gracious will of God. His judgment is the instrument of our salvation." Andrew R. Hay, "The Heart of Wrath: Calvin, Barth, and Reformed Theories of Atonement," Neue Zeitschrift für systematische Theologie und Religionsphilosophie 55, no. 3 (2013): 375.

${ }^{227}$ As G. C. Berkouwer indicates, in Barth, God's wrath is a form of His grace. G. C. Berkouwer, The Triumph of Grace in the Theology of Karl Barth, American ed. (Grand Rapids, MI: Eerdmans, 1956), 135.

${ }^{228}$ Barth is against the idea of divine election "as the description of a differing and differentiating attitude of God towards the totality of individual men as such; an attitude in which God . . . divides this totality of individuals into two sections or groups, electing here and not electing or rejecting there, with the aim and result of salvation and blessedness in the case of the former, perdition and damnation in the case of the latter." $C D$ II/2, 42. As Matthias Grebe points out, "For Barth, election includes simultaneously both a Yes and a No, election and reprobation." Matthias Grebe, Election, Atonement, and the Holy Spirit: Through and Beyond Barth's Theological Interpretation of Scripture, Princeton Theological Monograph Series (Eugene, OR: Wipf and Stock, 2014), 35. Following Barth's perspective, Torrance maintains that there is "election and damnation" and not "election or damnation." Thomas F. Torrance, "Predestination in Christ," Evangelical Quarterly 13 (1941): 125.
} 
totally recreated. Only the humanity recreated in this way is reconciled with God. ${ }^{229}$ This notion of God's wrath implies that the need of priestly mediation receives a new spin in the ontological model, when compared with the functional model. ${ }^{230}$ Christ the priest needs to deal with God's wrath against sinful humans not only by being the recipient and

${ }^{229}$ In Barth's language, "God kills only to make alive," "the Yes which in the end and after all is not concealed beneath God's No." $C D$ II/2, 263. For the Swiss theologian, God redeems by destructing. $C D$ IV/1, 222. In this view, God "effects a new creation ... in judgment and grace." $C D \mathrm{I} / 1,142$. Commenting on Barth's sermon on March 9, 1913, McCormack points out that, for Barth, "the house in which men and women live ... would have to be torn down. Not one stone would be left standing on another. If God were to become master of this house, it would have to be rebuilt from the ground up." Bruce L. McCormack, Karl Barth's Critically Realistic Dialectical Theology: Its Genesis and Development, 1909-1936 (Oxford; New York: Clarendon Press; Oxford University Press, 1995), 101. In this same sermon, Barth stipulates that "judgement too cannot be the last word of God. Judgement too must be a means and the way of His grace. When God judges and punishes, He is at the same time the Creator who calls new life into existence." ["Auch das Gericht mußte ein Mittel und Weg seiner Gnade sein. Auch wenn Gott verurteilt und straft, ist er zugleich der Schöpfer, der neues Leben ins Dasein ruft.” März: Markus 13,1-2. In Predigten 1913 (GA I.8). Available at Digital Karl Barth Library, http://solomon.dkbl.alexanderstreet.com (accessed 17 February 2015)]. Translation taken from McCormack, Karl Barth's Critically Realistic Dialectical Theology, 102.

${ }^{230}$ It is important to highlight here that Barth and Torrance do not reason from sin and divine wrath to Christ's person and work. Rather, the starting point of their reflections is Christ, and from Him they explore the conception of sin, God's wrath, divine predestination and all other theological themes. Nonetheless, the person and work of Christ is still an answer to the sin problem and, thus, to the reality of divine wrath. The decisive difference is epistemological, in the sense that Christ is the starting point for the human knowledge of other theological themes. In the present description, I have started with the need for the priesthood of Christ (which includes the discussion of sin and divine wrath) before moving to His priesthood itself because Christ's priesthood still addresses the sin problem and the wrath of God.

However, this description only attempts to organize the ideas that Barth and Torrance presumably articulate by using Christ as the starting point of their reflection. Besides the idea of divine predestination in Barth and Torrance, Barth's approach to hamartiology is also a significant example of such epistemological decision. More specifically, his definition of sin as pride, sloth, and falsehood derives from his reflection on the threefold office of Christ (see table below, which summarizes what Barth explains in $C D$ IV/1, 145146). As Jorgenson points out, in Barth, the "threefold basis of the knowledge of sin is drawn from the threefold revelation of Jesus Christ." This means that sin is understood as the human opposition to what "God did in Jesus Christ; sin as pride in opposition to the humiliation of God in Jesus Christ, sin as sloth in opposition to the exaltation of humanity in Jesus Christ, and sin as falsehood in opposition to the witness of our atonement as evidenced in Jesus Christ." Jorgenson, "Karl Barth's Christological Treatment of Sin," 448.

\begin{tabular}{|l|l|l|l|}
\hline Threefold Office & Christological Aspect & Answer to Sin as & Soteriological Content \\
\hline Priest (Christ as God) & God's self humiliation & Human act of pride & Justification (God's verdict) \\
\hline King (Christ as man) & Exaltation of man by God & The sloth of man & Sanctification (God's direction) \\
\hline Prophet (unity) & Unity (God-man) & Falsehood of man & Calling (God's promise) \\
\hline
\end{tabular}


the propitiation of His wrath (the view of the functional model), ${ }^{231}$ but also by undergoing this wrath as a divine means for the transformation of humanity. ${ }^{232}$ In this sense, the ontological model highlights the idea that God is both the object (God's wrath is propitiated) and the subject (God transforms humanity) of Christ's priestly mediation. In other words, in the context of sin, the priesthood of Christ is needed for divine propitiation and human transformation.

In summary, there is an existential (non-historical fall) broken relationship between God and human beings since the beginning of creation. This situation requires a priestly mediation of Christ that propitiates the divine wrath against sinful humans and that also uses the judgment of this wrath to transform them. In the description below of other components of the priesthood of Christ, I will spell out how the ideas introduced in this section are elaborated in the ontological model, starting with the agent of the

\footnotetext{
${ }^{231}$ Barth and Torrance follow the traditional Protestant perspective that Christ's priesthood is described by the propitiation of the wrath God. The Swiss theologian assumes that this priesthood is understood through the idea of sacrifice for sin, in the context of the separation of a sinful people and God (see $C D$ IV/1, 275-277). According to this point of view, Barth interprets the priestly death of Jesus as substitutionary. In his words, "Jesus Christ as the priestly Representative of all men, that is, as the One in whom in the name of all, and therefore for us, the human covenant-breaker was put to death." Ibid., 102. More specifically, this substitutionary death is propitiatory. "To be flesh means to exist . . . under the wrath and judgment of the electing and loving God." Hence, Christ "stands under the wrath and judgment of God, He is broken and destroyed on God." Ibid., 174-175. Similarly, Torrance highlights that Christ the priest "bears our sins," in a substitutionary way. For him, we are "sinners who need the mediation of Christ in order to go to the Father." Torrance, Incarnation, 146, 11.

${ }^{232}$ Barth and Torrance see this twofold relationship (propitiation and transformation) with the judgment of the wrath of God in the death and resurrection of Jesus, His destroyed humanity and His new humanity. For the Swiss theologian, God "is the One who is both gracious and wrathful, who both makes alive and kills, who both elects and rejects in this way. And this has been actualised in a single person [Christ], so that we cannot deny either aspect, or separate them, but can and must understand the one by the other, and see in the whole, i.e., in the one human figure." $C D$ II/2, 393. In this way, "the sentence executed and revealed in Jesus Christ and His death and resurrection, the No and the Yes with which God vindicates Himself in relation to covenant-breaking man, with which He converts him to Himself and therefore reconciles him with Himself. He does it by the destruction of the old and the creation of a new man." $C D$ IV/1, 96. Likewise, Torrance speaks about "the judgment accomplished upon the humanity of Christ, and now in his humanity our new right humanity has been established before God.” Torrance, Incarnation, 186.
} 
priesthood.

The Agent of the Priesthood

The idea that the priesthood of Christ is required to propitiate the divine wrath and at the same time to undergo this judgment to transform human beings implies that the person of Christ the priest (the agent of the priesthood) is the pivotal element of the understanding of this priesthood in the ontological model. To put it sharply, propitiation and transformation are not merely functions that Christ performs as a priest, but an event in His own being. According to this view, the person of the incarnate Christ is not construed merely as the agent of priestly actions, executing a salvific work, but He is the priestly or salvific work itself. ${ }^{233}$ In short, Christ is the agent who acts upon Himself. This ontological conception of the priesthood of Christ is particularly observed in two notions: (1) Christ does not merely make atonement, He is the atonement; (2) the threefold office of Christ does not characterize sequential phases of His work. ${ }^{234}$

\footnotetext{
${ }^{233}$ Discussing Christ's atoning reconciliation, Barth claims that "Jesus Christ is not what He isvery God, very man, very God-man - in order as such to mean and do and accomplish something else which is atonement. But His being as God and man and God-man consists in the completed act of the reconciliation of man with God." $C D$ IV/1, 126-127. The Swiss theologian indicates that Christ's "being as a man is the whole of His action, suffering and achievement. His being as a man is His work." CD III/2, 59 . Likewise, Torrance emphasizes that "the atonement is his person in action, not the action by itself." Torrance, Incarnation, 108.

${ }^{234}$ For studies on Christology in the respective theologies of Barth and Torrance, see Christopher R. J. Holmes, "The Person and Work of Christ Revisited: In Conversation with Karl Barth," Anglican Theological Review 95, no. 1 (2013): 37-55; Paul Dafydd Jones, The Humanity of Christ: Christology in Karl Barth's Church Dogmatics (London; New York: T\&T Clark, 2008); Adam Neder, "History in Harmony: Karl Barth on the Hypostatic Union," in Karl Barth and American Evangelicalism (Grand Rapids, MI; Cambridge, UK: Eerdmans, 2011), 148-176; Darren O. Sumner, Karl Barth and the Incarnation: Christology and the Humility of God (London: Bloomsbury, 2014); Cornelius van Til, Barth's Christology (Philadelphia: Presbyterian and Reformed Publishing Company, 1962); George Hunsinger, "Karl Barth's Christology: Its Basic Chalcedonian Character," in The Cambridge Companion to Karl Barth, ed. John Webster (Cambridge: Cambridge University Press, 2000), 127-142; Paul D. Molnar, Incarnation and Resurrection: Toward a Contemporary Understanding (Grand Rapids, MI: Eerdmans, 2007), 1-44, 81-120; Paul D. Molnar, Thomas F. Torrance: Theologian of the Trinity (Farnham, England; Burlington, VT: Ashgate, 2009), 111-136; Robert T. Walker, "Incarnation and Atonement: Their Relation
} 
According to the first notion, "Jesus Christ is the atonement," reconciliation occurs in the being of Christ. ${ }^{236}$ Barth argues that reconciliation "is not merely outward but" is an "inward" event that "corresponds . . . to being," as it is “necessarily enclosed in" Christ. ${ }^{237}$ Assuming that Christ is both God and man as one person, reconciliation takes place in His being in the sense that divinity and humanity are united in His person. ${ }^{238}$ Exploring this ontological reconciliation in Christ, the Swiss theologian highlights what happened to the person of Christ that actually produced reconciliation in Him. For instance, he speaks of Christ culticly as the "High-priest sacrificing Himself."239 This concept is also expressed in judicial language. The judgment "happened in His person, as His accusation and condemnation and destruction. He judged, and it was the Judge who was judged, who let Himself be judged."240 Thus, and Inter-Relation in the Theology of T. F. Torrance," Participatio 3 (2012): 1-63; Gunther Pratz, "The Relationship between Incarnation and Atonement in the Theology of Thomas F. Torrance," Journal for Christian Theological Research 3 (1998). For helpful information on the development of Barth's Christology in CD, see Bruce L. McCormack, "The Person of Christ," in Mapping Modern Theology: A Thematic and Historical Introduction, ed. Kelly M. Kapic and Bruce L. McCormack (Grand Rapids, MI: Baker Academic, 2012), 169-171; Bruce L. McCormack, "Christonomie," in Barth Handbuch, ed. Michael Beintker (Tübingen: Mohr Siebeck, 2016), 226-231.

${ }^{235}$ CD IV/1, 34. See also ibid., 122. Barth also speaks about the "act of atonement made in Him." Ibid., 131. See also ibid., 135.

${ }^{236}$ Barth stipulates that "in the being of Jesus Christ as such, is atonement." $C D$ IV/1, 126. The Swiss theologian argues that "the reconciliation of the world with God and the conversion of the world to God took place in Him. To that extent He Himself, His existence, is this reconciliation.” Ibid., 135.

Likewise, Torrance maintains that "reconciliation takes place within the personal Being of the Mediator" or "within the incarnate constitution of his Person as Mediator." Thomas F. Torrance, The Mediation of Christ (Grand Rapids, MI: Eerdmans, 1984), 73.

${ }^{237} C D \mathrm{IV} / 1,123$.

${ }^{238}$ Barth emphasizes that "the reconciliation of the world with God takes place in the person of man" who "is also true God." $C D, \mathrm{IV} / 1,130$.
${ }^{239} C D \mathrm{II} / 2,474$.
${ }^{240} C D$ IV/1, 222. 
Christ is the subject (the Judge) and object (judged) of judgment. In his turn, Torrance enlarges the scope of the ontological reconciliation in Christ by regarding the incarnation as a "redeeming event."241 The Scottish theologian stipulates that the atonement begins with the incarnation and finishes with the resurrection and ascension. ${ }^{242}$ According to this view, "the hypostatic union means such a union of the Son with our own human nature under the servitude of sin and judgment, that it is one long act of atoning and sanctifying reconciliation, in which he both judges our sin and enmity, and restores our human nature to its true relation with the Father and therefore to its perfect nature."243 Therefore, Torrance conceives the atoning reconciliation as an act (not functions), but a long act that encompasses the entire life, death, resurrection, and ascension of Christ. This idea of the incarnation as an atoning act (1) construes the "hypostatic union not simply in terms of a state of union, but in terms of a divine movement of grace, ${ }^{244}$ and (2) stipulates (like Barth) that Christ sinlessly assumed "our fallen humanity." ${ }^{, 245}$ According to these two

\footnotetext{
${ }^{241}$ Torrance, Incarnation, 82. The Scottish theologian conceives "reconciliation not simply in terms of Christ's work on the cross, but in terms of his incarnation." Ibid., 226.

${ }^{242}$ In his words, "even when we begin with his incarnation . . . we are beginning right away with the atonement, for his birth, as the beginning of his incarnate person, is one end of the atoning work, with the resurrection and ascension as the other end." Ibid., 37.

${ }^{243}$ Ibid., 206. As Geroge Hunsinger emphasizes, in Torrance, "the incarnation reaches its fulfillment in the atonement." George Hunsinger, The Eucharist and Ecumenism: Let Us Keep the Feast (New York: Cambridge University Press, 2008), 150.

${ }^{244}$ Torrance, Incarnation, 215.

${ }^{245}$ Torrance claims, "If Jesus Christ did not assume our fallen flesh, our fallen humanity, then our fallen humanity is untouched by his work-for 'the unassumed is the unredeemed', as Gregory Nazianzen put it." Ibid., 62. For the Scottish theologian, "If Christ assumed neutral or perfect human nature ... then the humanity of Christ is merely instrumental in the hands of God." Ibid., 212. At the same time, he affirms the sinlessness of the incarnate Christ, who "did not become flesh of our flesh in a sinful way, by sinning in the flesh." Actually, "by remaining holy and sinless in our flesh, he condemned sin in the flesh he assumed." Ibid., 63. The same emphasis on a fallen but not sinful human nature of Christ is found in Barth. See, for example, $C D \mathrm{I} / 2,153$.
} 
premises, Torrance argues that "in the very act of assuming our flesh the Word sanctified and hallowed it, for the assumption of our sinful flesh is itself atoning and sanctifying action. ${ }^{246}$ In other words, "in his holy assumption of our unholy humanity," Christ's "purity wipes away our impurity, his holiness covers our corruption. ${ }^{.247}$ Hence, the Scottish theologian advances the idea that God heals human nature by communicating grace through the incarnation (grace as ontological healing). ${ }^{248}$

This ontological notion of atonement in Christ is associated with an ontological rather than functional conception of Christ's threefold mediatorial office. Barth criticizes the traditional idea that this office refers to "three mediatorial functions" or "different stages in the course of the history of Jesus, ${ }^{249}$ which has "the prophetic office at the first (Galilean) stage, the priestly at the second (the passion) and the kingly at the third (the exaltation). ${ }^{, 250}$ Considering that the priestly and kingly offices in this scheme are characterized respectively by the humiliation (cross) and exaltation (resurrection/ascension) of Christ, Barth's critique rejects the notion that the humiliation and exaltation of Christ are "two 'states' ... which succeed one another." ${ }^{, 51}$ Rather, Christ's priestly humiliation and His kingly exaltation refer respectively to God's selfhumiliation in Christ (emphasis: Christ as God) and to human beings exalted by God in

\footnotetext{
${ }^{246}$ Torrance, Incarnation, 63.

${ }^{247}$ Ibid., 82.

${ }^{248}$ Torrance points out that "the divine nature was able to save and redeem that which it assumed into oneness with itself." He views "the assumption of our humanity" as "a sanctifying and healing act." Ibid., 207-208.

${ }^{249} C D \mathrm{IV} / 3.1,15$.

${ }^{250} \mathrm{CD} \mathrm{II} / 2,431$.
} 
Christ (emphasis: Christ as man), where "humanity is exalted in Him by the humiliation of Godhead." ${ }^{252}$ In this sense, the priestly office corresponds to the "Son of God who became what we are [incarnation], going into the far country, and as such He suffers as the Judge judged in our place [cross], as the High-priest offering Himself as the sacrifice," while the kingly office describes the "Son of Man returning to His Father's house and He acts as such, namely, as the royal man who is the object of the pure divine good-pleasure. ${ }^{, 253}$ In this ontological interpretation, the priesthood of Christ is construed as events in God, particularly, the incarnation and the sacrifice at the cross. As a result of these events in God, human beings are exalted in the man Jesus Christ (Barth's account of Christ's kingly office). Special emphasis is given here to God as the agent of Christ's priesthood ("the divine Agent"), meaning that Christ "is not an instrument of divine action" but "He acts Himself divinely." ${ }^{254}$ In his turn, Torrance elaborates on the relationship between the incarnation and God's priestly humiliation in Christ. ${ }^{255}$ To the notion that humiliation and exaltation are not "two events following one another," he adds that such events take place "at the same time all through the incarnate life of Christ." ${ }^{256}$ In this view, the incarnation itself is a "twofold movement" of humiliation and

${ }^{251} C D$ IV.1, 133.

${ }^{252}$ Ibid., 131. See also ibid., 145-146.

${ }^{253}$ CD IV.3.1, 275

${ }^{254} \mathrm{CD} \mathrm{I} / 2,105-106$. Barth argues that the human priests described in the OT "could only hint at this divine action." Thus, "they all signify the divine Agent, i.e., God Himself humanly present, God's own Son.” Ibid., 84.

\footnotetext{
${ }^{255}$ See the connection between Christ's priesthood and His humiliation in Torrance, Incarnation, 57.

${ }^{256}$ Torrance, Atonement, 210. For Andrew Burgess, Torrance's account of Christ's heavenly priesthood implies a sequential view of humiliation-exaltation, and this constitutes the main difference
} 
exaltation, constituting a "divine condescension and humiliation, in which the Son ... took upon himself our alienated humanity," and at the same time an exaltation of "our poor human being into healing communion with the life of God. ${ }^{, 257}$ Following this perspective, the Scottish theologian believes that "Christ the mediator ... bridges the chasm of hell in his own incarnate person, and not only in his bodily suffering." ${ }^{258}$ However, Torrance does not reduce reconciliation to the incarnation. As mentioned above, he views the incarnation as the beginning of the reconciliation, while the resurrection is its end. More specifically, the resurrection is "the completion of that saving work" and is related to the "ontological structure of the mediator himself.",259 I will explore the completion of the saving work in the discussion below regarding the actions of the priest, as in this section on the agent of the priesthood I focused on the person of Christ.

In summary, the need of divine propitiation and the transformation of humanity are intimately associated with the person of Christ the priest, as these atoning reconciliatory events (that are not historical sequential acts) take place in His own being. In this ontological perspective, Christ is the priest who sacrifices (subject) Himself (object), which means that $\mathrm{He}$ is both the subject and the object of reconciliation. The priestly office means God's self-humiliation in Christ, which includes the assumption of fallen humanity (incarnation) and the suffering on the cross (sacrifice). In this priestly

between the Scottish theologian and Barth in this issue. Andrew Burgess, The Ascension in Karl Barth (Hampshire, England; Burlington, VT: Ashgate, 2004), 125-133.

\footnotetext{
257 Torrance, Incarnation, 206-207.

${ }^{258}$ Ibid., 255.
} 
self-humiliation, God is both the subject and the object of atoning reconciliation (the propitiation element). The priestly divine humiliation is followed by the exaltation of humanity (the transformation element), which takes place in the man Jesus Christ. For Torrance, this exaltation or transformation begins in the incarnation. These ideas will be further clarified in the depiction of the actions of the priest.

\section{The Actions of the Priest}

The emphasis of the ontological model on the being of Christ as the locus of the atoning reconciliation does not exclude an account of His actions as priest. However, these actions are intimately related to His person. The model attempts to ontologically integrate the person and work of Christ, His being and acting. ${ }^{260}$ In large measure, this integration is articulated by making the being of Christ the object of His own salvific action. Following this perspective, Christ's threefold office refers not only to His actions, but particularly to His being or person. In this ontological understanding of the offices of Christ, Barth and Torrance tend to reject a division or sequentiality of functions or activities. ${ }^{261}$ The Scottish theologian even stipulates that the prophetic office is "part of

259 Torrance, Atonement, 212.

${ }^{260}$ Barth attempts to explain "the action and work of Jesus Christ by His person and being," and "His person and being by His action and work." CD IV/3.1, 275. The Swiss theologian claims that Christ's "being as a man is the whole of His action, suffering and achievement. His being as a man is His work." CD III/2, 59.

${ }^{261}$ In his remarks on the humiliation and exaltation of Christ, Barth argues that "His one work ... cannot be divided into different stages or periods of His existence, but . . f fills out and constitutes His existence in this twofold form." CD IV/1, 133. Therefore, the Swiss theologian affirms that Christ's work is one (without stages or periods), even though it has more than one form. Similarly, Torrance claims that the twofold movement of humiliation and exaltation "are not two acts, but one act," a "“downward' movement of grace in an 'upward' movement of sanctification." Torrance, Incarnation, 207. 
the priestly office, ${ }^{262}$ in the sense that the mediation of the word and the law of God (a prophetic work) is the primary activity of the priesthood and constitutes the basis for the liturgical mediation of the sacrifice, the second activity of the priesthood. ${ }^{263}$ In this view, as far as the priesthood of Christ is concerned, the mediation of the word refers to the Pauline emphasis on the atonement as the "expiation and justification before the word or law of God," whereas the liturgical sacrificial mediation relates to the emphasis of Hebrews on the atonement as "Christ's high priestly oblation of himself and his heavenly intercession." ${ }^{264}$ Thus, the activities of the priesthood are understood under the concept of atonement, which includes judicial and liturgical aspects. In this understanding, Christ's sacrificial death and His heavenly intercession are aspects of the liturgical sacrificial mediation. As I describe the actions of the priest, I will discuss the notion of judicial and liturgical mediation and then the ideas of sacrifice and heavenly intercession.

The distinction between judicial (word/law) and liturgical or cultic (sacrifice) mediation in the ontological model is not strict. According to Barth, there is a correspondence between them, even though the judicial imagery better explains the work of Christ. ${ }^{265}$ Despite the importance of the cultic imagery in the biblical materials

\footnotetext{
${ }^{262}$ Torrance, Atonement, 59.

${ }^{263}$ For Torrance, the mediation of the word of God is the primary function of the OT priest because "the priestly function of Aaron [liturgical mediation of sacrifice] was in dependence upon the priestly function of Moses in mediating the word and law of God." In this sense, "the word and law were primary, the sacrificial liturgy was secondary." The Scottish theologian even suggests that the tension between prophets and priests in several parts of the OT was actually a conflict between the law/word and sacrifice/liturgy, where "the priestly element sought to make itself independent of the mediating word given in the law" Ibid., 63. See also ibid., 17.

${ }^{264}$ Ibid., 73.

${ }^{265}$ Even though Barth clearly chooses the judicial or forensic framework for his treatment of the work of Christ, he acknowledges the possibility, in principle, of using other frameworks. Under the assumption that "theology can speak only approximately," he indicates that the work of Christ can be
} 
(particularly Hebrews, but also present in Pauline and Johannine writings), ${ }^{266}$ the Swiss

theologian considers it distant from the modern world, more difficult, less clear, and less

comprehensive than the forensic imagery. ${ }^{267}$ In his preference for the forensic imagery,

Barth attempts to highlight similarities between the cultic and forensic imageries, as long

as he can observe points in the former that correspond to the latter. ${ }^{268}$ Overall, he

emphasizes two common points: (1) as judge or priest, Christ takes the place of man, ${ }^{269}$

and (2) receiving the judgment as judge or being the sacrifice as priest, the work of

explained through "other lines of approximation" besides the "forensic imagery," such as imageries like financial/ransom, military/victory over the devil. CD IV/1, 274. Nevertheless, the Swiss theologian thinks that these two imageries are not comprehensive (logically and exegetically) enough to provide a proper framework for the systematic construction of the doctrine of the atonement. See ibid.

${ }^{266}$ In Barth's estimation, the cultic framework belongs to "the most primitive Christianity," has "great nearness to the" OT, and its language is very significant in the NT, especially the expressions "lamb of God" and "His blood." In fact, the account of Christ's priesthood in older Protestant dogmatics is an attempt to elaborate the work of Christ according to the cultic framework. Ibid. For a helpful study on Barth's use of the cultic framework in comparison with the forensic framework, see John L. Drury, "The Priest Sacrificed in Our Place: Karl Barth's Use of the Cultic Imagery of Hebrews in Church Dogmatics IV/1, §59.2," (Paper presented at the 1st Annual Barth Conference, Thy Word is Truth: Reading Scripture Theologically with Karl Barth, Princeton Theological Seminary, May 21-24, 2006), http://www.drurywriting.com/john/The_Priest_Sacrificed_in_Our_Place.pdf (accessed 30 December, 2016).

${ }^{267} C D$ IV/1, 275. Barth refers to the cultic framework as a "material which is already difficult would have been made even more difficult by trying to understand it in a form which is now rather remote from us." The Swiss theologian believes that, by formulating the work of Christ from the perspective of the forensic framework, his approach enables us "to see the matter better and more distinctly and more comprehensively ... than would have been possible even at the very best if we had committed ourselves radically to a cultic view." An example of such weaknessess of the cultic framework is the difficulty of the older dogmatics in their exposition of the priesthood of Christ, which "at their heart slip into forensic notions," as "they did not bring out the specific features on the cultic standpoint and terminology." Ibid.

${ }^{268}$ According to Barth, the fact that he did not choose the cultic framework "need not prevent us from now trying briefly to see and test from this different standpoint, which is so very important in New Testament thinking, the knowledge which we have gained in the framework of this other outlook." Ibid. The Swiss theologian presents the following correspondence between the two frameworks: (1) "Jesus Christ took our place as Judge" - "He is the Priest who represented us," (ibid) (2) He took our place as the judged and (3) He was judged in our place- "He gave Himself to be offered up as a sacrifice to take away our sins," (ibid., 277) and (4) He acted justly in our place - "in our place He has made a perfect sacrifice. He who as the perfect Priest took the place of all human priests, by offering Himself” (ibid., 281).

\footnotetext{
${ }^{269}$ Ibid., 277.
} 
reconciliation was finished in Christ, in the sense that it took place in Him. ${ }^{270}$ Hence, Christ the priest accomplished His work for us in a "single action" that is "effective once and for all ... with His entry into the innermost tabernacle, the Holiest of Holies of God Himself." 271 This correspondence of the two imageries implies that Barth interprets the action of Christ the priest on the basis of his forensic conception. While Torrance sees the judicial or forensic mediation as part (the primary part) of Christ's priesthoodatonement as justification before God's law, the Swiss theologian conceptualizes the priesthood of Christ in the liturgical or cultic imageries, which is different, although correspondent and somehow dependent on the forensic imageries. ${ }^{272}$ I have used the term imagery in this paragraph because they do not seem to have in themselves ontological bearing as the action in the being of God. They are only images of, or pointers to, a transcendent reality.

$$
\begin{aligned}
& { }^{270} \text { Ibid., } 283 . \\
& { }^{271} \text { Ibid., } 276 .
\end{aligned}
$$

${ }^{272}$ In other words, the primacy of the judicial mediation in Torrance means that this mediation is the primary activity of Christ as priest, whereas in Barth this primacy implies that the judicial mediation is not part of the priestly activity per se but conceptually informs the understanding of that activity. In fact, Torrance's distinction between judicial and liturgical mediations in Christ's priesthood is somehow unclear. If the liturgical mediation involves Christ's sacrifice and heavenly intercession, what is exactly the content of the judicial mediation? Would not the judicial mediation be materially characterized by His sacrifice on the cross? If so, would not this mediation be identical to the liturgical sacrificial mediation? If the answer to this question is negative, on the grounds that both the judicial mediation and the liturgical mediation refer to the cross but using different languages or frameworks to interpret this event, then we come to Barth's position, who does not see the judicial mediation as a priestly activity per se. With this implication in mind, as far as Torrance's account of Christ's priestly activities is concerned, I will focus my description below on what he calls liturgical mediation. In regards to Barth, his position that the saving work of Christ can be described by different frameworks or imageries, among them the cultic framework, ultimately implies that Christ acting as priest is only "another symbolical representation of the atonement." Ibid., 275. Barth argues that this "image indicates the fact. But the fact is greater and more powerful than the image. It necessarily transcends it." Ibid. I doubt that, by using the language of symbolic representation, the Swiss theologian is suggesting that the notion of Christ acting like a priest goes beyond (which is the idea of going beyond, being greater, and transcending) any human idea of Christ as priest. In fact, the language of symbolic representation seems to imply that, in reality, Christ is not a priest. In this case, priesthood would be only metaphor of the work of Christ. 
Regarding the ideas of sacrifice and heavenly intercession in the ontological model, the single act of sacrifice is the key concept of the action of Christ the priest in the ontological model. Informed by Hebrews that the main priestly function is to offer sacrifice, ${ }^{273}$ Barth interprets Christ's priesthood in terms of a substitutionary sacrifice that happened in Him at the cross, and this is the climax of His single and complete priestly action. ${ }^{274}$ Likewise, as mentioned above, Torrance conceives the priesthood of Christ as a liturgical sacrificial mediation that includes His heavenly intercession. For him, sacrifice and intercession are a single act performed by Christ the priest, not two activities. In contrast to the two sequential priestly activities of the offering of sacrifice and the intercession performed in the OT sanctuary, there is only "one act in the incarnate person of Christ" because He is "both the lamb and the priest." ${ }^{\text {275 }}$ Therefore, Christ's life and sacrifice has an intercessory character. ${ }^{276}$ In the ontological model, the one act of Christ the priest corresponds to Him as one person, the locus of the atoning activity. ${ }^{277}$

The concept of sacrifice in this model can be described by three basic characteristics: (1) obedient suffering, (2) divine action, and (3) destruction of sin. First, as priest and victim (sacrifice), Christ is the obedient servant who undergoes the path of

${ }^{273}$ Ibid., 277.

${ }^{274}$ These are the key points I mentioned above, at the end of my description of Barth's correspondence between the forensic and cultic frameworks.

275 Torrance, Atonement, 93.

${ }^{276}$ Torrance affirms, "In high priestly intercession Jesus Christ offered himself in sacrifice." Ibid., 67. The Scottish theologian sees intercession in "the actual historical events of the life and passion of Christ." Torrance, Royal Priesthood, 12.

${ }^{277}$ As Torrance emphasizes, "Once and for all Christ sacrificed himself presented himself before God as our sacrifice thus entering into the presence of God as our advocate and mediator to be accepted by him. It is all one indivisible act in one indivisible person. . . the atonement in act is identical with Christ himself." Torrance, Atonement, 94. 
suffering. ${ }^{278}$ According to Torrance, this is the obedience of man to $\operatorname{God}^{279}$ and

encompasses Christ's death (passive obedience) and His incarnate life (active

obedience). ${ }^{280}$ This means that, in a broad sense, the active obedience of Christ in His life is part of the priestly sacrifice. ${ }^{281}$ Thus, the principle of substitution is not restricted to Christ's death, but is already at work in the incarnation, ${ }^{282}$ and the obedience of His life substitutes the disobedience of human beings. According to this perspective, Christ's whole life is a sacrifice that reaches its completion on the cross. ${ }^{283}$ In other words, Christ's life (and not only death) is a substitutionary sacrifice. Second, while the idea of obedience highlights the human activity of the priest, the ontological model sees Christ's sacrifice as a divine activity. ${ }^{284}$ Torrance stipulates that this sacrifice is a transcendent

${ }^{278}$ See $C D$ I/1, 387. See also $C D$ IV/1, 143; Torrance, Incarnation, 57.

${ }^{279}$ For Torrance, "the whole incarnate life of Jesus is" a "priestly representation and obedience from the side of man to God." Torrance, Incarnation, 147.

${ }^{280}$ Torrance claims that Christ performed "expiation through his obedient submission to God in life and death." Ibid., 77. Drawing from Calvin's idea that the obedience of Christ pays the price of salvation and from the concept in Reformed theology of the passive and active obedience of Christ, the Scottish theologian points out that "the whole course of Christ's active obedience is absolutely integral to his work of reconciliation, and that atonement cannot be limited to his passive obedience, that is to his passive submission to the penalty for our sin inflicted upon him in his death." Ibid., 80-81. Torrance stipulates that Christ's passive and active obedience corresponds respectively to the forensic justification (external, non-imputation of sins) and the communion (internal, sharing in His human righteousness) of human beings with Christ's resurrected life. Ibid., 81-82.

${ }^{281}$ Torrance sees the "work of the cross . . . beginning immediately after his [Christ's] birth, increasing in his growth into manhood, and deepening in intensity as he entered his public ministry. His whole life is his passion." Ibid., 110; italics mine.

${ }^{282}$ In his description of the movement of redemption, Torrance emphasizes "God coming to man in order to restore man to God, of God taking man's place in order to give man God's place-the principle of substitution and the principle of incarnation." Ibid., 40.

283 Torrance argues that God's condemnatory judgment on Christ "takes place supremely on the cross, but the cross reveals what was taking place all the time in the incarnate life of the Son." Ibid., 112. He adds that God executes His judgment "in the incarnate life of Jesus, and above all in his death." Ibid., 150 .

\footnotetext{
${ }^{284}$ Torrance stipulates that the work of reconciliation involves both divine and human acts (the
} 
event in God, ${ }^{285}$ as He bears the sins of the world. ${ }^{286}$ Similarly, Barth affirms that God condemns and at the same time assumes the condemnation. ${ }^{287}$ Third, the idea of sacrifice does not emphasize punishment, ${ }^{288}$ but the elimination of sin/evil through the destruction of the person. ${ }^{289}$ In Barth's words, in the substitutionary sacrifice of Christ on the cross,

human action - obedience and sacrifice — is seen as a response to the divine action), as in the incarnation "one person acts both from the side of God, and from the side of man." Ibid., 184, 186.

${ }^{285}$ According to Torrance, "The sacrifice of the Son on earth derives from and remains one with a transcendent sacrifice in God." Speaking of the "lamb slain before the foundation of the world," the Scottish theologian argues that the "the atonement begins in the will of the Son to become man," and that "the historical crucifixion is grounded in a transcendent act of pure grace . . . although the transcendent act of self-giving and self-humbling fulfils itself in our human estate, in the death of the cross, it does not cease to be transcendent act." Ibid., 75.

${ }^{286}$ For Torrance, "it is God in Christ who suffers and bears the sin of the world, and reconciles the world to himself." He adds, "If the deity of Christ is denied, then the cross becomes a terrible monstrosity." Ibid., 189.

${ }^{287}$ According to Barth, in Christ God made "His own not only the guilt of man but also his rejection and condemnation, giving Himself to bear the divinely righteous consequences of human sin, not merely affirming the divine sentence on man, but allowing it to be fulfilled on Himself." $C D$ IV/1, 175. As Garry Williams highlights, for Barth, the atonement is "a reflexive act, an event in which God acts upon himself." Garry J. Williams, "Barth's Doctrine of the Atonement," in Engaging with Barth: Contemporary Evangelical Critiques, ed. David Gibson and Daniel Strange (New York: T\&T Clark, 2008), 241.

${ }^{288}$ Even though Barth indicates that punishment is "not completely rejected," this is not the main point. $C D \mathrm{IV} / 1,253$. Similarly, Torrance avoids the idea of Christ being punished by the Father. According to his reading of the NT, "the whole concept of propitiation together with that of wrath, judgement and forgiveness is drawn into the personal Father-Son relationship," and "the notion of priesthood" is "anchored deep in the personal and family relationship between God and his people." In fact, the NT "speaks of the penal-substitutionary aspect of atonement, not in the detached forensic categories that have developed in the Latin west . . but in terms of the intimacy of the Father-Son relation." In this way, agreeing with John McLeod Campbell, the Scottish theologian assumes that "we cannot think of Christ being punished by the Father in our place and the New Testament nowhere uses the word kolazo, punish, of the relation between the Father and the Son." Torrance, Atonement, 72.

${ }^{289}$ For Barth, the main idea of Christ's sacrifice is "not that He has suffered what we ought to have suffered," even though "this is true," but that "in His own person He has made an end of us as sinners and therefore of sin itself by going to death as the One who took our place as sinners. In His person He has delivered up us sinners and sin itself to destruction. He has removed us sinners and sin, negated us, cancelled us out: ourselves, our sin, and the accusation, condemnation and perdition." Therefore, "not by suffering our punishment as such, but in the deliverance of sinful man and sin itself to destruction, which He accomplished when He suffered our punishment, He has on the other side blocked the source of our destruction." In short, in the passion of Christ God "attacks and destroys at its very root the primary evil in the world." $C D$ IV/1, 253-254. Similarly, Torrance argues that "in the incarnate life of Jesus, and above all in his death, God does not execute his judgment on evil simply by smiting it violently away . . but by entering into it from within . . . to let the whole of human evil go over him." Torrance, Incarnation, 150. 
"His person made an end of us as sinners." ${ }^{290}$ In the light of Christ's resurrection, this destruction is followed by the creation of a new humanity. ${ }^{291}$ In short, the ontological model describes Christ's sacrifice as the substitutionary human obedience of His life (Torrance) and death, as a transcendent event in God in which He assumes the condemnation of human beings, and as the destruction of evil in humanity that allows their re-creation.

The understanding of Christ's heavenly intercession in the ontological model presupposes that His reconciliatory work was finished/completed in His death and resurrection. ${ }^{292}$ In this substitutionary death, sinful human beings were condemned and destructed, and in Christ's resurrection they have been re-created as a new humanity. ${ }^{293}$

${ }^{290} C D$ IV/1, 253. As Williams indicates, for Barth, there is a "primacy of the destruction of sin over punishment," where "the punishment of sin is a means to another, higher end, the termination of sinful man and his replacement by the new man constituted in Jesus Christ." Therefore, "although Barth affirms the idea of satisfaction, it is not the divine hostility to sin that is satisfied, for God does not require retribution for sin to himself and his own justice. Rather, the divine love is satisfied by the destruction of sinful man through the cross." Williams, "Barth's Doctrine of the Atonement," 243, 246. According to Donald Bloesch, in Barth, "what occurs in the cross is more than the defeat of sin and the vindication of righteousness: there sin is removed from the life of man and replaced by righteousness." Hence, "Barth does not break completely with the traditional understanding of substitution," but he "sees in the event of the atonement not simply the removal of the penalty of sin but the renewal of the world." Donald G. Bloesch, Jesus Is Victor!: Karl Barth's Doctrine of Salvation (Eugene, OR: Wipf and Stock, 2001), 50-52.

${ }^{291}$ Barth indicates that the divine judgment in Christ "brought in a new man, founded a new world and inaugurated a new æon-and all this in His passion." $C D$ IV/1, 254. The Swiss theologian argues that "the suffering and death of Jesus Christ are the No of God in and with which He again takes up and asserts in man's space and time the Yes to man which He has determined and pronounced in eternity." Ibid., 257. Torrance stipulates that "man's wrong has been set aside in and with the judgment accomplished upon the humanity of Christ, and now in his humanity our new right humanity has been established before God." Torrance, Incarnation, 186.

${ }^{292}$ As Torrance points out, Christ's resurrection means "the completion of" His "saving work." Torrance, Atonement, 212. Barth talks about Christ's "finished work of reconciliation," which was "finished in Him." CD IV/1, 283. Horton argues that, for Barth, "everything that happens on this side of Golgotha" is not necessary "for human salvation per se." Michael S. Horton, "Covenant, Election, and Incarnation: Evaluating Barth's Actualist Christology," in Karl Barth and American Evangelicalism (Grand Rapids, MI; Cambridge, UK: Eerdmans, 2011), 139.

${ }^{293}$ According to Barth, in "the sentence executed and revealed in Jesus Christ and His death and resurrection," the divine "No and the Yes," God converts human beings "to Himself and therefore 
In contrast to the sacramental and functional models, there is no further subjective salvific application to individual human beings of the reconciliation objectively accomplished by Christ. In Him, their reconciliation is achieved and salvifically appropriated. ${ }^{294}$ Barth argues that the death and resurrection of Christ did not create a possibility of salvation that needs to be appropriated by human beings. ${ }^{295}$ Because the person of Christ is the locus of atoning reconciliation and the material content of the atonement, human reconciliation is already a reality in Him - there is nothing to be further salvifically appropriated. ${ }^{296}$ This position raises the question of how the heavenly

reconciles" them "with Himself. He does it by the destruction of the old and the creation of a new man." $C D$ IV/1, 96. The Swiss theologian claims that Christ "was justified by God in His resurrection from the dead. He was justified as man, and in Him as the Representative of all men all were justified." Ibid., 305306. Likewise, Torrance believes that the resurrection of Christ means that "we have the new humanity in perfect union with God." Torrance, Incarnation, 195. The Scottish theologian argues that "our resurrection has already taken place and is already fully tied up with the resurrection of Christ." Torrance, Atonement, 208.

${ }^{294}$ Torrance affirms that Christ "was at once the fulfilled act of reconciliation on the part of God toward man, but he was also the fulfilled appropriation of that reconciliation on the part of man toward God." Torrance, Incarnation, 126. The Scottish theologian stipulates that "Christ must be recognised as acting in our place in all the basic acts of man's response to God: in faith and repentance, in obedience and prayer, in receiving God's blessing and in thanksgiving for it." Thomas F. Torrance, "Karl Barth and the Latin Heresy," Scottish Journal of Theology 39, no. 4 (1986): 479. Torrance states, Christ "has believed for you, fulfilled your human response to God, even made your personal decision for you, so that he acknowledges you before God as one who as already responded to God in him." Torrance, The Mediation of Christ, 94. For helpful information on Torrance's rejection of the traditional ordo salutis, characterized by a sequence of salvation accomplished and salvation applied, see James J. Cassidy, "T. F. Torrance's Realistic Soteriological Objectivism and the Elimination of Dualisms: Union with Christ in Current Perspective," Mid-America Journal of Theology 19 (2008): 165-194; Elmer M. Colyer, How to Read T.F. Torrance: Understanding His Trinitarian \& Scientific Theology (Downers Grove, IL; Eugene, OR: InterVarsity; Wipf and Stock, 2007), 218-219; Kye Won Lee, Living in Union with Christ: The Practical Theology of Thomas F. Torrance (New York: Peter Lang, 2003), 214; Molnar, Thomas F. Torrance, 178; Habets, Theosis in the Theology of Thomas Torrance, 125-129.

${ }^{295}$ Barth rejects the idea that the objective reconciliation of Christ created a possibility that needs to become a subjective actuality. He is against the distinction between objective and subjective, or possibility and actuality in the atonement. See $C D$ IV/1, 285. In his view, the "participation of ours in the person and work of Jesus Christ does not have to be added as a second thing. As the one thing which has to be done it is already wholly and utterly accomplished in Him." CD II/1, 157-158. Similarly, Torrance argues that Christ's work is "a finished work and not a mere possibility." Torrance, Atonement, 188. See also ibid., 187, 189.

${ }^{296}$ As Barth emphasizes, "The turn from Jesus Christ to us has already been executed and is a fact 
intercession of Christ is understood in the ontological model. In contrast to the traditional idea of an intercession that applies salvation to human beings, ${ }^{297}$ the heavenly intercession is interpreted along the lines of a full and eternal reality of reconciliation in Christ that is somehow accessible to earthly human beings. For the Swiss theologian, the ascension means that Christ, the ontological reality of human complete reconciliation, becomes contemporary to all times and to all human beings. ${ }^{298}$ In his turn, the Scottish theologian attempts to elaborate more on the heavenly priesthood of $\mathrm{Christ}^{299}$ and,

in Him, that in and with Him we, too, are there as those for whom He is and has acted." CD IV.1, 285.

${ }^{297}$ Barth criticizes the account of the priesthood of Christ in "older dogmatics" for the distinction between the person/work of Christ and the application of His work to human beings (applicatio salutis). For him, this idea of application implies the wrong notion that something needs to be added to the once for all work of Christ. CD IV/1, 314. As Williams explains, in Barth, "the work of Christ is not ... something external, which is then applied to the sinner. . . Rather, the sinner is included within the objective work of Christ." Williams, "Barth's Doctrine of the Atonement," 249.

298 According to Barth, Christ "stands before His Father now in eternity for us, and lives for us in God Himself as the Son of God He was and is and will be. Thus our appropriation of what He has won for us has not first to be executed by us. By the fact that He is for us in eternity in God Himself the man who is ready for God, it is executed in eternity, in God Himself, by Him, in the eternal continuation of His highpriestly office." He adds, "It is not another work that begins at this point, a work that will have to be ours." In fact, "this representing of Jesus Christ is an eternal representing and therefore one which is contemporary to all time." CD II/1, 156; italics mine.

299 Torrance reports that, in a conversation with Barth, he expressed his qualms regarding the "account of the ascended Jesus Christ in $C D$ IV/3, in which Christ seemed to be swallowed up in the transcendent Light and Spirit of God, so that the humanity of the risen Jesus appeared to be displaced by what he called 'the humanity of God' in his turning toward us. I had confessed to being astonished not to find at that point in Barth's exposition a careful account of the priestly ministry of the ascended Jesus in accordance with the teaching of the Epistle to the Hebrews about the heavenly intercession of the ascended Christ, which would have been fully consonant with Barth's anticipatory references to the high-priestly ministry of Christ in $C D$ IV/1 (cf. 'The Verdict of the Father') and with his persistent emphasis on the vicarious humanity of Christ." Thomas F. Torrance, "My Interaction with Karl Barth," in How Karl Barth Changed My Mind, ed. Donald K. McKim (Grand Rapids, MI: Eerdmans, 1986), 62; italics mine. Building on Torrance's criticism, Douglas Farrow also disapproves Barth's "unfortunate neglect of the priestly office." Douglas Farrow, "Karl Barth on the Ascension: An Appreciation and Critique," International Journal of Systematic Theology 2, no. 2 (2000): 143. See also Douglas Farrow, "Ascension and Atonement," in The Theology of Reconciliation, ed. Colin E. Gunton (London; New York: T\&T Clark, 2003), 68-82; Douglas Farrow, Ascension and Ecclesia: On the Significance of the Doctrine of the Ascension for Ecclesiology and Christian Cosmology (Edinburgh: T\&T Clark, 1999), 229-254. For a depiction of how Farrow expands Torrance's critique, see Burgess, The Ascension in Karl Barth, 109-161. In light of his criticism, Torrance attempts to elaborate more on the heavenly priesthood of Christ. His description of this priesthood focuses on three chief concepts, namely, self-oblation, prayer/intercession, 
likewise Barth, his reflection is related to the notion of time. According to Torrance, the ascended humanity of Christ is the content of the prayers and worship of earthly believers directed to God in heaven. ${ }^{300}$ This view assumes a close connection between Christ the heavenly priest and the eucharist in the church. ${ }^{301}$ Two points, however, nuance this connection. First, while Christ is described in His "eternal advocacy of us or intercession

and blessing/benediction. First, the "endless self-oblation" of His ascended humanity before the Father is qualified by Christ's "self-offering to the Father" in the ascension, a "thank-offering or tribute which we offer to the King of Kings." In this view, the person of Christ is the ontological "content and sole reality of the worship and prayer of man," and in this sense He is "the eternal leader of our prayer and intercession," which means that the worship of the church is an echo of this priestly intercession. Second, the "ontological content" of Christ's "eternal intercession or advocacy for us" is the "whole existence of the incarnate Son" in the indivisibility of His person and act. Third, the worship of the church is characterized by a communion (koinonia) with Christ through the distribution of the spiritual gifts that takes place in the celebration of the Lord's Supper. In other words, Christ the priest blesses the church with the Spirit and then believers become participants of His priesthood in terms of their service to Him. Torrance, Space, Time and Resurrection, 115-118; Torrance, Atonement, 277. In Burgess' estimation, even though Torrance uses more of the language and concepts of Christ's ascended priesthood, the outcome of this theology is not much different from Barth. Indeed, "considering the nature of his criticism of Barth, Torrance's treatment of Jesus' ascended high priesthood is remarkably brief." He adds, "Torrance's treatment of Jesus' endless self-offering" is not much different from Barth's emphasis that the "entirety of Jesus' life is a selfoffering." Burgess, The Ascension in Karl Barth, 122. Burgess concludes, "It is hard . . to see how this goes beyond Barth in achieving any insight into Jesus' ascended agency on our behalf." Ibid., 117. See also ibid., 119.

${ }^{300}$ For Torrance, Christ is the real and complete content of the worship of humankind. Christ's the priest "became our brother man and He offered on our behalf a human obedience, a human response, a human witness and a human amen, so that in Him our human answer to God in life, worship, and prayer is already completed." Torrance, Royal Priesthood, 14.

${ }^{301}$ The Scottish theologian stipulates that the eucharist "represents" Christ's "advocacy and prayer for us." Considering that the eucharist is the focus of Torrrance's account of the worship of the church in connection with the priestly intercession of Christ, the he argues that the eucharist, "while being the worship of men on earth, is essentially a participation in the worship of the heavenly sanctuary which Jesus Christ their ascended High Priest renders to the Father in the oblation of his endless life." Torrance, Theology in Reconciliation, 110. In this sense, "the risen and glorified Lord comes to meet us and gives himself to us that we, united with him through communion in his body and blood, may be lifted up with him into the holiest in the power of his resurrection and exaltation, and worship the Father with, in and through him." Ibid., 121. Therefore, Torrance believes that "we worship the Father through the priesthood of the Son" Ibid., 111. This is different from worshipping the Father through the priesthood of the divine Son, and therefore requires the human mediation of Christ in heavenly prayer and worship to God (by definition, the divine Christ does not pray and worship God). Ibid., 116. The Scottish theologian criticizes the theological trend initiated after the Arian crisis of the fourth century that, by emphasizing the divinity of Christ, assimilated "the mediatorship of Christ to his Lordship, and a Priesthood interpreted in terms of his mediating divine holiness to man, not in offering holiness from the side of man to God." Ibid., 115. 
on our behalf," ${ }^{302}$ this description does not imply another salvific act performed by Him in heaven. Rather, what Christ did once and for all on earth is, through His resurrection and ascension, an "enduring event" that is "continuously operative" and "eternally valid before the Father," meaning that His salvific action on earth is "decisive for all time.,"303 Second, in contrast to the sacramental model, the eucharist is not identical with the priesthood of the heavenly Christ. ${ }^{304}$ For Torrance, the former is derivative ${ }^{305}$ or an echo of the latter through the communion (koinonia) established by the Spirit. ${ }^{306}$ With this idea of derivation in mind, the Scottish theologian argues that in the eucharist believers become participants of Christ's priesthood. ${ }^{307}$ These two assumptions-(1) the content of

302 Thomas F. Torrance, Conflict and Agreement in the Church, 2 vols. (London: Lutterworth Press, 1960), 2:144.

${ }^{303}$ Ibid., 2:144, 158, 180. The Scottish theologian argues that "the very existence of Christ among us, his life, work, crucifixion, resurrection, are all modes of his divine-human intercession." Torrance, Space, Time and Resurrection, 115-116.

${ }^{304}$ Torrance stipulates that "Christ's Priesthood and the Church's priesthood cannot be spoken of in univocal terms any more than Christ's sacrifice and the eucharistic sacrifice." Torrance, Conflict and Agreement in the Church, 2:195. Based on this assumption, Torrance believes that the problem of Catholicism is the univocal understanding of sacrifice and offering of God and the church. Ibid., 2:180.

${ }^{305}$ For Torrance, the eucharist is the "sacramental counterpart to the unique sacrifice of Christ" in the sense that the eucharist "echoes" it and "is derivative from it." Ibid., 2:180. In this sense, "what the Eucharist proclaims is not our offering but Christ's offering on our behalf, which only in that derivative way becomes our offering." Ibid., 2:183.

${ }^{306}$ According to Torrance, "The reconciliation wrought by Christ has been completed once and for all and by its very nature cannot be repeated, but it is given a counterpart in the worship and adoration and confession of the church in the form of the eucharistic prayer and praise echoing the heavenly intercession of Christ." Torrance, Atonement, 91; italics mine. In his remarks on "Christ's royal priestly ministry," the Scottish theologian maintains that "the church's communion in the body and blood of Christ through the Spirit," which is associated with the distribution of spiritual gifts, is an "echo the one priesthood of Christ." Ibid., 277. Furthermore, he mentions that "the Church in its eucharistic liturgy does not participate in that sacrifice except by echoing it in the counter-sacrifice of praise and thanksgiving." Torrance adds, "The earthly liturgy ... echoes the heavenly," and the "liturgy of heaven centres in the Self-presentation of the Lamb of God before the Father." Torrance, Royal Priesthood, 95-96. See also Torrance, Space, Time and Resurrection, 118.

${ }^{307}$ For Torrance, the church "is sacramentally and analogically derivative from" Christ's heavenly priesthood in the eucharist. "There in heaven is the ascended Lamb Himself ever before the Face of the Father; here on earth is the waiting Church of sinners . . . showing forth His death and pleading His 
Christ's heavenly priestly intercession is the eternity of His once and for all salvific action, and (2) the eucharist is derived but not identical to His heavenly priesthoodallow Torrance to delineate an interplay between new creation and old creation, which presupposes in the ontological model a respective distinction between new time and fallen time, ${ }^{308}$ where the reality of the new creation irrupts in the midst of old creation in the context of the eucharist. ${ }^{309}$ In this view, the eucharistic prayers and worship of believers $^{310}$ are replaced by the prayer and worship of the new humanity of new creation (the ascended Christ in His humanity), ${ }^{311}$ as the eucharist offers a taste of new creation in Christ, confirming the enduring reality of new creation to believers surrounded by the

sacrifice." And "both are united in the koinonia of the eternal Spirit, through whom Christ offered Himself to the Father, and through whom we are given to participate in that oblation made on our behalf." The Scottish theologian adds, "That is the profound mystery of Holy Communion, that the Church is given to participate (koinonein) in Christ's substitutionary Self-consecration." Torrance, Conflict and Agreement in the Church, 2:178. See further comments on the idea of participation depicted in the previous footnote.

${ }^{308}$ As Torrance indicates, "just as the original creation involved the creation of time, so this new creation involves new time, time that is no longer at variance with the eternal through sin, but time that is cleansed and restored to union with the eternal." Ibid., 2:162.

309 According to Torrance, "In this Supper the Church is given to taste and experience already the powers of the age to come; it is essentially a prelude to the new creation." Ibid., 2:139. In other words, to participate in the eucharist is to "taste the powers of the age to come through sacramental incorporation into the new creation." Ibid., 2:160. In this sense, the Scottish theologian sees the church as an eschatological reality in the eucharist. In his words, "in the Eucharist . . . the Church really becomes the Church, both as the ontological and eschatological reality." Ibid., 2:189.

${ }^{310}$ Torrance defines the eucharist as "essentially a prayer and hymn of thanksgiving." Ibid., 2:148.

311 Torrance argues that "the worship and ministry of the Church on earth must be governed by the fact that Christ substitutes himself in our place, and that our humanity with its own acts of worship, is displaced by his, so that we appear before God not in our own name . . . but solely in the name of Christ and solely in virtue of what he has done in our name and on our behalf." Thomas F. Torrance, Theology in Reconstruction (London: SCM Press, 1965), 167; italics mine. The Scottish theologian adds that "Christ's high-priestly prayer recorded in John 17 is perpetual in its virtue and ever obtains mercy for us in the presence of His Father; it is that intercession of Christ that stands behind our prayer when we approach God in the Name of Christ and plead His passion on our behalf, and offer ourselves to Him as sinners whom Christ has redeemed by His blood." Torrance, Conflict and Agreement in the Church, 2:149. 
earthly conditions of old creation. ${ }^{312}$ Both Barth's idea of the ascended Christ becoming contemporary to all times and Torrance's notion of new creation in Christ becoming particularly tasted in the eucharist are further clarified by the concept of time and eternity in the ontological model, which will be explored in chapter three.

In summary, the ontological model interprets the cultic activity of Christ the priest in the light of a judicial conception: His sacrifice (cultic) is substitutionary (judicial). The basic idea of this substitutionary sacrifice is not punishment, but the elimination of sin by the destruction of sinners in the death of Christ, which is followed by the actual recreation of human beings in His resurrection. This understanding of Christ's death and resurrection assumes that $\mathrm{He}$ is the object of His own salvific action. Under the assumption that His one person corresponds to one action, Christ's single priestly action is His sacrifice. This single action includes His whole life and death (Torrance), is an event in God, and has an intercessory character. Since Christ is the object of His own salvific action, the reconciliatory work was completed with His resurrection. Christ's death and resurrection did not create a possibility of salvation that would become actual in a subsequent subjective application to individual human beings. This implies that the (post-resurrection) heavenly intercession of Christ is not another salvific action. As the complete reality of reconciliation, the resurrected person Christ is contemporary/accessible to all times (Barth) and is the human ontological content of new creation tasted in the eucharist (Torrance).

I will conclude my depiction of the ontological model in this chapter by turning to

\footnotetext{
312 According to Torrance, "The significance of eucharistic communion lies in the fact that by the act of the eternal Spirit the believing Church is given to step over the eschatological boundary." Torrance,
} 
the goal of Christ's priesthood.

\section{The Goal of the Priesthood}

On the basis of the description above, the priesthood of Christ is necessary because of the existential broken relationship between humankind and God since the beginning of creation, which requires that Christ's priestly mediation propitiate the divine wrath and provide the transformation of human beings. In this mediation, He is both the subject and object of the priesthood. The reconciliation Christ performs (subject) takes place in His own being (object). ${ }^{313}$ A distinct point of this mediation is that Christ's substitutionary sacrifice is a means for the elimination of $\sin /$ evil by the destruction of sinners in His death, followed by the re-creation of human beings in His resurrection. ${ }^{314}$ In this context, there is no further subjective application of salvation to individual human

\section{Conflict and Agreement in the Church, 2:187.}

${ }^{313}$ In Him, both God and human beings are subjects and objects of His priesthood. In Christ, God humiliates Himself (subject) and is propitiated (object). In Christ, humanity is destroyed and recreated/exalted (object), and renders to God obedience and worship (subject-Torrance's emphasis). Torrance sees Christ's obedience and worship, among other acts, as the "fulfilled response of men toward God." Torrance, Space, Time and Resurrection, 115. This emphasis on the active role of Christ's humanity in His priesthood seems to be considered by some commentators as a corrective to Barth's lack of reflection on the human priesthood of Christ. Alan Torrance stipulates that Barth left the theme of Christ's priesthood underdeveloped, and this is evidenced by a lack of depth in his reflection on the sacraments and on the relationship between Christ's vicarious humanity in His continuing priesthood and the theology of worship. Alan Torrance, "The Trinity," in The Cambridge Companion to Karl Barth, ed. John B. Webster (Cambridge, UK; New York: Cambridge University Press, 2000), 82-83. Likewise, Colin Gunton argues that Barth does not give a proper treatment to Christ's continuing human priesthood. Colin E. Gunton, "Salvation," in The Cambridge Companion to Karl Barth, ed. John B. Webster (Cambridge, UK; New York: Cambridge University Press, 2000), 153, 157. In fact, Thomas Torrance makes a similar point when he claims that, in Barth, "the humanity of the risen Jesus" seems "to be swallowed up" by His divinity. Thomas F. Torrance, Karl Barth: Biblical and Evangelical Theologian (Edinburgh: T\&T Clark, 1990), 134.

${ }^{314}$ As Barth puts it, "Reconciliation is a comprehensive occurrence, embracing many in the One in whom it was made." $C D$ IV/1, 251. He adds, "The resurrection of Jesus Christ affirms that which is actual in His death, the conversion of all men to God which has taken place in Him." Ibid., 317. 
beings ${ }^{315}$ but rather access to the full and eternal reality of reconciliation in Christ, who is contemporaneous (divine eternity) to every individual in His revelation (Barth), and that can be tasted in the eucharist (Torrance). ${ }^{316}$

In this way, the goal of reconciliation in this model of Christ's priesthood is qualified by Barth's notion of revelation (Christ's prophetic office) and by Torrance's emphasis on the continuing priesthood of Christ in the eucharistic worship of the church. ${ }^{317}$ In principle, both qualifications are largely compatible views of the reality described by the goal of Christ's priesthood. The key to this compatibility is the connection between revelation and participation, which I will explore below. Simply stated, the goal of Christ's priesthood is to bring God and humankind to fellowship and communion, the original purpose of creation threatened by the dissolution of $\sin { }^{318}$ In the ontological model, this goal of reconciliation is already a complete

\footnotetext{
${ }^{315}$ According to Barth, "There can be no question of any repetition or representation of that event, or even of an actualisation which has still to be effected." Ibid., 295.

${ }^{316}$ Hunsinger suggests that Torrance, as Barth's student, sees "the full contemporaneity of Christ's person in his work here and now, and his work in his person" taking place in the eucharist. The connection between His contemporaneity and the sacrament established by Torrance was never "quite managed to carry through" in Barth's theology. George Hunsinger, Conversational Theology: Essays on Ecumenical, Postliberal, and Political Themes, with Special Reference to Karl Barth (New York: T\&T Clark, 2015), 36.

${ }^{317}$ Worship seems to mark, for Torrance, the fulfillment of the salvific work of Christ. In his words, "the redeeming and atoning work of Christ reaches out in fulfilment, in worship at the mercy-seat, in worship at the throne of God." He adds, "This aspect of the atonement" is "particularly evident in the worship and sacramental life of the church," more specifically in the "eucharist," in "the dramatic prayer in union with the mediation and intercession of our ascended high priest at the right hand of the Father." Torrance, Atonement, 71. The Scottish theologian stipulates that the "worship and praise of the church," understood as "its entry into the holy place in the name of Christ its high priest" is the moment when "the atonement reaches its appointed end or telos." Ibid., 93.

${ }^{318}$ For Barth, reconciliation is the "the resumption of a fellowship which once existed but was then threatened by dissolution." $C D$ IV/1, 22. In this sense, "the work of atonement in Jesus Christ is the fulfilment of the communion of Himself with man and of man with Himself which He willed and created at the very first." Ibid., 36. According to Torrance, "The restoration of creation involves the restoration of creation to communion and fellowship with him . . . in reconciliation and atonement." Torrance, Incarnation, 115. The Scottish theologian defines the goal of atonement as "the resurrection of our human
} 
reality. However, the model needs to explain how such reality can be complete if reconciliation is not concretely observed in the present world (at least, not in its complete form). It is in this context that the concept of revelation becomes crucial for the ontological model. More specifically, reconciliation is incomplete only in terms of revelation, not in terms of its reality. ${ }^{319}$ The goal of Christ's priesthood awaits fulfillment only noetically, not ontologically. ${ }^{320}$ For Torrance, the NT "speaks of justification and reconciliation as the completed and finished work of Christ, and that aorist and perfect tenses are used to do that. ${ }^{321}$ Following this perspective, Barth describes the prophetic work of Christ as the "the disclosure of completed reconciliation and man's opening up to

nature in Christ into communion with the life of God." Torrance, Atonement, 228. He claims that Christ "achieved within our creaturely being the very union between God and man that constitutes the heart of atonement, effecting man's salvation and restoration to communion with God the Father." Torrance, Space, Time and Resurrection, 47. Considering that Barth and Torrance employ the language of "resumption" and "restoration" of this communion, it is debatable if the use of such language would be appropriate, as long as their interpretation of Gen 1-3 is not historical (see footnote 219 above).

${ }^{319}$ Barth argues that, "if we could see with God's eyes, we should realise that in spite of appearances everything is already very different, all things being made new and set right. The only thing is that we cannot see in this way. The actual alteration of our existence, of all things, of the whole being of the world, is hidden from us in the sense that it cannot be observed or experienced except in this event, in the living Jesus Christ Himself. The alteration of our situation effected in Him is concealed as it were by a veil which our eyes cannot penetrate." CD IV/3.1, 316-317. Likewise, Torrance points out that "looked [at] from the side of God, the whole work of salvation is accomplished in the Son, but looked at from the human side ... it is not seen to be completed and fulfilled as yet." Therefore, God's act of atonement, "from the point of view of revelation, is still outstanding or future, still to be fully and finally revealed or consummated." Torrance, Atonement, 174.

${ }^{320}$ According to Barth, "The work of atonement, the conversion of man to God, was done for all. The Word of God is spoken to all. God's verdict and direction and promise have been pronounced over all. To that extent, objectively, all are justified, sanctified and called. But the hand of God has not touched all in such a way that they can see and hear, perceive and accept and receive all that God is for all and therefore for them. . . . They do not know their justification, sanctification and calling as they have already taken place in Jesus Christ." CD IV/1, 148. Similarly, Torrance maintains that "justification is a complete reality awaiting disclosure." Torrance, Atonement, 134.

${ }^{321}$ Torrance, Atonement, 174. The Scottish theologian claims that the NT "emphasis is not on the future reality of the kingdom, but on the future of its full manifestation." As a matter of fact, "new creation" is "already consummated and waiting for eschatological unfolding or fulfilment in the advent presence of Christ." Torrance, Incarnation, 334, 338. 
it." ${ }^{322}$ This revelation is necessary because "the victory of Jesus . . . is not yet

consummated" according to "our sphere and circle of vision." 323 In this sense,

reconciliation takes place primarily (ontologically) in Christ, and secondarily (noetically)

"in the knowledge of salvation created by Him" in human beings. ${ }^{324}$ This knowledge,

however, is not only intellectual but entails participation in the event of salvation. ${ }^{325}$ The

knowledge is more than intellectual because the content of the reconciliation that is

revealed, as mentioned above, is not merely something Christ did (as the subject of

reconciliation) but is His own being (as the object of reconciliation). He is the content of

reconciliation and, consequently, of revelation. ${ }^{326}$ In other words, the revelation of

${ }^{322} C D$ IV/3.1, 220.

${ }^{323}$ Ibid., 262. Taking into account the traditional eschatological language of "already" and "not yet," Barth seems to understand the "not yet" as a description of the human vision of reconciliation, and not a depiction of the reality of the reconciliation. In other words, for him, the "not yet" is noetic, not ontic.

${ }^{324}$ Ibid., 217. Adrian Langdon acknowledges that there is in Barth a tendency "to reduce the ascension and parousia to a noetic realization of the reconciliation completed on the cross." Adrian Langdon, God the Eternal Contemporary: Trinity, Eternity, and Time in Karl Barth (Eugene, OR: Wipf \& Stock, 2012), 42. Horton highlights that "instead of redemption accomplished and applied," Barth's "duality is between redemption and attestation or event and recognition. So if the resurrection, the ascension, Pentecost, and the parousia lie on the attestation/recognition rather than redemption/event side of the line, it only follows that pneumatology, preaching, and sacraments can only fall on the "witness' side as well." Horton, "Covenant, Election, and Incarnation," 141-142. In Bloesch's words, "Barth does not deny the subjective dimension of the atonement, but he sees this basically as the apprehension and acknowledgment of the reconciliation already give in Jesus Christ.” Bloesch, Jesus Is Victor, 49.

${ }^{325}$ According to Barth, "The one who participates in this knowledge participates in the event of salvation itself." $C D$ IV/3.1, 217. The Swiss theologian depicts the knowledge created by revelation in the following way: (1) it is not "mere acceptance or reflection," "mere thought," "mere conviction," or "a subjective human attitude"; (2) "the whole man with all his possibilities and experiences and attitudes is grasped by the object which takes and retains the initiative in relation to him, and turned right about to face this object, to be wholly orientated upon it"; (3) "as a human action it takes place in participation in His action.” Ibid., 218, 220-221.

${ }^{326}$ For Barth, "revelation in fact does not differ from the person of Jesus Christ nor from the reconciliation accomplished in Him." $C D \mathrm{I} / 1,119$. See also the identification of reconciliation, revelation, and the being and work of Christ in $C D$ IV/3.1, 165. Similarly, Torrance argues that "revelation and atonement are ... inseparable, Christ revealing and Christ reconciling ... within the one person of Christ." Torrance, Incarnation, 37. He adds, revelation and reconciliation "are not two acts but one act, for revelation is part of reconciliation and reconciliation is part of revelation." Ibid., 57. 
reconciliation is Christ revealing Himself as the complete reality of reconciliation.

Therefore, the revelation that creates in human beings the knowledge of this complete reality implies the contemporaneous presence of Christ, who reveals Himself to them. On the basis of Christ's personal presence as revelation, the knowledge created by Him in human beings means participation and even impartation of the reconciliation in Christ. ${ }^{327}$

For Barth, "this expressing, imparting, telling and reminding, which are not just verbal and intellectual but supremely real and powerful, are the new and particular feature of reconciliation in its form as revelation, ... of the being and action of Jesus Christ in His prophetic office." ${ }^{328}$ Hence, this awareness of the reconciliation created in human beings by revelation awakes not only the intellect but also their entire life. ${ }^{329}$ While reconciliation is already a complete reality, the awareness and awakening created by

${ }^{327}$ Barth emphasizes that this knowledge "is a secondary event, related to the primary event fulfilled in the one Jesus Christ and participating in this on the ground of His free address of grace. Yet with no less reality it is itself also an event of salvation. In Christian knowledge Jesus Christ comes to be and is really present to man. What $\mathrm{He}$ does for him $\mathrm{He}$ also does to and in him. He gives him the freedom, permission and command to be the man he is in Him, the new creature, the justified and sanctified sinner, His brother, the child of God, the responsible witness of the atonement which has taken place in Him. Less than this we may not think or say of the event of true Christian knowledge." $C D$ IV/3.1, 220; italics mine.

${ }^{328}$ Ibid., 281. Barth stipulates that, "after the Easter," revelation also "takes place in the form of the impartation of the Holy Spirit." Ibid., 293. According to Katherine Sonderegger, Barth's notion of sanctification, which is defined by the idea of impartation, "is not repetition, or appropriation or disposition toward holiness, but rather only a following, an acknowledgment, a correspondence by sinners, standing under the Word in alien sanctification." Katherine Sonderegger, "Sanctification as Impartation in the Doctrine of Karl Barth," Zeitschrift für Dialektische Theologie 18, no. 3 (2002): 314.

${ }^{329}$ According to Barth, in Christ's revelation "He discloses and manifests and announces and imparts Himself. ... Their life already actualised in Him, in order that the place and power of sin, from which they are already liberated and separated in Him, should be destroyed in them too, in order that the alteration of the situation between God and man, which has validly taken place for them, should be effective and manifest in them too, in order that they, too, should grasp the grace of God which in Him is fully and unreservedly addressed to them already, in order that they, too, should thus begin to live by this grace. This is the outreaching, embracing and comprehending of reconciliation in its prophetic determination. It expresses itself. Its peculiar feature in this determination is that it shares with the world the fact that it is the world already reconciled with God. By this impartation it awakens and allows and commands it to know and experience and take itself seriously as such, to act as such, and therefore to exist as the reconciled and not the unreconciled world. It tells all those who do not yet know it that what has 
Christ's revelation demands from human beings recognition and gratitude expressed in service and praise ${ }^{330}$ For the Swiss theologian, this awaking knowledge is created only by revelation, as until Christ's final parousia "the alteration of the human situation" in reconciliation can be seen "only by faith and not by sight.",331

While in Barth the participation of human beings in the complete reality of reconciliation takes place through Christ's revelation, Torrance adds some features to the participation in this revealed reality, particularly in his emphasis on the incarnation and the Lord's Supper. The Scottish theologian stipulates that there are three types of union or communion with God: (1) consubstantial (union/communion in the Trinity), (2) hypostatic (union/communion of the natures of Christ), and (3) koinonia (union/communion of human beings with God through the Spirit, partakers of the divine nature). ${ }^{332}$ Without disregarding the importance of Christ's death and resurrection, ${ }^{333}$

taken place among them is their own justification and sanctification." $C D$ IV/3.1, 280.

${ }^{330}$ In Barth's words, "What remains for us is simply to recognise and respect it with gratitude in that provisional praise." $C D$ IV/2, 516. In this sense, the prophetic work of Christ demands "gratitude and obedience and service." $C D$ IV/3.1, 217. Similarly, Torrance associates the restoration of the fellowship of human beings with God (reconciliation) with obedience and adoration. Torrance, Incarnation, 115. In addition, he stipulates that service (as a servant) is the form in which the church participates in Christ's priesthood. See Torrance, Atonement, 277; Torrance, Royal Priesthood, ix; Torrance, Space, Time and Resurrection, 118.

${ }^{331} C D$ IV/1, 318-319. "It is not yet, however, the light of the altered world itself which we can expect on the ground of this alteration. It is not yet the revelation of the altered creation, of the children of God as they are transformed by what has taken place for them and to them in Jesus Christ. It is not yet the time of the resurrection of all the dead. Obviously, therefore, it is not yet the time of the fulfilment of the resurrection which has come to them in Jesus Christ. To that extent it is not yet the fulfilment of His parousia and presence and salvation in the world reconciled by Him." Ibid., 319.

${ }^{332}$ Torrance, Atonement, 231. This idea of koinonia describes Torrance's notion of theosis. For a helpful study on this theme in Torrance, see Habets, Theosis in the Theology of Thomas Torrance.

${ }^{333}$ Torrance also sees the communion of humankind with God as a result of Christ's resurrection. He speaks of "the resurrection of our human nature in Christ into communion with the life of God." Torrance, Space, Time and Resurrection, 67. For him, in Christ's resurrection is "new humanity in perfect union with God." Torrance, Incarnation, 195. 
Torrance indicates that the goal of a reconciled communion between human beings and God is already a reality in the hypostatic union. He views Christ's incarnation "as our sanctifying union with his divine nature. ${ }^{, 334}$ At the same time, the Scottish theologian highlights the participation of humankind in the revealed reality of reconciliation in terms of koinonia, "our participation in" the "completed work of atonement.",335 According to Torrance's idea of koinonia, this participation takes place in the liturgical activity of the church. ${ }^{336}$ More specifically, in the Lord's Supper the ascended Christ "comes to meet us and gives himself to us that we, united with him through communion in his body and blood, may be lifted up with him into the holiest in the power of his resurrection and exaltation, and worship the Father with, in and through him. ${ }^{, 337}$ Furthermore, there is in the Lord's Supper the distribution of spiritual gifts sent by Christ through the Spirit. By using these gifts, believers participate in Christ's priesthood in terms of service to Him. ${ }^{338}$ Therefore, the goal of communion is already a reality in the hypostatic union, and the participation (koinonia) in the revealed reality (a reality made complete through

\footnotetext{
${ }^{334}$ Torrance, Incarnation, 82. The Scottish theologian claims that "our human nature is united to his divine nature in the unity of the one person of the Son." Ibid., 80. Indeed, the hypostatic union is a communion between divinity and humanity. Ibid., 221. However, Torrance emphasizes that "human nature was not divinised, but only raised into union and communion with God," as the Greek Fathers held a "mild form of communicatio idiomatum" that "did not involve mutual penetration of the two natures." Ibid., 223.

${ }^{335}$ Torrance, Incarnation, 171.

${ }^{336}$ For Torrance, believers participate "through the Holy Spirit in the mystery of Christ." Ibid., 172. As a result of the atonement, the koinonia takes place in the church in the "fellowship of word and sacrament." Ibid., 173.

${ }^{337}$ Torrance, Theology in Reconciliation, 121. In his remarks on the koinonia of the eucharist, Torrance points out that "the Spirit who makes us feed upon Christ," and that the eucharist "becomes the effective form of participation which he grants to us in his self-offering through the eternal Spirit to God the Father." Ibid., 119.

${ }^{338}$ In Torrance's account of the eucharist as "koinonia with Christ," spiritual "gifts are distributed" to the church, and by using them as one body the church participates in His priesthood "through its service to him." Torrance, Space, Time and Resurrection, 118.
} 
atonement) of reconciliation is particularly characterized by liturgical worship (Lord's Supper) and service (the church exercising its spiritual gifts).

In summary, the goal of Christ's priesthood is to bring God and humankind to communion, the original purpose of creation that did not characterize the original creation. While this goal of reconciliation is already a complete reality (ontologically in Christ), it is still incomplete in terms of its revelation (noetically in human beings) until the parousia. ${ }^{339}$ Because this revelation is the disclosure of the reality in Christ, its content is His own presence, and the human reception of this revelation entails some kind of participation in this revealed reality. Barth emphasizes that this presence is contemporaneous to all human beings, while Torrance emphasizes the eucharistic presence in the Lord's Supper. The Swiss theologian describes the human participation in terms of the creation of an awaking awareness (the form of participation) that leads to gratitude, worship, and service (results of participation). The Scottish theologian regards worship and service as forms of participation founded in the Lord's Supper. Both cases involve partial participation because the revealed reality of reconciliation is not complete yet. I would say that this participation could be described as a partial awaking awareness (Barth) or a liturgical taste (Torrance) of the complete reality of reconciliation.

Before I move to the end of the present chapter, it is important to highlight two points that will be helpful for the consideration of the ontological model in the next steps of this research. Both points are related to the innovative feature of this model, namely, that reconciliation is already a complete reality that does not involve any further

\footnotetext{
${ }^{339}$ In this sense, the parousia is the completion of the revelation of the reality of reconciliation, and not a completion of the reality of reconciliation.
} 
application to human beings. The first point has to do with the consistency of this position and the second concerns the meaning of Christ's priesthood in light of this position. First, the model may face the challenge of not being fully consistent with the idea that reconciliation is already a complete reality with no further application, inasmuch as the notion of participation in the model sounds like application. Barth's idea that Christ's revelation is not only intellectual implies more than noetic participation and Torrance's conception of eucharistic koinonia has ontological overtones. Furthermore, the model does assume that the parousia will bring about an eschatological alteration of our present reality (e.g., the eschatological resurrection of the dead). ${ }^{340}$ However, the model seems to make sense of this potential discrepancy by stipulating that our realm (where the reality of reconciliation is not complete) and Christ's heavenly realm (where the reality of reconciliation is complete) are asynchronous, that is, they operate in different types of temporality. This idea will be explained and analyzed in the next chapter. Second, what does the priesthood of Christ accomplish in the context of all this discussion? Simply put, in Christ's priesthood, God reconciles Himself to the world as a human being. Assuming that Christ's death and resurrection fully execute the reality of this reconciliation, everything that comes after the resurrection (e.g., heavenly intercession) has only a revelatory character that allows our conscious participation in that complete reality. Therefore, strictly speaking, the priestly reconciliatory activity is effectively Christ's sacrifice on the cross. In this sacrifice, God humiliated and condemned Himself as a human being. This condemnation meant the destruction of evil

${ }^{340}$ See footnote 331 above. 
and the re-creation of humanity in Himself (the incarnate God). What this picture of Christ's priesthood seems to imply is that God acted historically/temporally upon Himself (the incarnate God) on earth, whereas the priesthood of the ascended Christ takes a different form of temporality, as a revelatory activity. Hence, as I have indicated at the outset of the depiction of the ontological model in this chapter, a full picture of Christ's priesthood requires an engagement with the concept of time in this model, which will be undertaken in chapter three.

Having provided this general description of Christ's priesthood in the ontological model, I will conclude the present chapter by briefly summarizing and comparing the sacramental, the functional, and the ontological models.

\section{A Brief Comparison of the Models}

Taking into account that the description of the models of Christ's priesthood in this chapter was organized according to four components (need, agent, actions, and goal), I will follow that sequence in this brief summary and comparison of the models based on similarities and differences. In each component, comparative comments are accompanied by a table summary. Before I start this comparison, however, a clarification is necessary. We may find an overlap or a difference of ideas between the three models in each component of Christ's priesthood. Nevertheless, the way these ideas are articulated (or even not articulated) in relationship with other notions formulated in the model produces a systematic conceptual force that leads to a specific emphasis of the model. In other words, a model is more than the sum of its parts. An idea may be present in the model, but not be part of its emphasis, because the idea has no systematic conceptual force (at 
least not a dominant one) in its relationship with other notions. ${ }^{341} \mathrm{I}$ begin this comparison with the need for Christ's priesthood.

\section{The Need for Christ's Priesthood}

\section{All three models understand Christ's priesthood as a reconciliatory mediation}

needed because of the sin problem. Nevertheless, each model has a specific emphasis

regarding this problem. ${ }^{342}$ Similarities and differences can be organized according to two

main questions: (1) What is the problem of sin?; (2) Why is CP necessary? The answers

to the first question (see Table 1) are initially two. According to the sacramental model,

the basic problem is an ontological disorder that hinders the teleological movement from

${ }^{341}$ One example of this systematic principle is the idea of propitiation in the sacramental model. The fact that this idea is present in Aquinas does not mean that propitiation has a dominant conceptual force (emphasis) in the sacramental model (and even in Aquinas), as it does in the functional model.

${ }^{342}$ Allen Jorgenson provides a basic framework for the understanding of sin in Christian theology. In this framework, original sin can be understood in terms of content (concupiscence) or lack of content (privatio of original justice). These conceptions are represented "by Augustine and Anselm, respectively." Jorgenson, "Karl Barth's Christological Treatment of Sin," 461. In Augustine, "the guilt of concupiscence is forgiven in baptism," but "remains as a force in the baptized. For this reason the baptized continue to battle the flesh in that concupiscence undoes the original justice that orders the flesh in its conflict with the spirit. Augustine understands this disorder as hereditary in that the primal pair's 'carnal concupiscence' is both a penalty of their original sin and the infection which is passed on in the carnal act. Concupiscence, as such, is both a cause and an effect and provides a view of original sin that is something other than privation." Ibid., 441. On the other hand, "by locating human sin in the human rational nature," and not in the flesh, "Anselm identifies the will as the means for the transmission of original sin rather than the carnal act of procreation." Ibid., 441-442. In Aquinas' synthesis, sin is concupiscentia and privatio, as "the latter" is "the formal element of original sin and the former" is "the material element." Ibid., 443. In his turn, Luther's "synthetic contribution" consists in his proposal "that original justice" is "understood as faith and fear of God," and that this justice "was originally part of being human" and not a superadded grace. This means that the lack of original justice (faith) was not a disorder but actually "marred humanity." "While this lack is forgiven in Baptism, its presence as concupiscence remains and presumes the need for the Holy Spirit to mortify the flesh." Ibid., 446. In Calvin, original sin is described as "a depravity with two attendant realities; guilt and the fruits of sin. The former is present in so far as humans bear a 'contagion' that justly deserves punishment and the latter is asserted to correct the definition of original sin as privation that lacks the nuance of the fruitful nature of sin." Ibid., 447. Finally, "Barth eschews the traditional identification of original sin as concupiscence and privatio. Indeed, his interest in original sin is somewhat muted." Ibid., 457. Jorgenson's explanation provides an interesting perspective for the comprehension of the nuances of the sin problem in the sacramental, functional, and ontological models, as far as Aquinas, Luther, Calvin, and Barth are concerned. 
human beings to God. For the functional model, the basic problem is a moral rebellion of human beings against God. The ontological model follows the functional model on this point. Indeed, the status of creation lies in the background of these answers, and similarities are found on this regard from the vantage point of the discussion of the goal of $\mathrm{CP}$ in the present chapter. The evolutionary dynamics of the teleological movement presumed by the sacramental model assumes that the original creation was incomplete. Similarly, the functional model (Calvin) stipulates that Adam in his pre-fallen condition would pass to a better life, which also assumes incompleteness in original creation.

Likewise, the ontological model affirms that, in contrast to the functional model and the classical version of the sacramental model (Aquinas), there was never a golden age in which creation was not characterized by sin. Therefore, in different ways, the three models view the original creation as incomplete and in need of fulfillment. Thus, whether the problem of sin is seen primordially as ontological disorder or moral rebellion, the incompleteness of original creation lies in the background. More specifically, sin either describes (theistic evolution—ontological model, O'Collins) or deepens (historical fall— Aquinas, functional model) this incompleteness.

Table 1. The need for CP (sacramental, functional, and ontological models)

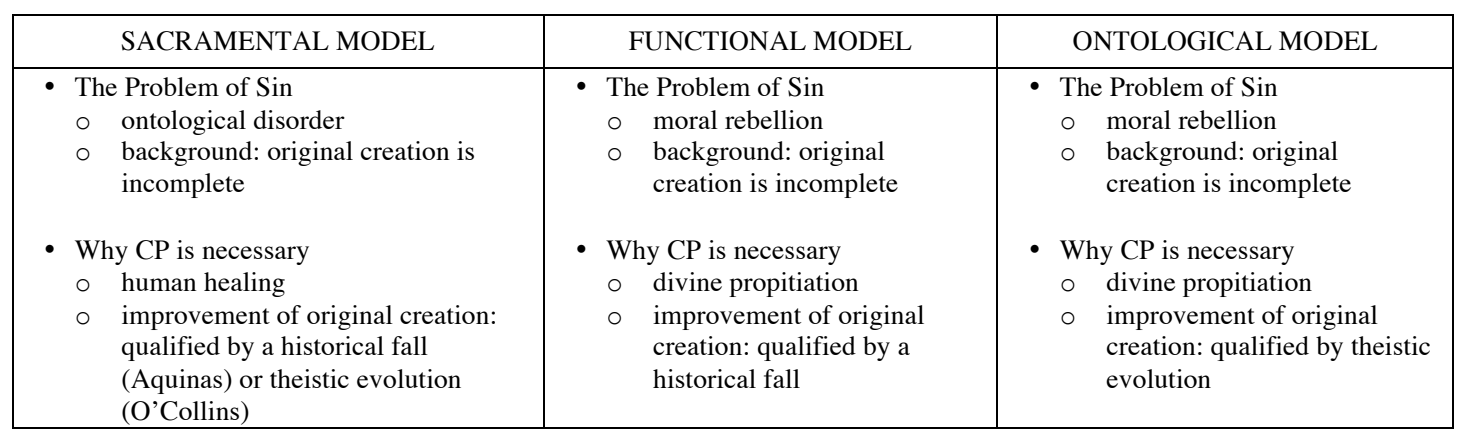


Why, then, is CP necessary? According to the answers given in the previous paragraph regarding the problem of sin, the answers are initially two. If the basic problem is an ontological disorder that misses God as the target, the focus of the solution is on the ontological healing of human beings (sacramental model). On the other hand, if the basic problem is a moral rebellion that targets God (functional and ontological models), the solution will be focused on the propitiation of the offended/wrathful God. To put it more sharply, in the first answer $\mathrm{CP}$ is necessary primordially to heal human beings, and in the second answer it is necessary chiefly for the propitiation of God. From the broader perspective of the incompleteness of original creation, $\mathrm{CP}$ is ultimately needed to improve original creation, either directly (theistic evolution) through the activities of ontological healing (O'Collins) and divine propitiation (ontological model) or indirectly (historical fall, the incompleteness of original creation is now addressed under the new conditions of sin) through these same activities (Aquinas and Calvin respectively).

\section{The Agent of the Priesthood}

All three models view Christ, the agent of the priesthood, as a divine-human person. Therefore, in light of the need for His priesthood outlined above, the following questions will guide the comparisons regarding the agent of CP: (1) How is Christ's divinity involved in His priesthood? (2) How is Christ's humanity involved in His priesthood? Taking into account the first question, the sacramental model answers that the divinity of Christ is the main agent of the priesthood that works salvifically for the healing of human beings and the improvement of creation (see Table 2). According to the functional model, Christ's divinity guarantees the eternity and power of the priesthood in the work of divine propitiation and the improvement of creation. For the ontological 
model, the divinity of Christ in His priesthood implies that God is not only the object but also the subject of divine propitiation, the locus of salvific reconciliation. The selfhumiliation of God takes place in Christ as priest. At least two points of comparison emerge from these interpretations of the divinity of Christ in the context of the agency of His priesthood. First, in the sacramental model the divine agent focuses His priestly activity upon human beings, while in the functional and ontological models this agent focuses on God. Second, while the functional model seems to see the agency of the divine Son working to propitiate God the Father, the ontological model tends to draw a more general picture of God acting upon Himself. In this way, the divinity of Christ seems to be the agent of the priesthood in the ontological model.

Table 2. The agent of CP (sacramental, functional, and ontological models)

\begin{tabular}{|c|c|c|}
\hline SACRAMENTAL MODEL & FUNCTIONAL MODEL & ONTOLOGICAL MODEL \\
\hline $\begin{array}{l}\text { - Agency: Christ's divinity } \\
\circ \quad \text { Main agent } \\
\circ \quad \text { Focus: acts toward human } \\
\text { beings }\end{array}$ & $\begin{array}{l}\text { - Agency: Christ's divinity } \\
\circ \quad \text { Guarantees: eternity and } \\
\text { power of the priesthood } \\
\circ \quad \begin{array}{l}\text { Focus: God (second person } \\
\text { propitiates the first person) }\end{array}\end{array}$ & $\begin{array}{l}\text { - Agency: Christ's divinity } \\
\circ \text { Main agent } \\
\circ \text { Subject/object of the priesthood } \\
\text { (acts upon Himself) } \\
\circ \quad \begin{array}{l}\text { Focus: God Himself (self- } \\
\text { humiliation) }\end{array}\end{array}$ \\
\hline $\begin{array}{l}\text { - Agency: Christ's humanity } \\
\circ \quad \text { His human life as the scope } \\
\text { of the priesthood } \\
\circ \quad \text { Human nature as the } \\
\text { instrument of the divine } \\
\text { agency (point of contact } \\
\text { with the physical world) }\end{array}$ & $\begin{array}{l}\text { - Agency: Christ's humanity } \\
\circ \quad \text { Main agent } \\
\circ \quad \text { Performs priestly } \\
\\
\quad \text { functions/actions (obedience, } \\
\text { teaching, sacrifice) }\end{array}$ & $\begin{array}{l}\text { - Agency: Christ's humanity } \\
\text { O Earthly form of God's self- } \\
\text { humiliation } \\
\circ \quad \begin{array}{l}\text { Recipient of the benefits of the } \\
\text { priesthood }\end{array}\end{array}$ \\
\hline
\end{tabular}

Regarding the question on how Christ's humanity is involved in the priesthood, His humanity is a crucial feature of the interpretations of Christ as the agent of the priesthood in the three models. The sacramental model views Christ's entire human life 
as His priesthood. In the functional model, His obedience, ${ }^{343}$ teaching, and sacrifice are priestly activities performed by the man Christ. In the ontological model, the incarnation is seen already as God's self-humiliation and human exaltation in Christ (although the cross and the resurrection are the climax of these events). However, the emphasis of the three models on Christ's human priestly agency receives support from different assumptions operative in each model. The sacramental model regards Christ's entire human life as His priesthood because His humanity is the point of contact of the divine with the physical world. In other words, the divine Christ is the main agent of the

${ }^{343}$ Bruce McCormack's comments on the notion of Christ's obedience in Calvin, especially when seen from the perspective of the differences between justification in Catholic and Protestant traditions, and shows significant distinctions between the sacramental and functional models. In the context of justification, the first difference is between an immediate divine imputation (Reformers) and a system of mediation of the church (Aquinas). In McCormack's words, "the Reformers forensic understanding of justification" implies "an immediate divine imputation" that "renders superfluous the entire Catholic system of the priestly mediation of grace by the Church." Bruce L. McCormack, "What's at Stake in Current Debates over Justification? The Crisis of Protestantism in the West," in Justification: What's at Stake in the Current Debates, ed. Mark Husbands and Daniel J. Treier (Downers Grove, IL; Leicester, England: InterVarsity Press; Apollos, 2004), 82. The second difference refers to the idea of imputation. While Aquinas sustains negative imputation (non-imputation of sin), the Reformers affirm negative and positive (the alien justice of Christ) imputation. According to McCormack, this difference provides the conceptual basis for the Reformer's distinction of justification and sanctification, which does not exist in Catholicism. As far as Aquinas is concerned, "in that the infusion of grace brings about the forgiveness of sins ... the 'non-imputation of sin' is the effect of an infusion of justifying grace." Thus, "Thomas limits 'imputation' to its negative side, the non-imputation of sin. Of what would later be thought of as a positive imputation of Christ's righteousness, Thomas knew nothing. In its place is the infusion of grace into the soul (i.e., regeneration). But this also means that the work of God 'in us' was made the basis of God's forgiveness. And that was precisely the point at which the Reformers would finally have to raise the necessary objection." In the Protestant alternative, justification is "a twofold imputation. . . Christ's righteousness is 'imputed' to us and, on that basis, we are forgiven (i.e., the negative nonimputation of sin is contained in the positive imputation of Christ's righteousness)." McComarck concludes, "It is the role played by the imputation of Christ's righteousness in justification, and that alone, which makes possible the Protestant distinction between justification and sanctification." If regeneration is "the basis of the nonimputation of sin — as Thomas has it — there remains no reason to distinguish between the two." Ibid., 9092. The idea that the positive imputation is the key to distinguish the Protestant and Catholic understanding of justification leads to a particular emphasis on the importance of Christ's human obedience. Calvin argued that "the righteousness that is made ours in justification is the acquired righteousness of Christ, that is, that righteousness which the God-man acquired through the acts of obedience performed through His divine-human unity." In this sense, "the redemptive significance of the life of Christ is not made to consist in the cleansing of a diseased human nature," as a result of the contact of His human nature with the essential righteousness of His divinity, but "in the establishing of a divine-human righteousness. It is the creation of a new humanity." McCormack, For Us and Our Salvation, 22-23. 
priesthood that works through the concrete instrumentality of His humanity. On the other hand, considering that the functional model interprets $\mathrm{CP}$ from the perspective of the performance of functions/activities, the main agent of the CP seems to be the human Christ, as the man Christ performs the priestly activities (as mentioned above, His divinity basically gives power and eternity to these activities). In the ontological model, the humanity of Christ is significant because, in God, it is the human recipient of the benefits (human transformation) of the priesthood.

The Actions of the Priest

The comparison of the priestly actions of Christ in the three models can be organized according to the following questions: (1) How are His actions seen as a whole? (2) What are the priestly actions of the earthly Christ? (3) What are the priestly actions of the ascended Christ? Regarding the first question, the sacramental model tends to view Christ's priestly action as one (see Table 3 ). The unifying principle here is the notion of Christ's invisible sacrifice, which has different forms of material expression and effective communication to human beings (sacraments). Similarly, the ontological model sees His action as one. But the unifying principle in this model is the one person of Christ, who is the object of His own priestly actions. On the other hand, the functional model emphasizes distinct and subsequent actions in Christ's priesthood, particularly His teaching, His sacrifice on the cross, and the heavenly intercession. This leads us to the discussion of the second question. According to the principle of invisible sacrifice, Christ's entire earthly life of devotion to God is a sacrifice in the sacramental model, and this sacrifice assumes a visible and material expression on the cross. For the functional model, Christ's earthly teachings are considered priestly activities, but the main emphasis 
lies on His penal substitutionary sacrifice on the cross. Likewise, even though Christ's life (especially when in prayer) and death are regarded as intercessory in the ontological model, the focus is on His substitutionary sacrifice on the cross, which means the destruction of sin/evil. In this way, the life and/or ministry of the earthly Christ is counted as priestly activity in all three models.

Table 3. The actions of CP (sacramental, functional, and ontological models)

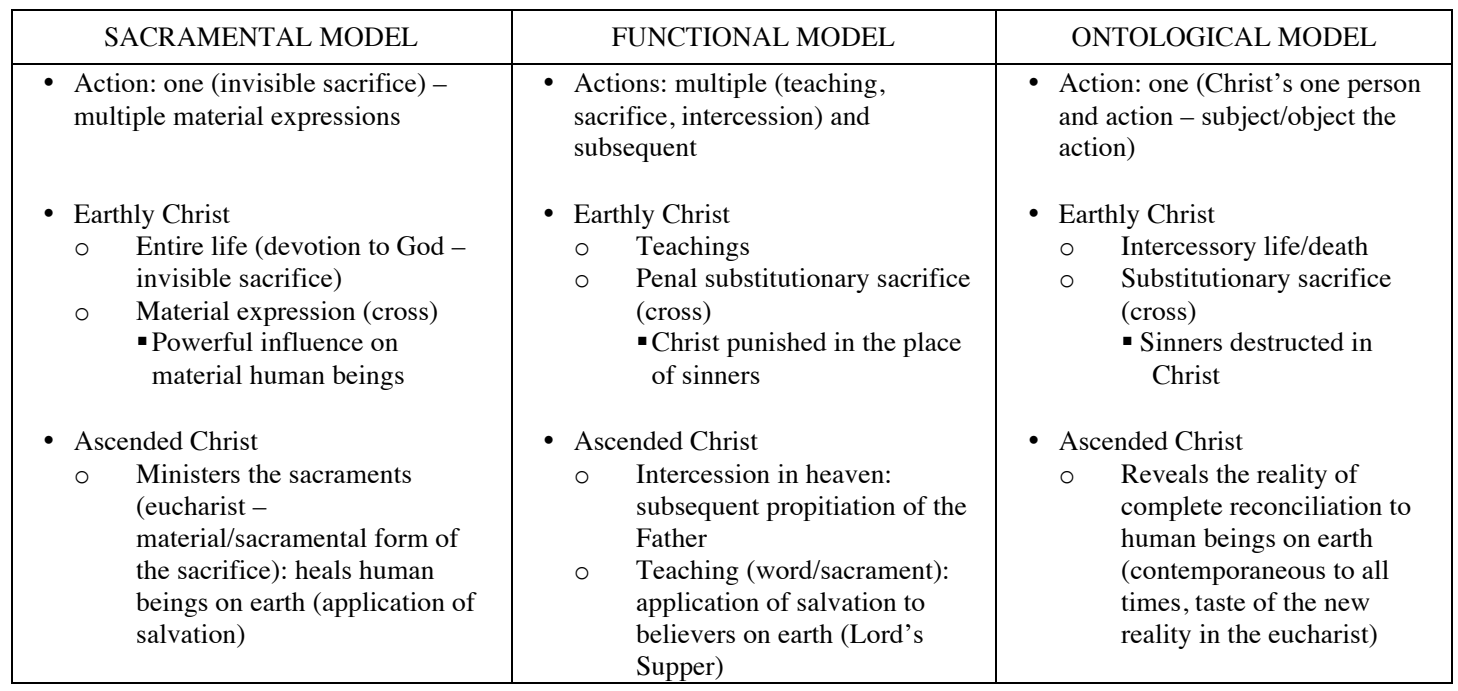

While there are distinct emphases (devotion, teaching, intercession) in the understanding of this priestly activity, the major differences are found in the interpretation of His sacrifice on the cross. In the sacramental model, which emphasizes that $\mathrm{CP}$ is needed for the healing of human beings and views divinity as the main agent of $\mathrm{CP}$ that acts through the instrumentality of His humanity, the material expression of Christ's sacrifice on the cross is basically understood as a powerful influence on material human beings. For the functional model, which emphasizes that $\mathrm{CP}$ is needed for divine 
propitiation and views His humanity as its main agent, the sacrifice of the cross describes the human Christ receiving the wrath of God in the place of elected human beings (propitiation by punishing Christ in the place of sinful human beings). In the ontological model, which emphasizes that CP is needed for divine propitiation but views God as its main agent, God as a human being takes the destructiveness of evil/sin (death) upon Himself in the cross and destroys it (propitiation by destructing sinful human beings in Christ). ${ }^{344}$

With regard to the priestly actions of the ascended Christ, the sacramental model emphasizes the sacraments of the church (particularly the eucharist), which are ultimately ministered by the ascended Christ. According to the principle of invisible sacrifice, the eucharist is a material/sacramental form of Christ's sacrifice that effectively heals human beings. For the functional model, the emphasis is on Christ's ongoing heavenly intercession, which is a subsequent salvific activity that propitiates God the Father on the basis of the earthly sacrifice on the cross. This model also assumes that the priestly teaching of Christ continues after His ascension in the form of word and sacrament, which effectively applies (especially through the Lord's Supper) salvific grace to human

${ }^{344}$ With regard to the sacramental model, a notion of divine propitiation compatible with its whole system could be discerned in the healing of human nature. The argument would follow like this: (1) human beings characterized by the disorder of sin do not follow the intended movement of creation toward God; (2) by not following the movement that leads them to their true end, human beings face the negative consequences of going through a path that is actually contrary to their true nature (this would be the experience of the wrath of God, which is not the active reaction of an offended God, but a natural consequence according to the structure of creation); (3) the healing of human nature leads human beings to their intended movement toward God, which means that they do not experience the negative consequences of going against their true nature. In other words, there is no more wrath of God. This wrath was, in this way, propitiated. I have outlined this account of divine propitiation on the basis of $S T$ III, q. 22, a. 3; q. 49, a. 4. These texts were read in the context of my description of the sacramental model in this study. 
beings. In the ontological model, the ascended Christ reveals ${ }^{345}$ the reality of complete

reconciliation in His contemporaneity to all times, offering a taste of this new reality in

the eucharist. In contrast to the sacramental and functional models, the ontological model

attempts to avoid the notion of subjective salvific application of the priestly actions in

Christ (the reality of salvation) to concrete human beings. ${ }^{346}$ Overall, only the functional

\begin{abstract}
345 According to Horton's interpretation of Barth, "the subsequent events" after the cross "in the economy of grace are merely revelatory rather than constituent elements of God's redemptive work." Horton, "Covenant, Election, and Incarnation," 132.

${ }^{346}$ The discussion of subjective salvific application here is not merely related to the discussion on whether concrete human beings receive the benefits of Christ's priestly action through or without union with Christ. In other words, the main point here is not a decision between ordo salutis and the union (on this point I am referring to-without necessarily subscribing to - the assumption that ordo salutis is a postreformational construction and is different from the soteriological notion of the Reformation about union with Christ. See, e.g., A. T. B. McGowan, "Justification and the Ordo Salutis," in Justification in Perspective: Historical Developments and Contemporary Challenges, ed. Bruce L. McCormack [Grand Rapids, MI: Baker Academic, 2006], 148-149). Both of these accounts could include a subjective salvific application, and the functional model could potentially accommodate both readings of subjective application. In either case, strictly speaking, the reality of salvation takes place in human beings at the moment of this application (even though these accounts could argue that the reality of salvation for human beings already took place in Christ). The novelty of the ontological model is that the reality of salvation in human beings took place in Christ, as $\mathrm{He}$ is the object of His priesthood. This view invalidates the idea of subjective application, at least in terms of the reality of salvation taking place in human beings, because such reality does not need to be communicated from Christ to them. To put it differently, the view advanced by the ontological model implies that when the reality of salvation took place in Christ, human beings were already in Him, so their subjective appropriation of salvation already happened in Him. My conclusion here is that a comparison of Calvin (and even the Finnish interpretation of Luther) and Torrance on the notion of union with Christ in the context of the eucharist does not necessarily undermine the distinction of the functional and ontological models. A close association of Torrance with Calvin regarding the reality of salvation taking place in human beings in the context of the eucharistic union with Christ, would imply that the Scottish theologian is inconsistent in his adoption of the barthian view of the reality of salvation in Christ. Hunsinger uses the terminology of salvation in the perfect tense (already accomplished in Christ) and salvation in the present or future tense (which I could refer to my comments about the moment of the application). Calvin is ambiguous in regards to salvation in the perfect tense and salvation in the present/future. According to Hunsinger, "like Barth (but unlike Calvin), Torrance has an unambiguous grasp on how salvation must be spoken of essentially in the perfect tense." On the other hand, "like Calvin (but unlike Barth), Torrance" connects the sacraments with "union and communion with Christ," seeing "the sacraments as vehicles of testimony that impart the very Christ whom they proclaim (by the gracious operation of the Holy Spirit), as opposed to Barth, who insists on seeing them 'ethically' as no more than a grateful human response to a prior divine grace not mediated or set forth by the sacraments themselves." George Hunsinger, "The Dimension of Depth: Thomas F. Torrance on the Sacraments of Baptism and the Lord's Supper," Scottish Journal of Theology 54, no. 2 (2001): 157, 159. In this article, Hunsinger does not make the distinction I do here between the reality of salvation (in the perfect tense) for human beings and in human beings, which I find necessary in this discussion. Nevertheless, he does emphasize elsewhere the novum of Barth's soteriology (presumably followed by Torrance): for Barth, "the simultaneity of justification and sanctification ... takes place at the level of our objective participation in Christ before it
\end{abstract}


model focuses on a salvific activity in heaven. In the sacramental and ontological models the emphasis is on the activity of the ascended Christ on earth, either sacramentally healing human beings (sacramental model) or revealing to them the complete reality of human reconciliation already effected by God in Christ (ontological model).

\section{The Goal of the Priesthood}

All models seem to indicate that the goal of Christ's priesthood is the reconciliation of human beings with God. However, the models conceptualize this goal in different ways. The following questions will guide the comparison of the models: (1) What is the nature of the reconciliatory goal? (2) How does CP lead to this goal? Regarding the first question, the sacramental model emphasizes an ontological reconciliation, described in terms of a teleological union, a participation of human beings in God, which is ultimately the goal of original creation (see Table 4). This brings creation to its fulfillment. While the themes of ontological union and the eschatological vision of God as the goal of original creation are also found in the functional model, the emphasis of this model is on a moral reconciliation characterized by the grace of God's

ever takes place at the level of our active participation. He thereby forcibly shifts the whole axis of salvation (justification and sanctification) away from what takes place in us existentially ... to that has taken place apart from us preveniently in Christ. . . . This shift is one of the most striking and momentous moves in his soteriology." George Hunsinger, Evangelical, Catholic, and Reformed: Doctrinal Essays on Barth and Related Themes (Grand Rapids, MI: Eerdmans, 2015), 202. In Hunsinger's distinction of objective (which I call here the reality of salvation in human beings) and existential/active participation, the latter is not where our participation in Christ ultimately takes place. Coming back to my remarks on the eucharist, while Hunsinger believes that Torrance's account of the sacraments (especially the eucharist) is an improvement on Barth (see Hunsinger, "The Dimension of Depth," 175), it is my judgment that, if not carefully nuanced, this account can be easily read as subjective application, and this reading contradicts his commitment to the barthian idea of salvation in the perfect tense. My suggestion is that Torrance's conception of the effects of the eucharist on human beings should not be read as subjective application of salvation, but as an intersection of old time and new time that allows a taste of the new creation (new time). This point will be elaborated in the next chapter. In my view, this is the reading that can protect Torrance from self-contradiction on this issue. 
forgiveness, who justifies and then sanctifies human beings. The ontological model pushes the functional model a little further by assuming that creation is in need of moral reconciliation since the beginning. The major emphasis of the ontological model is that the locus of the reality of reconciliation is Christ. In His divine-human person, God and humanity are reconciled. In this view, the goal of CP is already an ontological reality.

Table 4. The goal of CP (sacramental, functional, and ontological models)

\begin{tabular}{|c|c|c|}
\hline SACRAMENTAL MODEL & FUNCTIONAL MODEL & ONTOLOGICAL MODEL \\
\hline $\begin{array}{l}\text { How } \begin{array}{l}\text { CP leads to this goal } \\
\text { divine agent uses material } \\
\text { instruments } \\
\text { ontological healing of } \\
\text { human beings } \\
\text { guides the teleological } \\
\text { movement towards God }\end{array}\end{array}$ & $\begin{array}{l}\text { - How CP leads to this goal } \\
\text { sacrifice on the cross and } \\
\text { heavenly intercession: } \\
\text { propitiate the Father } \\
\text { Mediates the forgiveness } \\
\text { and transformation of } \\
\text { human beings through } \\
\text { material instruments }\end{array}$ & $\begin{array}{l}\text { - How } \text { CP leads to this goal } \\
\text { Achieved: in Christ, God destroyed } \\
\text { (cross) and re-created human beings } \\
\text { (resurrection) } \\
\text { Revelation (new reality): Christ } \\
\text { contemporary to all times, use of } \\
\text { material instruments }\end{array}$ \\
\hline
\end{tabular}

In this context, how does $\mathrm{CP}$ lead to the reconciliatory goal? In the sacramental model, the ontological reconciliation is reached through the healing of human beings. Through material instruments (Christ's humanity, sacraments), the divine agent in CP produces this ontological healing that leads human beings in their teleological movement towards God. According to the functional model, the moral reconciliation is reached primordially through the propitiation of the Father. The transformation of human beings, also mediated by material instruments (word/sacrament), is dependent and subsequent to His forgiveness. In this case, CP leads to the reconciliatory goal by primordially propitiating the Father (in His earthly sacrifice on the cross and in His heavenly 
intercession), and then by mediating forgiveness and transformation to human beings through material instruments. In the context of the ontological model, the reconciliatory goal is already a complete reality (considering that its locus is Christ). However, it still needs to be revealed to human beings. In this sense, while $\mathrm{CP}$ already achieved the goal ontologically, it is still working to reach the goal of revealing what was achieved. In regards to the goal already achieved, in the person of Christ, God produced the moral reconciliation by destroying sinful human beings in His own death and by re-creating them in His own resurrection. In terms of the goal still to be reached, Christ is revealing the new reality of reconciliation by means of His contemporaneity to all times, using material instruments to provide a taste of this new reality.

Having provided this brief comparison of the models of Christ's priesthood, I will explore in the next chapter the macro-hermeneutical principles of reality assumed by each one of these three models. 


\section{CHAPTER 3}

\section{A STUDY OF MACRO-HERMENEUTICAL PRINCIPLES OF REALITY IN THE MODELS OF CHRIST'S PRIESTHOOD}

\section{Introduction}

The previous chapter provided a general description of three theological models of Christ's priesthood (sacramental, functional, and ontological models) from a systematic perspective (need, agent, actions, and goal). This general description prepared the ground for the study of the macro-hermeneutical principles of reality assumed by each model, which is the task of the present chapter. The relationship between the general description of the models (chapter 2) and the description of the macro-hermeneutical principles of reality (chapter 3) they assume can be clarified in the following way: The focus of the previous chapter was on the priesthood of Christ (need, agent, actions, and goal), whereas now the focus is on the priesthood of Christ. ${ }^{1}$ In other words, the present chapter intends to observe, from a macro-hermeneutical perspective, how ontological assumptions about Christ inform the interpretation of His priesthood in the sacramental,

\footnotetext{
${ }^{1}$ I am not assuming here that this is the whole picture of the priesthood of Christ. For example, this priestly intercession includes not only Christ but also human beings. However, the focus of the present study is Christological. Thus, I do not deal with anthropology per se in this analysis. At the same time, I do take into account anthropological conceptions as long as they are related with my Christological study. Despite this delimitation, the present study does offer an ontological picture of human beings in the context of Christ's priesthood, as the Christological analysis of this chapter includes a treatment of the humanity of Christ (see the section Humanity), which is arguably the same human nature of human beings in general (I am not considering here the notion of a sinful or fallen human nature), and the nature of His interaction with human beings after his ascension (see the section Cosmology).
} 
functional, and ontological models.

To facilitate the study of these hermeneutical presuppositions and the comparison of their role in each model, I have selected three macro-hermeneutical principles of reality operative in the understanding of Christ in His priesthood. As in the previous chapter, the book of Hebrews is the source for my minimal formal description of the reality of Christ. Overall, it is possible to describe the reality of Christ, who is a priest in Hebrews, as follows: (1) He is God, (2) He became a human being on earth, and (3) ascended to heaven. ${ }^{2}$ Therefore, the priesthood of Christ is formally described here as the priesthood of a God-man who was on earth and ascended to heaven. Accordingly, the understanding of Christ's priesthood is largely defined by the interpretation or material description of the categories (1) Divinity, (2) Humanity, and (3) Cosmology (earth and heaven), with reference to Christ. Hence, these three formal categories constitute the macro-hermeneutical principles of reality selected for the present study. Considering that these principles are ontological in nature, I will ascertain in which way time/timelessness and space/spacelessness factor in the interpretation of each model regarding the three principles of reality. ${ }^{3}$

As a basic outline of this chapter, I will first describe how each theological model of Christ's priesthood interprets the principles of reality (divinity, humanity, and

\footnotetext{
${ }^{2}$ Even though this formal description should not include at this point a precise definition of its categories, as this definition constitutes the material description of each model, I briefly indicate here how these broad categories can be generally found in the exposition of Christ in the book of Hebrews: (1) God (Heb 1:9-10); (2) Human (Heb 2:14, 17); (3) Earth/World (Heb 1:6; 10:5) and Heaven (4:14; 8:1; 9:24).

${ }^{3}$ The categories of time and space are explored by Jenson and Gorman in their studies of the priestly cult in the Hebrew Bible. See Gorman Jr, The Ideology of Ritual; Jenson, Graded Holiness. However, I am not aware of scholarly treatments of the priesthood of Christ that deal with these categories.
} 
cosmology) with reference to Christ, indicating the main implications of these interpretations for the understanding of His priesthood in the specific model under discussion. Then, at the end of the chapter, I will summarize and briefly compare the interpretations of the macro-hermeneutical principles of reality and their implications in the sacramental, functional, and ontological models. My initial step is to materially describe the principles of reality in the sacramental model.

\section{The Sacramental Model}

\section{Divinity: Christ and the Concept of Divine Nature}

In this analysis of the ontology of God in the sacramental model, I will focus on how this model conceptualizes the divine nature and its implications for divine action. This conceptualization informs the comprehension of Christ's divinity and also His relationship with other members of the Godhead, which will be discussed later in the implications of the conception of divinity for the notion of Christ's priesthood.

In order to affirm the perfection and transcendence of God, the sacramental model, among other things, ${ }^{4}$ negatively defines divine nature by the absence of

\footnotetext{
${ }^{4}$ O'Collins explains that God can be described in two basic ways. First, from a "biblical, experiential, and concrete" perspective, He is both transcendent and immanent. In His transcendent characteristics, "God is supremely mysterious, indefinable, or even unknowable," dwelling "beyond our sense experience 'in approachable light', without beginning or end (= eternal)," and "beyond the material world (=utterly spiritual) and all its categories of gender and class-infinitely wise, holy, apart, untouchable." On the other hand, God is also "“within' or immanent—personal, relational, perfectly loving, and intimately compassionate; the creator of all things and lord of history, who is, nevertheless, 'closer' to us than we are to ourselves." Second, from a philosophical standpoint, He is "perfectly free and perfectly good (as being personal and of the highest perfection), the ground of all being and of all life. God is subsistent Being itself . .., the one necessary, infinite Being who is utterly self-sustaining, selfdetermining, and therefore totally self-explanatory." The Jesuit theologian seems to assume that the biblical and philosophical ways of describing God are compatible. He maintains that "in her creeds, liturgy, and teaching the Church has, for the most part, simply repeated the firmly held biblical attributes of God as one, all-powerful, eternal, all-good, and so forth. But, from the second century, strains of Platonic, Stoic, and Aristotelian thought have provided more exact analysis." O'Collins, Christology, 230-232.
} 
components (God is simple), ${ }^{5}$ movement (God is unmovable), ${ }^{6}$ change (God is immutable), ${ }^{7}$ time (God is eternal/timeless), ${ }^{8}$ and space (God is immaterial). ${ }^{9}$ Aquinas affirms the interconnection of such characteristics, especially considering that they (components, movement, change, time, and space) involve potentiality (imperfection), that is, a lack of actuality (perfection). ${ }^{10}$ For instance, movement involves composition

\footnotetext{
${ }^{5}$ For O'Collins, "God is infinitely simple and profoundly uncomplicated —unlike spatial and temporal beings that are divided or separated into parts." O'Collins, Christology, 232. This is similar to Aquinas' affirmation of the absolute simplicity of God, explaining that "there is neither composition of quantitative parts in God, since He is not a body; nor composition of matter and form." Hence, "God is nowise composite, but is altogether simple." $S T$ I, q. 3, a. 7. For further details, see his discussion of "The Simplicity of God" in q. 3. For Aquinas, something is perfect inasmuch as it lacks nothing, being pure actuality. See q. 4, a. 1. By affirming these attributes, he intends to show that God is a complete and selfsubsistent reality. In contrast, something characterized by composition, movement, change, and time is necessarily defined by potentiality and depends on other things to achieve actuality. For additional information on the attributes of God in Aquinas, see Davies, The Thought of Thomas Aquinas, 44-117; Stump, Aquinas, 92-158; Rudi te Velde, Aquinas on God: The 'Divine Science' of the Summa Theologiae, Ashgate Studies in the History of Philosophical Theology (Aldershot, Hants, England; Burlington, VT: Ashgate, 2006), 77-94; Peter Weigel, Aquinas on Simplicity: An Investigation into the Foundations of His Philosophical Theology (Oxford; New York: Peter Lang, 2008).

${ }^{6}$ O'Collins describes God as "the uncaused cause or unmoved mover." O'Collins, Christology, 232. According to Aquinas, "God is the First Mover, and is Himself unmoved." ST I, q. 3, a. 1. The medieval theologian defines motion as "the reduction of something from potentiality to actuality," and argues that "whatever is in motion must be put in motion by another." He concludes, "It is necessary to arrive at a first mover, put in motion by no other; and this everyone understands to be God." q. 2, a. 3.
}

${ }^{7}$ For Aquinas, "God is altogether immutable." Considering that "everything which is in any way changed, is in some way in potentiality," God is "pure act, without the admixture of any potentiality." ST I, q. 9, a. 1. For further details, see his discussion of "The Immutability of God" in q. 9.

${ }^{8}$ O'Collins points out that "God is timeless (or beyond any temporal succession)." O’Collins, Christology, 114. Aquinas contrasts eternity and time by saying that "eternity follows immutability, as the idea of time follows movement. Hence, as God is supremely immutable, it supremely belongs to Him to be eternal." ST I, q. 10, a. 2. I am aware that, for Aquinas, God's "eternity includes all times" q. 10, a. 2, ad 4. However, this statement should be understood in light of his definition of eternity and time. First, eternity is contrasted to time and movement (see q. 10, a. 2). Second, God moves things without experiencing movement (see q. 2, a. 3). Third, since time is "the numbering of movement" (q. 10, a. 1, ad 2), when God causes things to move he implicitly causes time to exist. Hence, God causes things to move without experiencing movement, and causes time to exist without experiencing it. In short, Aquinas' statement that God's "eternity includes all times" follows this perspective of causality: all times are included in God's eternity in the sense that He causes them to exist.

${ }^{9}$ O'Collins maintains that God is "non-spatial, that is to say, incorporeal and immaterial." O'Collins, Christology, 114. For Aquinas, "it is impossible that matter should exist in God." ST I, q. 3, a. 2.

${ }^{10}$ Aquinas underlines that something "is perfect in proportion to its state of actuality, because we 
and change: "everything which is moved acquires something by its movement, and attains to what it had not attained previously"11_a new attainment means a new component of the being or thing in movement, implying change. In other words, movement (and thus, composition and change) characterizes an imperfect being, who needs to attain something that he/she/it currently lacks. According to this view, to say that God is perfect means that He does not lack anything. ${ }^{12}$ Thus, He is not characterized by movement, composition, or change. Furthermore, as time is defined as the measure of movement and is composed by successive parts (not simple), ${ }^{13}$ God must be timeless. In other words, God is eternal in the sense that He is "outside of movement" and "has no succession, being simultaneously whole." ${ }^{, 14}$ Hence, eternity/timelessness is simple (whole, without parts), unmovable (without succession), and unchangeable. Finally, considering that "matter is in potentiality," 15 God must be immaterial, meaning that His being is defined as cognition. ${ }^{16}$ Just as God is simple, unmovable, and eternal/timeless, so call that perfect which lacks nothing of the mode of its perfection." ST I, q. 4, a. 1; italics mine.

${ }^{11}$ ST I, q. 9, a. 1. Since "in everything which is moved, there is some kind of composition to be found," God is unmovable because in Him "there is no composition, for He is altogether simple." Therefore, "movement in no way belongs to Him." Ibid.

${ }^{12}$ God is "perfect, because He lacks not." ST I, q. 4, a. 2.

${ }^{13}$ Time is "the numbering of movement" (ST I, q. 10, a. 1, ad 2) and is "successive" (ST I, q. 10, a. 1, ad 5). In Aquinas' words, "eternity follows immutability, as the idea of time follows movement. Hence, as God is supremely immutable, it supremely belongs to Him to be eternal.” ST I, q. 10, a. 2.

${ }^{14}$ ST I, q. 10, a. 1.

${ }^{15}$ ST I, q. 14, a. 1. "It is impossible that matter should exist in God. First, because matter is in potentiality." Ibid.

${ }^{16}$ For Aquinas, in God "being and understanding are identical." SCG IV, 11.7. "Free from all matter and potentiality ... God is cognitive." ST I, q. 14, a. 3. "The immateriality of a thing is the reason why it is cognitive." As "God is in the highest degree of immateriality . . . He occupies the highest place in knowledge." q. 14, a. 1. Indeed, "man is said to be after the image of God, not as regards his body," but "according to his intelligence and reason, which are incorporeal." q. 3, a. 1, ad 2. 
is His cognition or knowledge. His knowledge is simple or "not discursive"-it does not operate in a sequence of thoughts (without parts). Timelessly, He "sees all things together [at once], and not successively."17

The assumption that Christ is God implies that the characteristics mentioned above are found in the understanding of Christ's divine nature. ${ }^{18}$ According to Aquinas, (1) the nature of Christ's divinity is "altogether simple;"19 (2) He proceeded "from the Father by eternal generation;"20 (3) in the incarnation there was "no change" in His divine nature, "but only on the part of the human nature,",21 and (4) the intellectual (nonspatial) nature of the pre-incarnate Christ is observed in His eternal/timeless generation, which is "an intellectual emanation." 22 As the Word, the pre-incarnate Christ is God's act of understanding Himself, and because the divine intellect is eternal/timeless, God has

${ }^{17}$ ST I, q. 14 , a. 7.

${ }^{18}$ It is important to note that, as far as O'Collins is concerned, the references to the understanding of the divine nature discussed in the paragraph above are found in his book on Christology. In his Christology, the Jesuit theologian suggests a "two-directional nature of our thinking about his divinity." One goes from God to Christ, seeking to identify God's attributes and then acknowledge that they are to be found in Christ, and the other direction goes from Christ to God, attempting to shape our notion of God in light of Christ. O'Collins, Christology, 234.

${ }^{19}$ ST III, q. 2, a. 4; italics mine.

${ }^{20}$ ST III, q. 3, a. 2; italics mine.

${ }^{21}$ ST III, q. 16, a. 6, ad 2; italics mine. Aquinas points out that "what belongs to the Divine Nature is predicated of the human nature - not, indeed, as it belongs essentially to the Divine Nature, but as it is participated by the human nature. Hence, whatever cannot be participated by the human nature (as to be uncreated and omnipotent), is nowise predicated of the human nature. But the Divine Nature received nothing by participation from the human nature; and hence what belongs to the human nature can nowise be predicated of the Divine Nature." q. 16, a. 5, ad 3.

${ }^{22} S C G$ IV , 11.7. Aquinas maintains that "the Son of God proceeds naturally from the Father as the Intellectual Word." $S T$ III, q. 23, a. 3. In this context, the biblical statement "this day have I begotten You" (Ps 2:7) is interpreted as the eternal/timeless generation of Christ. SCG IV, 11.17. Aquinas points out that this idea of eternal/timeless generation of Christ shows the error of the Arians, who introduced the notion of time in the generation of Christ. See ibid. The medieval theologian also refers to Prov 8:24-25 in his explanation of the eternal generation of the Word, which in this passage is identified as Wisdom. See $S C G$ IV, 11.18 . 
always understood Himself, and "His Word necessarily always existed in God." ${ }^{23}$ In order to avoid spatial and temporal categories, ${ }^{24} \mathrm{O}^{\prime}$ Collins prefers the language of Christ's divine eternal/timeless ${ }^{25}$ existence rather than the expression Christ's preexistence, because the latter implies a temporal sequence in which the divine Christ existed 'before' His incarnation. ${ }^{26}$ Moreover, in contrast to the human cognitive system that "must gather knowledge gradually," "the divine system simply knows all things directly and eternally" at once, which means that Christ's divine mind "does not think in

${ }^{23}$ SCG IV, 11.10. Aquinas stipulates that, in contrast to the generation or birth of corporeal things, the eternal generation of the Word does not involve motion or succession. Rather, "the Word of God is at once conceived, brought forth, and present." SCG IV, 11.18. The notion of the Word as God's act of understanding is stated in the following way, in God's "act of understanding, the intellect conceives and forms the intention or the essence understood, and this is the interior word." SCG IV, 11.7. By being the eternal/timeless act of God understanding Himself, the Word of God (Christ) is "necessarily the image of God in His essence" (Col 1:15) or "the figure of the substance of God" (Heb 1:3), in the sense that "the word conceived in the intellect is the image or the exemplar of the substance of the thing understood." SCG IV, 11.14-15.

${ }^{24}$ Christ "belongs to an order of being other than the created, temporal one. His personal, divine existence transcends temporal (and spatial) categories; it might be better expressed as trans-existence, meta-existence, or, quite simply, eternal existence." O’Collins, Christology, 248; italics mine.

${ }^{25}$ For O'Collins, "through sharing in the divine attribute of eternity" the divine Christ "exists timelessly, given that eternity is in itself timeless." In fact, "eternity and eternal life . . . are not to be reduced to any such temporal duration. The eternal 'now' of the divine existence means perfect union and simplicity in unchangeable fullness of life, with no parts and with no relations of before and after, no having-been and no going-to-be." In his view, the classical definition of eternity given by Boethius“'interminabilis vitae tota simul et perfecta possessio' (the all- at-once, complete, and perfect possession of endless life) (Consolatio philosophiae, 5.6)" and "“all-at-once' (simul) positively and 'endless' (interminabilis) negatively" — is misleading because it recalls "time and temporal duration." Ibid., 248.

26 "To speak of the Son of God as pre-existing his incarnation and even the very creation of the world (when time began) could be (wrongly) taken to imply a 'before' and 'after' for his personal, divine existence. An addition that Constantinople I made to the Nicene Creed, 'begotten from the Father before all ages' ... might mislead us into thinking here of temporal succession as if the Son merely anteceded or 'antedated' everything that later began (in/with time). Hence, we strain language (in an anthropomorphic fashion) when we speak of the Logos personally existing and being active 'before' the incarnation." Ibid. Likewise, Raymond Brown argues that Christ's divine eternity (as timeless) is opposed to the idea of Christ's preexistence. In his words, "preexistence is a more exalted category than thinking of Jesus becoming God's Son in time but from another viewpoint there is no 'pre' in the timeless realm of God." Raymond E. Brown, An Introduction to New Testament Christology (New York: Paulist, 1994), 147. 
the propositional and discursive way., 27

This understanding of divine nature has significant implications for the notion of divine action. One is the idea that "God causes things by His intellect" or "knowledge.",28 For Aquinas, things happen because God knows them in Himself, and not that He gains knowledge or information from what happens to them in time. ${ }^{29}$ Ultimately, the locus of the reality of temporal things or beings is not the world, but God's timeless intellect. ${ }^{30}$ In this ontological context, the medieval theologian elaborates the notion of divine providence, defined as "the type of the order of things towards their end" that necessarily "pre-exist in the divine mind." ${ }^{31}$ In fact, God's providence involves two aspects: (1) "the type of the order of things foreordained towards an end,"32 and (2) "the execution of this order," which may include "certain intermediaries of God's providence,"33 called

${ }^{27}$ O'Collins, Christology, 258.

${ }^{28}$ ST I, q. 14, a. 8. For helpful information about the causality of the divine ideas in Aquinas, see Gregory T. Doolan, Aquinas on the Divine Ideas as Exemplar Causes (Washington: Catholic University of America Press, 2008). For studies on God's knowledge in Aquinas, see James Brent, "God's Knowledge and Will," in The Oxford Handbook of Aquinas, ed. Brian Davies and Eleonore Stump (Oxford; New York: Oxford University Press, 2011), 158-172; Davies, The Thought of Thomas Aquinas, 124-138; Stump, Aquinas, 159-188.

${ }^{29}$ For Aquinas, God sees "things not in themselves, but in Himself; inasmuch as His essence contains the similitude of things other than Himself." ST I, q. 14, a. 5. "What is outside Himself," God "does not see except in Himself." ST I, q. 14, a. 5, ad 1.

${ }^{30}$ The medieval theologian claims that "things are more truly in God than God in things." ST I, q. 8 , a. 3, ad 3. Because of that, "the knowledge of God is the cause of things according as things are in His knowledge." ST I, q. 14, a. 8, ad 2.

${ }^{31} S T$ I, q. 22, a. 1. Aquinas believes that this order of things also has room for contingency, because "God wills some things to be done necessarily, some contingently." Thus, "to some effects He has attached necessary causes, that cannot fail; but to others defectible and contingent causes, from which arise contingent effects." ST I, q. 19, a. 8.

${ }^{32}$ ST I, q. 22, a. 1.

${ }^{33}$ ST I, q. 22, a. 3. "God has immediate providence over everything, because He has in His intellect the types of everything." Also, "He has beforehand the type of those effects in His mind." Ibid. 
"secondary causes." ${ }^{34}$ O'Collins seems to agree that temporal things are a replication of the mind of the eternal/timeless God, as he apparently understands time as a reproduction of timeless eternity. ${ }^{35} \mathrm{He}$ also explains the action of a timeless and non-spatial God in a temporal and spatial world by affirming that God, the first or primary cause, acts through intermediaries or secondary causes. ${ }^{36}$ Therefore, God's timeless and non-spatial action produces temporal and spatial effects in the world by means of temporal and spatial intermediaries. $^{37}$

An important distinction between Aquinas and O'Collins in the understanding of divine action is the notion of predestination. For the medieval theologian, as a "part of providence," 38 timeless predestination is a "type of the ordering of some persons towards

${ }^{34}$ ST I, q. 22, a. 3, ad 2. "There is no distinction between what flows from free will, and what is of predestination; as there is not distinction between what flows from a secondary cause and from a first cause. For the providence of God produces effects through the operation of secondary causes." q. 23, a. 5.

${ }^{35}$ O'Collins seems to subscribe to Plato's view of "time as 'the eternal image of eternity, moving according to number' (Timaeus, 37d)." According to this perspective, he argues that "eternity transcends time but without being apart from it; eternity and time should be considered together. Through the attribute of eternity God is present immediately and powerfully to all times." O'Collins, Christology, 248.

${ }^{36}$ Ibid., 113. The Jesuit theologian conceives action in terms of cause and argues that God's action is not alongside other actions. He suggests two analogies of divine action, namely, the way in which the human mind controls bodily actions and the way human beings influence one another. Ibid., 115.

${ }^{37}$ The Jesuit theologian points out that "every effect and phenomenon in the world has God as its primary or first cause." Ibid., 113. The primary cause is timeless and non-spatial, while the secondary causes are spatio-temporal. In his words, "unlike created, secondary causes, God is neither spatial nor temporal." Ibid.

${ }^{38}$ ST I, q. 23, a. 3. The part of providence that refers to "those who turn aside from that end" is called "reprobation." Ibid. For helpful secondary literature on the notions of providence and predestination in Aquinas, see Harm Goris, "Divine Foreknowledge, Providence, Predestination, and Human Freedom," in The Theology of Thomas Aquinas, ed. Rik Van Nieuwenhove and Joseph Wawrykow (Notre Dame, IN: University of Notre Dame Press, 2005), 99-122; Jill Raitt, "St. Thomas Aquinas on Free Will and Predestination," Duke Divinity School Review 43, no. 3 (1978): 188-195; Lee H. Yearley, "St. Thomas Aquinas on Providence and Predestination," Anglican Theological Review 49, no. 4 (1967): 409-423; Davies, The Thought of Thomas Aquinas, 158-168; Stump, Aquinas, 455-478. 
eternal salvation, existing in the divine mind." ${ }^{, 39}$ Similarly to providence, predestination has a twofold structure: (1) "the act of predestination," which is God's eternal/timeless act, and (2) "the term and effect of predestination" in time. ${ }^{40}$ This twofold structure suggests that God has only one act, which is simultaneously whole, and not a sequential or successive series of acts. Indeed, "the newness of an effect produced by God does not demonstrate newness of action in Him," whereas its effect was not present from eternity, but existed at that time when, from all eternity, He ordained it."42 Nonetheless, the Jesuit theologian does not seem to agree with Aquinas' idea of divine predestination. ${ }^{43}$ Rather, he points out that God's action is

${ }^{39}$ ST I, q. 23, a. 2. For the eternal/timeless character of predestination, see a. 2, ad 3 and 4. According to Aquinas, the execution of predestination "is in a passive way in the predestined, but actively in God." q. 23, a. 2. The medieval theologian argues that predestination is not caused by the divine foreknowledge of merits of the saved. See q. 23, a. 5.

${ }^{40} S T$ III, q. 24, a. 3.

${ }^{41}$ SCG II.35.2. "God acts voluntarily in the production of things, but not in such fashion that there be some other intermediate action of His, as in us the action of the motive power intervenes between the act of the will and the effect, as we have also previously shown. On the contrary, God's act of understanding and willing is, necessarily, His act of making." SCG II.35.3.

${ }^{42}$ SCG II.35.3. The eternal act of God preordains its effects not only in the sense that it determines "that this thing is to be such and such, but that it is to be at this particular time." Ibid. Aquinas compares this notion to a physician who "determines that a dose of medicine is to be drunk at such and such a particular time, so that, if his act of will were of itself sufficient to produce the effect, the effect would follow anew from his previous decision, without any new action on his part." Ibid.

43 The theme of predestination is not explored in Christology, Jesus Our Redeemer, and Jesus Our Priest. In other writings, O'Collins is sympathetic to the Molinist idea of middle knowledge as a way to reconcile God's foreknowledge and authentic human freedom. According to middle knowledge, "God knows and takes into account decisions that rational creatures would freely make in any situation in which they might be placed." This is "more than knowing mere possibilities but less than a vision of actual future events." Gerald O'Collins, Rethinking Fundamental Theology: Toward a New Fundamental Theology (Oxford; New York: Oxford University Press, 2011), 11. The Jesuit theologian seems to reject the view that "God determines 'in advance' what human beings will decide and do; hence the divine knowledge about their actions is simply based on 'predetermining decrees'." Ibid., 20. In fact, he defines predestination as "being elected for salvation through the eternal foreknowledge and will of God (see Mt 20:23; Jn 10:29; Rom 8:28-30; Eph 1:3-14)," and denies Calvin's double predestination. He argues that "predestination should not be pushed to the point of denying either God's universal saving will (1 Tm 2:3-6) or human freedom." CDT, 3 ed. (2013), s.v. "predestination." The contrast between O'Collins and Aquinas on the issue of predestination is clarified by the fact that the idea of middle knowledge was developed by a 
characterized by "love and freedom," which "allows for endless variation in the Godworld relationship and, in particular, for effects that are qualitatively distinct from God's 'ordinary work' in creating and then sustaining creation." ${ }^{, 4}$ O’Collins does not explain how this variation occurs, but he does not see a variation in God (primary cause) in the relationship with human beings in the notions of reconciliation and divine judgment. For him, reconciliation in the NT "does not point to God being changed or reconciled to human beings; rather it is God or God through Christ who effects reconciliation by changing us. $" 45$ Hence, there is no reconciliation in God, but only in human beings. Second, God's judgment on human beings is not interpreted as an action "“from

Jesuit_Louis de Molina (1535-1600), and opposed by the Dominicans_-particularly by Doming Bañez (1528-1604), who understood predestination from a Thomistic perspective. "Between 1598 and 1607 a commission, De Auciliis, met in Rome" in order to solve the debate between Jesuits and Dominicans, but the commission "failed to resolve the issue. It ended by forbidding Jesuits to brand the Dominicans Calvinists and the Dominicans to call Jesuits Pelagians." CDT, 3 ed. (2013), s.v. "molinism." "Although officially the dispute was left undecided, the Dominican Bañezians emerged victorious, in the sense that their theory became generally recognized as the Thomistic doctrine." Goris, Divine Foreknowledge, Providence, Predestination, and Human Freedom, 100. As a Jesuit, O'Collins criticizes the Dominican position (Bañez) by saying that it "does not seem to do full justice to human freedom." However, he affirms that "this debate indicates that the deepest theological questions cannot finally be answered adequately. The divine mystery has the first and the last word." CDT, 3 ed. (2013), s.v. "molinism." For additional information about the debate between Jesuits and Dominicans, see Willian Lane Craig, "The Middle-Knowledge View," in Divine Foreknowledge: Four Views, ed. James K. Beilby, Paul R. Eddy, and Gregory A. Boyd (Downers Grove, IL: InterVarsity Press, 2001), 121-122; Margaret J. Osler, Divine Will and the Mechanical Philosophy: Gassendi and Descartes on Contingency and Necessity in the Created World (Cambridge; New York: Cambridge University Press, 2004), 133; Peter Johannes Thuesen, Predestination: The American Career of a Contentious Doctrine (Oxford; New York: Oxford University Press, 2009), 139-142. For helpful information on Molinism and middle knowledge, see Eef Dekker, Middle Knowledge, Studies in Philosophical Theology (Leuven, Belgium: Peeters, 2000); Hasker, God, Time, and Knowledge, 19-52; David Basinger, "Divine Control and Human Freedom: Is Middle Knowledge the Answer?" Journal of the Evangelical Theological Society 36, no. 1 (1993): 55-64; Dean Allan Kowalski, "Conditionals of Freedom as Bivalent: A Defense of Middle Knowledge," (Ph.D. dissertation, The University of Wisconsin, 2000); Howard Prather Short, “On Middle Knowledge,” (Ph.D. dissertation, The University of Oklahoma, 2007); Thomas P. Flint, Divine Providence: The Molinist Account, Cornell Studies in the Philosophy of Religion (Ithaca, NY: Cornell University Press, 2006).

${ }^{44}$ O’Collins, Christology, 115.

${ }^{45}$ O'Collins, Jesus Our Redeemer, 15. 
outside," but as He allowing "the natural consequences of sin to work themselves out.",46 Thus, divine judgment is not a divine action that responds to a human action. Even though these statements are not explicitly related to the view of God as simple and timeless/non-spatial, they do cohere with a God who is not influenced by what happens in the world and does not act in response to human actions. To put it more sharply, the Jesuit theologian seems to suggest the possibility of variation only at the level of secondary/temporal causes (human beings). Hence, while he attempts to eschew the idea that human actions (secondary causes) are ultimately temporal effects of God's timeless action (the primary cause) in his notion of variation in the God-world relationship, it is difficult to see how this conception of a timeless God does not lead to timeless predestination. ${ }^{47}$ If God does allow some freedom or variation for the secondary causes, how does He know about this variation in His non-discursive/timeless intellect? The logical answer would be that He does not know it from its reality in time, but rather from His own mind. Moreover, this knowledge implies causation, because any distinction between knowing and causing would be incoherent with a simple and timeless God. In this case, there is no real variation in the secondary causes.

In summary, the conception of divine nature in the sacramental model implies that God's timeless and non-spatial action (singular) is the primary cause that produces a

\footnotetext{
${ }^{46}$ Ibid., 52. This is O'Collins interpretation of the Genesis account of the Flood, which is "understood as a powerful symbol of the intrinsic self-destructiveness of human sin." Ibid.

${ }^{47} \mathrm{O}$ 'Collins seems to suggest the possibility of variation at the level of secondary/temporal causes. However, if secondary causes are a temporal reflection of the timeless primary cause, there is no real variation here. If God does allow some freedom for the secondary causes, then the following questions is raised: how does God know about this variation in His non-discursive and timeless intellect? He cannot know it from its reality in time. If He knows the variation from Himself, then He is ultimately causing it, since any distinction between knowing and causing would be incoherent with a simple, timeless, and nondiscursive intellect.
} 
series of material and temporal effects (plural) in the world, by means of the actions (plural) of secondary temporal/material causes. This notion of divine nature and action informs not only the comprehension of Christ's divinity, but also sets the stage for the understanding of His incarnation and salvific work on earth, which will be explored below in the discussion of humanity as the second principle of reality in this study.

\section{Humanity: Christ and the Concept of Human Nature}

The conception of a timeless and non-spatial divine nature in the sacramental model implies that Christ's humanity is a secondary (temporal/material) cause by which the divine primary (timeless/non-spatial) cause produces material and temporal effects in the spatio-temporal world. For Aquinas, God acts indirectly (by means of an instrument) to guide the historical movement, which involves sequential or successive acts in time, of creatures to their end. ${ }^{48}$ Moreover, he understands instrumentality in the context of a hierarchy between created beings and God, where lower created beings are directed to Him by higher beings. ${ }^{49}$ In this way Christ's humanity is part of God's activity in

\footnotetext{
${ }^{48}$ According to "the principle of their being," says Aquinas, "God touches each thing immediately, by causing and preserving it." However, in regards to "things being directed to God as to their end," He directs them through an instrument or "medium between the creature and God." ST III, q. 6, a. 1, ad 1 (for further information on how God works in things, see ST I, q. 105, a. 5). According to this view, while God acts directly and immediately in the creation and preservation of creatures, His historical guidance is performed by means of instruments. In the first case, a simple and timeless God acts directly in an immediate and instantaneous way. In the second case, a simple/timeless God does not act in a sequential or successive way in history, unless He acts indirectly through temporal/spatial instruments.

${ }^{49}$ God directs things to their end through an instrument or "medium between the creature and God," as "lower creatures are directed to God by higher." ST III, q. 6, a. 1, ad 1. As William S. Brewbaker summarizes, "Thomas believes beings exist in a hierarchy of perfection with God, the immutable, spiritual intellect, at the top and with corruptible, inanimate matter at the bottom. In between (in descending order of perfection) are angels, humans, animals, and plants." William S. Brewbaker III, "Thomas Aquinas and the Metaphysics of Law," Alabama Law Review 58, no. 3 (2007): 605. See SCG IV.11; ST I.77.2. For a helpful selection of Aquinas' writings on the ladder of being, see Thomas Aquinas, Selected Philosophical Writings, trans. Timothy S. McDermott, Oxford World's Classics (Oxford; New York: Oxford University Press, 2008), 115-194. In his discussion on the hierarchy of being in Aquinas, Edward Mahoney indicates
} 
directing things to their end, which is Himself. ${ }^{50}$ As lower beings are directed by higher ones, human beings are historically guided to their teleological end by Christ's humanity, which is the instrument by which God works salvifically in space and time. ${ }^{51}$ The medieval theologian even understands Christ's incarnation in the context of God's timeless act of predestination, ${ }^{52}$ which distinguishes the eternal/timeless act of God and its temporal effect. As a temporal effect, the incarnate Christ is the cause of human salvation. ${ }^{53}$ However, He is not the primary cause of salvation, "because by one and the same act God predestinated both Christ and us. ${ }^{, 54}$ Hence, the humanity of Christ is a secondary cause (an instrument) of salvation.

Even though O'Collins does not seem to agree with Aquinas' view of divine timeless predestination, the Jesuit theologian does assume that Christ's humanity is an instrument of God's presence in the spatio-temporal world. In his view, the incarnation

that "a creature participates more in being and has more unity as it approaches the First Being." Edward P. Mahoney, "Metaphysical Foundations of the Hierarchy of Being According to Some Late-Medieval and Renaissance Philosophers," in Philosophies of Existence: Ancient and Medieval, ed. Parviz Morewedge (New York: Fordham University Press, 1982), 172.

${ }^{50}$ It is in the context of "things being directed to God as to their end" through "a medium between the creature and God" that Aquinas situates the "assumption of human nature by the Word of God." ST III, q. 6 , a. 1 , ad 1 .

${ }^{51}$ Aquinas summarizes the instrumentality of the humanity of Christ in the context of His salvific activity that directs human beings to their end, as follows: "Full participation of the Divinity, which is the true bliss of man and end of human life; . . . is bestowed upon us by Christ's humanity." ST III, q. 1, a. 2.

52 "Christ was predestined," in the sense that the union of His divine and human natures "falls under the eternal predestination of God." ST III, q. 24, a. 1. See also q. 3, a. 8, ad 2. According to this view, predestination "is a certain Divine preordination from eternity of those things which are to be done in time," and the incarnation "is something done in time by God." ST III, q. 24, a. 1.

${ }^{53}$ For Aquinas, God eternally predestined or decreed that salvation should be achieved through Jesus Christ. The salvific work of Christ presupposes, he adds, that the "eternal predestination covers not only that which is to be accomplished in time, but also the mode and order in which it is to be accomplished in time." ST III, q. 24, a. 4.

54 Ibid. 
explains how a timeless and non-spatial God can "be present to human beings and so, in that sense, be located in space and time." ${ }^{55}$ He adds, "By personally assuming the human condition, the incarnate Son of God provided the bodily, spatial-temporal component . . . on the divine side," supplying "the bodily 'requirement' on the side of God."56 The notion of incarnation as a spatio-temporal component of a non-spatial and timeless God implies that Christ's humanity is a mediatorial instrument of the divine presence. For the Jesuit theologian, while "presence is communicated immediately" "between the divine persons of the Trinity," in the case of human beings presence "happens symbolically," that is, "through the mediation of our voices, our actions, and things which have some special connection with us." ${ }^{, 57}$ The assumption that presence in the human context is always "mediated and never strictly and exclusively immediate presence" 58 seems to presuppose that spatio-temporal things, such as human voice and action, are not presence itself, but instruments that mediate it. ${ }^{59}$ Ultimately, humanity itself, while a spatiotemporal reality, can be considered an instrument of presence. Thus, Christ's humanity instrumentally mediates God's presence in the spatio-temporal world. ${ }^{60}$

\footnotetext{
${ }^{55}$ O’Collins, Christology, 341.

${ }^{56}$ Ibid.

${ }^{57}$ Ibid., 342.

${ }^{58}$ Ibid.

${ }^{59}$ This notion seems to be compatible with O'Collins' view that "our bodies enable us to communicate" (ibid., 256), which appears to conceive the human body as a necessary instrument of communication. More specifically, the body is viewed instrumentally.

${ }^{60}$ This perspective presupposes a strong gap between a timeless/non-spatial God and temporal/spatial human beings. For O'Collins, the assumed "'gap' between the space-time universe and a Creator by nature non-spatial and eternal" is a challenge for philosophers and fundamental theologians. O'Collins, Rethinking Fundamental Theology, 20.
} 
The idea that Christ's humanity is a spatio-temporal instrument of divine presence

and action in the world and, consequently, a secondary cause of salvation, informs the ontological notions of Christ's divine and human natures and their respective functions.

First of all, Christ's twofold nature presupposes a twofold nativity. In His divinity He was born of the Father in timeless eternity (eternal generation), while in His humanity He was born from Mary in time (temporal generation). ${ }^{61}$ In this context, $\mathrm{O}^{\prime}$ Collins highlights that Christ's divine and human natures imply the miraculous coexistence of two "mutually exclusive sets of characteristics" in His person- "being simultaneously eternal, incorruptible, immutable, and non-spatial, on the one hand, and temporal, corruptible, changeable, and spatially determined, on the other." ${ }^{\prime 62}$ In this way, there is no ontological

${ }^{61}$ ST III, q. 35, a. 2. Aquinas makes the following remarks about the humanity of Christ in time: (1) "the Word of God from all eternity had complete being in hypostasis or person; while in time the human nature accrued to it" (ST III, q. 2, a. 6, ad 2); (2) "the temporal sonship, whereby Christ is said to be the Son of Man, does not constitute His person, as does the eternal sonship; but is something following upon the temporal nativity" (ST III, q. 3, a. 5, ad 1); (3) "by union with the Person, the Man receives omnipotence in time, which the Son of God had from eternity" (ST III, q. 13, a. 1, ad 1); (4) "in Christ there is a twofold nature: one which He received of the Father from eternity, the other which He received from His Mother in time" (ST III, q. 35, a. 2). For O'Collins, the double generation is part of the confession of Chalcedon (AD 451), in which the "scheme of double 'consubstantiality' matched the dyad of eternal/temporal generation." O'Collins, Christology, 171. "The double, eternal/temporal generation of the Son flowered with Irenaeus (Adversus haereses, $2.28 .6 ; 3.10 .2$ ) and a century later even more clearly with Lactantius (Divinae institutiones, 4.8.1-2)." Later, "Cyril of Jerusalem (c.313-386) included the double "nativity': 'his birth is twofold: one, of God before time began; the other, of the Virgin in the fullness of time' (Catecheses, 15.1)." Also, "Cyril of Alexandria cultivated the theme of the Word's double generation: the first, eternal and divine, the second in history and 'according to the flesh' (e.g ., Quod unus sit Christus 721e, 731e, 734b, 740d, 746c, 747a, and 752e)." This theme "figured prominently in Cyril's second letter to Nestorius (February 430 ). In his Tome or dogmatic letter of June 449 to Flavian, bishop of Constantinople, Leo the Great endorsed the language of Christ's double birth, eternal for his divine nature and temporal for his human nature. Two years later, this language passed into the Chalcedonian definition of faith." Ibid. In this sense, "the person of the Son of God exists eternally and timelessly," while "His historical humanity began its existence within the temporal order." Ibid., 238. "The incarnation involves a divine being who is by definition eternal, without a body, and unlimited in power, knowledge, and presence (i.e., omnipotent, omniscient, and omnipresent) personally taking up an existence that is temporal, partly material, and thoroughly limited in power, knowledge, and presence. Through the incarnation, God, who is pure Spirit, assumes (and not merely creates and conserves) matter; the eternal, timeless God personally enters time. The incarnation involves an immortal, unchanging divine person becoming subject to change and, above all, death." Ibid.

${ }^{62}$ O’Collins, Christology, 238. For Aquinas, this incompatibility of characteristics affects the 
interchange of properties (communicatio idiomatum) between Christ's divine and human natures. ${ }^{63}$ Aquinas points out that "all the properties of the human, just as of the Divine Nature, may be predicated equally of Christ," but with proper qualification: He is created and passible in His humanity, and uncreated and impassible in His divinity. ${ }^{64}$

Accordingly, Christ's divine and human natures also have mutually exclusive activities. Functions performed by His humanity justify the need of its instrumental activity inasmuch as they are not directly performed by His divinity. ${ }^{65}$ One example of these functions is the mediation of the divine presence in the spatio-temporal world (O’Collins), as I have indicated above. Other examples are prayer and passibility. As a sequential expression of thoughts and wishes, prayer implies a discursive mind, which belongs to human, not divine, cognition in the sacramental model. ${ }^{66}$ According to

notion of temporal nativity (human generation) in the sense that "the filiation by which Christ is referred to His Mother cannot be a real relation, but only a relation of reason," because "every relation which is predicated of God from time does not put something real in the eternal God." ST III, q. 35, a. 5. The medieval theologian explains, "temporal nativity would cause a real temporal filiation in Christ if there were in Him a subject capable of such filiation. But this cannot be; since the eternal suppositum cannot be receptive of a temporal relation." q. 5, a. 5, ad 1; italics mine.

${ }^{63}$ In his remarks on the communicatio idiomatum, O'Collins criticizes the tendency of modern writers defining this concept as "attributing the properties of one of Christ's two natures to the other." For the Jesuit theologian, historically, this concept "involves naming the person of Christ with reference to one nature (e.g., 'the Son of God') and attributing to him a property that belongs to the other nature ('died on the cross')." O'Collins, Christology, 173.

${ }^{64}$ ST III, q. 16, a. 8, ad 2. For further information about divine impassibility in Aquinas, see Brian Leftow, "God's Impassibility, Immutability, and Eternity," in The Oxford Handbook of Aquinas, ed. Brian Davies and Eleonore Stump (Oxford; New York: Oxford University Press, 2011), 173-186.

${ }^{65}$ Despite this distinction, Aquinas defends the unity in these activities because "the human nature shares in the operation of the divine nature, as an instrument shares in the operation of the principal agent." $S T$ III, q. 19, a. 1. As Aquinas points out, "the operation of Christ's human nature, as the instrument of the Godhead, is not distinct from the operation of the Godhead; for the salvation wherewith the manhood of Christ saves us and that wherewith His Godhead saves us are not distinct; nevertheless, the human nature in Christ, inasmuch as it is a certain nature, has a proper operation distinct from the divine." q. 19, a. 1, ad 2.

${ }^{66}$ In his remarks on Christ's eternal/timeless divinity, Aquinas claims that His knowledge did not advance, since He had the whole perfect knowledge "at once" from the beginning. But according to His temporal humanity, "the acquired knowledge of Christ is caused by the active intellect which does not 
Aquinas, "to pray belongs to Christ as man," as His divinity could not pray ("the divine will of itself is effective of whatever He wishes by it") ${ }^{67}$ Considering Christ's human action as a secondary cause of salvation under divine predestination, the medieval theologian claims that His human prayer is a temporal effect of God's timeless predestination and, thus, Christ prayed only for those predestined for salvation. ${ }^{68}$ Since O'Collins avoids Aquinas' position on predestination, he probably does not agree with the medieval theologian on this point. But the overall idea that prayer belongs to Christ's human mind does cohere with the views of the Jesuit theologian.

In regards to passibility, Aquinas argues that the incarnate Christ "assumed a passible body ${ }^{\prime 69}$ in order to work instrumentally for human salvation in the sufferings of His body. As I mentioned above, the medieval theologian conceives instrumentality from a hierarchical perspective, where lower beings or parts work instrumentally for higher ones. This means that the sufferings of Christ's body work instrumentally for His soul, ${ }^{70}$ which is an instrument of His divinity. Likewise, Aquinas stipulates that in His passion

produce the whole at once, but successively; and hence by this knowledge Christ did not know everything from the beginning, but step by step, and after a time.” $S T$ III, q. 12, a. 2, ad 1.

${ }^{67}$ ST III, q. 21, a. 1.

${ }^{68}$ Aquinas highlights that Christ "did not pray for all those who crucified Him, as neither did He for all those who would believe in Him; but for those only who were predestinated to obtain eternal life through Him." ST III, q. 21, a. 4, ad 2.

${ }^{69}$ ST III, q. 12, a. 4, ad 3. In the context of Christ, Aquinas seems to define passibiliby especially as the capability of experiencing hunger, thirst, suffering, and death. See q. 5, a. 2. For further information about the passibility of Christ in Aquinas, see Paul Gondreau, The Passions of Christ's Soul in the Theology of St. Thomas Aquinas (Scranton, PA: University of Scranton Press, 2009), 101-460. O'Collins affirms the traditional view of divine impassibility because he finds "it very difficult to envisage God as both suffering (essentially and even eternally?) and also saving us from our suffering and sin." O'Collins, Jesus Our Redeemer, 46.

${ }^{70}$ Christ's soul "was the source of meriting," whereas the body "was the subject of suffering" and "thereby the instrument of His merit." ST III, q. 49, a. 6, ad 1. 
"Christ's actions and sufferings operate instrumentally in virtue of His Godhead for the salvation of men." ${ }^{, 71}$ In other words, salvation is a result of the power of Christ's divine nature, and not merely of the death of His body. ${ }^{72}$ The hierarchical and instrumental relationship between Christ's divinity, His soul, and His body is central to Aquinas' notion of Christ's human nature and its union with the divine nature. ${ }^{73}$ Christ's humanity is defined as a composition of soul and body, ${ }^{74}$ where the body is lower and works

${ }^{71}$ ST III, q. 48, a. 6.

${ }^{72} S T$ III, q. 50, a. 6, ad 1. For the medieval theologian, the divine nature "was not separated from the body at Christ's death, much less was He separated from the soul." But "His soul when separated from the body did go down into hell," while "His body was laid in a sepulchre." ST III, q. 50, a. 3; q. 49, a. 6.

${ }^{73}$ As a modern theologian, O'Collins does not emphasize the relationship of Christ's body and soul in his discussion of the humanity of Christ, as Aquinas does. The Jesuit theologian enumerates the following necessary properties of a human being: "organic, bodily existence, coupled with rationality, free will, affectivity, and memory." Also, human beings are dynamic (in the sense of constant development), social, limited (especially to space and time), and transcendent (going beyond themselves). O'Collins, Christology, 234-235. With regard to the relationship between Christ's divine and human natures he claims that "Christ should be understood as a "subject-in-relation" who "acted/acts through his two rational and volitional principles of operation - his divine and human natures." Ibid., 243. For Aquinas, the incarnate Christ is composed by three elements which, in order of importance, are "the Word" (divine nature), the soul (human nature), and the body (human nature). ST III, q. 1, a. 1. Based on this hierarchical order, and its implied notion of hierarchical instrumentality, the medieval theologian affirms that the union of Christ's human and divine natures takes place "through the medium of the soul." ST III, q. 6, a. 1. See also q. 6, a. 1, ad 1. Aquinas points out that "the soul was united immediately with the Word," while "the body was united with the Word through the soul." ST III, q. 49, a. 6, ad 3. See also q. 33, a. 2; q. 50, a. 3. By being nobler than the body in "the rank of dignity," the soul is the "midway between God and flesh." ST III, q. 6, a. 1. The main reason for this conception of superiority of the soul over the body rests on the idea of intellect. Since Aquinas conceives God's nature as an intellect, the human "intellect is the highest and noblest of the parts of the soul, and the most like to God." In this sense, the soul "has a capacity for God, being in His likeness." ST III, q. 6, a. 2. See also q. 33, a. 2. For Aquinas, intellect is called "spirit" in the Bible, and he mentions Eph 4:23 in this context. ST III, q. 6, a. 2.

${ }^{74}$ Christ's human nature is understood according to the Aristotelian "double unity" of "soul and body." $S T$ III, q. 2, a. 1, ad 2. Aquinas rejects two views on human nature, one that holds that it has "being of itself, away from matter" (Platonists), and another that argues that this nature exists "in an intellect either human or divine." In contrast to both these views, he believes that "human nature cannot be without sensible matter." This conclusion is based on the Aristotelian notion that "sensible matter belongs to the specific nature of sensible things, and is placed in its definition," which means that "flesh and bones" are "in the definition of man." $S T$ III, q. 4, a. 4. In this way, "the body lives by the soul" (ST III, q. 2, a. 5, ad 3), and "if the soul is absent, there are no bones nor flesh." $S T$ III, q. 5, a. 3. The medieval theologian stipulates that in the statement "'the Word was made flesh" (John 1:14), "flesh" is taken for the whole man," which includes soul and body. Facing the objection that Jesus did not assume a soul, which argues that John 1:14 does not mention a soul but only flesh, he answers that this passage intends to show the humility of the incarnation. Quoting Augustine, he argues that "'in all that union the Word is the highest, 
instrumentally for the soul. Likewise, His humanity is lower and works instrumentally for His divinity. ${ }^{75}$

In summary, Christ's spatio-temporal humanity is distinct from His timeless and non-spatial divinity. This distinction assumes that Christ had a twofold birth (timeless/divine and temporal/human), and has a twofold cognition (nondiscursive/divine and discursive/human). Moreover, such distinction depicts the ontological gap between God and human beings, bridged through the instrumentality of Christ's humanity. In this sense, His humanity is a spatio-temporal instrument (secondary cause) of the divine presence in the world (O'Collins) and for the divine guidance of the historical teleological movement of creatures to God in the context of His timeless predestination (Aquinas). I will further explore these conceptions of Christ's divinity and humanity in the discussion on Christ and cosmology below.

\section{Cosmology: Christ, Heaven, and Earth}

In this last principle of reality to be described in the sacramental model, I will

and flesh the last and lowest. Hence, wishing to commend the love of God's humility to us, the Evangelist mentioned the Word and flesh, leaving the soul on one side, since it is less than the Word and nobler than flesh.' Again, it was reasonable to mention flesh, which, as being farther away from the Word, was less assumable, as it would seem." ST III, q. 5, a. 3, ad 1. For further information on Aquinas' view on human nature in general and Christ's human nature, see Davies, The Thought of Thomas Aquinas, 207-226; Stump, Aquinas, 189-306; Paul Gondreau, "The Humanity of Christ, the Incarnate Word," in The Theology of Thomas Aquinas, ed. Rik Van Nieuwenhove and Joseph Wawrykow (Notre Dame, IN: University of Notre Dame Press, 2005); Pasnau, Thomas Aquinas on Human Nature.

${ }^{75}$ Aquinas contrasts two views of the humanity of Christ as the instrument of divinity, one defended by Nestorius and the other by Damascene. For Nestorius, "the human nature was assumed by the Word merely as an instrument, and not into the unity of the hypostasis. And therefore he did not concede that the man was really the Son of God, but His instrument." Conversely, Damascene affirmed that "the human nature in Christ is an instrument belonging to the unity of the hypostasis." Aquinas subscribes to this second view of the instrumentality of Christ's humanity. ST III, q. 2, a. 6, ad 4. According to Paul Gondreau, "the 'instrumentality' of Christ's humanity, is a doctrine inherited from John Damascene but modified and extended according to the refinements of his Aristotelian mind." Gondreau, The Passions of Christ's Soul in the Theology of St. Thomas Aquinas, 154. 
focus on the relationship of the resurrected ascended Christ with heaven and earth, observing how the concepts of divinity and humanity explored above are related to cosmology or the ontological structure of the world. ${ }^{76}$ A key notion in this model is that incarnation and resurrection/ascension have inverse relationships with space and time. The former describes a timeless/non-spatial divine being receiving or assuming (not becoming) a temporal/spatial human nature, while the latter depicts a temporal/spatial human nature becoming somehow timeless/non-spatial. From a cosmological perspective, the incarnation is a movement from heaven to earth, and the resurrection/ascension is a movement from earth to heaven. In the movement toward earth, the emphasis is on a spatio-temporal reality, whereas the timeless/non-spatial reality is dominant in the movement toward heaven. Overall, the earth is characterized chiefly by temporal/spatial realities, and heaven is described mainly as a timeless/non-spatial reality.

The glorification of Christ's resurrected and ascended humanity is at the center of this discussion. In simple terms, the glorified humanity of Christ is defined as a more God-like condition, ${ }^{77}$ and described as a liberation from time and space. ${ }^{78}$ Aquinas argues

\footnotetext{
${ }^{76}$ For helpful information on Aquinas' cosmology, see Oliva Blanchette, The Perfection of the Universe According to Aquinas: A Teleological Cosmology (University Park: Pennsylvania State University, 1992). Overall, Aquinas adopted his cosmology from Aristotle. Brian Leftow, "God's Omnipotence," in The Oxford Handbook of Aquinas, ed. Brian Davies and Eleonore Stump (Oxford; New York: Oxford Univeristy Press, 2011), 182.

${ }^{77}$ According to Aquinas, in the different glory of His resurrected body, Christ "did not return to the familiar manner of life, but to a kind of immortal and God-like condition." ST III, q. 55, a. 2. Likewise, O'Collins points out that the transformed human existence of the raised and glorified Christ "became even more like unto God.” O'Collins, Christology, 117.

${ }^{78} \mathrm{O}$ 'Collins indicates that the glorious transformation of the resurrection "brought a dramatic change in the human operations of the risen Jesus: their liberation from the normal, earthly limitations of time and space." O'Collins, Jesus Our Redeemer, 201. The Jesuit theologian believes that Christ's resurrection increased and elevated His human powers. Ibid. Furthermore, he argues that "the incarnation provided a new way for a divine person to be present somewhere and (through the transformation of his resurrection) everywhere." O'Collins, Christology, 341. Aquinas stipulates that the glorified body is one of
} 
that the glory of the soul coming from Christ's divinity overflows in His body, turning it impassible, ${ }^{79}$ and $\mathrm{O}^{\prime}$ Collins claims that glorification refers to the spiritualization of matter. ${ }^{80}$ Therefore, glorification is in some sense the reversal of incarnation. While the incarnation meant that the spiritual (timeless/non-spatial) being or the divine Christ was attached to a material (spatio-temporal) human nature, glorification implied the spiritualization (timeless/non-spatial) of the material (spatio-temporal) human nature of Christ. ${ }^{81}$ This view of glorification impacts the conceptualization of Christ's ascension to heaven, where ideas of ascension as movement and heaven as a place are avoided. Taken at face value, the biblical account of the ascension (Acts 1:9-11) describes it as a movement from earth to heaven. Since movement is a spatio-temporal phenomena by

the reasons why the resurrected Christ was able to enter a room with locked doors (John 20:26) and vanish from the sight of the disciples (Luke 24:31), even though He was a true human being with flesh and bones (cf. Luke 24:37-43). ST III, q. 54, a. 1. I emphasize here that this was one of the reasons, because the medieval theologian argues that "Christ had this not only from the condition of His glorified body, but also from the power of His Godhead, by which power it may happen that even bodies not glorified are miraculously unseen." q. 54, a. 1, ad 2. Quoting Augustine, Aquinas compares those occurrences with the fact that Christ was born from a virgin mother. q. 54, a. 1, ad 1. However, he also affirms that, given the spiritual condition the glorified body, in the sense that it is "subject to the will of the spirit" (the intellectual aspect of the soul), "whoever has a glorified body has it in his power to be seen when he so wishes, and not to be seen when he does not wish it." q. 54, a. 1, ad 2.

${ }^{79}$ For Aquinas, this did not happen to Christ's humanity at the beginning of His incarnation because He needed to fulfill the work of salvation "in a passible body." ST III, q. 45, a. 2. See also q. 49, a. 6, ad 3. But this passibility was no longer necessary after His death. See q. 54, a. 2. In fact, "in the passion He merited His exaltation by way of recompense even on behalf of His body," and therefore "the body, which from charity was subjected to the passion, should receive recompense in glory." ST III, q. 49, a. 6, ad 2 .

${ }^{80}$ According to O'Collins, resurrection and glorification are "the full and final personalizing and spiritualizing of matter," in which the human spirit dominates matter and the body serves the glorified spirit. O’Collins, Jesus Our Redeemer, 255.

${ }^{81}$ For O'Collins, while "the incarnation involved the timeless Son of God taking on a temporal existence, resurrection from the dead involves" a temporal being "becoming eternal" or timeless, "to the extent that created beings can participate in the divine attribute of eternity." Gerald O'Collins, "Our Risen Selves: What Does Resurrection Mean for Us?" America, 9 April, 2012, 14. 
definition, ${ }^{82}$ there are at least two attempts of conciliation in the sacramental model

between a spatio-temporal ascension and a primordially non-spatial/timeless

glorification. Aquinas attributes the ascendant movement to Christ as man, not as God, stipulating that some movement can be ascribed to His glorified humanity. ${ }^{83}$ On the other

hand, O'Collins seems to maintain that the ascension is a non-spatial/timeless reality that

is described in the Bible according to human language, which in its limitation can only

use spatio-temporal concepts. ${ }^{84}$ As he does not appear to assume a temporal sequence of

the events after Christ's death, the Jesuit theologian conflates the ascension with the death of Christ ${ }^{85}$ and chiefly with His resurrection. ${ }^{86}$ For these reasons, the sacramental

\footnotetext{
${ }^{82}$ Aquinas argues that, although divine power/action is instantaneous (not temporal/spatial), the disciples were able to see Christ using His divine power in the ascension in a way that was not instantaneous (temporal/spatial), that is, they saw Him being uplifted to heaven. He explains that while the divine power is instantaneous, its effect does not need to be so. Rather, the effect "is received in things according to their capacity, and as God disposes." In this case, "a body is incapable of being moved locally in an instant, because it must be commensurate with space, according to the division of which time is reckoned." ST III, q. 57, a. 3, ad 3.

83 "Christ ascended into heaven as man, but not as God." ST III, q. 57, a. 2. "The ascension in no wise belongs to Christ according to the condition of His divine nature; both because there is nothing higher than the divine nature to which He can ascend; and because ascension is local motion, a thing not in keeping with the divine nature, which is immovable and outside all place." Ibid. The medieval theologian claims that, even though there is no "movement in God Himself, because He is utterly unchangeable," some movement may be attributed to Christ on the basis of His human nature. ST III, q. 57, a. 1, ad 1.

${ }^{84}$ Based on the assumption that "human beings absorb and express events in terms of time and space," O'Collins declares that "the first Christians took in and stated what had happened to the person of Jesus in terms of time (the resurrection) and space (the ascension). He had risen again on the third day and ascended into heaven." Gerald O'Collins, "Christ's Resurrection and Ascension," America 160, no. 11 (1989): 263. The Jesuit theologian advocates that "to the extent that the final reality of resurrection is more than a spatio-temporal reality, language fails." O'Collins, Jesus Our Redeemer, 254.

${ }^{85} \mathrm{O}$ 'Collins portrays a form of Christ's ascension from earth to heaven using the priestly language of Hebrews. In his words, "Christ's passage through death to heaven" is "like the Jewish high priest moving behind the curtain or veil (Exod. 26:31-5) right into the Holy of Holies (Heb. 9:3). Christ has passed through the heavens (4:14) and entered the inner shrine of God (6:19-20)." Even though Christ died by crucifixion (6:6), the author of Hebrews "imagines the body of Christ moving into the heavenly sanctuary and not onto the cross." In this way, the Jesuit theologian conflates the death of Christ, with a form of ascension and the Day of Atonement. JOP, 52-53. This interpretation seems to imply that Christ's soul went to heaven at His death, while His dead body was still on earth.
}

${ }^{86}$ Collins associates the ascension of Christ primarily with His resurrection. In his words, 
model tends to deny that God's heaven is a place. ${ }^{87}$ In fact, place or space is understood in this model as a conceptual container. ${ }^{88}$ According to this view, God and Christ's

"originally resurrection and exaltation seem to have been relatively independent interpretations of the same event." He suggests the following evidences for that affirmation: (1) "death is followed by resurrection (for example, 1 Cor 15:3-4; Mark 9:31)"; (2) "death is followed by heavenly exaltation (for example, Phil 2:89) or entering into glory (for example, Luke 24:26)"; (3) "death is followed by resurrection and the effective continuation of resurrection by enthronement at 'God's right hand' (for example, Rom 8:34)"; (4) "resurrection and exaltation are used interchangeably to describe what followed Jesus' death (Luke 24:26 = 24:46)." Gerald O'Collins, Believing in the Resurrection: The Meaning and Promise of the Risen Jesus (New York: Paulist Press, 2012), 57. For the Jesuit theologian, Christ's "resurrection was much more than a mere coming back to life under the normal conditions of our present existence." It also involved the fact that "Jesus went up into heavenly glory to sit at the right hand of the Father." O'Collins, "Christ's Resurrection and Ascension," 263.

${ }^{87}$ In his remarks about heaven, O'Collins maintains that "according to primitive religious understanding, the place in or beyond the sky where the gods live. The Bible reflects an early cosmology about the vault of heaven resting on pillars (Job 26:11). It speaks of heaven as the place where God is enthroned (Pss 11:4; 115:16) and from which God descends (Exod 19:18-20), but recognizes that 'heaven and earth' cannot contain God (see Gen 1:1; $1 \mathrm{Kgs}$ 8:27)." For the Jesuit theologian, heaven is "the 'place' or state where the blessed will dwell forever with God through Christ's glorified humanity." $C D T, 3$ ed. (2013), s.v. "heaven." The emphasis on the word place and the qualification of heaven as a state seem to imply that, for O'Collins, heaven is more a state of being than a place. It seems that, in his understanding, the idea of heaven as a place is related to a primitive cosmology, which in his view is adopted by the Bible. A similar emphasis on the word place is found in his affirmation that "through the ascension motif, Luke (Luke 24:51; Acts 1:9-11) and John (John 20:17) ... associate the risen Jesus with the 'place' now known to be his-heavenly glory." O'Collins, Christology, 106. In the context of Aquinas' conception of heaven, the medieval theologian affirms the existence of an empyrean heaven (this is not God's heaven-see footnote 89 below), which is probably "the higher corporal place," "the highest heaven," and the "heaven of the angels." $S T$ I, q. 68, a. 4, ad 1. This heaven is basically "motionless" (ST I, q. 66, a. 3, ad 2), "outside the region of change," and the place of human "final beatitude" or salvation (ST I, q. 102, a. 2, ad 1; see also $S T$ III, q. 49, a. 5, ad 2). In fact, the empyrean heaven appears to be portrayed in terms of aeviternity, "which is a mean between eternity and time." ST I, q. 10, a. 5. In other words, aeviternity is similar to eternity, in the sense of being "simultaneously whole," but it is also compatible with time, particularly with the temporal succession of "'before' and 'after." ST I, q. 10, a. 5, ad 2. "Aeviternity in itself has no 'before' and 'after,' which can, however, be annexed to it; while eternity has neither 'before' nor 'after,' nor is it compatible with such at all." ST I, q. 10, a. 5. However, the medieval theologian appears to indicate that the presence of time in aeviternity will disappear in the future. According to him, "sensible corporeal things," which includes human beings, "are movable in the present state of the world, for by the movement of corporeal creatures is secured by the multiplication of the elements. But when glory is finally consummated, the movement of bodies will cease. And such must have been from the beginning the condition of the empyrean." ST I, q. 66, a. 3, ad 1. The question that seems unanswered by Aquinas, at least explicitly, is whether the ascended Christ experiences aeviternity in His glorified ascended humanity, in the sense of still experiencing time and movement in some degree, or His glorified body already came to this point of final consummation where the movement of His body ceases. For helpful information about conceptions of heaven in the Middle Ages, see Jan Swango Emerson and Hugh Feiss, eds., Imagining Heaven in the Middle Ages: A Book of Essays, Garland Reference Library of the Humanities (New York: Garland, 2000).

${ }^{88}$ For Aquinas, space or "place is a thing" (ST I, q. 8, a. 2) and "implies the notion of containing" (ST III, q. 49, a. 5, ad 2). 
glorified humanity are non-spatial because they cannot be contained by anything. ${ }^{89}$ For Aquinas, heaven is used metaphorically with reference to God in Scripture, ${ }^{90}$ and God and Christ have no real seat in heaven. ${ }^{91}$

With regard to the earth, the sacramental model holds that the ascended Christ is sacramentally present in the eucharist. According to the medieval theologian, this means that Christ is not present as a body in a place, and that He is not in motion. ${ }^{92}$ Arguably,

${ }^{89}$ Aquinas claims that God in His being is "outside all place." ST III, q. 57, a. 2. He argues that "in some way God is in every place ... as He is in all things giving them being, power and operation; so He is in every place as giving it existence and locative power." $S T$ I, q. 8, a. 2. This statement seems to indicate that God is every place by His power, not in terms of His being. As the medieval theologian highlights, "incorporeal things are in place not by contact of dimensive quantity, as bodies are but by contact of power." ST I, q. 8, a. 2; italics mine. Therefore, God in His being is outside all place. In his discussion of the ascension of Christ above all the heavens, Aquinas mentions that "the first heaven" is a container that "has the formality of first place." In this heaven, "bodies need in themselves to be in a place, in so far as they are contained by a heavenly body." However, "glorified bodies, Christ's especially, do not stand in need of being so contained, because they draw nothing from the heavenly bodies, but from God through the soul." Thus, nothing prevents "Christ's body from being beyond the containing radius of the heavenly bodies, and not in a containing place." ST III, q. 57, a. 4, ad 2.

${ }^{90}$ Aquinas maintains that when the term heaven in Scripture is used in reference to the Trinity, it has a metaphorical meaning ( $S T$ I, q. 68, a. 4), particularly implying that this is not a spatial heaven (ST I, q. 61 a. 4, ad 3). In effect, this notion of metaphorical heaven appears to be similar to his understanding of the expression above all the heavens, which is the destination of Christ's ascension and the heavenly realm of God. ST III, q. 57, a. 4, ad 1; q. 57, a. 4, ad 5. "Above heaven there is nothing, the word 'above' signifies only an imaginary place, according as it is possible to imagine other dimensions beyond those of the heavenly body." $S T$ I, q. 46, a. 1, ad 8. In other words, when referred to God, heaven or above all the heavens refer to a place only according to the human limited way of thinking, not in terms of reality. A similar situation in Aquinas' thought occurs when it is said that "an angel was, or is, or will be." This kind of statement "is to be taken in a different sense according to the acceptation of our intellect, which apprehends the angelic existence by comparison with different parts of time." Nevertheless, in terms of reality, "in the very being of an angel ... there is no difference of past and future, but only as regards accidental change." ST I, q. 10, a. 5, ad 3.

${ }^{91}$ With regard to Christ's exaltation at the right hand of God, Aquinas indicates that this does not refer to space or place. Quoting Damascene, he states that "we do not speak of the Father's right hand as of a place, for how can a place be designated by His right hand, who Himself is beyond all place?" ST III, q. 58, a. 1, ad 1. Rather, "Christ is said to sit at the Father's right hand inasmuch as He is on equality with the Father in respect of His divine nature, while in respect of His humanity, He excels all creatures in the possession of divine gifts." q. 58 , a. 4 ..

${ }^{92}$ ST III, q. 75, a. 1, ad 3. In this sense, "Christ's body is upon many altars, not as in different places, but 'sacramentally." Ibid. Furthermore, Aquinas argues that "Christ's body does not begin to be present in this sacrament by local motion." q. 75, a. 2. "Strictly speaking," Christ "is immovably in this sacrament." q. 76, a. 6. "Christ is not moved locally of Himself, but only accidentally, because Christ is not in this sacrament as in a place." Ibid. 
this sacramental presence is consistent with Christ's non-spatial/timeless presence in heaven. ${ }^{93}$ Likewise, O'Collins stipulates that, being free from time and space, the ascended Christ is present everywhere. In his words, Christ's glorified God-like condition "has made His entire life" and temporal "history irrevocably present." reveals Christ's worldwide presence, ${ }^{95}$ and the Holy Spirit and the church are crucial for the ubiquitous presence of His risen body in the world. ${ }^{96}$ In fact, he considers the church the visible form of Christ's presence in its preaching and sacraments. ${ }^{97}$ In short, the

\footnotetext{
${ }^{93}$ The twofold emphasis on Christ's body in the sacrament as unmovable and not in a place seems to be directly related to His condition in heaven. Aquinas points out that if Christ's body was present in the sacrament by local motion, as coming to a place, "it would cease to be in heaven." $S T$ III, q. 75 , a. 2. In addition, he appears to assume that because "Christ's body is at rest in heaven," "it is not movably in this sacrament." q. 76, a. 6. Therefore, Aquinas' attempt to differentiate the forms in which the body of Christ is present in heaven and in the sacrament, by distinguishing Christ "being in Himself" in heaven and being sacramentally on earth ("In Christ, being in Himself and being under the sacrament are not the same thing." q. 76, a. 6. Christ's body "is in heaven under its own species, and on many other altars under the sacramental species." q. 76, a. 5, ad 1.), ensures that Christ in His being is heaven when He present in the sacrament. It appears that the same characteristics of the reality of Christ in heaven are predicated on His sacramental presence on earth. This seems to suggest an interplay between the heavenly Christ and the earthly sacramental Christ, where the effects of His sacramental presence on earth appear to be derived from His very presence in heaven.
}

${ }^{94}$ O'Collins, Jesus Our Redeemer, 260. This presence means the liberation from time, in which the eternal/timeless ascended Christ "possesses fully his whole human story." Ibid. The Jesuit theologian provides the following answers to the question on how a human history in time can "be resurrected in an existence which is not temporal" but eternal/timeless: (1) "Time and eternity are not exclusively different. Just as some kind of eternal life can already be present in temporality, so there could be some kind of temporality in eternal life"; (2) "Time is more than a pure and mere succession of events (as someone in the tradition of David Hume (1711-76) would lead us to believe), but has also something cumulative about it. Every moment is a coming together of many things which are all somehow preserved." Hence, "resurrected life could be a coming together of a whole, accumulated past which remains present to us. In resurrection our time is summed up and completed." Ibid. With regard to the liberation from space, Christ's resurrection and glorification "freed his human condition to be actively present everywhere." The ubiquitous presence of Christ's risen body in the world represents a continuation of His earthly ministry "in a new and enhanced fashion." Ibid., 201.

${ }^{95}$ O'Collins argues that "nothing expresses better the new communicative power of Jesus than the Eucharist, his worldwide presence and offer to communicate a life that will never end." Ibid., 259.

96 "The first Easter produced the outpouring of the Holy Spirit and the emergence of the Church, two essential elements in the new, saving presence of the risen Christ." O'Collins, Christology, 347.

${ }^{97}$ O'Collins maintains that, "for the baptized, the Church bodies forth the living presence of the risen Jesus. She forms the visible verification of his invisible but actively real presence. He exercises the 
sacramental model seems to maintain that the non-spatial/timeless ascended Christ is

present in the spatio-temporal earth through material instruments, especially the church,

and particularly the eucharist.

This idea of instrumentality or material mediation assumes a sacramental

understanding of the world or a sacramental cosmology, ${ }^{98}$ in which created (spatio-

temporal) things have the potential of being signs that contain eternal (non-spatial/

timeless) realities. ${ }^{99}$ In this context, God uses spatio-temporal signs in order to be present

in the created world and to convey spiritual (non-spatial/timeless) blessings. ${ }^{100}$ Aquinas

explains such divine activity in terms of instrumental causality (spatio-temporal signs

primary ministry in and through the service of the word and all the sacraments. Whenever the gospel is preached and the sacraments are administered, the risen Christ is personally and effectively present to help believers share in his perfect union with and presence to the God whom he called "Abba." Ibid.

${ }^{98}$ According to Kenan Osborne, "There is the possibility of sacramentality throughout all creation, since the world, the cosmos in its entirety, in its temporal, historical, and existential dimensions, is a possible locus for sacramentality." Kenan B. Osborne, Christian Sacraments in a Postmodern World: A Theology for the Third Millennium (New York: Paulist Press, 1999), 146. For similar affirmations of a sacramental structure of created reality, see Edward Kilmartin, "Theology of the Sacraments: Toward a New Understanding of the Chief Rites of the Church of Jesus Christ," in Alternative Futures for Worship: General Introduction, ed. Regis A. Duffy (Collegeville, MN: Liturgical Press, 1987), 158; Louis Marie Chauvet, Symbol and Sacrament: A Sacramental Reinterpretation of Christian Existence (Collegeville, MN: Liturgical Press, 1995), 551-553; Judith Marie Kubicki, The Presence of Christ in the Gathered Assembly (New York: Continuum, 2006), 18; Rudolf B. Brun, "Cosmology, Cosmic Evolution, and Sacramental Reality: A Christian Contribution,” Zygon: Journal of Religion \& Science 37, no. 1 (2002): 190; Hans Boersma, "Sacramental Ontology: Nature and the Supernatural in the Ecclesiology of Henri De Lubac," New Blackfriars 88, no. 1015 (2007): 242, 273; Hans Boersma, Heavenly Participation: The Weaving of a Sacramental Tapestry (Grand Rapids, MI: Eerdmans, 2011), 9; Hans Boersma, Nouvelle Théologie and Sacramental Ontology: A Return to Mystery (Oxford: Oxford University Press, 2012), 289.

${ }^{99}$ Osborne highlights that "a sacrament involves a relationship between sign and reality. The sign is not the reality, nor is it of the same value as the reality. If one is in direct contact with a reality, no signs are needed." Kenan B. Osborne, Sacramental Theology: A General Introduction (New York: Paulist Press, 1988), 35. In his explanation of sacramental ontology, Boersma highlights that "historical realities of the created order" serve "as divinely ordained, sacramental means leading to eternal divine mysteries. The interpenetration of sign (signum) and reality (res)" means "that external, temporal appearances" contain “spiritual, eternal realities.” Boersma, Nouvelle Théologie and Sacramental Ontology, 289.

100 According to Osborne, as "profoundly temporal" and "profoundly spatial," "sacramentality is God's action within a thoroughly temporalized and existential event." Osborne, Christian Sacraments in a Postmodern World, 70, 74. 
mediate instrumentally the effects of the divine action), ${ }^{101}$ and $\mathrm{O}^{\prime}$ Collins describes it as "personal causality"102 (spatio-temporal mediate the divine presence). An implication of this perspective is the understanding of Christ's humanity as the "primordial sacrament" and the church as the "foundational sacrament" (concretely realized in the sacraments), which are spatio-temporal signs that convey a spiritual (non-spatial/timeless) reality. ${ }^{103}$ Working through this causality, Christ ultimately produces a world where the movement of bodies will cease (Aquinas), ${ }^{104}$ and promotes a glorification or spiritualization of

${ }^{101}$ Contemporary theology labels Aquinas' position as instrumental causality. See Osborne, Sacramental Theology, 50; David N. Power, "Sacraments in General," in Systematic Theology: Roman Catholic Perspectives, ed. Francis Schüssler Fiorenza and John P. Galvin (Minneapolis: Fortress Press, 2011), 475. Power points out that Aquinas closely linked the "Aristotelian idea of instrumental efficient cause ... with the Platonic notion of a participation in the form or exemplar of the one who causes, Christ." Ibid., 474. For Osborne, "both matter and word . . . are instrumental" in Aquinas. "The sacramental rite is only an instrumental, secondary agent." Osborne, Sacramental Theology, 50, 52. In the twentieth century, Karl Rahner and Edward Schillebeeckx developed the Thomistic perspective in terms of symbolic causality, while Jean-Luc Marion and Louis-Marie Chauvet rejected the notion of causality in the sacraments and affirmed the idea of symbolic gift. For a helpful summary and explanation of these contemporary developments, see Power, "Sacraments in General," 481-490. See also Bernhard Blankenhorn, "The Instrumental Causality of the Sacraments: Thomas Aquinas and Louis-Marie Chauvet," Nova et Vetera 4, no. 2 (2006): 255-294.

102 O'Collins, Jesus Our Redeemer, 213. For the Jesuit theologian, the sacraments actualize Christ's presence, and effect "a particular relationship between the risen Christ and ourselves - his presence to us and our presence to him." O'Collins points out that the divine presence is mediated by a temporalspiritual "component." In this way, "God, being purely spiritual and non-spatial," is "present to human beings," "even if not . . . in a spatial-temporal way." Moreover, he highlights the idea of physical mediation by saying that "all seven sacraments involve the human body and things done to the body." Gerald O'Collins, "Vatican II on the Liturgical Presence of Christ," Irish Theological Quarterly 77, no. 1 (2012): $9,10,14$. O'Collins idea of mediation of presence and personal causality is consistent with contemporary theological works on sacramental grace, which depict grace not 'as a 'thing,' but as 'presence' or a 'relationship." According to this depiction, the sacraments "“cause' an intensification of this relationship." Osborne, Sacramental Theology, 63.

${ }^{103}$ According to O'Collins, "modern theology speaks of (a) Christ as the primordial sacrament (Ursakrament) or the efficacious sign of God's grace; and (b) the church he established as the foundational sacrament (Grundsakrament), which is realized concretely in the life of the seven sacraments." $C D T, 3$ ed. (2013), s.v. "sacrament." See also Osborne, Sacramental Theology, 10-14, 69-84, 89-94.

${ }^{104}$ For Aquinas, "sensible corporeal things . . . are movable in the present state of the world .... But when glory is finally consummated, the movement of bodies will cease. And such must have been from the beginning the condition of the empyrean." ST I, q. 66, a. 3, ad 1. 
matter in the entire cosmos (O'Collins). ${ }^{105}$ In his evolutionary conception of

cosmology, ${ }^{106}$ the Jesuit theologian conceives this final spiritualization of matter as God

working from inside creation, which required especially the incarnation of Christ. ${ }^{107}$

After His ascension, the church functions as His humanity on earth in its sacramental

activity, ${ }^{108}$ and when human beings finally attain their "ultimate destiny," Christ's

"glorified humanity" will be eternally "the means by which" they "enjoy the fullness of

salvation." ${ }^{109}$ This perspective seems to assume a sacramental view of the world (created

\begin{abstract}
${ }^{105}$ Based on Pierre Teilhard de Chardin, O'Collins suggests that both human beings and the entire cosmos will experience something similar to Christ's resurrection and glorification, particularly in terms of the progressive transformation and spiritualization of matter, which is mediated by Christ Himself. "As 'the Personal Heart of the Cosmos', the risen Christ inspires and releases the basic energy of love that progressively carries both humanity and the material universe towards its future goal." O'Collins, Jesus Our Redeemer, 267. In this sense, the "redemptive reconciliation will bring into conformity with the divine plan not only human beings but also their cosmic environment, which will be completed, spiritualized, and transformed." The Jesuit theologian believes that "at the end God will be free to change the laws of nature, so as to transform the material world." Ibid., 265-266. For him, "resurrection brings matter to a most intense participation in the universe and in the life of God. By being raised from the dead, human beings as embodied spirits will not only belong in a new way to the universe but will also in a new way share in the divine life. As both material and spiritual beings they will receive their ultimate divinization so as to 'live to God' (Rom. 6: 10). In his bodiliness the risen Jesus himself takes part in a most intense way in the life of the universe, and is a 'piece' of this material world which has already been inserted into the life of God-to be fully and finally with God." Ibid., 258. At the same time, O'Collins adds, "we should always remember the difference between Christ's case and ours." Ibid., 252. For information about Chardin's view, see Pierre Teilhard de Chardin, Science and Christ (New York: Harper \& Row, 1968), 27-76; Christopher F. Mooney, Teilhard De Chardin and the Mystery of Christ (London: Collins, 1966), 120, 135; Robert L. Faricy, All Things in Christ: Teilhard De Chardin's Spirituality (London: Collins, 1981), 13-31.
\end{abstract}

${ }^{106}$ O'Collins claims that "the theory of biological evolution" provides an "admirable picture ... of God working with wisdom and power "from the inside' to bring about higher forms of life and eventually the emergence of human beings." CDT, 3 ed. (2013), s.v. "evolution."

${ }^{107}$ See O’Collins, Jesus Our Redeemer, 40.

${ }^{108}$ As Osborne emphasizes, "Jesus in his humanity" is "a sacrament of God," while the church is "a sacrament of Jesus." After His "resurrection, Jesus is no longer visible, tangible, perceptible." Therefore, "the Church begins to function as sacrament." Osborne, Sacramental Theology, 45, 74. See also Power, "Sacraments in General," 480.

${ }^{109}$ O'Collins, Jesus Our Redeemer, 225. See also JOP, 269. This is an elaboration on Karl Rahner's idea that "the Word - by the fact that he is man and insofar as he is this-is the necessary and permanent mediator of all salvation, not merely at some time in the past but now and for all eternity." Karl Rahner, The Theology of the Spiritual Life, Theological Investigations (Baltimore: Helicon Press, 1967), 45. See also Gerald O'Collins, Incarnation, New Century Theology (London: Continuum, 2002), 36-41. 
and redeemed) where ultimate (spiritual) reality is never directly attained by creatures, but always mediated by external signs (in this case, the glorified humanity of Christ). ${ }^{110}$ In summary, the sacramental model holds that the resurrected ascended Christ is in a heavenly non-spatial/timeless realm (heaven is not a place) and is also present and active in the earthly spatio-temporal realm. His interaction with these two realms presupposes a sacramental structure of the world, in which the non-spatial/timeless reality of Christ's presence and activity is mediated and effected by the use of created (spatiotemporal) beings or things, particularly the sacraments of the church.

Having described these principles of reality in the sacramental model, I will briefly explore below their implications for the understanding of Christ's priesthood.

\section{Implications for Christ's Priesthood}

In this discussion about the principles of reality, I have indicated that the sacramental model assumes an ontological incompatibility or gap between timeless/spaceless ${ }^{111}$ divinity and the spatio-temporal world of creation. According to this ontological perspective, the divine timeless and non-spatial action is the primary cause of material and temporal effects in the world, by means of the actions of secondary temporal/material causes. This conception presupposes a sacramental structure of the

\footnotetext{
${ }^{110}$ According to Osborne, there are two types of relationship between sign and reality: (1) Separable - "the sign becomes superfluous once the reality has been attained"; (2) Inseparable - a sign is always necessary "to reveal the reality," because it "is never attained directly." In his remarks on contemporary thought about sacramental causality, Osborne argues that sacraments are the second type of sign or symbol, "which must always be present, since the reality to which they point can only be present in and through a symbol." Osborne, Sacramental Theology, 62, 67. O'Collins' affirmation of the eternal mediatorial role of Christ's glorified humanity is coherent with this sacramental understanding of the inseparability between sign and reality.

${ }^{111}$ For the sake of convenience, I use the terms non-spatial and spaceless interchangeably.
} 
world, where created beings or things can be instrumentally used by God to carry His presence and effect His action. In this context, God's salvific action (primary cause) reaches human beings through the instrumentality of Christ's humanity (secondary cause or sacrament). The sacramental structure of the world also allows that the presence and actions of the resurrected ascended Christ, whose glorified humanity is in a more godlike condition, to be instrumentally effected in the world particularly through the sacraments performed in the church (secondary causes).

In the previous chapter I outlined the understanding of Christ's priesthood in the sacramental model in the following way: (1) His priesthood is needed to solve the ontological and moral distance between human beings and God; (2) this priesthood encompasses Christ's entire human life; (3) Christ's priestly actions on earth and in heaven are conceived as His internal disposition that takes the form of visible actions by means of material instruments (sacraments). In this sense, the crucifixion was the climactic materialization of His earthly decisive devotion in the last supper, and the eucharist is the visible earthly expression of the invisible heavenly self-offering (intercession) of Christ before the Father; and (4) the goal of union or eternal participation of human beings in God results from the eternity of His priesthood.

The ontological incompatibility or gap between timeless/spaceless divinity and the spatio-temporal world implies that the distance between human beings and God, addressed by Christ's priesthood, is particularly characterized by the dichotomy between temporality and timelessness, between spatiality and spacelessness. According to a sacramental structure of the world, the humanity of Christ is the main aspect of His mediatorial priesthood because it is the spatio-temporal instrument or secondary cause 
that effects temporally and spatially the divine salvific action or primary cause which is timeless/spaceless. In this context, the ultimate reality of the priestly activity is timeless and spaceless, as the invisible sacrifice (primary cause) and the visible sacrifice (secondary cause) are respectively described as timeless-spaceless and spatio-temporal realities. Although the importance of the crucifixion can be emphasized in this model, it does not constitute the ultimate reality of Christ's sacrifice (or the primary cause of salvation). ${ }^{112}$ The crucifixion is a spatio-temporal instrument or sacrament that manifests temporally and spatially the ultimate reality of His sacrifice. Similarly, the eucharist instrumentally manifests in time and space Christ's invisible (timeless-spaceless) sacrifice, communicating its benefit (His very timeless/spaceless being) to spatiotemporal human beings.

Actually, the sacrament of the eucharist is a secondary cause of the priestly action of the ascended Christ (the primary cause). It is important to notice that the principles of reality adopted by the sacramental model entail that any activity of Christ in heaven should not be understood in a spatio-temporal way. Christ's eternal intercession in heaven is depicted in this model as the presentation of His own humanity to God, so that He can have mercy on human beings (Aquinas), or as Christ blessing people by presenting His sacrificial self-offering to the Father (O'Collins). However, how should this intercession be understood, considering that God, heaven, and even the ascended

\footnotetext{
112 Interestingly, Nieuwenhove points out that "when one examines the Catholic theological scene of the last fifty years or so, one is bound to be struck by the fact that the most important Catholic theologians (such as Schillebeeckx, Rahner and Küng) fail, or refuse, to attribute salvific significance to the crucifixion itself." Rik Van Nieuwenhove, "St. Anselm and St. Thomas Aquinas on 'Satisfaction': Or How Catholic and Protestant Understandings of the Cross Differ," Angelicum 80 (2003): 159. This tendency seems to be compatible with the principles of reality of the sacramental model.
} 
glorified humanity of Christ are defined as timeless-spaceless realities? First, how does Christ present His humanity to God in heaven? Does this presentation imply that $\mathrm{He}$ shows to God something that was not shown before (temporality) in a place (spatiality) where He was not before (temporality)? The principles of reality adopted by the sacramental model invalidate this ontological possibility. Second, how does a timelessspaceless God, with His non-discursive mind, see the humanity of Christ being presented to Him in heaven and, then, react with an attitude of mercy for human beings? O'Collins seems to be more coherent than Aquinas with the timeless-spaceless notion of God, when he interprets Christ's heavenly intercession only in terms of blessing people (a one-sided mediation targeting only human beings), and not as appeasing God (which would be a two-sided mediation targeting both God and human beings). Indeed, the concepts of Christ providing satisfaction for the divine wrath and making an intercessory petition/prayer that leads the Father to forgive human beings are not ontologically applicable to a timeless-spaceless God, as an ontological interpretation of these concepts would require a before and after (temporality) in God's mind and action. ${ }^{113}$ Therefore, the

\footnotetext{
${ }^{113}$ Levering relates Christ's priestly work with God's timeless-spaceless immutability in the following way: "Christ's priestly action does not cause God to forgive us by an outpouring of love, but rather removes the impediments in us to God's merciful outpouring of love." Levering, "Christ the Priest," 407. Likewise, in his discussion of the medieval notion of satisfaction, Nieuwenhove indicates that "the idea that God's anger was somehow appeased by the sacrifice of his Son" implies the "unacceptable" concept "of a changeable God." He concludes that salvation "affects us and our relation with God rather than God himself." Nieuwenhove, "St. Anselm and St. Thomas Aquinas on 'Satisfaction'," 169. Similar to Levering and Nieuwenhove, Davies affirms that any petition to God and also His divine forgiveness do not refer to God Himself but only to human beings. He argues that the belief on divine immutability precludes the notion "that God's act of forgiveness involves him in going through a process of any kind. ... To say that God has forgiven us is equivalent to saying that we have changed direction and turned to him." Davies, The Thought of Thomas Aquinas, 336. Furthermore, Davies recognizes that "petitionary prayer makes no sense given the traditional claim that God is immutable, because he changelessly wills what he wills from eternity and nothing that we can do or say can make any difference when it comes to what God wills." He claims that Aquinas "cannot think of prayer as having a causal effect on God" and that "he does not think of it as informing God or as changing him in any way." Brian Davies, "Prayer," in The Oxford Handbook of Aquinas, ed. Brian Davies and Eleonore Stump (Oxford; New York: Oxford University Press, 2011),
} 
principles of reality assumed in the sacramental model preclude a literal intercession before the Father. Consequently, the ontological focus of the priestly work of the ascended Christ is on earth, not heaven. Whereas His humanity was the spatio-temporal instrument or the sacrament of God before the ascension, the sacramental activity of the church is the spatio-temporal instrument of the glorified humanity of Christ in heaven. Through them, human beings receive salvific grace, as they participate in the divine nature by means of His glorified body, which is temporally-spatially mediated in the eucharist.

The principles of reality of the sacramental model also allow different nuances for the understanding of Christ's priesthood, which are exemplified by Aquinas' and O'Collins' positions. As a medieval theologian, the former believes in a literal Fall and, in this context, Christ's redemptive priestly work leads human beings back to the ideal condition of the beginning of this world. According to his understanding of redemption as a return, he stipulates (1) a two-sided mediation in which the ideas of divine satisfaction and appeasement point to a condition that needs to be reversed; (2) an incarnation that was required by human sin; and (3) an eternal priesthood of Christ in terms of its eternal effects, because at the end human beings will return to their original condition, which does not demand a mediation through spatio-temporal instruments anymore. On the other

471. Aquinas emphasizes that petitions in prayer cause something in human beings, not in God. First, in his perspective, prayer informs us, not God. In other words, prayer does not make "our needs or desires" known to God, but reminds us "of the necessity of having recourse to God's help in these matters." ST IIIII, q. 83, a. 2, ad 1. Second, and more importantly, prayer is a secondary cause or a way through which human beings "obtain what God has appointed" (q. 83, a. 2, ad 2) in his timeless predestination. The medieval theologian explains that human beings pray not to "change the Divine disposition, but that by those actions they may achieve certain effects according to the order of the Divine disposition." Through prayer we "impetrate that which God has disposed to be fulfilled by our prayers." q. 83, a. 2. 
hand, as a contemporary theologian, O'Collins subscribes to the premise of theistic evolution or evolutionary creation that there is a progression, and not an interruption such as a literal Fall, between God's creation and redemption. ${ }^{114}$ In this case, Christ's priestly work is a continuation of the actualization of the divine plan, and not a return to an ideal condition. According to this perspective, the Jesuit theologian affirms (1) an one-sided mediation in which God blesses human beings through the priestly work of Christ; (2) an incarnation that was originally intended by God in His plan of creation-redemption; and (3) an eternal priesthood of Christ in terms of the eternal mediation of His glorified humanity, because created beings never attain ultimate reality directly. In the ontological structure of creation, as planned by God, human beings always need a sacramental mediation. Overall, while the notion of redemption as a return (Aquinas) leads to an emphasis on the moral distance ( $\sin$ ) between God and human beings, the concept of creation-redemption as a progression (O'Collins) entails an emphasis on the ontological distance (the structure of creation) between them. However, both concepts of redemption can be articulated from the standpoint of a timeless-spaceless God, which implies a divine non-discursive mind that timelessly determines the history of the world and the priestly work of Christ. In the framework of redemption as a return, God decided that (1) the Fall would take place after creation, (2) fallen creatures would be under divine punishment and anger, and (3) the incarnate Christ would work as a priestly mediator to save human beings. In the framework of redemption as a continuation of creation, God

\footnotetext{
${ }^{114}$ Following this perspective, Christopher Southgate declares that "a strong emphasis within contemporary Christian theology is on creation as a continuous process, rather than something completed at the beginning." Christopher Southgate, The Groaning of Creation: God, Evolution, and the Problem of Evil (Louisville: Westminster John Knox, 2008), 15.
} 
established the progressive mediatorial work of Christ in creation-redemption.

Nevertheless, in light of the teleological movement of human beings toward God, which implies an ontological distance (even in the perfect creation assumed by Aquinas) between humankind and God, ${ }^{115}$ the distinction of redemption as a return (Aquinas) and creation-redemption as progress ( $\mathrm{O}^{\prime}$ Collins) does not have a decisive impact on the understanding of Christ's priesthood. In both cases, human beings evolve toward their goal, and His priesthood serves this larger purpose. Hence, Christ's priesthood is not ultimately defined in terms of redemption of sin, as His priesthood assists human beings evolve toward a goal that was not achieved when they were created.

Having studied the macro-hermeneutical principles of reality in the sacramental model, I will turn now to the discussion of those principles in the functional model.

\section{The Functional Model}

\section{Divinity: Christ and the Concept of Divine Nature}

In this description of the ontology of God in the functional model, I will outline how this model depicts in broad strokes the divine nature and action, inasmuch as such depiction informs the comprehension of Christ's divinity and also His relationship with other members of the Godhead, which is a topic to be discussed later in the implications of the conception of divinity for Christ's priesthood.

The functional model attempts to avoid the discussion about the being of God. ${ }^{116}$

\footnotetext{
${ }^{115}$ I describe this idea in the descriptions of the need and the goal of Christ's priesthood in the sacramental model, which are found in chapter 2.

${ }^{116}$ Overall, as Ziegler points out, "there is no discussion of God's essence and attributes" in the Institutes. "Calvin is not interested in an abstract knowledge of God," as God's "essence is incomprehensible." Roland F. Ziegler, "Luther and Calvin on God: Origins of Lutheran and Reformed
} 
As Luther emphasizes, apart from the created things or coverings ${ }^{117}$ that God uses to reveal Himself, the divine nature is incomprehensible and we should not speculate about it. In his conception, God's uncovered nature refers to the hidden God, namely, God in His majesty and terrible power. ${ }^{118}$ The German theologian seems to assume that the hidden God is non-spatial and timeless, ${ }^{119}$ which is one of the reasons why He is unfathomable to spatio-temporal human beings. ${ }^{120}$ Stipulating that the beginning of God's creation marks "the beginning of time" and that "our mind cannot grasp what lies outside time," he argues that "it is folly to argue much about God outside and before time, because this is an effort to understand the Godhead without a covering, or the uncovered divine essence," which is "an area where there is no measure, no space, no

Differences," Concordia Theological Quarterly 75, nos. 1-2 (2011): 78-79. For useful discussions about God in Calvin and Luther, see Brian A. Gerrish, "To the Unknown God : Luther and Calvin on the Hiddenness of God," The Journal of Religion 53, no. 3 (1973): 263-292; Thomas F. Torrance, "Calvin's Doctrine of the Trinity," Calvin Theological Journal 25, no. 2 (1990): 165-193; Christine Helmer, "God from Eternity to Eternity: Luther's Trinitarian Understanding," Harvard Theological Review 96, no. 2 (2003): 127-146; Dale Arthur Johnson, "Luther's Understanding of God," Lutheran Quarterly 16, no. 1 (1964): 59-69; Lohse, Martin Luther's Theology, 207-218; Althaus, The Theology of Martin Luther, 20-24.

${ }^{117}$ For Luther, it is "insane to argue about God and the divine nature without the Word or any covering." He speculates, "Perhaps God appeared to Adam without a covering, but after the fall into sin $\mathrm{He}$ appeared in a gentle breeze as though enveloped in a covering." Thus, because of the depravation and corruption of sin, human beings "cannot recognize God or comprehend His nature without a covering. It is for this reason that those coverings are necessary." $L W, 1: 11$ (Lectures on Genesis, 1535).

${ }^{118}$ Luther affirms that we should "refrain from investigating the Divine Majesty and His terrible works. God does not want us to learn to know Him in this way. You cannot nakedly associate with His naked Godhead. . . . For you cannot grasp God in Himself." LW, 16:55 (Lectures on Isaiah, 1527-1528 [chap. 6]). For additional information on Luther's understanding of the hidden God, see Steven D. Paulson, "Luther on the Hidden God," Word \& World 19, no. 4 (1999): 363-371.

${ }^{119}$ According to Scott Ickert, "Luther adopts the standard view that God is transcendent in timeless eternity," which means that "timelessness is a component of divine transcendence." Scott S. Ickert, "Luther on the Timelessness of God," Lutheran Quarterly 7, no. 1 (1993): 53. Luther concurs with Augustine's view that, for God, "neither a past nor a future, but outside of time and in eternity everything is in present time." In other words, "in eternity, where there is no time, neither past nor future, but a perpetual today." Based on 2 Pet 3:8, he points out that "the beginning, the end, and the middle of time are but one moment with God." LW, 12:52-53 (Commentary on Psalm 2, 1532).

\footnotetext{
${ }^{120}$ For Luther, "the Divinity cannot be grasped and understood, such as being outside time, before
} 
time." 121 Therefore, Luther presupposes that the uncovered or hidden God is non-spatial and timeless. These presuppositions reveal ontological commitments about the being of God that should be supposedly avoided in the functional model. In other words, the model inevitably assumes that the hidden God has some specific ontological features.

Another topic that reveals ontological assumptions regarding the divine nature in this model is the notion of divine knowledge. ${ }^{122}$ According to Calvin, God has a timeless knowledge, that is, in His "knowledge there is nothing future or past, but all things are present." ${ }^{123}$ In this view, all things are present to God not merely as ideas of His imagination, but as actual realities before Him. ${ }^{124}$ This notion implies that all things are simultaneous (without the sequential flow of past-present-future) for God, and this is not simply a statement about His idea of them but rather about their actual reality. ${ }^{125}$

the world." LW, 1:11 (Lectures on Genesis, 1535).

${ }^{121}$ Ibid., 10-11. The German theologian affirms that human beings should not speculate "what has been outside time or before time" neither what "God was doing before there was any time," as "God was incomprehensible in His essential rest before the creation of the world," and "now, after the creation, ... He is still incomprehensible." Ibid.

\footnotetext{
${ }^{122}$ As Michael Saia indicates, "technically speaking, Calvin does not describe God's nature as timeless, but rather his knowledge." However, his notion of God implies that God lives "outside of time or in some state similar to the "ever-present now." In this sense, "Calvin's position contributed nothing new to the doctrine of timelessness." Michael R. Saia, Does God Know the Future? A Biblical Investigation of Foreknowledge and Free Will (Fairfax, VA: Xulon Press, 2002), 44. The following studies support the view that Calvin conceived God as timeless: Edward R. Wierenga, "Timelessness Out of Mind: On the Alleged Incoherence of Divine Timelessness," in God and Time: Essays on the Divine Nature, ed. Gregory E. Ganssle and David M. Woodruff (Oxford; New York: Oxford University Press, 2002), 153; Helm, "Divine Timeless Eternity," 28; Oliver D. Crisp, "Calvin on Creation and Providence," in John Calvin and Evangelical Theology: Legacy and Prospect, ed. Sung Wook Chung (Louisville, KY: Westminster John Knox Press, 2009), 50; Louis P. Pojman and Michael Rea, Philosophy of Religion: An Anthology, 7th ed. (Stanford, CT: Cengage Learning, 2013), 61.

${ }^{123}$ ICR 3.21.5.

${ }^{124}$ In Calvin's words, “They are present in such a way that He not only conceives them through ideas, as we have before us those things which our minds remember, but he truly looks upon them and discerns them as things placed before him." Ibid.

${ }^{125}$ This conception of divine knowledge describes what Calvin understands by God's
} 
Likewise, Luther claims that God sees things in time in a timeless way, as before Him "there is no reckoning of time."126 The German theologian explains, "God does not see time longitudinally; He sees it transversely, as if you were looking transversely at a tall tree lying before you. ${ }^{" 127}$ It is not clear if, in Luther, this divine transversal (timeless) cognition of things presupposes that God sees things as they are in Himself, as Aquinas and Calvin do in their notion of God's timeless knowledge. Luther's attempt to make some room for God seeing things in time (longitudinally) ${ }^{128}$ seems to indicate that he is not bound to the idea that God does not see things outside of Himself. However, the German theologian does not articulate an account of divine nature that allows for a timeless and a temporal (longitudinal) cognition in God, in which He sees things both in and outside of Himself. ${ }^{129}$

foreknowledge: "All things always were, and perpetually remain, under his eyes.” Ibid.

${ }^{126}$ LW, 30:196 (Sermons on the Second Epistle of St. Peter, 1523). "With our reason we cannot look at time in any other way than longitudinally. Beginning with Adam, we must count one year after the other until the Last Day. But in God's sight everything is in one heap. ... Here there is neither measure nor number." Hence, "Adam, the first man, is just as close to Him as the man who will be born last before the Last Day." Ibid. See also ibid., 30:113-114; 13:99-100.

${ }^{127}$ Ibid., 30:196.

${ }^{128}$ Commenting on Gen 22:12, Luther suggests a twofold cognition in God: "one, eternal and invisible, by which God sees things before they are in existence; the other, by which he observes things that exist." Thus, "by means of that second vision, with which He looks at existing things, God did not see Mary before she existed, and yet He saw her from eternity." Ibid., 4:132 (Lectures on Genesis, 1539-1540 [chaps. 22-23]). This second type of cognition is different from the explanation of God's eternal/timeless knowledge, because it assumes that He sees things in time and not only in Himself.

${ }^{129}$ I am aware that Luther could answer that we should be "satisfied with this picture" and avoid "that inquisitiveness of the human intellect, which wants to investigate His majesty." Ibid., 4:133. Nevertheless, the German theologian seems to break his own rule, as he provides details about the timelessness and the cognition of the hidden God. The quotation above represents Luther's conclusion about "those expressions of Scripture when God is described in terms of human form and actions." For him, "they are transferred from human beings to God because of the feebleness of our understanding." Ibid. Luther's ambiguity on God's cognition is also evident in his interpretation of Gen 22:12, where he highlights that the "expression 'now I know' must be understood in a simple manner, although" he does "not reject the explanation of the fathers that God is speaking in human fashion." Ibid. 
The notion of timelessness is evident in the description of the divinity of Christ, who “cannot be categorized under 'time' or under 'creature,' but it is above 'time' and "creature." "130 In his explanation that the Son of God is "begotten from eternity," Luther maintains that, since "God is outside time, a spiritual being," the biblical statement "'You are My Son, today I have begotten You"' (Ps 2:7; Heb 1:5) does not refer to God begetting "something temporal, something physical, but brings forth something like Himself, that is, eternal and spiritual."131 In this perspective, the eternal generation of the

${ }^{130}$ Ibid., 52:42-43 (sermon on John 1:1-14, between 1521-1522).

${ }^{131}$ Ibid., 12:47 (Commentary on Psalm 2, 1532). It is important to highlight that Calvin did not read Ps 2:7 as the eternal generation of the Son, because Acts 13:33 applies this passage to Christ's resurrection. See $C B C$, Commentary on the Psalms. However, this does not necessarily mean that the French theologian rejects the traditional belief of the eternal/timeless generation of the Son. In fact, he appears to affirm this belief. He argues that the Father "is the fountainhead and beginning of deity" in terms of "order and degree." ICR 1.13.23-24. Calvin adds, "He is the Son of God, because the Word was begotten by the Father before all ages." Ibid., 1.13.23. "He was eternal God solely because he was the Word begotten by the eternal Father" Ibid., 2.14.7. "The Son of God . . . was the eternal Word begotten before all ages from the Father." Ibid., 1.13.24. Calvin seems to suggest that "the eternal begetting of wisdom" is depicted in Prov 8:22 and refers to Christ. Ibid. Obviously, if the eternity of the generation is not timeless, then the moment that the Son was begotten by the Father was preceded by a time when the Son did not yet exist. In contrast to Calvin's position, this conclusion would represent a rejection of the eternity of the Son. Even though the French theologian does not explicitly define eternal generation as timeless, this qualification appears to be implied in the following statements: "the Son of God . . had by virtue of eternal generation always possessed sonship." Ibid., 2.14.5; italics mine. "God would not have been called 'Father' from the beginning unless there had already at that time been a reciprocal relationship to the Son" Ibid., 2.14.7; italics mine. However, Calvin does seem to question the idea of continuous begetting. He asks, "what is the point in disputing whether the Father always begets? Indeed, it is foolish to imagine a continuous act of begetting, since it is clear that three persons have subsisted in God from eternity." Ibid., 1.13.29. The idea of continuous begetting was introduced by Origen and defended by the school of Alexandria. For further information, see John Behr, The Way to Nicaea, The Formation of Christian Theology (Crestwood, NY: St. Vladimir's Seminary Press, 2001), 193-194; Christine Christ-Von Wedel, Erasmus of Rotterdam Advocate of a New Christianity, Erasmus Studies (Toronto; Buffalo; London: University of Toronto Press, 2013), 133-134. Brannon Ellis appears to indicate that the eternal generation may be understood either as "timelessly perfect" or as "a timeless process." Brannon Ellis, Calvin, Classical Trinitarianism, and the Aseity of the Son (Oxford: Oxford University Press, 2012), 64n1. However, Ellis does not elaborate on this distinction. Apparently, the notion of continuous begetting fits in the category of timeless process, while the position advanced by Calvin belongs to a timelessly perfect generation. According to Benjamin W. Swinburnson, there are two schools of interpretation of Calvin's notion of the eternal generation of the Son. Both agree that he "embraced a form of the doctrine of the eternal generation of the Son, but they disagree as to how he defined it." The main point of contention is whether he accepted or rejected the Nicene idea of "communication of essence in eternal generation." Swinburnson argues for Calvin's acceptance. Benjamin W. Swinburnson, "John Calvin, Eternal Generation, a Communication of Essence: A Reexamination of His Views,” Kerux 25, no. 1 (2010): 27. 
Son takes place in the eternal present (today) of timeless eternity. ${ }^{132}$ Associated with the idea of timelessness is the notion of the non-spatiality of the divine Christ. Regarding Christ's earthly (spatio-temporal) birth, the German theologian assumes that, in His nonspatial immutability, Christ's divinity “cannot pass from one place to another as creatures do," and affirms that the divine Christ "was already in the Virgin's womb in essence and in person, as he was also in all other places, everywhere, according to the nature and character and power of divinity." 133 According to this idea of divine non-spatiality, Luther assumes that God "does not utter any physical speech," which relates to his understanding that Christ is the eternal Word in the sense that God's nature "is pregnant with a Word or a conversation in which He engages with Himself in His divine essence and which reflects the thoughts of His heart." ${ }^{134}$ This is "an invisible and

With regard to the idea of order and degree, Calvin claims that "in respect to order and degree the beginning of divinity is in the Father, yet we say that it is a detestable invention that essence is proper to the Father alone." ICR 1.13.24. "The Father . . is the beginning of deity, not in the bestowing of essence, ... but by reason of order." Ibid., 1.13.26. In his comments about the Trinity in Calvin, T. Torrance points out that ontologically there can be no "before or after in the eternal relations in God," but "a significant distinction of order is to be considered." Torrance, "Calvin's Doctrine of the Trinity," 177.

${ }^{132}$ For Luther, "The adverb 'today' refers to that eternal nativity of the Son ... the most present nativity, ... without a beginning and without an end." $L W, 12: 52$. The German theologian believes that the word "today" may also refer to the second birth of Christ, namely, His birth in time or His incarnation. Ibid., 29:113-114 (Lectures on Hebrews, 1517-1518). According to Luther, Christ "has two births, or two natures." The "first birth" was "not in time but from all eternity," while the second birth was "the temporal, human birth." Ibid., 15:292-294 (Treatise on the Last Words of David, 1543). In other words, Christ has a twofold nativity, "outside time and within time." Ibid., 12:53 (Commentary on Psalm 2, 1532).

${ }^{133}$ Ibid, 37:62 (That These Words of Christ, “This is My Body, " etc., Still Stand Firm Against the Fanatics, 1527). Luther maintains that the divine Christ "did not climb down from heaven as on a ladder or descend as by a rope," as He was "already present in essence and in person in the Virgin's womb, and had to assume humanity there." Ibid.

${ }^{134}$ Ibid., 22:9-10 (Sermons on the Gospel of St. John-chapters 1-4, 1537-1540). Luther indicates that "Christ is neither a mathematical word nor a physical word, but a divine and uncreated 'Word' which signifies substance and a person because the divine "Word' is divinity." Thus, "philosophically, a word means a sound or voice; but theologically speaking, word signifies the Son of God." Martin Luther and Mitchell Tolpingrud, "Luther's Disputation Concerning the Divinity and Humanity of Christ," Lutheran Quarterly 10, no. 2 (1996): 162. 
incomprehensible conversation" that "God alone sees, hears, or comprehends."

The association of Christ with God's thoughts, in the context of non-spatiality and timelessness, is also part of the conception of divine action in the functional model. The simultaneity of thoughts in God's timeless mind precludes any chronological distinction between divine foreknowledge and predestination, which means that these are not different activities of the divine mind. In other words, divine foreknowledge is identified with predestination, because what God contemplates is not different from His decision/decree or action. For Calvin, God "foresees future events only by reason of the fact that He decreed that they take place."136 Thus, divine action is particularly defined as predestination, which is “God's eternal decree, by which He compacted with Himself what He willed to become of each man. For all are not created in equal condition; rather, eternal life is foreordained for some, eternal damnation for others." 137 The idea of divine

${ }^{135} L W, 22: 9-10$.

${ }^{136}$ ICR 3.21.6. For Calvin, "God foreknew what end man was to have before he created him, and consequently foreknew because he so ordained by his decree." Thus, "God not only foresaw the fall of the first man, and in him the ruin of his descendants, but also meted it out in accordance with his own decision." Ibid., 3.21.7. Similarly, Luther affirms God's timeless predestination, conceiving divine foreknowledge in terms of action. This idea is emphasized in On the Bondage of the Will (1525). For instance, the German theologian argues that "God foreknows nothing contingently, but that he foresees and purposes and does all things by his immutable, eternal, and infallible will." Thus, "everything we do, everything that happens, even if it seems to us to happen mutably and contingently, happens in fact nonetheless necessarily and immutably, if you have regard to the will of God. For the will of God is effectual and cannot be hindered, since it is the power of the divine nature itself." $L W, 33: 37-38$. As a result, the "omnipotence and the foreknowledge of God . . . completely abolish the dogma of free choice." Ibid., 33:189. In short, God's "foreknowledge is not simply seeing, but acting." Ickert, "Luther on the Timelessness of God," 55. Johnson points out that "predestination is an implicit part of Luther's understanding of God's dealings with men, but Luther does not attempt to explain it, for he sees it as a part of the mystery of the Godhead." Johnson, "Luther's Understanding of God," 64. For further information on Luther's conception of divine predestination, see Fredrik Brosché, Luther on Predestination: The Antinomy and the Unity between Love and Wrath in Luther's Concept of God, Acta Universitatis Upsaliensis, Studiae Doctrinae Christianae Upsaliensia 18 (Stockholm: Almqvist \& Wiksell, 1978); James Edward McGoldrick, "Luther's Doctrine of Predestination," Reformation \& Revival 8, no. 1 (1999): 81-103.

${ }^{137}$ ICR 3.21.5. In his explanation of "God's eternal election," Calvin affirms that "salvation is freely offered to some while others are barred from access to it." Ibid., 3.21.1. The French theologian seems 
action, described in terms of the timeless predestination performed by God's mind, informs the mediatorial role of Christ. More specifically, God's eternal/timeless predestination is the cause of Christ's mediation. ${ }^{138}$ Besides the decree about the incarnation, ${ }^{139}$ Christ was “appointed to appease God's wrath with his sacrifice, and to blot out our transgressions with his obedience." ${ }^{, 140}$ In other words, Christ the mediator is the secondary cause of salvation, which is dependent on God's predestination (primary cause). ${ }^{141}$ One implication of this hierarchy of causes is that the mediatorial work of

to disassociate salvation or damnation from human choice because he thinks that free will implies merit. He believes that everything is taken away "from free will in order not to leave any place for merits." Ibid., 2.5.2. With regard to those being saved, "God's grace ... is the rule of the Spirit to direct and regulate man's will" in the work of regeneration. Ibid., 2.5.15. On the other hand, "God is said to blind and harden the reprobate, to turn, incline, and impel, their hearts. ... The nature of this activity is by no means explained if we take refuge in foreknowledge or permission." Ibid., 2.4.3. Even Satan is considered an instrument of God in His work with the reprobate. For Calvin, "Satan is properly said . . . to act in the reprobate over whom he exercises his reign, that is, the reign of wickedness. God is also said to act in His own manner, in that Satan himself, since he is the instrument of God's wrath, bends himself hither and thither at His beck and command to execute His just judgments." Ibid., 2.4.2. For helpful discussions of predestination in Calvin, see Muller, Christ and the Decree, 16-38; Paul Jacobs, Prädestination Und Verantwortlichkeit Bei Calvin (Darmstadt: Wissenschaftliche Buchgesellschaft, 1968); Wilhelm Niesel, The Theology of Calvin, trans. Harold Knight (Philadelphia: Westminster Press, 1956), 159-181; Wendel, Calvin, 263-284; Charles Partee, "Predestination in Aquinas and Calvin," Reformed Review 32, no. 1 (1978): 14-22.

${ }^{138}$ Referring to the fact that "Christ became our Redeemer and the partaker of our nature," Calvin argues that "these two" aspects "were joined together by God's eternal decree." ICR 2.12.5. Quoting Augustine, Calvin believes that "there is no more illustrious example of predestination than the mediator himself." Ibid., 2.17.1.

139 "Now it was of the greatest importance for us that he who was to be our Mediator be both true God and true man. If someone asks why this is necessary, there has been no simple (to use the common expression) or absolute necessity. Rather, it has stemmed from a heavenly decree, on which men's salvation depended." Ibid., 2.12.1.

${ }^{140}$ Ibid., 2.17.1.

${ }^{141}$ Assuming that salvation is "founded upon the decision of divine election alone" (ibid., 3.22.5), Calvin maintains that the beginning of "Christ's merit" is not in Him, but in "God's ordinance, the first cause.” Ibid., 2.17.1. In regards to the relationship between Christology and predestination in Calvin, Edmondson and Muller agree that Christ the mediator and God's decree do not function at the same level: whereas the decree is eternal/timeless (the vertical/timeless causal axis of salvation-Mueller), the person and work of Christ are the execution of this decree in time (the horizontal/temporal vertical causal axis of salvation-Mueller). However, they reject the conclusion that Christ is merely the instrument of divine predestination. While the incarnate Christ is subordinated to God's predestination in His office of mediator, 
Christ focuses on those who are elected by God for salvation. Calvin emphasizes that Christ takes "under his protection all whom the Father wishes to be saved." ${ }^{142}$ In other words, God's eternal/timeless predestination defines not only the person and work of Christ the mediator, but also the target people of His work.

In summary, the functional model describes the divine nature as non-spatial and timeless. According to this ontological framework, the divinity of Christ is described by the idea of eternal/timeless generation. In this view of the divine nature, divine action is understood particularly in terms of eternal/timeless predestination, in which God's knowledge (foreknowledge) is basically identified with His decision or action (predestination). ${ }^{143}$ In this context, Christ's mediation is caused and informed by timeless predestination. $^{144}$

Having discussed divinity as the first principle of reality in the functional model, I turn to the description of the second principle, namely, humanity.

Christ as the eternal Son was also the author of the decree, since it was defined by the Trinity. Therefore, Christ is both the author (as divine) and the executor (as divine-human) of predestination. Edmondson, Calvin's Christology, 96, 113-114, 147-149; Muller, Christ and the Decree, 10, 21, 25, 27, 37-38.

${ }^{142}$ ICR 3.24.6. Calvin seems to interpret John 6:37-39, 44; 17:6, 12 according to this perspective. Considering that Christ's mediatorial work accords with the Father's predestination, the French theologian argues that "though Christ interpose as a Mediator, yet he claims the right of electing in common with the Father, 'I speak not of you all: I know whom I have chosen' (John 13:18). If it is asked whence he has chosen them, he answers in another passages 'Out of the world;' which he excludes from his prayers when he commits his disciples to the Father (John 15:19).” Ibid., 3.22.7.

${ }^{143}$ According to Ziegler, the presuppositions about God adopted by Luther and Calvin allow them to choose different paths. Calvin chooses the doctrine of double predestination. Trying to avoid double predestination, Luther chooses the distinction between the hidden and revealed God. While the former pays the price of disregarding biblical "statements on universal grace," the latter embraces an "almost unbearable" tension in God. Ziegler, "Luther and Calvin on God," 87-88. Calvin opts for a twofold divine action (double predestination), whereas Luther maintains a twofold God (hidden/revealed God). paragraph.

${ }^{144}$ For remarks on the relationship between God's predestination and Christ's work, see previous 


\section{Humanity: Christ and the Concept of Human Nature}

Overall, similarly to the sacramental model, the humanity of Christ in the functional model is conceived as a spatio-temporal instrument of mediation of the spiritual (non-spatial) and eternal (timeless) God. It could be said that, for Luther, Christ's humanity is a (spatio-temporal) covering for the hidden (non-spatial/timeless) God, allowing (spatio-temporal) human beings to know Him. ${ }^{145}$ The distinction between the hidden (absconditus) and revealed (revelatus) God seems to present two faces of God. While the hidden God (God in Himself) is terrible and powerful in His majesty, which is associated with the law and predestination, the revealed God (God pro nobis) in the incarnate Christ demonstrates "the love, the goodness, and the sweetness of God. You will see His wisdom, His power, and His majesty sweetened and mitigated to your ability to stand it." 146 According to this perspective, by assuming a human nature Christ is able

${ }^{145}$ Affirming Christ as "our way to God," Luther argues that "to keep us from striving to observe God in Himself . . . He came into the flesh . . . in which we might behold God dwelling bodily." $L W$, 16:55 (Lectures on Isaiah, 1527-1528 [chap. 6]). In this sense, Luther claims, "cling to Christ, otherwise you will hear the Father Himself speaking against you when He says (Matt. 17:5): 'Listen to Him." Hence, "the incarnation of Christ powerfully calls us away from speculating about the divinity." Ibid. In this sense, the Christian religion "does not begin at the top," but "at the bottom," which means that "all speculations about the Majesty, all thoughts of works, traditions, and philosophy_indeed, of the Law of God itself" must be put aside, and "you must pay attention only to this Man, who presents Himself to us as the Mediator." $L W$, 26:30 (Lectures on Galatians [1-4], 1535). For Ickert, Luther's conception of Christ indicates that he "tends to interpret God's timeless eternity by his timely reality, his eternity by his history." In other terms, "God's timeless transcendence, an attribute of God's nakedness" can only be understood by "the historical reality of the Word-the divine mask." Thus, "with the advent of the Word we move from one mask to another, from timelessness, which conceals the mysterious God of cross and resurrection, to the Word made flesh, which in the fullness of time and under that which is contrary to all expectation of God's immutable glory, reveals the true hidden majesty of the Lord and creator of time." Ickert, "Luther on the Timelessness of God," 52-53. In the words of Werner Elert, "Christ is the temporalizing of God." Werner Elert, The Structure of Lutheranism, trans. Walter Hansen, vol. 1 (St. Louis: Concordia, 1962), 478. Among Luther's Christological writings, his understanding of the humanity of Christ is particularly expressed in the following texts: Confession Concerning Christ's Supper (1528), The Marburg Colloquy (1529), The Word became Flesh (1539), On the Divinity and Humanity of Christ (1540).

${ }^{146}$ Ibid., 26:30. According to Ziegler, "in Luther research the question has been asked whether there is a dualism in Luther and if Luther has a unified concept of God." There is a "contradiction" between "the hidden and revealed God," "between the God who is preached as merciful and good and the God who 
to mediate or reveal the hidden God to human beings, even though the picture of the hidden God seems to be incompatible with the revealed God for the limited human mind.

Indeed, Luther and Calvin understand the instrumentality of Christ's humanity in different ways, as they hold distinct views on how Christ's human nature relates to His divine nature (communicatio idiomatum). Emphasizing the unity between the two natures and the actual exchange of characteristics between them, Luther's position implies that the human nature of Christ is a spatio-temporal instrument in the sense that it communicates properties to His divine nature (e.g., passibility, physical touch) and also receives properties from the divine nature (e.g., different modes of presence). The German theologian strongly highlights the union between Christ's human and divine natures through his notion of communicatio idiomatum (communication of properties), ${ }^{147}$ which is not explained by analogies such as the union of soul and body, as they are incapable of expressing the profound unity of Christ's humanity and divinity. ${ }^{148}$ With

nevertheless permits men to remain in sin and even hardens them in their sin," and "Luther does not provide a solution." Ziegler, "Luther and Calvin on God," 64, 74-75. This contradiction seems to involve Luther's "two ways of approaching the question of time and eternity in God, the metaphysical-theological and the biblical-theological," which "run parallel to one another, not always harmoniously." Ickert, "Luther on the Timelessness of God," 58-59.

${ }^{147}$ According to this notion, "those things that are attributed to the human being may rightly be asserted with respect to God; and, on the other hand, those things that are attributed to God may rightly be asserted with respect to the human being." Luther and Tolpingrud, "Luther's Disputation Concerning the Divinity and Humanity of Christ," 152. Joar Haga's statement that Luther does not conceive the humanity of Christ as an instrument refers to a notion of instrumentality that does take into account Luther's understanding of communicatio idiomatum. See Joar Haga, Was There a Lutheran Metaphysics? The Interpretation of Communicatio Idiomatum in Early Modern Lutheranism, Refo500 Academic Studies (Göttingen: Vandenhoeck \& Ruprecht, 2012), 61. For further studies on Luther's view of communicatio idiomatum, see Dennis Ngien, "Chalcedonian Christology and Beyond: Luther's Understanding of the Communicatio Idiomatum," The Heythrop Journal 45, no. 1 (2004): 54-68; Johann Anselm Steiger and Carolyn Schneider, "The Communicatio Idiomatum as the Axle and Motor of Luther's Theology," Lutheran Quarterly 14, no. 2 (2000): 125-158.

${ }^{148}$ Luther and Tolpingrud, "Luther's Disputation Concerning the Divinity and Humanity of Christ," 155. "I confess two natures, but they can never be separated. This makes a unity which is a greater and a more sure conjunction than that of soul and body because these are separated, but the two natures are 
regard to the communication of properties from the human to the divine nature, "that which I assert with respect to Christ the human being," Luther states, "I correctly assert also with respect to God - that God suffered, was crucified."149 Even though "God cannot be crucified nor can God suffer," by becoming a human being "God is capable of suffering." 150 Therefore, the German theologian claims that "Christ, the impassible son of God," suffered and was crucified as God and man. ${ }^{151}$ In fact, the communicatio idiomatum enabled God not only to suffer, but to be touched. ${ }^{152}$ Furthermore, according to Luther's idea of communicatio idiomatum, the humanity of Christ receives properties from His divine nature. In terms of spatiality, Christ's divinity enables His humanity to have three different modes of presence, namely, the circumscribed/corporeal, the

never separated." Ibid., 161. However, Luther does believe that, by assuming a human nature, Christ assumed "that which consists of a soul and flesh." Ibid., 167. For useful studies on Luther's anthropology, see Denis Janz, Luther and Late Medieval Thomism: A Study in Theological Anthropology (Waterloo, ON, Canada: Wilfrid Laurier University Press, 1983); Wilfried Joest, Ontologie Der Person Bei Luther (Göttingen, Germany: Vandenhoeck \& Ruprecht, 1967).

${ }^{149}$ Luther and Tolpingrud, "Luther's Disputation Concerning the Divinity and Humanity of Christ," 160. "That unity of the two natures in one person is so great that they are equal in predication; they communicate their attributes to each other just as if he were only God or only a human being." Ibid., 168.

${ }^{150}$ Ibid., 161. "From eternity God has not suffered, but now that God has been made a human being, God is capable of suffering." Ibid. Because of the communicatio idiomatum, "those things which Christ suffered are attributed also to God because they are one." Ibid., 174-175.

${ }^{151}$ Ibid., 161. According to Ngien, "Luther transcends the Alexandrian Christology by asserting the idea of a real communication that moves not only from the divine nature to the human nature, but also from the human nature to the divine nature." Ngien, "Chalcedonian Christology and Beyond," 62.

However, Althaus points out that Luther sometimes hesitates in affirming that the deity suffered. Althaus, The Theology of Martin Luther, 198. For further information on Luther's notion of divine passibility, see Dennis Ngien, The Suffering of God According to Martin Luther's 'Theologia Crucis' (New York: Peter Lang, 1995).

${ }^{152}$ For Luther, "the one who touches the [incarnate] Son of God touches the divine nature itself." Luther and Tolpingrud, "Luther's Disputation Concerning the Divinity and Humanity of Christ," 164. Ngien argues that, for Luther, "the divine nature was present throughout the earthly life of Jesus, and was not untouched by the whole affair of the incarnation." Ngien, "Chalcedonian Christology and Beyond," 59. 
uncircumscribed/spiritual, and the repletive/divine modes. ${ }^{153}$ First, according to the “circumscribed corporeal mode of presence," Christ "walked bodily on earth" and "occupied and yielded space according to his size."154 Second, in His "uncircumscribed, spiritual mode of presence" Christ "neither occupies nor yields space but passes through everything created as he wills." 155 This mode of presence was employed by Christ "when he was born in his mother," "when he left the closed grave" in His resurrection, and then when he "came through closed doors" in His appearance to the disciples. ${ }^{156}$ Third, in "the divine, heavenly mode . . . all created things are ... permeable and present to" Christ, as far as He is God. ${ }^{157}$ This mode refers to divine omnipresence, by which the incarnate Christ "is simultaneously present in all places whole and entire, and fills all places, yet without being measured or circumscribed by any place, in terms of the space which it occupies. $" 158$

Conversely, Calvin emphasizes the distinction between Christ's human and divine natures. ${ }^{159}$ For him, the humanity of Christ is a spatio-temporal instrument in the sense

${ }^{153}$ As Luther indicates, "The one body of Christ has a threefold existence, or all three modes of being at a given place." LW, 37:222 (Confession Concerning Christ's Supper, 1528).

${ }^{154}$ Ibid. For further information about this mode of presence, see ibid., 37:215.

${ }^{155}$ Ibid., 37:222.

${ }^{156}$ Ibid., 37:223. Luther seems to believe that this is the way in which "angels and spirits are in certain places. For an angel or devil can be present in an entire house or city; again, he can be in a room, a chest or a box, indeed, in a nutshell. The space is really material and circumscribed, and has its own dimensions of length, breadth, and depth; but that which occupies it has not the same length, breadth, or depth as the space which it occupies, indeed, it has no length or breadth at all.” Ibid., 37:215.

${ }^{157}$ Ibid., 37:223. For Luther, "Wherever God is," Christ "must be also." Ibid.

${ }^{158}$ Ibid., 37:216. According to this divine mode, "Everything is full of Christ through and through, even according to his humanity." Ibid., 37:218.

${ }^{159}$ For helpful information about the humanity of Christ in Calvin, see Ho-Jin Ahn, "The Humanity of Christ: John Calvin's Understanding of Christ's Vicarious Humanity," Scottish Journal of 
that it enables the person of Christ (not His divine nature) to do things that cannot be done by His divine nature (e.g., to suffer, be seen or touched). ${ }^{160}$ In this perspective, Christ's divinity is "so joined and united with his humanity that each retains its distinctive nature unimpaired, and yet these two natures constitute one Christ." ${ }^{161}$ In contrast to Luther, the French theologian suggests that the best example of the distinction and conjunction of Christ's divine and human natures is the analogy of the unity and distinction of body and soul. ${ }^{162}$ Accordingly, Calvin assumes that the communication of properties is only a figure of speech, and not an ontological exchange of

Theology 65, no. 2 (2012): 145-158; R. Michael Allen, "Calvin's Christ: A Dogmatic Matrix for Discussion of Christ's Human Nature," International Journal of Systematic Theology 9, no. 4 (2007): 328-397; M. Dominice, L'humanité De Jésus d'après Calvin (Paris: Je Sers, 1933); Torrance, “The Vicarious Humanity and Priesthood of Christ in the Theology of John Calvin," 69-84.

${ }^{160}$ In Calvin's words, "Surely God does not have blood, does not suffer, cannot be touched with hands. But since Christ ... was true God and also true man," He "was crucified and shed his blood for us." ICR 2.14.2. "When the Lord of glory is said to be crucified [1 Corinthians 2:8], Paul does not mean that he suffered anything in his divinity." Ibid., 4.17.30.

${ }^{161}$ Ibid., 2.14.1. Edmondson argues that Calvin's "commitment to the immutability of the divine nature" resulted in the notion labeled as extra-calvinisticum, the idea that Christ in His divine nature has always been with God in heaven and with human beings on earth. According to this notion, "To say that Christ in his divinity was joined to his human nature in the virgin's womb does not mean that he was contained therein, for he continued to dwell in heaven and throughout the earth in his ubiquitous being as the Word of God." Hence, in the incarnation the divine Christ "descended from heaven ... without leaving heaven." Edmondson, Calvin's Christology, 212-213. For further information about the extracalvinisticum, see Willis, Calvin's Catholic Christology; Heiko Augustinus Oberman, "The 'Extra' Dimension in the Theology of Calvin," Journal of Ecclesiastical History 21, no. 1 (1970): 43-64.

${ }^{162}$ Calvin emphasizes that neither substance (soul, body) "is so mingled with the other as not to retain its own distinctive nature. For the soul is not the body, and the body is not the soul. Therefore, some things are said exclusively of the soul that can in no wise apply to the body; and of the body, again, that in no way fit the soul; of the whole man, that cannot refer-except inappropriately - to either soul or body separately." ICR 2.14.1. The French theologian also understands the humanity of Christ according to the dichotomy of body and soul. See $I C R$ 2.13.2. Such constitution of Christ's humanity is highlighted in Calvin's explanation of His sacrificial death. For him, the idea of Christ's descent into hell refers to the spiritual suffering of His soul. "If Christ had died only a bodily death, it would have been ineffectual," since He needed to "grapple hand to hand with the armies of hell and the dread of everlasting death" in order to "undergo the severity of God's vengeance, to appease his wrath and satisfy his just judgment." Thus, Christ gave not only His body "as the price of our redemption," but "He paid a greater and more excellent price in suffering in His soul." ICR 2.16.10. 
characteristics. ${ }^{163}$ He argues that, in some cases, Scripture attributes to Christ "what must be referred solely to his humanity,"164 in other cases it mentions "what belongs uniquely to his divinity; and sometimes what embraces both natures but fits neither alone." 165 In summary, the functional model conceives the humanity of Christ as a spatiotemporal instrument of mediation of the non-spatial/timeless God. Among other things, the human nature is described by a dichotomy of body and soul, and contrasted to the

${ }^{163}$ Calvin asserts that the communicatio idiomatum is only a "figure of speech" by which the Scriptures "so earnestly express this union of the two natures that is in Christ as sometimes to interchange them." ICR 2.14.1. "The communicating of characteristics or properties consists in what Paul says: 'God purchased the church with his blood' [Acts 20:28], and 'the Lord of glory was crucified' [1 Cor 2:8]. John says the same: 'The Word of life was handled' [1 John 1:1]. Surely God does not have blood, does not suffer, cannot be touched with hands. But since Christ, who was true God and also true man, was crucified and shed his blood for us, the things that he carried out in his human nature are transferred improperly, although not without reason, to his divinity. Here is a similar example: John teaches 'that God laid down his life for us' [1 John 3:16]. Accordingly, there also a property of humanity is shared with the other nature. Again, when Christ, still living on earth, said: 'No one has ascended into heaven but the Son of man who was in heaven' [John 3:13], surely then, as man, in the flesh that he had taken upon himself, he was not in heaven. But because the selfsame one was both God and man, for the sake of the union of both natures he gave to the one what belonged to the other." Ibid. 2.14.2. According to Tylenda, "The communication of idioms" in Calvin "is not a real ontological communication of properties (whereby the characteristics of one nature ontologically belong to the other nature), but it is the assigning of attributes to a person or subject." Joseph N. Tylenda, "Calvin's Understanding of the Communication of Properties," Westminster Theological Journal 38, no. 1 (1975): 64. McCormack criticizes the lack of reflection on the hypostatic union in Calvin and stipulates that his avoidance of an ontological communication of idioms is related to the concept of divine immutability. McCormack, For Us and Our Salvation, 9, 33.

${ }^{164}$ ICR 2.14.1. "He is called 'the servant of the Father' [Isa 42:1]; he is said to have 'increased in age and wisdom ... God and men' [Luke 2:52], and not to 'seek his own glory' [John 8:50]; 'not to know the Last Day' [Mark 13:32]; not to 'speak by himself' [John 14:10], and not to 'do his own will' [John 6:38]; he is said to have been 'seen and handled' [Luke 24:39]. All these refer solely to Christ's humanity. In so far as he is God, he cannot increase in anything, and does all things for his own sake; nothing is hidden from him; he does all things according to the decision of his will, and can be neither seen nor handled. Yet he does not ascribe these qualities solely to his human nature, but takes them upon himself as being in harmony with the person of the Mediator." Ibid. 2.14.2; italics mine.

${ }^{165}$ Ibid. 2.14.1. With regard to Christ's divinity, Calvin argues that "what Christ said of himself, 'Before Abraham was I am,' [John 8:58] — was far removed from his humanity. . . Paul declares him to be 'the first-born of all creation ... who was before all things and in whom all things hold together' [Col 1:15, 17]. Also, he says that he was 'glorious in his Father's presence before the world was made' [John 17:5]; and that he is working together with his Father [John 5:17]. These qualities are utterly alien to man. Therefore they and their like apply exclusively to his divinity." Ibid. 2.14.2; italics mine. In reference to both Christ's humanity and divinity, Calvin maintains, "for one reads there neither of deity nor of humanity alone, but of both at once: he received from the Father the power of remitting sins [John 1:29], of raising to life whom he will, of bestowing righteousness, holiness, salvation; he was appointed judge of the living and 
divine nature by its passibility. Two conceptions of the instrumentality of Christ's humanity derive from two different emphases about the relationship of His human nature with His divine nature. According to the emphasis on the unity of the natures (Luther), Christ's humanity enables His divinity to experience human characteristics (e.g., passibility) and, at the same time, is enabled by the divine nature to experience divine characteristics (e.g., omnipresence). In accordance to the emphasis on the distinction of the natures (Calvin), Christ's humanity does what cannot be done by His divine nature (e.g., human passibility and divine impassibility). In both emphases, the divine nature is impassible by default. The difference is that, for Luther, the divine nature can experience passibility through the human nature.

My next step is to describe the third principle of reality in the functional model, namely, cosmology.

\section{Cosmology: Christ, Heaven, and Earth}

In the description of this principle of reality in the functional model, I will focus on the interaction of the resurrected ascended Christ with heaven and earth, highlighting how the concepts of divinity and humanity explored above relate to cosmology or the ontological structure of the world in this model.

According to the functional model, the notion of God being in heaven is a metaphor (Luther) that accommodates non-spatial realities to human spatial cognition (Calvin). Hence, with reference to God, heaven is non-spatial. Luther tends to understand the biblical language about heaven and the throne of God metaphorically. With regard to 
the idea of "God as sitting on a throne," he emphasizes that "uneducated persons" do not recognize this as a figure of speech, but "immediately think of a golden throne marvelously adorned, although they know that no such material is found in heaven."166 This notion of heaven is compatible to his description of the life to come, which is different from the physicality (space) and sequentiality (time) that characterizes the present earthly life. ${ }^{167}$ Likewise, Calvin maintains that the term "heaven" represents the best way the finite human mind can express "unspeakable glory," since "wherever our senses comprehend anything they commonly attach it to that place." ${ }^{\prime 168}$ Accordingly, he rejects the idea that God is actually in a place called heaven. For him, God "is not confined to any particular region but is diffused through all things." ${ }^{169} \mathrm{He}$ is "beyond all place," which means that there is nothing "earthly or physical about Him, lest we

${ }^{166} \mathrm{LW}, 1: 15$ (Lectures on Genesis, 1535). In his contention against Zwingli's view that the eucharistic elements are the body of Christ in a metaphorical sense because $\mathrm{He}$ ascended into heaven, Luther highlights that "the figure of speech could much more conveniently be found in the word "heaven," rather than in the Lord's Supper. LW, 38:41 (The Marburg Colloquy and the Marburg Articles, 1529). Luther justifies a metaphorical understanding of heaven by saying that this word is "used in Scripture in various meanings." Ibid. For further information about Luther's conception of heaven, see Hans Schwarz, "Luther's Understanding of Heaven and Hell," in Interpreting Luther's Legacy: Essays in Honor of Edward C Fendt, ed. Fred W. Meuser and Stanley D. Schneider (Minneapolis: Augsburg, 1969), 83-94.

${ }^{167}$ In Luther's words, "this life amounts to eating, drinking, sleeping, digesting, begetting children, etc. Here everything goes by number: hours, days, and years in succession. Now when you want to look at the life to come, you must erase the course of this life from your mind. You dare not think that you can measure it as this life is measured. There everything will be one day, one hour, one moment." $L W$, 30:196 (Sermons on the Second Epistle of St. Peter, 1523).

${ }^{168}$ ICR 3.20.40. For Calvin, the term heaven "is only a metaphor. Since it is an abstract notion, the Scripture uses a concrete image which corresponds to the highest thing visible, because our 'ignorance' and 'stupidity' prevents us from under-standing the abstract." J. H. Mazaheri, "Calvin and Augustine's Interpretations of 'the Father in Heaven'," Revue d 'histoire ecclésiastique 106, no. 3-4 (2011): 448-449. See also Christopher B. Kaiser, "Climbing Jacob's Ladder: John Calvin and the Early Church on Our Eucharistic Ascent to Heaven," Scottish Journal of Theology 56, no. 3 (2003): 250-251.

${ }^{169}$ ICR 3.20.40. Calvin seems to find biblical support for this argument in $1 \mathrm{Kgs} 8: 27$; Isa 66:1; Acts $7: 49 ; 17: 24$. 
measure him by our small measure." ${ }^{170}$ These statements reveal the assumption that being in a place implies being confined and measured.

Taking into consideration the different accounts provided by Luther and Calvin regarding the relationship between Christ's human and divine natures discussed in the section above on Humanity, the functional model accommodates two interpretations of the presence of the ascended Christ in heaven. One interpretation holds that Christ is in heaven according to the divine mode of presence-omnipresent (Luther: Christ's third mode of presence). ${ }^{171}$ Hence, Christ's ascended body is not physically present in a particular place with the Father_although Christ still can employ His circumscribed mode of presence, but is everywhere. ${ }^{172}$ In Luther's words, “Christ's body is everywhere because it is at the right hand of God which is everywhere." ${ }^{173}$ While this interpretation assumes that the humanity of Christ receives the divine property of ubiquity from His divine nature, the other interpretation maintains that the humanity of Christ, in order to be a real humanity, is distinct from His divinity, which means that the humanity of the soul." Ibid.

${ }^{170}$ Ibid. Calvin claims that when we seek God "we must rise above all perception of body and

${ }^{171}$ Affirming that Christ is in heaven according to His third mode of presence, that is, the divine or ubiquitous mode, Luther claims in his disputation against Zwingli that the biblical notion that the ascended Christ is at the right hand of God in heaven does not imply that He cannot be in the sacrament at the same time, since the right hand of God is not "a particular place in heaven." LW, 37:213 (Confession Concerning Christ's Supper, 1528).

${ }^{172}$ Even though Luther indicates that the ascended Christ can still employ His circumscribed mode of presence, "He is not in God or with the Father or in heaven according to this mode," as "God is not a corporeal space or place." Ibid., 37:222. Luther points out that the ascended Christ will employ His circumscribed mode of presence in the Parousia. Ibid.

${ }^{173}$ Ibid., 37:213. For further information about the ubiquity of the ascended Christ in Luther, see David R. Law, "Descent into Hell, Ascension, and Luther's Doctrine of Ubiquitarianism," Theology 107, no. 838 (2004): 250-256. 
ascended Christ is not ubiquitous as His divinity (Calvin). ${ }^{174}$ In other words, the second interpretation stipulates that Christ's ascended body has limited dimensions and is localized in a place in heaven. ${ }^{175}$ Calvin seems to assume that the ascension was a bodily ${ }^{176}$ and visible movement ${ }^{177}$ into a place in heaven. ${ }^{178}$ Moreover, he argues that the ascended Christ "entered a sanctuary not made with hands" to appear "before the Father's face as our constant advocate and intercessor." ${ }^{179}$ Calvin appears to indicate that the notion of Christ entering a heavenly sanctuary is not a metaphorical idea. In his criticism

${ }^{174}$ Calvin calls Luther's position the "monstrous notion of ubiquity." ICR 4.17.30.

${ }^{175}$ According to Calvin, "Christ's body is limited by the general characteristics common to all human bodies, and is contained in heaven (where it was once for all received) until Christ return in judgment [Calvin seems to refer to Acts 3:21] . . so we deem it utterly unlawful to draw it back under these corruptible elements or to imagine it to be present everywhere." Ibid., 4.17.12. "The body of Christ from the time of his resurrection was finite, and is contained in heaven even to the Last Day." Ibid., 4.17.26. In fact, Calvin argues that the conception that Christ's glorified body is "invisible and infinite," being "in many places at once and not held in any space," constitutes a denial "the resurrection of the flesh" and an affirmation that Christ's "body was swallowed up by his divinity." For the French theologian, "if to fill all things in an invisible manner is numbered among the gifts of the glorified body, it is plain that the substance of the body is wiped out, and that no difference between deity and human nature is left. Then, if Christ's body is so multiform and varied that it shows itself in one place but is invisible in another, where is the very nature of a body, which exists in its own dimensions ... ?" Ibid., 4.17.29. See also ibid., 4.17.17, 19,24 , and 28. Assuming that "the true nature of a body to be contained in space, to have its own dimensions and its own shape" Calvin stipulates that the fact that the resurrected Christ "went in to his disciples through closed doors" in John 20:19 needs to be understood in the same way that He, before the resurrection, walked upon the water (Matt 14:25) miraculously. Ibid., 4.17.29.

${ }^{176}$ According to Calvin, Christ's "body was raised up above all the heavens." Ibid., 2.16.14. "He entered heaven in our flesh.” Ibid., 2.16.16.

${ }^{177}$ Referring to Acts $1: 11$, the French theologian affirms the visible form of Christ's second coming based on the visibility of His ascension. "He will come down from heaven in the same visible form in which he was seen to ascend." Ibid., 2.16.17. The idea of movement seems to be implied in the statement that "'departing' and 'ascending' do not signify giving the appearance of one ascending and departing, but actually doing what the words state." Ibid., 4.17.26.

178 "But why do we repeat the word 'ascension' so often? Does it not imply moving from one place to another? They deny this: according to them, height signifies only the majesty of his rule. But what is the manner of the ascension itself? Is he not lifted up on high before his disciples' very eyes? Do not the Evangelists clearly relate that he was received into heaven?" Ibid., 4.17.27; italics mine. "We safely infer that his abode is now in heaven." Ibid. "By His ascension into heaven" Christ "made it plain that it is not in all places, but when it passes into one, it leaves the previous one." Ibid., 4.17.30

${ }^{179}$ Ibid., 2.16.16. 
of those who defend the ubiquity of Christ's humanity, he states that they "drag Christ's body from the heavenly sanctuary." 180 Depicting the heavenly intercession, the French theologian stipulates that Christ "turns the Father's eyes to his own righteousness to avert his gaze from our sins." ${ }^{181}$ This emphasis on the Father's eyes implies that Christ's intercession does not involve bodily (kneeling) or oral (pleading) communication with the Father, but it is only a physical appearance before Him. ${ }^{182}$ However, when such description of the intercession of Christ is compared with the non-spatial/timeless understanding of God and heaven described above, one wonders whether the language of Christ entering the heavenly sanctuary in order to appear before the Father really depicts a spatio-temporal reality or this is only a spatio-temporal metaphorical expression that accommodates a non-spatio/timeless reality to the spatio-temporal cognition of the human mind. ${ }^{183}$

Regarding the earth, the functional model embraces the sacramental presence of the ascended Christ on earth. As this presence is related to His presence in heaven, the

\footnotetext{
${ }^{180}$ Ibid., 4.17.30. In his words, "The greatest and truest priest of the church had not figuratively entered the inner precincts of the veil to the Holy of Holies but through express and steadfast truth had entered the inner precincts of heaven to a holiness real and eternal, also commends himself to the prayers of believers." Ibid., 3.20.20. "Having entered the heavenly sanctuary, even to the consummation of the ages," Christ "alone bears to God the petitions of the people." Ibid.

${ }^{181}$ Ibid., 2.16.16. Calvin adds, Christ "so reconciles the Father's heart to us that by his intercession he prepares a way and access for us to the Father's throne. He fills with grace and kindness the throne that for miserable sinners would otherwise have been filled with dread." Ibid.

${ }^{182}$ For Calvin, Christ is not "kneeling before God" and pleading "as a suppliant for us," but “appears before God's presence.” Ibid., 3.20.20.

${ }^{183}$ For McDonnel, “Calvin's emphasis on Christ's body having its place in heaven can be misleading. He did not think of Christ's body being assigned to a definite place in heaven." Indeed, "He is quite aware that there is not a celestial circumscription reserved to the divinity and the glorified creatures, that the glorified body of Christ is not bound by the Aristotelian category of place. Christ is not in a place in heaven, but he is there as in a space of place." McDonnell, John Calvin, the Church and the Eucharist, 226-227.
} 
two interpretations of the presence of Christ in heaven lead to two different accounts of His sacramental presence on earth. The interpretation that Christ is not physically present in heaven holds that He is physically present in the eucharistic elements (Luther). ${ }^{184}$ The German theologian explains that Christ is present both in heaven and in the sacrament. ${ }^{185}$ He is in the sacrament according to the uncircumscribed/spiritual mode of presence (the second mode of presence), ${ }^{186}$ and is also in heaven according to the divine/ubiquitous mode of presence (the third mode of presence). ${ }^{187}$ Therefore, like in heaven, on earth Christ is not present in the sacrament as circumscribed in a place (this would be the first mode of presence). ${ }^{188}$ On the other hand, the interpretation that Christ is physically present in heaven leads to the conclusion that He is not physically present in the eucharistic elements (Calvin). The French theologian argues that the body of Christ is truly present in the sacrament, ${ }^{189}$ but in a spiritual (not physical) way through the power

\footnotetext{
${ }^{184}$ In his contention against Zwingli's view that the eucharistic elements are the body of Christ in a metaphorical sense because He ascended into heaven, Luther highlights that "the figure of speech could much more conveniently be found in the word 'heaven," rather than in the Lord's Supper. $L W, 38: 41$ (The Marburg Colloquy and the Marburg Articles, 1529). For Luther, in the Lord's Supper the mouth of believers "receives the body of Christ." He uses the language of "eating Christ's body." Ibid., 38:46, 55. The German theologian advocates the substantial presence of Christ in the eucharistic elements but not in terms of transubstantiation. For him, "Christ is in the sacrament substantially as he was born of the Virgin." Ibid., 38:30. However, "the bread and wine in themselves remain unaltered and unchanged." Ibid., 37:217 (Confessions Concerning Christ's Supper, 1528).

185 "I confess that the body is in heaven, I also confess that it is in the sacrament." Ibid., 38:58. See also ibid., 38:29; 37:213.

${ }^{186}$ Ibid., 37:216-217 (Confessions Concerning Christ's Supper, 1528).

${ }^{187}$ This point was explained in the paragraph above regarding Luther's understanding of Christ's presence in heaven.

${ }^{188}$ In Luther's words, Christ's "body is not in the sacrament as in a place." Ibid., 38:61 (The Marburg Colloquy and the Marburg Articles, 1529).

189 "In his Sacred Supper" Christ "bids me take, eat, and drink his body and blood under the symbols of bread and wine. I do not doubt that he himself truly presents them, and that I receive them." ICR 4.17.32. "Take and eat the body which was once for all offered for our salvation, in order that when we
} 
of the Holy Spirit. ${ }^{190}$ These two accounts of Christ's sacramental presence on earth affirm in different ways the conviction assumed by the functional model that the ascended

Christ works salvifically with believers on earth by means of the word ${ }^{191}$ and the sacraments, ${ }^{192}$ whose climax is His real presence in the eucharistic elements. ${ }^{193}$ Thus, the

see ourselves made partakers in it ... the power of his life-giving death will be efficacious in us." Ibid., 4.17.1. "The Lord's body was once for all so sacrificed for us that we may now feed upon it, and by feeding feel in ourselves the working of that unique sacrifice." Ibid. Calvin rejects a purely symbolic view of the Lord Supper when he indicates that "there are some who define the eating of Christ's flesh and the drinking of his blood as ... nothing but to believe in Christ." In contrast to this view, he argues that Christ's "life passes into us and is made ours - just as bread when taken as food imparts vigor to the body," because "the soul must truly and deeply become partaker of Christ that it may be quickened to spiritual life by his power." Calvin is aware of the fact that his view has an ontological emphasis, since he underlines that the difference between these two views "small difference indeed in words, but no slight one in the matter itself." Ibid., 4.17.5. Quoting Chrysostom, he affirms that "Christ makes us his body not by faith only but by the very thing itself." Ibid., 4.17.6. Redding and Canlis argue that Calvin's understanding of the role of the Spirit in the Lord's Supper implies a non-substantial, but relational (Redding), view of grace and of participation in Christ. Redding, Prayer and the Priesthood of Christ in the Reformed Tradition, 88; Julie Canlis, "Calvin, Osiander, and Participation in God," International Journal of Systematic Theology 6, no. 2 (2004): 177, 184.

190 "For us the manner is spiritual because the secret power of the Spirit is the bond of our union with Christ." ICR 4.17.33. Meyer qualifies the idea of spiritual presence in Calvin by highlighting that "it is inadequate to explain this presence simply as a 'virtual' or a 'spiritual' presence. Rather this communication of Christ's presence as expressed in Calvin's teaching is 'a divine spiritual event that includes the bodily and hence not a 'pure' spiritual event."' Boniface Meyer, "Calvin's Eucharistic Doctrine, 1536-39," Journal of Ecumenical Studies 4, no. 1 (1967): 64. In his criticism of "those who conceive no presence of flesh in the Supper unless it lies in the bread" (which would be Luther's position), Calvin emphasizes that "the question is therefore only of the manner, for they place Christ in the bread, while we do not think it lawful for us to drag him from heaven." ICR 4.17.31; italics mine. "I reject only absurd things which appear to be either unworthy of Christ's heavenly majesty, or incompatible with the reality of his human nature." Ibid., 4.17.32; italics mine.

${ }^{191}$ For Luther, "Christ no longer preaches physically but is present with the Word and preaches to the spirits in their hearts." LW, 30:114 (Sermons on the First Epistle of St. Peter, 1522).

${ }^{192}$ The German theologian stipulates, "Nobody will obtain salvation ... without external things," which highlights especially the physical necessity of the word, baptism, and the eucharist- "all these are indeed externals, but they are included in the Word. Hence the Holy Spirit works nothing without them." LW, 3:274-275 (Lectures on Genesis, 1539 [chapter 19]).

${ }^{193}$ For Luther argues that Christ is present "in baptism, the Supper, and preaching until the end of the age." $L W, 38: 29$ (The Marburg Colloquy and the Marburg Articles, 1529). "Christ gives himself to us in many ways: first, in preaching; second, in baptism; [third,] in brotherly consolation; fourth, in the sacrament, as often as the body of Christ is eaten." Ibid., 38:19. In the context of the Lord's Supper, "the words are not only the sound of a man who speaks them but of God who conveys [something] to the person who eats the bread," and this effect is particularly produced by the bodily presence of Christ in the eucharistic elements. Ibid., 38:41. More specifically, “The body [of Christ] nourishes man's body for eternity. When the mouth receives the body, a person acquires a kind of immortality. For the word on the 


\title{
functional model presupposes that Christ conveys spiritual blessings and realities (His
}

\author{
own body) by means of physical instruments (the spoken word and the sacramental
}

\author{
elements). ${ }^{194}$ According to Luther, these instruments are masks of the hidden God being
}

basis of God's command supplies strength." Ibid., 38:57. According to Calvin, "Christ Himself is the matter of the Supper" (ICR 4.17.33) and effects "redemption, righteousness, sanctification, and eternal life, and all the other benefits Christ gives to us." Ibid., 4.17.11. "In the mystery of the Supper, Christ is truly shown to us through the symbols of bread and wine, his very body and blood," so "that we may grow into one body with him," and "having been made partakers of his substance, that we may also feel his power in partaking of all his benefits." Ibid. For helpful information on Calvin's understanding of the sacraments and the Lord's Supper, see M. Eugene Osterhaven, "Calvin on Word and Sacrament, and Man," Reformed Journal 8, no. 5 (1958): 21-24; Herman Bavinck, "Calvin's Doctrine of the Lord's Supper," Mid-America Journal of Theology 19 (2008): 127-142; Meyer, "Calvin's Eucharistic Doctrine," 47-65; Brian A. Gerrish, Grace and Gratitude: The Eucharistic Theology of John Calvin (Minneapolis, MN: Fortress, 1993); McDonnell, John Calvin, the Church and the Eucharist.

${ }^{194}$ Luther explains, "When God sends forth his holy gospel he deals with us in a twofold manner, first outwardly, then inwardly. Outwardly he deals with us through the oral word of the gospel and through material signs, that is, baptism and the sacrament of the altar. Inwardly he deals with us through the Holy Spirit, faith, and other gifts. But whatever their measure or order the outward factors should and must precede. The inward experience follows and is effected by the outward. God has determined to give the inward to no one except through the outward. For he wants to give no one the Spirit or faith outside of the outward Word and sign instituted by him." LW, 40:146 (Against the Heavenly Prophets in the Matter of Images and Sacraments, 1525). In this perspective, while the physical preaching of the apostles reaches the ears of the hearers, Christ reaches the hearts of the hearers spiritually. In this sense, the preaching of the word works sacramentally, as it is a physical instrument that conveys a spiritual effect. According to the German theologian, Christ "Himself comes, is spiritually present, and speaks and preaches to the hearts of the people, just as the apostles address their words orally and physically to the ears of the people." $L W$, 30:114 (Sermons on the First Epistle of St. Peter, 1522). Phillip Cary points out that, for Luther, the gospel is "a sacramental word." Phillip Cary, "Why Luther Is Not Quite Protestant: The Logic of Faith in a Sacramental Promise," Pro Ecclesia 14, no. 4 (Fall 2005): 452. For further information about the Word of God as a means of grace, see John T. Mueller, "Notes on Luther's Conception of the Word of God as the Means of Grace," Concordia Theological Monthly 20, no. 8 (1949): 580-600. In Luther's sacramentarian view, "when the words are spoken at the command and in the name of God," the sacraments "not only signify but also at the same time effect and offer that which they signify." $L W, 38: 41$ (The Marburg Colloquy and the Marburg Articles, 1529). According to Calvin's understanding of the sacraments as means of grace, God performs a physical accommodation of spiritual realities, through which the divine Spirit effects what the sacraments symbolize. In his view, as corporeal creatures, human beings "always creep on the ground, cleave to the flesh, and, do not think about or even conceive of anything spiritual." Therefore, God "tempers Himself to our capacity" by using corporeal elements as "a mirror of spiritual blessings." Quoting Chrysostom, the French theologian argues that, "if we were incorporeal," God "would give us" spiritual "things naked and incorporeal." "Now, because we have souls engrafted in bodies, he imparts spiritual things under visible ones." ICR 4.14.3. Calvin joins "reality and truth to the sign," since "God works through outward means." Ibid., 4.15.15. God "does not feed our eyes with a mere appearance only, but leads us to the present reality and effectively performs what it symbolizes." Ibid., 4.15.14. The French theologian agrees with Augustine, who defines the sacrament as "a visible form of an invisible grace." Ibid., 4.14.1. Calvin emphasizes "the working of divine grace in the sacraments" (Ibid., 4.14.7) and the "inner grace of the Spirit" making the sacraments "bear fruit" (Ibid., 4.14.17). Taking into account that "God accomplishes within what the minister represents and attests by outward action," the sacraments are considered "instruments" that God uses, as He produces "by invisible grace through the Holy Spirit" the 
used now by the ascended Christ, who previously revealed God through the mask or clothing of the humanity in His public ministry on earth. ${ }^{195}$ In this sense, the masks of the word and sacraments can be seen as a continuation of Christ's humanity on earth. ${ }^{196}$ This interpretation appears to emphasize a heavenly Christ who descends on earth through the word and sacraments, assuming that He is physically present in the Lord's Supper. On the other hand, the interpretation that assumes that Christ is spiritually present in the Lord's Supper, but physically present in heaven, seems to emphasize that believers somehow ascend to Christ through the sacraments. To put it more sharply, while the sacramental idea of the physical presence of Christ on earth tends to interpret Christ working to save

"whole fruit of the visible sacraments." Ibid., 4.14.17. In this context, the Lord's Supper is not "an empty symbol" (Ibid., 4.17.10) and the sacraments are not signs that "lack their own effect" (Ibid., 4.14.17). As McDonnell highlights, Calvin insists "that grace is given in the sacraments, and also through the sacraments." McDonnell, John Calvin, the Church and the Eucharist, 369. For the idea of the eucharistic elements as instruments of grace in Calvin, see also Redding, Prayer and the Priesthood of Christ in the Reformed Tradition, 88; Bavinck, “Calvin's Doctrine of the Lord's Supper," 134.

${ }^{195}$ In Luther's sacramental perspective, physical elements of creation veil "God, for in this life we cannot deal with God face to face." LW, 26:95 (Lectures on Galatians [1-4], 1535). Because human beings are not supposed to deal with God "naked but clothed and revealed in His Word," God "is dressed and clothed in His Word and promises, so that from the name 'God' we cannot exclude Christ." Ibid., 12:312 (Commentary on Psalm 51, 1532). In other words, "God must therefore be left to himself in his own majesty, for in this regard we have nothing to do with him, nor has he willed that we should have anything to do with him. But we have something to do with him insofar as he is clothed and set forth in his Word." $L W, 33: 139-140$ (On the Bondage of the Will, 1525). Referring to "the Son glorified and enthroned in majesty," Luther maintains that He is "enveloped in an image, namely, in the Word and the sacraments. These are His masks or His garments, as it were, in which He conceals Himself. But He is certainly present in these, Himself working miracles, preaching, administering the sacraments, consoling, strengthening, and helping. We see Him as we see the sun through a cloud. For now we cannot bear to see and look at His brilliant Majesty." LW, 24:67 (Sermons on the Gospel of St John [14-16], 1537). For additional information about the idea of divine masks in Luther, see Anthony J. Steinbronn, "Luther's Use of Larvae Dei," Concordia Journal 19, no. 2 (1993): 135-147.

${ }^{196}$ Lienhard argues that Luther closely relates Christ's bodily presence in the eucharist with His incarnation. "The incarnation continues in the sense that God continues to offer himself to us by the physical elements ... of the eucharist." These elements do not supplant "the humanity of Christ as such, but prolong it in some way, constituting his current way of being present." Lienhard, Luther, Witness to Jesus Christ, 220. See also Paul Wilhelm Gennrich, Die Christologie Luthers Im Abendmahlsstreit (Königsberg: Vandenhoeck \& Rupprecht, 1929), 28, 146; Kjell Ove Nilsson, Simul: Das Miteinander Von Göttlichem Und Menschlichem in Luthers Theologie, Forschungen Zur Kirchen Und Dogmengeschichte 17 (Göttingen: Vandenhoeck \& Ruprecht, 1966), 155-157. 
believers by sacramentally descending to the earth (Luther), the idea of a physical

presence in heaven tends to interpret Christ working to save them by sacramentally

ascending them to heaven (Calvin). Hence, in the second view there is a shift of emphasis

from earth to heaven. ${ }^{197}$ Instead of bringing the physical body of Christ to earth, the Holy

Spirit enables believers to ascend spiritually to heaven, where Christ is. ${ }^{198}$ In both

interpretations, the believers targeted by Christ's sacramental work are predestined by

God to benefit from this work. ${ }^{199}$ The second interpretation that emphasizes heaven

\begin{abstract}
${ }^{197}$ According to Cary, a crucial difference between Calvin and Luther in the sacraments is the "direction of attention." For Calvin, the "sacrament directs our attention away from earth to heaven." Cary, "Why Luther Is Not Quite Protestant," 464, 466, 480. McDonnell believes that Calvin is influenced by Plato in his notion of heaven and earth in the context of the Lord's Supper. In his words, "If the realities of which Calvin is speaking are biblical realities, his categories here are greatly influenced by Plato. The dialectic here is between the earthly and the heavenly, between the image and the intelligible reality. It is by means of the earthly sign that one participates in the heavenly body of Christ. The earthly sign assures us that we participate in the heavenly reality even though it must of necessity remain in heaven." According to this perspective, the idea of Christ's physical presence in the eucharistic elements, as affirmed in different ways by Catholics and Lutherans, "destroys the Platonic tension: sign becomes signified, the intelligible reality becomes the image, heaven comes to earth." McDonnell, John Calvin, the Church and the Eucharist, 231.
\end{abstract}

${ }^{198}$ For Calvin, "there is no need to draw Christ to earth that he may be joined to us." ICR 4.17.31. He adds that the wrong notion that Christ is physically "attached to the element of bread" draws "men's minds from heaven." Ibid., 4.17.12. Conversely, the correct understanding that Christ is in heaven indicates that, in the Lord's Supper, "we are lifted up to heaven with our eyes and minds, to seek Christ there in the glory of his Kingdom." Ibid., 4.17.18. Indeed, "in order that pious souls may duly apprehend Christ in the Supper, they must be raised up to heaven." Ibid., 4.17.36. In the Supper, "the only lawful adoration is that which does not rest in the sign, but is directed to Christ seated in heaven." Ibid., 4.17.37. Kaiser indicates that there are "at least 33 passages in Calvin's writings" that indicate that "Christians are raised up to heaven in the celebration of the eucharist." In contrast to a merely mental ascension that seems to be assumed by A. M. Hunter and Gordon Pruett, Kaiser argues for an actual ascent of the soul to heaven in Calvin. Kaiser, "Climbing Jacob's Ladder," 247-248, 252-253. See A. M. Hunter, The Teaching of Calvin: A Modern Interpretation, 2nd ed. (London: James Clarke, 1950), 187; Gordon E. Pruett, "A Protestant Doctrine of the Eucharistic Presence," Calvin Theological Journal 10, no. 2 (1975): 174. According to Redding, this spiritual ascension of believers to heaven is particularly associated with the priesthood of Christ: "Calvin sees the church being lifted by the Spirit in the act of worship into the presence of God through the High Priest, Jesus Christ." Redding, Prayer and the Priesthood of Christ in the Reformed Tradition, 88 .

${ }^{199}$ For Luther, "one should not inquire into the predestination of the hidden God but should be satisfied with what is revealed through the calling and through the ministry of the Word. For then you can be sure about your faith and salvation." LW, 5:50 (Lectures on Genesis, 1542). In other words, predestination is "guaranteed through the Son of God and the sacraments." Ibid., 5:46. The German theologian affirms that someone predestined is not "saved without the Son and without the sacraments or 
(Calvin) is even more specific. While non-believers may have contact with the bread and wine in the church on earth, only elected believers spiritually ascend to heaven through the Holy Spirit in the Lord's Supper to have communion with the physical Christ. ${ }^{200}$

In summary, under the assumption that being in a place implies confinement and

Holy Scripture.” In this sense, they strengthen believers “over against uncertainty and doubt.” Ibid., 5:43. As Ickert indicates, "Luther binds together revelation, Word, sacraments, faith and grace on the one hand, and speculation concerning God's foreknowledge and pre-destination, and the righteousness of works, on the other. Accordingly, God's revelation in time in which the timeless God achieves his identity as Savior, that is, through Word and sacraments, stands against all conjectures concerning divine foreknowledge and pre-destination." Ickert, "Luther on the Timelessness of God," 54. In the context of Calvinism, the notions of limited atonement and Christ's intercession have been debated especially after Kendall's study Calvin and English Calvinism to 1649. As Redding summarizes, according to Kendall's interpretation of Calvin, "Christ's priesthood on the cross at Calvary is for all humankind," while His ongoing intercessory priesthood in heaven "is for the elect only." Redding, Prayer and the Priesthood of Christ in the Reformed Tradition, 99. Assuming that "all which Christ did on the cross 'remains useless and of no value' until we believe," Kendall aligns the moment of belief with the ongoing intercession of Christ in heaven: "The origin of saving faith [is] in the intercessory work of Christ at the Father's right." This means that "the decree of election ... is not rendered effectual in Christ's death but in His ascension and intercession." Therefore, whereas "Christ died for all," His "intercession is for the elect only." R. T. Kendall, Calvin and English Calvinism to 1649, Oxford Theological Monographs (Oxford: Oxford University Press, 1979), 13, 16-17. Charles Bell agrees with Kendall that Calvin taught both a "doctrine of universal atonement" and "a doctrine of predestination in which faith is limited to the elect." However, he thinks that Calvin "did not link the doctrines of election and atonement in a logical order of cause and effect," and criticizes Kendall for not considering the "unity between Christ's atonement and his priestly intercession in Calvin's teaching." M. Charles Bell, Calvin and Scottish Theology: The Doctrine of Assurance (Edinburgh: Handsel, 1985), 17-18. In my opinion, Bell's affirmation of both universal atonement (in Christ's death and intercession) and Calvinist predestination is unsatisfactory, because it implies either a disruption of the unity between the intercession of Christ and the work of the Spirit applying the benefits of the atonement (saving faith and participation in Christ), or an incoherent picture of atonement and election. On the other hand, Muller and Helm agree with Bell that Kendall severs the unity of the priestly work of Christ in His death and intercession, but they reject the idea of universal atonement in Calvin. For them, the whole priesthood of Christ is an application of eternal predestination. See Muller, Christ and the Decree, 33-35; Muller, Calvin and the Reformed Tradition, 70-106; Paul Helm, Calvin and the Calvinists (Edinburgh: Banner of Truth Trust, 1982), 1-50; Paul Helm, "Calvin, English Calvinism and the Logic of Doctrinal Development," Scottish Journal of Theology 34, no. 2 (1981): 179-185. For an overview of the debate on limited atonement in Calvin, see Muller, Calvin and the Reformed Tradition, 70-71.

${ }^{200}$ Considering the Spirit as "the bond of our union with Christ," Calvin claims that "those who are devoid of Christ's Spirit" do not "eat Christ's flesh." Hence, in the case of unbelievers, Christ does not come to them. This view is different from the position that "the wicked receive Christ's body and blood without the power of the Spirit or any effect of grace." ICR 4.17.34. While those who maintain that Christ is physically present in the sacramental elements may argue that unbelievers do not receive the benefits of the body and blood of Christ (Calvin accuses this position of wrongly casting "Christ's body to dogs to eat." Ibid., 4.17.34), he goes one step further: Since Christ is physically in heaven, unbelievers do not have any contact with the body of Christ. The spiritual contact with the body of Christ is available through the Spirit only to the elect. Quoting Augustine, Calvin affirms, "In the elect alone do the sacraments effect what they symbolize." Ibid., 4.17.34. 
measurement, the functional model holds that God's heaven is non-spatial. In accordance with this conception about heaven, one interpretation (Luther) advances the idea that Christ is not physically present in a particular place with the Father in heaven, while the other interpretation seems to be incompatible with the conception of a non-spatial heaven in its emphasis on Christ's physical presence there (Calvin). With regard to the relationship between the ascended Christ and the earth, the functional model presupposes that He conveys spiritual blessings to believers by means of physical instruments (the word and the sacraments). The interpretation that assumes that Christ is not physically present in heaven tends to highlight that He sacramentally descends to earth through these physical instruments to bless believers, whereas the interpretation that Christ is physically present in heaven tends to indicate that He uses physical instruments to make believers sacramentally ascend to heaven so that they can have communion with Him. After the description of these principles of reality in the functional model, I will concisely outline below their implications for the understanding of Christ's priesthood.

\section{Implications for Christ's Priesthood}

In the discussion above about the principles of reality, I have pointed out that the functional model seems to assume an ontological distinction between a nonspatial/timeless God in heaven and spatio-temporal human beings on earth. Accordingly, heaven and earth are respectively understood as non-spatial/timeless and spatio-temporal realms. This ontological distinction, however, does not seem to be consistently maintained in the model. For instance, as I have indicated above, Calvin affirms a physical presence of Christ in heaven, and Luther's understanding of communicatio idiomatum stipulates that His divine nature experienced passibility on earth. Despite these 
glimpses of spatio-temporal interpretation, the humanity of Christ on earth appears to be considered the spatio-temporal instrument of mediation between a non-spatial/timeless God and spatio-temporal human beings. Likewise, the ascended Christ uses spatiotemporal instruments (the word and the sacraments) to work with believers on earth. In fact, this mediatorial work performed by Christ on earth and in heaven is caused and informed by divine timeless predestination, which is the true ontological "action" of a non-spatial/timeless God.

In the previous chapter, I outlined the understanding of Christ's priesthood in the functional model in the following way: (1) His priesthood is needed primarily because God's holy wrath condemns sinful human beings; (2) as the priestly agent, Christ is the mediator sent by the Father, and His redemptive/propitiatory priesthood is an added function to the mediatorial activity of creation and providence; (3) Christ's priestly mediation comprises the activities of penal substitutionary sacrifice, intercession, and teaching. The first two propitiate the wrath of God, while the latter provides comfort for the guilty conscience of believers. The first activity is an earthly event (the cross), whereas the other two are current ongoing heavenly activities; and (4) the goal of the priesthood is to provide salvation by the grace of God's forgiveness, which magnifies the glory of God for His great provision (sending the mediator) and generosity (forgiving), and ultimately lead believers to the eschatological immediate vision of God, the goal of creation. This last point regarding the goal of creation is similar to the sacramental model. If the discussion about the principles of reality revealed a potential for spatiotemporal interpretation, not systematically articulated from an ontological standpoint, in the ideas of a physical humanity of Christ in a non-spatial heaven (Calvin) and His non- 
spatial/timeless divine nature experiencing passibility on earth (Luther), other potential ontological challenges emerge from a comparison between the principles of reality and the understanding of Christ's priesthood in the model. In fact, the central idea that the priesthood of Christ is a propitiatory work does not seem to be ontologically supported by the principles of reality assumed in the model. It is difficult to ontologically conceptualize how Christ's priesthood propitiates the wrath of a non-spatial/timeless God. If God is a timeless/spaceless being, has a timeless knowledge and, therefore, performs a timeless action (predestination), the priestly activity of Christ on the cross (sacrifice) and in heaven (intercession) seem an unlikely candidate to propitiate a wrathful God. A timeless God cannot be propitiated. In fact, even His wrath is timeless, which means that the divine wrath is not caused by human sin in time, but is eternally constituted and therefore it can never "cease" to exist.

In this context, an ontological account of heavenly intercession seems problematic. Even though Calvin affirms the presence of a physical Christ in heaven, His intercessory interaction with a non-spatial/timeless Father seems puzzling. The conclusion that the language of propitiation is actually an accommodation to human cognition seems to be coherently drawn by the French theologian. ${ }^{201}$ Therefore, Christ's

\footnotetext{
${ }^{201}$ Referring to biblical passages such as "God was men's enemy until they were reconciled to grace by the death of Christ" (Rom 5:10); "They were under a curse until their iniquity was atoned for by his sacrifice" (Gal 3:10,13); "They were estranged from God until through his body they were reconciled" (Col 1:21-22), Calvin affirms that "expressions of this sort have been accommodated to our capacity that we may better understand how miserable and ruinous our condition is apart from Christ." ICR 2.16.2; italics mine. Referring to the language of appeasing God, the French theologian points out that "in some ineffable way, God loved us and yet was angry toward us at the same time, until he became reconciled to us in Christ." Ibid., 2.17.2. For useful studies on the language of divine accommodation in Calvin, see J. Todd Billings, Union with Christ: Reframing Theology and Ministry for the Church (Grand Rapids, MI: Baker Academic, 2011), 70-75; Jon Balserak, Divinity Compromised: A Study of Divine Accommodation in the Thought of John Calvin, Studies in Early Modern Religious Reforms (Dordrecht: Springer, 2006); Arnold Huijgen, "Divine Accommodation and Divine Transcendence in Calvin's Theology," in Calvinus Sacrarum
} 
heavenly intercession seems to constitute a metaphor, as far as His interaction with a non-

spatial/timeless Father is concerned. If all events are already a reality in the mind and will

of God (timeless predestination), Christ's priestly work is, in fact, a spatio-temporal

actualization of what is already real in God. However, whereas such actualization could

be conceptualized in the earthly spatio-temporal sacrifice on the cross, it is not clear how

a spatio-temporal actualization could take place in a non-spatial/timeless heaven. Thus,

the logical outcome is that Christ's heavenly intercession in the functional model seems

to be better understood as metaphorical.

In fact, the net effect of a divine propitiation that is not ontologically real is that

God is not really the object of Christ's priestly work, but only its author. ${ }^{202}$ In other

Literarum Interpres: Papers of the International Congress on Calvin Research, ed. Herman J. Selderhuis (Göttingen: Vandenhoeck \& Ruprecht, 2008), 119-130; David F. Wright, "Calvin's Accommodating God," in Calvinus Sincerioris Religionis Vindex: Calvin as Protector of the Purer Religion, ed. Wilhelm H. Neuser and Brian G. Armstrong (Kirksville, MO: Sixteenth Century Journal Publishers, 1997), 3-20; Wyatt, Jesus Christ and Creation in the Theology of John Calvin, xv, 48. Following this perspective of accommodated language, Calvin indicates that the notion of Christ's sacrifice and intercession propitiating God's wrath is powerful to move the human heart, as human beings do not eagerly accept or have deep gratitude for the divine work of salvation, unless their "minds are first struck and overwhelmed by fear of God's wrath and by dread of eternal death." ICR 2.16.2. Hence, Calvin attempts to solve the apparent contradiction between God's love and His wrath, and explain why "God, who anticipates us by his mercy," is described as "our enemy until he was reconciled to us through Christ." Ibid. The reconciliation provided by Christ did not change God in the sense that He began to love people who He previously hated. Rather, God the Father, in His love, "goes before and anticipates our reconciliation in Christ." Ibid., 2.16.4.

However, although the language of the divine wrath is an adaptation "to our feeble comprehension," this is not a false concept. Ibid., 2.16.13. For McCormack, "Calvin's solution to this 'contradiction' was not finally satisfactory. The notion of a divine accommodation is itself problematic, for it all too easily suggests that the way God reveals Himself to be is not finally commensurate with what He is in Himself."

According to this evaluation, Calvin makes "the righteousness of God, abstracted from His love, the object toward which the atonement of Christ is directed." McCormack concludes that "Calvin's difficulty in this area was due in no small measure to the scant attention he gave to the classical problem of the attributes of God. His treatment of the being and attributes of God was thin, to say at least." McCormack, For Us and Our Salvation, 27-28.

202 This statement seems to be opposed by Wyatt. He claims that, "in Calvin's thought, God is both the author and the object of the work of reconciliation. One might attempt to argue that God is only the author of the work of reconciliation and that the language of wrath is therefore only an 'accommodation.' But this does not take into account the fact that only the elect actually receive the benefit of the atonement; the reprobate continue under the condemnation of God's wrath." Wyatt, Jesus Christ and Creation in the Theology of John Calvin, 48. However, Wyatt's comment here does not contradict my point 
words, the priestly actions of substitutionary sacrifice and intercession do not have God as their real object. In this case, Christ's sacrifice and intercession are only divine actions for the benefit of human beings, and not propitiatory acts before God. This would mean that, in the model, only the priestly activity of teaching appears to be ontologically grounded (meaning that the priestly action and its meaning is coherent with the principles of reality assumed in the model). As indicated above, in this activity the heavenly Christ provides comfort for the guilty conscience of believers on earth. According to the principles of reality assumed in the functional model, this activity is sacramentally performed through spatio-temporal instruments (the word and the sacraments) that reach elected spatio-temporal human beings.

After this analysis of the macro-hermeneutical principles of reality in the functional model of Christ's priesthood, my next step is to explore the principles of reality in the ontological model.

\section{The Ontological Model}

\section{Divinity: Christ and the Concept of Divine Nature}

In this discussion of God in the ontological model, I will briefly outline how the divine nature and action is understood in the model, inasmuch as this understanding informs the comprehension of Christ's divinity and His relationship as a priest with the other persons or modes of being of the Trinity. ${ }^{203}$ In many aspects, the ontological model

regarding divine propitiation. My main point is not that the language of the wrath of God is an accommodation, but that the language of propitiation of His wrath becomes an accommodation in this perspective, as God already elected in His timeless predestination those who will not be punished by His wrath. In this sense, God is only the author and not the object of the work of reconciliation.

${ }^{203}$ Barth avoids the concept of person in his reflection about the Trinity. For him, the Trinity has 
attempts to redefine the notion of divine nature and action affirmed by classical theism. Before I start the description of divinity in this model, it is noteworthy that a feature of this attempt is the affirmation that God is somehow spatio-temporal. Eventually, as I will explain below, the model does not represent a substantial redefinition of the classical understanding of the relationship between God and time, since God's time is conceptualized as simultaneity, which is equivalent to the non-sequentiality of divine timelessness in classical theism.

An appropriate starting point for the investigation of the concept of divinity in the ontological model is the question of the status of Christ's divinity in His incarnation. More specifically, from the perspective of the incarnation, is God immutable or mutable? Does God become? Did He undergo an ontological change in the incarnation? Since the ontological model does not conceive God as the “'Moved Unmover' of Whiteheadean process theology, ${ }^{, 204}$ God is not mutable in a panentheistic sense. On the other hand, the model is not confortable with the "'Unmoved Mover" ${ }^{\prime 205}$ of classical theism either. A chief concern with the "Unmoved Mover" is that it creates a separation/contradiction between God for us and God in Himself in the interpretation of the incarnation. As God cannot really become a man and live/act in space-time, there is behind Christ's earthly life/actions a God absconditus who is ontologically different (incompatible) to what is

three modes of being, not three persons. See, for example, $C D \mathrm{I} / 1,390,393,410$. By contrast, Torrance keeps the language of persons in the Trinity, according to his "onto-relational concept of divine persons." Thomas F. Torrance, The Christian Doctrine of God: One Being Three Persons (Edinburgh; New York: T\&T Clark, 2001), 102.

\footnotetext{
${ }^{204}$ Torrance, The Christian Doctrine of God, 239.

${ }^{205}$ Ibid.
} 
seen in the incarnate Christ. ${ }^{206}$ To be sure, the ontological model rejects any ontological separation of God in Himself and God for us. ${ }^{207}$ What is revealed in Christ refers directly

to God's being (God in Himself), even though the revelation in Christ does not give an

exhaustive view of God. ${ }^{208}$ This position has at least two related consequences for the

notion of God in the ontological model, one related to the conception of becoming in

\footnotetext{
${ }^{206}$ In Barth's words, there is in this case an ontological "rift or gulf in God Himself, between His being and essence in Himself and His activity and work as the Reconciler of the world." CD IV/1, 184. Agreeing with Barth, Torrance argues that "God is not one thing in himself and another thing in Jesus Christ - what God is toward us in Jesus he is inherently and eternally in himself. ... There is thus no God behind the back of Jesus Christ, but only this God whose face we see in the face of the Lord Jesus. There is no deus absconditus, no dark inscrutable God, no arbitrary Deity of whom we can know nothing." Torrance, The Christian Doctrine of God, 243.

${ }^{207}$ Torrance explains that "we may not properly separate knowledge of what God is toward us and for us from knowledge of what he is eternally in himself, but must consider them together in such a way that our thought moves back and forward between them, from what God is for us to what he is in himself and from what he is in himself to what he is for us." Torrance, The Christian Doctrine of God, 28. At the same time, he recognizes the importance of keeping a distinction between God in Himself (ontological Trinity) and God for us (economic Trinity) because His ineffable being "remains transcendent over all space and time." Ibid., 97. Barth expresses a similar understanding. He organizes the perfections or attributes of God under the categories of love (God as completely knowable to us) and freedom (God as completely unknowable to us), and rejects a separation - although he accepts a heuristic distinctionbetween "a God in Himself" (unknowable) "and a God for us" (knowable/revealed), "in which the essential being of God" is ultimately defined by the attributes of His sovereign/unknowable freedom, while the attributes of His love do not actually describe the fundamental reality of His being. $C D$ II/1, 343, 345. In Barth's words, when this separation is done "the essential being of God will probably be decisively sought in His sovereign freedom and the perfections proper to it, eternity, omnipotence and so on, while the love of God and its perfections, holiness, justice, mercy and so on, are treated nominalistically or seminominalistically as a question of mere economy, as non-essential, as perhaps purely noetic determinations, so that the final and decisive word in our doctrine of God is the affirmation of God as the impersonal absolute." The Swiss theologian concludes, "We cannot ... attribute to this whole distinction between God in Himself and God in His relation to the world an essential, but only a heuristic, significance. It does, of course, have this significance. That God is both knowable and unknowable to us, the One who loves and the One who is free." Ibid., 345.

${ }^{208}$ According to Barth, "we cannot discern the being of God in any other way than by looking where God Himself gives us Himself to see, and therefore by looking at His works." CD II/1, 261. Likewise, Torrance argues that "the economic Trinity and the ontological Trinity overlap with one another and belong to one another, and can no more be separated than the Act of God can be separated from his Being or his Being from his Act." Torrance, The Christian Doctrine of God, 8. A Christological interest can also be identified in this approach. Jesus Christ (God for us) is the revelation of what God is in Himself. This Christological interest is aligned with the theological projects of Barth and Torrance, as they intend to use Christology as the starting point of their theologies. Barth perceives "Jesus as the starting point of our thinking about the divine being." $C D$ III/2, 553. Likewise, Torrance highlights that it is in Jesus Christ "that we may really know God in accordance with the inmost nature of his eternal being." Torrance, The Christian Doctrine of God, 238.
} 
God, and the other for the relationship between God and space-time.

First, the ontological model attempts to make room for the idea of divine becoming, especially in the context of the incarnation. ${ }^{209}$ Instead of interpreting this becoming under the panentheistic rubrics of the 'Moved Unmover', the model seeks to formulate a dynamic conception of the being of God as Self-Moved. ${ }^{210}$ Such attempt assumes that "the one being of God" is a "dynamic being, not static being but unique divine becoming." ${ }^{211}$ As matter of fact, several moves can be identified in the ontological model that point to a divine becoming or a dynamic being: (1) the affirmation of potentiality in God and the emphasis on His freedom ${ }^{212}$; (2) the acknowledgment of a before and after in the life of God-He became Creator (He has not been always Creator) and became incarnated, died and resurrected in Christ (He has not been always man and

\footnotetext{
${ }^{209}$ Barth guides this discussion posing the Latin question Quo iure Deus home? (CD IV/1, 184). Scott Swain correctly indicates that, with this question, the Swiss theologian asks, how or "by what right or inner law of the divine being did God become a man?" Scott R. Swain, The God of the Gospel: Robert Jenson's Trinitarian Theology (Downers Grove, IL: InterVarsity, 2013), 59. Barth comments on this question defining the incarnation as God "becoming a creature, becoming a man - and how this is possible to God without the alteration of His being is not self-evident." $C D$ IV/1, 185. Likewise, Torrance highlights the idea of becoming in the incarnation. "In Jesus Christ God has become what he never was before, a human being, the Creator has become a creature." In the incarnation, "the eternal Word of God became historical event, and the eternal became time. The fact that in the incarnation God became man without ceasing to be God, tells us that his nature is characterised by both repose and movement, and that his eternal Being is also a divine Becoming." Torrance, The Christian Doctrine of God, 241-242.

${ }^{210}$ For Barth, "God's being is being which knows, wills and decides of itself, and is moved by itself." He adds, "The being of God as we know it from revelation is moved in itself." $C D$ II/1, 268. Similarly, in Torrance's discussion about the being of God, the Scottish theologian speaks of the "selfmoving God." Torrance, The Christian Doctrine of God, 237.

211 Torrance, The Christian Doctrine of God, 237.

${ }^{212}$ According to Barth, "In God all potentiality is included in His actuality and therefore all freedom in His decision." $C D$ I/1, 157. Similarly, Torrance highlights "the biblical conception of the freedom of God who ... is eternally new and constantly surpasses himself in all that he does." Torrance, The Christian Doctrine of God, 239.
} 
has not always had these human experiences $)^{213}$; (3) the notion of God becoming

passible $^{214}$ in Christ (assuming that He suffered not only in his humanity but also in his

divinity $^{215}$ ); (4) the affirmation that God can change His mind or attitude in some

${ }^{213}$ Torrance speaks of a "before and after the creation" and a "before and after the incarnation." He points out that "God was always Father, but not always Creator." Hence, "the creation of the world and of mankind was an utterly new event for God." In fact, "the creation registered a distinct 'moment' in the eternal life of God." More importantly, the incarnation was "an absolutely new event for God: "the Word became flesh.' God was not always incarnate. He was always God the Son as well as God the Father and God the Holy Spirit, but not always God become man in Jesus Christ in whom divine and human nature are for ever united." In other words, "in Jesus Christ God has become what he never was before, a human being, the Creator has become a creature." Furthermore, "the death and resurrection of God incarnate in space and time" were events "utterly new even for God, .. . God crucified and risen again." Torrance even adds the Pentecost, arguing that what happened there "was not only quite new in the experience of mankind, but something incomprehensibly new in the life and activity of the eternal God and the mode of his presence to all flesh.” Torrance, The Christian Doctrine of God, 237-238, 241.

${ }^{214}$ For Barth, in the act of giving Himself to humanity, God "ordained the surrender . . . of His own impassibility." CD II/2, 163. Likewise, Torrance argues that "it was Christ as God and God as Christ who suffered for us and our salvation." Torrance, The Christian Doctrine of God, 248. The Scottish theologian adds that "the notion of divine impassibility would evidently exclude the possibility of any real movement of God in a loving and vicarious self-identification with us in incarnation and redemption which would posit a deep gulf between God as he is in himself and God as he is toward us." Ibid., 250. Torrance seems to agree with Barth that God surrendered His impassibility or became somehow passible. He points out that God is "intrinsically impassible for in its own divine Nature he is not moved or swayed by anything other than himself or outside of himself." Quoting Athanasius' remarks on Jesus' pain, the Scottish theologian claims that "“" one cannot say that these things are natural to Godhead, but they came to belong to God by nature." Torrance, The Christian Doctrine of God, 248.

${ }^{215}$ For Torrance, "it cannot be said that Christ suffered only in his humanity and not in his divinity," with the caveat that "the kind of physical and emotional suffering Christ endured in his incarnate historical existence in body and spirit is not the kind of suffering that we may attribute to God." Torrance,

The Christian Doctrine of God, 252. For comments on Torrance's view of divine impassibility, see Molnar, Thomas F. Torrance, 147-158. Torrance interprets the sacrifice of the rite of the Day of Atonement that culminated in the holy of holiness as something that takes place in the being of God. In his words, "The fact that the ritual of sacrifice on the Day of Atonement . . . culminated hidden behind the veil in the holy of holies, taught Israel that the ultimate ground and rationale of atonement is hidden deep in the mystery of God's own Being into which it is impossible to intrude." Torrance, The Mediation of Christ, 45. According to Barth, "In Himself God cannot be affected either by the possibility or by the reality of that will which opposes Him. He cannot be affected by any potentiality of evil." But "when from all eternity He elected to be one with man in Jesus Christ, He did it with a being which was not merely affected by evil but actually mastered by it." $C D$ II/2, 163. McCormack suggests that "the death of Jesus Christ . . , precisely as a human experience, is understood by" Barth "to be an event in God's own life." Bruce L. McCormack, "Grace and Being: The Role of God's Gracious Election in Karl Barth's Theological Ontology," in The Cambridge Companion to Karl Barth, ed. John Webster (Cambridge: Cambridge University Press, 2000), 98. For studies on Barth's notion of divine impassibility, see Bruce L. McCormack, "Divine Impassibility or Simply Divine Constancy? Implications of Karl Barth's Later Christology for Debates over Impassibility," in Divine Impassibility and the Mystery of Human Suffering, ed. James Keating and Thomas Joseph White (Grand Rapids, MI: Eerdmans, 2009), 150-186; George Hunsinger, Reading Barth with Charity: A Hermeneutical Proposal (Grand Rapids, MI: Baker Academic, 2015), 168-169. 
situations (e.g., negative reaction to $\sin ,{ }^{216}$ positive response to intercessory

mediation ${ }^{217}$ ); and (5) the concept of multiplicity in God's being, ${ }^{218}$ instead of the

classical idea of simplicity. ${ }^{219}$ These moves, however, to use Torrance's words, do not

assume that "God ever becomes other than he eternally is or that he passes over from

becoming into being something else, but rather that he continues unceasingly to be what

he always is and ever will be in the living movement of his eternal Being." ${ }^{220}$ In fact,

${ }^{216}$ Torrance claims that human sin causes "a real 'change' in God's mind and attitude toward man," making His judgment on sin necessary. In other words, sin does not affect solely the human mind and attitude toward God, but also God's mind and attitude toward sinful humans. Torrance, Incarnation, 227.

${ }^{217}$ For Barth, biblical passages that speak of God repenting (e.g., Gen 18:20-22; Exod 32:9-14; Num 11:1-2; Amos 7:1-6) of His judgment because of the intercession of a human being "are not merely figurative." CD II/1, 498. See ibid., 496-497. The Swiss theologian rejects the interpretation that God's repentance in the Bible means "only an alternation in man in his relation to God, but not an alternation in God in His relation to man." Ibid., 498. The Swiss theologian argues that God "promises to go back and does in fact go back on warnings and even judgments which have already fallen." Ibid. Barth wants to acknowledge God as "the real subject of" His "real history." Ibid., 502. God is "not prevented from advancing and retreating, rejoicing and mourning, laughing and complaining, being well pleased and causing His wrath to kindle." Ibid., 498.

${ }^{218}$ For Barth, "the multiplicity, individuality and diversity of the perfections of God are those of His simple being, which is not therefore divided and then put together again. In God multiplicity, individuality and diversity do not stand in any contradiction to unity. Rather the very unity of His being consists in the multiplicity, individuality and diversity of His perfections." CD II/1, 332.

${ }^{219}$ Barth criticizes the "semi-nominalistic" notion of classic theism that "the multiplicity of the divine attributes" does not actually refer to the nature of God per se but to the "discursiveness of the human intellect and the manifoldness of the created world." Ibid., 335. In other words, the multiplicity belongs to the being of God (ontic), and not merely to the human way of understanding of God (noetic).

${ }^{220}$ Torrance, The Christian Doctrine of God, 242. The Scottish theologian adds, God's "Becoming is not a becoming on the way toward being or toward a fullness of being, but is the eternal fullness and the overflowing of his eternal unlimited Being. Becoming expresses the dynamic nature of his Being. His Becoming is, as it were, the other side of his Being, and his Being is the other side of his Becoming. His Becoming is his Being in movement and his Being in movement is his Becoming in a way which we cannot adequately grasp or express." Ibid. Barth affirms that principle that God becomes what He already is by maintaining that God Himself is both the basis and goal of His attributes and actions. God "has no basis which is not Himself, no goal which is not Himself and no standard or law which is not Himself. . . He is His own basis, goal, standard and law.” $C D$ II/1, 468. Following Jüngel's interpretation of Barth's theological ontology, McCormack argues that, for Barth, God does not become, but "has his being "in becoming." Bruce L. McCormack, Orthodox and Modern: Studies in the Theology of Karl Barth (Grand Rapids, MI: Baker Academic, 2008), 259. See Eberhard Jüngel, God's Being Is in Becoming: The Trinitarian Being of God in the Theology of Karl Barth (London: Bloomsbury, 2014). 
God's potentiality is grounded in His own actuality. ${ }^{221}$ According to this view, in the incarnation God "became toward us what he eternally is."222 To put it another way, incarnation, and also creation, did not change God. ${ }^{223}$ Indeed, the ontological model prefers the language of God's "dynamic unchangeableness" 224 or "constancy" rather than the traditional idea of divine immutability. ${ }^{225}$ To use the current divide in Barth scholarship as an example, the logic that God becomes what He already is can basically assume two ontological forms of the dynamic idea of being-in-act ${ }^{226}$ : essentialism or actualism. ${ }^{227}$ In principle, both forms agree that God has a stable aspect (being) that

${ }^{221}$ As Barth points out, "In God all potentiality is included in His actuality." $C D \mathrm{I} / 1,157$.

${ }^{222}$ Torrance, The Christian Doctrine of God, 237. According to Barth, "This possibility [the incarnation of God] is included in His unalterable being." $C D$ IV/1, 187.

223 Torrance, The Christian Doctrine of God, 237-238. In these "new" events, "God does not change but remains ever one and the same ... without ceasing to be what he eternally was and is and ever will be in himself." Ibid., 238. For instance, "God was not different after the creation from what he was before it." Ibid., 241. Barth assumes that in the incarnation God became a creature "without an alteration of His being. . . . He does not give up being God in becoming a creature." CD IV/1, 185 .

${ }^{224}$ Torrance, The Christian Doctrine of God, 237. For Torrance, "We must think of all the changes in God's mighty acts of creation and redemption which constantly surprise us as flowing from and reposing upon his eternally unchanging life." Ibid., 236.

${ }^{225}$ For Barth, "God's constancy — which is a better word than the suspiciously negative word 'immutability' - is the constancy of His knowing, willing and acting and therefore of His person." CD II/1, 495. According to this perspective, the opposite of God's constancy is not mutability per se, but "the unholy mutability of men" (see Isa 1:21f). Ibid., 496. The Swiss theologian qualifies this constancy as God not becoming nor being "other than He is in Himself from eternity and in eternity." Ibid., 502. For Torrance, God is "constant in faithfulness but not immutable." Thomas F. Torrance, Space, Time, and Incarnation (Edinburgh: T\&T Clark, 1997), 75.

${ }^{226}$ The idea of being and becoming is observed in Barth's dynamic notion of God's being-in-act. For him, "God's being is event, the event of God's act." Hence, "God exists in His act. God is His own decision. God lives from and by Himself." $C D$ II/1, 271-272. In other words, "the whole being and life of God is an activity." $C D$ IV/1, 7. For Torrance's remarks on the oneness of act and being in God, see Torrance, The Christian Doctrine of God, 4, 6, 22, 24, 30, 95, 115, 149, 152, 194, 236, 243. In principle, the idea of being-in-act enables the ontological model to avoid the classical divide between God for us (action) and God in Himself (being). As Barth indicates, God is not "who He is only in His works. Yet in Himself $\mathrm{He}$ is not another than $\mathrm{He}$ is in His works." CD II/1, 260.

${ }^{227}$ As McCormack indicates, in an essentialist ontology (classical theism) God is "complete in itself apart from and prior to all" His "actions and relations," and in a (Barthian) actualist ontology the 
precedes and grounds His dynamic aspect (becoming). The disagreement lies on what constitutes the stable and dynamic aspects. Closer to classical theism, the essentialist view holds that the stable aspect refers to God's identity (triune) and essential properties (aseity, simplicity, eternality, impassibility), while the dynamic aspect is described by His “self-determination" (election), His decision to be God for us (incarnation). ${ }^{228}$

Conversely, the actualist view stipulates that God's identity and properties are defined by His self-determination. ${ }^{229}$ Therefore, according to these two views, the ground of God's becoming is either His essential being or His decision (self-determination). However, these two options can only characterize a real becoming if God's being or decision precedes His becoming chronologically, and not merely logically. ${ }^{230}$ Otherwise, the

essence of God is "given in the act of electing." McCormack, "Grace and Being," 98-99. According to this classification, McCormack is the main representative of the actualist interpretation of Barth's ontology, while Paul Molnar and George Hunsinger are the main representatives of the essentialist view. While the notion that "Barth understood election to be an eternal act of Self-determination, an act whose primary 'object' was none other than God Himself," is "beyond dispute," McCormack identifies the key point of the debate as "the question of whether God's eternal act of Self-determination had ontological consequences for God Himself and, if so, what they might be." McCormack, "Christonomie," 228. For a helpful study on the debate of the relationship between the being of God and divine election in Barth, see Kevin W. Hector, "God's Triunity and Self-Determination: A Conversation with Karl Barth, Bruce McCormack and Paul Molnar," International Journal of Systematic Theology 7, no. 3 (2005): 246-261.

${ }^{228}$ Hunsinger, Reading Barth with Charity, 165. This position is closer to classical theism because in this view Barth tempers his actualist tendencies (Hegel) with the classical idea of the divine perfection of being (Anselm). Ibid., 163.

${ }^{229}$ According to McCormack, the logic of Barth's mature doctrine of election implies that "election is the event in God's life in which he assigns to himself the being he will have for all eternity." McCormack seems to give ontological content to divine election (self-determination) to secure divine immutability. In regards to the incarnation, for instance, he explains that God "is not changed on an ontological level by this experience for the simple reason that his being, from eternity, is determined as a being-for this event." Therefore, "as a consequence of the primal decision in which God assigned to himself the being he would have throughout eternity (a being-for the human race), God is already in pretemporal eternity - by way of anticipation — that which he would become in time." McCormack, "Grace and Being," 98-100.

${ }^{230}$ Addressing the debate of essentialism and actualism in Barth's doctrine of God, as represented respectively by Molnar and McCormack, Hector highlights that the language of God's self-determination preceding His triune being (actualism) or God's triune being preceding His self-determination (essentialism) does not assume a chronological sequence, but establishes only a logical precedence. See 
language of becoming would be a misleading label for some kind of God's act of selfrepetition. ${ }^{231}$ The question whether the ontological model supports a chronological divine

becoming leads us to the discussion of God and time in this model.

The ontological model attempts to avoid (without completely rejecting, as Barth explicitly states) ${ }^{232}$ the characterization of God as timeless-spaceless. ${ }^{233}$ Assuming that

Hector, "God's Triunity and Self-Determination," 246, 258. The assumption of a chronological sequence would imply that either God's triune being (actualism) or His self-determination (essentialism) is not eternal, since it would be chronologically preceded by something else. Such implication is avoided in Barth scholarship because it does not fit into Barth's theology.

${ }^{231}$ I am borrowing here Barth's language of God in self-repetition. For instance, in his explanation that "the constancy of God is not . . in conflict with the life of God," he argues that God lives in "eternal self-repetition." CD II/1, 492. Furthermore, he describes the triune God in terms of self-repetition. In his words, God is "one Subject, not three. But He is the one God in self-repetition, in the repetition of His own and equal divine being." $C D \mathrm{IV} / 1,205$. The secondary literature on Barth also employs this language to discuss the idea of divine being and action. Paul Collins mentions the divine becoming as a repetition: "the being of God is a repetition or a becoming." Paul M. Collins, Trinitarian Theology, West and East: Karl Barth, the Cappadocian Fathers, and John Zizioulas (Oxford; New York: Oxford University Press, 2001), 29. Sang Lee points out that "Barth dealt with the issue of being and becoming in the divine being," using "the concept of self-repetition or self-reiteration to conceive God's involvement in time." In this view, "Jesus Christ is the event of God's temporal reiteration." Sang Hyun Lee, "Jonathan Edwards's Dispositional Conception of the Trinity: A Resource for Contemporary Reformed Theology," in Toward the Future of Reformed Theology: Tasks, Topics, Traditions, ed. David Willis-Watkins, Michael Welker, and Matthias Gockel (Grand Rapids, MI: Eerdmans, 1999), 445. Holmes speaks about God's action or "self-movement" in Barth as "a repetition of God's being." Christopher R. J. Holmes, Revisiting the Doctrine of the Divine Attributes: In Dialogue with Karl Barth, Eberhard Jüngel and Wolf Krötke (New York: Peter Lang, 2007), 74. Aaron Smith argues that "God has his being in eternal self-repetition ... in the concrete modality of the Word's ongoing realization." Aaron T. Smith, A Theology of the Third Article: Karl Barth and the Spirit of the Word (Minneapolis: Fortress, 2014), 82.

${ }^{232}$ Barth indicates that Jesus Christ "is the refutation of the idea of a God who is only timeless." He adds, "God Himself is not only timeless, but that in this readiness for time, in the timeless ordering and succession of His triune being, He is also temporal." In a sense, God is "both timeless and temporal. He is timeless in that the defects of our time, its fleetingness and its separations, are alien to Him and disappear, and in Him all beginning, continuation and ending form a unique Now, steadfast yet moving, moving yet steadfast." $C D$ II/1, 616-618; italics mine.

${ }^{233}$ According to Torrance, "Far from being some kind of timeless eternity or eternal now that devalues or negates time, the real time of God's eternal Life gives reality and value to the created time of our life." Torrance, The Christian Doctrine of God, 241. Similarly, Barth maintains that "the eternal God does not live without time. He is supremely temporal. For His eternity is authentic temporality." $C D$ III/2, 437. Emphasizing the freedom of God, he challenges the idea that God is a "non-spatial and timeless spirit." For him, "non-spatiality and timelessness on the one hand and spatiality and temporality on the other, do not enclose and imprison Him, so that He is confined by His being." The Swiss theologian adds, "If we call God infinite, measureless, limitless, spaceless and timeless, this does not mean that we will try to exclude, deny or even question that He is the One who in His whole action posits beginning and end, 
the language of timelessness-spacelessness establishes a negation or devaluation of timespace, the model seeks to formulate a positive relationship of God and time-space. In fact, God's eternity is temporal and His presence is spatial. Barth, who is more explicit than Torrance in explaining what this means, stipulates that God as creator has in Himself the prototypes of time and space, which are the form of creation. ${ }^{234}$ The idea of prototype does not mean that the space-time of creation has its origin in a mere timeless-spaceless being called God, ${ }^{235}$ because "God does not do anything which in His own way He does

measure and limit, space and time." And "God does not do anything which in His own way He does not have and is not in Himself." CD II/1, 467. For studies on time in Barth and Torrance, see Christophe Chalamet, "No Timelessness in God: On Differing Interpretations of Karl Barth's Theology of Eternity, Time and Election," Zeitschrift für Dialektische Theologie 4 (2010): 21-37; Kim, Time, Eternity, and the Trinity, 191-240; Li Qu, Concrete Time and Concrete Eternity: Karl Barth's Doctrine of Time and Eternity and Its Trinitarian Background (Carlisle, United Kingdom: Langham Monographs, 2014); Li Qu, "Newton, Einstein and Barth on Time and Eternity," Scottish Journal of Theology 67, no. 04 (2014): 436449; Richard Henry Roberts, "Barth's Doctrine of Time: Its Nature and Implications," in Karl Barth: Studies of His Theological Method, ed. Stephen Sykes (Oxford; New York: Clarendon Press; Oxford University Press, 1979), 88-146; Langdon, God the Eternal Contemporary; Luco Johan van den Brom, "Time and Eternity in Christian God-Talk," Zeitschrift für Dialektische Theologie 4 (2010): 38-66; Mark James Edwards, "The Divine Moment: Eternity, Time, and Triune Temporality in Karl Barth's Church Dogmatics," (Princeton Theological Seminary, 2013); George Hunsinger, "Jesus as the Lord of Time According to Karl Barth," Zeitschrift für Dialektische Theologie 4 (2010): 113-127; Douglas Alan Trook, "The Unified Christocentric Field: Toward a Time-Eternity Relativity Model for Theological Hermeneutics in the onto-Relational Theology of Thomas F. Torrance," (Ph.D. Dissertation, Drew University, 1986). For studies on space in Barth and Torrance, see Elizabeth Jarrell Callender, "A Theology of Spatiality: The Divine Perfection of Omnipresence in the Theology of Karl Barth," (Ph.D. Dissertation, University of Otago, 2011); Stephen H. Webb, Jesus Christ, Eternal God: Heavenly Flesh and the Metaphysics of Matter (Oxford; New York: Oxford University Press, 2011), 287-292; David Wilkinson, Christian Eschatology and the Physical Universe (London; New York: T\&T Clark, 2010), 129-131; Chan Ho Park, Transcendence and Spatiality of the Triune Creator, European University Studies Series XXIII, Theology (Bern; New York: Peter Lang, 2005), 81-94.

${ }^{234}$ Describing time and space as the form of God's creation, Barth highlights that "the prototypes in God's being in Himself which correspond to this form are His omnipresence in regard to space, and His eternity in regard to time." $C D$ II/1, 612. Barth even clarifies the distinction between eternity (God Himself) and time (God's creation). For him, "eternity is not created. Eternity is God Himself. For as God is self-existent, He is also His own dimension. But time is willed and created by God as a reality distinct from Himself." CD III/2, 526.

${ }^{235}$ Torrance, for example, criticizes Newton for identifying objective or mathematical time and space "with the mind of God, which contains and imposes objective order upon the universe. God contains the universe, however, without being affected by it impassibly and immutably." Thomas F. Torrance, The Ground and Grammar of Theology: Consonance between Theology and Science (Edinburgh: T\&T Clark, 2001), 68. The Scottish theologian claims that, on the basis of "Newton's dualism, what Kant did was to 
not have and is not in Himself." ${ }^{, 236}$ It is important to notice that this statement emphasizes that God is temporal and spatial in His own way, which means that His space-time is not univocal to the space-time of creation. ${ }^{237}$ The rejection of univocality is clearer in the description of God's temporality than in the depiction of His spatiality. Regarding space, God the creator is "the principle of space," but not "a non-spatial principle." 238 In this sense, biblical passages about the presence of God among creatures_-particularly those referring to Him dwelling in an earthly sanctuary or temple — should not be interpreted figuratively (non-spatially). ${ }^{239}$ In this view, God's omnipresence means that "there is no transfer absolute time and space from the mind of God to the mind of the human knower.” Ibid., 26.

${ }^{236} C D \mathrm{II} / 1,467$.

${ }^{237}$ The same idea is found in Torrance, who maintains that "we may speak of the 'place' and 'time' of God in terms of his own eternal life and his eternal purpose in the divine love." In this sense, " "time' for God himself can only be defined by the uncreated and creative life of God, and 'place' for God can only be defined by the communion of the persons in the divine life." Torrance, Atonement, 291.

${ }^{238} C D$ II/1, 471. Barth indicates that "the spatiality of God is to be distinguished from the spatiality of every other being by the fact that it is the spatiality of the divine being." Ibid., 470. He adds, "In virtue of His own proper spatiality God is present in space and in all the spaces of His creation. Note that He is present. This implies both distinction and relationship." Barth believes that the ideas of distinction and relationship, implied in the concept of presence, suggest some kind of distance (spatiality). In his words, "where there is distance, there is necessarily one place and another place. To this extent God's presence necessarily means that He possesses a place, His own place, or, we may say safely, His own space. The absolute non-spatiality of God, deduced from the false presupposition of an abstract infinity, is a more than dangerous idea. If God does not possess space, He can certainly be conceived as that which is one in itself and in all." Ibid., 468. The Swiss theologian contends that, according to Scripture, "the relation of God to space is an absolutely free and superior relationship, but it definitely does not say that it is a negative relationship or, consequently, that God is non-spatial. There is nowhere where God is not, but He is not nowhere. . . . He is always somewhere." Ibid., 471.

${ }^{239}$ Barth comments on Solomon's prayer in $1 \mathrm{Kgs}$ 8:27-30. "Will God indeed dwell on the earth?' This prayer does not dispute that God actually dwells on earth. Indeed, this is expressly affirmed in the later verses, but it clearly points to the fact that God dwells on earth in His own way, not in the way in which anyone else dwells on earth. 'Behold, the heaven and heaven of heavens cannot contain thee.' Thus heaven and any place higher than heaven cannot as such be God's place. Again, this does not dispute that God dwells in heaven." The Swiss theologian adds, "Although there is a strong emphasis on the particularity with which God possesses space beyond all other spaces, there is also no denial but the assertion that He does actually possess space, His particular space, and that He possesses it also in other spaces, in heaven and on earth." Ibid., 469. Following this perspective, Barth argues that the presence of God in Exod 24:16; 25:8; 29:45 should not be understood "figuratively but literally." Ibid., 479. It is interesting to notice that Exod 25:8; 29:45 and $1 \mathrm{Kgs}$ 8:27-30 discuss or refer to the presence of God in a 
place where He is not present in His essence." ${ }^{240}$ With regard to time, the difference between God's time and creation time centers on the difference between simultaneity ${ }^{241}$ (God's time) and sequentiality (creation time). ${ }^{242}$ More specifically, God has "His own time, superior to ours, undisturbed by the fleetingness and separations of our time, simultaneous with all our times." ${ }^{243}$ Interpreting God's eternity as pre-temporality, temporality, and post-temporality, ${ }^{244}$ Barth indicates that His eternity is "not timelessness," but "simultaneity . . of past, present and future."245 This simultaneity

sanctuary or a temple. For Barth, in the biblical way of thinking, the idea of God's presence in a place precedes the notion of omnipresence, and not the other way around. See ibid., 478, 483, 485.

${ }^{240}$ Ibid., 470.

${ }^{241}$ Barth does speak of God's reality as “eternal simultaneity and successiveness” (ibid., 343), but his emphasis is on simultaneity. In his words, "Even the eternal God does not live without time. He is supremely temporal. For His eternity is authentic temporality, and therefore the source of all time. But in His eternity, in the uncreated self-subsistent time which is one of the perfections of His divine nature, present, past and future, yesterday, to-day and to-morrow, are not successive, but simultaneous." CD III.2, 437.

${ }^{242}$ Similarly, Torrance distinguishes between the "uncreated time of God and the created time of our world." Torrance, The Christian Doctrine of God, 209.

${ }^{243}$ CD II/1, 613. In Barth's words, "In Himself and in all things God is simultaneous.” Ibid., 608. He adds that God is "before and beyond all time and equally before and beyond all non-temporality. He is . .. the possessor of life completely, simultaneously and perfectly, and therefore to the inclusion and not the exclusion of the various times, beginning, succession and end.” Ibid., 611.

${ }^{244}$ Barth stipulates that the divine eternity is (1) pre-temporal, (2) supra-temporal, and (3) posttemporal. Ibid., 620, 630-631. First, the pre-temporality of God means that "His existence precedes ours and that of all things." In His pre-temporality, God determined everything that would take place in time, including time itself. Also, in the "pure time" of this "pre-time" the eternal Son was appointed "for the temporal world." Ibid., 621-622. Second, God's supra-temporality means that He is "co-temporal" or "intemporal," and describes "His presence in time." Ibid., 626. See also ibid., 623-624, 626-627, 629. Third, the divine post-temporality refers to the goal of eternity, the completion of all God's works. Ibid., 629-630. The Swiss theologian seems to combine these three concepts (pre-temporality, supra-temporality, posttemporality) with the threefold language that all things are from Him, in Him, and for Him (ibid., 631-632), and that God was, is, and will be (see CD III/2, 545). Furthermore, Barth uses his threefold conception of divine eternity to criticize the Reformers for interpreting God's eternity only as pre-temporality. See $C D$ II/1, 631 .

${ }^{245} C D$ III/2, 526. In other words, "eternity is not timelessness. It is beginning, middle and end in fulness, for it is all three simultaneously." Ibid., 558. It is important to clarify that, for Barth, "eternity is not . . . an infinite extension of time." CD II/1, 608. Thus, the key word that defines God's eternity is simultaneity. As Hunsinger indicates, in Barth, eternity includes "past, present, and future in the mode of 
means that, for Him, "beginning, succession and end are not three but one, not separate as a first, a second and a third occasion, but one simultaneous occasion. ${ }^{, 246}$ Accordingly, there is no 'not yet' for God. ${ }^{247}$ At least two conclusions may be drawn from such understanding of divine temporality. First, taking into account the contrast of simultaneity and sequentiality, God's time and creation time are equivocal. The same word (time) is used to describe two different things. Second, it is not clear why the idea of simultaneity, which logically rejects sequentiality, should be called temporal. In fact, the notion of temporal simultaneity does not seem to be too far from the timeless eternity of classical theism, which also rejects sequentiality. ${ }^{248}$ Indeed, Barth underlines that God is timeless in the sense that "the defects of our time, its fleetingness and its separations, are alien to Him." ${ }^{249}$ I will leave the discussion on why sequential time is a "defect" of creation in the ontological model for the section below on Cosmology.

According to this notion of God's time as simultaneity, the language of divine

simultaneity." Hunsinger, "Jesus as the Lord of Time According to Karl Barth," 126.

${ }^{246} C D$ II/1, 608. For Barth, "eternity does not lack absolutely what we know as present, as before and after, and therefore as time. Rather this has its ultimate and real being in the simul of eternity. Eternity simply lacks the fleeting nature of the present, the separation between before and after." Ibid., 613.

${ }^{247} C D$ III/2, 545.

${ }^{248}$ In his idea of God's eternal now Barth attempts to avoid the notion that all things are present to God in reality before their actual creation. In his words, "from the fact that God's eternity in its eternal Now embraces and contains all parts of time and all things in itself simultaneously and at one moment, we cannot deduce the general truth that things are present to God either in physical reality or even in intention . . . from eternity. God knows them and wills them. In this way they are certainly present to Him from eternity, enclosed in the Now of eternity even before their existence and without it. But they have their existence and also their co-existence with God only in the positive act of the divine creation." $C D$ II/1, 614 . It is not clear how Barth can sustain this statement without an affirmation of sequentiality in God, since it is the notion of sequentiality that can sustain the idea that created things did not actually exist before creation.

${ }^{249} C D$ II/1, 617. Likewise, Torrance claims that the "finite distinctions and limits between past, present and future . . . do not characterise the eternal Life of God." Torrance, The Christian Doctrine of God, 242. 
becoming mentioned above does not appear to describe an ontological event. His essential being or His decision does not seem to actually ground a divine becoming because they cannot ontologically precede anything in God, who is a simultaneous being. ${ }^{250} \mathrm{~A}$ significant example of this point is Barth's account of divine action, in which he applies the same ontic/noetic distinction he criticizes in the traditional account of the attributes of God. ${ }^{251}$ In his words, "the action of God in His reconciliation of the world with Himself in Jesus Christ is unitary. This action consists of different 'moments' with a different bearing." ${ }^{252} \mathrm{He}$ appears to qualify these different moments noetically, by saying that "we cannot see it [the unitary action] all at once." ${ }^{" 253}$ To put it differently, the divine action is ontologically one, but the human perception of it is manifold, as if it were sequential actions. The action that is ontologically one, but noetically manifold in the sequence of time, is constantly repeated (each time with a different noetic bearing) in sequential time. Thus, God's "executed decision" was "executed once for all in eternity, and anew in every second of our time. ${ }^{254}$ What is executed once for all in the simultaneity of God's eternity is a constant new event in the sequentiality of creation time. This is also the case of the eternal generation of the Son before all time (which is

\footnotetext{
${ }^{250}$ Indeed, Hector criticizes both the essentialist and the actualist views of the barthian doctrine of God by affirming the "simultaneity of God's triunity and self-determination." Hector, "God's Triunity and Self-Determination," 258. See also ibid., 259, 261.

${ }^{251}$ Barth criticizes the "semi-nominalistic" notion of classic theism that "the multiplicity of the divine attributes" does not actually refer to the nature of God per se but to the "discursiveness of the human intellect and the manifoldness of the created world." $C D$ II/1,335. In other words, the multiplicity belongs to the being of God (ontic), and not merely to the human way of understanding of God (noetic).

$$
\begin{aligned}
& { }^{252} C D \text { IV/2, } 501 . \\
& { }^{253} \text { Ibid., } 502 . \\
& { }^{254} C D \text { II/ } 1,271 .
\end{aligned}
$$
}


not related to Ps 2:7). ${ }^{255}$ The expression "before all time" is not "a temporal definition," 256 but it includes time. ${ }^{257}$ This inclusion means that, as an eternal and transcendent event over all time, "it takes place to-day," "it took place yesterday," and "it will take place tomorrow," since "what is real in God" (eternity) "must constantly become real" (according to time). ${ }^{258}$ According to this view, the divine becoming takes place only in the context of sequential time as an act of self-repetition. While the divine action is ontologically one, its self-repetition takes the form of manifold and different actions for the human perception under the conditions of sequential time.

In summary, the ontological model attempts to formulate a dynamic account of divine nature and action, making some room for the ideas of divine becoming, potentiality, passibility, sequentiality, changeability, and multiplicity. However, these ideas are interpreted under the presuppositions that, although God is somehow spatiotemporal, He only becomes what He already is (self-repetition), and His time is not sequential but simultaneous. According to these presuppositions, the divine becoming, potentiality, passibility, sequentiality, changeability, and multiplicity take place only in the space-time of creation. In the context of the sequential time of creation, the divine act of self-repetition takes the form of becoming. The action that is ontologically one,

\footnotetext{
${ }^{255}$ According to Barth, he agrees with Calvin that Ps 2:7 does not refer to the eternal begetting of the Son by the Father, but to "the appearing of the Messiah King in time." Ibid., 625.

${ }^{256} C D \mathrm{I} / 1,427$. Torrance seems to agree with this point when he argues that "the incarnation was not a timeless event like the generation of the Son from the Being of the Father." Torrance, The Christian Doctrine of God, 144. In this statement, the Scottish theologian indicates that while the incarnation is a temporal event, the eternal generation of the Son is a timeless event.

${ }^{257}$ Ibid., Barth affirms that the language that the Son was eternally begotten from the Father is a figure of speech, as it portrays a reality that is beyond human understanding. See ibid., 430-434, 436-437.

${ }^{258}$ Ibid., 427.
} 
according to the principle of simultaneity, is repeated in the sequence of time in the form of manifold actions. It is precisely here that there is room for the dynamic ideas of divine becoming, potentiality, passibility, sequentiality, changeability, and multiplicity.

Nevertheless, it is not clear how they can ultimately have an ontological status (even though the ontological model pushes in that direction), since the divine being is simultaneous by definition. Perhaps, they would be a secondary ontological form of the divine being and action in the spatio-temporal realm of creation. But again, it is not clear how this formulation would be compatible with a simultaneous divine being. Overall, the impression is that the dynamic nature of divinity in this model has a noetic, not an ontological status.

Having discussed divinity as the first principle of reality in the ontological model, I turn now to the description of humanity, the second principle in this model.

\section{Humanity: Christ and the Concept of Human Nature}

The attempt to affirm a dynamic view of divinity, where God is somehow able to experience temporality, spatiality, suffering, and relative mutability, as indicated above, seems to be related to the understanding that Christ's human nature is not merely a material tool required to enable His divinity to experience instrumentally these characteristics of the life of human beings. ${ }^{259}$ In other words, according to this conviction, the divine Christ experiences such characteristics as a human being, and not through a

${ }^{259}$ Both Torrance and Barth attempt to argue that God is able to have a direct contact with the material world. As Torrance puts it, "God was not simply using the humanity of Christ as his organ or instrument, while he remained transcendent to it all." Torrance, Incarnation, 227. Similarly, Barth argues that "the divine being must be allowed to transcend both spirit and nature, yet also to overlap and comprehend both." $C D$ II/1, 266. 
human nature. This perspective supports the conception of the ontological model that, in Christ, God is both the subject and object of the priestly work. ${ }^{260}$ Christologically speaking, an instrumental human nature implies that God is the subject of the priestly action (He acts through the instrument), but not its object. ${ }^{261}$ It is noteworthy that the language of Christ as the subject and object of the priesthood, in which His human nature is not understood merely in an instrumental way, aligns with the notion of the ontological model that the incarnate Christ is the electing God and the elected human being, ${ }^{262}$ the subject and object of salvific predestination. ${ }^{263}$

At this point, it is important to delineate how Christ's humanity is conceptualized in the context of His person as the subject/object of election and of the priestly action. It could be said that the priestly work is in the service of salvific election ${ }^{264}$ (the divine

\footnotetext{
${ }^{260}$ See in the previous chapter the discussion regarding The Agent of the Priesthood in the Ontological Model.

${ }^{261}$ The language of object here means that an action is not directed toward God. God is not the recipient of an action. It is in this sense that $\mathrm{He}$ is not an object of priestly action. For instance, He is not propitiated by a priestly action because He does not receive an action.
}

${ }^{262}$ For Barth, the problem of the traditional doctrine of predestination is to see "God as the Subject of the election and man as its object." $C D$ II/2, 52. He argues that, in reality, Christ is the "the electing God" and "the elected man." Ibid., 59. Likewise, Torrance refers to Christ as "the elect one and as the electing one." Torrance, Incarnation, 113. In this view, "in Jesus Christ, it is revealed that the election of one for all becomes salvation for all in the rejection of one for all." Ibid., 52. For helpful studies on election in Barth and Torrance, see David Gibson, Reading the Decree: Exegesis, Election and Christology in Calvin and Barth (London; New York: T\&T Clark, 2009); Myk Habets, "The Doctrine of Election in Evangelical Calvinism: T. F. Torrance as a Case Study," Irish Theological Quarterly 73, no. 3-4 (2008): 334-354.

${ }^{263}$ Barth speaks of Christ as "the subject and object" of predestination. $C D$ II/2, 102. Similarly, Torrance argues Christ is "the judging God and the judged man at the same time." Torrance, Incarnation, 113.

${ }^{264}$ Barth argues that the NT speaks of the election of the man Jesus "as our Savior, Head and Priest." $C D$ II $/ 2,108$. Thus, election precedes priesthood, at least logically. 
eternal decision to save human beings in $\mathrm{Christ}^{265}$ ), in the sense that the priestly work noetically $^{266}$ (see previous section on Divinity) actualizes election. Taking into account the distinction between subject and object, the notion that Christ is the electing God (subject) clearly situates His humanity on the object side. This does not necessarily mean that His humanity is passive in His priesthood. Christ acts as a man. However, the subject of election (and of the priesthood) is God. In Christ, God noetically ${ }^{267}$ (see previous section on Divinity) acts as a man. However, by situating Christ's humanity on the object side of such action, this does not mean that His divinity is not an object as well. In Barth's words, "God elected or predestinated Himself." 268 The difference is that, in Christ, there is a positive predestination of man and a negative predestination of God. To put it more sharply, there is a double predestination according to His divine and human natures. In Christ's human person, God is the object of reprobation or death (God reprobates Himself or, using a priestly language, He sacrifices Himself) and man is the object of salvation or life. ${ }^{269}$ Obviously, as one person, the humanity of Christ is involved

\footnotetext{
${ }^{265}$ For Barth, "in the beginning, before time and space as we know them, before creation ... God anticipated and determined within Himself . . . that the goal and meaning of all His dealings with the as yet non-existent universe should be the fact that in His Son He would be gracious towards man, uniting Himself with him." Ibid., 101. The Swiss theologian concludes, "Whoever is elected is elected in Christ and only in Christ." Ibid., 62.

${ }^{266}$ The word noetically is not explicitly stated by Barth or Torrance, but it is implied in the account of Divinity in the ontological model. Without ontological temporality, God does not really act in time. At best, His action is a noetic action in the sense of revealing election in time.

${ }^{267}$ The explanation for the use of noetically here is the same of the previous footnote.

${ }^{268}$ Ibid., 162.

${ }^{269}$ In Christ, "God has ascribed to man ... election, salvation and life; and to Himself He has ascribed ... reprobation, perdition and death." Ibid., 163. Torrance claims that God has revealed Himself in Jesus Christ as sharing our lot" and making Himself poor, that we through His poverty might be made rich." Torrance, Space, Time, and Incarnation, 75. Furthermore, he argues that "it is God in Christ who suffers and bears the sin of the world, and reconciles the world to himself." He adds, "If the deity of Christ is denied, then the cross becomes a terrible monstrosity." Torrance, Incarnation, 189.
} 
in the two events of reprobation and salvation, but in different levels. In the case of reprobation, His humanity is the form ${ }^{270}$ in which God reprobates Himself. But in the case of salvation, the humanity of Christ per se is the object of salvation. ${ }^{271}$

In fact, this account of election seems to imply that the human person of Christ is some kind of micro-cosmos where the reconciliation of God and human beings takes place. ${ }^{272}$ In this context, His human nature must be conceived in such a way that allows God to be the real object of reprobation and also human beings to be saved. To be more specific, Christ's humanity must have a non-instrumental relationship with divinity and human beings. As mentioned above, if His humanity is an instrument of the acting divinity, divinity cannot be the real object of the reprobatory action (negative election). To give an example, if God sacrifices Himself through the instrumentality of Christ's humanity, the actual object of this sacrifice is His humanity, and not His divinity. Likewise, if His humanity is an instrument to communicate salvation to concrete human beings, Christ's humanity is not the real object of salvific action (positive election). In this case, Christ is not the elected man. Rather, His humanity is only a means of election. Concrete human beings are the actual elected (object). In short, if Christ's humanity is an instrument of His divinity, the man Jesus becomes the object of reprobation.

Furthermore, if His humanity is an instrument for the salvation of human beings, the man

\footnotetext{
${ }^{270}$ In this section, I use the word form in a non-technical philosophical way. In other words, I am simply saying that God is in human form, a mode of existing.

${ }^{271}$ As indicated in the previous chapter, the ontological model conceives salvation basically as human transformation. This transformation entails the elimination of sin/evil by means of the destruction of sinful human beings, which is followed by the (re-)creation of transformed human beings. This is seen in Christ's death (destruction) and resurrection (re-creation).

${ }^{272}$ Barth, for example, indicates that "the theme of the divine election is primarily the relationship between God and man in the person of Jesus Christ." CD II/2, 177.
} 
Jesus cannot be the object of salvific election. Therefore, Christ's humanity needs to be conceptualized as the form ${ }^{273}$ (not instrument) of His divinity in reprobation, and as the form (not instrument) of human beings in salvation. Hence, in my view, the ontological model would need to formulate a dynamic notion of divinity that includes the ability to suffer (passibility), which enables God to be the object of Christ's sacrifice, and a corporate conception of human beings who are ontologically connected with the humanity of Christ, allowing the conclusion that the salvation of the man Jesus Christ automatically means the concrete salvation of human beings.

At this point, a few questions may be raised. Does the ontological model have conceptual resources for a non-instrumental view of Christ's humanity? More importantly, are there resources to support a dynamic conception of divinity and a corporate notion of human beings ontologically connected to the man Jesus? In the next paragraphs I will present arguments for the following concise answer: There are some resources that could be further elaborated to substantiate these conceptions, namely, a monistic view of humanity and a relational view of space-time. But they do not seem to be sufficiently developed to support these conceptions in the ontological model.

There are some logical moves in the arguments of the ontological model that tend to view the constitution of Christ's humanity, and by extension the constitution of human being in general, in terms of a strong union between soul and body. ${ }^{274}$ In his "concrete

\footnotetext{
${ }^{273}$ In this sense, God receives reprobation as (in the form of) a human being.

${ }^{274}$ According to Barth, 'Far from existing as the union of two parts or two 'substances,' He
} [Christ] is one whole man, embodied soul and besouled body: the one in the other and never merely beside it; the one never without the other." $C D$ III/2, 326. Similarly, Torrance affirms, "We do not find St Paul, anymore than in the Old Testament, any body/soul or body/mind dualism." Torrance, Atonement, 438. "We are not bodiless spirits but psycho-physical beings," a "whole body-and-soul reality." Torrance, Space, 
monism," ${ }^{275}$ Barth correlates time-space with soul-body, stipulating that the soul is "movement in time" and has the body as its "inalienable spatial complement." 276 In contrast to the Greek dualism that dominates the Christian traditional anthropology, ${ }^{277}$ the human soul is the life of the body, ${ }^{278}$ which implies that the soul "cannot exist for itself." ${ }^{279}$ This idea of concrete monism is significant because the dualism of soul and body, as assumed in the sacramental model, entails an instrumental relationship of the body with regard to the soul, which in Christ patterns the instrumental relationship of His

Time and Resurrection, 178. The Scottish theologian emphasizes that human existence is "not separable from the material universe, for man precisely as man is body of his soul as well as soul of his body," forming the "wholeness of . . soul-body." Torrance, The Christian Doctrine of God, 226.

${ }^{275}$ Barth points out that "soul and body" are not "two parts," but "two moments of the indivisibly one human nature, the soul as that which quickens and the body as that which is quickened and lives. It is to this concrete monism that we found ourselves guided by the biblical view and the biblical concept of the 'soul." CD III/2, 393; italics mine. Marc Cortez indicates that, "from one perspective, Barth's ontology is clearly monistic." However, the holistic language employed by the Swiss theologian "does not resolve the body/soul question," and it seems that "his ontology at least implicitly affirms some form of dualism." For Cortez, Barth's focus is not on the body/soul question, but "on understanding the implications that the person and work of Jesus Christ as the true human and the covenantal relationship in which all humans have been summoned to participate have for understanding human nature." Marc Cortez, "Body, Soul and (Holy) Spirit: Karl Barth's Theological Framework for Understanding Human Ontology,” International Journal of Systematic Theology 10, no. 3 (2008): 328-330. For further studies on Barth's anthropology, see Daniel J. Price, Karl Barth's Anthropology in Light of Modern Thought (Grand Rapids, MI: Eerdmans, 2002); Stuart D. McLean, Humanity in the Thought of Karl Barth (Edinburgh: T\&T Clark, 1981).

276 Assuming that the "soul is movement in time," Barth asks, "How could it be this if it did not have an inalienable spatial complement, if it had no place?" $C D$ III/2, 373.

${ }^{277}$ Barth points out that in this traditional anthropology "the soul is spiritual, non-spatial, indissoluble, and immortal; the body material, spatial, dissoluble and mortal." Ibid., 380. He clearly rejects the "doctrine of the immortality of the soul," and considers as "quite unbiblical" the notion that the soul is an "immortal spiritual substance of human reality, contrasted with the body as its lower and mortal part." Ibid., 378-379.

${ }^{278}$ In Barth's words, "soul is life. What is lifeless is souless." Ibid., 374. The soul is "the besouling of a material body," "the principle of its becoming and being alive." Ibid., 376-377. He sees the soul as life, activity, inner being, the "product of the breath of God." Ibid., 373-374.

${ }^{279}$ Ibid., 373. For Barth, "the soul is not a being for itself, and it cannot exist for itself. Soul can awake and be only as soul of a body." Ibid. 
humanity with regard to His divinity. ${ }^{280}$ Therefore, as long as the ontological model moves away from a dualistic conception of human nature, there is more room for a noninstrumental view of Christ's humanity. To be sure, the non-instrumentality of the human body in the context of anthropology is not an argument against the instrumentality of human nature as such in the Christological context of divine and human natures. However, the non-instrumentality of the human body could be a step in this direction. Another important conceptual resource in the ontological model, specially emphasized by Torrance, is the relational interpretation of space-time. If a monistic view of human nature could be an initial step in the articulation of a non-instrumental conception of Christ's humanity, the relational view of space-time can be useful for the formulation of an account of Christ's divinity that experiences space-time without the need of the instrumentality of His humanity. According to this relational view, time and space are not things in themselves but the form or characteristic of creation. ${ }^{281}$ Hence, space-time is not a container (the container view) in which creatures are contained, but a

\footnotetext{
${ }^{280}$ See the description of Humanity in the sacramental model, which is outlined above in this chapter.

${ }^{281}$ According to Barth, "Created time" is "co-created." This means that "time is not a something, a creature with other creatures, but a form of all the reality distinct from God, posited with it, and therefore a real form of its being and nature." $C D$ III/2, 438. Similarly, as Hunsinger emphasizes, eternity is not an entity but a characteristic. "Eternity for Barth is not the container in which God lives. It is a predicate of God's triune being." George Hunsinger, Disruptive Grace: Studies in the Theology of Karl Barth (Grand Rapids, MI: Eerdmans, 2000), 189. Torrance points out that "we are accustomed . . . to imagine space as something abstract and as something in itself, as though space could exist or be an entity in itself quite apart from the things it 'contains'. Thus we work with a dualism between 'space' and the things thought to be 'in it', and so think it possible to have 'empty' space." However, "space and time should not be conceived in themselves as abstract entities but only in relation to active agents and therefore relationallythey are not 'receptacles' apart from bodies or forces, but are functions of events in the universe and forms of their orderly sequence and structure." Torrance, Atonement, 288-289. David Fergusson argues that, drawing on relativity theory, Torrance advances a relational view of space and time, where time and space are defined by functions or forces of other principles that relate with them. David Fergusson, "The Ascension of Christ: Its Significance in the Theology of T. F. Torrance," Participatio 3 (2012): 99. See also, Molnar, Thomas F. Torrance, 124-136.
} 
characteristic they relate to (the relational view). ${ }^{282}$ Because space-time is not a container, God is not inside or outside space-time. Rather, this is a matter of God relating to creation, more specifically, to a spatial-temporal creation. Since God's being is different from created human beings, His relationship is distinct from their relationship with spatiality-temporality. ${ }^{283}$ Thus, God and humankind experience temporality and spatiality in different ways. ${ }^{284}$ In this sense, in Christ's humanity, God does not start to experience temporality and spatiality. Rather, what happens is that He can experience them in a new way, that is, in a human way.

However, considering the interpretation above regarding Divinity embraced by the

\begin{abstract}
${ }^{282}$ Torrance rejects what he calls the "Greek container conceptions of space," arguing that the "Greek fathers" did not accept "the pre-Christian Greek conceptions of space as a "container', or "receptacle'." The Scottish theologian stipulates that in this notion of container there is an "interdependence between the container and its contents." In his reflections on Solomon's prayer (1 Kgs 8:27; $2 \mathrm{Chr} 2: 6)$ and the "presence of God bodily" in the incarnate Christ, Torrance affirms a "relational notion of space" instead of a "container notion." In this relational view, "there is no concept of space as an entity in itself apart from things and agents." Rather, "space and time come into being with creation as orderly functions of creaturely events," a "continuum of relations given in and with created existence." The Scottish theologian points out that Calvin did not "develop a thoroughly relational concept of space and time as the Greek fathers did; he merely rejects, with the fathers, any idea that the incarnation involves an enclosing of the deity of Christ within the limits of a containing vessel." Conversely, "the Lutherans ... operated with a receptacle notion of space," as "they took over" the "Ockamist form the Aristotelian concept of space." Torrance, Incarnation, 217-219. Torrance stipulates that Christological theories of kenosis and ubiquity presuppose a receptacle view of space. Torrance, Space, Time, and Incarnation, 35. He also claims that there are two forms of the receptacle view, a finite receptacle and an infinite receptacle. The idea of an infinite receptacle was emphasized by the Renaissance and in Newtonian science. Ibid., 37-38. In Kant, the human mind becomes the receptacle of space-time "which conditions and makes possible our knowledge of nature." Ibid., 43. The Scottish theologian advocates that, in contrast to this receptacle/container view, the relational and dynamic conception of space-time is consistent with the notion of space-time in relativity theory. Ibid., 45.

${ }^{283}$ As Torrance highlights, "Space and time are relational and variational or differential concepts defined in accordance with the nature of the force that gives them their field of determination." Thus, "time is to be understood as time for something, time in which we live our life . . and the 'time' of God is understood as the time in which God lives his own life." Likewise, "we must think of space as room for something, as place defined in terms of that which occupies it." In this sense, "man's place is defined by the nature and activity of man, and God's place is defined by the nature and activity of God." Torrance, Atonement, 289.
\end{abstract}

${ }^{284}$ According to Torrance, in the relational view, space and time are "differentially or variationally related to God and to man." Ibid., 285. 
ontological model as a principle of reality (see above), the relational view of space-time depicted in the previous paragraph does not seem to be able to substantiate a dynamic notion of God at the ontological level, inasmuch as God experiences time simultaneously, not sequentially. Therefore, it is difficult to ontologically sustain the thesis that in Christ God experiences time sequentially and to avoid an instrumental use of His humanity. In other words, without sequentiality, the notion of divine passibility seems ontologically void, at least in a historical sense, inasmuch as suffering is not chronologically preceded and caused by actions that take place in history. For instance, the suffering of the passible God would not be caused historically by what happens (physically or spiritually) on the cross. A divine "simultaneous" suffering seems to suggest an eternally existing experience. In this context, Christ's humanity seems to be a noetic instrument that historically reveals the eternal (simultaneous) suffering of God in the sequentiality of creation space-time. This historical revelation would be compatible with the idea of divine self-repetition in history that was highlighted in the discussion above about Divinity in the ontological model.

The simultaneity of God also informs the ontological connection of human beings to the man Jesus in this model. According to a chronological reading of the ontological model, the historical life, death, and resurrection of Christ are not simply Christological events in the place of human beings. Rather, individual human beings are somehow objectively in the humanity of Christ, ${ }^{285}$ particularly when these events took place. ${ }^{286}$

\footnotetext{
285 This is an example of a non-historical interpretation of ontology: all humanity is assumed "to be" chronologically and actually in Christ.

${ }^{286}$ As Berkouwer emphasizes, "The Church confesses 'not we, but He' as the essential element in Christ's vicarious suffering. Sometimes Barth gives the impression that he wishes to express this thought
} 
This chronological reading would seem to require an instantaneous visible transformation of individual human beings since Christ's resurrection, in the same way that His resurrection was visible and real for this model. ${ }^{287}$ In this case, the question would be: What makes what happens in Christ after His resurrection instantaneously real in human beings? In other words, what is the connection between His humanity and our humanity? The problem with these questions is that they assume a chronological or sequential view of divine salvific action (death then resurrection), and not a simultaneous action. Simultaneously, the man Jesus and all human beings are supposed to be eternally connected in God's election. ${ }^{288}$ In the simultaneous reality of God, human beings are (ontologically exist) already transformed and reconciled. ${ }^{289}$ In other words, in the

also... . But from everything it appears that this exchange does not exclude but includes our extinction." Berkouwer, The Triumph of Grace in the Theology of Karl Barth, 317. Likewise, Bloesch argues, "It is not that Christ bore the judgment of God in our place, thereby enabling us to escape judgment. Instead the judgment has been executed upon us in Christ, and therefore we and all men have already passed through this judgment." Bloesch, Jesus Is Victor, 50. With regard to Torrance's idea that in the incarnation Christ heals human nature, Cassidy points out that "in the incarnation we have God who takes to himself not just a man, but humanity itself." Cassidy, "T. F. Torrance's Realistic Soteriological Objectivism and the Elimination of Dualisms," 176.

${ }^{287}$ According to Gunton, Barth has received criticisms that Jesus Christ in his theology is "a kind of platonic form of humanity, so that salvation is universally achieved already, and its appropriation only a matter of knowing that we are saved." However, Gunton argues that "charges of Platonism must not obscure the fact that this universal salvation is not established by Barth in any way philosophically, but in God's personally active eternity." Gunton, "Salvation," 155-156.

${ }^{288}$ In his actualist interpretation of humanity, McCormack's reading of Barth suggests that divine election establishes the connection between Christ's humanity and our humanity. In McCormack's words, "The ground of the 'exaltation' of human 'nature' in the history of Jesus of Nazareth is to be found in the election of all human beings in Him. It is because all are in Him by virtue of election that He can constitute, through His lived obedience, human being as such." Bruce L. McCormack, "So That He May Be Merciful to All: Karl Barth and the Problem of Universalism," in Karl Barth and American Evangelicalism (Grand Rapids, MI; Cambridge, UK: Eerdmans, 2011), 227-228.

${ }^{289}$ Regarding the idea of simultaneity and election, Torrance argues that "election is . . . not some static act in a still point of eternity." Rather, election moves "into time as [the] living act that from moment to moment confronts people in Jesus Christ." In fact, "election is Christ ... and the act of election in him is once and for all, a perfectum praesens, an eternal decision that is ever present." Therefore, "election is contemporary with us." Torrance, Incarnation, 180. 
chronological reality space-time creation, the humanity of Christ reveals through the sequential events of His death and resurrection the new reality of reconciliation or new creation that already exists as a simultaneous reality in God (I will explore the relationship between old and new creation and their relationship with simultaneity and sequentiality in the next section, which deals with Cosmology). Moreover, I would say that the ontological model advances a non-instrumental interpretation of the humanity of Christ in space and time in the sense that the historical realities of the divine suffering and the human salvific transformation in the life of Jesus Christ already took place (and exist) ultimately and ontologically in the simultaneous/eternal reality of God, and not in our (sequential) history. In the experience of believers, Christ's humanity plays the role of a noetic instrument of the revelation of these eternally existing simultaneous realities (some kind of divine repetition) in sequential time.

In summary, in order to make Christ Himself the object of election (as man) and reprobation (as God in the form of man), the ontological model seeks to articulate a view of Christ's humanity that is not instrumental. From a non-instrumental perspective, His humanity would be the form in which God Himself supposedly suffers (divine passibility) the judgment in the place of sinful human beings. Likewise, Christ's humanity would be the form in which individual human beings are saved and become a new creation in God. To substantiate this interpretation and argue in favor of a noninstrumental understanding of Christ's human nature, the ontological model could further articulate ideas such as the monistic view of human nature and the relational conception of space-time. However, the assumption that God experiences time simultaneously, and not sequentially, rules out the idea that He is historically passible. Moreover, the lack of 
an ontological connection between the humanity of Christ and individual human beings in history points to the existence of an eternally (simultaneous) reconciled humanity (in the sense of concrete human beings) in God. As long as God's suffering and reconciled humanity are realities existing ultimately in a simultaneous God and not in our sequential history, the humanity of Christ is not instrumental. In this context, however, human beings would experience His humanity as a noetic instrument revealing these eternal simultaneous realities (divine self-repetition) in sequential history.

My next step is to describe the third principle of reality in the ontological model, namely, cosmology.

\section{Cosmology: Christ, Heaven, and Earth}

In the discussion of this principle of reality in the ontological model, I will focus on the interaction of the resurrected and ascended Christ with heaven and earth, highlighting how the concepts of divinity and humanity explored above relate to cosmology or the ontological structure of the world in this model.

The ontological model indicates that the resurrection of Christ is the beginning of a new age, having a revelatory character. ${ }^{290}$ In other words, "the risen Christ is the living

\footnotetext{
${ }^{290}$ According to Barth, "the old æon ... ends with the cross of Christ" and "the new one ... begins with His resurrection - this transition is revelation, is the light of fulfilled time." $C D \mathrm{I} / 2,56$. Regarding the revelatory character of the resurrection, the Swiss theologian points out that Christ's "work, His being and action, were not augmented by His resurrection. How could they be? His work was finished. Yet without this event following His life and death, His finished being and action, this alteration of the situation between God and man as accomplished in Him, would have remained shut up in Him, because it would have been completely hidden from the disciples and the world and us, being quite unknown and therefore without practical significance. Without this event it would have lacked the glory and revelation and therefore the prophetic character of His being and action. His life would still have been the life of the whole world, but it would not have been light shining in this world and illuminating it." $C D$ IV/3.1, 282 . For studies on Christ's resurrection in Barth, see Adam Eitel, "The Resurrection of Jesus Christ: Karl Barth and the Historicization of God's Being," International Journal of Systematic Theology 10, no. 1 (2008): 3653; John L. Drury, The Resurrected God: Karl Barth's Trinitarian Theology of Easter (Minneapolis:
} 
atonement" ${ }^{, 291}$ in person and that, fundamentally, the "whole physical universe has

already been resurrected in Christ," 292 the reality of this new age is particularly

characterized by the re-creation of time and space or the space-time of new creation. ${ }^{293}$

While Christ's resurrection reveals to believers this new reality in space and time, His

ascension somehow conceals it. ${ }^{294}$ Thus, the parousia will not bring about a reality

different from the resurrection, but will be a consummation of the revelation of the new

reality, a revelation that took place at first in the resurrection. ${ }^{295}$ In this view, resurrection

and parousia are a single event for Christ. They seem to be distinct events to human

beings because the new reality in Christ is largely hidden to the inhabitants of the earth

Fortress, 2014); R. Dale Dawson, The Resurrection in Karl Barth (Aldershot, England; Burlington, VT:

Ashgate, 2007).

${ }^{291}$ Torrance, Space, Time and Resurrection, 55. "The risen Christ is the living Atonement . . . not only in overcoming the separation of sin, guilt and death, but in consummating union and communion with God." In this way, "the divine life overflows freely through him into mankind." Ibid. The Scottish theologian affirms that "the resurrection and ascension bring the work of atoning reconciliation and recreation to their consummation in the humanity of Christ." Torrance, Atonement, 298.

292 Torrance, Space, Time and Resurrection, 55. Torrance explains that "the resurrection of Christ" is "the pledge that the whole physical universe will be renewed, for in a fundamental sense it has already been resurrected in Christ." Ibid.

293 Torrance points out that "the resurrection means the redemption of space and time." With the resurrection, "space and time are not abrogated or transcended" but "healed and restored." Torrance, Atonement, 247. Similarly, Barth speaks of God as re-creating time and healing "its wounds." CD II/1, 617.

${ }^{294}$ For Torrance, the ascension "means that this time of the new creation in Christ is hidden from us." Torrance, Atonement, 256.

${ }^{295}$ Regarding the resurrection, Barth explains that the resurrected Christ "is already He who comes, who restricts His coming to the circle of His then followers, and then interrupts it, to resume and complete it at a later point." Therefore, "nothing which will be has not already taken place on Easter Dayincluded and anticipated in the person of the one man Jesus. And so Jesus in His coming is simply the risen Jesus resuming and completing His coming," as "the time given for the conversion of the world, will then be completed." CD III/2, 489. See also ibid., 490, 496. Likewise, Torrance stipulates, "the final parousia of Christ will be more the apocalypse or unveiling of the perfected reality of what Christ has done than the consummating of what till then is an incomplete reality." Torrance, Space, Time and Resurrection, 152. 
due to His ascension. ${ }^{296}$

At this point, a question may be asked: What do these statements mean in light of the previous sections on Divinity and Humanity? To be more specific, what does the reality of new creation in the resurrected Christ mean in the context of a simultaneous divine action that is self-repeated (revealed) in the sequentiality of our time through the humanity of Christ? The answer seems to be that the historical resurrection is not the ultimate reality that marks the ontological beginning of a new creation. Such historical reading would seem to require a divine sequential action that chronologically does something at Christ's death and resurrection. Rather, what seems to happen in the historical resurrection is the revelation (self-repetition) of the simultaneous (eternally existing) reality of new creation in the divine Christ.

However, it appears that the humanity of Christ experienced some kind of change in the resurrection and ascension. This does not mean an immaterialization of Christ's body $^{297}$ or the rejection of any kind of spatiality regarding the ascended Christ at the right hand of $\operatorname{God}^{298}$ in the heavenly throne. ${ }^{299}$ At the same time, the ascension was not a literal

${ }^{296}$ Barth highlights that "for us ... the resurrection and the parousia are two separate events. But for Him [Christ] they are a single event." CD III/2, 490. In his remarks on the Gospel of John, the Swiss theologian argues that "Easter, Ascension, Pentecost and parousia are here seen as a single event." In this view, Easter and parousia are "different moments of one and the same act." Ibid., 497. For Barth, we should "see them together as forms of one and the same event," or "one continuous event in all its forms," as "the New Testament knows of only one coming again of Jesus Christ." CD IV/3.1, 293-294. For studies on the ascension in Barth, see Burgess, The Ascension in Karl Barth; Farrow, "Karl Barth on the Ascension," 127-150.

${ }^{297}$ Torrance maintains that " "the forty days' between the resurrection and the ascension" did not involve a "spiritualisation or immaterialisation of the body of Christ." Torrance, Atonement, 281.

${ }^{298}$ According to Barth, since "God Himself is spatial," "the biblical picture of the throne of God (at whose right hand His Son sits and is our Representative as the One who wears our humanity) is not merely a picture or symbol. For it denotes the real place of God, and as such the one which is superior to all other places." $C D$ II $/ 1,475$. 
event such as the rising of a balloon, but an affirmation that Christ left the earth and went to a higher side of the created world, ${ }^{300}$ as God's heaven is "not God Himself," but part of His creation. ${ }^{301}$ While the ontological model affirms some kind of spatiality in heaven, this spatiality is apparently incomprehensible, which means that the language of heavenly space seems to be equivocal to earthly space. ${ }^{302}$ According to a divine heavenly equivocal space (incomprehensible) and time (simultaneous), Christ manifested Himself in the mode of God in the resurrection, ${ }^{303}$ and since the ascension He exists and acts in this

\footnotetext{
${ }^{299}$ Barth speaks of a spatial presence of Jesus in the throne of God in heaven in connection with Heb 9:24. See ibid., 482. He emphasizes the "spatiality of Jesus Christ in heaven and on earth." Ibid., 483. In the incarnate Christ, especially the ascended one, "the Creator has given the creature not only space but His own most proper space. God has raised man to His throne." Ibid., 486. The Swiss theologian criticizes Luther's understanding of God's right hand as omnipresence. "In this interpretation of the right hand of God, the presence with which God is present to Himself in His supraheavenly place seems to melt or sink into His presence in general, His presence in creation. It has no biblical justification, but is clearly linked up with the fatal and, in this case, violently applied presupposition of all the older theology, that the essence of God is the non-spatial infinite, and that God is omnipresent as this non-spatial infinite." Ibid., 488. Barth argues that the ascended Christ is not "at a specific and limited point in creaturely space. Nor is He extended over all points in creaturely space as maintained by the original Ubiquitarianism of the Lutherans. $\mathrm{He}$ is to be sought in heaven 'at the right hand of God the Father Almighty' and therefore up above (Col. $\left.3^{1}\right)$. This does not mean, however, that $\mathrm{He}$ is imprisoned there ... It does not mean that $\mathrm{He}$ is prevented from being and working and revealing Himself here too." $C D$ IV/3.1, 357.

${ }^{300}$ Barth explains that "'heaven' in biblical language is the sum of the inaccessible and incomprehensible side of the created world ... There is no sense in trying to visualise the ascension as a literal event, like going up in a balloon. ... The point of the story is not that when Jesus left His disciples He visibly embarked upon a wonderful journey into space, but that when He left them He entered the side of the created world which was provisionally inaccessible and incomprehensible." CD III/2, 453-454. Similarly, Torrance indicates that, "in so far as" Christ "is man, truly and perfectly man, we must think of the ascension as related to the space and time of creaturely reality. But this involves a duality in itself, between our fallen space-time and redeemed space-time. ... In him space and time were recreated or renewed. We have no adequate language to describe this." Torrance, Atonement, 286.

${ }^{301}$ CD III/2, 453. See also Torrance, Space, Time and Resurrection, 129n8, which is a quotation from Barth. For the Swiss theologian, "heaven - or supernatural, imperceptible, spiritual reality-is not in any way to be identified with God," but is "God's creation, as earth is." CD II/1, 266. He adds, to say that "dwells 'in heaven,' ... does not deny that He is the Creator and Lord of heaven too and of all heavenly beings and all heavenly hosts." Ibid., 474.

${ }^{302}$ See the two previous footnotes above.

${ }^{303}$ In the context of a discussion about the resurrection, Barth argues, "In this time the man Jesus was manifested among them in the mode of God." CD III/2, 448.
} 
mode. $^{304}$

Ontologically speaking, the humanity of Christ in the resurrection and ascension is spatially incomprehensible and temporally simultaneous. ${ }^{305}$ The shift from an earthly spatiality and temporality to this other (divine) "spatiality" and "temporality" in the humanity of Christ is associated with the distinction of "fallen" time (old age/creation) and "redeemed" time (new age/creation). Fallen time ("our time") describes the time of sinful and condemned human beings, ${ }^{306}$ and is characterized by a negative sequentiality (past-present-future), namely, "the separation between before and after," beginning and end, and "the fleeting nature of the present" that flows away to the past or expects the future. $^{307}$ The time of this fallen world "runs backward," enslaving humankind in an irreversible movement to the dust of nothingness (decay and finally death). ${ }^{308}$ In contrast,

${ }^{304}$ According to Barth, the ascended Christ is in the "God-ward side of the universe, sharing His throne, existing and acting in the mode of God." Ibid., 454.

${ }^{305}$ In this discussion of Christ as the Lord of time, Barth claims that "His time acquires in relation to their times [the time of other human beings] the character of God's time, of eternity, in which present, past and future are simultaneous. Thus Jesus not only lives in His own time, but as He lives in His own time, and as there are many other times both before and after Him, He is the Lord of time." CD III/2, 440 . As Hunsinger emphasizes, "Because past, present and future occur simultaneously for God in eternity, the same is true for Jesus' time, since by virtue of his resurrection, his time is brought to exist in the mode of God." Hunsinger, "Jesus as the Lord of Time According to Karl Barth," 123.

${ }^{306}$ Barth qualifies this time as "lost, fallen, condemned time, as time that some day will cease to be." $C D \mathrm{I} / 2,49$. He adds, "The time we think we know and possess, 'our' time, is by no means the time God created. Between our time and God-created time as between our existence and the existence created by God there lies the Fall. 'Our' time, as Augustine and Heidegger in their own ways quite correctly inform us, is the time produced by us, i.e., by fallen man.” Ibid., 47 .

${ }^{307} C D$ II/1, 613. For Barth, in this time, "beginning, middle and end are distinct and even opposed as past, present and future." Ibid., 608. See also ibid., 617. Regarding the problem of the present, the Swiss theologian asks, "What is Now? What is the present? ... as we actually experience it, is no time at all, no duration, no series of moments, but only the boundary between past and future, a boundary which is never stationary, but always shifts further ahead. . . A Always it has already gone or not yet come. In practice, the present can be experienced only in the form of recollections and expectations." $C D$ III/2, 514. See also $C D$ $\mathrm{I} / 2,48$.

${ }^{308}$ Torrance, Atonement, 244. According to Torrance, "the kind of time we have in this passing world is the time of an existence that crumbles away into the dust, time that runs backward into 
the resurrected Christ (the new humanity, the new creation) constitutes the new "time" created by God for human beings. ${ }^{309}$ Instead of being characterized by the limits of sequentiality, this new "time" is qualified by the simultaneity of eternity, in which there is no fleetingness or separation. ${ }^{310}$ In this sense, the new creation has a new "time" in the heavenly Christ, but the complete revelation of this new "time" on earth will take place in the parousia. ${ }^{311}$ The new "time" of the resurrected Christ essentially describes Him as contemporary or simultaneous to all times, ${ }^{312}$ as His present includes past (His past did

nothingness." Ibid. Hence, time in this fallen world is "irreversible - time that flows only one way, backwards and down into the dust." Ibid., 248. The Scottish theologian concludes that "the kind of time we have in our fallen existence is refracted time." This is the "time within which we are all servants." Ibid., 255. Likewise, Barth concludes that sinful human beings experience a "continual loss of time." $C D$ III/2, 517. See also ibid., 514.

${ }^{309}$ See $C D \mathrm{I} / 2,50$. Affirming that the fallen time is resisted by Christ's resurrection, which "overcomes corruption and decay," Torrance stipulates that "the resurrection . . breaks redemptively through the framework of space and time as we know it in a fallen world." Torrance, Atonement, 246-247. In his comments on the "the resurrection of the man Jesus and his exaltation to the right hand of the Father," the Scottish theologian claims that "in Christ the time of human beings and life is wedded to eternity." Ibid., 256. Similarly, Barth speaks of "real time" breaking "in as new time, as the now and to-day of the Saviour." CD I/2, 53. The Swiss theologian seems to suggest that this new time is present on earth since Christ's incarnation. For Barth, in the man Jesus "God takes and has time for us ... He is temporal in unity and correspondence with His eternity," which means that "He is temporal in a way which also corresponds to man as His creature, in the original and natural form of the being of man in time before it was perverted and corrupted." In fact, "that Jesus is the Lord of time, He who was and is and is to come." $C D$ III/2, 519. My focus here on the resurrected Christ is justified on the grounds that it is at this point that Barth's conception of Jesus as the Lord of time has more significant implications for the understanding of His priestly intercession in heaven.

${ }^{310}$ In Barth's language, the new time is "eternal time." Advocating that Christ "is still flesh even in His glory at the right of God the Father," Barth argues that "the time God has for us, as distinguished from our time that comes into being and passes away, is to be regarded as eternal time." $C D \mathrm{I} / 2,50$.

${ }^{311}$ In this sense, Barth considers the new time a promise. For him, "human existence no longer possesses its time as that which is to be taken for granted in its created state. Its possession of time ... has now become the object of a special promise, a work of special divine goodness." Ibid., 47; italics mine.

${ }^{312}$ Barth seems to enlarge Luther's notion of Christ's ubiquity to include not only space, but time. While the German theologian emphasized the presence of the heavenly Christ in all places, the Swiss theologian sees His presence also in all times. See Hunsinger, "Jesus as the Lord of Time According to Karl Barth," 121. 
not cease to be) and future (His future already existed). ${ }^{313}$ For Barth, this is the reality of the simultaneity of time in God's eternity — God as the "I AM" - and also the meaning of the sameness of Christ's past, present, and future in Heb 13:8. ${ }^{314}$ The idea that Christ's future already existed in His contemporaneity is observed in the notion of divine predestination. God's decree is not merely a past decision, but is contemporaneous. ${ }^{315}$ Even though this decree is a complete work (once and for all), it is never temporally exhausted but is present before, above, and in every time. ${ }^{316}$

\footnotetext{
${ }^{313}$ Barth describes Christ's time as a "present" that "includes the past and future," as a "simultaneously present, past and future." $C D$ III/2, 465. Commenting on Heb 13:8, he argues that this passage "means more than that the man Jesus lived in a movement from yesterday through to-day to tomorrow." Ibid., 463. For the Swiss theologian, "Jesus Christ belongs not only to yesterday, or to-day, or an indefinite future. He belongs to all times simultaneously. He is the same Christ in all of them. There is no time which does not belong to Him. He is really the Lord of time." Ibid., 466. Barth claims that "the time of Jesus is not only a time like all others; it is also different from them. For all other times are confined to the three dimensions. They begin, they endure, and they come to an end. According to the standpoint of the observer, they are future, contemporary or past." However, "these limitations ... do not apply to the time of the man Jesus." The Swiss theologian explains the time of Jesus in the following way: (1) "the life of the man Jesus has a beginning, and His time was once future. Yet this does not mean that it did not then exist"; (2) "the life of Jesus has duration, and therefore it was once contemporary. Yet this does not mean that it was present only in its duration, and from the standpoint of contemporaries." Rather, "this present reaches back to His past when His time was still future, and forward to His future when His time will be past"; (3) "the life of Jesus comes to an end and therefore it became past. Yet," in the light of the resurrection, "this does not mean that it then ceased to be." Ibid., 463-464; italics mine.

${ }^{314}$ Referring to Exod 3:14 as "the being of Yahweh in time," Barth stipulates that "the allinclusive 'I am' rules out any notion that the three dimensions, present, past and future, simply follow one another in succession." In his Christological remarks, the Swiss theologian claims, "I [Christ] am all this simultaneously. I, the same, am; I was as the same; and I will come again as the same. . . That is why I am the Alpha and Omega, the beginning and the ending, the first and the last. Since my present includes the past and future it is both the first and last of all other times." Ibid., 465. According to Barth, "the removal of the limitations of its yesterday, to-day and tomorrow, of its once, now and then, is the distinctive feature of the time of the man Jesus. For as such, according to its manifestation in Easter-time, it is also the time of God; eternal time." Ibid., 464. For Barth's comments on Heb 13:8, see the previous footnote.

315 Torrance indicates that "the act of election in" Christ "is once and for all," which means that this is "an eternal decision that is ever present" in its "identity with the living person of Christ. As such election is contemporary with us.” Torrance, Incarnation, 180.

${ }^{316}$ For Barth, "God's predestination is a completed work of God, but for this very reason it is not an exhausted work, a work which is behind us. On the contrary, it is a work which still takes place in all its fulness to-day. Before time and above time and at every moment of time God is the predestinating God, positing this beginning of all things with Himself, willing and ordaining, electing and deciding, pledging and committing (us and first of all Himself)." $C D$ II/2, 183. Therefore, divine predestination "happened,
} 
Likewise, the notion that Christ's past does not cease to be, ${ }^{317}$ emphasized in the constant contemporaneity of His earthly history, is the meaning of the heavenly intercession (Rom 8:34; 1 John 2:1; Heb 7:25) of Christ's eternal priesthood. ${ }^{318}$ Even though the emphasis of this notion is on what happens after the ascension, a systematic reflection in light of the ontological commitments described in the previous sections on Divinity and Humanity gives the impression that the simultaneous divine salvific action did not take place (in an ultimate ontological sense) in Christ's earthly history, but was already simultaneously real in God's eternity. In other words, this earthly history would not be made eternal in the ascension, but would be already real in the simultaneous God. Barth does not seem to draw this implication of his own theology, but he emphasizes the

and it also happens," as "an act which occurs in the very midst of time no less than in that far distant pretemporal eternity.” Ibid., 184-185.

${ }^{317}$ According to Torrance, the history of the earthly Jesus is different from all other historical happenings in the sense that it does not flow away to the dust of the past. His history is not made up of "temporal or temporary actions" or characterized by the limits of "corruption and decay," but "remains eternally real and alive happening." Torrance, Incarnation, 67, 187. In his remarks on the "historical life of Jesus," Torrance points out "that historical happening is one that does not simply fall within the limits and corruption and decay of mere historical happening. Unlike other historical happenings that flow away into the past and tumble down into the dust, this historical happening remains eternally real and alive happening." Ibid., 67. For the Scottish theologian, "the deity of Christ is . . the guarantee that the actions of Christ are not in time only, not just temporary or temporal actions, but the eternal action of God, eternally real in the Godhead.” Ibid., 187.

${ }^{318}$ Barth reads these biblical passages of intercession under the assumption that Christ "not only did but does stand before God for us_-not in a different form but in exactly the same form as He stood before Him for us 'in the days of His flesh' as the Judge judged and the priest sacrificed." $C D$ IV/1, 314; italics mine. This same assumption underlies his reading of passages related to Christ's eternal priesthood in Hebrews $(5: 6 ; 6: 20 ; 7: 17,24 ; 9: 12,24 ; 10: 14)$, as is connected to his understanding of the sameness of Christ in Heb 13:8. The Swiss theologian claims, "It is no accident that the Epistle to the Hebrews which emphasises this so strongly brings out the To-day [contemporaneity] so sharply in the call to faith, repentance and obedience $\left(3^{7}, 15,4^{7}\right)$. These are just a few of the explicit statements of the New Testament about the eternal unity, or the temporal togetherness, of the humiliated and the exalted, the crucified and the risen Jesus Christ, the obedience of the Son and the grace of the Father." According to the assumption mentioned above, Barth stipulates that “a number of verses in the so-called 'high-priestly' prayer (Jn. 17) ought to be regarded even in the sense of the Evangelist himself as prayers of the exalted Christ for His own and for His work in the world. This unity and togetherness are-if we look back to the event of Easteramong the self-evident presuppositions of the whole of the New Testament." Ibid. 
contemporaneity or simultaneity of what happened in the life and death of Christ, "the atonement made then and there," to those who lived and live before and after this historical event. ${ }^{319}$ In this view, there is no sequence of actions-Christ's earthly sacrifice followed by His heavenly intercession — as affirmed by “older dogmatics," which would chronologically distinguish the person and work of Christ from a soteriology of applicatio salutis. ${ }^{320}$ Instead of initiating another type of action (heavenly intercession) that makes His atonement on earth contemporary and available to people throughout history, the resurrected/ascended Christ inaugurated another type of time, which makes His atonement contemporary to people at all times. ${ }^{321}$

In this context, the atonement of the cross does not come to human beings because Christ initiated a new intercessory activity in heaven that is contemporaneous to

${ }^{319}$ Ibid. In his words, this atonement comes "to us and become our atonement." Ibid. Barth elaborates on this question as follows. "How can that which has happened once, even if it did happen for us, be recognised to-day as having happened for us, seeing it does not happen to-day? . . How can that which happened once have happened for us when we who live to-day were not there and could not experience it ourselves? ... How can we to-day exist as those for whom it happened when it happened once and not to-day?" Ibid., 287. This is not only a temporal but also a spatial problem. See ibid., 288-290.

${ }^{320}$ Barth explains that "the doctrine of the munus sacerdotale the older dogmatics had a second section on the intercessio Christi side by side with the idea of the satisfactio vicaria," which attempted to solve the "transition from the understanding of the person and work of Christ to soteriology proper, to the question of the applicatio salutis." Ibid., 314. Barth's position seems to presuppose that the atoning work of Christ was finished with His death and resurrection. According to this presupposition, the applicatio salutis cannot be considered part of Christ's atoning work. In the applicatio salutis of older dogmatics there is a "temporal sequence, in which the Holy Spirit does His work here and now in men [which parallels Christ's intercession in heaven] - the outworking of the reconciliation accomplished there and then on Golgotha." In contrast, for Barth, there is not "a series of different divine actions, but only as the order of different 'moments' of the one redemptive occurrence coming to man in the simul of the one event," which means a collapse of "the dualism between an objective achievement of salvation there and then and a subjective appropriation of it here and now, in favour of a recognition of the simultaneity of the one act." $C D$ IV/2, 502-503.

${ }^{321}$ Barth argues that the resurrected Christ "did not continue to be enclosed in the limits of the time between His birth and death, but as the One who was in this time He became and is the Lord of all time, eternal as God Himself is eternal, and therefore present in all time." $C D$ IV/1, 313. Therefore, "the eternal action of Jesus Christ grounded in His resurrection is itself the true and direct bridge from once to always, from Himself in His time to us in our time. Because as crucified and dead $\mathrm{He}$ is risen and lives, the 
us, but because Christ is in another "time" where His life/death is contemporaneous to us (His intercessory life/death is now a heavenly intercession in the sense of being an ever present reality). ${ }^{322}$ According to this perspective, the intercession of the ascended Christ does not constitute a new activity in heaven for human salvation, but the universalization of His intercessory life and death (His once and for all salvific work) to all times on earth. In other words, in His resurrection and ascension, the earthly history of Christ is an ever present reality. ${ }^{323}$ In this view, the heavenly intercession of Christ "is the eternal act of the crucified and risen One for us, the one truly contemporaneous divine act to us, the Today, To-day! Of atonement." ${ }^{, 324}$ Because Christ's resurrection is a contemporaneous event, believers are not justified by God on the basis of an application (performed by the heavenly Christ) of the benefits of Christ's crucifixion in the past. Rather, if His

fact of His death on the cross can never be past, it can never cease to be His action." Ibid., 315.

322 According to the idea of "togetherness in time" of the resurrected Christ, the ascended Christ "not only did represent us, He does represent us. He not only did bear the sin of the world, He does bear it. He not only has reconciled the world with God, but as the One who has done this, He is its eternal Reconciler, active and at work once and for all. He not only went the way from Jordan to Golgotha, but He still goes it, again and again. His history did not become dead history. It was history in His time to become as such eternal history - the history of God with the men of all times, and therefore taking place here and now as it did then." Ibid., 313-314. In this sense, "there is no moment in which Jesus Christ is not Judge and High Priest and accomplishes all these things. There is no moment in which this perfect tense is not a present. There is no moment in which He does not stand before God as our Representative who there suffered and died for us and therefore speaks for us." Ibid., 315. "He is the same here and now as He was there and then: the Mediator between God and us men." Ibid., 314.

${ }^{323}$ According to Barth, "He who was crucified is risen, and as such He lives unto God (Rom. $6^{10}$ ). $\mathrm{He}$ is the same yesterday, to-day and for ever. This temporal togetherness of the Jesus Christ of Good Friday and the Jesus Christ of Easter Day as created by the divine verdict is the basis of life for men of all ages. And as such it is the basis of the alteration of their situation. The event of Easter Day is the removing of the barrier between His life in His time and their life in their times, the initiation of His lordship as the Lord of all time. What He has done in His time He has done as the Representative of all other men, as the elect man, for them. In His resurrection it is fixed that what He did in His time He did in their time for and to them." Ibid., 316. This entire notion seems to be based on the idea that the ascended Christ is ontologically (particularly in terms of space-time) like God. Barth argues that the resurrected Christ "is (in the same way as the One God) the one Mediator between God and man ( 1 Tim. $2^{5}$ ), He was this in the event of Good Friday to be it for ever." Ibid., 313.

$$
{ }^{324} \text { Ibid., } 316 .
$$


resurrection is contemporaneous to all human beings, "God's verdict when he raised Him to life beyond death was His verdict on them."325

In the transition from the existent and visible old time or old age to the full revelation of the already existent new time/age, ${ }^{326}$ the presence of the contemporaneous ascended Christ on earth is mediated by the Spirit ${ }^{327}$ through physical instruments in the church (such as Scripture, preaching, and the sacraments), ${ }^{328}$ which are somehow

${ }^{325}$ Ibid. As Barth emphasizes, "In Jesus Christ the alteration of the human situation did take place, and does take place to-day." Ibid., 317. The Swiss theologian interprets the NT imperatives about the dying of the old humanity (Rom 8:13; Col 3:9; Gal 5:24) as "consequences of the dying of man which has already taken place. They are commands to attest this event." Hence, "there can be no question of any repetition or representation of that event, or even of an actualisation which has still to be effected. It needs no completion or re-presentation." Ibid., 295.

${ }^{326}$ Barth argues that "the new time which already exists triumphs over the old which therefore still exists also." $C D \mathrm{I} / 2,56$. But he emphasizes that "the alteration of the human situation which has taken place in Him can be, and apart from the community is in fact, hidden from the world," being perceived "only by faith and not by sight." $C D$ IV/1, 318-319. Likewise, Torrance highlights that "the church ... lives ... in two times," in "the time of decay that flows down into the past and into the ashes of death, but also in the time of the risen Saviour and of the new creation that is already a perfected reality in him." Torrance, Atonement, 256.

${ }^{327}$ By implication, it is the Spirit who really performs a mediatory role, and not necessarily the ascended Christ. To put it differently, Christ is salvation in act, and the Spirit performs revelatory mediation of the new age in the old age.

${ }^{328}$ According to Barth, after Christ's ascension, “there began a time in which He was no longer, or not yet again, directly revealed and visible and audible and perceptible (as He had been) either to the disciples, the community, or the world: directly, of course, in the divine verdict pronounced in that event and received by them, but not without the mediation of recollection, tradition and proclamation; the living Word of God, but not without the ministry of the attesting word of man which is proclaimed and heard. There began a time in which He was and continues to be and ever again will be directly present and revealed and active in the community by His Spirit." $C D$ IV/1, 318. For the Swiss theologian, the "being of Jesus Christ is not directly present to us. It must be present to us and can be present to us only indirectly, namely, through the proclaiming of the Word first by Holy Scripture and then also by the Church. If the being of Jesus Christ is present to us, this occurs altogether in such a way that it is equated with the word as a physical medium of self-understanding and self-impartation on the part of the human spirit, the word of Scripture and the word of preaching becoming the Word of God." $C D \mathrm{I} / 1,138$. Therefore, the "Word of God is also natural and physical because without this it would not be the Word of God that is directed to us men as spiritual-natural beings, really to us as we really are. This is why the sacrament must stand alongside preaching. This is why preaching itself is also a physical event." Ibid., 134. In this sense, the Swiss theologian claims that "Jesus Christ becomes contemporaneous through Scripture and proclamation." Ibid., 150. Likewise, Torrance stipulates that "communion with Christ through the Spirit gives the church participation here and now in the mystery of Christ, which takes concrete forms in the word and sacrament." Torrance, Space, Time and Resurrection, 305. The Scottish theologian adds, "Although we communicate with him [Christ] immediately through the Spirit, he is mediated to us in our sense experience 
analogous to the earthly spatio-temporal humanity of Christ. ${ }^{329}$ Concerning this point, two emphases may be discerned in the ontological model.

The first emphasis (Barth) sees the physical instruments as revelatory pointers or witnesses of the new time/age. ${ }^{330}$ Concisely, Scripture is a witness of past revelation, ${ }^{331}$ and on this basis proclamation and the sacraments proclaim future revelation in the form of promise. ${ }^{332}$ In the condition of witness, preaching does not put the Lordship of Christ

only through the sacramental elements." Ibid., 310. For studies on the sacraments in Barth and Torrance, see James J. Buckley, "Christian Community, Baptism, and Lord's Supper," in The Cambridge Companion to Karl Barth, ed. John Webster (Cambridge: Cambridge University Press, 2000), 195-211; Hunsinger, “The Dimension of Depth," 155-176; Molnar, Thomas F. Torrance, 295-394. Barth seems to consider himself a new-Zwinglian in his understanding of the sacraments. See $C D$ IV/3, 130.

${ }^{329}$ Barth assumes that "the spiritual nature of the Word of God as distinct from naturalness, corporeality, or any physical event. We hasten to add that there is no Word of God without a physical event. The fact that preaching and sacrament belong to it is also a reminder of this. So, too, is the letter of Holy Scripture. So finally and supremely is the corporeality of the man Jesus Christ. But all this does not justify us in saying that the Word of God is equally and in the same sense both spiritual and also natural or physical. There is here in all forms of the Word of God an upper and lower aspect." $C D \mathrm{I} / 1,133$; italics mine. The identification of the Word of God with Christ is evident in the statement that "Jesus Christ Himself lives in the message of His witnesses, lives in the proclamation of His Church . . experience of God's Word, then, must at least be also experience of His presence." Ibid., 206. The Swiss theologian seems to make a parallel between Christ's humanity, Scripture, and proclamation when he claims, "It is by choice that the Word of God is identical with the humanity of Christ, Holy Scripture, and proclamation, and is thus a temporal event." Ibid., 157. Barth explains that "the event of revelation . . has everywhere a natural, bodily, outward and visible component-from the creation . . ., by way of the concrete existence of the people of Israel in Palestine, the birth of Jesus Christ, His physical miracles, His suffering and death under Pontius Pilate, His physical resurrection, right down to His coming again and the resurrection of the body." $C D$ II/1, 265.

${ }^{330}$ According to Barth's definition, a witness points "in a specific direction beyond the self and on to another." $C D \mathrm{I} / 1,111$. Therefore, Scripture, preaching, and sacrament are witnesses in the sense that they point to revelation, which is beyond them.

${ }^{331}$ For Barth, Scripture "is not in itself and as such God's past revelation." Rather, "the Bible, speaking to us and heard by us as God's Word, bears witness to past revelation.” Ibid. The Swiss theologian stipulates that Scripture can become an instrument of present revelation. In his words, "the Bible is God's Word to the extent that God causes it to be His Word, to the extent that He speaks through it." Ibid., 109. In this case, Barth argues that Scripture "must be proclaimed in the Church" in order "to become God's Word for us.” Ibid., 121.

332 Barth speaks of "revelation attested in Holy Scripture and proclaimed in preaching and sacrament." Ibid., 160. He explains that "preaching and sacrament are . . . the promise of future revelation on the basis of the revelation that has already occurred." Ibid., 92. Taking into account that preaching and sacrament are proclamation, they seem to be qualified by Barth as instruments and witnesses, as he describes the significance of proclamation as "only secondary, and indirect, that of an instrument and 
in effect, but only attests that it "is already in effect." ${ }^{, 333}$ Similarly, the sacraments are a symbolic expression of the reality that the church is gathered around Jesus in its

worship. $^{334}$

In its turn, the second emphasis (Torrance) views the physical instruments in a deeper level of revelation. They do not merely point to the new time/age but offer a taste of it. According to this second emphasis, the eucharist is a revelatory taste of the new time/age in the old time/age. ${ }^{335}$ While the new time in its wholeness is simultaneously one, the sequentiality of the old time implies a brokenness of the fractions of time (the fleeting nature of the present) that requires a constant repetition, in which what is given once and for all (eternity/new time) must be given anew (sequential/fallen time). ${ }^{336}$ In this

witness" with regard to the Christ's work. $C D$ IV/1, 315.

${ }^{333} C D \mathrm{I} / 1,153$. "Preaching does not put it [the lordship of Christ] into effect; preaching declares and confirms that it is in effect. It is proclamation of the Word of God when it proclaims it as something that is already in effect." Ibid.

${ }^{334}$ According to Barth, "There is obviously no baptism or Lord's Supper without His real presence as very God and very Man, both body and soul. But this presence cannot be regarded as restricted to what were later called the 'sacraments.' For these are only a symbolical expression of the fact that in its worship the community is gathered directly around Jesus Himself, and lives by and with Him, but that through faith He rules over the hearts and lives of all even apart from worship." CD III/2, 467-468; italics mine. See also $C D \mathrm{IV} / 1,296 ; \mathrm{I} / 1,95$.

${ }^{335}$ Torrance stipulates that the church lives already in the time of new creation (even though it still lives in the old time of this passing world) "through the koinonia of the Spirit." Torrance, Atonement, 256. The Scottish theologian sees the eucharist as the main locus of this koinonia. In his view, "as often as we communicate in the sacrament [the eucharist], we participate in the new time of that kingdom." Ibid., 260. In this way, he describes the eucharist as an "eschatological anticipation both of the Advent of the Son of Man and the rapture of the Church." Torrance, Conflict and Agreement in the Church, 2:189.

336 Torrance explains that, in Christ, "redemption has been wrought once and for all, nevertheless it is an event that involves this new time, and as such it transcends the limitations and relativities of history ... and endures for ever. It endures and abides for ever as new time just because it is indissolubly united to the eternal." Torrance, Conflict and Agreement in the Church, 2:162. The Scottish theologian believes that "baptism and eucharist as two aspects of the same event," but these two sacraments work with different temporal dimensions. In baptism, redemption is revealed according to the dimension of new time, as "a datum once and for all" and, therefore, it is celebrated only once. On the other hand, in the eucharist, redemption is revealed according to the dimensions of old time, as "a dandum which must be given anew, day by day, in the conditions of our fallen world." Ibid., 2:164. Because of this distinction between new and 
sense, the eucharist, constantly celebrated in the church, is an instrument for the revealed presence of new time in the midst of old time. ${ }^{337}$ When the new creation/time is completely revealed in the eschaton, ${ }^{338}$ the instrumentality of the eucharist will not be necessary anymore. ${ }^{339}$ The revelatory taste provided by the eucharist constitutes an echo of new time in fallen time, an echo of the heavenly worship before the throne of God in the church. ${ }^{340}$ In both emphases of revelatory pointers (Barth) and revelatory taste

old time, wholeness/simultaneity and division/sequentiality, redemption is "at once a complete reality and an eschatologically reiterated event until Christ comes." Ibid., 2:156. Torrance speaks of baptism as the "sacrament of justification" and the eucharist as the "sacrament of the sanctification." Torrance, Atonement, 307. The idea of sanctification as a complete reality (in Christ) being always given anew in the broken sequentiality of fallen or old time, as implied in Torrance's conception of eucharist, is similar to Barth's notion of sanctification. According to Hunsinger, the Swiss theologian understands sanctification not as a "process of gradual growth" (the "more and more" of Calvin), but as an "again and again, continually from without, and ever anew." Hunsinger, Evangelical, Catholic, and Reformed, 211. Again, the complete reality is sequentially perceived only because of the present human condition in time. Hunsinger adds, "Justification and sanctification were, for Barth, two ways of describing reconciliation as a whole. Although they took place in Christ simultaneously, we cannot apprehend them simultaneously, but only sequentially." Ibid., 204-205. Therefore, sanctification in the ontological model, to use Hunsinger's language, is not a final state to be reached through a growing process. Rather, it is a "provisional anticipation" of the final state of redemption. See ibid., 214-215. For further information regarding Torrance's idea of justification and sanctification, see Torrance, Theology in Reconstruction, 150-168.

${ }^{337}$ For Torrance, the eucharist "is the form which our sacramental union with Christ takes place within the brokenness and the divisions of history, in which the Church inevitably partakes, are revealed to be but the shell of the old life which passes away." Torrance, Conflict and Agreement in the Church, 2:173. In this sense he describes the eucharist as a "temporal repetition or continuity in the relativities of historical succession." Therefore, in the eucharist, "the Church transcends itself in the new creation . . transcends its embroilment in the passing forms of this world." Ibid., 2:174.

${ }^{338}$ According to Torrance, "The sacraments tell us ... that the reality of the new creation is temporal fact here and now, even though its reality, veiled since the ascension of the Lord, is yet to be unveiled at the parousia. The New Testament emphasis upon the future is not so much the future of the reality but the future of its full manifestation, so that the eschatological tension involved in the sacraments is the tension between the time of a present but hidden reality and the time of the same reality revealed in the parousia." Ibid., 2:163.

${ }^{339}$ For Torrance, the sacraments "will finally break up at the parousia," as they "will give way to literal reality." Ibid., 2:173-174. He adds, "In the Eucharist the wholeness of its union in Christ is received only sacramentally in the brokenness of time, and the more that wholeness presses toward its complete unveiling at the parousia the more evident does it become that the forms of the Church's existence in this passing world are broken up in order that the abiding reality of the new creation may appear." Ibid., 2:173.

${ }^{340}$ See Torrance, Atonement, 71; Torrance, Royal Priesthood, 95-96. Torrance believes that the eucharist brings about a twofold participation (a general participation in baptism, and a special participation of ministry in the eucharist) in the priesthood of Christ. Torrance, Royal Priesthood, 74, 82. However, the 
(Torrance), the contemporaneous Christ uses physical instruments in His interaction with human beings on earth, but they are witnesses of the reality of Christ (new creation/time) or echoes of His reality in fallen time.

Overall, the ontological model advances the idea that old time (sequentiality) will be eschatologically replaced by new time (simultaneity). ${ }^{341}$ The first elucidation necessary here is whether the new time should be named time. ${ }^{342}$ More specifically, is it ontologically meaningful to call non-sequentiality time? Since the simultaneity of new time actually refers to the simultaneity of eternity, is there a significant ontological difference between new time and eternity that justifies the use of these two different

Scottish theologian affirms that "the priesthood of the Church is not a transcription in the conditions of this passing age of the heavenly Priesthood of Christ. No transubstantiation or fusion between the two is involved." The priesthood of the church is "not a translation into terms of space and time of a heavenly order" nor a historical "replica of an eternal and celestial reality." Ibid., 97. According to Torrance, it is "not easy to state precisely the relation between the ministry of the Church and the ministry of Christ described as participation." In contrast to Catholicism, this is not "a relation of identity." On the other hand, against the "sectarian view of the Church or ministry," this is "not another ministry different from the ministry of Christ, or separable from it." In fact, this participation is defined in terms of service. "The Church participates in Christ's ministry by serving Him who is Prophet, Priest, and King." Ibid., 37. This service is described as "the edification of the whole Body" until it "reaches the fulness of Christ." Torrance points out that "this order of the ministry will pass away at the parousia, when the real priesthood of the one Body, as distinct from the institutional priesthood, will be fully revealed.” Ibid., 81 .

${ }^{341}$ I was not able to find in the writings of Barth and Torrance an explanation of the nature and shape of this eschatological event. While the present research is not an exhaustive study of Barth and Torrance, I suspect that the lack of interest of the ontological model in questions regarding the origin of this world (including the discussion on original $\sin$ ) is compatible with the lack of details in the model about the end of the present world.

${ }^{342}$ Van den Brom criticizes Barth's view of time (and I would add Torrance here) because he uses the term time for different cases. More specifically, he underlines "the differences between God's time" (related to the new time) "and human time" (the old time): "in God's time, past, present, and future are seen as a simultaneous unity or as nunc aeternitatis, whereas in human time there is the fleeting nature of the present and its separation from past and future." However, "the weak point in Barth's argument is that he does not give a clarification of why we should use the same word 'time' in both cases." Van den Brom adds, "The logic of Barth's arguments assuring us that God (1) is 'pure/real duration', (2) that he is 'absolutely real time', (3) that he is the prototype of time, and, at the same time (4) that he is simultaneously 'timeless', seems to me an obscure and paradoxical enterprise. The simplest solution of this paradox is the observation that Barth is equivocal on the subject of time." Van den Brom, "Time and Eternity in Christian God-Talk," 49. 
terms $?^{343}$ Furthermore, if the non-simultaneity of fallen time is a problem to be healed, is the non-simultaneity of space problematic as well? ${ }^{344}$ If so, why is there no mention of a new (simultaneous) space? ${ }^{345}$ In fact, these questions introduce an unclear ontological aspect of the conception of time-space in this model, namely, the transition from old time to new time. ${ }^{346}$ To be sure, the ontological model holds a relational view of space-time,

\footnotetext{
${ }^{343}$ Langdon highlights that one of the main criticisms that the doctrine of time in Barth has received is the charge of timelessness, which could be related in my view to his idea of simultaneity found in the accounts of new time and eternity. According to this critique, even though he attempted to escape the traditional view of timelessness in Christian theology he was not able to go too far from it. Langdon, God the Eternal Contemporary, 22-35. For examples of this type of criticism, see Robert W. Jenson, God after God: The God of the Past and the God of the Future, Seen in the Work of Karl Barth (Indianapolis: BobbsMerrill, 1969), 154; Roberts, "Barth's Doctrine of Time," 100-146; Colin E. Gunton, Becoming and Being: The Doctrine of God in Charles Hartshorne and Karl Barth (Oxford; New York: Oxford University Press, 1978), 181; Padgett, God, Eternity, and the Nature of Time, 141-145. Langdon adds that another type of criticism to Barth's doctrine of time concerns the problem of a fulfilled time (the reality of reconciliation as completely fulfilled), in which the church, the ascension and the future parousia receive inadequate attention. Langdon, God the Eternal Contemporary, 37-41. For examples of this type of criticism, see David Ford, Barth and God's Story: Biblical Narrative and the Theological Method of Karl Barth in the Church Dogmatics (Frankfurt am Main: Peter Lang, 1981), 145-146; Farrow, Ascension and Ecclesia, 229254.

${ }^{344}$ This point raises the question whether sequentiality is really a problem to be removed. Henry Blocher argues that "Barth expressly deprives succession of any ultimate significance." Indeed, "for theological meaning, Barth rejects the sequence of history, the "coming after' through successive stages." Henry Blocher, "Karl Barth's Christocentric Method," in Engaging with Barth: Contemporary Evangelical Critiques, ed. David Gibson and Daniel Strange (New York: T\&T Clark, 2008), 39. If sequentiality is a problem, this begs the question whether sequentiality (fallen time) was caused by sin or creation. Interpreting Barth, Langdon and Hunsinger disagree on this point. For the former, "time's falleness is not inherent in its being created." Rather, "fallen time ... is a result of human sin filling the created time humans are given." Langdon, God the Eternal Contemporary, 42. On the other hand, Hunsinger stipulates that "time's healing is distinct from salvation from sin," as "time's wounds ... are inherent in the good creation. They may be exacerbated and corrupted by sin, but they are not identical with it, nor are they hostile to God. When measured by eternity, they are merely imperfections, not corruptions." Accordingly, "the incarnation resolves a plight logically independent of sin, namely, the plight of transitoriness and dissolution into nonbeing." Hunsinger, Disruptive Grace, 204.
}

${ }^{345}$ Comparing Barth's notions of space and time, Callender finds a lack of distinct terms to speak of 'God's space' (i.e., 'eternity') in differentiation from 'creaturely space' (i.e., 'time'),' as he has distinct terms for God's time (eternity) and creaturely time (time). Callender, "A Theology of Spatiality," 241. In this dissertation I add to this comparison the fact that Barth and Torrance do not use the language of fallen space and new space as they do with time, even though they assume that space and time need to be healed.

${ }^{346}$ I agree with van den Brom that "Barth's distinction of revelation time and fallen time" (and I would add Torrance also) "causes rather more conceptual confusion than conceptual clarity." Van den Brom, "Time and Eternity in Christian God-Talk," 40. 
meaning that they are not entities in themselves or containers. ${ }^{347}$ Rather, different beings have distinct experiences of spatiality-temporality. Thus, God and human beings experience spatiality-temporality differently because they are different kinds of beings, establishing peculiar relationships with space-time (God simultaneously, and human beings sequentially). However, the idea of healing space-time seems to imply that they are considered entities in themselves (containers or even realities), with characteristics that need to be changed. ${ }^{348}$ In other words, the container/reality of sequentiality (old time) would be replaced by the container/reality of simultaneity (new time). ${ }^{349}$

A possible solution to the seemingly discrepancy of holding a relational view of time-space, on the one hand, and affirming a replacement of old time by new time, on the other, would be the explanation that the language of replacement is metaphorical. In this explanation, it is the transformation of humankind (new beings) that will bring about a new experience of temporality or a new relationship with time. Time as such does not change. Nevertheless, this option does not seem to be available to the ontological model, as the model holds that the being of humankind is already (and always) "changed" 350 in

\footnotetext{
${ }^{347}$ See the discussion above about Humanity in the ontological model.

${ }^{348}$ Van den Brom argues that by "using an independent entity named 'the time,"” Barth (and I
} would add Torrance) "neglects the fact that the notion of time is always used in relation to events, actions, life stories and processes. By distinguishing between God's reality and the reality of human creatures having their own time, Barth s reconstruction of the revelation event results in a realistic conception of time, that is to say: a container view of time which is independent of events or actions implied by this realistic concept." Van den Brom, "Time and Eternity in Christian God-Talk," 41-42.

349 As Van den Brom puts it, in "a clash between God's real time and the human fallen time, there is also present a clash of two different realistic time containers one of which will finally disappear." Ibid., 42.

${ }^{350}$ In fact, the entire logic of the ontological model, as described up to this point, indicates that there is no real change here. The reality of transformed human beings eternally exists in God. If there is change in the incarnate Christ, this is a noetic change. 
Christ. It is the difference of the nature of the times (old and new) that makes this new being (existing in simultaneous temporality) invisible to us. To put it more sharply, the difference of times is necessary for the connection between Christ's humanity and our humanity in the ontological model, as it justifies the gap between the full reality of a new humanity and the fallen humanity we see in our world. As a result, the relational view of time-space becomes unclear. Moreover, the transition from old time to new time does not seem to include a proper account of the status of space in this transition. ${ }^{351}$

In summary, the ontological model depicts the heavenly realm of the ascended Christ as incomprehensible spatiality and simultaneous time. Thus, His earthly spatiotemporal (characterized by sequentiality) humanity became a different (equivocal) spatiotemporal reality. After the resurrection, Christ not only exists in this incomprehensible and simultaneous reality, but He Himself is a micro- $\operatorname{cosmos}^{352}$ that contains the reality of the new creation of the earthly world, including the new humanity of concrete human beings. This new reality is particularly characterized by a new (simultaneous) time that will replace the reality of old (sequential) time of the fallen world. In short, the ontological model describes the resurrection and ascension of Christ as the transformation of His earthly atoning history into an eternal (simultaneous/contemporaneous) event that becomes present at all times. This

${ }^{351}$ Discussing the status of space, and even time, in the new creation, Wilkinson is unsatisfied with the depth of Torrance's proposal. He asks, "How is space-time different? Torrance uses the language of redemption, healing and restoration." However, "for someone who specifically states that he wants to explore this issue in both theological and scientific terms, Torrance is then disappointing in actually describing what it means for space-time to be healed and restored." Wilkinson, Christian Eschatology and the Physical Universe, 131.

${ }^{352}$ I use the term micro-cosmos here to refer to the person of Christ. However, the term is not ontologically precise, as He contains all humanity actually, which would be in fact a macro-cosmos. 
"transformation" is the ontological reality of His priestly heavenly intercession.

Furthermore, the ontological model depicts Christ's death and resurrection as the precise eschatological moment when the transformation of human beings and of the world takes place. However, in contrast to this chronological reading that presupposes some kind of ontological turning point in the transformation of human beings and the world as taking place in Christ's historical death-resurrection-ascension, the assumption that God has a simultaneous being and action (described in the section above on Divinity) leads to the understanding that the reality of Christ's earthly atoning history (God's salvific action) was already a simultaneous/contemporary event in God, that is revealed (repeated) in the sequential reality of this world through the earthly humanity of Christ. Until the complete revelation of the reality of the new creation in Christ (the parousia) that will replace sequential time by simultaneous time, the ascended simultaneous/contemporaneous Christ uses physical instruments as revelatory pointers or as a revelatory taste of the new creation to human beings on earth.

After the description of these principles of reality in the ontological model, I will briefly outline below their implications for the understanding of Christ's priesthood.

\section{Implications for Christ's Priesthood}

The principles of reality depicted above indicate that simultaneity (timeless in the sense of rejecting sequentiality) is a significant ontological feature of divine reality in the ontological model. God "becomes" or "acts" in earthly (sequential) history only noetically as an ever present event of self-repetition of what He already is in His (simultaneous) eternity, never in an actual real historical sense. This self-repetition may take the form of manifold, even interconnected, actions (especially for the discursive 
minds of human beings) in sequential time.

The idea of simultaneity also conditions the way this model views the person of Christ, who is simultaneously the subject and object of election, the electing God and the elected man. As the object of election, He is simultaneously the object of reprobation as God and the object of salvation as man. According to the principle of divine simultaneity, the ultimate reality of reprobation and salvation, which are eternal non-sequential divine actions, does not seem to be found in earthly (sequential) history through the ontological instrumentality of Christ's humanity, but in the eternal (simultaneous) action of God.

Consequently, in the ontological model, the earthly humanity of Christ seems to be a noetic instrument of revelation of the eternal (simultaneous) action, mediating a divine self-repetition in the sequentiality of historical time. In fact, the principle of simultaneity also characterizes the ascended Christ, who is in the heavenly realm of incomprehensible spatiality and is contemporaneous to all times (simultaneous time).

Furthermore, Christ has in Himself the reality of the new creation of the earthly world, including the new humanity of concrete human beings, and this new reality is defined by a new (simultaneous) time that will replace the reality of old (sequential) time of the fallen world in the complete revelation of the parousia (a full divine selfrepetition). Until this complete revelation, the ascended simultaneous/contemporaneous Christ uses physical instruments (church worship: Scripture, preaching, sacraments) as revelatory pointers or as a revelatory taste of the new creation to earthly human beings in old creation (sequential time).

In the previous chapter, I outlined the understanding of Christ's priesthood in the ontological model as follows: (1) His priesthood is needed primarily because of the 
existential (non-historical fall) broken relationship between humankind and God existing since the beginning of creation, which requires a mediation that propitiates the divine wrath and transforms human beings, perfecting the incomplete original creation; (2) as the priestly agent, Christ is both the subject and object of the priestly reconciliation, as it "takes place" (not as historical sequential acts) in His own being. In this way, His priesthood means mainly God's self-humiliation in Christ in the incarnation and sacrifice. Also, in the resurrected human Christ, "took place" the ontological transformation of human beings (overcoming or healing of the broken relationship between God and human beings existing since creation); (3) Christ's one person, who is the object of His own priestly actions, corresponds to one action, and His single priestly action is the substitutionary sacrifice, which includes His whole intercessory life and death. Christ's substitutionary death means the elimination of sin by the destruction of sinful human beings in Him, leading to their re-creation in His resurrection (Torrance even sees some re-recreation beginning in the incarnation); and (4) the goal of the priesthood is to bring God and humankind to communion, which is already a complete reality in Christ, but will be fully revealed in the parousia. Until then, human beings on earth can have some kind of participation in this reality in the form of an awaking knowledge or liturgical taste of the complete reconciliation in Christ, as the ascended Christ (including His earthly life and death) is contemporaneous to all times (Barth) and mediates glimpses of the new creation in the eucharist (Torrance).

Before I start to clarify features of the priesthood of Christ through the principles of reality in the ontological model, I will concisely highlight what a reading of the components (need, agent, actions, and goal) of His priesthood alone seems to imply. 
First, when a priestly propitiation of the divine wrath in Christ's sacrifice followed by the transformation of human beings in His resurrection is seen from the perspective that God's wrath is part of His salvific grace, the potential conclusion of universalism seems to be a challenge for the representatives of the model, who do not subscribe to this conclusion. ${ }^{353}$ According to universalism, Christ's priesthood benefits all human beings without exception. This universal scope of salvation would match the original incompleteness of creation, as all creation (including all human beings) is eschatologically led through His priesthood to its perfect fulfillment for the first time.

Second, a reading of the need for Christ's priesthood, without an awareness of the principles of reality in the ontological model, gives the impression that the basic incompleteness of original creation is the moral rebellion of human beings since the beginning.

Third, the reading on the agent of the priesthood seems to indicate that God suffers at the cross, and human beings are transformed in Christ's resurrection. Such reading implies a chronological sequence in which a historical God experiences His selfhumiliation (suffering) at the cross. Likewise, the transformation of human beings takes place historically/chronologically in the resurrection. In this sense, Christ is the object of His priestly action particularly at those historical moments.

${ }^{353}$ Barth (see, e.g., CD II/2, 417-418) and Torrance (see, e.g., Atonement, 187-188) reject universalism by affirming divine freedom and criticizing formal logic. However, while the salvific actions of God cannot be squared in human logic, there is no meaningful theological articulation without conclusions and implications, and the criticism of such implications should not be simply dismissed on the excuse that the critique employs formal logic. See Williams, "Barth's Doctrine of the Atonement," 266268. For studies about the debate of universalism in Barth and Torrance, see 'McCormack, "So That He May Be Merciful to All," 227-249; Oliver D. Crisp, “On Barth's Denial of Universalism,” Themelios 29, no. 1 (2003): 18-29; Tom Greggs, "Jesus Is Victor': Passing the Impasse of Barth on Universalism," Scottish Journal of Theology 60, no. 2 (2007): 196-212; Habets, "The Doctrine of Election in Evangelical 
Fourth, a reading of the actions and goal of the priesthood gives the impression that Christ becomes contemporary to every time only at the resurrection/ascension. In short, this reading assumes that the priesthood of Christ would not be a reality at all if the incarnation, the cross, the resurrection, and the ascension had not taken place in history.

However, this does not seem to be the ontological view that emerges when one reads the ontological model in light of its interpretation of the principles of reality.

First, with regard to the incompleteness of original creation, a moral rebellion against God since the beginning of the world does not seem to be the only important problem of creation. Sequential time appears to be a significant problem as well. The ontological model strongly emphasizes that a new creation will replace sequential time by simultaneous time. The need to eradicate sequential time is implicitly part of the need for Christ's priesthood, in the sense that His priestly work leads creation to completion, and this completion includes simultaneous time.

Second, as far as the priestly work is a salvific divine work and God has a simultaneous being (who "becomes" only what He already is, and therefore, does not become but eternally exists) and action, the ultimate reality of Christ's priesthood is not historical but eternal/simultaneous. Accordingly, the humanity of Christ allowed a historical revelation of the eternal reality of the priesthood, which is repeated in the sequentiality of time through the instrumentality of proclamation and sacraments. The incarnation, cross, resurrection, and ascension, and their ongoing repetition in proclamation and sacrament can be regarded as real for us in sequential time. But the

\footnotetext{
Calvinism," 334-354.
} 
ultimate reality behind Christ's priesthood does not seem to be constituted by these historical events. On the contrary, the priestly action of Christ is one because the divine action is simultaneously one.

Third, God does not become the object of Christ's priesthood for the first time in the earthly life and death of the incarnate Christ. And, apparently, the ascension did not eternalize the historical life of Christ. This would imply sequentiality in God, a different reality before and after the ascension. In His simultaneity this was already an eternal reality. Even the salvation of human beings in Christ, which is part of the sequential completion of creation in chronological history, was already a reality in the simultaneous God at the beginning of creation. Therefore, it is not only the ascended Christ who performs a noetic priesthood who reveals a reality accomplished on the cross. Rather, the incarnate Christ and all His earthly life and death (even the cross) seem to be a revelation of a salvific priesthood that is already a reality in the simultaneous God. In other words, the priesthood of the earthly and ascended Christ would be a revelation that repeats a divine reality in the sequentiality of time.

Would the representatives of the ontological model agree with this conclusion? This is a difficult question to be answered. What this study attempts to show is that when we put together their description of Christ's priesthood and their view of divinity, humanity, and cosmology with reference to Christ, this seems to be the logical outcome. Having studied the macro-hermeneutical principles of reality in this model, I will conclude this chapter by briefly summarizing and comparing the interpretation of these principles in the sacramental, the functional, and the ontological models. 


\section{A Brief Comparison of the Models}

The brief summary and comparison outlined here is similar to the one found at the end of the previous chapter. I will follow the sequence used in this chapter for the study of the macro-hermeneutical principles of reality in each model (God, humanity, cosmology, and implications). Moreover, comparative comments (similarities and differences) are accompanied by a table summary, and focus on the systematic articulation of the ideas and not merely the presence or absence of a specific notion.

\section{Divinity: Christ and the Concept of Divine Nature}

The models affirm or are logically close to the idea that God, in His perfection, is timeless/spaceless in His being (for instance, immutable, simple, impassible, nondiscursive knowledge), and consequently His eternal (timeless/spaceless) action is described by His will (predestination). This notion is nuanced in different ways (see Table 5). The sacramental model is more explicit on that, the functional model is less explicit, and the ontological model is logically close to this in its notion of simultaneity.

\section{Table 5. Divinity (sacramental, functional, and ontological models)}

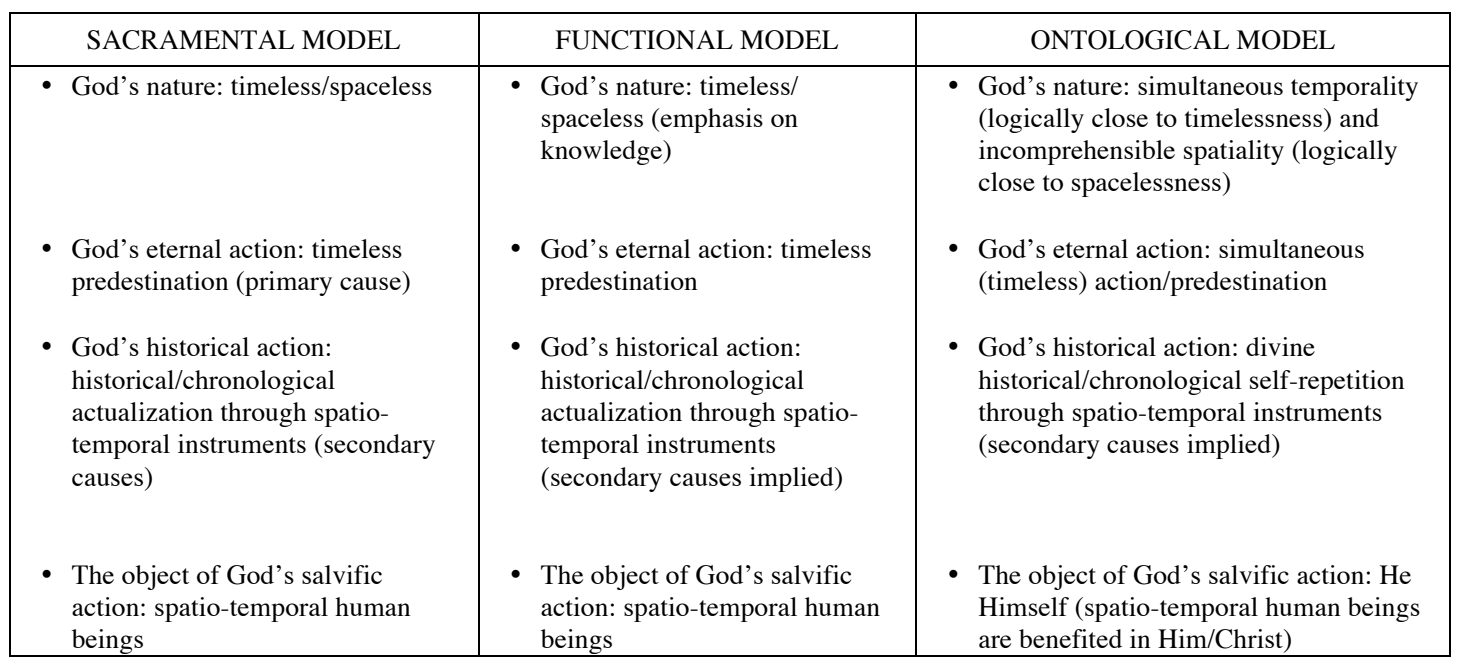


The sacramental model argues that His eternal action takes place in history through secondary (temporal/material) causes in the spatio-temporal world. The functional model does not emphasize secondary causes. However, as long as it highlights God's timeless knowledge and predestination the use of spatio-temporal instruments (secondary causes) seems unavoidable for understanding divine action in history. At the same time that the ontological model attempts to affirm that God is spatio-temporal, His spatiality in this model is incomprehensible and His time is simultaneous, which means that space and time are conceptualized equivocally and without a substantial difference from the timeless-spaceless view.

Inasmuch as the similarity with the timeless-spaceless view is established, the historical action of God takes place through the use of earthly spatio-temporal instruments that repeat the simultaneous divine action into the sequentiality of earthly time. Hence, in all models, what is already a timeless or simultaneous reality in God is actualized or repeated into sequential time. I use the nuanced distinction between actualized and repeated to capture the innovation of the ontological model in comparison with the other models.

While the sacramental and functional models see spatio-temporal human beings as the object of God's salvific (predestinarian) action, and this action is therefore carried through spatio-temporal instruments to reach them, His timeless action is actualized in this way in the spatio-temporal realm of creation. On the other hand, the ontological model stipulates that God is the object of His own salvific action, and human beings are universally benefited with that in Christ. However, this would not be a spatio-temporal 
actualization of the divine simultaneous action, but simply a spatio-temporal revelatory repetition of what is already real in God.

\section{Humanity: Christ and the Concept of Human Nature}

Obviously, the three models agree that Christ's humanity is spatio-temporal (see Table 6). However, they stipulate different levels of relationships between Christ's humanity and divinity, from the perspective of space-time. In the sacramental model, this relationship seems to be consistent with the idea of divine timelessness/spacelessness.

Table 6. Humanity (sacramental, functional, and ontological models)

\begin{tabular}{|l|l|l|}
\hline \multicolumn{1}{|c|}{ SACRAMENTAL MODEL } & \multicolumn{1}{|c|}{ FUNCTIONAL MODEL } & \multicolumn{1}{c|}{ ONTOLOGICAL MODEL } \\
\hline $\begin{array}{l}\text { Christ's human nature: spatio- } \\
\text { temporal }\end{array}$ & $\begin{array}{l}\text { - Christ's human nature: spatio- } \\
\text { temporal }\end{array}$ & $\begin{array}{l}\text { Christ's human nature: spatio- } \\
\text { temporal }\end{array}$ \\
$\begin{array}{l}\text { Instrumentality: secondary cause } \\
\text { (spatio-temporal) of divine } \\
\text { timelessness/spacelessness }\end{array}$ & $\begin{array}{l}\text { Instrumentality: secondary cause } \\
\text { (spatio-temporal) of divine } \\
\text { timelessness/spacelessness }\end{array}$ & $\begin{array}{l}\text { Instrumentality: secondary cause } \\
\text { (spatio-temporal) of divine } \\
\text { simultaneity (logically close to } \\
\text { timelessness/spacelessness) }\end{array}$ \\
$\begin{array}{l}\text { Goal of the instrumentality: } \\
\text { historical actualization }\end{array}$ & $\begin{array}{l}\text { Goal of the instrumentality: historical } \\
\text { actualization }\end{array}$ & $\begin{array}{l}\text { Goal of the instrumentality: } \\
\text { historical revelation }\end{array}$ \\
$\begin{array}{l}\text { Central instrumental role: } \\
\text { passibility (impassible divinity) }\end{array}$ & $\begin{array}{l}\text { Central instrumental role: passibility } \\
\text { (impassible divinity) }\end{array}$ & $\begin{array}{l}\text { Central instrumental role: } \\
\text { historical revelation of } \\
\text { simultaneous (logically timeless) } \\
\text { passibility }\end{array}$ \\
\hline
\end{tabular}

The spatio-temporal humanity of Christ is viewed as a secondary cause or instrument of the divine action in the world. In principle, the functional model also appears to interpret Christ's humanity as a spatio-temporal instrument of His nonspatial/timeless divinity. Even Luther's conception of communication of properties assumes the distinction of spatio-temporal humanity and non-spatial/timeless divinity, inasmuch as Christ's divinity experiences passibility through His humanity (and His 
humanity experiences omnipresence through the divinity).

In the sacramental and functional models, a central instrumental role of Christ's humanity is the experience of passibility in His sacrifice. Christ suffers on the cross through His humanity. The ontological model stipulates that that it is God Himself, as the object of His own action, who suffers on the cross. In this case, a simultaneous God does not experience passibility in the sequentiality of history (cross), but His suffering is eternally (simultaneously) constituted. According to this perspective, Christ's humanity would be an instrument that reveals/repeats divine passibility in the sequentiality of history. Since Christ is the object of divine election (which includes the reprobation/suffering of God and the salvation/transformation of human beings), and not human beings per se, there is no need of a historical application of the salvific divine action to human beings. In this way, the instrumentality of Christ's humanity is more salvific revelation than salvific actualization.

\section{Cosmology: Christ, Heaven, and Earth}

All the three models seem to assume that God's heaven is a timeless/spaceless environment while the earth is obviously spatio-temporal (see Table 7).

As already mentioned, the ontological model does not use this language. Rather, it attempts to describe a spatio-temporal heaven, but its spatiality and temporality are respectively incomprehensible and simultaneous, which characterizes an equivocal use of the terms space and time that is not substantially different from the timeless/spaceless view that also rejects the notion of sequentiality. 


\section{Table 7. Cosmology (sacramental, functional, and ontological models)}

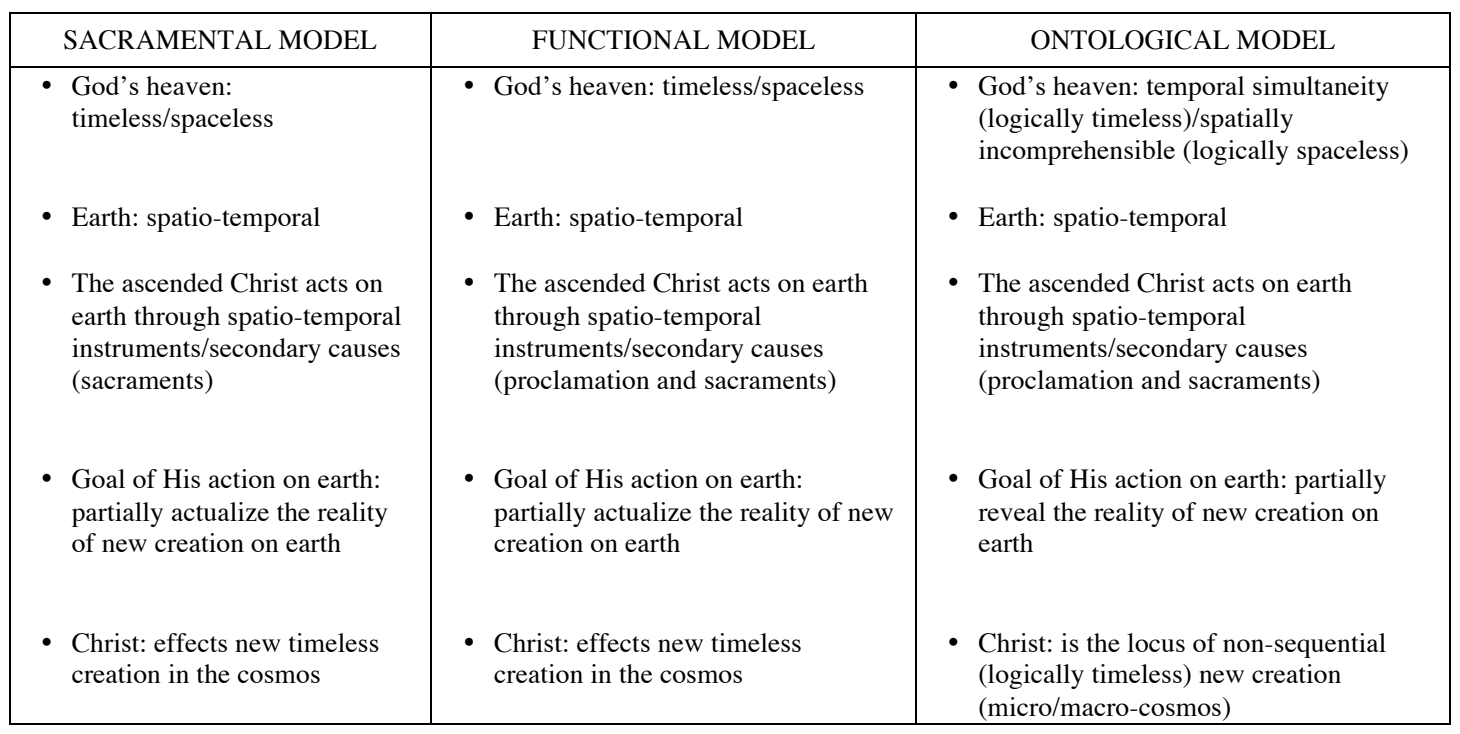

In the sacramental model, the ascended Christ is in a timeless/spaceless realm, and His presence and activity on earth are mediated by spatio-temporal instruments (secondary causes), particularly the sacraments. In principle, the functional model appears to hold a similar assumption, especially in its account of the sacraments. In its turn, the ontological model strongly emphasizes the existence of two realms of reality, one characterized by sequential time (this old creation) and the other by simultaneous time (the new creation). This model has a strong emphasis on this point because the new creation (including transformed human beings) already exists in Christ, who is a kind of micro-cosmos that contains the new creation. In this case, sacraments do not transform human beings per se, bringing about sequentially a partial reality of new creation (as in the sacramental and functional models) in the midst of old creation, but offers sequentially a revelatory witness or a taste of the complete reality of new creation in 
Christ.

\section{Implications for Christ's Priesthood}

In this brief comparison of the implications of the macro-hermeneutical principles of reality for the priesthood of Christ in the three models explored in this research (see Table 8), I will comparatively highlight the main implications of these hermeneutical presuppositions for each structural component of Christ's priesthood.

\section{Need}

With regard to the need for the priesthood, all the three models assume that original creation is incomplete. The presupposition that God is timeless/spaceless, shared by the three models, implies that this incompleteness is intended by the timeless will of God. The ontological model, with its cosmological presupposition that a simultaneous new creation will replace the sequentiality of old creation, indicates that, besides the human rebellion since the beginning, the incompleteness is characterized by sequential time.

Taking into account in what sense Christ's priesthood is necessary, the idea of ontological healing in human beings advanced by the sacramental model is qualified by the instrumentality of spatio-temporal instruments that includes Christ's humanity and the sacraments. The emphasis on divine wrath that requires Christ's priestly propitiation in the functional model seems ontologically problematic when one considers the presupposition of divine timelessness. The wrath of a timeless God is eternally constituted, and not caused by something external to Himself in chronological history. By claiming that God is eternally the agent and the subject of propitiation, the ontological model seems to be more coherent with the presupposition of a timeless God, because His 
wrath and propitiation are found in His simultaneous being, and not in chronological

history. But that would seem to imply that the conflict between good and evil observed in

history is ontologically found in the essential being of God.

Table 8. Implications for CP (sacramental, functional, and ontological models)

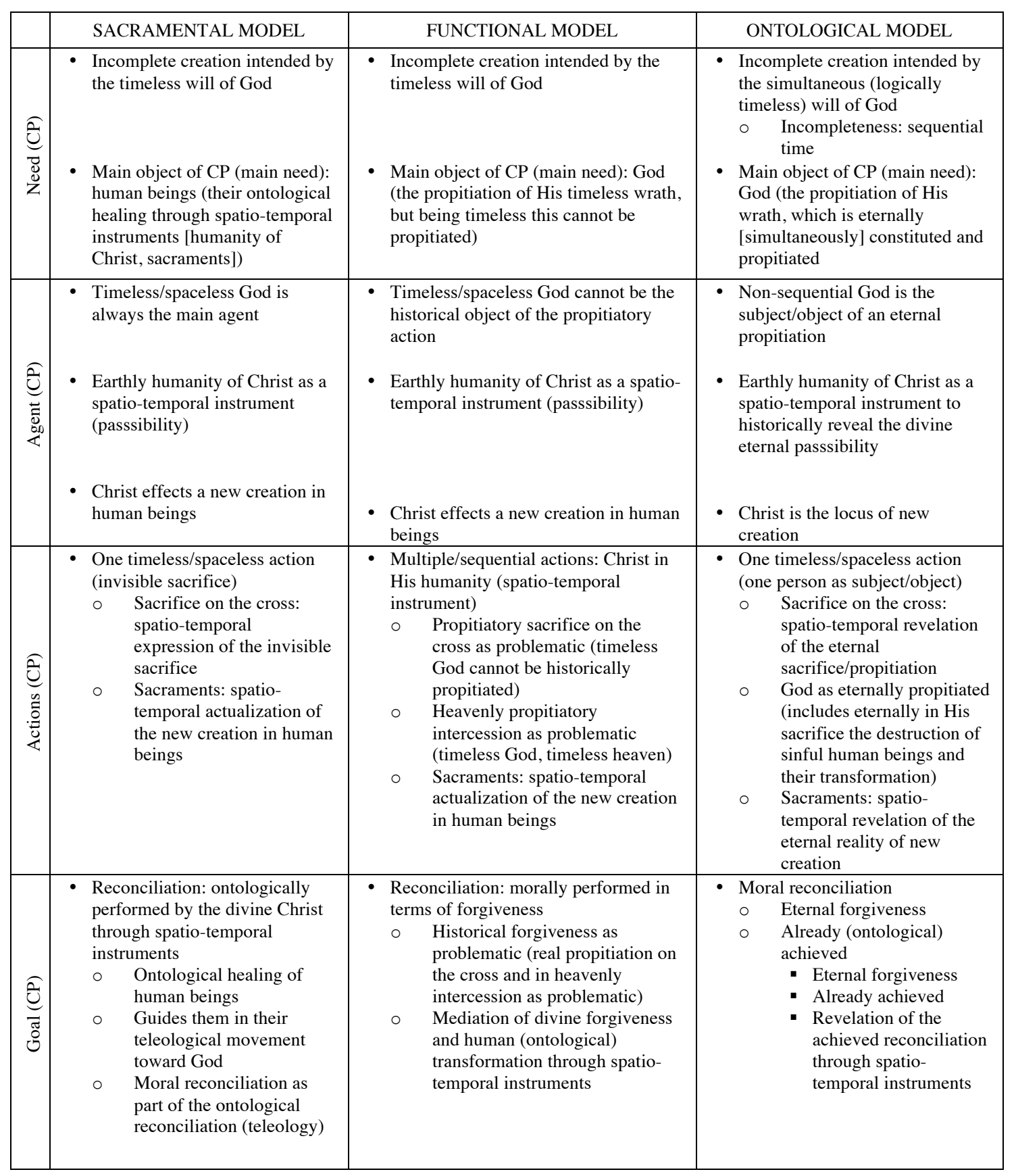




\section{Agent}

As far as the agent of the priesthood is concerned, a timeless/spaceless presupposition of God's being and action favors the idea that He is the subject of the priesthood, as He cannot be the object of a chronological action performed outside of Himself.

This implication favors the sacramental model, which sees the movement of Christ's priestly activity moving from God to human beings for their healing. In this context, the earthly humanity of Christ is a spatio-temporal instrument (secondary cause) that historically actualizes the divine timeless action, particularly in terms of passibility. While the functional model also shares the human body of Christ as instrumentality for passibility, it is difficult for this model to ontologically sustain the view that the actions of the human Christ, or even of Him as God the Son, are directed toward the Father. As the Son, Christ's action is timeless. Furthermore, a timeless God cannot be the object of the historical actions of the human Christ.

The ontological model seems to solve this Protestant dilemma by making the timeless God the subject and object of His action. He is eternally self-propitiated, and the benefits of this propitiation are enjoyed by a transformed humanity in the eternal Christ. Furthermore, divine passibility is also eternally constituted in this model, which means that Christ's humanity is the instrument of historical revelation of the divine suffering. An ontological consequence of the decision of making God the timeless object of the priesthood is that Christ is seen as the timeless locus of new creation (and transformed human beings), while the sacramental and functional models have Christ historically and partially actualizing new creation in human beings. 


\section{Actions}

In the context of the actions of the priest, the emphasis of the sacramental model (one invisible sacrifice) and of the ontological (one person as subject/object) model on one action is compatible with the presupposition of a timeless divine action. On the other hand, the notion of the functional model that the actions are multiple and sequential is incompatible with this presupposition, which means that these actions would be performed by Christ in His humanity (as a spatio-temporal instrument), and not in His divinity. This interpretation would partially fit the earthly actions of Christ, but it seems ontologically problematic for a heavenly propitiatory intercession before a timeless/spaceless Father in a timeless/spaceless heaven. However, even the idea that Christ's sacrifice on the cross is propitiatory seems ontologically problematic when associated with the presupposition of a timeless/spaceless God, who cannot be historically propitiated.

The sacramental model is ontologically coherent with this presupposition when it stipulates that this is a spatio-temporal expression of an invisible sacrifice. The ontological model is also ontologically coherent with this presupposition when it assumes that the destruction of sinful human beings in the sacrificial self-humiliation of God is interpreted as an eternal (non-historical) event. Thus, Christ's historical sacrifice is a revelation (spatio-temporal repetition) of the eternal sacrifice. Likewise, the sacraments are a spatio-temporal revelation of the eternal reality of new creation. In the sacramental and functional models the sacraments are a spatio-temporal actualization of the new creation in human beings. 


\section{Goal}

Regarding the goal of the priesthood, the sacramental model is ontologically consistent with the presuppositions about Divinity, Humanity, and Cosmology. In order to achieve the goal of ontological reconciliation, the divine Christ priesthood uses spatiotemporal instruments to ontologically heal human beings and guide their teleological movement toward God.

The functional model, on the other hand, seems to have a lack of ontological coherence between the idea of moral reconciliation, in which divine forgiveness is based on the propitiatory work of Christ (earthly sacrifice and heavenly intercession), and the presupposition of a timeless God. This God cannot forgive human beings historically (as an action that responds to another action). However, the functional model is coherent with this presupposition and the presuppositions regarding Cosmology, in the notion that divine forgiveness and human transformation are mediated through spatio-temporal instruments.

The ontological model seems to solve the ontological inconsistency related to the divine forgiveness of a timeless God by ultimately locating this forgiveness in (timeless/simultaneous) eternity, and not by understanding it historically. The ontological model is also compatible with its own interpretation of the macro-hermeneutical principles of reality when it assumes that the goal of Christ's priesthood is already ontologically achieved, if this is seen eternally and not historically (not through the work of the earthly Christ), and that the spatio-temporal instruments mediate a revelation of this reality.

Overall, this comparison of implications seems to indicate that the sacramental and the ontological models of Christ's priesthood tend to be more ontologically 
consistent with their respective interpretations of the principles of reality. From a historical perspective, the Reformation (the functional model) represented a reaction to Roman Catholicism (the sacramental model in the Thomistic form), while modern Protestant theology (where the ontological model is located) attempted to adjust classical Protestant theology. It is possible that the functional model formulated an account of Christ's priesthood that represents an alternative to the sacramental model (in the Thomistic form), without paying special attention to the interpretation of the principles of reality. This would explain the reason why the sacramental and functional models have different accounts of Christ's priesthood, while maintaining a similar interpretation of the principles of reality. In fact, the same challenge of ontological coherence faced by the sacramental model in the Thomistic form is shared by the functional model, namely, the notion of propitiation.

As I have indicated in this study, the idea of divine propitiation seems ontologically incompatible with a non-spatial/timeless interpretation of the principles of reality. Either the notion of propitiation is dropped (as in the sacramental model in O'Collins' form) or the principles of reality are revised and adjusted (as in the ontological model). In the case of the sacramental model, O'Collins' rejection of the idea of propitiation seems to reveal that this model can be internally coherent without this idea. The principles of reality of the sacramental model seem to be built for a notion of God as subject of Christ's priesthood, but not its object. Human beings are the object and, thus, the earth is the main realm of this priesthood, not heaven.

The situation is different for the functional model, as the notion of divine propitiation is perhaps the chief idea in its understanding of Christ's priesthood. To 
affirm that God is the primary object of this priesthood requires not only a different ontological interpretation of God, but also a special focus on heaven (God's realm). ${ }^{354}$ Indeed, this move would be probably related to a reinterpretation of the role of Christ's humanity. Interestingly enough, both Luther's understanding of the incarnation- the divinity of Christ becoming able to experience passibility — and Calvin's understanding of the humanity of the ascended Christ being physically/spatially present in heaven, call for a more active role of Christ's humanity in His intercessory work and have ontological implications that could be further elaborated toward an alternative (spatio-temporal) interpretation of the principles of reality. These could be indicators that the functional model should systematically formulate its own interpretation of the principles of reality. ${ }^{355}$ Even the sequentiality of the functions of earthly sacrifice and heavenly intercession in the context of divine propitiation appears to imply some kind of temporality (at least in terms of sequence) in the divine salvific actions. Since the

\footnotetext{
${ }^{354}$ Michael Jones sees in Luther an emphasis on the priesthood of Christ in the heavenly realm, and not on the earthly. He writes, "for Luther the dimension of Christ's priesthood that is most important is the heavenly one not the earthly realm." From a historical perspective, Luther highlights the spiritual dimension or "the interior aspect of Christ's priesthood, possibly in part as an antidote to all the external disarray the Augustinian saw in the sixteenth-century church. In fact, his stress on Christ's heavenly intercession, rather than on his priestly activity in the world, has a parallel stress on the interior and spiritual dimensions of man over any of his external actions of worship, liturgy and especially sacrifice." Jones, Toward a Christology of Christ the High Priest, 187, 165.

${ }^{355}$ In his discussion of the theology of the Reformers, Canlis indicates that "all theology necessarily comes with ontology: the issue is not whether one is ontological or not, but whether one is aware of the ontology with which he or she is working." Canlis, Calvin's Ladder, 72n82. Some scholars attempt to develop the ontological assumptions embedded in the conception of forensic justification in Protestant theology. Jenson and Gritsch, for example, emphasize the role of the word and its implications for human ontology. For them, "human reality is not a substance given prior to all community. Rather, humanity happens in the event of communication, in the speaking and hearing the word." In a nutshell, "what I am is decided by what is said to me." Eric W. Gritsch and Robert W. Jenson, Lutheranism: The Theological Movement and Its Confessional Writings (Philadelphia: Fortress, 1976), 67-68. Similarly, McCormack sees "forensicism (rightly understood!)" as "the basis for an alternative theological ontology to the one supposed in Roman and Eastern soteriology." In his view, "God's verdict . . . creates the reality it declares." Thus, "the judicial act for God is never merely judicial; it is itself transformative." McCormack, "What's at Stake in Current Debates over Justification?" 106-107.
} 
functional model did not seem to work on the reformulation of its ontological presuppositions, the only aspect of Christ's priesthood in this model that seems to find ontological support in the principles of reality is the one related with the word/sacraments. ${ }^{356}$ Curiously, this aspect is a point of relative similarity with the sacramental model, as it involves an instrumental (spatio-temporal instruments) application of grace that has human beings as objects, and does not refer to divine propitiation.

Just as O'Collins' rejection of the idea of propitiation can be interpreted as a modern attempt to give more cohesion to the sacramental model, the ontological model could be seen as a modern corrective (from the perspective of those who follow this model) of the functional model or classical protestant theology. As mentioned above, the ontological model tends to be more internally coherent, pointing to an eternal (simultaneous) propitiation. As a result, the coherence achieved by the ontological model does not seem to have room for a real (ontological) historical propitiatory intercession of the ascended Christ in heaven nor His previous intercessory activities on earth, and this seems to be contrary to the intended conception of the functional model, even though the principles of reality of the functional model were not adjusted to ontologically support this conception. Still, the ontological model did realize the need to formulate a more dynamic view of God and His heavenly realm that would be distinct from the timelessspaceless paradigm of classical theism. Despite its notion of simultaneity, which arguably

\footnotetext{
${ }^{356}$ For McCormack, the notion of "eucharistic feeding" in Protestant theology is an ontological "residual Catholic content" that the Reformers inherited, that is not aligned with the implicit ontology embedded in the idea of forensic justification. McCormack, "What's at Stake in Current Debates over Justification?" 111, 106.
} 
did not seem to have moved the model far from this classical paradigm, the ontological model does offer significant resources for its intended dynamic view, such as the monistic conception of humanity and a relational notion of space-time.

These remarks reveal that a comparison of the theological account of Christ's priesthood with the ontological assumptions related to Christ (macro-hermeneutical principles of reality) provides a fruitful hermeneutical reflection on doctrine, especially when the work of Christ is put together with the doctrine of God. While the theological language about the work of Christ seems to be more aligned with sequentiality (temporality), the ontological assumptions that permeate the doctrine of God are closer to non-sequentiality (timelessness) in the models. The situation seems ontologically problematic particularly when the heavenly work of Christ is considered, as His intercessory role takes place in the divine realm and is related to God. This ontological difficulty (from a logical standpoint) in a model does not necessarily invalidate the positive contribution of the model for our understanding of Christ's priesthood. However, because of this difficulty, the doctrine of this priesthood in such a model tends to lack systematic force in Christian theology.

Taking this ontological difficulty into account, the disagreements observed in the models reveal different attempts in which the sequentiality (temporality) implied in the language about Christ's heavenly work is articulated with a non-sequential (timeless) view of God, especially when modern logical adjustments in the sacramental (when O'Collins is compared with Aquinas) and in the ontological (when compared with the functional model) are acknowledged, as indicated in the previous paragraphs. In fact, moves toward a more sequential or temporal view can be identified in all models, but in 
different degrees. In a smaller degree, in the sacramental model, Aquinas' conception of divine propitiation in the theological account of Christ's priesthood would be a pointer to sequentiality in divine ontology, but this was adjusted by O'Collins's rejection of propititiation. In the functional model, pointers to temporality are found both in the sequentiality of functions in the theological account of Christ's priesthood and in the ontological assumptions of His divinity becoming able to experience passibility (Luther) and of His humanity being physically/spatially present in heaven (Calvin). Lastly, pointers toward temporality in the ontological model are somehow evident in the intention to reformulate the interpretation of macro-hermeneutical principles of reality from a spatio-temporal perspective, which include the doctrine of God, heaven, a monistic view of humanity, and a relational conception of space-time.

This hermeneutical comparison of the sacramental, functional, and ontological models seems to warrant a constructive work that learns from the logic of their disagreements, reformulations, and implications, and also interprets the pointers toward sequentiality (temporality) in these models as a motivation to articulate a more dynamic view of the macro-hermeneutical principles of reality, seeking a higher degree of ontological coherence between the priestly work in heaven and the doctrine of God. In fact, this is the hermeneutical motivation behind the endeavors of the next chapter, in which I will attempt to outline an alternative model that intends to be informed by a reading of Hebrews (arguably the primary scriptural source for any model of Christ's priesthood in Christian theology) regarding not only the theological account of this priesthood but also the interpretation of its macro-hermeneutical principles of reality. 


\section{CHAPTER 4}

\section{THE HISTORICAL MODEL: AN ALTERNATIVE SYSTEMATIC ARTICULATION OF CHRIST'S PRIESTHOOD BASED ON HEBREWS}

\section{Introduction}

In the previous chapters, I described three theological models of Christ's priesthood (sacramental, functional, and ontological models) from a systematic perspective, indicating the macro-hermeneutical principles of reality or ontological presuppositions assumed by each model. As far as these three models are concerned, chapter 2 focused on the priesthood of Christ (need, agent, actions, and goal), whereas chapter 3 concentrated on the priesthood of Christ (divinity, humanity, and cosmology). From a systematic and hermeneutical standpoint, these two chapters offered an outline of major theological articulations of the doctrine of Christ's priesthood in Christian theology, and demonstrated how ontological assumptions inform them.

As the next step in this study, I move now from models in Christian theology to a systematic interaction with Scripture, more specifically with the epistle to the Hebrews, which is the main source for an understanding of Christ's priesthood. ${ }^{1}$ I acknowledge, however, that the sacramental, functional, and ontological models also interact with

\footnotetext{
${ }^{1}$ I have indicated the reasons for selecting Hebrews as the main source of the doctrine of Christ's priesthood in the introduction of the second chapter and also in the explanation of the third step of this research in the methodology delineated in the first chapter.
} 
Hebrews, ${ }^{2}$ and Aquinas, Luther, and Calvin even have commentaries on this epistle. ${ }^{3}$ An engagement with the reading of Hebrews in each model goes beyond the scope of this research, as this dissertation focuses on a systematic articulation of basic conceptual components of Christ's priesthood and its macro-hermeneutical principles of reality. Because biblical commentaries are organized textually/verse-by-verse rather than thematically/conceptually, chapters 2 and 3 privileged systematic expositions of the representatives of each model instead of the biblical commentaries that some of them have. In fact, one of the contributions of the present chapter is the systematic focus in the reading of Hebrews.

For the systematic interests of this dissertation, the present chapter heuristically benefits from chapters 2 and 3, as they made us aware of key ideas and presuppositions employed in Christian theology for a systematic interpretation of Christ's priesthood. Such awareness can assist a theological reflection based on Hebrews in two interrelated ways: (1) it helps the researcher not to adopt (as far as possible) ideas or presuppositions unconsciously or uncritically in this constructive study of Christ's priesthood, and (2) it triggers important systematic questions that the researcher may bring to the study, making this biblical reflection more relevant for a dialogue in Christian theology regarding core issues in the systematic understanding of Christ's priesthood.

\footnotetext{
${ }^{2}$ In chapters 2 and 3, I have mentioned references to Hebrews in the theological articulation of the sacramental (see pages 47n62, 49n71, 52n85, 55n94, 59n105, 164n85), functional (see pages 77n162-164, $78 \mathrm{n} 171,81 \mathrm{n} 183,182 \mathrm{n} 132$ ), and ontological (see pages 108, 115n299, 236n299, 239n313, 239-240, 240n318) models.

${ }^{3}$ For helpful introductions to Christology in the commentaries of Hebrews by Aquinas, Luther, and Calvin, see Jon C. Laansma and Daniel J. Treier, eds. Christology, Hermeneutics and Hebrews: Profiles from the History of Interpretation (London: Bloomsbury T\&T Clark, 2012), 84-134.
} 
In order to facilitate the comparison with the models outlined in the previous chapters, and also to help me systematically organize an alternative/constructive proposal of Christ's priesthood, I will use the same formal structure employed in chapters 2 and 3. Therefore, the present chapter begins with a treatment of the priesthood of Christ (components: need, agent, actions, and goal) and moves to a description of the macrohermeneutical principles of reality, the priesthood of Christ (components: divinity, humanity, and cosmology), and their implications for the understanding of His priesthood. Considering the systematic interests of this research, the style of the discussion of each component mentioned above is not exegetical. This approach does not deny the fact that exegesis is essential for a proper theological reflection of Christ's priesthood in Hebrews. Rather, the style attempts to convey a clear and concise articulation of the basic ideas of the model. In order to scripturally support this conceptual construction, general statements in the text are backed up by exegetical notes or references in the footnotes. In the process of my research, these general statements are, in fact, conclusions that I have drawn after the exegetical investigation that is summarized in the footnotes. Another background information that informed my conceptual articulation below is found in the Appendix, where I describe the terminology for Christ's priesthood in the context of the structure of Hebrews.

For the sake of convenience, I label the constructive proposal of this chapter historical model. As it will become evident later, this label highlights a significant aspect of Christ's priesthood in Hebrews, namely, the sequence of events and actions that contextualize or characterize His priesthood in heaven.

According to the sequence adopted in chapter 2, I will begin the discussion of the 
components of Christ's priesthood in this chapter with an account of the need of His

priesthood.

\title{
The Priesthood of Christ: ${ }^{4}$ Components of His Priesthood
}

As it will become evident in the discussion below, the present study

acknowledges that Hebrews elaborates on Christ's priesthood focusing on a soteriological

perspective. According to this focus, His priesthood is basically understood as a

mediatorial role centered on the resolution of the sin problem. ${ }^{5}$ Hence, while recognizing

\begin{abstract}
${ }^{4}$ Two significant studies on the notion of Christ's priesthood in Hebrews are McKelvey, Pioneer and Priest; Vanhoye, Old Testament Priests and the New Priest, 67-238. I will refer to these studies in the discussion below in the footnotes. See also Keijo Nissilä, Das Hohepriestermotiv Im Hebräerbrief: Eine Exegetische Untersuchung (Helsinki: Oy Liiton Kirjapaino, 1979). For further studies on the priesthood of Christ in Hebrews, see footnote 7 in chapter 2. Considering the doctrinal focus of the present research, I will concentrate on the teaching of this priesthood as presented in Hebrews. A comparison between this motif in Hebrews with conceptual frameworks related to priesthood in the time when the epistle was written, as Manson attempts to explore in 'You Are a Priest Forever,' is beyond the scope of this research.
\end{abstract}

${ }^{5}$ A potential argument that could minimize this focus is the contention that in Hebrews Christ is (high) priest forever $(5: 6 ; 6: 20$ [high priest]; 7:17, 21,24), which seems to imply that His priesthood will be still in place after the resolution of the sin problem. This implication could mean that Christ's priesthood is not merely soteriological but is an active mediation even in the world without sin. While a full account of the mediation of Christ that could adequately evaluate this argument goes beyond the scope of the present study, I do not think that this argument is able to minimize the view that Hebrews focuses on a soteriological perspective of the priesthood of Christ. My conclusion here is supported by two points

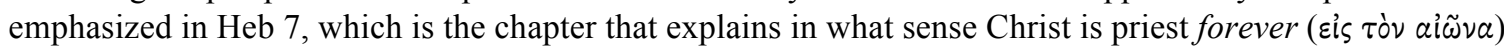
according to the order of Melchizedek, a principle derived from Ps 110:4 and already enunciated in 5:6 and

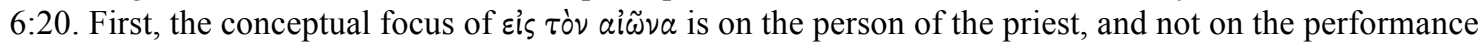
of the priestly role. In other words, the emphasis is not on the fact that Christ performs His priesthood forever, but that He is a priest forever. This focus on the person of the priest is spelled out in terms of an endless life $(7: 3,16,24)$. In this sense, Christ is a priest forever because He lives forever. According to this line of thought, Christ will not cease to be a priest after the resolution of the sin problem. Second, when Hebrews elaborates on the implications of Christ as priest forever for His priestly role, the focus is on the results or effects of His priestly activity. This focus is particularly evident in 7:24-25. Building on the affirmation of 7:24 that Christ "holds his priesthood permanently since he lives forever" (NET), 7:25

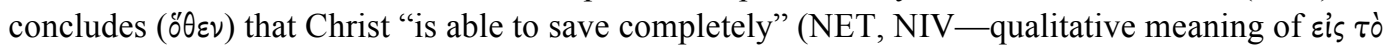
$\pi \alpha \nu \tau \varepsilon \lambda \dot{\varepsilon} \varsigma)$ or "forever" (NASB-temporal meaning of $\pi \alpha \nu \tau \varepsilon \lambda \varepsilon \dot{s})$. The qualitative and temporal meanings of

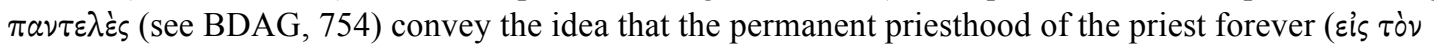

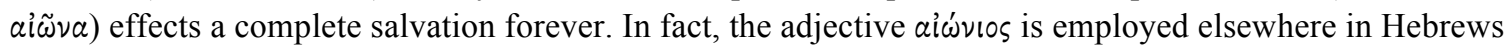
to describe the endless results of Christ's priestly work: eternal salvation (5:9), eternal redemption (9:12), eternal inheritance (9:15), eternal covenant (13:20). Therefore, the language of Christ as priest forever (5:6; $6: 20 ; 7: 17,21,24)$ parallels the language of the endless soteriological effects or results $(5: 9 ; 7: 25 ; 9: 12,15$; 
that Christ's mediation is not restricted to soteriology, ${ }^{6}$ the concept of priesthood explored here focuses on the resolution of the sin problem. Perhaps, a canonical ${ }^{7}$ investigation of Christ's priesthood would enlarge the concept of priesthood to His mediation in general (not only soteriology), but this is a topic for another study. ${ }^{8}$ With this clarification briefly given in advance regarding the focus of this

13:20) of His permanent priesthood (7:24). My elaboration of these two points ([1] the conceptual focus of

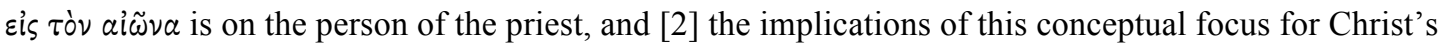
priestly role emphasize the endless results of His priestly activity) shows that the forever language for the priesthood of Christ is compatible with the soteriological perspective of His priesthood, and not against that perspective. The elaboration, however, and does not automatically rule out a potential interpretation of a non-soteriological mediatorial role of Christ's priesthood after the resolution of the sin problem, if this notion is uncovered by a future canonical study of this theme in connection with the references in Hebrews to Christ as (high) priest forever. It is noteworthy that a discussion about the meaning of the eternity of Christ's priesthood is found in the sacramental model (see above The Goal of the Priesthood in The Sacramental Model, chapter 2), where Aquinas interprets this eternity in terms of the eternal effects of His priesthood and O'Collins construes this eternity in reference to the endless mediation of Christ's humanity. Just as my remarks on Heb 7 in this footnote are not aligned with the ontological contours of what Aquinas specifies as the eternal effects of Christ's priesthood, I am not suggesting that a potential broader interpretation of the role of His priesthood (going beyond soteriology) is necessarily aligned with the ontological articulation of what O'Collins specifies as the eternal mediation of Christ.

${ }^{6}$ See my remarks on the mediatorial role of Christ in creation, salvation, and revelation in The Agent of the Priesthood below.

${ }^{7}$ I have indicated in footnote 3 above why the notion of Christ as priest forever in Hebrews per se is not enough to substantiate a broad conception of Christ's priesthood, in which He would perform a nonsoteriological priestly mediatorial activity after the resolution of the sin problem. Rather, this conception of priesthood needs to be grounded elsewhere in Scripture and, then, connected with Christ as priest forever in Hebrews.

\footnotetext{
${ }^{8}$ My openness to this possibility has been motivated by my interaction with Richard Davidson's ideas. I explain in Recommendations for Further Research (chap. 6), the basic canonical notions that might have the potential to generate a broad conception of priesthood that is not distinct from all forms of Christ's mediatorial activity, including His mediation in the world before and after sin. While the details are found in chap. 6, I outline here the main points: (1) the notion of priesthood seems to be present in the Bible in a world before (e.g., priestly language is used for the work assigned to man in Eden) and after (in Revelation, the saved will be priests) sin; (2) Prov 8 appears to indicate that Christ was installed as the divine mediator between a transcendent God and finite creatures, and a potential parallel between both Prov 8 and Hebrews with Ps 2 could suggest that Christ's royal priestly mediation in Hebrews would constitute not only the salvation of human beings but also the full recovery (after the resolution of the sin problem) of Christ's royal mediation at the beginning of creation. These two points, however, are only potential hints of a broad conception of Christ's priesthood. Indeed, the first point is not Christological, but only shows that the language of priesthood is not restricted to soteriology. Further research is needed to potentially substantiate these points Christologically and systematically articulate these and other ideas for a clear picture of Christ's mediation.
} 
research on the soteriological perspective of the concept of Christ's priesthood, as one aspect of His broader mediation, I move to the discussion of the first conceptual component of His priesthood, namely, the need for Christ's priesthood.

\section{The Need for Christ's Priesthood}

The need for Christ's priesthood in Hebrews centers on the problem of sin. The idea that sin requires priestly work is evident in the first allusion to Christ's priesthood (1:3), where sins demand purification or cleansing (noun $\left.\varkappa a \theta \alpha \rho ı \mu{ }^{\prime} \varsigma\right),{ }^{9}$ and is more explicit in the priestly expiation (verb i $\left.\lambda \alpha \sigma^{\prime} \varkappa o \mu a \iota^{10}\right)$ of sins $(2: 17)$ and the priestly offering of sacrifice for sins $(5: 1){ }^{11}$ Therefore, the notion of cleansing $\operatorname{sins}^{12}$ and the nature of $\sin ^{13}$ in Hebrews ${ }^{14}$ are helpful windows for understanding the sin problem and,

\footnotetext{
${ }^{9}$ For McKelvey, 1:3 introduces the priesthood of Christ in Hebrews. McKelvey, Pioneer and Priest, 35. According to Attridge, "although the terminology of high priest and explicit reference to the cross are absent here, an essential feature of Christ's priestly work is adumbrated in this phrase." Harold W. Attridge, The Epistle to the Hebrews: A Commentary on the Epistle to the Hebrews, Hermeneia (Philadelphia: Fortress, 1989), 45. See also Luke Timothy Johnson, Hebrews: A Commentary, NTL (Louisville, KY: Westminster John Knox Press, 2006), 71; William L. Lane, Hebrews 1-8, WBC (Dallas: Thomas Nelson, 1991), 15.
}

${ }^{10}$ See BDAG, 473-474. While some translations opt for propitiation (see, e.g., ESV, NASB), NJB and RSV render this verb as expiate, and others prefer the term "atonement" (see NIV, NET, NRSV).

${ }^{11}$ See also 7:27; 9:26.

${ }^{12}$ See the idea of purification also in $9: 14,22-23 ; 10: 2,22$. In his remarks of the purification of sins in 1:3, Ellingworth indicates that "Hebrews sees sins and their remedy in cultic terms." Paul Ellingworth, The Epistle to the Hebrews: A Commentary on the Greek Text, NIGTC (Grand Rapids, MI; Carlisle, England: Eerdmans; Paternoster, 1993), 102. Attridge explains that "( $\varkappa a \theta \alpha p ı \mu$ ós $)$ is relatively rare in the New Testament as a designation for Christ's atoning sacrifice, appearing only here and at 2 Pet 1:9. The term is common for cultic purification in the LXX and in the New Testament." Attridge, The Epistle to the Hebrews, 46.

${ }^{13}$ In his discussion of $\sin$ in Hebrews, Ellingworth points out that "Hebrews uses á $\mu \alpha \rho \tau i$ in the singular $(3: 13 ; 4: 15 ; 9: 26,28 ; 10: 6,8=$ Ps. 40:8; Heb. 10:18; 11:25; 12:1, 4), but more often in the plural $(1: 3 ; 2: 17 ; 5: 1,3 ; 7: 27 ; 8: 12=$ Je. 31:34; Heb. 10:2, 3, 4, 11, 12, 17 = Je. 31:34; Heb. 10:26), without discernible difference of meaning, except that the plural by definition is not used of the fundamental state of sin." Moreover, "Hebrews, like Paul, tends to speak of $\sin (\mathrm{s})$ in absolute terms, for example, without a possessive pronoun (exceptions 7:27; 8:12= Je. 31:34; 9:28; 1 Cor. 15:3, 17; Gal. 1:4; Eph. 1:2; 1 Thes. 2:16; 1 Tim. 5:24)." Furthermore, "apart from passing references to adultery and the love of money 
consequently, the need for Christ's priesthood. ${ }^{15}$

The sin problem seems to impact (1) the relationship of human beings with God,

(2) human beings themselves, and (3) creation at a cosmic level (heavenly things).

\section{The Relationship of Sinful Human Beings with God}

The idea that sin breaks the relationship of human beings with God is implied in the concept that Christ enables believers to draw near to God in His continuous priestly intercession $(7: 25),{ }^{16}$ as this concept assumes that human beings are previously distant

(13:4f.), Hebrews says little about individual sins, and contains no list of vices comparable to Rom. 1:2931; Gal. 5:19-21; or 1 Pet. 4:3. The fundamental sin for Hebrews is that of unfaithfulness to God, which

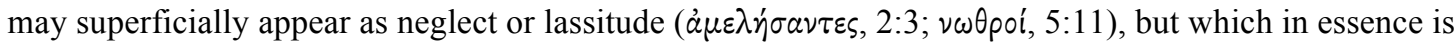
rebellion against God's will, and more specifically apostasy $(2: 1-4 ; 3: 7-19 ; 6: 4-6 ; 10: 26-31)$." Ellingworth, The Epistle to the Hebrews, 102. For a study on sin in Hebrews, see Hermut Löhr, Umkehr Und Sünde Im Hebräerbrief, Beihefte Zur Zeitschrift Für Die Neutestamentliche Wissenschaft Und Die Kunde Der Älteren Kirche (Berlin: de Gruyter, 1994), 11-135. See also Udo Schnelle, Theology of the New Testament, trans. M. Eugene Boring (Grand Rapids, MI: Baker Academic, 2009), 641-642.

14 The topic of sin is more emphatically explored in sections of exhortation $(2: 1-4 ; 3: 7-4: 13 ; 6: 4-$ $8 ; 10: 26-31)$. Most of these passages are part of the so-called "warning passages in Hebrews (Heb. 2.1-4; 3.7-4.13; 5.11-6.12; 10.19-39; 12.1-29).” B. J. Oropeza, “The Warning Passages in Hebrews: Revised Theologies and New Methods of Interpretation," Currents in Biblical Research 10, no. 1 (2011): 81.

${ }^{15}$ Hebrews strongly emphasizes that the sin problem is not adequately solved by the Aaronic priesthood. The exposition of the superior appointment and offering of the Son as high priest (5:1-10; 7:128; 8:3-10:18) highlights the limitations of the Aaronic priesthood. An important limitation was that the animal sacrifices offered by these priests could not take away the sins of the people $(10: 4,11)$. This explains why they were constantly repeated $(10: 2,3,11)$. The multiplicity of sacrifices attests the ineffectiveness of the Aaronic priesthood. In this way, this priesthood could not bring perfection $(\tau \varepsilon \lambda \varepsilon i \omega \sigma \mathrm{i} \varsigma$,

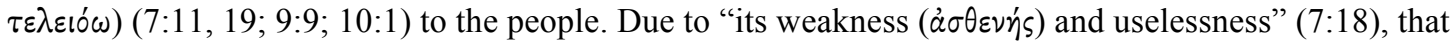
priesthood needs to be replaced by a new priesthood (see 7:12, 18; 8:7). The underlying assumption of this argument of replacement is that the Aaronic priesthood does not constitute the reality of the priestly work. It has a shadow $\left(\sigma x \iota^{\prime}\right)$ of the good things to be done by the real priesthood, but it is not the form of these

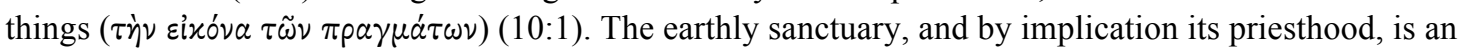

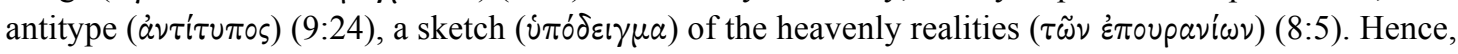
the Aaronic priesthood does not need to be replaced because it is a fallacy. Rather, the earthly sanctuary, and by implication its priesthood, was intended by God (see 8:5). As a shadow, the Aaronic priesthood was a limited anticipation of the coming reality of Christ's priesthood. It is the reality of His priesthood that

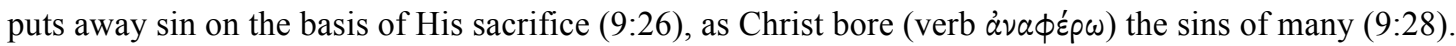
Therefore, the reality of His priesthood sanctifies and perfects (verb $\left.\tau \varepsilon \lambda \varepsilon \iota^{\circ} \omega\right)$ believers (10:14).

${ }^{16}$ I indicate here the Greek language in 7:25 for the following concepts in this statement: enabling 
from God. ${ }^{17}$ The negative impact of sin on this relationship is described in terms of a broken covenant. Christ's mediation of a new/better covenant $(8: 6 ; 9: 15 ; 12: 24$; see also

\section{$7: 22 ; 10: 29 ; 13: 20)$ is necessary because a previous covenant was broken $(8: 9 ; 9: 15),{ }^{18}$}

which implies a transgression of the divine $\operatorname{law}^{19}$ as expressed formally in the

Decalogue. ${ }^{20}$ As a matter of fact, the ark of the covenant in the Most Holy Place of the

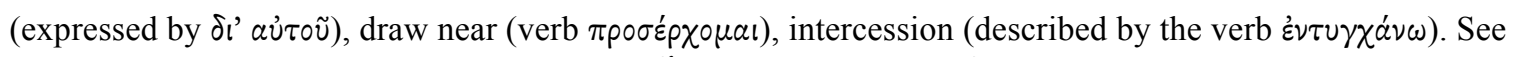

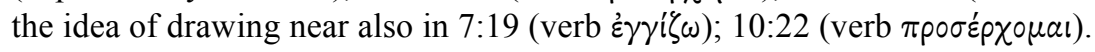

${ }^{17}$ The sins of the people are mentioned in 7:27, which are the reason of Christ's once for all offering.

${ }^{18}$ While in 8:9 the breaking of the covenant is depicted as someone not continuing in it, 9:15 speaks of "transgressions ( $\pi \alpha \rho \alpha \beta \dot{\alpha} \sigma \varepsilon \omega \nu)$ commited under the first covenant." Unless otherwise indicated, all Bible references in English are from ESV.

${ }^{19}$ There are at least four arguments for the interpretation of these transgressions as the breaking of

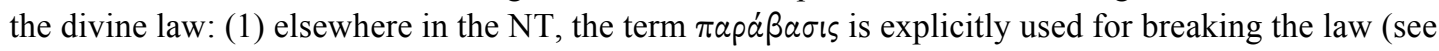
Rom 2:23; 4:15); (2) in the promise of the new covenant in Heb 10:16-17, the sins of the first covenant are

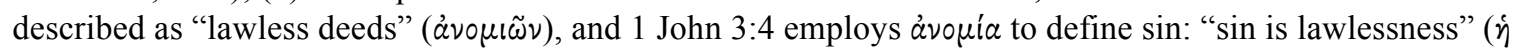

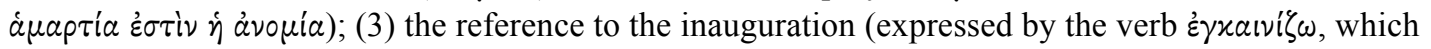
conveys in this context the meaning of "ratify, inaugurate, dedicate," BDAG, 272) of the first covenant

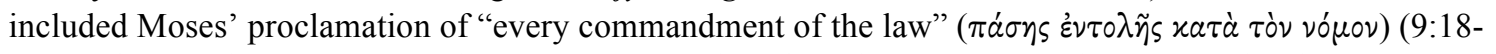
19); and (4) in the sanctuary of the first covenant, the ark of the covenant in the Most Holy Place contained the tablets of the covenant $(9: 1,3-4)$, which gives to the Decalogue a special place in the context of the priestly work in the sanctuary. Regarding point 3, scholars agree that this is a reference to Exod 24:3-8 (especially vv. 3 and 7). See Attridge, The Epistle to the Hebrews, 257; Gareth Lee Cockerill, The Epistle to the Hebrews, NICNT (Grand Rapids, MI; Cambridge, U.K.: Eerdmans, 2012), 408; Ellingworth, The Epistle to the Hebrews, 467; Johnson, Hebrews, 241; Craig R. Koester, Hebrews: A New Translation with Introduction and Commentary, AB 36 (New Haven, CN: Yale University Press, 2001), 426; Lane, Hebrews 9-13, 244. Assuming that Exod 24 "rounds out the literary complex that began with chapter 19," Nahum Sarna argues that chap. 24 describes initially "an elaborate rite of ratification ... after which Moses is called upon to ascend Mount Sinai in order to receive the tangible, permanent symbol of the covenant: the two stone tablets into which the Decalogue is incised." Nahum M. Sarna, Exodus: The Traditional Hebrew Text with the New JPS Translation, The JPS Torah Commentary (Philadelphia: The Jewish Publication Society, 1991), 150.

${ }^{20}$ The reference to commandment in 7:18 does not diminish the importance of the Decalogue. Even though the noun qualified by the adjectives $\dot{\alpha} \sigma \theta \varepsilon v \varepsilon \dot{\varepsilon} \varsigma$ and $\dot{\alpha} \nu \omega \phi \varepsilon \lambda \varepsilon^{\prime} \varsigma$ (uselessness) is $\dot{\varepsilon} \nu \tau 0 \lambda \dot{\eta}$

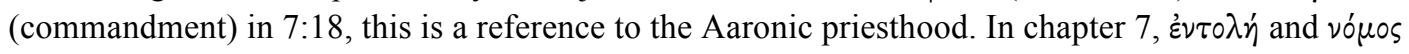
(law) - which are associated in vv. 5, 16- are the entity that establishes and regulates the Aaronic priesthood $(7: 5,12,16,19,28$; see also $8: 4 ; 9: 22 ; 10: 1,8)$. In fact, the law appoints high priests $(7: 28)$ and

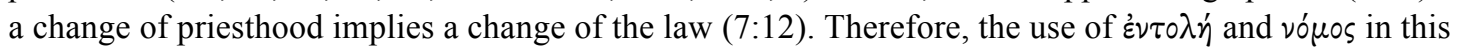
context refer to the Aaronic priesthood. In his remarks about the law in Hebrews, Schenck stipulates that "the principal concern of the author so far as the Law is concerned is its sacrificial system and its priests."

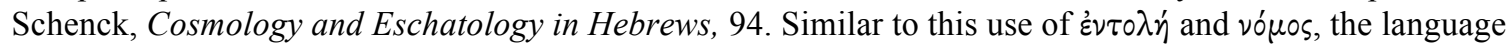


earthly sanctuary contained the tablets of the covenant $(9: 1,3-4)$. This seems to indicate that the priestly work is performed with reference to the Decalogue, in the sense that the priestly activities amend the broken relationship between human beings and God caused by the human transgressions of His law.

This picture of transgression explains the human need for forgiveness. In the

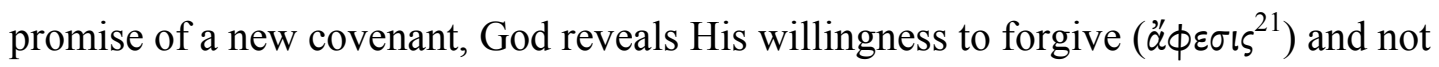

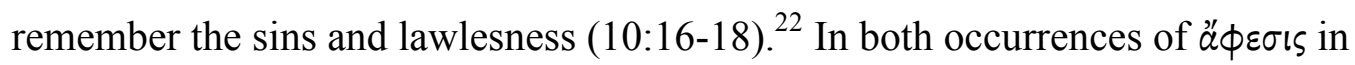
Hebrews, forgiveness takes place in the priestly context of sacrificial offering (see 10:18;

of $\delta_{1} a \theta^{\prime} \varkappa \eta$ (covenant) refers to priesthood in 8:6-7 and also in 7:22; 9:4, 15. In chapter 9, the first covenant is described by the earthly sanctuary $(9: 1-5)$ and the service of Aaronic priests (9:6-10). On the other hand, the better and new covenant has Christ as its mediator $(7: 22 ; 8: 6 ; 9: 15)$. In these three references to the better/new covenant, the context of this mediation is His priesthood (see 7:21; 8:1-2, 4; 9:11-14). In this sense, the idea of a replacement of covenants (8:7) means a replacement of priesthood.

${ }^{21}$ BDAG presents a twofold meaning of this word: (1) "the act of freeing and liberating from someth. that confines, release fr. captivity" and (2) "the act of freeing from an obligation, guilt, or punishment, pardon, cancellation." The occurrences of this term in Heb 9:22; 10:18 appear under the second meaning. BDAG, 155. According to Louw and Nida, "the focus of the meaning" of this word "is upon the guilt of the wrongdoer and not upon the wrongdoing itself. The event of wrongdoing is not undone, but the guilt resulting from such an event is pardoned. To forgive, therefore, means essentially to remove the guilt resulting from wrongdoing." $L \& N \$ 40.8$. William Johnsson provides a helpful discussion about the meaning of ä $\phi \varepsilon \sigma \iota \varsigma$ in Hebrews. Concisely, he argues that $\alpha$ " $\phi \varepsilon \sigma \iota \varsigma$ describes a "“definite putting

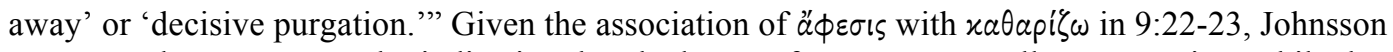
compares these two terms by indicating that the latter refers more generally to purgation, while the former is a more specific reference to purgation, namely, "a purgation with finality." He points out that the argument of 9:22 is the following: "Whereas, according to the law, almost everything was purged in blood [but not everything; there were exceptions], for definitive putting away of defilement there must be blood applied." Furthermore, Johnsson compares ä $\phi \varepsilon \sigma ı \varsigma$ with $\tau \varepsilon \lambda \varepsilon i \omega \sigma \iota \varsigma$, affirming that while the latter '“('perfection,' incorporation) has the 'subjetive' benefits of Christ's blood in view (access to God with the

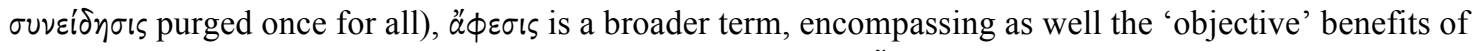
that blood. Thus, the following verse" (9:23) "proceeds with oũv—'therefore' - to talk about the purgation of the heavenly things." William G. Johnsson, "Defilement and Purgation in the Book of Hebrews," (Ph.D. Dissertation, Vanderbilt University, 1973), 326, 328. Whereas I find all this discussion of ä $\phi \varepsilon \sigma \varsigma \varsigma$ in Hebrews very helpful, it is unclear to me why Johnsson rejects a conceptual association of ä $\phi \varepsilon \sigma ı s$, and even of the work of Christ as whole in Hebrews, with the notion of sin as a broken relationship between human beings and God (see ibid., 325).

${ }^{22}$ I indicate here the Greek language in 10:16-18 for the following concepts in this statement: not

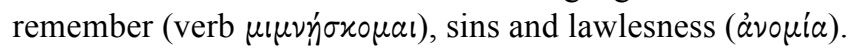


9:22), which seems to indicate that priestly mediation is necessary for divine forgiveness.

Conversely, when there is no divine forgiveness, the end result is divine judgment and punishment of sinful human beings. For example, in the exhortations of Hebrews, there are at least three instances where this result is indicated $\left(2: 1-4^{23} ; 3: 7-4: 13^{24} ; 10: 26-\right.$ $31^{25}$ ). The general picture of sin as apostasy in these exhortations depicts a refusal of salvation (2:3) and of the sacrificial blood of Christ by people who had already been benefited by it (10:29). Thus, His priesthood does not solve the sin problem of those who

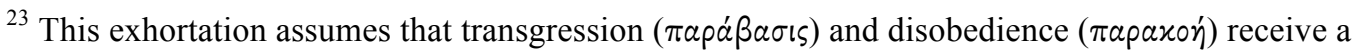
just divine retribution or punishment (noun $\left.\mu 1 \sigma \theta \alpha \pi \circ \delta \circ \sigma^{\prime} \alpha\right)(2: 2)$. In opposition to this attitude of refusal, the author of Hebrews exhorts the audience to not neglect (verb $\left.\alpha \mu \varepsilon \lambda \varepsilon^{\prime} \omega\right)$ the salvation spoken by the Lord (2:3; see also $2: 1 ; 12: 25)$.

${ }^{24}$ This exhortation warns against a hardening of the heart when the divine voice is heard (Heb 3:7$8,15 ; 4: 7)$. On the basis of Ps 95:7-11, in light of the rebellion of Num 13-14, this hardening takes the form

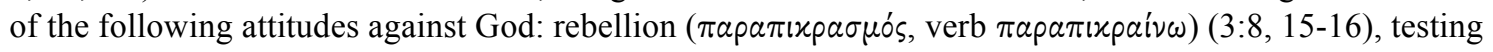

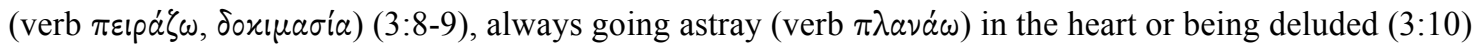

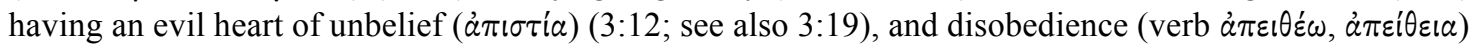
$(3: 18 ; 4: 11)$. Because of that, God is provoked or offended (verb $\pi \rho \circ \sigma \circ \chi \theta i \xi \omega)(3: 10,17)$. In His wrath (opy $\left.\eta^{\prime}\right)$, God gives a retribution or punishment for this sinful condition and action $(3: 11 ; 4: 3)$. With this idea of divine judgment in view, we must render an account of ourselves to God (4:13), an account that includes even "the thoughts and intentions of the heart" (4:12). For a more nuanced interpretation of 4:13, conveying the idea of "a word we must give in response to the word heard," see Gene R. Smillie, " The

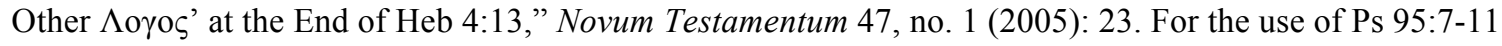
in light of the rebellion of Num 13-14, see Attridge, The Epistle to the Hebrews, 114; Ellingworth, The Epistle to the Hebrews, 212-214; Cockerill, The Epistle to the Hebrews, 153; Lane, Hebrews 1-8, 84.

${ }^{25}$ Intensifying the discussion on the neglect of salvation and the divine judgment (see also 6:4-8), the exhortation of 10:26-31 focuses on a situation of continuous deliberate ( $\varepsilon$ xov $\left.\sigma^{\prime} \omega \varsigma\right) \sin (10: 26)$, where a former informed (10:26, "after receiving the knowledge of the truth") and sanctified believer rejects Christ and His sacrificial blood (10:29). In 10:26, "A $\mu a \rho \tau a \nu o ́ v \tau \omega \nu \dot{\eta} \mu \tilde{\omega} \nu$ : the present participle suggests continuous

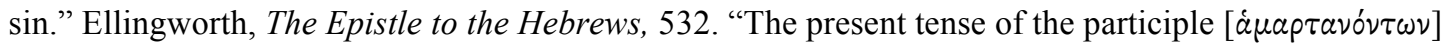
suggests that the sin involved is not a single act, but a continuing rejection of Christ." Attridge, The Epistle to the Hebrews, 292. The language of continuous sinning appears in ESV, NASB, NIV, NET, and NRSV.

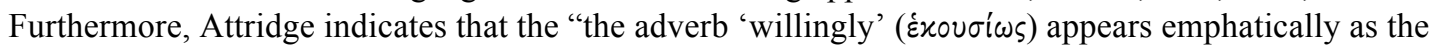
opening word." He suggests that this "language derives from the Pentateuchal distinction between willful or high-handed and inadvertent sins that was widely recognized in post-biblical Judaism. As the sequel indicates, our author has in mind a specific willful sin, that of apostasy." Ibid. See also Ellingworth, The Epistle to the Hebrews, 592. The exhortation of 10:26-27 concludes that, in this situation, "there no longer remains a sacrifice for sins, but a fearful expectation of judgment" (xpí $/ \varsigma)$. Such judgment is described as

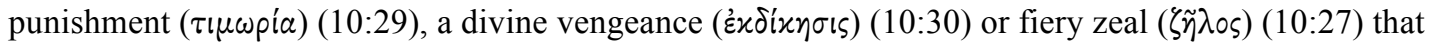

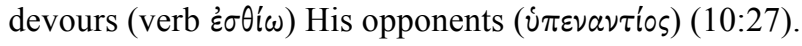


eventually reject Him, even though the benefits of this priesthood were initially effective in their life. When this is the case, it is God's judgment that solves the sin problem by destroying that people. ${ }^{26}$ Therefore, in the context of the broken relationship of human beings with God, either the priesthood of Christ solves the sin problem by mediating divine forgiveness for repented human beings or they will face God's destructive judgment. $^{27}$

\section{Sin and Human Beings}

The second aspect impacted by the sin problem are the human beings themselves.

In this case, Christ's priesthood is necessary to deal with their guilty conscience and their weakness with temptation/trial. While the guilty conscience appears to be related to the broken relationship with God, described by the breaking of His law, the weakness seems to refer to the ontological or moral ${ }^{28}$ constitution of sinful human beings. ${ }^{29}$ Regarding the

\footnotetext{
${ }^{26}$ The idea of real apostasy seems to invalidate the notion of universalism (everyone is benefited by Christ's salvific priesthood) and the classical concept of predestination (those predestined to damnation cannot be benefited by Christ's salvific priesthood at all). The concept of apostasy in Hebrews is debated among Calvinists ("the ones who are in danger of apostasy in Hebrews are not elect or 'genuine' believers") and Arminians (there is "a real possibility that believers can abandon salvation"). For a helpful overview of different contemporary interpretations of the warning passages in Hebrews, see Oropeza, "The Warning Passages in Hebrews," 81-100. For a history of the interpretation of these passages, see C. Adrian Thomas, A Case for Mixed-Audience with Reference to the Warning Passages in the Book of Hebrews (New York: Peter Lang, 2008), 25-96. While I agree with Oropeza that Calvinist-Arminian debates were not part of the immediate audience of Hebrews (see Oropeza, "The Warning Passages in Hebrews," 83.), I would argue that Hebrews must be studied to inform this debate. In the Calvinist-Arminian debate, three basic positions may be outlined: (1) believers can really apostatize (Arminian view), (2) apostates were never genuine believers (Reformed view), and (3) Hebrews warns about physical punishment and not absolute apostasy (Moderate Reformed view). See Herbert W. Bateman, Four Views on the Warning Passages in Hebrews (Grand Rapids, MI: Kregel, 2007). The prominent place of apostasy in Hebrews is highlighted by George Rice, who suggests that this concept is fundamental for the structure of the epistle. See George E. Rice, "Apostasy as a Motif and Its Effect on the Structure of Hebrews," AUSS 23, no. 1 (1985): 29-35.

${ }^{27}$ As explained above, God's destructive judgment is preceded by His call to salvation. Only when this call is rejected, people put themselves in a position to face God's destructive judgment.

${ }^{28}$ In this section, I do not distinguish the meaning of the terms ontological and moral. Rather, I use
} 
guilty conscience, the connection between divine forgiveness and the human conscience is established by the association of forgiveness and purification/cleansing $(9: 22),{ }^{30}$ and the conception of purification as eliminating the consciousness of sins (10:2). The consciousness of believers needs to be perfected (9:9), purified/cleansed from dead works (9:14), and the heart sprinkled/cleansed from an evil consicence (10:22). ${ }^{31}$ This language of consciousness appears to imply a feeling of guilt. ${ }^{32}$ According to this perspective, the purification of sins involves the elimination of a guilty conscience that was aware of the breaking of the divine law.

them synonymously, in a general way.

${ }^{29}$ Even though I looked for potential hints in Hebrews to identify an OT background that could further substantiate this point in light of LXX language, this conclusion about the concept of weakness derives from my reflection of Hebrews itself, as exposed below. However, from a canonical perspective,

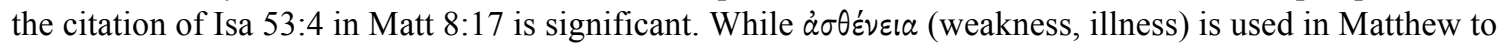
describe the Christological fulfillment of Isa 53 ("He took our illnesses and bore our diseases," italics mine), this Greek term is not employed in the LXX. Rather, the language of Matthew is closer to the MT, focusing on the idea of sickness (חיז:). See Craig L. Blomberg, "Matthew," in Commentary on the New Testament Use of the Old Testament, ed. G. K. Beale and D. A. Carson (Grand Rapids, MI; Nottingham: Baker Academic; Apollos, 2007), 32. Nevertheless, it is noteworthy that the word in the LXX is áuaptía. In fact, Isa 53:4-5 MT associates the concepts of sickness (v. 4) and sins (v. 5), as v. 5 employs the

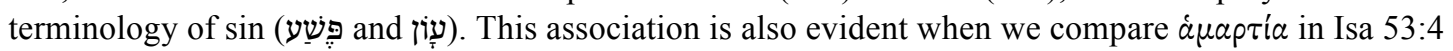
LXX with á $\sigma \theta^{\varepsilon} \nu \varepsilon 1 \alpha$ in the citation of the MT version in Matt 8:17.

${ }^{30}$ I indicate here the Greek language in 9:22 for the following concepts in this statement: forgiveness (ä $\phi \varepsilon \sigma \zeta)$, purification ( $\varkappa a \theta a \rho i \zeta \omega)$.

${ }^{31}$ I indicate here the Greek language in 9:9, 14 and 10:22 for the following concepts in this statement: perfected (verb $\left.\tau \varepsilon \lambda \varepsilon \varepsilon^{\prime} \omega\right)$ ), purified/cleansed (verb $\left.x a \theta a \rho i \zeta \omega\right)$, sprinkled/cleansed (verb $\dot{\rho} a v \tau i \zeta(\omega)$ ),

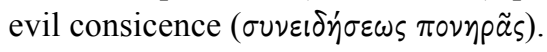

${ }^{32}$ This idea is reflected in the NIV rendition of 10:2 ("felt guilty") and 22 ("guilty consicence"). In

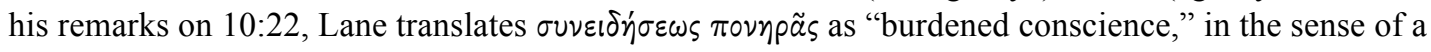

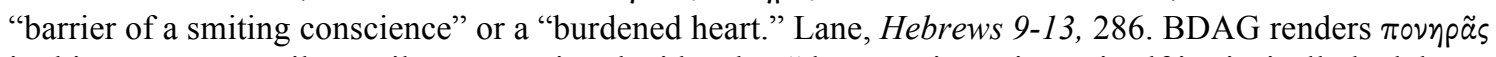
in this passage as evil or guilty, conveying the idea that "the conscience is not itself intrinsically bad, but evil deeds load it with a bad content." BDAG, 851. For studies on the human conscience in the NT, see C. A. Pierce, Conscience in the New Testament (London: SCM Press, 1955); J. Stelzenberger, Syneidesis Im

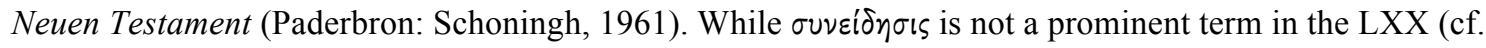
Eccl 10:20; Wis 17:10), the concept of feeling guilty can be observed in several occurrences of the verb אשם in the Torah (Lev 4:13, 22, 27; 5:2-5, 17, 23; Num 5:6; see also Hos 5:15), rendered in these instances by NJPS and ESV as realizing guilt. 
With regard to the weakness of sinful human beings, they need mercy $(2: 17$;

$4: 16),{ }^{33}$ help (2:18), sympathy (4:15), and gentle dealing (5:2), because of their condition of $\sin (2: 17)$, test/temptation (2:18), and weakness $(4: 15) \cdot{ }^{34}$ In contrast to Christ, the human experience of test/temptation is normally followed by $\sin (4: 15)$, and this weakness requires sacrifice for sins $(5: 2-3 ; 7: 27-28) .{ }^{35}$ It seems that this language of weakness describes the sinful ontological or moral constitution of human beings in the fallen world ${ }^{36}$ and, assuming that the human experience of test/temptation in this weak

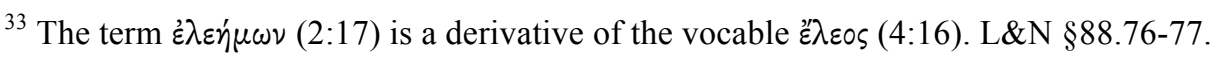

${ }^{34}$ Hebrews also indicates that human beings in need of priesthood are characterized by ignorance

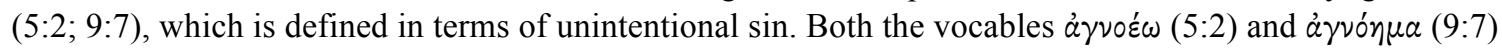
describe unintentional sins or sins of ignorance in these passages. BDAG, 13. The reason I have not included this point in the list of needs is that it is not clearly connected with the priesthood of Christ, but is associated with the Aaronic priesthood. It is possible that Hebrews establishes a contrast between unintentional sins $(5: 2 ; 9: 7)$ and the deliberate continuous sin that rejects the salvific and sacrificial blood of Christ $(10: 26,29)$, with the implication that His priesthood targets only unintentional sins. However, in the absence of arguments and passages in Hebrews that confirm this contrast and implication, I am not convinced that this is necessarily the case. For helpful information regarding the scholarly debate about the distinction of unintentional and intentional sins in the context of the Aaronic priesthood, see Roy Gane, Cult and Character: Purification Offerings, Day of Atonement, and Theodicy (Winona Lake, IN: Eisenbrauns, 2005), 202-213; Richard M. Davidson, Song for the Sanctuary: A Graduate Textbook on the Biblical Doctrine of the Sanctuary (Berrien Springs, MI: Andrews University Press, Forthcoming), chap. 12 (The kind of sin involved). The main difference between Gane and Davidson in their respective evaluative dialogues with the literature can be summarized as follows. In Gane's view, Num 15:22-31 outlines two extreme categories of sins, namely, (1) unintentional/non-defiant (vv. 24-29) and (2) intentional/defiant (vv. 30-31). The former can be expiated, the latter cannot. While the unintentional category is mentioned in the purification offering of Lev 4 (vv. 4:2, 22, 27; cf. also 5:15, 18), Lev 5 (vv. 1, 5-6, 20-26 MT [6:1-6 ESV]) points to an intermediate category of intentional/non-defiant sin, which can be expiated. Conversely, in Davidson's perspective, the roots שגה/שגג, from where the traditional translation unintentional sins comes from, convey a broader meaning that describes all non-rebellious sins, both intentional and unintentional. Hence, Lev 4 and Num 15 include intentional/non-defiant sins. In short, Gane's position implies two major categories of sin, with a third intermediary category between them: unintentional, intentional/non-defiant, and intentional/defiant. On the other hand, Davidson's view implies two categories of sin, where the first one includes two subcategories: non-defiant (intentional and unintentional) and defiant. How would these two positions impact the reading of $\dot{\alpha} \gamma \nu \circ \varepsilon \dot{\varepsilon} \omega(5: 2)$ and $\dot{\alpha} \gamma \nu \delta^{\prime} \eta \mu \alpha$ (9:7) in Hebrews, if the interpretation is informed by the OT background? On the basis of Gane's position, these Greek terms would refer literally to unintentional sins in Hebrew. Conversely, if Davidson's view is assumed, the terms would correspond more broadly to non-defiant (including intentional and unintentional) sins in Hebrew.

\footnotetext{
${ }^{35}$ The language of weakness ( $\left.\dot{\sigma} \sigma \theta^{\varepsilon} v \varepsilon ı\right)$ in Hebrews appears in 4:15; 5:2; 7:28 and 11:34.

${ }^{36}$ The association of human weakness and sin in Hebrews (5:2-3) along with the meaning of
} 
condition is normally followed by sin, they need expiation. In contrast, the language of weakness is not applied to Christ in Hebrews. ${ }^{37}$ Rather, He was qualified by the experience of suffering and test/temptation, meaning that He is able to mercifully help ${ }^{38}$ those being tested/tempted in their weaknesses $(2: 18 ; 4: 15) .{ }^{39}$ Whereas Hebrews does not seem to specify how He helps those being tempted, in light of the general principle taught in 1 Cor 10:13 (God provides a way to endure temptation), a canonical interpretation of this point would seem to suggest that Christ helps people being tempted by assiting them

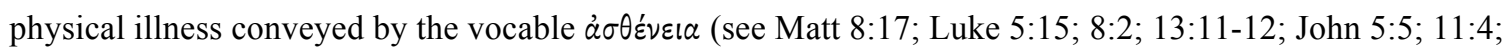
Acts 28:9; 1 Tim 5:23) seem to support the idea that human weakness in Hebrews describes the ontological constitution of human beings in the fallen world. However, physical illness is not the only meaning of

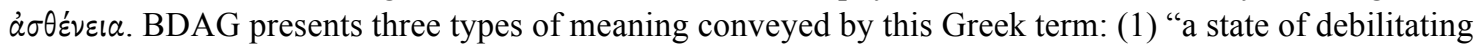
illness, sickness, disease"; (2) "incapacity for someth. or experience of limitation, weakness"; (3) "lack of confidence or feeling of inadequacy, weakness." BDAG, 142. The second and the third meanings do not

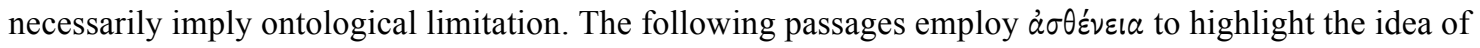
human limitation, but they do seem to imply an ontological sinful constitution of human beings: Rom 6:19; 8:26; 1 Cor $2: 3 ; 15: 43 ; 2$ Cor $11: 30 ; 12: 5,9,10 ; 13: 4$; Gal 4:13.

${ }^{37}$ For instance, 7:28 establishes a contrast between the weakness ( $\left.\dot{\alpha} \sigma \theta \varepsilon \dot{\varepsilon} \nu \varepsilon ı\right)$ of earthly high priests and the perfection (expressed by the verb $\left.\tau \varepsilon \lambda \varepsilon \iota^{\prime} \omega\right)$ of the Son.

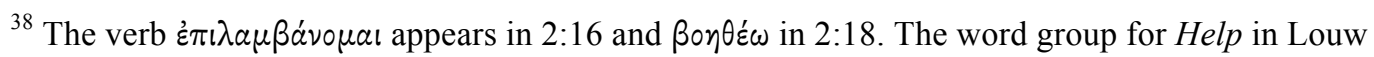
and Nida includes these two verbs. The authors acknowledge that these terms may "possess certain contrastive features of meaning, at least of a connotative type, but there is no specific evidence of this in NT usage.” L\&N $\$ 35.1$ (see note 2).

${ }^{39}$ I indicate here the Greek language in 2:18 and 4:15 for the following concepts in this statement:

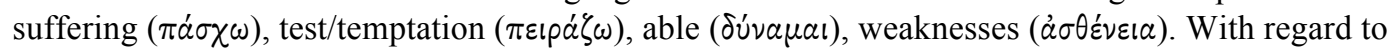
$\pi \varepsilon i p a ́ \zeta \omega$, BDAG assigns both meanings (test and temptation) to the occurrences of this Greek word in Heb 2:18. See BDAG, 793. NJB and NRSV opt for test while other translations prefer temptation (see, e.g., ESV, NASB, NT, NIV). The concept of Christ's priestly mercy and sympathy in 2:17 and 4:15 is

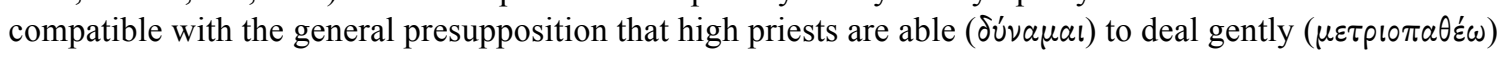
with those who are "ignorant and wayward" (5:2). While Christ shares with earthly (high) priests this

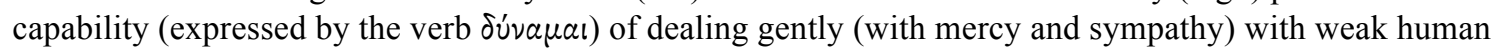
beings, the reasons that justify this capability are not the same. The reason for Christ's capability is His experience with test/temptation $\left(\pi \varepsilon ı \alpha^{\prime} \zeta \omega\right)$, which is an experience that He shares with all human beings $(2: 18 ; 4: 14)$. On the other hand, the reason for the capability of earthly (high) priests is their condition of weakness $(\dot{\alpha} \sigma \theta \dot{\varepsilon} v \varepsilon ı)(5: 2 ; 7: 28)$. This condition seems to involve sin, as $5: 3$ elaborates on $5: 2$ by indicating that sacrifices for sins are required for both the high priest and the people. On this point, the disparity between earthly high priests and Christ is clear. His experience with test/temptation did not involve sin (4:15). Furthermore, 7:28 establishes a contrast between the weakness ( $\dot{\alpha} \sigma \theta \dot{\varepsilon} v \varepsilon ı)$ of earthly high priests and the perfection (expressed by the verb $\tau \varepsilon \lambda \varepsilon 10$ (o) of the Son. 
to resist temptation. This help, however, does not eliminate the personal struggle against $\sin /$ unbelief that is expected from a believer (Heb 10:32, 35, 36; 12:1, 4). ${ }^{40}$ From an anthropological reflection based on Heb 4:15; Matt 26:41 and Rom 8:5-7, ${ }^{41}$ the ontological weakness of believers who experience temptation could be described as a condition where the mind is unable to sustain a course of action or an attitude in accordance to the divine law. This inability is not a result of an evil body hindering the guidance of a virtuous mind, but of a struggle between the mind being willing to do the will of God (His law) and the lack of fortitude or strength to perform acts in accordance with this desire of the mind. According to this view, the idea that Christ helps people to resist temptation implies that $\mathrm{He}$ is able to give to the human will the necessary strength to carry out a course of action or an attitude in accordance to the divine law.

In short, in a world characterized by the sin problem, human beings have a guilty conscience because of the transgressions through which they break their relationship with God. Because of their past experience of sinning, they are ontologically weak or prone to fall into temptation. The priesthood of Christ is needed in both cases, as it provides

\footnotetext{
${ }^{40}$ In Heb 10, the exhortation emphasizes endurance against unbelief (10:35-36, 39). In chap. 12, endurance is explicitly opposed to $\sin (12: 1,4)$.

${ }^{41}$ While Heb 4:15 establishes the connection between weakness ( $\left.\dot{\sigma} \sigma \theta \varepsilon \dot{v} v \varepsilon \mid \alpha\right)$ and temptation (expressed by the verb $\pi \varepsilon ı \rho^{\prime} \zeta(\omega)$ ), Matt 26:41 (see also Mark 14:38) provides a helpful link between these concepts and the notion of flesh ( $\sigma \dot{\alpha} \rho \dot{\xi} \dot{\alpha} \sigma \theta \varepsilon \nu \eta \dot{\zeta})$. In the context of Jesus' sorrow at Gethsemane, He warns His sleepy disciples (including Peter, Matt 26:37) that they should "watch and pray" to "not enter into temptation. The spirit indeed is willing, but the flesh is weak" (Matt 26:41). The narrative indicates that, instead of opposing immaterial (spirit) and material (flesh) anthropological entities in one person, Jesus seems to suggest that the mind is conflicted, thinking in two opposing directions. Without divine help, conceptualized here in terms of prayer, weak human beings are not able to follow God's will, even when they have good intentions. The experience of Peter illustrates this principle. While he strongly affirmed his loyalty to Jesus (vv. 33, 35), his words did not confirm this loyalty when he was tested (vv. 69-75). The notion that the anthropological conflict takes place in the mind is highlighted by Jesus' warning about the necessity of watching and praying, as these are primarily mental actions by which believers attempt to discipline themselves on the basis of God's assistance. Furthermore, Rom 8:5-7 contrasts the life according
} 
forgiveness/purification of sins and also assists believers to resist temptation.

\section{Sin and Creation at a Cosmic Level}

The last point regarding the impact of the sin problem refers to creation at a

cosmic level—heavenly things ( $\tau \dot{a}$ ėđoupávia) (9:23). In the sections below, I will explore

the ontological meaning of heavenly things (section on Cosmology) and what their

purification probably means (section The Goal of the Priesthood). For now it will suffice

to say that according to my conclusions in these two sections the heavenly things describe

the existence of a sanctuary in heaven and that this sanctuary where Christ ministers for

our salvation needs to be purified from $\sin .{ }^{42}$ As far as the need for Christ's priesthood is

to the flesh and the life according to the spirit in terms of setting the mind ( $\phi \rho \circ v \varepsilon \dot{\omega} \omega)$ and mindset ( $\phi \rho o ́ v \eta \mu \alpha)$.

${ }^{42}$ Ellingworth summarizes the scholarly debate regardind the meaning of the purification of the heavenly things in Heb 9:23 in eight main interpretations: "(1) A sacrifice is offered in advance, as a kind of 'immunisation' (Spicq), to prevent the heavenly sanctuary from becoming defiled when sinners enter it (Riggenbach). (2) The fall has contaminated even the heavenly sanctuary. Spicq describes this view as 'nonsense'; it is, however, defended by Lane. It certainly has no point of contact with the context, though, as Michel remarks, the author may have known more than he expressed. (3) The heavenly sanctuary requires to be purified by the destruction of Satan, or more generally of supernatural powers of evil (Aquinas; tentatively Bleek; Héring; Michel). This is different from the picture in 2:14, and still more in Col. 1:20, which speaks of the reconciliation of supernatural powers. (4) The idea that 'the heavenlies' are the people of God or the Church militant (Luther, F. F. Bruce, Montefiore) has little contact with the context (except possibly $\dot{\tau} \pi \dot{\varepsilon} \rho \dot{\eta} \mu \tilde{\omega} \nu$, v. 24), is difficult also in 8:5, and is often supported by reference to texts outside Hebrews, such as Eph. 2:22; 1 Pet. 2:5. It is true that Hebrews speaks of Christians as 'God's house' (3:6), and represents believers as sharing already in the worship of heaven (12:22-24), but that is

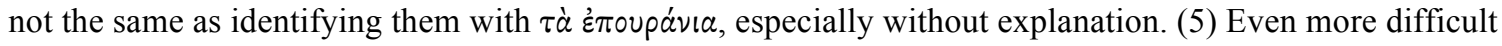

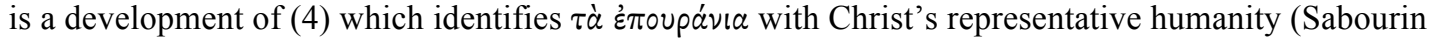
1968.248-255). (6) Attridge develops (4) differently, to suggest that 'the heavenly or ideal realities cleansed by Christ's sacrifice are none other than the consciences of the members of the new covenant.... In Hebrews ... [the] language of cosmic transcendence is ultimately a way of speaking about human interiority (262). At the less than 'ultimate' level, however, the significance of the transcendent language

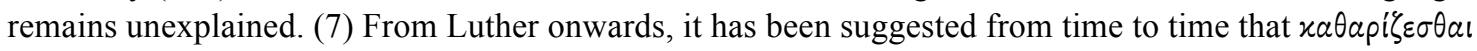
should not be understood in v. 23b; but this is unnatural in itself, and leaves entirely open the question of what v. 23b does mean. (8) The explanation which best accords with the context is well expressed in the NJB note: 'The 'purification' of the sanctuary, whether the earthly or the heavenly one, does not necessarily imply any previous 'impurity': it is a consecratory and inaugural rite' (so Bleek, Spicq, P. E.

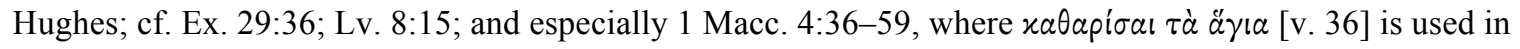

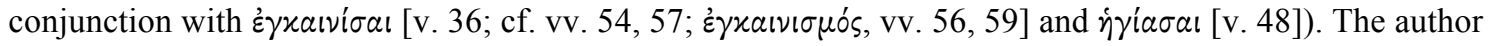
is still thinking of the dedication of a sanctuary, not yet of the perfecting of worshippers, as in 9:28; 
concerned, it is important to explore the plausibility of the implied idea that the sin problem reaches heaven, a cosmic level of God's creation, and that this realm also requires priestly purification. Even though some scholars are uneasy with the idea of sin contaminating heaven, ${ }^{43}$ others affirm the conception of cosmic contamination involving the heavenly sanctuary. ${ }^{44}$

From a canonical perspective, the idea that the sin problem impacts all creation, including the heavenly realm, is quite plausible. On the basis of a typological-cosmic reading of the allusions to Lucifer in Ezek 28:11-19 and Isa $14: 12-15,{ }^{45}$ the sin problem is

10:1ff." Ellingworth, The Epistle to the Hebrews, 477. As I will elaborate in The Goal of the Priesthood below, the interpretation of inauguration does not exclude the idea of previous impurity or a sin that needs to be purified, as the last interpretation described by Ellingworth seems to indicate.

43 Spicq qualifies this idea as “nonsense.” Ceslas Spicq, L'Épitre Aux Hébreux, 2 vols. (Paris: Libraire Lecoffre, 1952-1953), 2:266-267." Attridge regards the "notion that heaven is in need of cleansing" paradoxical, and he decides not to follow this interpretation. Attridge, The Epistle to the Hebrews, 262. For Bruce, a conception of the cleansing of "the heavenly dwelling-place of God in something like material terms," going beyond the interpretation of a defiled human conscience, is far from the intentions of the author of Hebrews. F. F. Bruce, The Epistle to the Hebrews, NICNT (Grand Rapids, MI: Eerdmans, 1964), 218-219.

${ }^{44}$ See Cockerill, The Epistle to the Hebrews, 416-417; Koester, Hebrews, 421; Lane, Hebrews 913, 247. Touching on the issue of the intellectual background of Hebrews, Cockerill argues that "those who contend that Hebrews is dependent on the radical heavenly/earthly dichotomy characteristic of Platonic dualism have the most difficulty explaining how the heavenly world required cleansing." Cockerill, The Epistle to the Hebrews, 416. For Koester, "sin affects all creation," and the geographical distance between earthly sinners and heaven is not a problem for the understanding of contamination. According to the picture of the OT, "although people were not understood to sin within the Tabernacle, the sanctuary was threatened by defilement from people's sins. In the same way, one need not envision heavenly beings committing sins to think that purification of heaven would be appropriate." Koester, Hebrews, 421.

Likewise, Lane affirms that Heb 9:23, "informed by the Levitical conception of the necessity for expiatory purification," assumes that "the heavenly sanctuary had . . become defiled by the sin of the people." Lane, Hebrews 9-13, 247.

${ }^{45}$ I am aware of warnings that these passages should not be applied to Satan, as many church fathers did, because this would detach the passages from their literary setting. See Leslie C. Allen, Ezekiel 20-48, WBC (Dallas: Thomas Nelson, 1998), 95. However, there are substantial studies that indicate that these texts point to a cosmic figure also, and not simply to an earthly monarch only. See Lamar Eugene Cooper, Ezekiel, NAC (Nashville: Broadman \& Holman, 1998), 264-270; Richard M. Davidson, "Ezekiel 28:11-19 and the Rise of the Cosmic Conflict," in The Great Controversy and the End of Evil: Biblical and Theological Studies in Honor of Ángel Manuel Rodríguez in Celebration of His Seventieth Birthday, ed. Gerhard Pfandl (Silver Spring, MD; Nampa, ID: Review and Herald, Biblical Research Institute; Pacific Press, 2015), 57-69; Richard M. Davidson, "The Chiastic Literary Structure of the Book of Ezekiel," in To 
depicted as taking place in heaven. ${ }^{46}$ According to Souza's investigation of these

passages, the setting in heaven where the sinful activity of the cosmic figure (Lucifer)

took place was actually the heavenly sanctuary. ${ }^{47}$ If this cosmic figure could sin there, it

is logically plausible that human sins could impact (pollute) the heavenly sanctuary for a

certain period of time (until its purification, Heb 9:23). Since Heb 9:23 seems to establish

a typological principle of purification, where the cleansing of the earthly sanctuary points

to the purification of the heavenly sanctuary, ${ }^{48}$ the implied pollution of the heavenly

sanctuary appears to be informed by the principle of defilement of the earthly sanctuary

depicted in the Hebrew Bible, defined by a transference of sins to the sanctuary. ${ }^{49}$ The

contamination of the sanctuary through purification offerings meant the removal of sins

Understand the Scriptures: Essays in Honor of William H. Shea, ed. David Merling (Berrien Springs, MI:

Siegfried H. Horn Archaeological Museum, 1997), 87; Jose M. Bertoluci, "The Son of the Morning and the Guardian Cherub in the Context of the Controversy between Good and Evil," (Th.D. Dissertation, Andrews University, 1985); Henry van Dyke Parunak, "Structural Studies in Ezekiel," (Ph.D. Dissertation, Harvard University, 1978), 372-373; Elias Brasil de Souza, "The Heavenly Sanctuary/Temple Motif in the Hebrew Bible: Function and Relationship to the Earthly Counterparts," (Ph.D. Dissertation, Andrews University, 2005), 245-265, 278-292.

${ }^{46}$ Ezekiel 28 speaks of the "anointed guardian cherub ... on the holy mountain of God." (v. 14). However, at some point "unrighteousness was found in" him (v. 15). As Isa 14:12-15 highlights, he fell from heaven because of his sinful desire to be greater than God.

${ }^{47}$ See de Souza, "The Heavenly Sanctuary/Temple Motif in the Hebrew Bible," 245-265, 278292. On the basis of a typological-cosmic reading of Ezek 28:11-19 and Isa 14:12-15, which does not diminish the explicit references to the kings of Tyre (Ezek 28:12) and Babylon (Isa 14:4), it is possible to postulate that the sin problem impacts the heavenly realm in some way.

${ }^{48}$ Especially indicated by the language of necessity (ává $\gamma \varkappa \eta$ ). For further information about the typological use of the language of necessity in Hebrews, see Richard M. Davidson, "Typology in the Book of Hebrews," in Issues in the Book of Hebrews, ed. Frank B. Holbrook (Silver Spring, MD: Biblical Research Institute, 1989), 170.

${ }^{49}$ For helpful information regarding the pollution of the sanctuary, see Gane, Cult and Character, 144, 148, 162-164, 177; Angel M. Rodríguez, "Transfer of Sin in Leviticus," in The Seventy Weeks, Leviticus, and the Nature of Prophecy, ed. Frank B. Holbrook (Silver Spring, MD: Biblical Research Institute, 1986), 169-197; Alberto R. Treiyer, "The Day of Atonement as Related to the Contamination and Purification of the Sanctuary," in The Seventy Weeks, Leviticus, and the Nature of Prophecy, ed. Frank B. Holbrook (Silver Spring, MD: Biblical Research Institute, 1986), 198-227. 
from the offerer. ${ }^{50}$ This transference or contamination throughout the year made the sanctuary polluted, requiring its purification in the ritual of the Day of Atonement. It is precisely in the description of this ritual that the idea of transference of expiable sins is implied, as the sanctuary is purged of the sins of the Israelites (see Lev 16:16, 19-20, 3334). ${ }^{51}$ On the basis of this general principle of contamination of the earthly sanctuary, the reference to the purification of the heavenly sanctuary in Heb 9:23 appears to assume that the sins of repented human beings defile as they are transferred to the real sanctuary in heaven by the ministration of Jesus Christ. This contamination requires a purification performed by Christ's priesthood.

\section{Summary}

In summary, according to the historical model, the priesthood of Christ is needed to solve the sin problem. This problem impacts (1) the relationship of human beings with God, (2) human beings themselves, and (3) creation at a cosmic level (heavenly things). First, there is a broken covenantal relationship between human beings and God, described

${ }^{50}$ The contamination of the sanctuary is mentioned or implied in two groups of passages in the Pentateuch. The first group refers to sins that defile the sanctuary and are not expiable, as far as the sinner is concerned (see Lev 20:3; 15:31; Num 19:13,20). The other group describes sins that are transferred from the offerer to the sanctuary "through outer-altar and outer-sanctum purification offerings performed at the sanctuary," that is, through regular purification offering rituals throughout the year (not the Day of Atonement). Gane, Cult and Character, 177. Regarding the first group, there are two basic situations when these sins take place, namely, the offering of children to Molech (Lev 20:3) and when someone touches a corpse and does not cleanse himself/herself (Num 19:13, 20). According to Gane, this type of contamination has two crucial characteristics: (1) the sins "pollute the sanctuary from a distance when they are committed"; (2) sinners are cut off from Israel. Ibid., 144, 148, 162. Conversely, Rodríguez has a different view regarding point 1 . Instead of an immediate contamination of sins, as indicated by Gane, Rodríguez stipulates on the basis of Ezek 23:38-39 that the contamination of the sanctuary takes place when the sinner comes to the sanctuary in the state of impurity. See Rodríguez, "Transfer of Sin in Leviticus," 175.

${ }^{51}$ According to Gane, the contamination of the sanctuary with expiable sins "do not pollute the sanctuary at the time when they occur," but subsequentely through the regular purification offering ritual. Gane, Cult and Character, 164. 
especially by the transgression of the divine law. In this context, a priestly mediation is necessary for divine forgiveness and thereby restores unity between God and human beings. This forgiveness negatively means that forgiven human beings will not face God's destructive judgment, and positively means that the covenantal relationship between forgiven human beings and God is restored. Second, human beings themselves have at least two basic problems because of sin, namely, a guilty conscience and weakeness in temptation. A guilty conscience results from the awareness of the transgression of the divine law and the broken covenantal relationship with God. In this way, the priesthood of Christ is necessary to purify or eliminate this guilt in the mind of human beings on the basis of the divine forgiveness mediated by His priesthood. Regarding human weakness in facing temptation, which relates to the fallen ontological and moral constitution of human beings, the priesthood of Christ is necessary to help believers endure temptation and sin and thereby live victorious godly lives. Third, the $\sin$ problem impacts creation at a cosmic level, meaning that the heavenly realm, and more specifically the heavenly sanctuary, is somehow affected by sin. In light of the rituals of the earthly sanctuary, the sins of repented human beings defile the heavenly sanctuary and require a priestly purification.

The summary above provides the context for the discussion of the next component of the priesthood of Christ, namely, the agent of this priesthood.

The Agent of the Priesthood

The picture of Christ as the agent of the priesthood in Hebrews is informed by His divinity and humanity. While the focus of the priestly agency is on His humanity, He already worked only as divine as an intermediary agent of creation, and $\mathrm{He}$ is also an 
eschatological divine-human intermediary agent of divine revelation. I will begin this section with the elaboration of the broad notion of intermediary agency, which enriches our perspective of the more specific notion of His priesthood, and then move to the importance of Christ's humanity for His priesthood itself, namely, His preparation for this role and His appointment as (high) priest.

\section{The Notion of Intermediary Agency}

Before the description of the appointment of Chris as (high) priest (5:1-10; 7:128), Hebrews presents a rich Christology. ${ }^{52}$ In $1: 1-14$, the $\operatorname{Son}^{53}$ is an eschatological ${ }^{54}$ divine messenger ("God has spoken to us in a Son,"55 1:2), the divine appointed heir of

\footnotetext{
${ }^{52}$ For surveys on the history of interpretation of Christology in Hebrews, see Helmut Feld, Der Hebräerbrief (Darmstadt: Wissenschaftliche Buchgesellschaft, 1985), 65-82; Andreas Stadelmann, "Zur Christologie Des Hebräerbriefes in Der Neueren Diskussion," in Theologische Berichte 2: Zur Neueren Christologischen Diskussion (Zürich: Benziger Verlag, 1973), 135-221; Erich Grässer, "Der Hebräerbrief 1938-1963," Theologische Rundschau 30, no. 2-3 (1964): 214-223. A recent overview of methodological approaches to the study of the Christology of Hebrews is found in Brian C. Small, The Characterization of Jesus in the Book of Hebrews, Biblical Interpretation Series (Leiden; Boston: Brill, 2014), 2-14. Studies on the Christology of Hebrews include: Friedrich Büchsel, Die Christologie Des Hebräerbriefs (Gütersloh: C. Bertelsmann, 1922); Franz Laub, Bekenntnis Und Auslegung: Die Paränetische Funktion Der Christologie Im Hebräerbrief (Regensburg: Pustet, 1980); William R. G. Loader, Sohn Und Hoherpriester: Eine Traditionsgeschichtliche Untersuchung Zur Christologie Des Hebräerbriefes (Neukirchen-Vluyn: Neukirchener, 1981); Harris L. MacNeill, The Christology of the Epistle to the Hebrews (Chicago: University of Chicago Press, 1914); Kevin B. McCruden, Solidarity Perfected: Beneficent Christology in the Epistle to the Hebrews (Berlin: De Gruyter, 2008); Harm H. Meeter, The Heavenly High Priesthood of Christ: An Exegetico-Dogmatic Study (Grand Rapids, MI: Eerdmans-Sevensma, 1916); Alexander Nairne, The Epistle of Priesthood: Studies in the Epistle to the Hebrews, 2 ed. (Edinburgh: T\&T Clark, 1915); Angela Rascher, Schriftauslegung Und Christologie Im Hebräerbrief (Berlin: Walter de Gruyter, 2007), 101-202; Mathias Rissi, Die Theologie Des Hebräerbriefs: Ihre Verankerung in Der Situation Des Verfassers Und Seiner Leser (Tübingen: Mohr Siebeck, 1987), 45-91; von Joseph Ungeheuer, Der Grosse Priester Über Dem Hause Gottes, Die Christologie Des Hebräerbriefes (Würzburg: H. Stürtz, 1939); Heinrich Zimmermann, Die Hohepriester: Christologie Des Hebräerbriefes (Paderborn: Ferdinand Schöningh, 1964).

${ }^{53}$ In chap. 1, Christ is referred as Son (see vv. 2, 5, 8).

${ }^{54}$ The eschatological language is found in the expression "in these last days" ( $\dot{\varepsilon} \pi$ ' $\dot{\sigma} \sigma \chi \alpha \dot{\alpha} \tau \cup \tau \tilde{\omega} \nu$ $\dot{\eta} \mu \varepsilon \rho \tilde{\omega} \nu \tau 0 \cup \dot{\tau} \omega \nu)(1: 2)$.

${ }^{55}$ This is Guthrie's label for the whole introduction of Hebrews. See George H. Guthrie, "The Structure of Hebrews Revisited," (paper presented at the Annual Meeting of the Society of Biblical
} 
all things $(\pi \dot{\alpha} \nu \tau \omega \nu)(1: 2)$, the intermediary agent $\left(\delta \iota^{\prime} \circ \tilde{v}\right)$ of the creation of the world

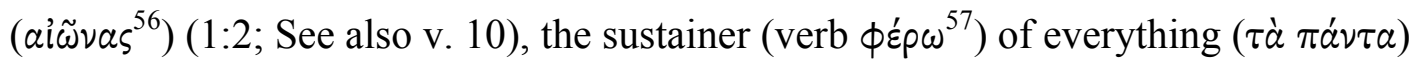
(1:3). Furthermore, He as the Son is God (1:8-9; See also v. 3$)$ and co-regent king $(1: 3,8-$ 9, 13; See also v. 5). As mentioned previously, the priesthood is alluded to in the purification of sins performed by the Son (1:3). In this way, Christ's intermediary role includes soteriology (dealing with sins), protology (creation), and eschatological divine revelation. In Hebrews, ${ }^{58}$ His priesthood is more related to the intermediary role of dealing with sins, and this role necessarily requires His human incarnation, a topic to be discussed below.

Because the present chapter investigates Christ's priesthood on the basis of the book of Hebrews, I tend to use the concept of mediation to refer to His intermediary role in general (protology, soteriology, and revelation), and the concept of priesthood to refer to the more specific intermediary role in soteriology. However, I am aware that a canonical investigation of Christ's priesthood can potentially enlarge the concept of priesthood to what I currently call mediation. I offer more details about this possibility in

Literature, Washington, DC, 2006), https://hebrews.unibas.ch/documents/2006GuthrieH.pdf (accessed 28 December, 2016), 2 (Figure 2: the Structure of the Book of Hebrews). For information about the priesthood of Christ in the structure of Hebrews, see the Appendix.

${ }^{56}$ According to BDAG, this term has four meanings: (1) "a long period of time, without ref. to beginning or end"; (2) "a segment of time as a particular unit of history, age"; (3) "the world as a spatial concept, the world"; (4) "the Aeon as a person, the Aeon." The third meaning is assigned to ai $\tilde{\omega} v a s$ in Heb 1:2. BDAG, 32-33. NJB translates it as ages and NIV as universe.

${ }^{57}$ This verb appears in the participle form ("sustaining," NIV, NJB). For further information regarding the meaning of this verb, see BDAG, 1052.

${ }^{58}$ As mentioned in chap. 6, in recommendations for further studies, it is possible that elsewhere in Scripture the scope of Christ's priesthood includes priestly actions in a world without sin, before and after the existence of the sin problem. However, this possibility does not seem to be emphasized in Hebrews. 
the conclusion of this dissertation, when I suggest topics for further research. For now, with the distinction employed in the present study between mediation and priesthood (the latter is part of the former) in mind, I move to the discussion of Christ's humanity as a pre-requisite for His soteriological priesthood.

\section{Christ's Humanity as a Pre-requisite}

With regard to the importance of Christ's humanity for His priesthood, Heb 1:52:18 ${ }^{59}$ moves from an emphasis on His divinity to a stress on His humanity, with a

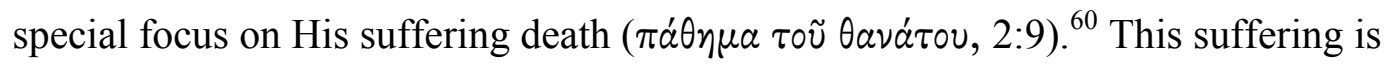

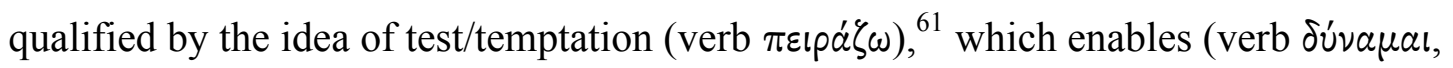
$2: 18)$ Jesus as high priest $(2: 17)$ to help (verb $\beta \circ \eta \theta \varepsilon ́ \omega)$ human beings in their trials/temptations $(2: 18)$. This help seems to spell out the notion that Jesus is a merciful

${ }^{59}$ Guthrie labels each part of exposition I ("The Position of the Son, Our Messenger, in Relation to the Angels"- -1:5-2:18) in the following way: (A) "The Son Superior to the Angels (1:5-14)"; Exhortation (2:1-4); (transition AB) "The Superior Son, to Whom all things are Submitted, for a Time Became Lower than the Angels (2:5-9)"; (B) "The Son Lower than Angels (i.e., among humans) to Suffer for the 'sons' (i.e., heirs) (2:10-18)." Guthrie, "The Structure of Hebrews Revisited," https:/hebrews.unibas.ch/documents/2006GuthrieH.pdf (accessed 28 December, 2016), 2 (Figure 2: the Structure of the Book of Hebrews). For information about the priesthood of Christ in the structure of Hebrews, see the Appendix.

${ }^{60}$ While in the introduction and the first part of exposition I the Son is divine, in the transition $(2: 5-9)$ to the second part of this exposition and the second part itself (2:10-18) the divine Son becomes and exists as a human being. His incarnation is crucial because of the necessity of His death $(2: 9,14)$. Jesus

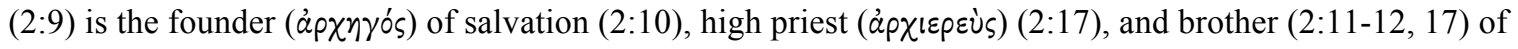
human beings (the seed of Abraham, 2:16).

${ }^{61}$ In his remarks on 2:18, Attridge indicates that "the testing in view is not located in the temptations of Jesus, but in his suffering." Attridge, The Epistle to the Hebrews, 96. Lane explains that the suffering of death was the climax of Christ's fidelity to God, that is, this was the "extreme test" by which He proved to be faithful. Lane, Hebrews 1-8, 66. The possibility of different renditions of the relationship

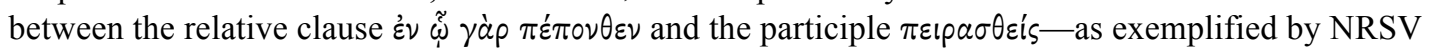
("because he himself was tested by what he suffered") and ESV ("because he himself has suffered when tempted"), and explained by Cockerill (NRSV translates "the participle as causal and the relative as instrumental," while ESV construes "the relative as causal and the participle as temporal." Cockerill, The Epistle to the Hebrews, 152n129.) — does not impact my point here. I simply assume that Christ's death described His suffering and testing. 
high priest $(2: 17) .{ }^{62}$ The connection of suffering and high priesthood explains why Jesus needed to become a human person in order to be this high priest (see 2:17-18). More precisely, "He had (verb ỏ $\phi \varepsilon i \lambda \omega)$ to be made like His brethren in all things, so that He

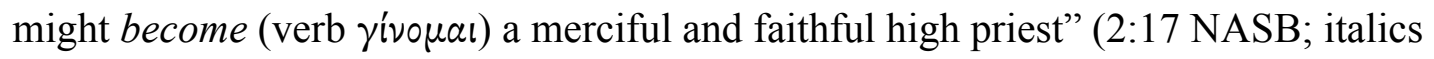
mine). ${ }^{63}$ Overall, Christ's incarnation, temptation, suffering, and death are seen as preparatory for His role as (high) priest, especially considering His priestly mercy and help on behalf of human beings.

The language of necessity (had to be made) and of becoming high priest intertwines two concepts that are significant for the understanding of Christ as priestly agent, namely, (1) His preparation for this role and (2) His appointment as high priest. I will make some remarks about the notion of priestly appointment below.

\section{The Notion of Priestly Appointment}

The idea of appointment is at the center of the general definition of a high priest provided in Hebrews: A high priest is someone "appointed (verb $\varkappa \alpha \theta i \sigma \tau \eta \mu \iota^{64}$ ) on behalf of men in things pertaining to God, in order to offer both gifts and sacrifices for sins" $(5: 1$ NASB; italics mine). Whereas the second part of this definition specifies the action of the priest elaborated in the section on Christ's priestly offering $(8: 3-10: 18),{ }^{65}$ the exposition

\footnotetext{
${ }^{62}$ As Lane points out, Christ's help (2:18) proves that He is a compassionate or merciful high priest (2:17). Lane, Hebrews 1-8, 66.

${ }^{63}$ Hebrews 4:15 specifies that this similarity between the incarnate Christ and human beings excludes the idea of sin.

${ }^{64}$ This verb is in the passive form in 5:1. For information regarding its meaning, see BDAG, 492.

${ }^{65}$ Hebrews 8:3 introduces this section by reaffirming the definition of $5: 1$, but emphasizes the priestly offering. Guthrie, "The Structure of Hebrews Revisited," https://hebrews.unibas.ch/documents/2006Guthrie.pdf (accessed 28 December, 2016), 24.
} 
of the priestly appointment of the Son $(5: 1-10 ; 7: 1-28)$ clarifies the nature of this appointment (centered on the idea of divine calling) and the meaning of an appointment on behalf of human beings (centered on the idea of priestly compassion).

As far as the appointment on behalf of human beings, Christ's priestly compassion $(2: 17 ; 4: 15)$ is not based on the fact that He shared the weaknesses of human beings, ${ }^{66}$ but that He shared the experience of test/temptation $(2: 18 ; 4: 15) .{ }^{67}$ While Aaronic high priests were appointed in their weaknesses, the appointment of the Son is related to His perfection (7:28). Instead of using the language of weakness in reference to Christ, Hebrews emphasizes that He was perfected $(2: 10 ; 5: 9 ; 7: 28)$ through suffering $\left(2: 10^{68} ; 5: 8-9\right),{ }^{69}$ where suffering is associated with the notion of learned obedience $(5: 8-$ 9). Thus, the idea that Christ was made perfect does not presuppose previous moral imperfection (see 7:26-28), but a learning experience, which involved deep emotional ("loud cries and tears") "prayers and supplications" in the face of death (5:7). ${ }^{70}$

${ }^{66}$ In 4:15 our weaknesses are contrasted with His test/temptation without sin. See also 7:26-27.

${ }^{67}$ Similar to the Aaronic priesthood, Christ is called by God and sympathizes with human beings. However, the nature of His calling is different from the calling of that priesthood, and the basis of His compassion for human beings is distinct from that of the Aaronic priesthood. While priests "deal gently" with weak human beings because these priests are also characterized by weaknesses (which requires sacrifices for sins for both the priests and the people) $(5: 2-3 ; 7: 27-28)$, Christ is merciful (2:17) and sympathetic (4:15) to weak human beings because He was tested/tempted as they are $(2: 18 ; 4: 15)$.

${ }^{68}$ In 2:10, God made the founder of salvation perfect (verb $\tau \varepsilon \lambda \varepsilon$ เó $\omega$ ) through sufferings. BDAG defines perfection in Heb 2:10 as overcoming "an imperfect state of things by one that is free fr. objection, bring to an end, bring to its goal/accomplishment." In this sense, "the completion and perfection of Jesus" may be understood as "the overcoming of earthly limitations." At the same time, BDAG is open to the possibility that $\tau \varepsilon \lambda \varepsilon \iota^{\prime} \omega$ in this verse implies "a consecration of Jesus." BDAG, 996.

${ }^{69}$ Although being "a son, he learned obedience through what he suffered. And being made perfect

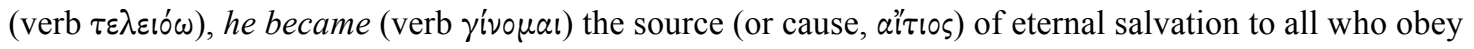
him" (5:8-9; italics mine). For the meaning of alıı

${ }^{70}$ In contrast to high priests who offered $(\pi \rho \circ \sigma \phi \varepsilon ́ \rho \omega)$ for themselves sacrifices because of their own sins (5:3), Christ offered ( $\pi \rho \circ \sigma \phi \varepsilon ́ \omega)$ for Himself prayers and supplications because of the threat of His 
With regard to the nature of the priestly appointment, there are at least three basic ideas to be explained: (1) the divine plan or call; (2) the ontological basis of the reality of the priesthood; and (3) the functional description of the appointment. First, a high priest cannot be self-appointed, but must be appointed or called by God. ${ }^{71}$ Christ was

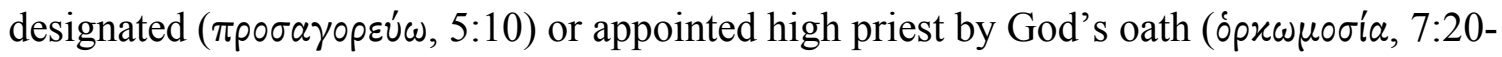
$21,28)$, whose content is essentially the affirmation that Christ is a priest forever $\left(\sum \dot{v}\right.$

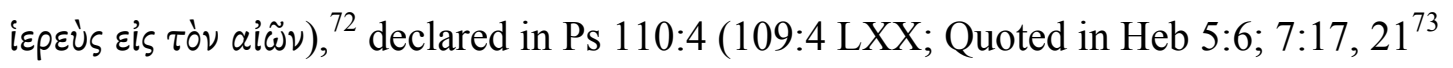
and alluded to in Heb $5: 10 ; 6: 20 ; 7: 11,15) .{ }^{74}$ This divine appointment seems to raise at

own death (5:7). BDAG indicates that the verb $\pi \rho \circ \sigma \phi \varepsilon ́ \rho \omega$ in these two passages is used literally $(5: 3)$ and figuratively (5:7). BDAG, 886.

${ }^{71}$ According to 5:4, a priest needs to be called $\left(\varkappa \alpha \lambda \varepsilon^{\prime} \omega\right)$ by God, that is, he does not take the honor of the priesthood for himself. This was the case of Aaron, who was called by God. Aaron received the

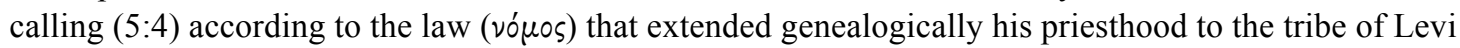
$(7: 5,11,28)$. For instances of vópos appointing or regulating the Aaronic priesthood in Hebrews, see 7:5, $12,16,19,28 ; 8: 4$.

${ }^{72}$ Hebrews 5:5 points out that Christ "did not glorified Himself so as to become a high priest" (NASB), but God said something to Him. This verse seems to imply that God called Christ to the priesthood. The content of what God said to Christ is the quotations of Ps 2:7 and 110:4 in Heb 5:5-6. Arguably, these quotations provide the content of the divine priestly calling of Christ.

${ }^{73}$ The basic difference between the quotation in Heb 7:21 in comparison with 5:5 and 7:17 is that the quotation ends with this affirmation, while the others start with it (I am following here the text of UBS which does not mention Melchizedek in 7:21). This difference seems to be at least partially explained by the fact that the author of Hebrews wishes to emphasize the idea of oath in 7:20-21. From the three

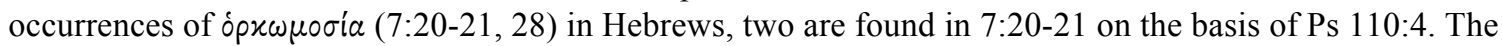
theme of oath is introduced negatively in the exhortation of 3:1-4:13 and positively in the exhortation of 5:11-6:20. In the first exhortation, the divine act of swearing or taking an oath (o $\mu \nu v \dot{\omega} \omega)$ is associated with God's wrath $(3: 11,18 ; 4: 3)$, whereas the verb ó $\mu \nu \cup ́ \omega$ and the noun ópxos (oath) in the second exhortation are used in the context of divine promise $(6: 13,16-17)$. According to BDAG, ó $\mu \nu$ úw means to swear, take an oath (BDAG, 705-706), and öpxos conveys the meaning of oath (BDAG, 723). The beginning of Ps 110:4

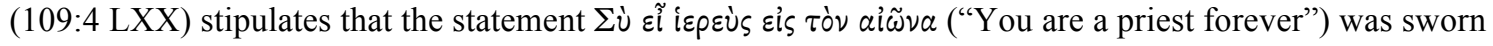
(aorist form of $o \mu \nu v ́ \omega$ ) by the Lord, and this oath will not change. The expression xai ov่ $\mu \varepsilon \tau \alpha \mu \varepsilon \lambda \eta \theta \dot{\eta} \sigma \varepsilon \tau \alpha$ l indicates that the Lord will not change His mind or have second thoughts about His oath. See this meaning

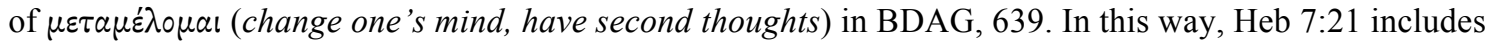
the specification " $\Omega \mu \circ \sigma \varepsilon \nu$ xúplos, xai oủ $\mu \varepsilon \tau \alpha \mu \varepsilon \lambda \eta \theta \eta \dot{\eta \varepsilon \tau \alpha l ~(" T h e ~ L o r d ~ h a s ~ s w o r n ~ a n d ~ w i l l ~ n o t ~ c h a n g e ~ h i s ~}$

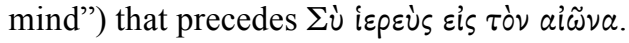

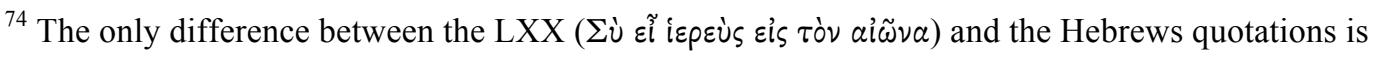


least two implications for the understanding of Christ as (high) priest: (a) considering that the book of Psalms predates the incarnation of Christ, His appointment as priest was intended, expressed, and revealed by God long before the Christological events narrated and explained in the NT; and (b) the unchangeability of God's oath (see Heb 7:21 ${ }^{75}$ ) lays

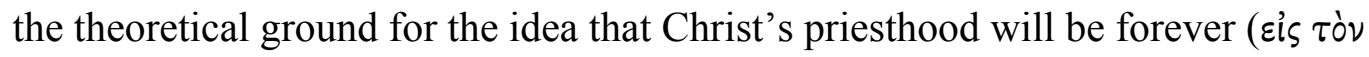

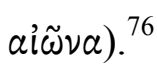

Second, while the intention of an eternal priesthood is observed in God's oath, Christ's endless life $(7: 16)$, which probably refers to His divine/human resurrected life, ${ }^{77}$ provides the ontological basis to the eternal reality of His priesthood (7:17). The use of Ps 110:4 in Heb 7:17 is introduced by the idea that Christ "has become ${ }^{78}$ (verb $\gamma^{\prime}$ ivo $u a l$, perfect tense) a priest $^{79} \ldots$ by the power of an indestructible $\left(\dot{\alpha} x \alpha \tau \alpha \dot{\lambda} \nu \tau \varsigma^{80} \varsigma^{80}\right)$ life" $(7: 16)$.

that the latter omits the verb عĩ.

${ }^{75}$ Hebrews 7:21 includes the specification " $\Omega \mu \circ \sigma \varepsilon \nu$ xúplos, xai oủ $\mu \varepsilon \tau \alpha \mu \varepsilon \lambda \eta \theta \dot{\eta} \sigma \varepsilon \tau \alpha$ l ("The Lord has

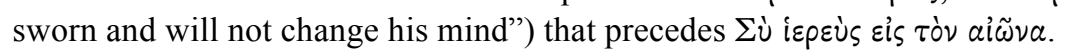

${ }^{76} \mathrm{I}$ have elaborated in footnote 3 above on the basic meaning of Christ as priest forever in

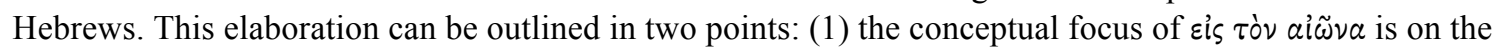
person of the priest; and (2) the implications of this conceptual focus for Christ's priestly role emphasize the endless results of His priestly activity. According to these two points, the forever language for the priesthood of Christ is compatible with the soteriological perspective of His priesthood in Hebrews.

${ }^{77}$ See Lane, Hebrews 1-8, 66; Koester, Hebrews, 355, 361. On the other hand, Cockerill assumes that the power of indestructible life describes the life of the Son since eternity. Cockerill, The Epistle to the Hebrews, 323-324. Attridge correctly emphasizes that "Hebrews does not specify whether this 'power' is a function of Christ's eternal nature or of the event of his exaltation. This is a problem related to the question of when Christ became High Priest." Attridge, The Epistle to the Hebrews, 203.

${ }^{78}$ The language of becoming priest is present not only in the rendition of ESV, but also in NASB, NET, NIV, NRSV, and RSV. in v. 15 .

${ }^{79}$ Even though the Greek term for priest is not present in v. 16, this verse refers to the term iepeìs

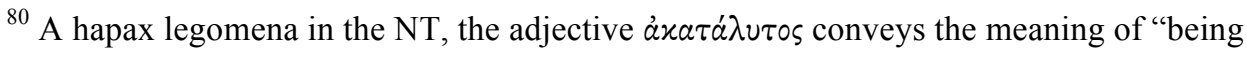
indestructible, endless." BDAG, 35. 
Therefore, the reality of His priesthood is ontologically grounded in Christ's eternal (divine) resurrected (human) life. ${ }^{81}$

Third, the functional description of the appointment associates the concepts of priesthood and kingship. Whereas in the section below, The Actions of the Priest, I will delineate the specific functions of Christ as (high) priest, I highlight here that His function as (high) priest cannot be seen in isolation from His role as co-regent king. ${ }^{82}$ The use of Ps 2:7 (emphasizing kingship) along with Ps 110:4 (emphasizing priesthood) in the context of Christ's divine calling to the priesthood (Heb 5:5-6 $6^{83}$ ) indicates that His royal

${ }^{81}$ This ontological basis is distinct from the reality of Aaronic priests, who were prevented from continuing their work because of their finite or mortal life, making their priesthood changeable and constituted by multiple priests in succession (see 7:23-24). In contrast to the mortal Aaronic priests

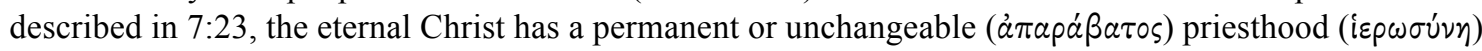
(7:24). A hapax legomena in the NT, the adjective á $\pi \alpha \rho \alpha \beta \beta \tau \tau$ s conveys the meaning of "permanent, unchangeable." BDAG, 97.

${ }^{82}$ See Felix H. Cortez, “'The Anchor of the Soul That Enters within the Veil': The Ascension of the 'Son' in the Letter to the Hebrews," (Ph.D. Dissertation, Andrews University, 2008), 259, 273, 443$445,457-458,460$.

${ }^{83}$ The use of Ps 110:4 in Heb 5:6 takes place in the context of the first description of Christ's divine calling to the priesthood in Hebrews (see 5:4-5). What is striking in 5:5-6 is that the calling of Ps 110:4 in Heb 5:6 is preceded by another quotation from Ps 2:7 in Heb 5:5b, and both quotations in Heb 5:56 seem to be the content of the divine priestly calling declared to Christ that is announced in 5:5a and then initiated in 5:5b. In fact, Ps 2:7 ("You are my Son, today I have begotten you") was already cited in Heb $1: 5$ as the first quotation of a catena of quotations from the OT (see Heb 1:5-13, in the light of the last part of 1:3) through which Hebrews emphasizes that Christ was enthroned as a Davidic king. The context of Ps 2:7 is clearly royal (see, e.g., 2:6-8). In Heb 1:5, the quotation of Ps 2:7 is followed by the citation of 2 Sam 7:14, which speaks of the eschatological Davidic king who would be God's Son and who would have an everlasting kingdom (see 2 Sam 7:12-16). The reference to firstborn ( $\pi \rho \omega \tau o ́ \tau o x o s) ~(H e b ~ 1: 6)$ is also royal language (see Ps 89:27-88:28 LXX). In addition, the quotations of Pss 45:6-7 and 110:1 in Heb 1:8-9 and 13 respectively are explicit royal language. For an interpretation of 1:5-14 as a catena that largely refers to Christ's exaltation or session, see Attridge, The Epistle to the Hebrews, 50, 53; Cockerill, The Epistle to the Hebrews, 102; Ellingworth, The Epistle to the Hebrews, 108; Koester, Hebrews, 197, 199; Lane, Hebrews 1-8, 24; Kenneth L. Schenck, "The Celebration of the Enthroned Son: The Catena of Hebrews 1:5-14," Journal of Biblical Literature 120 (2006): 469-485. Ellingworth even seems to assume that the catena corresponds to "three stages of a coronation liturgy" found "in the OT and other ancient Near Easter texts, especially in Egypt." He explains that "the three stages of such a liturgy are typically (a) a declaration by God that he has adopted the king as his son (cf. v. 5); (b) the presentation of the king to his people, and his proclamation as king (cf. vv. 6-12); (c) the enthronement proper (cf. v. 13)." Ellingworth, The Epistle to the Hebrews, 108. It is noteworthy that the last quotation of this series (Heb 1:13) is from Ps 110:1, which seems to indicate that Hebrews, in consonance with the connection of kingship and priesthood in Ps 110, 
enthronement is construed as a divine priestly appointment. ${ }^{84}$

In short, the understanding of the priestly appointment of Christ derived from the quotations of Ps 110:4 in Hebrews can be stated in the following way: (1) this appointment was intended, expressed, and revealed by God long before His incarnation; (2) the unchangeability of God's oath lays the theoretical ground for Christ's everlasting priesthood; (3) Christ's resurrected endless life is the ontological basis of His everlasting priesthood; and (4) the appointment includes His royal enthronement.

\section{The Beginning of the Priestly Appointment}

The idea of priestly appointment and the language that Christ became (verb $\gamma^{\prime}$ (vopal $)$ (high) priest $(2: 17 ; 5: 5 ; 6: 20 ; 7: 16)^{85}$ raise the question about when this appointment actually took place. To put it more sharply, when did Christ become a (high) priest? Scholars have provided different answers to this question: incarnation, ${ }^{86}$ cross, ${ }^{87}$

presents Christ's priesthood as related to His kingship. For studies on Psalm 110 in Hebrews, see David R. Anderson, The King-Priest of Psalm 110 in Hebrews, Studies in Biblical Literature (New York: Peter Lang, 2001); Jared Compton, Psalm 110 and the Logic of Hebrews, Library of New Testament Studies (New York: Bloomsbury T\&T Clark, 2015); James Kurianal, Jesus Our High Priest: Ps 110,4 and the Substructure of Heb 5,1-7,28 (Frankfort am Main: Peter Lang, 2000).

84 The textual sequence of kingship and priesthood does not only characterize the priestly appointment pronounced by God in 5:5-6 but also the description of Christ as high priest in 8:1-2, namely, one "who has taken His seat at the right hand of the throne of the Majesty in the heavens, a minister in the sanctuary and in the true tabernacle, which the Lord pitched, not man" (NASB). Overall, both the key ideas of endless life (associated with the quotation in 7:17) and royal priesthood (related to the quotation in 5:6) find parallel with the description of Melchizedek in 7:1-3, who is also king-priest and does not have a genealogical record marking the beginning and end of his life.

85 There are other instances in Hebrews that use the language of becoming ( $\gamma^{\prime}$ ivo $\mu a \mathrm{l}$ ) in reference to Christ, without employing explicit priestly terminology (which does not mean that these instances are unrelated to His priesthood). In these instances, He became: better than angels (1:4), the source of eternal salvation (5:9), the guarantee of a better covenant (7:22), and higher than the heavens (7:26). I am aware that become is only one of the meanings conveyed by the term $\gamma^{\prime}$ ivo $\mu a$, but I am in agreement with most English translations by attributing this meaning to $\gamma^{\prime}$ ivo $\mu a l$ in the passages I have mentioned here. For other

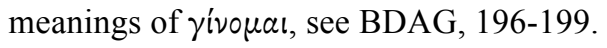

${ }^{86}$ See Aelred Cody, Heavenly Sanctuary and Liturgy in the Epistle to the Hebrews: The 
ascension. ${ }^{88}$ In my estimation, by declaring that Christ would not be a priest "if he were on earth," 8:4 appears to indicate that He began His priesthood officially in heaven. ${ }^{89}$

It is noteworthy that the becoming passages mentioned above $(2: 17 ; 5: 5 ; 6: 20$;

7:16) seem to agree with this perspective and are consistent with what was explained in

the subsections above. First, according to the ontological basis of Christ's priesthood, His

human life is a pre-requisite for Him to become a merciful and faithful high priest

Achievement of Salvation in the Epistle's Perspectives (St. Meinrad, IN: Grail Publications, 1960), 97; Scholer, Proleptic Priests, 193; Spicq, L'Épitre aux Hébreux, 2:111. Spicq affirms this in his interpretation of 5:5-6.

${ }^{87}$ See Ernst Käsemann, The Wandering People of God: An Investigation of the Letter to the Hebrews, trans. Roy A. Harrisville and Irving L. Sandberg (Minneapolis: Augsburg, 1984), 223. Käsemann seems to assume that Christ's death and ascension are one event: "Hebrews no longer regards Golgotha as an essentially earthly fact, but as the beginning of Jesus' ascension. For this reason alone the sacrificial death is already a component of the heavenly high priesthood." Ibid., 231. McKelvey appears to follow this perspective as he sees the cross and the ascension as one event. McKelvey, Pioneer and Priest, 36. For other scholars who see the cross as the beginning of the priesthood of Christ, see David Peterson, Hebrews and Perfection: An Examination of the Concept of Perfection in the "Epistle to the Hebrews", Society for New Testament Studies Monograph Series (Cambridge; New York: Cambridge University Press, 2005), 193-194; Ellingworth, The Epistle to the Hebrews, 185.

${ }^{88}$ See Ulrich Luck, "Himmlisches Und Irdisches Geschehen Im Hebräerbrief: Ein Beitrag Zum Problem Des Historischen Jesus Im Urchristentum," Novum Testamentum 6, no. 2-3 (1963): 205. Westcott seems to follow this position at least partially, with the caveat that he views the cross as a priestly act. In his words, "the offering of Christ upon the Cross was a High-priestly act, though Christ did not become 'Highpriest after the order of Melchizedek,' that is, royal High-priest, till the Ascension.” Brooke Foss Westcott, The Epistle to the Hebrews the Greek Text with Notes and Essays, Classic Commentaries on the Greek New Testament (London: Macmillan, 1903), 199. See also John H. Davies, "The Heavenly Work of Christ in Hebrews," in Studia Evangelica IV, ed. F. L. Cross (Berlin: Akademie-Verlag, 1968), 386-387; Rafael Gyllenberg, "Die Christologie Des Hebräerbriefes," Zeitschrift für systematische Theologie 11 (1934): 689. The view that Christ's priesthood began only at his ascension is historically associated with Socinianism. Peterson, Hebrews and Perfection, 191; Attridge, The Epistle to the Hebrews, 146n120. For information regarding the Socinian view on Christ's priesthood, Bruce A. Demarest, A History of Interpretation of Hebrews VII. 1-10 from the Reformation to the Present (Tübingen: Mohr Siebeck: 1976), 22; F. Socinus, De Jesu Christi Filii Dei Natura Sive Essentia Adversus Volarum (Amsterdam: Bibliotheca Fratrum Putanorum, 1656), 2:391-393.

${ }^{89}$ I do not follow the assumption affirmed by Attridge and Loader that the priesthood of Christ in Hebrews is an unsystematic concept derived from two divergent traditions that respectively refer to the passion of Christ on earth $(9: 14,26)$ and His heavenly intercession $(2: 17 ; 4: 14-16 ; 6: 20)$. See Attridge, The Epistle to the Hebrews, 146-147; Loader, Sohn und Hoherpriester, 238-250. 
$(2: 17),{ }^{90}$ and $\mathrm{He}$ "has become a priest . . by the power of" His resurrected "indestructible life." ${ }^{\prime 11}$ Second, the becoming is closely associated with the ascension (6:20). Hebrews related Christ's priesthood with His ascension ("high priest who has passed through the heavens," $4: 14)^{92}$ and stipulates that He became (verb $\gamma^{\prime}(v o \mu a l)$ a high priest officially when He entered "behind the curtain" into the heavenly presence of God (6:19-20; cf. 9:24) ${ }^{93}$ Third, in the context of the functional description of the royal-priestly appointment, ${ }^{94}$ the divine appointment in 5:5-7 combines Christ becoming priest with His enthronement as co-regent king in heaven (cf. 1:3-13; 5:5-6; 8:1-2; 10:12-13; 12:2) ${ }^{95}$ Therefore, taking into accout that Christ's priestly becoming is particularly related to His resurrected life, His ascension and heavenly enthronement, it is plausible to affirm that it

${ }^{90}$ See subsection above Christ's Humanity as a Pre-requisite.

${ }^{91}$ See the notion of the ontological basis of the reality Christ's priesthood in the subsection above The Notion of Priestly Appointment.

${ }^{92}$ Commentators see in this passage an implied affirmation of Christ entering the heavenly sanctuary as a priest. Cockerill, The Epistle to the Hebrews, 224; Koester, Hebrews, 282; Lane, Hebrews 1 $8,103$.

${ }^{93}$ In his remarks on the verb yivoual in 6:20, Ellingworth argues that Christ's "entry into the heavenly sanctuary, and his appointment as high priest, are one." Ellingworth, The Epistle to the Hebrews, 349. For Davies, Christ's entry into heaven in 6:20 "appears to come after his becoming High Priest, but the aorist $\gamma \varepsilon v o ́ \mu \varepsilon v o s$ need not to be taken to indicate chronological priority to $\varepsilon i \sigma \tilde{\eta} \lambda \theta \varepsilon v$. The natural sequence would be, first the Entry, then the Investiture." Davies, "The Heavenly Work of Christ in Hebrews," 386. According to a temporal understanding of the aorist participle (antecedent or contemporaneous), $\gamma \varepsilon v o ́ \mu \varepsilon v o s$ is antecedent or contemporaneous of $\varepsilon i \sigma \tilde{\eta} \lambda \theta \varepsilon v$. Daniel B. Wallace, Greek Grammar Beyond the Basics: An Exegetical Syntax of the New Testament (Grand Rapids, MI: Zondervan, 1996), 614. From this linguistic

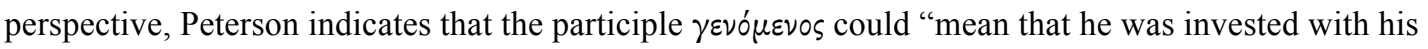
priesthood prior to, or simultaneously with, his entrance into the heavenly sanctuary." Peterson, Hebrews and Perfection, 192. In this context, my reading of $\gamma \varepsilon v o ́ \mu \varepsilon \nu \circ s$ in this verse tends toward a simultaneous interpretation of this participle and $\varepsilon i \sigma \tilde{\eta} \lambda \theta \varepsilon \nu$.

${ }^{94}$ See this concept in the subsection above The Notion of Priestly Appointment.

${ }^{95}$ Almost all these passages are explored by Felix Cortez in his study of Christ's ascension as the inauguration of His heavenly eschatological kingship in Hebrews. See Cortez, "'The Anchor of the Soul that Enters Within the Veil'." His study concentrates on 1:6; 4:14-16; 6:19-20; 9:11-14, 24-28; 10:19-25; $12: 18-25$. 
is the ascended Christ who officially became high priest.

Indeed, if Christ became high priest officially at the ascension, as I have already

emphasized above, ${ }^{96}$ His incarnation and test/temptation (see 2:17-18), His obedience and

perfection (see 5:7-10), and His resurrection (see 7:24-25) are related to His priestly

appointment, but as pre-requisites for His official priesthood. ${ }^{97}$ I employ the term

official $^{98}$ to describe the beginning of Christ's priesthood at the ascension because I

acknowledge that He seems to be proleptically referred to as priest before the ascension.

For instance, the technical language $\pi \rho \circ \sigma \phi \varepsilon ́ p \omega$, which is used for the (high) priest

\footnotetext{
${ }^{96}$ In the subsection Christ's Humanity as a Pre-requisite above, I have emphasized that His incarnation, temptation, suffering, and death are preparatory for His role as (high) priest.

${ }^{97}$ The meaning of Christ being made perfect (expressed by the verb $\tau \varepsilon \lambda \varepsilon \iota^{\prime} \omega$ in $2: 10 ; 5: 9 ; 7: 28$ ) in Hebrews has been debated in the literature. Overall, the principal meanings suggested are: (1) moral: "full moral perfection of His humanity" (Westcott) or "going through the various stages of" His "human life" (Cullmann), learned obedience in a fuller degree (McKelvey); (2) vocational: qualification to the priesthood (Peterson, Attridge), particularly expressed in the ability to sympathize (McKelvey); (3) cultic: consecration of a priest, as indicated in the LXX (see, e.g., Exod 29:9, 29, 33, 35; Lev 21:10) by the use of $\tau \varepsilon \lambda \varepsilon \iota^{\prime} \omega$ in the Pentateuch (Vanhoye, Silva), which would be ontologically interpreted as the transformation/glorification of Christ's humanity (Vanhoye); (4) eschatological: the fulfillment of glorification/exaltation (Silva); (5) theological: "unimpeded access to God" (Bruce, Sabourin, Scholer). See Bruce, The Epistle to the Hebrews, 44; McKelvey, Pioneer and Priest, 26-33; Peterson, Hebrews and Perfection, 66-73, 118; Sabourin, Priesthood, 183; Scholer, Proleptic Priests, 185-200; Vanhoye, Old Testament Priests and the New Priest, 83, 157, 165-168; Moises Silva, "Perfection and Eschatology in Hebrews," Westminster Theological Journal 39, no. 1 (1976): 61, 65, 68; Attridge, The Epistle to the Hebrews, 83-87; Cullmann, The Christology of the New Testament, 93; Westcott, The Epistle to the Hebrews, 49. This cursory overview of suggestions hardly makes justice to the nuanced treatment offered by each author. Furthermore, there may be an overlap among these positions (see McKelvey). As long as 2:17 and 5:9 (read in light of 5:8) indicate that Christ was made perfect through suffering, this earthly experience describes my idea of prerequisite for His heavenly priestly appointment. Such idea of perfection is basically vocational, and may include moral traces of stages of human experience and obedience in a fuller degree. If 7:28 reads Christ "made perfect forever" in connection with His exaltation (7:26), then, in light of 2:17 and 5:9, there is an emphasis on the result of Him made perfect, which could be described in terms of the cultic, eschatological, and the theological views.

${ }^{98}$ In his remarks on Heb 5:5-6, Cockerill emphasizes that "the association of Ps 110:4 with Ps 2:7 and Ps 110:1 suggests that God proclaimed him [Christ] High Priest at his exaltation. Although he may have been High Priest during his earthly life, he did not enter into the full exercise of that office until "he sat down at the right hand of the Majesty in heaven' (8:1; cf. 1:3)." Cockerill, The Epistle to the Hebrews, 239. My use of the term official attempts to capture this idea that the full exercise of Christ's priesthood began at His exaltation in heaven.
} 
offering sacrifices (cf. 5:1, 3; 8:3-4; 9:7, 9, 25; 10:1-2, 8, 11), ${ }^{99}$ is employed to refer to the earthly Christ offering up prayers and supplications (5:7; cf. John 17). ${ }^{100}$ Nevertheless, the language of priestly offering is also used for Christ's sacrifice (Heb 7:27; 8:3; 9:14, $25,28 ; 10: 10,12,14),{ }^{101}$ as He offered Himself $(7: 27 ; 9: 14,28)$ "to bear the sins of many" (9:28). When this information is put together with the idea that Christ's priesthood officially began at His ascension, a significant question is raised: Is the sacrifice on the $\operatorname{cross}^{102}(1)$ a mere preparation for His priesthood, (2) a proleptic reference to His official priesthood, or (3) part of His official priesthood? If properly articulated, concepts from these three options can be combined in the formulation of the answer. This means that the sacrifice on the cross is not merely a preparation for the priesthood, but it is also a crucial

${ }^{99}$ See also the priestly use of the cognate term ávaф́́pw in 7:27 and 13:15.

100 The identification of this priestly language being used for Christ's prayers is mentioned, for example, by Cockerill, The Epistle to the Hebrews, 241-242; Ellingworth, The Epistle to the Hebrews, 287; Koester, Hebrews, 288.

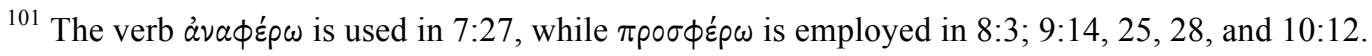
The noun $\pi \rho \circ \sigma \phi \circ \rho \alpha ́$ is used in 10:10, 14.

102 The use of ávaф́́pw in Heb 9:28 (to bear the sins of many) is similar to its employment in 1 Pet 2:24 (He himself bore our sins in his body [ $\sigma \omega \omega^{\prime} \mu \alpha \tau$ l] on the tree). The use of $\sigma \tilde{\omega} \mu \alpha$ in the latter passage can

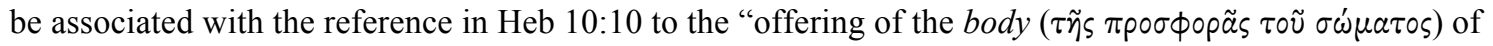
Jesus Christ." When these parallels are taken into account, and these Hebrews passages are read in light of 1 Pet 2:24, the offering of Christ is identified as the sacrifice on the cross. In fact, the expression हis $\tau \dot{0}$

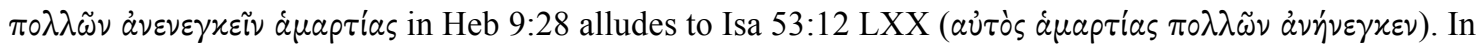

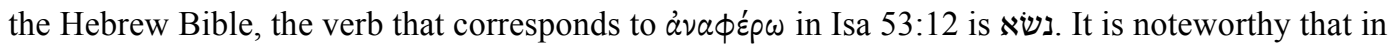
passages related to the priesthood in the Torah, נשא is used to describe priestly bearing. In Exod 28, this bearing is related to the priestly garments. Aaron would bear the names of the people of Israel in the shoulder pieces of the ephod (Exod 28:12) and in the breastpiece of judgment (Exod 28:19) regularly before the Lord. As the breastpiece would have the Urim and the Thummim, Aaron would "bear the judgment of the people of Israel on his heart before the Lord regularly" (Exod 28:30). Furthermore, with his turban on the forehead, Aaron would "bear any guilt from the holy things that the people of Isarel consecrate as their holy gifts. It shall regularly be on his forehead, that they may be accepted before the Lord" (Exod 28:38). In its turn, the priestly bearing described by נשא in Lev 10:17 related to the sacrificial system. According to this passage, the priests had to eat the sin offering, when "its blood is not brought into the inner part of the sanctuary" (Lev 10:18; cf. 6:26, 29-30), to "bear the iniquity of the congregation, to make atonement for them before the Lord" (Lev 10:17). 
form of preparation. As already mentioned in the subsections above, ${ }^{103}$ Christ was

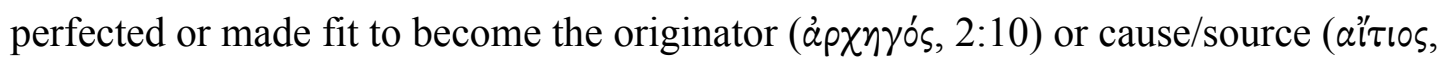
5:9) of salvation. This becoming is spelled out in terms of "being designated by God a high priest after the order of Melchizedek" (5:10; cf. 7:28). It is noteworthy that this process of being perfected centers on the experience of suffering (2:10;5:8-9; cf. 2:18), particularly the "suffering of death" (2:9; cf. 5:7-8). From this standpoint, His death on the cross was the climax of Christ's preparation for the priestly office to be performed officially in His resurrected ascended state. However, the cross can be interpreted also as a proleptic reference to His official priesthood and even as part of it. But this interpretation will be explored below in the section The Actions of the Priest.

\section{Summary}

In summary, Christ as the agent of the priesthood is divine and co-regent king. $\mathrm{He}$ is not only a priestly intermediary agent, but also the protological intermediary agent of creation and the eschatological intermediary agent of divine revelation. The fact that $\mathrm{He}$ became a human being is essential for His priesthood, as it enabled Him to experience suffering and death. As the author of salvation, Christ was perfected by God through deadly suffering. This situation in the face of death was an experience of learned obedience to God. In addition, this situation of test/temptation enabled Him to become a merciful high priest who can help human beings in their trials/temptations. With regard to the nature of Christ's priestly appointment, He was appointed by God's oath, who appoints Him as everlasting priest. This appointment was intended, expressed, and

${ }^{103}$ See Christ's Humanity as Pre-requisite and The Notion of Priestly Appointment. 
revealed by God long before Christ's incarnation. His everlasting priesthood is based on the unchangeability of God's oath and on His resurrected endless life. Also, the priestly appointment includes Christ's royal enthronement. The priestly appointment, by which Christ became (high) priest, became officially effective since the ascension.

Having described the agent of the priesthood, I will explore His priestly actions.

\section{The Actions of the Priest}

The account of Christ's priestly actions in Hebrews can be organized in three parts that refer to past, present, and future actions. ${ }^{104}$ This organization is similar to Cullmann's tripartite conception of Christ's priesthood in Hebrews, mentioned in the introduction of this dissertation. ${ }^{105}$ The main difference derives from the idea advanced in the section above (The Agent of the Priesthood) that Christ's priesthood officially began at His ascension. Thus, while Cullmann speaks of the first part of the priesthood as Christ's past work on earth (His sacrifice on the cross), this dissertation suggests a more nuanced view of Christ's past priestly work, spelled out in terms of a complex notion of sacrificial offering that includes the sacrifice on the cross (see $9: 28 ; 10: 12 ; 13: 10-12)$ and its official heavenly presentation to the Father at the ascension. Whereas the first part of Christ's official priestly actions centers on the heavenly presentation of His sacrifice, the second part describes His present ongoing intercession on behalf of believers, and the third part concerns the eschatological judgment and the final salvation at His second

\footnotetext{
${ }^{104}$ Regarding the location of references to Christ's priestly actions in Hebrews, before the specific section on Christ's priestly offering $(8: 3-10: 18)$, there are at least three references $(1: 3 ; 2: 17 ; 7: 25)$ to His priestly actions.

105 See pages $1-2$.
} 
coming. Obviously, the second (intercession) and the third (judgment/salvation) parts are performed on the basis of the first part (the offering of His sacrifice). In short, I refer to the three types of Christ's priestly actions as (1) the heavenly offering of His earthly sacrifice; (2) ongoing intercession; and (3) eschatological judgment and salvation.

\section{The Heavenly Offering of His Earthly Sacrifice}

In this subsection I will discuss the complex notion of sacrificial offering. As part of this discussion, I will explore an interpretation mentioned at the end of the last section (The Agent of the Priesthood), namely, that the cross can be seen as a proleptic reference to Christ's official priesthood and even as part of it.

Based on a cursory reading of Christ's sacrificial offering in Hebrews, ${ }^{106}$ one may conclude (in agreement with Cullmann) that this offering simply refers to His death on the cross. But a close reading of Hebrews reveals a more complex notion of sacrificial offering. At least three lines of evidence can be observed regarding this complex notion, two in Hebrews itself and the third in the background of the Hebrew Bible.

The first line of evidence implies a priestly offering in heaven. According to Hebrews, the sacrificial offering is central for the priestly work. The introduction of the discussion on Christ's priestly appointment $(5: 1-10 ; 7: 1-28)$ highlights that a high priest is appointed "to offer (verb $\pi \rho \circ \sigma \phi \varepsilon ́ \rho \omega){ }^{107}$ gifts and sacrifices for sins" (5:1). This formula

\footnotetext{
${ }^{106}$ There are several references to Christ's offering in Hebrews. 7:27 (verb áva $\phi \dot{\varepsilon} \rho \omega$ ) and 9:14 (verb $\pi \rho \circ \sigma \phi \varepsilon ́ p \omega$ ) indicate that Christ sacrificially offered Himself. The offering in 7:27 is preceded by a

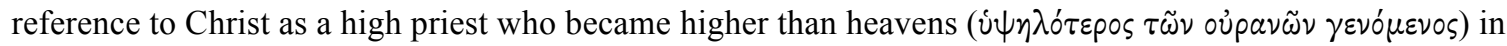
v. 26. In its turn, 9:14 specifies that His offering is related to His blood, and was directed to God. In 10:10, the author mentions "the offering ( $\pi \rho \circ \sigma \phi \circ p \tilde{\varsigma} \varsigma$ ) of the body of Jesus Christ." The offering in both 7:27 and 10:10 is qualified by the adverb $\dot{\phi} \dot{\alpha} \pi a \xi$ (once for all). Heb 10:12-14 also refer to the offering of Christ.

${ }^{107}$ The Greek terminology for the concept of cultic offering in Hebrews comprises the related
} 
is repeated in the introduction (8:3) of the discussion on Christ's offering (Heb 8:310:18). ${ }^{108}$ Therefore, Christ has something to offer as a high priest (8:3b). But the surprising information is that the emphasis of His offering seems to be in heaven, not on earth. Christ would not be a priest if He were on earth $(8: 4),{ }^{109}$ because priests offer sacrifices in the earthly sanctuary (8:4-5). Indeed, the priestly service is described in terms of offerings in the sanctuary setting. While Aaronic priests offer gifts/sacrifices (8:4) in their service in the earthly sanctuary (8:5), Christ is the high priest ministering in the true sanctuary in heaven $(8: 1-2)$, which is the pattern $(\tau \dot{\tau} \pi \circ \varsigma)$ of the sketch and shadow, the earthly sanctuary (8:5). ${ }^{110}$ Hence, in this discussion of Christ's priestly

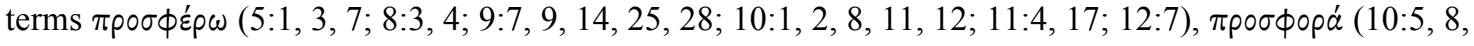
$10,14,18)$, and ávaф́́pw $(7: 27 ; 9: 28 ; 13: 15)$. For their lexical meaning, see BDAG, 75, 886-887; L\&N $\S 53.16-17$.

${ }^{108}$ While the sections on Christ priestly appointment (5:1-10; 7:1-28) and on Christ's priestly offering (Heb 8:3-10:18) begin with the same formula (compare 5:1 and 8:3), the focus of the discussion introduced by 5:1 is on the appointment of the priest to perform sacrificial offering, and the focus of the discussion introduced by $8: 3$ is on the sacrificial offering that is performed by the appointed priest.

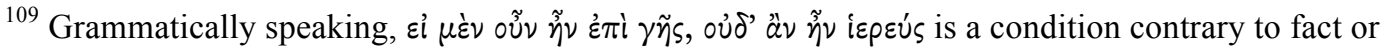
a second clause condition. A. T. Robertson, A Grammar of the Greek New Testament in the Light of Historical Research (Bellingham, WA: Logos Bible Software, 2006), 1015; Wallace, Greek Grammar Beyond the Basics, 696. As Koester explains, this condition has the following effect in terms of meaning: "If he were on earth (but he is not), he would not be a priest (although in fact he is a priest)." Koester, Hebrews, 377. Theologically speaking, Ellingworth argues that to take this verse to mean that "Jesus had never "been on earth"" is a misunderstanding. Ellingworth, The Epistle to the Hebrews, 405. Conversely, Moffitt maintains that "8:4 clearly locates Jesus' priestly ministry in heaven, after his life and death on earth." In this way, "when he claims that Jesus was not a priest—let alone a high priest—on earth (8:4), and goes on to stress that Jesus made his atoning offering before God in the heavenly tabernacle, his belief in Jesus' bodily resurrection suggests that he means exactly what he says. Jesus was only qualified to become high priest after his resurrection. Only after this event was he further able to enter into God's presence in heaven to offer his atoning sacrifice there." David M. Moffitt, Atonement and the Logic of Resurrection in the Epistle to the Hebrews, Supplements to Novum Testamentum (Leiden; Boston: Brill, 2011), 198, 228. My argument of Christ being a high priest officialy in heaven in 8:4 is close to Moffitt's position and different from Ellingworth' view.

${ }^{110}$ I indicate here the Greek language in 8:5 for sketch ( $\left.\dot{\pi} \delta \delta \varepsilon \varepsilon^{\prime} \gamma \mu \alpha \tau \iota\right)$ and shadow $(\sigma x \iota \tilde{\alpha})$. The term ن $\pi \circ \delta \varepsilon i ́ \gamma \mu a \tau \iota$ appears in 4:11; 8:25; 9:23 and conveys two basic meanings: (1) "an example of behavior used for purposes of moral instruction, example, model, pattern"; (2) "an indication of someth. that appears at a subsequent time, outline, sketch, symbol." The first meaning appears in 4:11, while the second is found in 8:5 and 9:23. BDAG, 1037. The option for the translation sketch agrees with NET and NRSV. 
offering, the emphasis is on heaven.

The second line of evidence specifies in what sense the priestly offering is related to the sanctuary setting. In 9:24-25 there are two basic contrasts, one regarding the heavenly and the earthly sanctuaries and the other about Christ's offering and the offerings of Aaronic high priests. The first contrast is between the true and heavenly sanctuary, where Christ entered, and the earthly human-made antitype of the true sanctuary (9:24). Then, there is the contrast of Christ's one offering (expressed by the verb $\pi \rho \circ \sigma \phi \varepsilon ́ p \omega)$ and the offerings of Aaronic high priests performed every year (9:25). The interesting point is how the comparison of the offerings is delineated. The offering of Christ, who entered the heavenly sanctuary $(9: 24)$ by means of His own blood $(9: 12)$, is contrasted with the multiple times that the high priest entered the earthly sanctuary with blood that is not his own $(9: 25) .{ }^{111}$ Thus, the point here is that the priestly offering is performed, not by killing the victim on the outer altar, but by entering into the sanctuary with $^{112}$ its blood. Therefore, in this context, the focus of Christ's priestly offering is in His entrance into the heavenly sanctuary. However, this priestly entrance into the sanctuary cannot be seen in isolation from the sacrifice of the victim on the outer altar, as

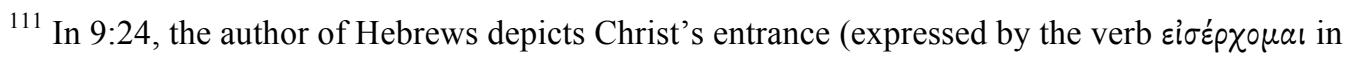
the aorist form — see also $6: 19-20 ; 9: 12)$ into the heavenly holy places ( $\check{a} \gamma 10 \varsigma)$ "to appear in the presence of God on our behalf." What is noteworthy in v. 25 is the emphasis that Christ did not enter "to offer (verb

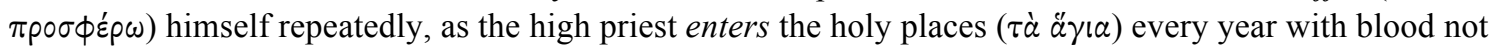
his own" (italics mine).

${ }^{112}$ While I use this language here, in contrast to Thompson and Brooks, I do not assume that Christ manipulated blood or that his sacrifice took place (even metaphorically) in the heavenly sanctuary, because I understand that He went to the heavenly sanctuary after His resurrection, and not right after His bloody death (this point will be further elaborated below in the discussion of the macro-hermeneutical principles of reality). For their interpretation on Christ's blood in heaven, see James W. Thompson, The Beginnings of Christian Philosophy: The Epistle to the Hebrews (Washington, DC: Catholic Biblical Association of America, 1982), 108; Walter Edward Brooks, "Perpetuity of Christ's Sacrifice in the Epistle to the Hebrews," Journal of Biblical Literature 89, no. 2 (1970): 210-211. 
the entrance is with its blood. From the typological perspective of the Aaronic priesthood, this entrance with sacrificial blood was directly dependent on the suffering (verb $\pi \dot{\sigma} \sigma \chi \omega)$ of the sacrificial victim, ${ }^{113}$ since the high priest carries the blood of the sacrifice into the sanctuary. In this sense, if Christ had to offer Himself often by repeatedly entering the sanctuary, as the Aaronic high priests did (9:25), He "would have had to suffer repeatedly" as well (9:26). In contrast to this situation of repetition, Christ's one entrance (9:12) follows His one sacrifice (10:10).

The third line of evidence clarifies, from the perspective of the OT background, this complex notion of sacrificial offering that includes the killing of the victim on the outer altar and the priestly entrance into the sanctuary with its blood. A conceptual distinction regarding the reality of an offering may be helpful in this clarification. An account of sacrificial offering could emphasize, for example, what (the sacrifice) is being offered or to whom (the recipient) it is being offered. The heavenly offering focuses on Christ presenting the sacrifice on the cross to God the Father, who receives/accepts the offering. This idea is supported by the priestly offerings described in the Hebrew Bible. In Leviticus, sacrificial offerings were not complete without a final movement toward God, expressed either vertically or horizontally. ${ }^{114}$ For instance, the vertical movement is seen in the smoke of sacrifices going "up toward the deity in heaven (cf. Ps 11:4)"115 in

\footnotetext{
${ }^{113}$ My interpretation here assumes that Christ's action of entering in the heavenly sanctuary is subsequent to His sacrificial death on the cross, as these two actions are necessarily connected by His resurrection. This interpretation is clearly different from Attridge's idea of only one action, which tends to suppress His resurrection - "Christ's sacrificial death is not an act distinct from his entry into God's presence." Attridge, The Epistle to the Hebrews, 264.

${ }^{114}$ I am indebted to Dr. Roy Gane for this insight, as it will become evident in the footnotes below.

${ }^{115}$ Gane, Cult and Character, 62.
} 
the burnt offerings, grain offerings, and peace offerings, as they are called "an offering by fire of a soothing aroma to the Lord" (Lev 1:13, 17; 2:2, 9; 3:5 NASB). ${ }^{116}$ Indeed, the root of the Hebrew term for burnt offering (עלדה ist, which literally means ascending, going up. ${ }^{117}$ In its turn, the horizontal movement is observed when the high priest had to bring sacrificial blood into the sanctuary ("before the Lord," Lev 4:6, 17) in the purification offering for the sins of the anointed priest (Lev 4:3, 5-7) and of the whole congregation of Israel (Lev 4:13, 16-18), and even bring sacrificial blood into the Most Holy Place ("before the Lord," Lev 16:12-13) on the Day of Atonement (Lev 16:1415). ${ }^{118}$ In Hebrews, these two movements (going up and going into the sanctuary) are achieved by Christ's ascension, as He went up to heaven (Heb 4:14) in order to enter into the heavenly sanctuary (Heb 6:20; 9:12, 24-25) to offer His sacrifice (that took place on the cross) to God for us (Heb 9:24-25). ${ }^{119}$ According to the OT background, the slaughtering of the victim (death), was absolutely necessary, but was not a defining

\footnotetext{
${ }^{116}$ The expression "offering by fire" translates the Hebrew word wִ which means "offering made by fire." HALOT, 93.

${ }^{117}$ See HALOT, 828, 830-831. See Roy Gane, Leviticus, Numbers, The NIV Application Commentary (Grand Rapids, MI: Zondervan, 2004), 69.

${ }^{118}$ Gane even detects a vertical movement in the priestly manipulation of blood in the purification offering. In his words, the "blood of purification offering is applied to the horns of an altar, whether the outer altar in the case of an outer-altar offering $(4: 25,30,34)$, the incense altar in the outer-sanctum offering (vv. 7, 18), or both in the inner-sanctum offering $(16: 16 \mathrm{~b}, 18)$. Since the horns are the highest parts of an altar, applying blood prominent in a vertical direction, in which smoke of sacrifices or incense goes up toward the deity in heaven (cf. Ps 11:4)." Gane, Cult and Character, 62. In this way, "blood was extended toward God in two directions: vertically toward his heavenly dwelling (Ps 11:4) and horizontally toward his Presence enthroned above the ark in the earthly Most Holy Place (Ex. 25:22; Num. 7:89; 1 Sam. 4:4; 6:2; 2 Kings 19:15).” Gane, Leviticus, Numbers, 107-108.
}

${ }^{119}$ Gane compares this sacrificial background in Leviticus with the fact that "after his death on the cross, Christ ascended to heaven (cf. Judg. 13:20). When he appeared to Mary Magdalene just after his resurrection, he said to her: 'Do not hold on to me, because I have not yet ascended to the Father' (John 20:17, NRSV). This verse suggests that after appearing to Mary, Jesus ascended to heaven that day, after which he returned to earth and appeared to his other disciples for several weeks before permanently ascending (Luke 24; Acts 1)." Gane, Leviticus, Numbers, 69. 
priestly attribution. While others could do the slaughtering in non-calendric sacrifices, ${ }^{120}$ the exclusive priestly attribution was to initiate the movement of the sacrifice toward God after the slaughtering, either by burning the victim on the altar of sacrifice (offerings by fire) ${ }^{121}$ or by taking its blood into the sanctuary (purification offering). ${ }^{122}$ This background provides additional support to the idea that Christ begins His priesthood officially at the ascension in His movement to the heavenly sanctuary.

What these three lines of evidence have shown is that Christ's priestly offering does not simply refer to His death on the cross but, according to a more complex notion of sacrificial offering, it emphasizes the entrance of the resurrected ascended Christ in the heavenly sanctuary to officially present His earthly sacrifice to the Father. To be sure, the cross can be seen typologically as the outer altar where Christ's sacrificial offering took place on earth (cf. 13:10-12), but that sacrifice needed to be subsequently presented in the sanctuary in heaven. ${ }^{123}$ According to this standpoint, in what sense is the cross a proleptic

${ }^{120}$ See Lev $1: 5 ; 3: 2,8,13 ; 4: 15,24,29,33$. In calendric sacrifices, the priests slaughtered the animals for the community (see Num 28-29, which includes the Day of Atonement in 29:7-11). This priestly activity for the community is explicit in the description of the Day of Atonement in Lev 16:15. I am indebted to Dr. Roy Gane for this insight.

${ }^{121}$ See Lev $1: 9,13,17 ; 2: 2,9,16 ; 3: 5,11,16$. This was the vertical movement mentioned above.

122 See Lev 4:5-7, 16-18; 16:14-15. This was the horizontal movement indicated above. As mentioned in footnote 157, in cases when the priests applied sacrificial blood on the horns of the altar of burnt offering $(4: 25,30,34)$, there is an idea of vertical movement toward God.

${ }^{123}$ As it will become evident in my discussion below, I am not following here the Socinian theory of atonement, nor even a recent similar view expounded by Moffitt. The similarity of Moffitt's proposal with Socinianism is acknowledged by Moffitt himself and highlighted by Kibbe. See Moffitt, Atonement and the Logic of Resurrection in the Epistle to the Hebrews, 199n130, 257n76; Michael Kibbe, "Is It Finished? When Did It Start? Hebrews, Priesthood, and Atonement in Biblical, Systematic, and Historical Perspective," The Journal of Theological Studies 65, no. 1 (2014): 25-26. While I agree with these theories as far as I affirm that the priesthood of Chris takes place officially in heaven, it seems to me that they provide a narrow account of the sacrifice on the cross. According to the Socinian view, "Jesus' death was neither propitiatory nor satisfactory nor substitutionary," but it was a preparation for His offering in heaven. In this way, the "'expiatory sacrifice' takes place as Jesus continually offers himself for our sins in the heavenly sanctuary." Kibbe, "Is It Finished?" 27. The more elaborated theory offered by Moffitt specifies 
reference to Christ's official priesthood and even part of it? The answer will depend on how the complex notion of sacrificial offering is observed. If the complex notion is viewed from the perspective of two distinct sequential moments (earthly sacrifice and heavenly entrance), the emphasis on the heavenly entrance as the official priesthood implies that the sacrifice on the cross is a proleptic reference to Christ's official priesthood in heaven. On the other hand, if the complex notion is viewed from the perspective of the unity of two inseparable moments, the emphasis on the heavenly entrance as the official priesthood implies that the sacrifice on the cross necessarily presupposes that this earthly sacrifice will be officially presented in heaven. From the perspective of this necessary presupposition, the cross is already part of Christ's official priesthood.

So far I have explained the contours of the complex notion of Christ's priestly offering. Before I move to the next subsection, I need to explore briefly the soteriological

in which way the cross was preparatory for the atoning priesthood in heaven. Drawing on studies on the OT sacrifical ritual, Moffitt believes that the key to the understanding of the OT sacrifices is the manipulation of blood, and that blood signifies life, not death (this is his reading of Lev 17:11). According to this background, Christ's offering is the offering of His resurrected life in heaven, and not of His death on earth. The cross is a preparation for His heavenly offering because sacrifices in the OT were necessary for the obtention of blood, which was then presented by the priest to God as life, not death. In other words, the priestly entrance with blood in the sanctuary is equivalent to Christ's presentation of His life to God in the heavenly sanctuary. See Moffitt, Atonement and the Logic of Resurrection in the Epistle to the Hebrews, 218-219, 257-258, 271-272, 285. Whereas I find the Socinian theory of an expiatory sacrifice in heaven problematic, I also disagree with Moffitt's notion that sacrifical blood does not signify death. In fact, I concur with Compton that Lev 17:11 "emphasizes death - life given in the place of another's life - rather than life released." Jared Compton, review of Atonement and the Logic of Resurrection in the Epistle to the Hebrews, by David Moffitt, Trinity Journal 36, no. 1 (January 2015): 134. For a helpful study of blood in Hebrews, which among other aspects outlines basic interpretations of sacrifical blood (including the view of blood as life in Milligan and Westcott) and concludes that the concept of blood in Hebrews is ambivalent, meaning both life and death, see Hermann V. A. Kuma, The Centrality of Aĩu (Blood) in the Theology of the Epistle to the Hebrews: An Exegetical and Philological Study (Lewiston, NY: Edwin Mellen Press, 2013). A Socinian/Moffittian approach that locates Christ's priesthood exclusively in heaven also locates atonement exclusively in heaven, considering the cross as merely preparatory for the atonement. Conversely, my suggestion is that the cross is the atoning sacrifice and the heavenly priesthood is a continuation of what was initiated at the cross. 
meaning of this priestly offering. In fact, Hebrews seems to indicate that the heavenly offering to God, performed ${ }^{124}$ by Christ at His ascension, resulted in a "purification

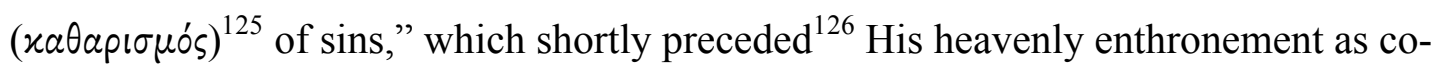
regent king $(1: 3) .{ }^{127}$ In light of $9: 15$, this purification probably refers to the

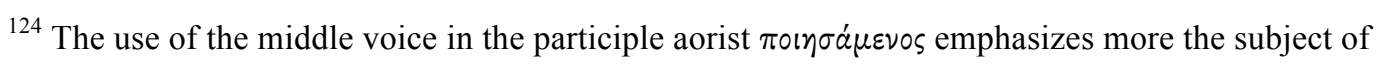
the action than the action itself. While "the active voice emphasizes the action of the verb; the middle emphasizes the actor [subject] of the verb." Wallace, Greek Grammar Beyond the Basics, 415. Wallace indicates that the direct middle, where "the subject acts on himself or herself," in the NT "is quite rare," since "the Hellenistic tendency toward explicitness" led to an increasing replacement of the use of direct middle by the employment of the reflexive active. Ibid., 416. According to this perspective, I classify the middle voice that describes Christ making ( $\pi \circ \eta \eta \sigma a ́ \mu \varepsilon v o s)$ purification in Heb 1:3 as an intensive middle (conveying the idea that He acts by himself), which is defined as "focusing attention in the subject, as if the

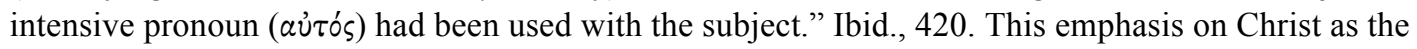
subject of the action is consistent with Heb 1:1-4, which is a passage that focuses on who the Son is, what He did, and what happened to Him.
\end{abstract}

${ }^{125}$ In several instances of the word group to which the adjective $x a \theta a p ı$ rós belongs (that includes

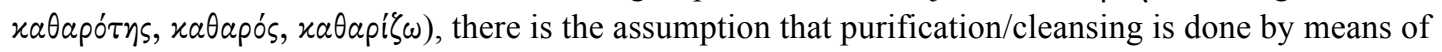
sacrificial blood (see 9:13-14, 22-23; 10:1-2, 4).

${ }^{126}$ This statement takes into consideration the syntactical relationship between the participle aorist

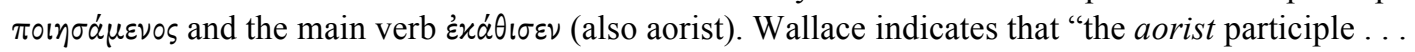
usually denotes antecedent time to that of the controlling verb. But if the main verb is also aorist, this participle may indicate contemporaneous time." Ibid, 614; see also Robertson, A Grammar of the Greek New Testament in the Light of Historical Research, 860. Therefore, if $\pi \circ \eta \eta \alpha \dot{\mu} \mu \varepsilon \nu \circ$ is taken in a temporal sense (as a temporal adverbial participle), the action of Christ making purification anteceded or was

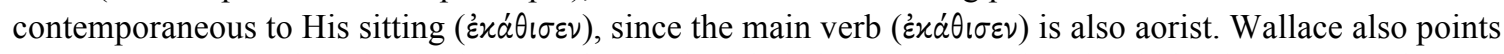
out that "if a particular adverbial participle is to be labeled as temporal, this should be the primary element the author wishes to stress (because almost all participles, whether adverbial or not, are temporal in at least

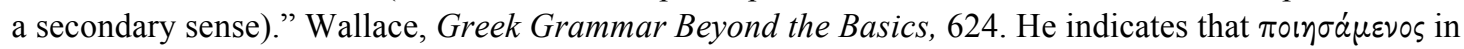
Heb 1:3 "is both temporal and causal," meaning that Christ sat down when He made purification of sins (temporal sense) and because He made purification of sins (causal sense). Ibid., 624n30. If this causal sense

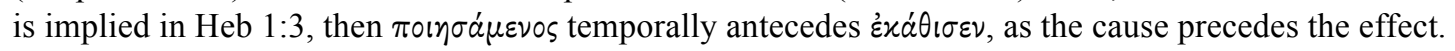
Wallace indicates that "the antecedent participle should be translated after doing, after he did, or if very close to the time of the main verb, when." Daniel B. Wallace, The Basics of New Testament Syntax: An Intermediate Greek Grammar (Grand Rapids, MI: Zondervan, 2000), 272. Taking this information into account, the translation of $\pi \circ \eta \eta \sigma a ́ \mu \varepsilon v o \varsigma$ as "when He made purification," suggests a short temporal precedence. Assuming that the priesthood of Christ began at His ascension, His priestly purification of sins shortly preceded His enthronement and, thus, I opt for the rendition "when He made purification" (see NASB, NRSV, NET) instead of "after He made purification" (see ESV, NIV).

${ }^{127}$ In 10:12, His sitting at the right hand of God appears to be shortly preceded by His sacrificial offering for sins. Likewise the relationship between $\pi \circ \eta \eta \sigma \alpha \mu \varepsilon \nu \circ \varsigma$ and $\dot{\varepsilon} x \dot{\alpha} \theta 1 \sigma \varepsilon \nu$ in $1: 3$, the aorist participle

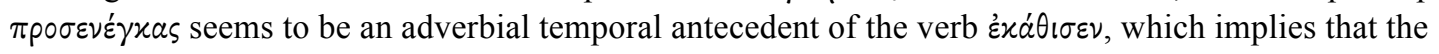
sitting took place shorly after the offering. Assuming that the priesthood of Christ began at the ascension, His priestly cleansing offering for sins took place between the ascension and His royal sitting, that is, 
redemption/forgiveness of sins or "transgressions under the first covenant." In other

words, the official beginning of Christ's priesthood at His ascension meant the

forgiveness of the sins of God's covenantal people committed before the beginning of

this priesthood.

However, this purification or forgiveness does not mean the final resolution of the

sin problem. This statement is particularly true when the priestly action of ongoing

intercession is considered.

\section{Ongoing Salvific Mediation}

The ongoing priestly activity of salvific mediation includes Christ's intercession

for forgiveness before the Father and the action of empowering believers through the

Holy Spirit. I will outline the meaning of these two types of action below.

Intercession for forgiveness

The priestly activity of Christ's ongoing intercession is emphasized in 7:25. ${ }^{128}$

shortly before the enthronement. In his remarks on 1:3, David Moffitt argues that "the Son's assumption of the throne at God's right hand" takes "place after he had performed some activity that effected purification for sin." Moffitt, Atonement and the Logic of Resurrection in the Epistle to the Hebrews, 48. In Heb 12:2, there is the sequence of the cross and the sitting at the right hand of God. However, the context of this passage indicates that its emphasis is not on Christ dealing with sin before His kingly sitting, as in 1:3 and 10:12, but on the endurance that Christ showed on the shameful cross before His exalted kingly sitting. The focus on endurance is evidenced by the occurrences of the noun $\dot{\pi} \pi \mu \circ \nu \eta^{\prime}$ in $12: 1$ and the verb $\dot{\pi} \pi \mu_{\varepsilon} \varepsilon \omega$ in 12: 2, 3, and 7. Furthermore, from a linguistic standpoint, the verbs for endurance (i $\pi \circ \mu \varepsilon \dot{\varepsilon} \omega)$ and sitting $\left(\kappa a \theta_{i} \zeta \omega\right)$ in 12:2 respectively appear in the aorist and perfect tenses in the indicative mood. This contrasts with the linguistic construction found of $1: 3$ and 10:12, where an aorist participle ( $\pi \circ \eta \eta \sigma \alpha \mu \varepsilon v o s$ and $\pi \rho \circ \sigma \varepsilon v \varepsilon \gamma x a \varsigma$, respectively) describes Christ's dealing with sin and is associated with the aorist indicative

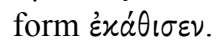

128 The context emphasizes that Christ's continuous (resurrected) life guarantees a permanent priesthood (v. 24), not prevented by death (see v. 23) characterized by continual intercession. In the Greek text, Christ remains (expressed by the verb $\mu \varepsilon \dot{v} \omega$, which conveys the meaning of continuing to live in this

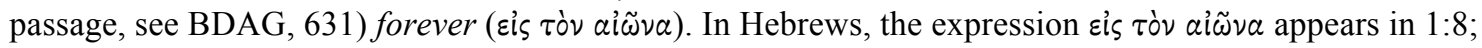
$5: 6 ; 6: 20 ; 7: 17,21,28 ; 13: 8,21$. Four $(5: 6 ; 6: 20 ; 7: 17,21)$ of these eight occurrences refer explicitly to the priesthood of Christ, as they quote Ps $110: 4$ to highlight that Christ is a priest forever according to the order 
This intercession is indeed salvific, as it provides ${ }^{129}$ complete/eternal salvation $^{130}$ for those who come to God through Him. ${ }^{131}$ Hence, salvation and intercession are associated with access to God, which is made possible through Christ. While the sacrificial or priestly offering was once for all $(7: 27 ; 9: 12 ; 9: 26,28 ; 10: 10)$, the salvific intercession is continual. This point implies that Christ's ongoing intercession is not accompanied by a new or continual offering, but it is performed on the basis of the once-for-all offering.

The language of a way to God made available through Christ's intercession assumes that human beings are distant or have no access to God by themselves. However, with reference to God, what is the nature of this intercession? Why does He need an intercessor to receive fallen human beings? Does God have to be convinced by this intercessor to be merciful toward believers? Taking into account that He is the one who appointed Christ as high priest (see section above The Agent of the Priesthood) for this intercession, the answer to the last question is negative. With regard to the first question,

of Melchizedek. Taking these occurrences into account, the idea of Christ's continuous intercession in Heb 7:25 seems to specify what the eternity of His priesthood means. In 7:24, the eternal priesthood is described

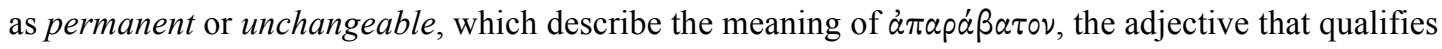

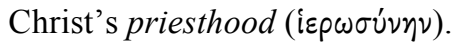

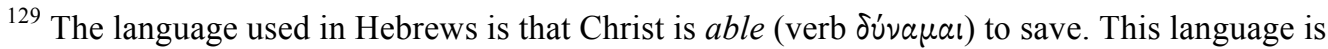
also used in the context of His priesthood in Heb 2:18; 4:15. I take the idea indicated by Lane that "the

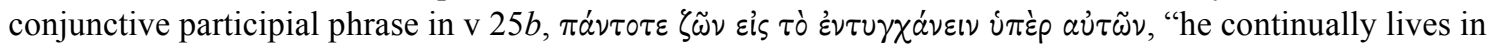
order to intercede for them," is causal, "supplying a further reason for the ability of the exalted priest to save absolutely." Lane, Hebrews 1-8, 190.

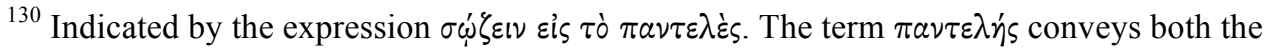
meaning of "a very high standard of quality or completeness" and of an "unlimited duration of time." Therefore, it can be translated as completely or forever. BDAG, 755. Elsewhere in the NT, this term occurs in Luke 13:11, probably with the meaning of quality or completeness. Besides the occurrence of $\sigma \omega_{1}^{\prime} \zeta \varepsilon(\nu$ in $7: 25$, the language of salvation appears in Hebrews in $1: 14 ; 2: 3,10 ; 5: 7,9 ; 6: 9 ; 9: 28 ; 11: 7$. In 2:10; 5:9; $9: 28$, Christ is somehow portrayed as the agent of salvation.

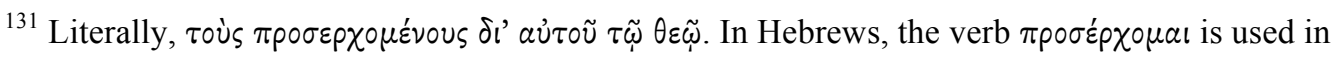
$4: 16 ; 7: 25 ; 10: 1,22 ; 11: 6 ; 12: 18,22$. This verb is used in the context of a priestly work in $4: 16 ; 7: 25 ; 10: 1$, 22 . 


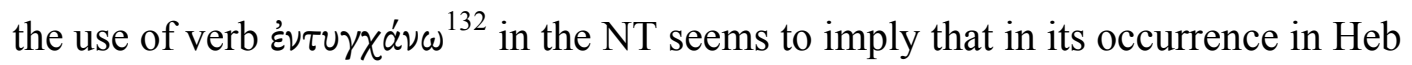
7:25 $5^{133}$ (read along with 9:24) ${ }^{134}$ God is the authority before whom the intercessor presents a case to save believers. ${ }^{135}$ This picture emphasizes a legal notion of intercession, where God is conducting the salvation of believers in a righteous way, instead of a merely personal conception of intercession that would describe Christ attempting to appease or change God's mind on behalf of human beings. In fact, the

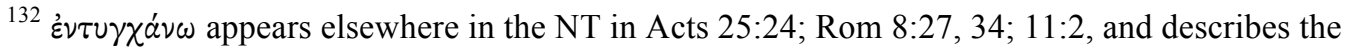
action of intercession or appeal (see BDAG, 341; L\&N \$33.347). The idea of continual intercession in 7:25

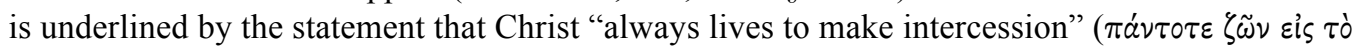

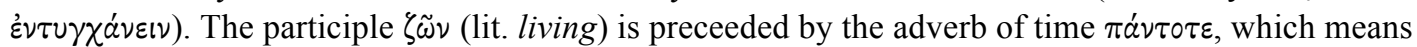
always or at all times. See BDAG, 755. The NT occurrences of $\dot{\varepsilon} v \tau \nu \gamma \chi \dot{\alpha} \nu \omega$ are used either negatively (Acts 25:24; Rom 11:2), in the sense that an appeal is done against a person (Acts 25:24) or a people (Rom 11:2), or positively (Rom 8:24,34; Heb 7:25), as it describes an appeal or intercession for a people, expressed by the genetive form of $i \pi \dot{\varepsilon} \rho$.

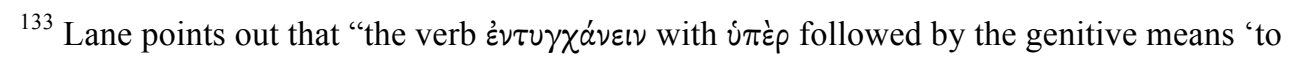
approach on behalf of someone'; when the one approached is God the expression frequently comes to mean 'pray' (cf. Wis 8:21; 16:28; Philo, Moses 1.173)." Lane, Hebrews 1-8, 190. Following a similar perspective, Koester argues that "Christ's intercession first means requesting help for those who are being tested, and second it involves petitions for forgiveness, which extend the benefits of Christ's once-for-all sacrifice to particular sins." For him, "the strongest reasons for assuming that intercession in Hebrews involves petitions for forgiveness are that Heb 7:26-27 mentions human sin, that Christ's priestly work involves making atonement (2:17), and that the new covenant brings forgiveness (Heb 8:12; 10:17)." Koester, Hebrews, 371, 366. On the other hand, Cockerill does not seem to believe that this intercession is a present actual petition to God because Christ's "sacrifice has been accepted." Cockerill, The Epistle to the Hebrews, 336-337. In his turn, Ellingworth maintains that the language of intercession in Heb 7:25 "is too general to determine whether prayer for help or for forgiveness is intended. Such partial parallels as 2:18; $4: 15 ; 5: 2,7$ suggest the more inclusive meaning 'help.' Where the forgiveness of sins is specifically mentioned, as in 9:22;10:18, it is linked with Christ's one sacrifice rather than with his continuing intercession." Ellingworth, The Epistle to the Hebrews, 392. In my view, the positions advanced by Cockerill and Ellingworth are too narrow when compared with the interpretations offered by Lane and Koester.
}

\footnotetext{
${ }^{134}$ Hebrews 9:24 reads, "For Christ has entered, not into holy places made with hands, which are copies of the true things, but into heaven itself, now to appear in the presence of God on our behalf" (italics mine). Scholars associate the last line of 9:24 with Christ's present intercession in 7:25. See Attridge, The Epistle to the Hebrews, 264; Ellingworth, The Epistle to the Hebrews, 479; Johnson, Hebrews, 243-244; Cockerill, The Epistle to the Hebrews, 418; Koester, Hebrews, 422.

${ }^{135}$ While the passages where the NT occurrences of $\dot{\varepsilon} v \tau \gamma \gamma \chi \alpha \dot{ } \nu \omega$ are found do not explicitly mention a courtroom scenario, many of them assume that there is a formal or divine authority to whom a petition is addressed (cf. Acts 25:24; Rom 8:34; 11:2; see also Dan 6:13 LXX).
} 
intercession of Christ in Rom 8:34 ${ }^{136}$ is part of the explanation of why there is no

condemnation against God's elect and it is associated with the idea that God justifies

them. ${ }^{137}$ The language of condemnation and justification is clearly judicial.

A canonical indication of the association of legal intercession and cultic expiation

is found in 1 John 2:1-2. ${ }^{138}$ The intercessory role of Christ as our advocate

$(\pi \alpha \rho \alpha x \lambda \eta \tau \propto \nu){ }^{139}$ with the Father, if ${ }^{140}$ we sin, is directly ${ }^{141}$ related to the fact that Jesus is

\begin{abstract}
${ }^{136}$ Romans 8:34 emphasizes that Christ intercedes for us as ascended co-regent king. He "is the one who died - more than that, who was raised - who is at the right hand of God, who indeed is interceding for us." The language of Christ's intercession at "the right hand of God" in Rom 8:34 is compatible with the information in Heb 8:1 that Christ, the "high priest," "is seated at the right hand of the throne of the Majesty in heaven." Furthermore, the idea of divine justification in Rom 8:33-34 seems to be conceptually similar to the salvation mentioned in Heb 7:25, and the notion of no condemnation in Rom 8:33-34 appears to be consistent with the access of God through Christ in Heb 7:25.
\end{abstract}

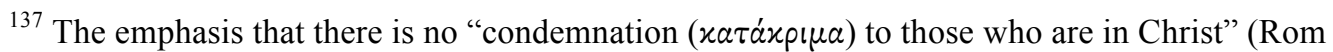
8:1) is the very first idea of chapter 1 . The notion of no condemnation reappears in vv. 33-34: "Who shall

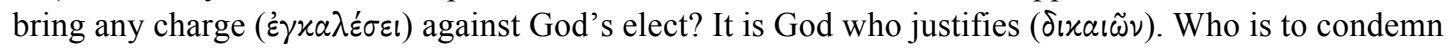

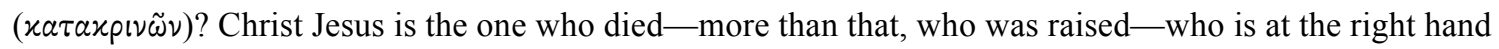
of God, who indeed is interceding for us." Arguably, there is a parallel between the two questions in vv. 33-

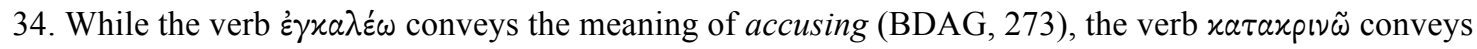
the idea of pronouncing a sentence (BDAG, 519). The first answer explains that God's justification eliminates the possibility of accusation. Similarly, the second answer stipulates that Christ's death, resurrection, and royal heavenly intercession excludes the possibility of condemnation. The parallel between accusation and condemnation in the questions suggests that there is a parallel between the answers, namely, that God's justification is associated with Christ's death, resurrection, and intercession. Probably, this justification is based on His death/resurrection/intercession. It is noteworthy that the contrast between condemnation $(\varkappa a \tau \alpha \dot{x} \rho \mu \alpha)$ and justification ( $\delta \varkappa \alpha i \omega \mu \alpha)$ was already emphasized in Rom 5:16, 18.

${ }^{138}$ Scholars tend to associate John 2:1 with the intercession of Heb 7:25. See Daniel L. Akin, 1, 2, 3 John, NAC (Nashville: Broadman \& Holman, 2001), 81; Rudolf Schnackenburg, The Johannine Epistles: A Commentary, trans. Reginald and Ilse Fuller (New York: Crossroad, 1992), 87; Stephen S. Smalley, 1, 2, 3 John, WBC (Dallas: Thomas Nelson, 1984), 36.

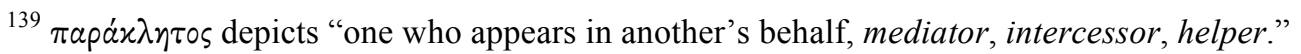
BDAG, 766. For the legal meaning of $\pi \alpha \rho \alpha x x \lambda \eta \tau \circ$ in Greek writings, see Kenneth Grayston, "The Meaning of Parakletos," Journal for the Study of the New Testament 13 (1981): 67-82. The basic idea is of a sponsor or patron "who speaks on behalf of the accused." Colin G. Kruse, The Letters of John, PNTC (Grand

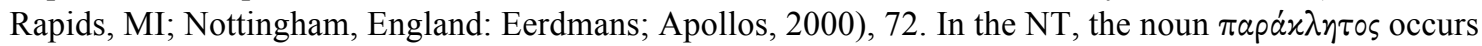
only in Johannine literature (John 14:16, 26;15:26; 16:7; 1 John 2:1). While in the Gospel of John this

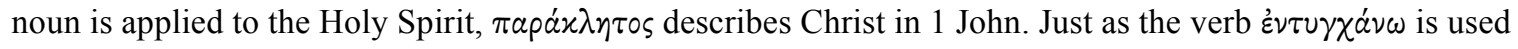

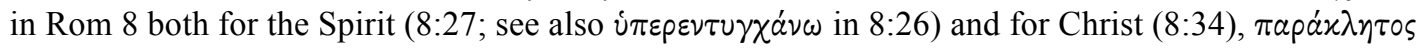
describes both the Spirit and Christ in the Johannine writings.

${ }^{140}$ The conditional sentence establishes a "logical relationship" of "cause and effect: If sin 


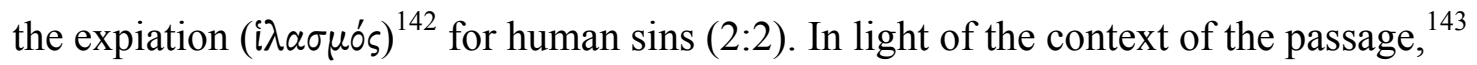

this expiatory intercession is associated with purification/cleansing from sin by means of

Jesus' blood (1:7) and with God's forgiveness of sins, cleansing believers from

unrighteousness if they confess their sins (1:9). In this scenario, both the Son who

intercedes (2:1) and the Father who forgives (1:9) are righteous ( $\delta^{\prime}$ xalos). A systematic

explanation of this picture could be delineated as follows: when a believer confesses

his/her sins in prayer, ${ }^{144}$ Christ intercedes for him/her before the Father on the basis of

His sacrifice on the cross that was presented to the Father at the ascension. As the legal

authority to whom this case is presented, the Father forgives the believer. With this

process in view, God's forgiving action is righteous. It is noteworthy that in Rom 3:25-

happens (cause), then the Paraclete (Jesus) is there with the Father for us (effect)." Akin, 1, 2, 3 John, 78.

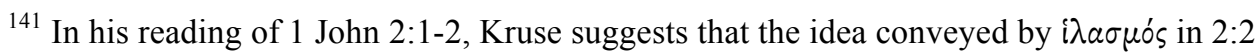

juxtaposes the idea conveyed by $\pi \alpha \rho a ́ x \lambda \eta \tau o s$ in $2: 1$. In 2:1 Christ "appears as an advocate in court," and in 2:2 "as a sacrificing priest in the temple." Kruse, The Letters of John, 73.

${ }^{142}$ While I follow here the translation for i $\lambda \alpha \sigma \mu o ́ s$ adopted by RSV, I am aware that most versions opt either for propitiation (ESV, NASB, YLT) or atoning sacrifice (NIV, NRSV, NET). Considering that the debate about the language of propitiation and/or expiation is related especially with the decision to interpret God as the subject or the object of the sacrificial offering, I will briefly address this point below.

${ }^{143}$ As Stephen Smalley indicates, 2:1-2 is the third time (cf. 1:7,9) that the author comes to the question of forgiveness of sins using the adversative $\dot{\varepsilon} \dot{\alpha} \nu$. Smalley, 1, 2, 3 John, 35.

${ }^{144}$ Arguably, prayer is implicit in the idea of confession (1 John 1:9). Interestingly, the verb

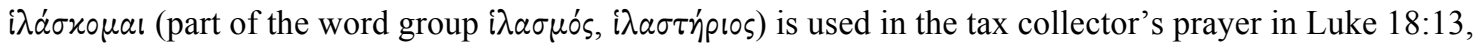
where he begs for divine forgiveness: "God, be merciful ( $i \lambda \alpha \dot{\sigma} \sigma \eta \tau i$ ) to me, a sinner!" The imperative

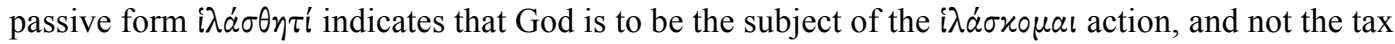

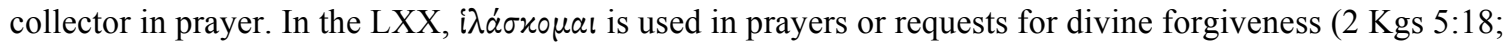
2 Chr 6:30; Pss 24:11 [25:11 MT]; 78:9 [79:9 MT]). Except Ps 79:9 MT, in these passages, i $\lambda \alpha ́ \sigma x o \mu a \iota$ corresponds to the qal form of (to forgive, see HALOT, 757) in the MT. In Ps 79:9 MT, i $\lambda \lambda^{2} \sigma x o \mu \alpha$ เ corresponds to the piel form of כפר (to cover, atone, forgive, see HALOT, 494-495). Furthermore, i $i \lambda \dot{a} \sigma x o \mu \alpha$ เ is used in the LXX to describe God's decision to forgive (Exod 32:14; Pss 64:4 LXX [65:4 MT; 65:3 ESV]; 77:38 LXX [78:38 MT]) or not to forgive (2 Kgs 24:4; Lam 3:42). In these passages, i $\lambda a ́ \sigma x o \mu a ı$ corresponds to three verbs in the MT: the qal form of (2 Kgs 24:4; Lam 3:42), the piel form of כפרז (Pss $64: 4 ; 77: 38)$, and the niphal form of נחם (Exod 32:14 — this verb in the niphal conveys the idea of being sorry or to regret, see HALOT, 688). 
26, which uses a cognate of i $\lambda \alpha \sigma \mu o ́ s$, God put forward Jesus as mercy-seat/expiation (i $\left.\lambda a \sigma \tau \eta^{\prime}(\circ)\right)^{145}$ "by His blood, to be received by faith," to show that God is righteous in justifying those who have faith in Jesus. ${ }^{146}$ The importance of showing this divine righteous procedure could be further enlightened by the canonical information that Satan constantly accuses God's people (Rev 12:10), either because of their defilement/unworthiness (Zech 3:1) or by questioning their intentions (Job 1:9).

All this canonical reading is relevant for the understanding of the priestly action

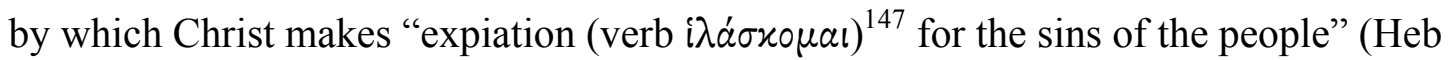
2:17 RSV). The explanation of this priestly action, however, requires clarification regarding scholarly debates on the interpretation of i $\lambda$ á $\sigma$ xopal. For the systematic purposes of this research, I will summarize these debates in two basic questions: (1) When does Christ perform this action? ${ }^{148}$ (2) Is the Father addressed somewhat by this

${ }^{145}$ See BDAG, 474. The other NT occurrence of this term is in Heb 9:5, where it is translated as mercy seat (ESV, NASB, RSV, NRSV, YLT, NET). NET and YLT also translate it in Rom 3:25 as mercy seat. Compare the idea expressed in Rom 3:25 (using i $\lambda \alpha \sigma \tau \tau^{\prime}$ p $10 \nu$ ) with the statement of 1 John 4:10 that God "loved us and sent His Son to be the expiation (i $\lambda \alpha \sigma \mu \dot{\partial} \nu)$ for our sins" (RSV). For helpful information regarding i $\lambda \alpha \sigma \tau$ ńp $10 \nu$ in Rom 3:25, see Valentin Zywietz, "Representing the Government of God: Christ as the hilasterion in Romans 3:25," (M.A. thesis, Andrews University, 2016).

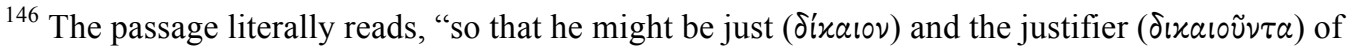
the one who has faith in Jesus" (Rom 3:26). The righteousness of God in this act of justification centers on the fact that, in His "forbearance, He had passed over former sins" (Rom 3:25). Therefore, without the sacrifice of Christ, this merciful forbearance would be unrighteous or unjust. While the focus of this passage seems to be on sins committed before the cross, the principle that God's mercy is righteous also applies to sins committed after the cross. The only difference is that His righteous mercy toward repented sinners before the cross required a further action (the sacrifice of Christ), whereas His righteous mercy toward repented sinners after the cross is already based on the sacrifice of Christ.

${ }^{147}$ In the context of the NT occurrences of the word group i $\lambda \dot{\alpha} \sigma x o \mu a l$ (Luke 18:13; Heb 2:17),

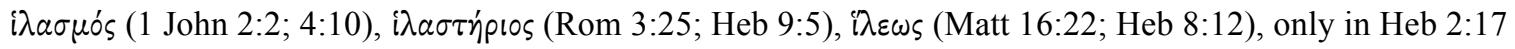

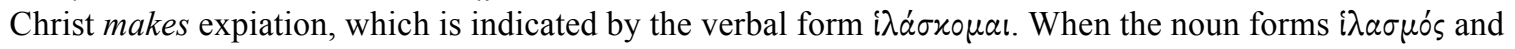
i $\lambda \alpha \sigma \tau$ '́plos are used, Christ is the propitiation/expiation (1 John 2:2; 4:10) or the mercy-seat/propitiatory (Rom 3:25) respectively. For the meanings of these Greek words, see BDAG, 473-474.

${ }^{148}$ Attridge (past action), Cockerill (past action, and perhaps present action), and Ellingworth 
action? ${ }^{149}$ With regard to the first question, the infinitive present form i $i \alpha$ á $\kappa \varepsilon \sigma \theta a \iota$ in Heb 2:17 does not specify the temporal moment of the priestly action. Assuming that Christ's priesthood began at His ascension, $i \lambda \alpha ́ \sigma x o \mu a l$ in this passage may refer to the action described in the subsection above (The Heavenly Offering of His Earthly Sacrifice) that involved the purification of sins (1:3) or transgressions committed under the first covenant (9:15). In this context, the offering of Christ's sacrifice to the Father at the

(present action) could be taken as three different answers to this question. Attridge argues that this expiation (i $\lambda \alpha \dot{\sigma} \sigma \varepsilon \sigma \theta a l$ ) "is not through Christ's continual intercession for his followers, but through his singular sacrificial death" (past action). Attridge, The Epistle to the Hebrews, 96. Cockerill seems to agree with Attridge, but he is also open to the possibility of a present activity: the author of Hebrews "probably has Christ's 'once-for-all' sacrifice in view, though the present tense of his infinitive leaves room for the continuing application of the benefits of that sacrifice to God's people." Cockerill, The Epistle to the Hebrews, 150. For Ellingworth, "the present i $\lambda \dot{\alpha} \sigma x \varepsilon \sigma \theta a$ l denotes continuous activity by one who remains a

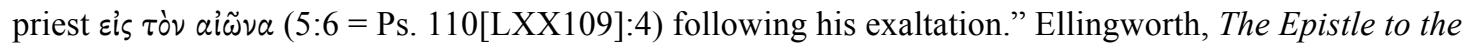
Hebrews, 188.

${ }^{149}$ This question refers to the debate of the group word that i $\lambda$ á $\sigma$ xopal belongs as expiation (subjective view) or propitiation (objective view). As Akin helpfully summarizes, "On the 'subjective' view, God is the subject of the action. He removes the defilement of sin by causing it to be covered. This is what is meant by 'expiation.' Often proponents of this view minimize or deny the presence of personal wrath on God's part toward the sinner. On the objective view, God is the object of an offering of sin, that is, God's wrath is placated. This is what is meant by 'propitiation.' Proponents of this view often include both propitiation and expiation as two aspects of the same atoning sacrifice of Jesus." Akin, 1, 2, 3 John,

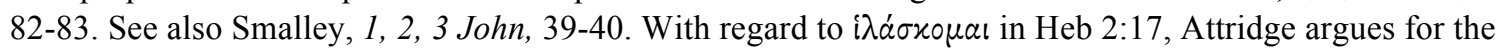
concept of expiation. In his words, "In Hebrews, Christ's sacrifice is always directed at removing sin and its effects, not at propitiating God." Attridge, The Epistle to the Hebrews, 96n192. See also Ellingworth, The Epistle to the Hebrews, 189. In a mediate position, Cockerill and Koester affirm the meanings of both expiation (removal of sin from the sinner) and propitiation (God's wrath). Cockerill, The Epistle to the Hebrews, 151; Koester, Hebrews, 241. In their turn, Lane and Morris affirm the meaning of propitiation, and not merely expiation. Lane, Hebrews 1-8, 66; Leon Morris, The Apostolic Preaching of the Cross, 3 ed. (Grand Rapids, MI: Eerdmans, 1965), 202-204. For a sample of Bible translations, RSV and NJB have expiation, ESV and NASB opt of propitiation, and NIV, NRSV, and NET prefer atonement. In a recent article, James Allman points out that C. H. Dodd's article "I $\Lambda$ A $\Sigma K E \Sigma \Theta A I$, Its Cognates, Derivatives, and Synonyms, in the Septuagint" (Journal of Theological Studies 32 [1931], 352-360) and its argument against the notion of i $\lambda \alpha \sigma x o \mu \alpha \mathrm{l}$ as propitiation in the Bible exercised a major influence in NT scholarship. Among the evangelical reactions to this argument, Morris' book stands out as a strong affirmation of the concept of propitiation, which is not related to the capricious anger of pagan deities. Similar to Cockerill and Koester,

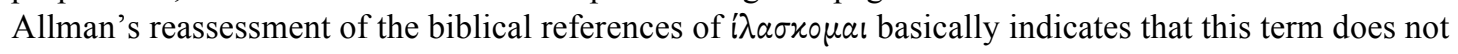

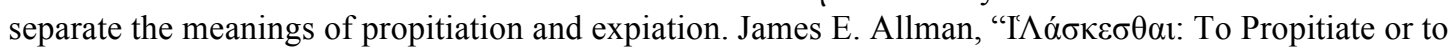
Expiate?" Bibliotheca sacra 172, no. 687 (2015): 335-355. 
ascension implied His intercession to effectively ${ }^{150}$ forgive the sins committed by repented believers in the time of the AT or in the time before Christ's sacrifice and ascension. Only with Christ's work this forgiveness became a reality (see Heb 10:1-4) and a legal/righteous procedure on the part of God (see Rom 3:25-26). Furthermore, considering that sin is still a problem for believers living after the time of Christ's ascension (see, e.g., Heb 2:18; 3:13; 4:15-16; 7:25; 10:26; 12:1, 4; 1 John 1:7, 9; 2:1-2), and that their confession (cf. 1 John 1:9) and faith (cf. Rom 3:25) are necessary for the expiation/forgiveness of their sins, it could be said that Christ continues to expiate sins by means of His ongoing intercession before the Father in heaven on the basis of His once for all sacrifice on earth. In this sense, believers who live after the ascension of Jesus are invited to come to God in prayer, ${ }^{151}$ by means of Christ's priesthood, to find mercy (cf. Heb $4: 14-16 ; 7: 25 ; 10: 19-22)$.

According to this conception, there is no room for the idea that Christ already finished His salvific work in heaven and that salvation is merely applied to the believer by the Holy Spirit on earth, as if the Spirit were a deliverer on earth of what is already done in heaven even before the confession of sins uttered by a repented believer in

\footnotetext{
${ }^{150}$ In this sense, i $i \lambda \dot{\sigma} \sigma x o \mu a l$ in Heb 2:17 depicts the expiation or forgiveness of sins to which God had mercifully "passed over" (Rom 3:25) before Christ's salvific work, but that were effectively expiated (and, therefore, righteously forgiven, see Rom 3:26) by means of His sacrifice and priesthood. Obviously, I do not deny the fact that divine forgiveness was available to these believers before Christ's salvific work. However, in light of Hebrews (see, e.g., 10:1-4), this forgiveness assumed or pointed (by means of the offering of sarifices that were a shadow of the Christological reality) to the future work fulfilled in Christ.

${ }^{151}$ Peterson suggests that believers draw near to God in Hebrews "through worship and prayer." Peterson, Hebrews and Perfection, 199. According to Nils Dahl, the idea of drawing near to God in Hebrews is not about a mystical experience of ascending to heaven, but means prayer. Nils Alstrup Dahl, "A New and Living Way: The Approach to God According to Heb 10:19-25," Interpretation 5, no. 4 (1951): 408.
} 
prayer. ${ }^{152}$ Rather, Christ's intercessory work in heaven is an active mediation of divine

forgiveness for repented believers who confess their sins and pray for God's mercy.

Therefore, prayer is not merely a human response or acceptance of God's forgiveness. To

be sure, God was already willing to forgive even before prayer. But there is real

forgiveness on His part at the moment of prayer, mediated by the intercession of Christ.

Hence, the present earthly work of the Holy Spirit with human beings parallels the present heavenly work of Christ before the Father. ${ }^{153}$

The preceding comments already indicated the positive answer to the second

\begin{abstract}
${ }^{152}$ This affirmation resists unqualified statements of works of systematic theology, such as the following: "God applies Christ's objective work on the cross progressively by the Spirit through a series of movements." While "Christ the Son provided complete redemption through his obedient life and atoning death," "the Holy Spirit applies, makes effective, and preserves the redemption Christ bought to those who believe." Bruce A. Demarest, The Cross and Salvation: The Doctrine of Salvation, Foundations of Evangelical Theology (Wheaton, IL: Crossway, 2006), 36, 44. In light of the "completed work of Christ as mediator of redemption," "the work of salvation, wrought in Christ, is subjectively realized in the hearts and lives of sinners." Berkhof, Systematic Theology, 415-416. "We do not experience God's amazing salvation - planned by the Father in eternity past and accomplished by Jesus in the first century — until the Holy Spirit applies that salvation to our lives." Robert A. Peterson, Salvation Applied by the Spirit: Union with Christ (Wheaton, IL: Crossway, 2015), 13. I am aware that these statements may be nuanced to fit with the intercessory work of Christ in heaven, since these scholars affirm this intercessory activity as salvific. However, they tend to interperet the ongoing salvific activity of Christ in heaven in terms of a movement from heaven to earth by which salvation is subjectively applied to the believer through the Holy Spirit. See Demarest, The Cross and Salvation, 446; Robert A. Peterson, Salvation Accomplished by the Son: The Work of Christ (Wheaton, IL: Crossway, 2012), 228, 237, 242-243, 247; Berkhof, Systematic Theology, 352-353, 424. When Demarest and Peterson elaborate on the work of Christ before the Father, they speak of Christ praying to the Father for the preservation of the saints until final salvation, and Peterson interprets this in light of Jesus' prayer for Peter in Luke 22:31-32. Demarest, The Cross and Salvation, 446; Peterson, Salvation Accomplished by the Son, 228, 244, 249. According to Peterson, Christ's ongoing "intercession saves ... because it is one means by which God enables his people to continue in faith and obedience." While Christ's life, death, resurrection, session, and His sending of the Spirit are necessary for the justification of believers, His intercession is necessary for their perseverance. Peterson, Salvation Accomplished by the Son, 248. What is missing from this picture is the explicit affirmation that intercession provides divine forgiveness, that is, cleansing from sins (1 John 1:7, 9; 2:1-2). Notice that Peterson does not even mention the words forgiveness or purification from sins in his remarks on 1 John 2:1-2. See ibid., 245-247. In short, my point here is the following: Without a clear emphasis on the reality of divine forgiveness and purification from sins in the context of the intercessory activity of Christ for prayers from repented believers, the idea that salvation was already completely accomplished in the first century is affirmed. What remains for Christ's intercession is only a conservation of what was already done. Accordingly, the new and distinctive feature of salvation after the first century is the subjective application of salvation performed by the Holy Spirit.

${ }^{153}$ See the summary of this discussion in the next footnote.
\end{abstract}


question highlighted above: The Father is addressed by Christ's i $\lambda \alpha \dot{\sigma} \approx o \mu \alpha$ l action, but this answer is different from the debate of $i \lambda{ }^{\prime} \sigma x o \mu a l$ as expiation (subjective view) or propitiation (objective view). ${ }^{154}$ Overall, the debate does not question the fact that God is the subject of the $i \lambda a ́ \sigma x o \mu a$ action, as He cleanses human beings from sin. The main point of the discussion is whether God (the Father) is firstly the object of Christ's

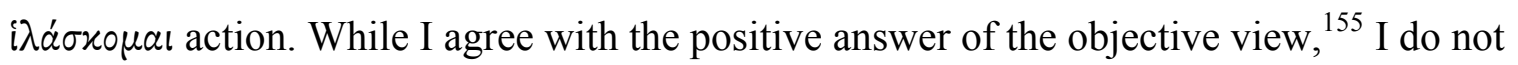

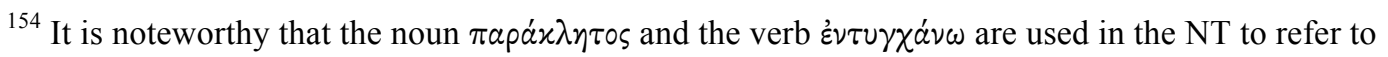
the present work of both the Holy Spirit and Christ. As a $\pi \alpha \rho a ́ x \lambda \eta \tau o s$ on earth, the Spirit teaches the disciples of Christ and bring to their remembrance the teaching of Jesus (John 14:26), while Christ as a $\pi a \rho a ́ x \lambda \eta \tau o s$ intercedes for them in heaven before the Father (1 John 2:1). In His intercession "with groanings too deep for words" on earth, the Spirit seems to vocalize a prayer that amends the improper prayers of believers (Rom 8:26). The intercession by groaning suggests that His intercession takes place in the context of "the sufferings of the present time" (Rom 8:18), "the bondage to corruption" (Rom 8:21), in which there is an expectation of "the redemption of our bodies" (Rom 8:23). Thus, the intercession of the Spirit is actually a participation in the human expectation of redemption that constitutes an intercessory prayer, in our place, according to the will of God (Rom 8:27). Whereas the intercession of the Spirit is more related to the human/earthly level of expectation (redemption) and prayer, the intercession of Christ (cf. Rom 8:34) is more related to the divine/heavenly level of justification (no condemnation). It could be argued that Christ's heavenly intercession is the foundation for the earthly intercession of the Spirit, since there would be no expectation of redemption if the saints were under condemnation.

${ }^{155}$ It is instructive to observe the OT background provided by the use of the verb $\dot{\xi} \xi i \lambda a ́ \sigma x o \mu a l$, which is related to and more commonly employed in the LXX than i $\lambda \dot{\alpha} \sigma x o \mu a l$ (Friedrich Büchsel,

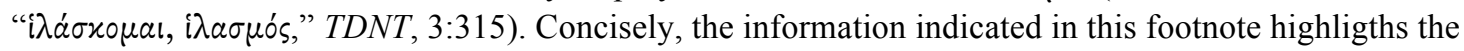
idea that God is the authority before whom the $\xi^{\prime} \xi \iota \lambda \dot{\alpha} \sigma x o \mu a l$ activity is performed for the forgiveness of sins. From the 106 occurrences of this verb in the LXX, 49 appear in the book of Leviticus, which highlights the predominant cultic connotation of the term in the LXX. In many occurrences, $\xi^{\prime} \xi \imath \lambda \dot{\sigma} \sigma x o \mu a$ l describes or is related to an atoning activity performed by a priest for the forgiveness (expressed by $\dot{\alpha} \phi i \eta n \mu)$ of sins (see, e.g., Lev 4:20, 26, 31, 35; 5:6, 10, 16, 18, 26 [ESV 6:7]; 19:22). Except in Lev 5:6, where there is no explicit term for forgiveness in the MT, the verb á $\phi i n \mu l$ (LXX) corresponds to the verb (MT). It is noteworthy that this activity ( $\dot{\xi} \xi 1 \lambda \alpha \dot{\sigma} \sigma \alpha \mu a l)$ is related to God, as the offering is "to the Lord" ( $\varkappa v p i \omega$, Lev 4:31), "of the Lord" (xupíou, Lev 4:35), or for the offense "against the Lord" ( $x$ pí $\omega$, Lev 5:6). I am following the English translations of the LXX provided by Lancelot Charles Lee Brenton, The Septuagint Version of the Old Testament: English Translation (London: Samuel Bagster and Sons, 1870) and Rick Brannan, Ken M. Penner, et al., eds., The Lexham English Septuagint (Bellingham, WA: Lexham Press,

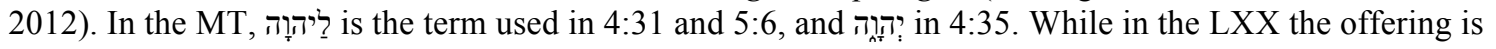
for the offense (expressed by the verb $\pi \lambda \eta \mu \mu \varepsilon \lambda \varepsilon \dot{\varepsilon} \omega$ ) against the Lord in 5:6, the word the meanings of guilt and guilt-offering (see HALOT, 96). The sentence of the Hebrew text seems to indicate that

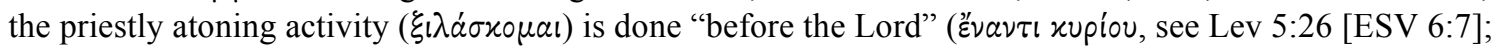
10:17; 16:30; 19:22; 23:28; Num 15:25, 28). As $L E H$ indicates, है $v a v \tau \iota$ can also be translated as in the

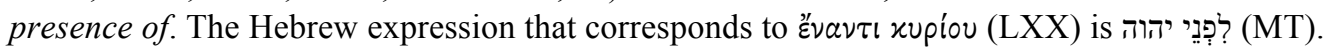


follow the explanation of a personal propitiation, where God's wrath is placated by

Christ's sacrifice. This explanation tends to depict a God attempting to deal with His

mixed feelings of love and anger. To be sure, the language of God's wrath against sinners

is biblical, as it stresses His revulsion of evil. However, for the purposes of this research

on Christ's priesthood, this language is basically an expression of God's justice ${ }^{156}$ and

refers particularly to His eschatological judgment. ${ }^{157}$ In Hebrews, the references to the

wrath of God $(3: 11 ; 4: 3)$ or His judgment $(4: 13 ; 10: 25-31 ; 12: 23,25-26,29 ; 13: 4)$ mostly

warn against the eschatological danger of rejecting the salvation mediated by Christ. ${ }^{158}$

${ }^{156}$ Romans $1: 18 ; 2: 8 ; 3: 5$ emphasize that God's wrath (opyń) is against unrighteousness or injustice ( $\dot{\alpha} \delta\left(x_{i} \alpha\right)$. Rom 4:15 implies that the wrath is a consequence of the transgression of the law. In his account of God's wrath as judgment, Norman Gulley speaks of "God's holy love." See Norman R. Gulley, Systematic Theology: God as Trinity (Berrien Springs, MI: Andrews University Press, 2011), 46-48. For a helpful overview of God' wrath in the Bible, including its basic terminology in the Hebrew Bible and in the NT, see Jim West, "Divine Wrath," Lexham Theological Wordbook, ed. Douglas Mangum et al.

(Bellingham, WA: Lexham Press, 2014). West properly points out that "the biblical notion of divine wrath is closely associated with God's holiness, judgment, and compassion.” Ibid.

${ }^{157}$ Romans 2:5 mentions "the day of wrath when God's righteous judgment will be revealed." See also Rom 2:8; Col 3:6; 1 Thess 1:10; Rev 6:16, 17; 11:18; 14:10; 16:19; 19:15.

158 The two references to the wrath (opy $\left.\eta^{\prime}\right)$ of God in Hebrews $(3: 11 ; 4: 3)$ appear in a section of exhortations (3:1-4:16) that begins and ends with the importance of Christ's priesthood. In 3:1, the author invites the audience to consider "Jesus, the apostle and high priest of our confession." His basic concern is that the audience needs to "hold fast our confidence" (3:6; cf. v. 14), and not be hardened by "an unbelieving heart" (3:12; cf. v. 8, 10) as the desert generation mentioned in Ps 95:7-11 LXX (3:7-11). It is precisely in quotations from Ps 95:11 that the two occurrences of óp $\gamma$ ' appear in Heb 3:11; 4:3. The attitude of unbelief on the part of the desert generation was followed by God's judgment or wrath: This generation did not enter His rest (the promised land) with Joshua (cf. 3:17; 4:6,8). Taking into account this negative example of the desert generation (4:11), the audience is warned about a future judgment (4:13). In order to avoid the same outcome of that generation, the audience of Hebrews is urged to "hold fast our confession," since "we have a great high priest who has passed through the heavens, Jesus, the Son of God" (4:14). Because of His sympathy for us in our weakenssess (4:15), we may "with confidence draw near to the throne of grace" and find "mercy and grace" (4:16). In summary, while the audience of Hebrews is urged to "hold fast" and take advantage of having Jesus as high priest, the opposite attitude of giving up that implies a disregard or rejection of Christ's priesthood leads to a situation similar to the end of the desert generation, that is, the person will face God's wrath in His eschatological judgment. This teaching is clearly expressed in 10:19-31. It is noteworthy that 4:14-16 and 10:19-25 form an inclusio (see the Appendix). While the verses that precede the beginning of the inclusio in 4:14-16 emphasize the reality of God's judgment (see, e.g., 4:11-13), the same emphasis occurs with the verses (see 10:26-31) that follow the end of the inclusio in 10:19-25. Similar to 4:14-16, 10:19-23 urges the audience to take advantage of Christ's priesthood and "hold fast the confession" (10:23). Considering that "the Day is drawing near" $(10: 25)$, a reference to the 
Therefore, the Father is addressed by Christ's i $\lambda \alpha$ axoua action, not to have His personal anger against sinners placated (propitiation), but to be the legal authority to righteously forgive repented sinners on the basis of Christ's past sacrifice and present priestly intercession, especially in light of the eschatological judgment. It is in this sense of forgiveness that I translate $i \lambda a ́ \sigma x o \mu a ı$ as expiation.

\section{Empowerment of believers}

The activity of mediating forgiveness is accompanied by the action of strengthening believers, as Christ "is able to help those who are being tempted" (Heb $2: 18)$. This action seems to take place especially in situations where believers are tempted to abandon their commitment to God when they are challenged to face suffering. ${ }^{159}$ Besides this emphasis on the temptation that involves suffering, Christ's merciful help is also available in the context of other types of temptation experienced by believers in their weaknesses (4:14). ${ }^{160}$ Indeed, Christ not only helps believers to remain faithful to God by

eschatological divine judgment spelled out in 10:27-31, the author alerts believers about the danger of a life that continues on sinning deliberately (10:26), which includes in its description treating Christ the mediator with disdain (10:29). Hence, a rejection of Christ's priesthood results in facing divine judgment. In light of God's eschatological judgment, the author of Hebrews urges the audience to not reject salvation (2:1-3; $12: 25-26)$.

159 This statement has in view the following points in Hebrews: (1) temptation seems to be particularly associated with suffering $(\pi \dot{\alpha} \sigma \chi \omega)$. Hebrews 2:18 explains that Christ "is able to help those being tempted" "because He himself has suffered ( $\pi \varepsilon ́ \pi \circ \nu \theta \varepsilon \nu)$ when tempted." In 5:7-8, His suffering appears to be described in terms of His struggles with the threat of death (cf. 13:12); (2) victory over temptation means faithfulness to the will God in the form of endurance, no matter the difficulties or challenges being faced. In the midst of His struggles with the threat of death, Christ was obedient $(5: 8)$ or faithful (cf. $2: 17 ; 3: 2)$ to the will of God (10:7, 9-10). In his suffering, Christ endured (12:2-3); and (3) the exhortations of Hebrews imply that the audience is being tempted to give up the Christian faith (cf. 3:6, 14; $4: 14 ; 10: 23-25 ; 35-36,38-39 ; 12: 1$ ), as believers face difficulties (cf. 10:32-34; 12:3-4; 13:13-14).

Therefore, in the context of temptation, Christ is not only the example to be followed by believers (cf. 12:2$4 ; 13: 12-13)$, but He is their merciful helper as high priest $(2: 17-18 ; 4: 15)$.

${ }^{160}$ While Christ's priestly help in 2:18 is based on His temptation in suffering, His priestly mercy in 4:15 is based on His temptation "in every respect . . as we are, yet without sin" (italics mine). Taking 
strengthening them to endure temptation, but He enables believers to faithfully serve God

as priests as well. To be more precise, by means of Christ's priesthood, believers are to

spiritually enter ${ }^{161}$ the heavenly sanctuary in prayer (10:19-22) and continually offer

sacrifices ${ }^{162}$ of praise $^{163}$ to God and of altruistic actions toward others ${ }^{164}$ (13:15-16),

into account the transition devices in the structure of Hebrews, there is an overlap of keywords and concepts in 2:17-18 and 4:14-16, as the latter builds on the former. For this reason, I read the information in 4:14-16 as a continuation of what was presented in 2:17-18. In his explanation of transition techniques used in Hebrews, Guthrie identifies the presence of "hook words"- "a transition technique by which the end of one unit and the beginning of the next were stitched together by the use of a repeated term or terms" - in 2:17-18 and 4:14-16, which indicates "a dynamic transition from 2:10-18 to the point at which the author resumes his Christological exposition at 4:14 and following." Guthrie, "The Structure of Hebrews Revisited," https://hebrews.unibas.ch/documents/2006Guthrie.pdf (accessed 28 December, 2016), 14-15, 18.

${ }^{161}$ It is clear in 10:19-21 that they can enter the heavenly sanctuary ( $\left.\tau \tilde{\omega} \nu \alpha \dot{\alpha} \gamma^{\prime} \omega \nu\right)$ because of Christ: (1) this entrance is by means of His blood and flesh (vv. 19-20), which seems to refer to Christ's sacrifice;

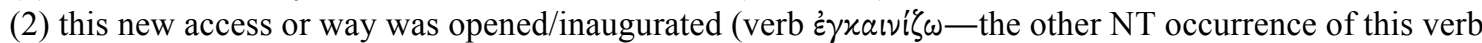
is in Heb 9:18, which refers to the inauguration of the first covenant. In the LXX, this verb is used for the

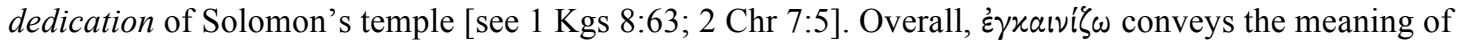
renew or ratify, inaugurate, dedicate. BDAG, 272) by Him (v. 20). If this verse is read along with 6:19-20, Christ opens/inaugurates this way for believers by being the forerunner ( $\pi$ ó $\delta$ popos, 6:20), the one who

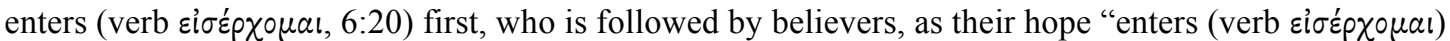

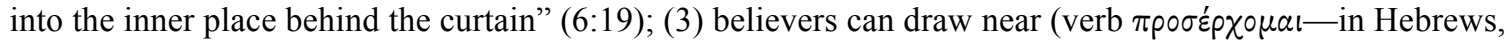
this verb appears in $4: 16 ; 7: 25 ; 10: 1,22 ; 11: 6 ; 12: 18,22)$ because Christ is a great/high "priest over the

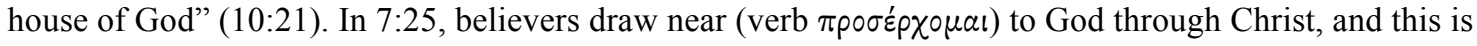
related to His heavenly intercession for them. In short, it could be said that believers are invited to perform the priestly action of entering the heavenly sanctuary on the basis of (a) Christ's sacrifice, (b) His entrance into the sanctuary, and (c) His continual intercession for them. Hence, believers implicitly become priests in terms of having access to God on the basis of Christ's priestly actions. His sacrifice is considered here a priestly action in the sense that the earthly sacrifice is offered in heaven, which would constitute the meaning of His entrance into the heavenly sanctuary.

162 Believers are invited to perform the priestly action of continually ( $\delta \dot{\imath} \dot{\alpha} \pi \alpha \nu \tau \grave{c} \varsigma$ ) offering up a

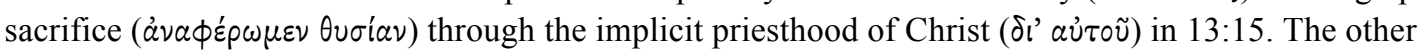
occurrence of the expression $\delta \iota^{\prime}$ a $\tau \tau o \tilde{u}$ in Hebrews is found in 7:25, where believers draw near to God through Christ ( $\left.\delta \imath^{\prime} a \cup \dot{\tau} \sigma \tilde{u}\right)$, and this is related to His heavenly intercession for them. Therefore, it could be said that believers act as priests on earth, offering sacrifices to God (praise, altruism), on the basis of

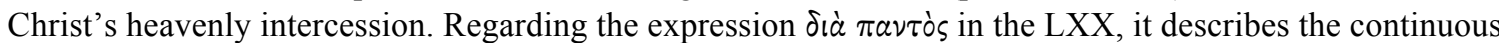
fire on the altar of burnt offerings (Lev 6:6 LXX; 6:13 ESV), and even the continuous burnt offering (Num $28: 10,15,23,24,31 ; 29: 6,11,16,19,22,25,28,31,34,38)$ itself.

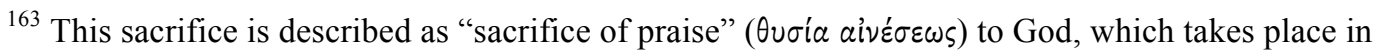

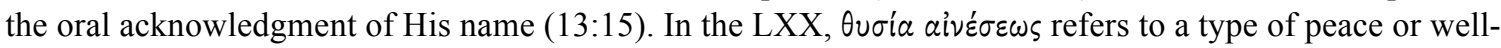
being offering, the offering for thanksgiving (e.g., Lev 7:12, 13, 15).

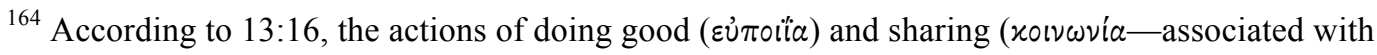


which are activities (entering the sanctuary and offering sacrifices) proper to priests. ${ }^{165}$

The implicit ${ }^{166}$ priesthood of believers in Hebrews is consistent with explicit references to their priesthood elsewhere in the NT (1 Pet 2:5, 9; Rev 1:6; 5:10; 20:6; cf. Exod 19:6). ${ }^{167}$

In fact, the reference of 1 Peter seems to add proclamation of the Savior (2:9) as a type of spiritual sacrifice (2:5). These priestly actions of Christ in favor of believers, both in helping them to remain faithful to God by strengthening them to endure temptation and in enabling believers to faithfully serve God as priests, seem to be performed in conjunction with the work of the Spirit. In Hebrews, the Spirit speaks ${ }^{168}$ to believers about a divine voice $(3: 7-8 ; 4: 7)$ that attempts to lead them to obedience or faithfulness to God $(4: 11) .{ }^{169}$

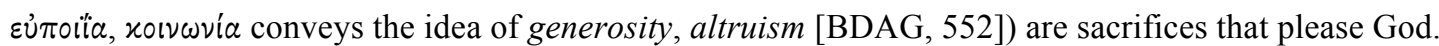

${ }^{165}$ For studies on the priesthood of believers in Hebrews, see Lambertus Floor, "The General Priesthood of Believers in the Epistle to the Hebrews," in Ad Hebraeos: Essays on the Epistle to the Hebrews (Pretoria: Die Nuwe-Testamentiese Werkgemeenskap van Suid-Afrika, 1971), 72-82; Scholer, Proleptic Priests.

${ }^{166}$ While believers act as priests (entering the sanctuary and offering sacrifices), as indicated above, they are not explicitly identified in Hebrews as priests.

${ }^{167}$ Like Hebrews, 1 Peter highlights that believers are to offer "spiritual sacrifices acceptable to God through Jesus Christ" (2:5). In Revelation, Christ's salvation makes believers priests to God (1:6; 5:10; 20:6). Arguably this point is associated with Hebrews' emphasis that believers have access to God and enter the sanctuary through Christ. Hence, they are to serve God as priests. Indeed, Rev 7:14-15 eschatologically describes the multitude of saved, "before the throne of God," serving (verb $\lambda a \tau p \varepsilon \dot{\omega} \omega$, which has a priestly connotation in Heb 8:5; 13:10) "him day and night in his temple." This service appears to be spelled out in terms of praise in the context of worship (see Rev 7:11), as the saved cry out "with a loud voice, 'Salvation belongs to our God who sits on the throne, and to the Lamb"' (Rev 7:10). For studies on the priesthood of believers in the NT, see Nelson, Raising up a Faithful Priest, 141-168; Vanhoye, Old Testament Priests and the New Priest, 243-318.

${ }^{168}$ While the author of Hebrews is quoting the words spoken by the Spirit (3:7) in 3:7-11 from Ps 95:7-11 LXX, he seems to emphasize that these words are spoken to believers "today." First, the autor states that the Holy Spirit "says" ( $\lambda \varepsilon \dot{\gamma} \varepsilon \varepsilon, 3: 7)$. Second, after quoting this Psalm he intentionally repeats the verse that contains the term "today" ( $\sigma \dot{\eta} \mu \varepsilon \rho \circ$ ) twice (see $3: 7,15 ; 4: 7$ ). Third, he elaborates on the term "today" twice (see $3: 13 ; 4: 7$ ), applying it to the present condition of believers.

${ }^{169}$ The exhortation of 3:1-4:13 begins with an emphasis on the faithfulness of Jesus and Moses with regard to God $(3: 2,5)$. However, the author questions whether believers will remain faithful (see 3:6). The quotation from Ps 95:7-11 LXX in Heb 3:7-11 reveals that the desert generation under Moses' leadership was disobedient $(3: 18)$ or unfaithful. The exhortation stresses that the people under Jesus' 
Furthermore, the salvation experienced by believers before the second coming of Christ

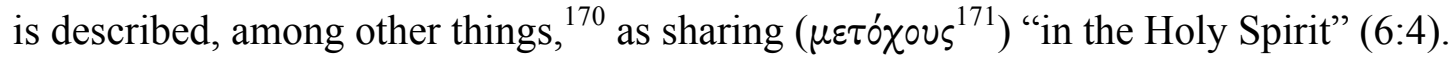

Therefore, it could be said that, as Christ helps believers to endure temptation, the Spirit speaks to form in them a faithful heart to God. As Christ empowers belivers to serve God with praises, altruism, and proclamation, the Spirit is with them, probably through the distribution of gifts $(2: 4){ }^{172}$

In short, the ongoing salvific mediation of Christ is particularly characterized by His intercession for forgiveness before the Father and His empowering of believers to faithfully serve God. The last point to be considered in this account of the priestly actions of Christ is the eschatological judgment and final salvation, which is briefly covered below.

\section{Eschatological Judgment and Salvation}

The third aspect of Christ's priestly actions, namely, the eschatological judgment

leadership (NT believers) should not follow the example of disobedience of the desert generation (4:11). In both cases, the desert generation and NT believers, the voice of the Spirit attempts to produce a faithful human heart obedient to God.

${ }^{170}$ In 6:4-5, the list contains: "been enlightnened," "have tasted the heavenly gift," "have tasted the goodness of the word of God and the powers of the age to come."

${ }^{171}$ As an adjective associated with persons, in Heb 3:14, believers share ( $\mu \varepsilon ́ \tau \circ \chi \circ$ ) in Christ, if they hold their "original confidence firm to the end." The plural form of the noun $\mu \varepsilon \dot{\tau} \tau \chi \circ \varsigma$ is translated as partners (Luke 5:7) and companions (Heb 1:9).

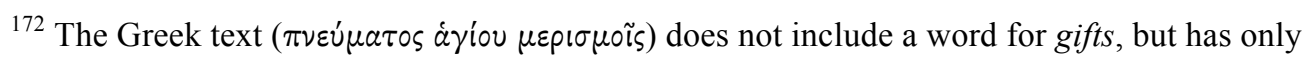
distributions ( $\mu \varepsilon \rho \vdash \sigma \mu о \tilde{\varsigma}$ ). However, overall, translators have interpreted $\mu \varepsilon \rho\llcorner\sigma \mu o \tilde{s}$ as a reference to spiritual gifts (see, e.g., ESV, NASB, NIV, NRSV, RSV, NET). In the context of 2:3-4, these gifts are a testimony

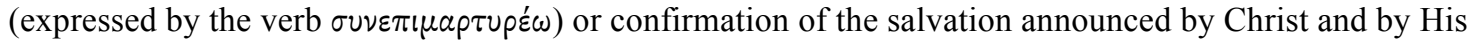
disciples. From a NT canonical perspective, it is noteworthy that in 1 Cor 12:3-11 the gifts are distributed by the Spirit, while in Eph 4:7-12 the ascended Christ is the one who gives the gifts. Therefore, the work of Christ and of the Spirit are interrelated. In light of the information that the asended Christ sent the Spirit (see John 15:26; 16:7; 20:22; Acts 2:33), it could be said that Christ gives the gifts through the Spirit. 
and salvation, is not substantially elaborated in Hebrews. To use Cullmann's words, it "is only mentioned" in 9:27-28 "and not fully developed." ${ }^{173}$ The idea indicated by 9:27-28 is that, in a brief overview between the first and second comings of Christ, His death and sacrificial offering is followed by eschatological judgment and the final salvation of believers. ${ }^{174}$ The basic distinction between these two phases (sacrificial offering and eschatological judgment/salvation) is that the former aims at the removal of sins from believers, while the latter does not deal with sin anymore (9:28). ${ }^{175}$ Therefore, the eschatological judgment and salvation belong to the resolution of the sin problem.

The language of divine judgment occurs in several places in Hebrews (see 4:12; $6: 2 ; 9: 27 ; 10: 27,30 ; 12: 23 ; 13: 4) .{ }^{176}$ When this language is associated with Christ, a destructive judgment awaits those who despise Him and His work (10:26-27, 29-31). Conversely, the eschatological judgment means salvation for believers (9:27-28). This final salvation is associated with Christ's second coming appearance (9:28), assuming that the first appearance refers to His sacrificial offering $(9: 26,28)$. If these two

${ }^{173}$ Cullmann, The Christology of the New Testament, 104.

${ }^{174}$ In the comparison of vv. 27-28, there is a parallel between anthropology (v. 27) and Christology (v. 28). While the sequence in anthropology is death and judgment, the sequence in Christology is sacrificial offering and final salvation for believers. In this parallel, the death of human beings is related to the sacrificial death of Christ and the eschatological judgment is related to the final salvation of believers. First, the comparison between the death of human beings and the death of Christ

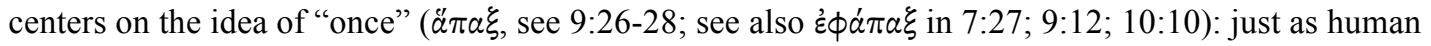
beings die once, Christ was offered once. Second, eschatological judgment and final salvation stand together.

175 The removal of sins by means of Christ's sacrificial offering is portrayd in terms of bearing

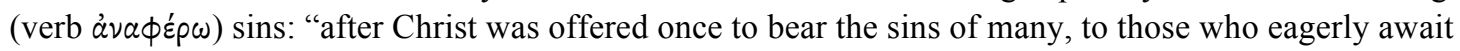
him he will appear a second time, not to bear sin but to bring salvation" (9:28 NET). In 9:26, a similar passage that relates Christ's once sacrifice with human sin, the language of removal of sins is explicit: "he has appeared once for all at the end of the ages to put away (verb á $\theta \dot{\varepsilon} \tau \eta \sigma \varsigma)$ sin by the sacrifice of himself."

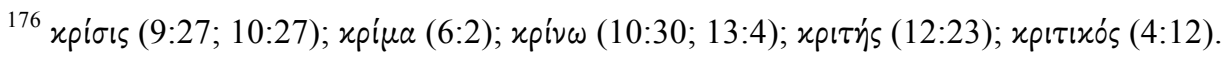


appearances describe the first and second coming of Christ to earth, ${ }^{177}$ they seem to be respectively followed and preceded by His appearing before God in heaven on behalf of human beings. Just as Christ's sacrificial offering requires a movement from earth to heaven, as Christ goes into God's presence to present His earthly sacrifice (9:24-25), the eschatological judgment and salvation imply a movement from heaven to earth, as Christ comes from God's presence to make judgment and salvation a reality for human beings. Assuming that in these two movements the work of Christ is consistent with the will of the Father, in the first movement, what is done on earth (sacrifice) needs to be subsequently validated by God in heaven (in this sense there is a sacrificial offering in heaven, but not without its previous reality on earth). My suggestion regarding the second movement is that, presumably, what will be done on earth (judgment and salvation), needs to be previously validated by God in heaven (in this sense there is judgment and salvation in heaven, but not without their subsequent reality on earth). To be sure, the first movement is more detailed in Hebrews than the second, as the offering includes an appearance before God (9:24-25). ${ }^{178}$ However, the second movement seems to be not

${ }^{177}$ Elsewhere in the NT, the verb фavepów is used for the appearances of Christ in His first (1 Tim $3: 16 ; 1$ Pet $1: 20 ; 1$ John $1: 2 ; 3: 5,8$ ) and second (1 Pet 5:4; 1 John 2:28; 3:2) comings. In fact, the use of фavepów in 1 John 3:5 and Heb 9:26 are similar, in the sense that this verb is related with the putting away of sin. In its turn, the verb ópá is used elsewhere in the NT for the appearances of Christ to people after His resurrection (Luke 24:34; Acts 9:17; 13:31; 26:16; 1 Cor 15:5-8).

178 There are three references to Christ appearing in 9:24-28. He appeared in the presence of God in heaven (9:24, verb $\varepsilon \mu \phi a v_{i}^{\prime} \zeta \omega$, root $\left.\phi a \imath \nu \omega\right)$, He appears on earth for His sacrifice on the cross $(9: 26$, verb

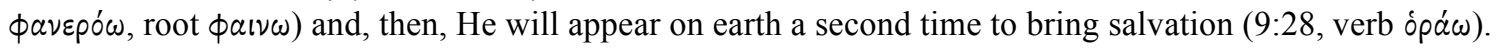
Therefore, there is one reference to a heavenly appearance and two references to an earthly appearance. The heavenly appearance is related to and follows the first earthly appearance, since the heavenly appearance is a presentation before God of His earthly sacrificial appearance. As indicated previously, the offering in 9:25 is described in terms of entering the sanctuary. This implies that Christ's sacrificial offering was complete when He entered the heavenly sanctuary, in the presence of God (9:24). This point was elaborated above in the subsection The Heavenly Offering and His Earthly Sacrifice. 
only implied in Hebrews (9:27-28), ${ }^{179}$ but also canonically consistent with a messianic/Christological interpretation of "the Son of Man" (Jesus) coming to "the Ancient of Days" (God the Father) in heaven, in a context of divine judgment, to eschatologically receive the everlasting kingdom and bring it to believers on earth (Dan 7:13-14, 18, 22, 27; cf. vv. 9-10, 26; Mark 14:62). ${ }^{180}$ It is noteworthy that the discussion of the eschatological judgment in Heb 10:25-31 even seems to include hints of investigative or legal procedure before the executive judgment, as the language of witnesses in the context of the Mosaic law (10:28) is used in comparison to the eschatological judgment (10:28-31).

In short, the eschatological judgment and salvation refer to the conclusion of Christ's soteriological priesthood, as far as the resolution of the sin problem. With this

179 This point is highlighted by Cortez. In his remarks on 9:25-28, he argues that "the experience of human beings consisting in 'death' and 'judgment' represents two phases in the ministry of Jesus." Indeed, "the first 'appearance' of Jesus Christ (9:26) is an event that included both a sacrifice on earth and Jesus' appearance before God in heaven. The second phase is represented by 'judgment.' Hebrews 9:28 argues that the 'second' appearance has the purpose of 'saving' those who are 'eagerly waiting' ... for him. Almost all commentators see here a reference to the second coming. I think this is correct, but, just as the first appearance involved acts on earth (sacrifice) and in heaven (appearance before God), the second appearance should include an act in heaven as well as on earth." Cortez, "The Anchor of the Soul That Enters Within the Veil'," 396-397n1.

${ }^{180}$ Without entering into details (and potential disagreements) regarding the interpretation of Dan 7, this basic notion is affirmed by Stephen R. Miller, Daniel, NAC (Nashville, TN: Broadman \& Holman, 1994), 207-213. For helpful information about a messianic/Christological interpretation of Dan 7:13, see Michael B. Shepherd, "Daniel 7:13 and the New Testament Son of Man," Westminster Theological Journal 68, no. 1 (2006): 99-111. In my view, to avoid a confusion between Christ's eschatological reception of the kingdom (Dan 7:13-14) and His heavenly enthronement at the ascension in the first century AD (as described, e.g., in Heb $1: 5-13 ; 2: 9 ; 10: 12$ ), it is important to acknowledge that the enemies of Christ's kingdom were not fully subjugated at His enthronement. Rather, He is "waiting from that time until his enemies should be made a footstool for his feet" (Heb 10:13; cf. 1:13; Ps 110:1). Therefore, the divine judgment against enemies (cf. Heb 10:27) is crucial for the fullness of Christ's kingdom. In a Christological reading of Dan 7:13-14, Christ's eschatological reception of the kingdom takes place in the context of divine judgment against the little horn, a chief enemy of God and His people (cf. Dan 7:9, 21-22, 25-27). After this destructive judgment, "the saints of the Most High shall receive the kingdom and possess the kingdom forever, forever and ever" (Dan 7:17; cf. v. 27). Read along with Hebrews, this interpretation of Dan 7 sounds like Christ coming to earth to bring final salvation to believers in the context of eschatological divine judgment (Heb 9:27-28), as His enemies have been eventually "made a footstool for 
resolution, Christ will bring complete salvation to believers in His second coming.

\section{Summary}

In summary, three types of Christ's priestly action can be discerned in Hebrews: (1) the heavenly offering of His earthly sacrifice; (2) ongoing salvific mediation; and (3) eschatological judgment and salvation. The first type was officially performed before the Father once at His ascension, so that the Father can accept Christ's earthly sacrifice on the cross. This acceptance established the basis for the other two types of priestly action and also meant the forgiveness of the sins of God's covenantal-repented people committed throughout history before the beginning of Christ's priesthood. The second type of Christ's priestly action is His ongoing salvific mediation, which includes intercession for forgiveness and empowerment of believers. As far as the intercession for forgiveness, when a believer confesses his/her sins in prayer, Christ intercedes for him/her before the Father. As the legal authority to whom this case is presented, the Father forgives the believer on the basis of Christ's past sacrifice and present intercession. ${ }^{181}$ With regard to the empowerment of believers, Christ helps them through the Holy Spirit to remain faithful to God, strengthening believers to endure temptation and enabling them to serve God in prayer, with praise, proclamation, and altruistic actions. Finally, the third type of Christ's priestly action involves eschatological judgment and salvation, which portray the conclusion of His soteriological priesthood.

his feet" (Heb 10:13; cf. 1:13; Ps 110:1).

${ }^{181}$ I do not share the view of a conceptual tension in Hebrews between Christ's heavenly (continual) intercession and the completion (once for all) of His high-priestly work. David Hay seems to affirm this view when he indicates that the "idea of eternal intercession" in 7:25 "is something of a "foreign body' in the epistle's theology." David Hay, Glory and the Right Hand: Psalm 110 in Early Christianity 
With the resolution of the sin problem, Christ will bring complete salvation to believers in His second coming.

As it will become evident in the next section (The Goal of the Priesthood), these three types of priestly action resemble three crucial moments of the Aaronic priesthood, namely, the inauguration of the priesthood (and of the sanctuary), the daily intercession performed in the first apartment of the sanctuary, and the judgment implied in the purification of the sanctuary performed on the Day of Atonement. In fact, the next section will provide a teleological framework that enriches the understanding of the meaning of Christ's priestly actions.

\section{The Goal of the Priesthood}

According to what has been described so far (The Need for Christ's Priesthood, The Agent of the Priesthood, and The Actions of the Priest), the priesthood of Christ is needed to solve the sin problem. In this context, His priestly work is necessary to (1) restore the covenantal relationship between human beings and God by mediating divine forgiveness; (2) purify/eliminate the guilty conscience of human beings (who are aware of their broken covenantal relationship with God, resulted from the transgression of the divine law) and help them endure temptation; and (3) purify the heavenly sanctuary, which has been defiled by human sin and reveals that the sin problem impacts creation at a cosmic level.

Christ was prepared/perfected for the priestly office through His incarnation and deadly suffering. In this process, He learned obedience to God and developed mercy in 
terms of His profound identification with human beings. Although His priestly appointment was divinely expressed/revealed long before His incarnation, it became officially effective at the ascension and was associated with His royal enthronement in heaven. In terms of priestly actions, at the ascension Christ officially presented to the Father His earthly sacrifice for the forgiveness of sins committed by repented believers who lived before the official beginning of Christ's priesthood. This official presentation also established the basis of His other two priestly activities. In His ongoing intercession, Christ mediates forgiveness of sins before the Father on behalf of repented believers in prayer and empowers them, through the Holy Spirit, to remain faithful to God when they face temptation and to serve God in prayer, with praise, proclamation, and altruistic actions. Then, the eschatological judgment and salvation mark the conclusion of Christ's soteriological priesthood. With the resolution of the sin problem, He will bring salvation to believers in His second coming.

While many aspects of this overall picture of Christ's priesthood point to specific goals to be achieved, ${ }^{182}$ my contention in this section is that the notion of covenant (mentioned in the need for Christ's priesthood) constitutes a teleological framework that deepens the understanding of Christ's priesthood and organize specific goals into a conceptual whole.

\section{Better/New Covenant and Goal}

Taking into account the most detailed reference to the new covenant (Heb 8,

\footnotetext{
182 Particularly, the three types of need for Christ's priesthood and the three types of His priestly action indicated above. There are also a couple of statements in the first chapters of Hebrews that seem to imply a goal to be achieved. For instance, the bringing of sons to glory $(2: 10)$ and their sanctification by Christ (2:11); the promise of entering the divine rest (4:11); and the inheritance of promises (6:12).
} 
quoting Jer 31:31-34), we find at least three features of this covenant that imply a goal:

(1) this covenant is an eschatological promise to be fulfilled ("the days are coming,"183

$8: 8)$; (2) the establishment of the new covenant (8:8) conveys the idea of teleological

fulfillment, as the verb $\sigma \cup \nu \tau \varepsilon \lambda \varepsilon^{\prime} \omega$ comes from the root $\tau \varepsilon \lambda \circ{ }^{184}{ }^{184}$ and (3) the promise of the

new covenant makes the previous covenant old $(8: 13) .{ }^{185}$

The basic notion that informs this eschatological fulfillment, that is, the transition

from a first good/old covenant to a better/new covenant, ${ }^{186}$ is that the first covenant was a

theoretical anticipation or a shadow that pointed to the reality of the better/new

covenant. ${ }^{187}$ Hence, the first covenant is not replaced because it did not bring into effect

183 The language of eschatological "days" also appears in 1:2; 8:10; and 10:16.

${ }^{184}$ This is not an argument simply based on etymological root. I mention the root here to reinforce the teleological meaning of the verb. According to BDAG, the verb $\sigma u \nu \tau \varepsilon \lambda \varepsilon^{\prime} \omega$ in v. 8 means "to carry out or bring into being someth. that has been promised or expected, carry out, fulfill, accomplish." BDAG, 975.

${ }^{185}$ This is the only instance where the language old is used in reference to the first covenant. This covenant is made, declared, or treated as old (verb $\pi \alpha \lambda \alpha \iota^{\prime} \omega$, see BDAG, 751) by the promise of the new covenant (8:13). Overall, the language is of a first covenant $(8: 7,13 ; 9: 1,15,18 ; 10: 9)$. Regarding 10:9, in the other occurrence of $\pi \rho \tilde{\omega} \tau 0 \varsigma$ and $\delta \varepsilon \dot{\tau} \tau \varepsilon \rho \varsigma$ in Hebrews (8:7), these words seem to refer to a first and second covenant. For studies on the covenant in Hebrews, see Ekkehardt Müller, "Jesus and the Covenant in Hebrews," in 'For You Have Strengthened Me': Biblical and Theological Studies in Honor of Gerhard Pfandl in Celebration of His Sixty-Fifth Birthday (St Peter am Hart, Austria: Seminar Schloss Bogenhofen, 2007), 189-208; Scott W. Hahn, "A Broken Covenant and the Curse of Death: A Study of Hebrews 9:1522," The Catholic Biblical Quarterly 66, no. 3 (2004): 416-436; Scott R. Murray, "The Concept of $\Delta 1 \alpha \theta \eta \dot{k n}$ in the Letter to the Hebrews," Concordia Theological Quarterly 66, no. 1 (2002): 41-60; John Dunnill, Covenant and Sacrifice in the Letter to the Hebrews, Society for New Testament Studies (Cambridge: Cambridge University Press, 1992); Richard B. Hays, “'Here We Have No Lasting City': New Covenantalism in Hebrews," in The Epistle to the Hebrews and Christian Theology, ed. Richard Bauckham, Daniel R. Driver, Trevor A. Hart, and Nathan MacDonald (Grand Rapids, MI: Eerdmans, 2009), 151-173; Peter Gräbe, "The New Covenant and Christian Identity in Hebrews," in Cosmology and New Testament Theology, ed. Richard Bauckham, Daniel Driver, Trevor Hart, and Nathan MacDonald (London: T\&T Clark, 2008), 118-127; Susanne Lehne, The New Covenant in Hebrews, Library of New Testament Studies (Sheffield: Sheffield Academic Press, 1997).

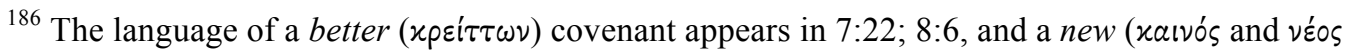
[12:24]) covenant is found in $8: 8 ; 9: 15 ; 12: 24$. This covenant is implicitly referred as new (xaเvós) in 8:13,

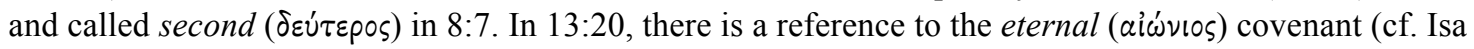
55:3; 61:8; Jer 32:40; Ezek 37:26).

${ }^{187}$ The references to the first covenant in Hebrews highlight its provisorional status (it will vanish 
what it was supposed to bring. Rather, the transition to a better covenant was originally intended by God in terms of a theoretical anticipation that gives room to its reality. To be more precise, the first covenant ${ }^{188}$ in Hebrews refers to three interrelated cultic elements: priesthood, sanctuary, and sacrifices. In the first covenant, the priesthood was composed by a large number of mortal and weak/sinful priests $(7: 23,28)$; the sanctuary was not the real/true/perfect one (see $8: 2,5 ; 9: 1,11,24)$; and the priestly service involved multiple ineffective sacrifices $(7: 27 ; 9: 9-10,25 ; 10: 1-4,11)$. Conversely, in the excellent reality of the new covenant, there is only one eternal and perfect/sinless high priest $(7: 16,24-26)$, who offerered an effective sacrifice once for all $(7: 27 ; 9: 24-28 ; 10: 10-12,14)$ and ministers in the real/true/perfect sanctuary $(8: 2,5 ; 9: 11,24) .{ }^{189}$

away because of the arrival of the new covenant, $8: 13 ; 10: 9)$. Indeed, the services (basically sacrifices,

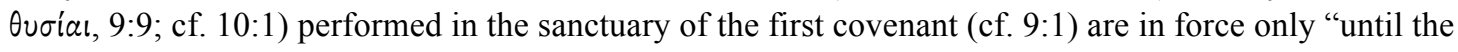

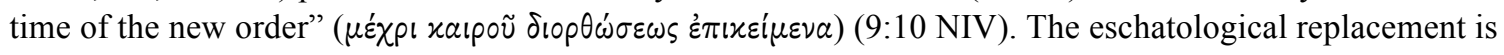

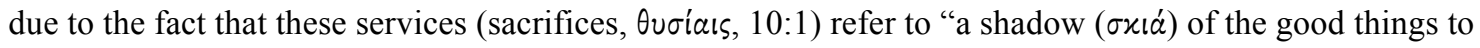

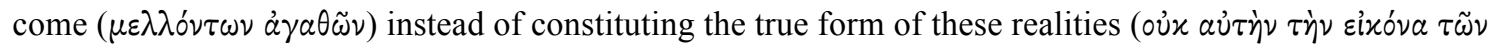
$\pi \rho a \gamma \mu \alpha ́ \tau \omega \nu)$ " (10:1; cf. 8:4b-5a). Therefore, by its own nature, the first covenant could not bring into effect the results that belong to the reality to which the first covenant contains only "a sketch and shadow

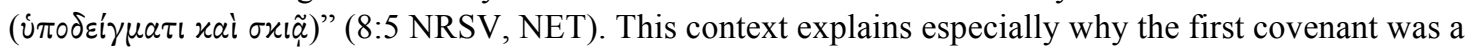
theoretical anticipation or shadow that pointed to the reality of the better/new covenant. Furthermore, the

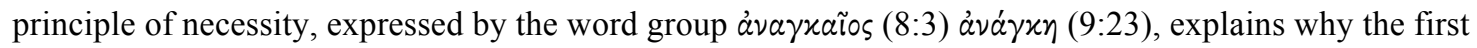
covenant was a theoretical anticipation or shadow that pointed to the reality of the better/new covenant. More specifically, there is a principle of necessity that implies a close relationship between the sketch (cf.

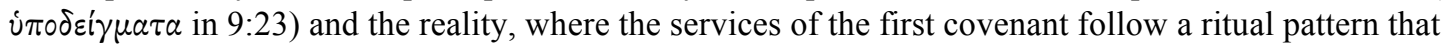
must take place in the reality of the better/new covenant.

${ }^{188}$ In Hebrews, the language of law ( $\delta$ vónos) is used to refer to the regulations of the priesthood (the order of Aaronic priests, 7:11-12,28) and its services (especially sacrifices) in the sanctuary setting in the context of the first covenant $(8: 3-4 ; 10: 1)$. Heb 9:1 explicitly indicates that the first covenant had

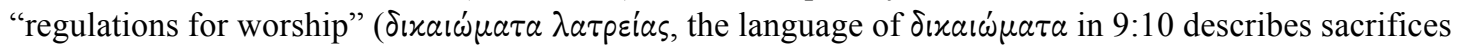

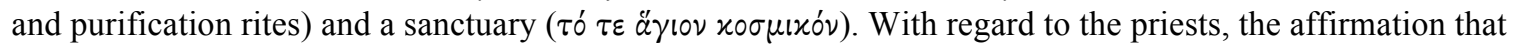
Jesus is mediator of a better covenant in His priestly ministry (8:6) appears to imply that, comparatively, Aaronic priests were mediators of the first covenant (cf. 8:5-4). Therefore, the language of law and of first covenant seem to be used interchangeably.

${ }^{189}$ Indeed, the better covenant is characterized by (1) a better priest (7:21-28) who performs (2) a better priestly work in a better sanctuary (8:1-6). First, with His priestly appointment (7:21), Christ "has become (perfect tense of $\gamma^{\prime}(v \circ \mu a l)$ the guarantee ( $\varepsilon^{\prime} \gamma \gamma$ vos) of a better covenant" (7:22 NASB). This better covenant seems to be associated with the idea that its priest (the resurrected Christ) will not be prevented 
It is noteworthy that the author of Hebrews explains the transition from the

priesthood, sanctuary, and sacrifice of the first covenant to those of the better/new

covenant by using quotations from the LXX (priesthood-Ps 110:4 in Heb 7:17, 21;

sanctuary_Exod 25:40 in Heb 8:5; sacrifice_-Ps 40:6-8 in Heb 10:5-9). ${ }^{190}$ This OT

foundation for the elaboration of the new elements in the better/new covenant show that

the realities of this covenant were originally intended by God to solve the sin problem, as

they would really take away sins from human beings (cf. Heb 10:4, 9:28). In other words,

in consonance with the divine plan, the priesthood of Christ aims at being the

eschatological agency that really removes sins from repented believers.

The author of Hebrews speaks of this eschatological reality in terms of promises.

In his words, the better covenant mediated by Christ's priesthood "has been enacted on

by death from continuing His office (7:23-24), and that He does not have the sinful weaknesses of other high priests (7:26-28). Second, the better covenant in 8:6 is described in terms of a superior priestly work. The idea that Christ is the mediator ( $\mu \varepsilon \sigma i \tau \eta \zeta)$ of a better covenant is associated with Christ's more excellent

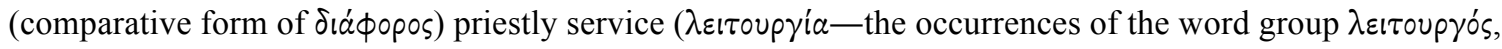
$\lambda \varepsilon i \tau o u p \gamma i a, \lambda \varepsilon i \tau o u p \gamma \varepsilon \dot{\varepsilon} \omega$ in Heb 8:2, 6; 9:21; $10: 11$ refer to priesthood) in the heavenly sanctuary (8:1-5-in

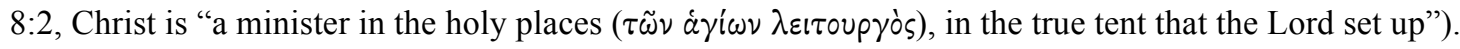

${ }^{190}$ First, the OT basis for the transition in terms of priesthood is Ps 110:4 (cf. Heb 7:17, 21), which appears particularly in the section on Christ's priestly appointment (Heb 7). In Heb 7, Ps 110:4 provides the key to explain why Christ can be a high priest without being a levite: He is a priest according to the order of Melchizedek. Second, the OT support for the transition of sanctuaries is Exod 25:40 (cf. Heb 8:5). Heb 8:4-5 stipulates that the services of the first covenant were performed in a sketch and shadow of the true heavenly sanctuary. The earthly sanctuary of the first covenant was constructed according to the type of the heavenly one. Therefore, the affirmation that Christ is the minister of the real sanctuary is grounded on the idea that this sanctuary actually precedes and is the paradigm for the sanctuary of the first covenant. Third, the OT basis for a transition from multiple sacrifices to only one sacrifice is Ps 40:6-8 LXX (cf. Heb 10:59). In contrast to the sacrifices of the first covenant (cf. Heb 10:8), Christ offered His own body (cf. Heb 10:5) to do the will of God (cf. Heb 10:7, 9). "By that will we have been sanctified through the offering of the body of Jesus Chris once for all" (Heb 10:10; italics mine). I am indebted to Richard Davidson's remarks on the use of the OT in these elaborations of priesthood, sanctuary, and sacrifice (and even the new covenant itself, Jer 31:31-34 in Heb 8:8-12) in Hebrews. In each of these cases, "the author of Hebrews introduces a departure from the Levitical type, but he substantiates such a change from the OT itself." Davidson, "Typology in the Book of Hebrews," 177. 
better promises" (8:6, NASB). ${ }^{191}$ The content of these promises (8:8-12; cf. Jer 31:31-34;

Heb 10:16-17) can be outlined as follows: (1) the divine laws will be internalized in the minds and hearts of God's covenantal people (8:10), (2) there will be a covenantal relationship between God and His people (8:10), (3) everyone will know God (8:11), and (4) God will forgive human sins (8:12). This is not to say that these four aspects were not available to human beings before the beginning of the salvific priesthood of Christ. But they were available as an experience grounded in the promise of Christ's salvific priesthood, and not in its reality yet. In terms of the reality of Christ's priesthood, as $\mathrm{He}$ mediates this covenant, Christ brings people to a covenantal relationship with God (initiation of points 1 to 4 ) and helps them to stay and grow in this covenant (continuation of points 1 to 4). This idea of initiation and continuation seems to be implied in the stages of fulfillment of the covenant suggested in the three types of Christ's priestly actions described in the section above (The Actions of the Priest). I infer these stages from the overall picture of the priesthood of Christ in Hebrews. I will outline these stages below.

\section{Stages in the Fulfillment of the Goal ${ }^{192}$}

Inauguration

The first type of priestly activity described in The Actions of the Priest was Christ's heavenly offering of His earthly sacrifice at His official inauguration as priest

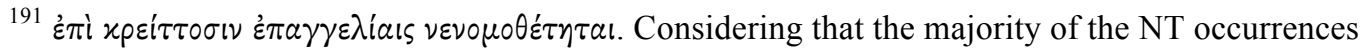
of $\dot{\varepsilon} \pi \alpha \gamma \gamma \varepsilon \lambda_{i} a$ is found in Hebrews $(4: 1 ; 6: 12,15,17 ; 8: 6 ; 9: 15 ; 10: 36 ; 11: 9,13,17,33,39)$, this seems to be a key word in this book.

${ }^{192}$ To be sure, each one of the stages described below could be considered a specific goal. Furthermore, I have indicated above several individual goals in Hebrews. However, I keep the language of goal (singular) because I see individual goals from the perspective of a conceptual whole that implies a progression leading to the the fulfillment of a final and larger goal.
} 
and king of the heavenly sanctuary. In terms of covenant, the goal of this activity seems

to be the inauguration of the new/better covenant, which is compared with the

inauguration of the first covenant $(9: 15-21) .{ }^{193}$ As Richard Davidson indicates, the

inauguration of the first covenant was a large "integrally bound-up complex of

inauguration/consecration events connected with the commencement of the Hebrew

cultus,"194 which included the presentation of commandments of the law, sacrificial

blood, and the consecration of the tabernacle with this blood $(9: 19-21) .{ }^{195}$ It is

noteworthy that the consecration/inauguration of the tabernacle involved the consecration

${ }^{193}$ According to Hahn, the term $\Delta \iota a \theta \eta \dot{k} \eta$ in Heb 9:16-17 should not be rendered as testament or will, but be consistent with the other occurrences of the term in Hebrews, which convey the meaning of covenant. In his words, "In the new covenant, Christ indeed dies, but he is a mediator (Heb 9:15; 12:24), not a 'testator.' Moreover, he does not die in order to leave an inheritance to the Church, but rather to enter the inheritance himself (Heb 1:3-4; 2:9; 9:11-12; 10:12-13), which he then shares with his 'brothers' (Heb 2:10-3:6). Clearly, then, the mode of the inheritance of salvation in Hebrews is based on a Jewish covenantal and not a Greco-Roman testamentary model." Scott W. Hahn, "Covenant, Cult, and the Curseof-Death: $\Delta \iota \alpha \theta \dot{\mathrm{K}} \eta$ in Heb 9:15-22," in Hebrews: Contemporary Methods, New Insights, ed. Gabriella Gelardini (Leiden; Boston: Brill, 2005), 70. In his remarks on 9:17, Hahn calls the attention to the

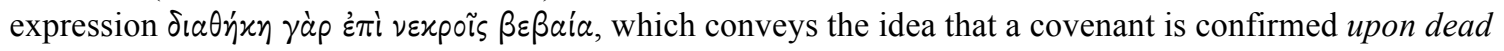
[bodies], which suggests the sacrifice of animals (see Gen 15:9-10; Jer 34:18-20). Ibid., 73, 75. As hinted in Heb 9:18-20, "the Sinai covenant is solemnized by the sprinkling of the people with the blood of the animal sacrifices after their solemn promise to obey the covenant stipulations (Exod 24:3-8), conveying the concept, 'As was done to the animals, so may it be done to us if we fail to keep the covenant." Ibid., 79. According to this view, "the purpose of Heb 9:16-17 is to explain why a death was necessary, given the predicament of the broken first covenant" indicated in 9:15. The explanation is that "where there is a covenant, it is necessary for the death of the covenant-maker to be endured [when transgressions have taken place]." The author of Hebrews "leaves open the possibility that the death of the covenant-maker might be borne by a designated representative, e.g., the high-priest Jesus. He only stresses that, because of transgression (Heb 9:15), someone must bear the curse-of-death" (compare with Heb 9:28; Isa 53 LXX). Ibid., 81-83. Following this perspective, "a broken covenant demands the death of the covenant-maker (Heb 9:16), and it is not being enforced while the offending covenant-maker lives (Heb 9:17)." Indeed, "the first covenant entailed the curse-of-death for those who broke it (Heb 2:2; 10:28), which Christ takes upon himself as Israel's corporate representative (Heb 2:9, 14; 9:28), thus freeing those under the first covenant from the curse-of-death (Heb $2: 15 ; 10: 14$ ) and providing for them a new and better covenant (Heb 9:28; 10:15-17; 12:22-24)." Ibid., 85.

${ }^{194}$ Richard M. Davidson, "Inauguration or Day of Atonement?: A Response to Norman Young's 'Old Testament Background to Hebrews 6:19-20 Revisited',' AUSS 40, no. 1 (2002): 72.

${ }^{195}$ Mary D'Angelo speaks of a conflation of the inauguration of the covenant, the consecration of the priests, and the inauguration of the sanctuary in Heb 9:16-21. See Mary Rose D'Angelo, Moses in the Letter to the Hebrews, Society of Biblical Literature Dissertation Series (Missoula, MT: Scholars Press, 
of Aaron and his sons to the priesthood (see Exod 40:9-15; Lev 8-9). ${ }^{196}$ Therefore, from a biblical typological perspective, ${ }^{197}$ the inauguration of the new/better covenant is a fitting framework for the understanding of the official initiation of Christ's priesthood in Hebrews. In this context, the passages that describe His entrance into the heavenly sanctuary $(6: 19-20 ; 9: 11-12,24-25)$ in the ascension $(4: 14)$ are pointing to the official inauguration of His priesthood, and by implication, as a complex of events, the inauguration of the heavenly sanctuary for His salvific priesthood. These events were necessary to inaugurate the promised new/better covenant.

This conception is obviously different from the traditional idea maintained in Hebrews scholarship that Christ's entrance into the heavenly sanctuary referred to the OT Day of Atonement (Lev 16). ${ }^{198}$ While the traditional idea emphasizes Christ's entrance

1979), 243-249.

${ }^{196}$ In Leviticus, the emphasis is on the consecration of Aaron and his sons to the priesthood. The consecration of the tabernacle appears in 8:10-11.

${ }^{197}$ Davidson tentatively defines biblical typology as "the study of certain OT salvation-historical realities (persons, events, institutions) which God specifically designed to correspond to, and to be prospective/predictive prefigurations of, their ineluctable (devoir-être) and absolutely escalated eschatological fulfillment aspects (inaugurated/appropriated/consummated) within NT salvation history." Richard M. Davidson, "Typological Structures in the Old and New Testaments," (Th.D. dissertation, Andrews University, 1981), 3. For studies on typology in Hebrews, see Davidson, "Typology in the Book of Hebrews," 121-186; Alberto R. Treiyer, "Antithetical or Correspondence Typology?," in Issues in the Book of Hebrews, ed. Frank B. Holbrook (Silver Spring, MD: Biblical Research Institute, 1989), 187-198.

${ }^{198}$ For a helpful overview of the Day of Atonement as the primary background for the understanding of Christ's ascension in Hebrews, see Cortez, "'The Anchor of the Soul That Enters Within the Veil"," 9-18. Cortez indicates that "a majority of expositors consider that Jesus' ascension in Hebrews is structured in three stages that correspond to the Day of Atonement ritual: (1) the passion and death of Jesus correspond to the immolation of the victim (Heb 9:13, 14), (2) the ascension to heaven corresponds to the entrance of the high priest into the holy of holies (9:11-12), (3) and Jesus' purification of believers corresponds to the purification of the heavenly sanctuary (9:23). Some add a fourth stage, Jesus' second coming corresponds to the exit of the high priest from the holy of holies on the Day of Atonement (9:28)." For extensive bibliographical information of scholars who advance these stages (which includes Craig Koester, Donald Hagner, Richard Nelson, Kennet Schenck, Norman Young, Gareth Cockerill, David deSilva, George Guthrie, Paul Ellingworth, William Lane, John Scholer, F. F. Bruce, Harold Attridge, David Peterson, William Loader), see ibid., 13n1, 16n1. Furthermore, Cortez provides a summary of the main arguments used in the secondary literature showing the inconsistencies between the Day of 
into the Most Holy Place, ${ }^{199}$ following the type of the Day of Atonement, ${ }^{200}$ the position

adopted in the present study has the whole sanctuary in view in its account of Christ's

entrance, as indicated in the OT type of inauguration. ${ }^{201}$ According to the OT

Atonement and the ascension of Christ in Hebrews: (1) "absence of 'affliction of the soul' in relation to Jesus' entrance into the heavenly sanctuary," (2) "the Azazel ritual is omitted," (3) "the sprinkling of Jesus' blood in heaven does not refer to the Day of Atonement ritual," (4) "the Day of Atonement provides only secondary imagery to Jesus' sacrifice." Ibid., 19-30. The third and the fourth points of the summary indicate the new covenant is the main reference for the sprinkling of Christ's blood in heaven and the primary imagery for His sacrifice. As Cortez mentions, "The only explicit references to the Day of Atonement are found in Heb 8-10 . . , but it is in these chapters where the institution of the new covenant dominates the argument." Ibid., 30.

${ }^{199}$ See stage (2) in the previous footnote.

${ }^{200}$ It is important to highlight, however, that the Day of Atonement did not focus only on the most holy place. Rather, it was the entire tabernacle that was purified on that day (see Lev 16:14-20). Therefore, the Day of Atonement also had the whole sanctuary in view, and not only the most holy place.

${ }^{201}$ In Cortez's helpful overview of suggestions in secondary literature regarding the primary OT background for the understanding of Christ's ascension in Hebrews, the idea of inauguration that I subscribe here is the one labeled as "Moses Inauguration of the Sanctuary." See Cortez, "The Anchor of the Soul That Enters Within the Veil'," 31-36. Cortez indicates that some "scholars allow for a double analogy of Jesus' ascension that would include the Day of Atonement and Moses' inauguration of the sanctuary," and Ellingworth is an example of that. Ibid., 31n1. It is noteworthy that Ellingworth maintains that in 9:11-14 the Day of Atonement is "the typological counterpart of the sacrifice and exaltation of Christ," while in 9:23 purification is interpreted as consecration or inauguration of the sanctuary. Ellingworth, The Epistle to the Hebrews, 445, 477. Similarly, Davies, Hurst, and Spicq interpret 9:23 in terms of inauguration of the sanctuary. See John H. Davies, A Letter to Hebrews, Cambridge Bible Commentary: New English Bible (London: Cambridge University Press, 1967), 91; Lincoln D. Hurst, The Epistle to the Hebrews: Its Background of Thought, Society for New Testament Studies Monograph Series (Cambridge; New York: Cambridge University Press, 2005), 38; Spicq, L'Épitre aux Hébreux, 2:267. More specific emphases on the idea of inauguration are offered by D'Angelo and Dahl. D'Angelo argues that દ่ $\pi \tau \varepsilon \lambda \varepsilon \tilde{\imath} \nu$ in Heb 8:5 means complete or consecrate, and not simply build. For her, the tabernacle was completed only when it was consecrated (Exod 40:33; Num 7:1). D'Angelo, Moses in the Letter to the

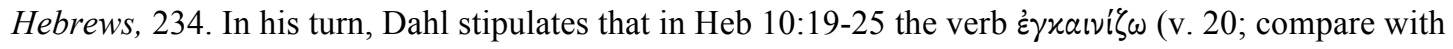
9:18) is a cultic term that conveys the idea of consecration or inauguration. Hence, Christ opened or consecrated the entrance to the sanctuary. In his words, "the opening of the way through the curtain as a cultic act of consecration, identical with the ratification of the new covenant." Dahl, "A New and Living Way," 403-404. A detailed proposal of the idea of the inauguration of the heavenly sanctuary is delineated in Richard M. Davidson, "Christ's Entry 'within the Veil' in Hebrews 6:19-20: The Old Testament Background," AUSS 39, no. 2 (2001): 175-190. As Cortez indicates, Davidson's proposal draws on Vanhoye's and Shea's literary analysis of the structure of Hebrews and assumes that "Heb 6:19-20; 9:1114, 24; and 10:19-22 are parallel passages that refer to the same event and sould explain one another." Cortez, "The Anchor of the Soul That Enters Within the Veil'," 32. Cortez provides a helpful 5-point summary of the arguments articulated by Davidson: (1) "Jesus is king and high priest. The fact that he is described in Hebrews as being a high priest 'according to the order of Melchizedek' makes clear that Hebrews does not wish to establish an Aaron-Jesus typology. Aaron is not king. Moses, instead, functions in Hebrews as a type of Jesus (3:1-6; 9:15-24). Moses functions as a king high priest, particularly in his role of inaugurator of the covenant, which includes the inauguration of the sanctuary. Moses entered the inner 
background, the Day of Atonement (cf. Lev 16:16, 18-20, 33) was not the only ritual that included an entrance into the most holy place. ${ }^{202}$ The other ritual that included this entrance was the ritual of inauguration or initial consecration of the sanctuary (cf. Exod 40:1-9; Lev 8:10-12; Num 7:1; Heb 9:21), which obviously preceeded the various rituals during the year that culminated on the Day of Atonement ritual. ${ }^{203}$

However, this does not mean that there are no points of contact between the Day of Atonement ritual and the inauguration of Christ's priesthood (and, accordingly, the inauguration of the new/better covenant and the eschatological salvific inauguration of the heavenly sanctuary). In fact, there are two points of contact that can be highlighted, one in terms of reality and the other in terms of parable. First, in terms of reality, while this study assumes that the typological OT Day of Atonement ritual points to the

room of the sanctuary as part of the inauguration rites (Exod 26:33; 40:1-9; Lev 8:10-12; and Num 7:1)";

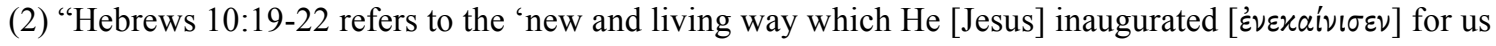
through the veil' (NASB). It is argued that the verb $\dot{\varepsilon} \gamma x a$ ivi $\zeta \omega$ is used here in a cultic sense just as in Heb 9:18 where it refers to the inauguration of the first covenant - which includes the inauguration of the Mosaic tabernacle (vv. 19-21). Therefore, the 'new and living way' denotes the heavenly sanctuary which is inaugurated by Christ"; (3) "Hebrews 9:12 refers to the sacrifices 'of goats and calves' ( $\tau \rho a ́ \gamma \omega \nu \nu$ xal $\left.\mu \sigma^{\prime} \alpha \omega \nu\right)$. The word for goats $(\tau \rho \alpha \dot{\gamma}(\omega \nu)$ does not appear in the sacrifices of the Day of Atonement in Lev 16 (LXX) but appears only in Num 7 where the inauguration rites of the sanctuary are described. There, the sacrifices of calves $(\mu \delta \sigma \chi \omega \nu)$ also appear. Thus Num 7-8 is the only place in the LXX where there is reference to the sacrifices of goats and calves ( $\tau \rho \alpha ́ \gamma \omega \nu$ xai $\mu o ́ \sigma \chi \omega \nu)$. Hebrews 9:19 mentions both kinds of animals for the sacrifice of the inauguration of the covenant"; (4) "Hebrews 9:24 describes Jesus' entrance into the heavenly sanctuary in the context of the inauguration of the new covenant and the tabernacle as described in 9:15-22. Richard M. Davidson concedes, however, that in this case the cleansing of the heavenly sanctuary remains ambiguous and refers to the inauguration of the sanctuary $(9: 15-22)$ as well as the Day of Atonement (9:25)." Ibid., 32-34. My view in this dissertation is aligned with Davidson's position. For a criticism of this position and Davidson's response to it, see Davidson, "Inauguration or Day of Atonement?," 69-88; Norman H. Young, "The Day of Dedication or the Day of Atonement?: The Old Testament Background to Hebrews 6:19-20 Revisited," AUSS 40, no. 1 (2002): 61-68. See also Roy Gane, "Re-Opening Katapetasma ('Veil') in Hebrews 6:19," AUSS 38, no. 1 (2000): 5-8.

\footnotetext{
${ }^{202}$ For further details about the Day of Atonement, see Gane, Cult and Character, 275-276.

${ }^{203}$ As Davidson claims, "Besides the Day of Atonement, the only other occasion in which the Most Holy Place was entered was by Moses in his (priestly) work of anointing/inaugurating the sanctuary before Aaron the high priest was anointed (Exod 40:1-9; Lev 8:10-12; Num 7:1)." Davidson, "Christ's Entry 'within the Veil' in Hebrews 6:19-20," 177.
} 
eschatological Day of Atonement, that is, the final judgment (see subsection Final

Purification below), this assumption does not imply that there will be sacrifices to be

offered in the final judgment as in the OT Day of Atonement ritual. Rather, the sacrificial

elements of the typological Day of Atonement were fulfilled in Christ's once for all

earthly sacrifice presented to the Father in heaven at the inauguration of the new/better

covenant in His ascension (cf. Heb 9:24-26). ${ }^{204}$ In fact, the sacrificial elements of all

rituals in the OT cultus (including the Day of Atonement) were fulfilled in the reality of

Christ's one sacrifice (cf. $7: 27 ; 10: 1,4,11-12) .{ }^{205}$

Second, in terms of parable, the Day of Atonement ritual is a parable (cf. 9:9) ${ }^{206}$

${ }^{204}$ In his study of the the unambiguous allusions to the Day of Atonement in Hebrews (9:6-7, 24$25 ; 10: 1-4)$, Johnsson highlights that "all ritual sacrifices — whether daily or yearly, public or privatepointed forward to the cross and met their sacrificial aspect in the death of Christ. However, other features of these could find their fulfillment only in connection with Christ's priestly ministry subsequent to Calvary." Following this perspective, he argues that "the Levitical Day of Atonement does have an initial fulfillment at the cross," as far as the sacrificial aspect is concerned. According to Johnsson, the unambiguous allusions to the Day of Atonement are used in Hebrews in the context of the discussion of the "efficacy of sacrifice." William G. Johnsson, "Day of Atonement Allusions," in Issues in the Book of Hebrews, ed. Frank B. Holbrook (Silver Spring, MD: Biblical Research Institute, 1989), 106, 115, 119. Therefore, the Day of Atonement is referred in Hebrews essentially in its sacrificial aspect.

${ }^{205}$ According to Hebrews, the sacrifices of the OT cultus, offered either daily $(7: 27 ; 10: 11)$ or yearly (10:1), were fulfilled (cf. 10:1) in Christ's one sacrifice. See also the first quotation indicated in the previous footnote.

${ }^{206}$ The Day of Atonement in 9:7 is part of a parable ( $\left.\pi \alpha \rho a \beta>\lambda \eta^{\prime}, 9: 9\right)$, in which the two apartments of the tabernacle (holy place and most holy place, cf. 9:1-5) and the correspondent daily (in the first apartment) and yearly (access to the second apartment, Day of Atonement) services represent two ages/covenants that correspond to two sanctuaries - the earthly/first tabernacle ( $\pi \rho \omega \dot{\tau} \tau \eta \varsigma \sigma \times \eta \nu \tilde{\eta} \varsigma$ - the heavenly sanctuary is referred in 9:11 as "the greater and more perfect tent [ $\sigma x \eta \nu \tilde{\eta} s]$ not made with hands." The use of $\sigma x \eta \nu \eta \tilde{s}$ in this verse seems to establish a contrast with the earthly/first tabernacle $[\pi \rho \omega \dot{\omega} \tau \eta s$ $\sigma x \eta \nu \tilde{\eta} s])$ and the heavenly sanctuary $\left(\tau \tilde{\omega} \nu \dot{\alpha} \gamma^{\prime}\left(\omega \nu\right.\right.$ - the other occurrences of $\tau \tilde{\omega} \nu \dot{\alpha} \gamma^{\prime}(\omega \nu$ in Hebrews [8:2; 10:19] refer to the heavenly sanctuary) (see 9:6-10). Therefore, the two types of time (daily and yearly services) and space (first and second apartments) in the cultus of the earthly sanctuary serve as a parable for the transition from the Aaronic priesthood to Christ's priesthood in terms of time (the age of the first covenant and the age of the new/better covenant) and space (the earthly sanctuary and the heavenly sanctuary). Considering that the second type of time (yearly) and space (second apartment) refers to the Day of Atonement and corresponds, in this parable, to the new covenant/heavenly sanctuary, one may ask what would be the parallel between the Day of Atonement and the new covenant/heavenly sanctuary in the parable. One possible answer would be that the heavenly sanctuary is the second apartment (the most holy place) and the work of Christ in that sanctuary corresponds only to the service of the Day of Atonement. 
of singularity in the new/better covenant, in contrast to the plurality in the first covenant exemplified by the daily service. ${ }^{207}$ On the Day of Atonement, only the high priest ( $\mu$ óvos

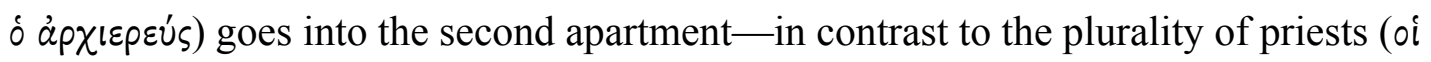

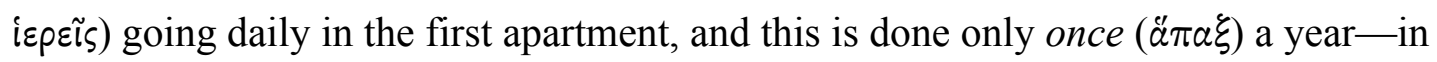

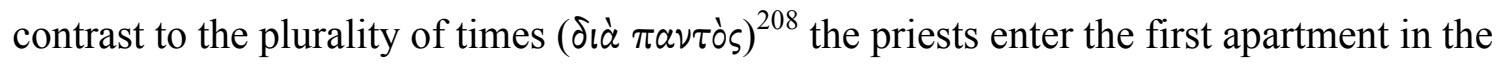

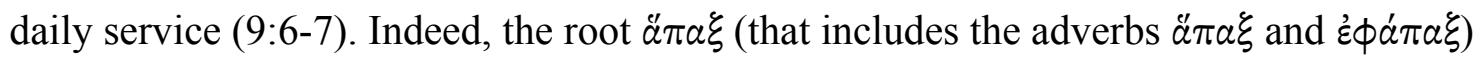
in Hebrews is used to describe the one sacrificial offering of Christ $(7: 27 ; 9: 26,28)$ and His one entrance into the heavenly sanctuary $(9: 12)$, in contrast to the plurality of sacrifices and entrances of the Aaronic priesthood in general. However, being part of the first covenant, even the OT Day of Atonement is characterized by plurality and repetition. In contrast to the work of Christ, the plurality/repetition of sacrifices and entrances into the sanctuary were performed every $(x \alpha \tau \alpha \dot{)})$ year $(9: 25 ; 10: 1,3)$.

In this parable, the Day of Atonement points to the fulfillment of the singularity of Christ as (high) priest and the singularity of His one offering in the inauguration of the

However, this answer is inadequate. First, from a broader perspective of the priesthood of Christ in Hebrews, His work in the heavenly sanctuary includes a continuous intercessory activity (see 7:25) that is similar, in terms of temporal continuity, to the daily activities performed in the first apartment of the earthly sanctuary. Second, from the standpoint of the spatial logic of the parable in 9:6-10, if the heavenly sanctuary is the second apartment (the most holy place), then, from the logic of transition emphasized in the parable, the earthly sanctuary would be the holy place. Nevertheless, it is obvious that the earthly sanctuary had two apartments and not only one. Hence, the logical point of the parable is that the transition from one apartment to the other in the earthly sanctuary represents the transition from one entire (earthly) sanctuary to another entire (heavenly) sanctuary.

207 The transition from plurality (first covenant) to singularity (new covenant) is discussed by Cortez as part of his argument that the Day of Atonement in Heb 9:6-10 functions as a metaphor of transition between the covenants. See Felix H. Cortez, "From the Holy to the Most Holy Place: The Period of Hebrews 9:6-10 and the Day of Atonement as a Metaphor of Transition," Journal of Biblical Literature 125 , no. 3 (2006): 543-544.

208 This expression means "always, continually, constantly." BDAG, 224. A literal translation of this expression in 9:6 reads, "at all times" (YLT). 
covenant at Christ's ascension. This inauguration provides the necessary framework for the daily mediation of the new/better covenant, which I will describe below.

\section{Daily mediation}

The second type of priestly activity described in The Actions of the Priest was Christ's ongoing salvific mediation. In terms of covenant, this could be compared to the

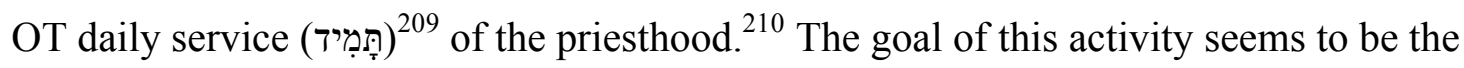
provision of divine forgiveness and the internalization of the divine laws in God's covenantal people (cf. 8:9, 12; 10:16-17), ${ }^{211}$ which are respectively related to Christ's mediatorial actions of intercession for forgiveness and empowerment of believers. Taking into account that Christ's once for all sacrifice is a distinctive feature of His priesthood (cf. 7:27; 10:11-12), His ongoing mediation is not accompanied by continuous sacrifices as in the daily service of the OT priesthood. Rather, His continuous mediation is based on the one sacrifice.

According to Hebrews, the goal of bringing people to a new covenantal relationship with God achieved at the beginning of Christ's heavenly priesthood does not

\footnotetext{
${ }^{209}$ In the typology of the first covenant, the connection between covenant and the priestly daily service is indicated in Hebrews: "The first covenant had regulations for worship ( $\lambda \alpha \tau \rho \varepsilon i a \varsigma)$ and an earthly place of holiness" (9:1). This worship in the earthly sanctuary of the first covenant is described in 9:6 in terms of daily service: "The priests go regularly into the first section, performing their ritual duties."

${ }^{210}$ See Exod 25:30; 27:20; 28:29-30, 38; 29:38, 42; 30:8; Lev 6:6, 13; 24:2-4, 8; Num 4:7, 16; $28: 3,6,15,23-24,31 ; 29: 6,11,16,19,22,25,28,31,34,38$.

${ }^{211}$ While the new covenant mentioned in 8:8-12 entails four promises (the internalization of the divine laws [8:10], a covenantal relationship between God and His people [8:10], universal knowledge of God [8:11], and divine forgiveness [8:12]), the reference to the new covenant in 10:16-17 mentions only the internalization of the divine laws (10:16) and divine forgiveness (10:17). In fact, these two promises seem to be the basis for the other promises in 8:10-12. The covenantal relationship between God and His people follows the internalization of the divine laws in $8: 10$. Likewise, divine forgiveness (8:12) is the cause of the universal knowledge of God (8:11), as indicated by the conjunction ö $\tau$ in 8:12.
} 
mean that His priesthood has achieved its ultimate goal. This notion is expressed in

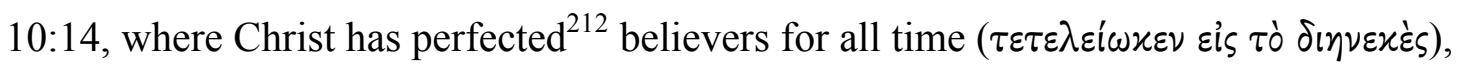

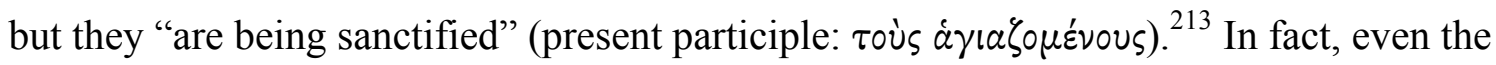
language of sanctification of believers is used in a complete and an incomplete sense in Hebrews. In a complete sense, this language is expressed in the perfect participle

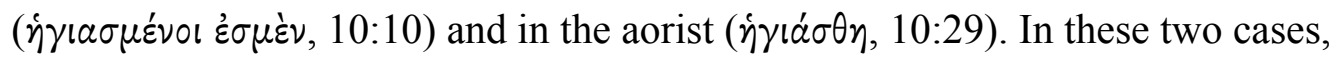
sanctification is related to Christ's sacrificial offering or blood, and seems to describe

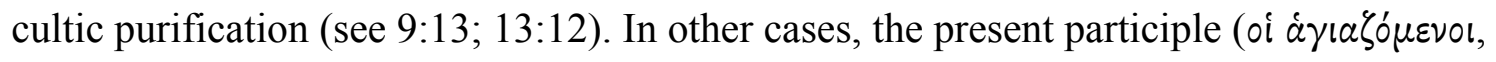
$2: 11$ ) is employed, such as in 10:14, and the incomplete sense of sanctification is clearly highlighted in the exhortation that believers should pursue holiness/sanctification ( $\dot{a} \gamma ı \alpha$ cós, 12:14). Likewise, the language of incompleteness appears in the idea that believers are "receiving (present participle: $\pi \alpha \rho a \lambda \alpha \mu \beta a ́ \nu \circ \nu \tau \varepsilon \varsigma)$ a kingdom" (12:28), in the

\footnotetext{
${ }^{212}$ Several passages imply that Christ's priesthood brings perfection (expressed by the noun $\tau \varepsilon \lambda \varepsilon^{\prime} \omega \sigma \iota \varsigma$ and the verb $\left.\tau \varepsilon \lambda \varepsilon \iota^{\prime} \omega\right)$ to human beings (see 7:11, 19;9:9;10:1,14) is closely related to a new and better covenant $(7: 22 ; 8: 6 ; 9: 15 ; 12: 24)$. The affirmation that Christ has perfected believers $\left(\tau \varepsilon \lambda \varepsilon \iota^{\circ} \omega, 10: 14\right.$; implied in $7: 11 ; 9: 9)$ involves the perfecting $(9: 9)$ or the purification of their conscience $(10: 1-2,22 ; 9: 14)$. The verb $\tau \varepsilon \lambda \varepsilon i o ́ \omega$ (to make perfect) comes from the root $\tau \varepsilon \lambda$ os suggests the idea of bringing to a teleological fulfillment. Just as Christ was made perfect in the sense of going through an experience that enabled Him to achieve the goal of being a merciful high priest, believers are made perfect by Christ's priesthood in the sense that His work enabled them to achieve the goal of being in a new covenantal relationship with God. Indeed, 7:19 seems to conceive the perfection of believers in terms of their drawing near to God through hope (see also 6:19), and in 9:14 the purification of the conscience from sins has the purpose of enabling them to serve God. This language of service ( $\lambda \alpha \tau \rho \varepsilon \dot{\omega} \omega)$ is also used in 12:28, where the author urges the audience to offer to God a grateful service. This service seems to be described in 13:1-17. See Cockerill, The Epistle to the Hebrews, 676. See also Koester, Hebrews, 554-556; Lane, Hebrews 9-13, 497-498.

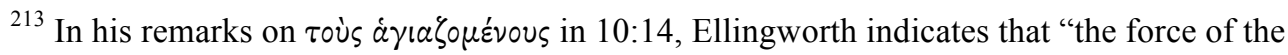
present participle, in apparent contrast with the perfect $\dot{\eta} \gamma\llcorner\alpha \sigma \mu \varepsilon \dot{v} 0$ o in v. 10 , is disputed . . . : is it timeless (so Riggenbach, Bruce), iterative ("those who from time to time receive sanctification"; unlikely in this context), or durative ("those who are in the process of sanctification"; so Michel)? The most likely explanations, not mutually exclusive, are (1) that the author felt that yet another perfect here would be redundant; and (2) that the present was used to balance the previous words and avoid the possible implication that Christians had already reached their goal." Ellingworth, The Epistle to the Hebrews, 511. In my discussion about 10:14, my point is precisely that the ultimate goal has not been yet achieved.
} 


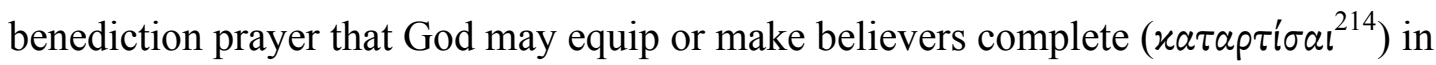
everything good to do His will, working in them through Jesus Christ (13:21), and in the statement that Christ will appear a second time for salvation (9:28).

Furthermore, the reality of sin was not completely eliminated, even among believers. The persistent reality of sin can be observed in three levels of information in Hebrews. First, believers depend on a merciful priestly expiation of their sins, as they constantly experience temptation $(2: 17-18)$ followed by $\sin (4: 15) .{ }^{215}$ Fortunately, Christ the high priest sympathizes (4:15) and intercedes constantly for them (7:25). Second, there are pastoral admonitions exhorting believers to resist or fight against $\sin (12: 4)$. They should lay aside $\sin (12: 1)$ and avoid the danger of becoming defiled $\left(\mu\left\llcorner\alpha \nu \theta \tilde{\omega} \sigma\left\llcorner\nu,{ }^{216}\right.\right.\right.$ 12:15). This reference to defilement provides the transition to a third level, characterized by strong warnings against defiant sins, which describe a rejection of the person and work that made the new covenant possible. ${ }^{217}$ Considering the persistent reality of sin,

\footnotetext{
${ }^{214}$ This verb, which is in the optative aorist form here, means to "put into proper condition," "adjust, complete, make complete." BDAG, 526. While the rendition equip is selected by ESV, NASB,

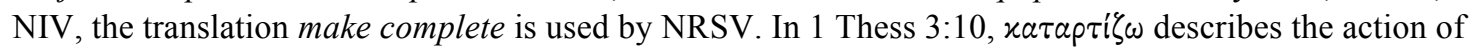
supplying. See also 1 Pet 5:10.

${ }^{215}$ This situation of temptation and sin describes the weaknesses of human beings (4:15).

${ }^{216}$ While the verb $\mu$ เiv $\nu \omega$ refers to sexual immorality in this passage (see 12:16) it has cultic overtones in the LXX. In fact, the majority of the LXX occurrences of this verb are found in Leviticus (32 times).

${ }^{217}$ In these warnings, believers should not neglect salvation $(2: 3)$ nor "be hardened by the deceitfulness of sin" ( $3: 13$; see also $3: 8,12,15 ; 4: 3)$, which is expressed in terms of rebellious disobedience (4:6-7). In fact, the apostasy of defiant sins is portrayed as intentionally causing a new crucifixion of Christ (6:4-6). The continuous practice of defiant deliberate sin leads to the breaking of their covenantal relationship with God, as "there no longer remains a sacrifice for sins" (10:26). This continuous practice is vividly portrayed as the trampling underfoot of Christ and the profanation of the blood of the covenant that had previously sanctified or purified the one who is now breaking the new covenant (see 10:29). The point of all these warnings against defiant sins is that they will lead to the condemnation of the divine judgment (see $2: 2-3 ; 4: 5-6,13 ; 6: 8 ; 10: 27-31$ ).
} 
believers in the new covenant still have their weaknesses, they still need to fight against sin, and they still run the risk of willfully breaking the covenant with defiant sins. The implication of this reality is that as high priest Christ not only brings people to a new covenantal relationship with God by means of the intercession of divine forgiveness, but also empowers them to remain and grow in this covenant. This would be the systematic meaning of the affirmation that $\mathrm{He}$ is the mediator of a better/new covenant $(8: 6 ; 9: 15$; $12: 24)$.

The ultimate effect of the daily mediation takes place with the final purification that fully establishes the new/better covenant. This last phase is spelled out below.

Final purification

The third type of priestly activity described in The Actions of the Priest was the eschatological judgment and salvation. In terms of covenant, the goal of this activity seems to be the final consummation of the new/better covenant, which typologically corresponds to the OT Day of Atonement. As indicated above on the discussion of Inauguration, while many scholars relate the Day of Atonement ritual with the ascension of Christ, I relate it with the eschatological judgment. To be sure, as highlighted in that discussion as well, the sacrificial aspect of this ritual was fulfilled with the Christ's earthly sacrifice and His ascension, and the Day of Atonement is a parable about the singularity seen in Christ's priesthood (one high priest, one entrance). However, the goal or logic of the Day of Atonement ritual as a whole, as a general judgment where God's covenantal people is finally and corporately purified, delineates the typological background for the eschatological judgment that brings about the consummation of the 
new/better covenant. ${ }^{218}$

Like the Christological daily mediation, the eschatological Day of Atonement does not involve the offering of sacrifices, given the uniqueness of Christ's sacrifice. Just as His daily mediation is based on His past sacrifice, the final purification is also based on the same past sacrifice. Furthermore, the final eschatological purification does not take away the purification or forgiveness of sins performed by Christ in His ascension (cf. 1:3; 9:15) or the expiation or forgiveness of sins performed by Him in His daily mediation (cf. $2: 17)^{219}$ but rather assumes them. Thus, in light of the typological OT sequence of daily service and Day of Atonement, the ultimate validity of the purification in Christ's ascension and of His ongoing expiation of sins has in view the final purification, when the sin problem will be completely eradicated.

In fact, both the purification of the inauguration and of an eschatological Day of Atonement can be potentially informed by the reference to the purification of the heavenly things or the heavenly sanctuary in 9:23. ${ }^{220}$ The former conveys the idea of

\footnotetext{
${ }^{218}$ In my view, the identification of the logic of the Day of Atonement with the ascension of Christ is problematic in the sense that the ascension of Christ does not fully eliminate the reality of the sin problem. I am assuming here that, from the vantage point of Hebrews, the repetition of the Day of Atonement every year is not part of the logic of the Day of Atonement. Rather, the repetition shows the weakness of a ritual that contains only a shadow of the reality of Christ's priesthood, namely, the incapacity to remove sins. When compared with the reality of Christ, who has the power to take away sins, the logic of the Day of Atonement is of a final elimination of sin.

${ }^{219}$ I explore these concepts above in The Actions of the Priest (see The Heavenly Offering of His Earthly Sacrifice and Ongoing Salvific Mediation, Intercession for Forgiveness).

${ }^{220}$ The elaboration of this statement in this paragraph is consistent with Doukhan's interpretation of Dan 8:14 and 9:24-27. Whereas the prophecy of 70 weeks in Dan 9:24-27 "foretells the coming of a Messiah by reference to the first ordination of the High Priest and his role in the continual offering," "the prophecy of 2300 evenings and mornings" in Dan 8:14 "foretells the coming of Kippur by reference to the princely figure of the High Priest in the service on the Day of Atonement. The two events are set up in connection with each other, and are placed in the same perspective, pointing in the same direction- to salvation." To support this view of Dan 9:24-27, Doukhan argues that "Daniel 9:24 and Ex. 29:36, 37 are the only biblical passages using the association of three specific motifs, namely atonement, anointing, and
} 
initial consecration of the sanctuary, whereas the latter is related to a complete

purification of the sins of the people accumulated in the sanctuary (a corporate

judgment). ${ }^{221}$ If the latter is implied, the purification of the heavenly sanctuary in 9:23

refers to the final judgment that leads to the consummation of the new/better covenant.

Grammatically speaking, the infinitive form of the verb $x a \theta a p i \zeta \omega$ does not provide an

answer for the time (e.g., past, present, future) of purification. What is affirmed is the

necessity of the heavenly things to be purified. ${ }^{222}$ Textually speaking, the statement in v.

23 is immediately surrounded by the discussion of the inauguration of the covenant (vv.

Most Holy." "In context, Ex. 29:36, 37 deals with the ordination of the first High Priest in Israel and refers to the institution of the 'continual burnt offering,' a token of God's presence among His people" (cf. Exod 29:42-44). Hence, "by echoing the text of Exodus 29, the prophecy of Daniel 9 directly connects the event of the atoning death of the Messiah with the ordination of the High Priest and the institution of the sign of permanence presence of God among His people, namely the continual burning offering." With regard to the view of Dan 8:14, Doukhan stipulates that "the prophecy of 2300 evenings and mornings implies the involvement of the High Priest as it relates to the Day of Atonement." The following arguments are offered to support this interpretation: (1) the LXX "has preserved a translation of Daniel 8:14 which points to the

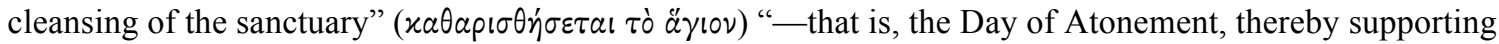
an old tradition of interpretation which was later adopted by Rashi"; (2) "the parallelism between the sequence of the events reported by Daniel 7 and that of Daniel 8 makes the judgment and the Day of Atonement coincide. This correspondence is also confirmed outside Daniel, by the liturgical and rabbinical Jewish tradition which relates the Day of Atonement to the Day of Judgment"; (3) "the unexpected use of the association of ram-goat in Daniel 8 alludes to the Levitical ritual of Kippur"; (4) "the designation of" שֵ "(prince) as the main personage involved there" (cf. Dan 8:11) "and His clothes of linen hint at the High Priest at work on the Day of Atonement." The term שׁ "points to the High Priest in many texts of the Old Testament (1 Chron. 15:22; 24:5; Ezra 8:24). Within the book of Daniel," this term "refers to Michael $(10: 5,13,21 ; 12: 1)$, whose garments are reminiscent of the Day of Atonement, the only day the priest was thus dressed (Lev. 16:4)"_- "cf. Sir 45:24 where the word prostates: prince designates the High Priest; cf. F1. Josephus, Ant. XII, r, 2; cf. 1 Macc. 13:42.” Jacques Doukhan, Daniel: The Vision of the End (Berrien Springs, MI: Andrews University Press, 1987), 37-38, 128n73.

${ }^{221}$ Gane emphasizes the idea that the Day of Atonement is as a corporate judgment in Israel. In his words, "Fates of Israelites are affected or even decided throughout the year according to the ways in which they relate to Yhwh. But separation between truly loyal and disloyal people is completed on the Day of Atonement. By the end of this day there are only two classes of Israelites: (1) a remnant who are morally 'pure,' that is, having no impediments to their relationship with Yhwh (Lev 16:30), and (2) those who have no future with Yhwh and his people (23:29-30). So we find that, within the Israelite cultic year, the Day of Atonement completes the determination of destinies on the national level and in this sense can be regarded as Israel's judgment day." Gane, Cult and Character, 306.

${ }^{222}$ Davidson, “Christ's entry 'within the veil' in Hebrews 6:19-20,” 186. 
18-21) and the ascension of Christ (v. 24). But it also has in view the Day of Atonement $(9: 25)$ and the eschatological judgment and salvation (vv. 27-28) that point to the consummation of the covenant. ${ }^{223}$

While the eschatological judgment is against those who decided to drift away from their covenantal relationship with Him (defiant sinners who broke the new/better covenant, cf. 10:26-31; 12:25-27), Christ will appear a second time for the salvation of those who are faithfully living in this covenantal relationship. This salvation seems to be connected with the teleological notions of bringing sons to glory $(2: 10)$, entering into divine rest (4:11), and the final inheritance of promises $(6: 12$; see also $9: 15 ; 10: 36 ; 11: 13$; 39). To use a covenantal language in its fullest sense, the God of Abraham will be the God of the saved, and they will be His people $(8: 10)$. They shall all know Him $(8: 11){ }^{224}$ Overall, this section indicated that the goal of Christ's priesthood is not limited to removing sins from human beings, but is more fully understood as establishing the reality of a covenantal relationship between God and human beings.

\footnotetext{
${ }^{223}$ In both cases, the sacrificial blood of Christ is the basis of purification (9:23), either for the initiation of the new covenantal relationship with God or the judgment that will fully consummate this relationship. More importantly, these two possible explanations are related to the initial and final goal of Christ's priesthood, the inauguration and consummation of the new covenantal relationship of believers with God. It is possible, therefore, that the language of purification of the heavenly sanctuary refers both to the inauguration of the covenant and the eschatological judgment that leads to the consummation of the covenant. According to Davidson, "while Heb 9:23 harks back to the inauguration, and the implications of this are drawn in v. 24, at the same time the nontemporal statement of v. 23 ('necessity ... to be cleansed') appears to be intentionally ambiguous, and the same language could also have reference to the Day of Atonement. Such a double meaning seems likely, inasmuch as the author, building upon this verse, shifts to unmistakable language of the Day of Atonement in vv. 25-28." Ibid., 187.

${ }^{224}$ Among the occurrences of the language of knowing (expressed by the verb ידעי) God in Jeremiah, from where Hebrews quotes the promise of a new covenant, two types of passages are identified. Negatively, unfaithful people are referred and accused by God as not knowing Him (2:8; 4:22; 9:2 MT [9:3 ESV], 5 MT [9:3 ESV]; 10:25). Conversely, from a positive perspective, to know God is to turn to Him wholeheartedly (24:7; see also 9:23 MT [9:24 ESV]; 22:16).
} 


\section{Summary}

In summary, the goal of Christ's priesthood is explained by the framework of the better/new covenant. The teleological nature of this covenant is revealed especially by the first covenant, which was a theoretical anticipation of the coming realities of Christ's sacrifice and His priesthood in the heavenly sanctuary. In fact, the reality of Christ's priesthood mediates or fulfills the covenant between God and human beings in three stages: (1) inauguration, (2) daily mediation, and (3) final purification.

First, the inauguration of the new/better covenant took place at the ascension of Christ and the official initiation of His priesthood in the heavenly sanctuary on the basis of His one sacrifice. This inauguration established the necessary framework for the daily mediation of the new/better covenant.

Second, the daily mediation aims at providing divine forgiveness and the spiritual internalization of the divine laws in God's covenantal people, on the basis of Christ's one sacrifice. In this phase, Christ constantly brings people to a new covenantal relationship with God by means of the intercession of divine forgiveness and also empowers them to remain and grow in this covenant. The ultimate effect of the daily mediation takes place with the final purification that fully establishes forever the new/better covenant.

Third, the final purification performed in the context of eschatological judgment and salvation represents the consummation of the new/better covenant, also based on Christ's one sacrifice. While the eschatological judgment is against those who decided to defiantly drift away from their covenantal relationship with Him (defiant sinners who continue to break the new/better covenant and refuse to repent, cf. $6: 4-6 ; 10: 26-31$; $12: 25-27)$, Christ will appear a second time for the salvation of those who are in this covenantal relationship. 
Having provided this description and elaboration of the priesthood (need, agent, actions, goal) of Christ in Hebrews, I move now to a second step, namely, the study of macro-hermeneutical principles of reality that ontologically support and inform the description and elaboration of the historical model of Christ's priesthood that has been delineated so far. As I mentioned before, this second step refers to the priesthood of Christ, which particularly refers to the ontological and cosmological notions expressed or implied in Hebrews about His divinity and humanity.

\section{The Priesthood of Christ: Hermeneutical Principles of Reality}

Arguably, an important contribution of the historical model is the interpretation of the macro-hermeneutical principles of reality on the basis of Hebrews. Given the influential role of the discussion regarding the intellectual background of the epistle for the study of ontology in Hebrews, I acknowledge that scholars who subscribe to Middle Platonism as the (or a) background of Hebrews find ontological support for a nonsequential view of Christ's priesthood, as they interpret God and heaven in Hebrews as timeless/spaceless realities. While I am aware of the debate about the intellectual background of Hebrews, I will not enter into this discussion for two reasons. First, this would make this study too lengthy, and there is already considerable scholarly discussion on this regard. ${ }^{225}$ This discussion shows that there are arguments for not adopting Middle

\footnotetext{
${ }^{225}$ For a helpful description of the main theories and issues involved in these debates, see Hurst, The Epistle to the Hebrews. Overall, there are four major proposals of the conceptual background of Hebrews: (1) Gnosticism, (2) Middle Platonism (e.g., Philo), (3) Palestianian Judaism (e.g., Qumran and other apocalyptic groups), (4) Graeco-Roman culture. Currenly, while the first proposal (Gnosticism) has been largely abandoned, the fourth one (Graeco-Roman culture) is a more recent project. This means that the focus of the debate is on Middle Platonism and Palestinian Judaism. Eric F. Mason and Kevin B. McCruden, eds., Reading the Epistle to the Hebrews: A Resource for Students (Atlanta: Society of Biblical
} 
Platonism as the conceptual background for Hebrews, even though its language may be considered similar. ${ }^{226}$ Second, the methodological procedure employed in this section moves from the text of Hebrews to ontology, instead of assuming an ontology first (from a specific intellectual background) and then moving to the reading of the text. This

Literature, 2011), 4. Representatives of these four proposals include, Gnosticism: Käsemann, The Wandering People of God; Middle Platonism: James W. Thompson, "What Has Middle Platonism to Do with Hebrews," in Reading the Epistle to the Hebrews: A Resource for Students, ed. Eric F. Mason and Kevin B. McCruden (Atlanta: Society of Biblical Literature, 2011), 31-52; Palestinian Judaism: Eric F. Mason, "Cosmology, Messianism, and Melchizedek: Apocalyptic Jewish Traditions and Hebrews," in Reading the Epistle to the Hebrews: A Resource for Students, ed. Eric F. Mason and Kevin B. McCruden (Atlanta: Society of Biblical Literature, 2011), 53-76; Graeco-Roman culture: Patrick Gray, "Hebrews among Greek and Romans," in Reading the Epistle to the Hebrews: A Resource for Students, ed. Eric F. Mason and Kevin B. McCruden (Atlanta: Society of Biblical Literature, 2011), 13-30.

226 The view that the conceptual background of Hebrews derives from Philo (Middle Platonism) reached its climax with Spicq in 1952. Subsequent scholarship (especially Williamson) challenged this view. Barrett was very influential in affirming eschatology, and not Platonic ontology, as the intellectual framework of Hebrews, even though he ackwnoledges that its language is similar to Middle Platonism. Geoffrey E. Sterling, "Ontology Versus Eschatology: Tensions between Author and Community in Hebrews," The Studia Philonica Annual 13 (2001): 191-192. See Spicq, L'Épitre aux Hébreux; Ronald Williamson, Philo and the Epistle to the Hebrews (Leiden: Brill, 1970); Charles K. Barrett, "The Eschatology of the Epistle to the Hebrews," in The Background of the New Testament and Its Eschatology: C. H. Dodd Festschrift, ed. W. D. Davies and D. Daube (Cambridge: Cambridge University Press, 1956), 363-393. After that period, there are still scholars who affirm the priority of Middle Platonism. Influential works of this view are Lala K. K. Dey, The Intermediary World and Patterns of Perfection in Philo and Hebrews (Cambridge, MA: Society of Biblical Literature, 1975); Thompson, The Beginnings of Christian Philosophy. Others have reassessed the relatationship of Hebrews with Jewish eschatology and Platonic ontology. Schenck and Sterling affirm that both Hebrews and Philo draw from a common Platonizing tradition, instead of stipulating some type of dependence of Hebrews on Philo. Kenneth L. Schenck, "Philo and the Epistle to the Hebrews: Ronald Williamson's Study after Thirdy Years," in The Studia Philonica Annual: Studies in Hellenistic Judaism, ed. D. T. Runia and G. E. Stirling (Atlanta: Scholars, 2002), 134135; Sterling, "Ontology versus Eschatology," 210-211. Another aspect of this reassessement is the suggestion of combinations of Middle Platonism and apocalyptic eschatology in Hebrews: (1) its temporal aspect is eschatological while the spatial/cosmological aspect is Platonic (Schenck), (2) the author has a Platonic perspective while the audience holds an eschatological view (MacRae), or (3) the author holds an eschatological position whereas the audience has a Platonic standpoint (Sterling). See Schenck, Cosmology and Eschatology in Hebrews, 23; Sterling, "Ontology versus Eschatology," 210; G. W. MacRae, "Heavenly Temple and Eschatology in the Letter to the Hebrews," Semeia 12 (1978): 196. Finally, there are those who agree with Barrett (and Williamson) that Hebrews is similar to Middle Platonism only at the level of language, but not in terms of thinking. See Barrett, "The Eschatology of the Epistle to the Hebrews," 393; Williamson, Philo and the Epistle to the Hebrews, 557; Cockerill, The Epistle to the Hebrews, 31; Peterson, Hebrews and Perfection, 131; Adams, "The Cosmology of Hebrews," 138; S. Nomoto, "Herkunft Und Struktur Der Hohenpriestervorstellung Im Hebräerbrief," Novum Testamentum 10 (1968): 18-19. I agree with authors who do not see a similarity of thinking between Hebrews and Neo Platonism. Given the engagement of Hebrews with OT texts, I concur with scholars whoc view the OT as the intellectual background of Hebrews. See King L. She, The Use of Exodus in Hebrews (New York: Peter Lang, 2011), 83; Adams, "The Cosmology of Hebrews," 138; Laansma, "The Cosmology of Hebrews," 142. 
hermeneutical methodology is similar to Vanhoozer's "theodramatic metaphysics," which "begins with the speech and acts of God, inquiring what God must be to have said and done that." ${ }^{227}$ In other words, the study seeks to uncover the ontology implicit in statements about what God says and does, and the same principle applies to the study of an implicit ontology of humanity and cosmology in Hebrews. With regard to cosmology in Hebrews, for instance, Ellingworth has this same methodological attitude. Instead of exploring "the influences which may have contributed to the cosmology of Hebrews," he focuses on the examination of "the relevant texts themselves, in order to discover how they relate to one another. ${ }^{, 228}$ As I will show in the subsections below, by using this methodology, I find a dynamic interpretation of the macro-hermeneutical principles of reality in Hebrews that support a sequential (temporal) view of Christ's priesthood.

\section{Divinity: Christ and the Concept of Divine Nature}

In this discussion of Divinity as the first hermeneutical principle of reality of the present section, I will deal with the reality of God. First, I will focus on divine reality in general in Hebrews and then on the reality of Christ's divinity in the epistle.

\section{The Reality of God}

References to God are found throughout Hebrews. ${ }^{229} \mathrm{He}$ is initially portrayed as

\footnotetext{
${ }^{227}$ Kevin Vanhoozer, Remythologizing Theology: Divine Action, Passion, and Authorship (Cambridge: Cambridge University Press, 2010), 79.

${ }^{228}$ Paul Ellingworth, "Jesus and the Universe in Hebrews," Evangelical Quarterly 58, no. 4 (1986): 338. This approach affirms the priority of moving "from text to background" and not "from background to text," which may imply an imposition of a possible background on the text. Schenck, Cosmology and Eschatology in Hebrews, 3.

229 The noun $\theta$ còs occurs 68 times in Hebrews. For a study on God in Hebrews, see Harold W. Attridge, "God in Hebrews," in The Epistle to the Hebrews and Christian Theology, ed. Richard
} 
speaking to human beings, in the past and more recently, ${ }^{230}$ through intermediaries

(prophets, the Son, 1:1-2). ${ }^{231}$ I will use this idea of God speaking to start a reflection

about divine reality in Hebrews. Then, I will draw inferences about divine reality from

the ideas of divine rest and God's reactions to human actions.

\section{God speaks}

Through the instrumentality of the prophets, God spoke literally "in various parts" $" 232$ and "in many ways" (1:1). ${ }^{233}$ The content of what He says are OT quotations $(1: 5-13 ; 3: 7,15 ; 4: 3,5,7 ; 5: 5-6 ; 7: 20 ; 8: 8 ; 10: 15-16) .{ }^{234}$ In some instances, God speaks to the Son $(1: 5,8-13 ; 5: 5-6 ; 7: 17,21)$. In others, He speaks to the audience of the epistle

Bauckham, Daniel R. Driver, Trevor A. Hart, and Nathan MacDonald (Grand Rapids, MI: Eerdmans, 2009), 95-110.

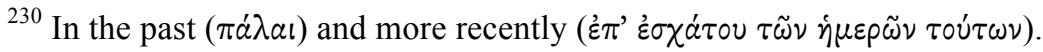

231 According to Cockerill, "God 'speaks' to his people . . . both by the words that he spoke to his people of old (Heb 3:7-4:11; 10:36-39) and by his conversations with his Son concering the Son's incarnation and exaltation (1:1-14; 2:11-13; 7:1-28; 10:5-10)." Cockerill, The Epistle to the Hebrews, 45.

${ }^{232}$ This is the literal translation of $\pi \circ \lambda u \mu \varepsilon p \tilde{\omega} \varsigma$. BDAG, 847.

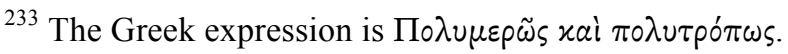

${ }^{234}$ While in $1: 1-2 ; 5: 5-6$ the verb $\lambda \alpha \lambda \varepsilon^{\prime} \omega$ is used, the verb $\lambda \varepsilon^{\prime} \gamma \omega$ is employed in $1: 5-7,13 ; 3: 7,15$; 4:3, 5, 7; 7:20; 8:8; 10:15-16. There is an overlap between God and the Holy Spirit speaking (cf. 3:7, 11 with $4: 4-5$, and $8: 8$ with $10: 15-16$ ). Christ speaks in $2: 12-13 ; 10: 5-7$, and believers are invited to speak in 13:6. In all cases, they speak through OT quotations. As Cortez indicates, "there is something unique to Hebrews' use of Scripture: the oral nature of the word of God and its immediacy." Cortez, "The Anchor of the Soul That Enters Within the Veil'," 435. His emphasis agrees with Pamela Eisenbaum's point that almost all Hebrews' quotations from the OT are "quotations of direct speech." Pamela Michelle Eisenbaum, The Jewish Heroes of Christian History: Hebrews 11 in Literary Context (Atlanta, GA: Scholars Press, 1997), 92. Therefore, it could be said that, in Hebrews, the word of God is not written ("the author of Hebrews does not use the common formula 'as it is written'”), but spoken. Cortez, "The Anchor of the Soul That Enters Within the Veil'," 438. See also, Kenneth L. Schenck, "God Has Spoken: Hebrews' Theology of the Scriptures," in The Epistle to the Hebrews and Christian Theology, ed. Richard Bauckham, Daniel R. Driver, Trevor A. Hart, and Nathan MacDonald (Grand Rapids, MI: Eerdmans, 2009), 321-336; Luke Timothy Johnson, “The Scriptural World of Hebrews,” Interpretation 57, no. 3 (2003): 240. 
$(3: 7,15 ; 4: 7) .{ }^{235}$ Indeed, the divine voice speaking today $(3: 7,15 ; 4: 7)$ denotes a temporal immediacy ${ }^{236}$ of what God says to the audience. ${ }^{237}$ This immediacy entails that believers should not refuse the warning of the divine voice that speaks from heaven, since that is the same voice that spoke powerfully at Mount Sinai in the past (12:19; cf. vv. 25-26). ${ }^{238}$ The reference to God speaking at Mount Sinai ${ }^{239}$ is helpful for understanding the reality of God, as this reference implies that the divine ability to speak in various parts and ways (1:1) and the temporal immediacy of a message recorded in the past should not be limited to the work of intermediary secondary causes, in this case, human prophets and the biblical text. ${ }^{240}$ Without disregarding the intermediary role of prophets and sacred

\footnotetext{
${ }^{235}$ For a description of "God's dialogue with the Son and His siblings" in Hebrews, see Attridge, "God in Hebrews," 103-108.

${ }^{236}$ Cockerill speaks of "the immediacy of God's word." Cockerill, The Epistle to the Hebrews, 44.

${ }^{237}$ According to this view, the word $\sigma \eta^{\prime} \mu \varepsilon \rho o v$ in Ps 2:7, which is a passage quoted by the author of
} Hebrews $(1: 5 ; 5: 5)$ and qualified as something that God spoke to the Son, could denote a sense of temporal immediacy between the audience of Hebrews and God addressing the Son. See Johnson's emphasis on the use of the word today as indicative of the immediacy of God's word in Johnson, "The Scriptural World of Hebrews," 241.

${ }^{238}$ Regarding the connection between $12: 19$ and 25-26, Koester emphasizes that in 12:26 God is identified as the voice of 12:19. Koester, Hebrews, 543. See also Attridge, The Epistle to the Hebrews, 379. Cockerill suggests a Christological interpretation of the one speaking in 12:25, in the sense that God "speaks in the present from heaven through the exalted Son." Cockerill, The Epistle to the Hebrews, 663. On the other hand, Ellingworth seems to avoid a Christological interpretation of this passage. He writes, "The strongest argument in favour of identifying Christ, not God, as 'the one who speaks,' is the mention of Christ, or more precisely his blood, as 'speaking' in v. 24. However, the author makes a similar unspecified change of subject in 8:5; and the theme changes here between the atonement, in v. 25, and the eschatological cataclysm, from v. 26. Since God is explicitly mentioned in vv. 28f., it is therefore on balance best to consider him as referred to implicitly, as often in Hebrews, from v. 25 onwards." Ellingworth, The Epistle to the Hebrews, 684.

${ }^{239}$ See especially Exod 19-20; Deut 4-5.

${ }^{240}$ The relationship betwee prophets and Scripture is highlighted by Johnson in the following way: "By constantly citing the LXX and by introducing such citations with verbs of speaking, Hebrews in effect treats texts as words from 'the prophets' through whom God spoke in the past. And because many of the verbs of introduction are in the present tense, the reader learns that God's speech through these prophetic words is not only past but also present." Johnson, "The Scriptural World of Hebrews," 240. 
texts, the multiplicity and immediacy of the divine speech should be attributed to the

reality of God Himself. To put it more sharply, the use of intermediaries is not

philosophically justified on the basis of an ontological or metaphysical gap between God

and human beings in terms of space-time, which would require the intermediary role of

spatio-temporal intermediaries (prophets, texts) to codify or transcribe an original divine

non-discursive (non-sequential, timeless/spaceless) divine message into the spatio-

temporal pattern of discursive speech. Rather, at Mount Sinai, the idea of distance

between God and human beings was related to the consuming glory of His presence, and

did not imply a divine inability to speak words discursively (spatio-temporal

sequence). ${ }^{241}$ God's speech, then, necessarily assumes a temporal interpretation of God's

\footnotetext{
${ }^{241}$ According to Exod 19-20 and Deut 4-5, it was not only Moses who could hear and understand God's voice, but the people of Israel as well. These passages highlight the mediation of Moses regarding the words spoken by God in the context of the people's fear of His glorious presence. In Exod 19:9 (italics mine), "the Lord said to Moses, 'Behold, I am coming to you in a thick cloud, that the people may hear

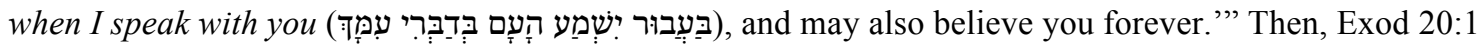
(italics mine) introduces the description of the 10 commandments in the following way, "And God spoke

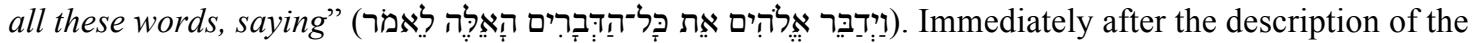
commandments spoken by God, vv. 18-19 reveal that "when all the people saw the thunder and the flashes of lightning and the sound of the trumpet and the mountain smoking, the people were afraid and trembled, and they stood far off and said to Moses, 'You speak to us, and we will listen; but do not let God speak to us, lest we die"” (see also Deut 5:5). In Deut 4:12, Moses reminds the people about that event: "the Lord

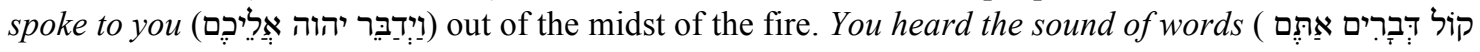

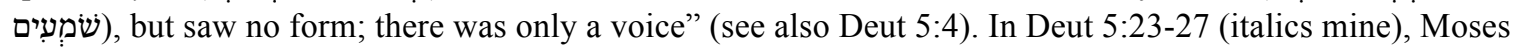

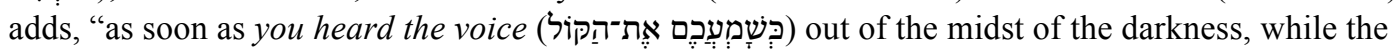
mountain was burning with fire, you came near to me, all the heads of your tribes, and your elders. And you said, 'Behold, the Lord our God has shown us his glory and greatness, and we have heard his voice

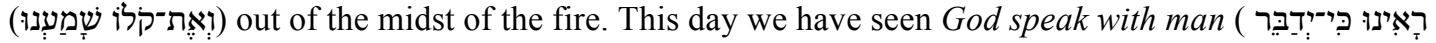

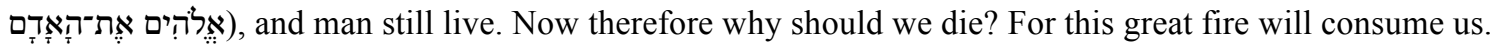

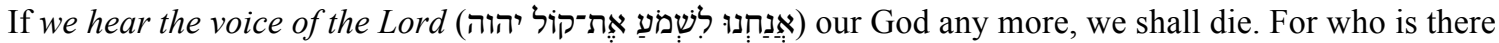
of all flesh, that has heard the voice of the living God speaking out of the midst of fire as we have, and has still lived? Go near and hear all that the Lord our God will say, and speak to us all that the Lord our God will speak to you, and we will hear and do it."' In his notes on Exod 19:9a, Jeffrey H. Tigay comments, "the people personally overhear God and Moses conversing." However, they "decline to hear Him directly following the Decalogue (20:16)." The Jewish Study Bible, 2nd ed., Jewish Publication Society (New York: Oxford University Press, 2014), 137. In his remarks on Deut 5:19-30, Bernard M. Levinson argues that "while the Decalogue was given directly to the people (v. 4; 4.10-13), the rest of the laws were mediated by Moses, at their plea (vv. 22-24, 4.14)." Ibid., 359. For the purposes of the present dissertation, my point is that as Exod 19-20 and Deut 4-5 highlight the fear of the people because of the consuming glory of God's
} 
reality (being). God exists and acts in space and time.

God reacts to human actions

Another significant idea about the divine reality that can be derived from God speaking is that He reacts to human actions (see 3:9-11; 4:3, 7). Heb 3:7-11 describes a situation according to the following sequence: (1) God speaks/His voice is heard (v. 7), (2) human beings rebelliously harden to His voice (v. 8, see v. 16), ${ }^{242}$ (3) God is provoked $^{243}$ by that (v. 10), and (4) He pronounces a judgment against them (v. 11). It is significant that point 2 is temporally qualified: He was "provoked for forty years" (v. 17). Thus, point 4 does not represent a capricious divine reaction to one event characterized by human rebellion, but it is God's final response to a continual practice of putting Him to test. Ontologically speaking, God not only reacts to human actions but He can be also the recipient or object of human action (be provoked) for a certain extension of time.

The idea of God being the recipient of actions is also implied in sacrifices offered to Him: ${ }^{244}$ Christ "offered Himself without blemish to God" (9:14), Abel "offered to God" an acceptable sacrifice (11:4), and believers are to "continually offer up a sacrifice of praise to God" (13:15-16). In these cases, God is not a passive recipient of the sacrificial actions directed to Him. Rather, God approved ${ }^{245}$ Abel's sacrificial gifts (11:4),

presence, these passages describe Him as being able to speak discursively, using sequential and human intelligible words, with human beings.

${ }^{242}$ In v. 9, this point 2 is portrayed as putting God to test (verb $\left.\pi \varepsilon \iota p a ́ \zeta \omega\right)$, and this human action is interpreted in terms of unbelief in vv. $12,19$.

${ }^{243}$ Verb $\pi$ po ${ }^{2} \chi \theta^{\prime} \zeta \omega$, which conveys the idea of being angry, offended, provoked. BDAG, 884.

${ }^{244}$ In the passages quoted $(9: 14 ; 11: 4 ; 13: 15-16)$, I have italicized the expression to God $(\tau \tilde{\omega} \theta \varepsilon \tilde{\omega})$.

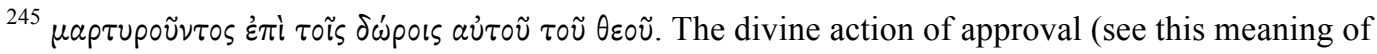


and He is pleased with the sacrifices offered by believers $\left(13: 16^{246}\right)$.

The language of divine acceptance is associated with God's pleasure, inasmuch as something is pleasing to Him (see 11:5-6; 12:28; 13:16, 21). ${ }^{247}$ As a requirement for someone to please God, faith is described as believing that He "is a rewarder of those who seek him" (11:6, NASB). Hence, God reacts not only in terms of being pleased but also by rewarding. The same principle applies in cases when He is not pleased. ${ }^{248}$ For instance, the fathers of Israel did not remain in God's covenant, and because of their unfaithfulness He neglected or had no concern for them (8:9). In a more forceful language, the divine judgment ${ }^{249}$ is described in terms of vengeance ${ }^{250}$ and repayment ${ }^{251}$ (10:30), which underline the idea of divine reaction against deliberate continual human sinful actions (see 10:26-29). ${ }^{252}$

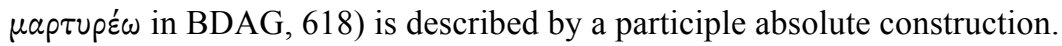

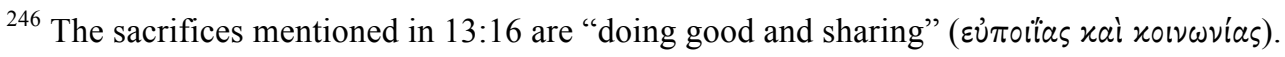

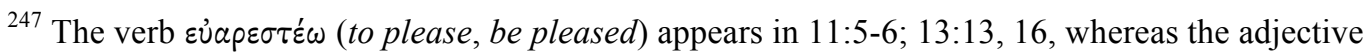

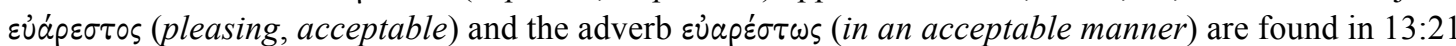
and 12:28 respectively. For information regarding the lexical meaning of these terms, see BDAG, 403.

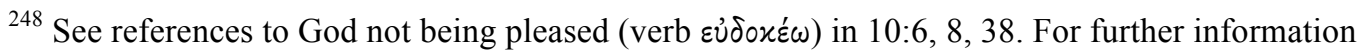
about $\varepsilon \dot{\delta} \delta \circ x_{\varepsilon} \omega$ conveying the meaning of being pleased, taking delight, see BDAG, 404.

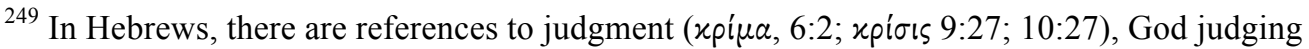
(verb xpiv $\omega, 10: 30 ; 13: 4)$, and God as judge ( $x \rho i \eta^{\prime} s, 12: 23$ ). For information regarding the lexical meaning of these terms, see BDAG, 567, 569-570.

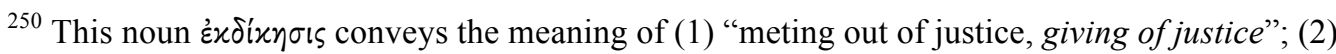
"retaliation for harm done, vengeance"; and (3) "penalty inflicted on wrongdoers, abs. punishment." BDAG, 301.

${ }^{251}$ Expressed by the verb $\dot{\alpha} \nu \tau \alpha \pi \circ \delta i \delta \omega \mu$. See BDAG, 87.

${ }^{252}$ From an ontological standpoint, a less personalistic interpretation of God's reaction (positively: reward; negatively: vengeance) could argue that this is a result of divine predestination (see the functional model in chaps. 2-3) or of the teleological structure of creation (see the sacramental model in chaps. 2-3). In the first case, God predetermined these two outcomes and also the two groups of people who would receive either reward or vengeance. In the second case, in the structure of the world designed by God, the 


\section{God reacts to Christ's sacrifice}

In the case of Christ's sacrifice, the acceptance of the Father seems to take place at Christ's appearance before the Father in the heavenly sanctuary $(9: 24) .{ }^{253}$ From an ontological standpoint, the acceptance of the sacrifice implies not only that $\mathrm{He}$ is a recipient of someone else's action, but also assumes a before and after in God's temporality. In other words, He accepts and is pleased with the sacrifice as and/or after it is offered to Him, and not before that. ${ }^{254}$ Thus, the pleasing acceptance is a divine reaction (change), which implies a temporal sequence of before and after: there was a time for the Father when Christ was not in His presence in the heavenly sanctuary, and there is a time for the Father when Christ is in His presence in the heavenly sanctuary. Furthermore, this language has also spatial implications for the understanding of God. While His omnipresence is assumed in the acceptance of the sacrifice offered by Abel and in His pleasure with the sacrifices offered by believers, ${ }^{255}$ as these sacrificial

teleology of creation naturally rewards at some point people whose actions are consistent with the laws ingrained in the structure of the world (the divine design), and naturally punishes at some point people whose actions go against the structure of creation. In both cases, God is not personally reacting in a temporal way (after) to a human action. Whereas these two types of interpretation of the language of divine reaction are able to explain ontologically how human beings are rewarded or punished by God, without assuming that $\mathrm{He}$ is personally reacting in a temporal way, these atemporal interpretations are unable to provide an ontological account of the biblical notion of divine pleasure, which is part of the picture of divine reaction in Hebrews. The language of divine pleasure in Hebrews implies that God is in some way the recipient or object of an external action. On the other hand, according to a timeless view of God, the biblical language of Him being pleased or displeased by a certain human action is ontologically impossible. This language becomes a meaningless metaphor without an ontological referent, as either God predetermined Himself to be eternally pleased or displeased toward different groups of human beings, with the implication that the eternal divine pleasure or displeasure is not influenced by human action; or human actions conform to or go against the teleological structure of creation, which could hardly be conceived in terms of the personal idea of pleasure or displeasure.

${ }^{253}$ As I have mentioned earlier, this reading is based on the idea that in 9:24-25 the offering (expressed by the verb $\pi \rho \circ \sigma \phi \varepsilon ́ \rho \omega$ ) is understood with a focus on the priestly entrance into the sanctuary.

${ }^{254}$ Even though He could be willing to accept and be pleased before the sacrifice is offered.

${ }^{255}$ Another significant example of God's omnipresence is the idea of a divine discernment of the 
actions were/are performed on earth, the idea of Christ appearing before the Father in the heavenly sanctuary seems to emphasize the importance of Christ meeting God in His heavenly place. This heavenly place is not merely equated with everywhere. Otherwise, God could simply observe and approve Christ's earthly sacrifice at the cross on the basis of His omnipresence, without any need for a further appearance of Christ before God in His heavenly place for us $(9: 24){ }^{256}$ Therefore, God's acceptance of Christ's sacrifice seems to take into account the importance of Christ appearing before God in His heavenly place.

\section{God rests}

The idea of divine rest in Hebrews is consistent with the temporality observed in the notions that God speaks and reacts. Heb 4:4-10 elaborates on the idea that "God rested on the seventh-day from all his works" $(4: 4)^{257}$ by using God's protological rest in the seventh-day as a paradigm for the eschatological Sabbath rest of His people, in which they can rest from their "works as God did from his",258 (4:10). The concept of divine rest,

thoughts and intentions of the human heart and the statement that "no creature is hidden from his sight, but all are naked and exposed to the eyes of him to whom we must give account" (Heb 4:12-13).

${ }^{256}$ In fact, the spatio-temporal sequentiality of sacrifice was already prefigured in the Aaronic priesthood. After (temporal language) the death of the sacrificial victim, there was a sacrificial movement mediated by the priest toward the divine place (spatial language), and this movement could be vertically toward heaven (fire, burnt offerings) or horizontally toward the most holy place (blood/purification offering). Hence, the notion of divine omnipresence did not invalidate the significance of the spatial idea of God in His most holy place. See my discussion on this point in the subsection above on The Heavenly Offering of His Earthly Sacrifice under The Actions of the Priest (The Priesthood of Christ in Hebrews).

${ }^{257}$ This is an allusion to Gen 2:2. UBS 5 , 864 .

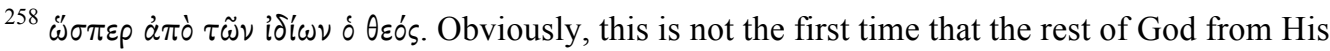
works in creation is used as a paradigm for the rest of human beings from their works. The fourth commandment in Exod 20:8-11 uses God's rest in creation as a paradigm for the weekly rest of human beings in the seventh-day Sabbath. 
by itself, can be attractive for a timeless view of God. However, since this rest is

qualified as being from works (that is, after works), and in the seventh-day (that is, after

six days), the rest is described in a temporal way.

Having articulated an understanding of divine reality implied in references to God

throughout Hebrews. I will focus on the reality of Christ as divine in Hebrews. ${ }^{259}$

\section{The Reality of Christ's Divinity}

In this section about the reality of Christ's divinity in Hebrews, I will explore

concepts of divine sameness and divine becoming.

\section{Divine temporal sameness}

Christ is addressed as $\operatorname{God}^{260}$ in the use of OT quotations in 1:8-12. ${ }^{261}$ The divine

\footnotetext{
${ }^{259}$ For a study on the divinity of Christ in Hebrews, see Richard Bauckham, "The Divinity of Jesus Christ in the Epistle to the Hebrews," in The Epistle to the Hebrews and Christian Theology, ed. Richard Bauckham, Daniel R. Driver, Trevor A. Hart, and Nathan MacDonald (Grand Rapids, MI: Eerdmans, 2009), 15-36.

${ }^{260}$ See also 1:3.

${ }^{261}$ In fact, God is the one who calls the Son God. Even though Hebrews does not mention that God is the one speaking through the OT quotations employed in 1:5-13, it is evident from vv. 5-6 that He is the speaker. The use of Ps 45:6-7 [44:7-8 LXX] in Heb 1:8-9 indicates that the Son is God (vocative $\delta$

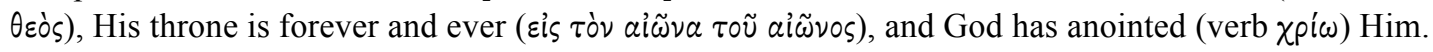
Thus, 1:8-9 implies a relationship between two persons referred as God, namely, one anointing and the other being anointed in a royal context. It could be argued that Hebrews has a Trinitarian view of God. Besides the two persons referred as God in 1:8-9, the Spirit speaks as God (cf. 3:7, 11 with 4:4-5, and 8:8 with 10:15-16). Regarding $\delta \theta$ còs in 1:8-9, the expression is taken as a vocative in the reading graded as "B"

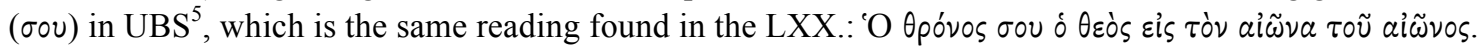

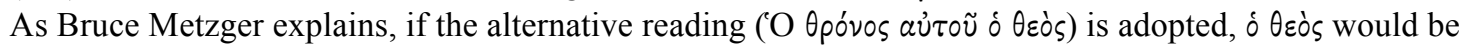
"the subject (or predicate nominative)," which would be translated as "God is thy throne (or, Thy throne is God)," a "highly improbable" interpretation. Metzger adds that, besides this "internal difficulty of construing a $\tau \leftarrow \circ \tilde{u}$," the Committee was impressed "by the weight and variety of the external evidence supporting бov." Bruce M. Metzger, A Textual Commentary on the Greek New Testament, 2nd ed., A Companion Volume to the United Bible Societies' Greek New Testament (4th rev. ed.) (London; New York: United Bible Societies, 1994), 593.
} 
Son is referred as the Creator ${ }^{262}$ of earth and heavens in the beginning. ${ }^{263}$ There is, however, an ontological contrast between the Creator and the earth and heavens (1:1112). The contrast centers on the notion that they will perish or pass away, but He will remain or live on ( $\sigma \dot{\nu} \delta^{\prime} \dot{\varepsilon} \delta ı \alpha \mu \varepsilon^{\prime} \nu \varepsilon ı \varsigma^{264}$ ). In fact, "the permanence of God is contrasted with the most permanent objects in the world, heaven and earth." ${ }^{265}$ In this contrast, heavens and earth are compared to a garment $\left(1: 11-12^{266}\right)$ or robe/mantle (1:12) that will become

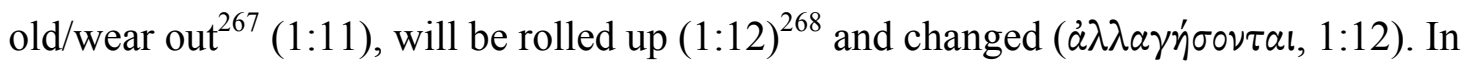

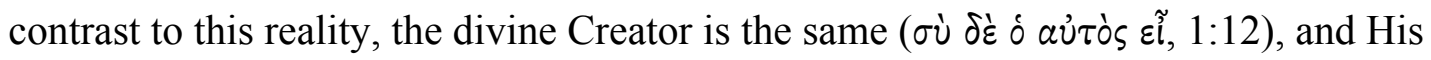
sameness is described in temporal language: "your years will have no end",269 (1:12).

Hence, the temporal description of God's sameness is contrasted to a change of becoming old and coming to an end, which are characteristics associated with the

${ }^{262}$ See also $1: 2$.

${ }^{263}$ This appears in the quotation from Ps 102:25-27 [101:26-28 LXX] found in 1:10-12. The Son is addressed as Lord (vocative xúpı).

${ }^{264}$ See BDAG, 233. The verb $\mu \varepsilon^{\prime} \nu \omega$ is employed in Heb 7:24 to emphasize that Christ has a permanent priesthood "because He continues forever."

${ }^{265}$ I am using here the words of Adele Berlin and Marc Zvi Brettler in their notes on Ps 102:27-29 of the Hebrew Bible. The Jewish Study Bible, 1381. In this point, Heb 1:10-12 quotes Ps 102:25-27 [101:26-28 LXX]. The idea that heaven and earth are the most permanent objects in the world is found in Eccl 1:4, where the earth remains or stands forever whereas a generation goes and another comes.

${ }^{266} \mathrm{I}$ am following the reading graded as "B" in $\mathrm{UBS}^{5}$ that includes ifé́ $\tau$ เov (garment) in 1:12.

267 The passive form of $\pi \alpha \lambda \alpha \iota \omega \theta \dot{\sigma} \sigma 0 \nu \tau \alpha \iota$ means to become old, conveying the idea of becoming useless. BDAG, 751.

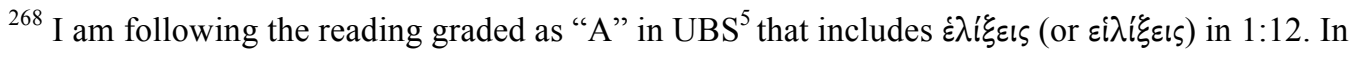
the other NT occurrence of the verb $\varepsilon \lambda i \sigma \sigma \omega$, the heaven vanishes "like a scroll that is being rolled up (verb $\varepsilon \lambda i \sigma \sigma \omega)$, and every mountain and island was removed from its place” (Rev 6:14). The verb $\dot{\varepsilon} \lambda \dot{i} \sigma \sigma \omega \operatorname{does}$ not appear in Ps 101:26-28 LXX, as the verb $\dot{\alpha} \lambda \lambda \alpha \dot{\alpha} \sigma \omega \omega$ is employed.

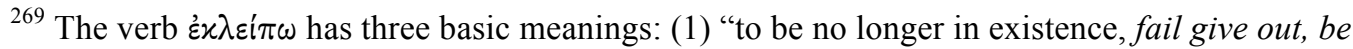
gone"; (2) "to go away from a place, depart"; (3) "to cease as state or event, fail, die out." BDAG, 306. 
temporality of creatures or created things in the current state of the world (that is, as a consequence of $\sin$ in the world). ${ }^{270}$ Hence, a temporal (not temporary) conception of divine sameness along the lines of 1:12 is not conceptually problematic as philosophical accounts of a timeless God may assume. In fact, the temporal sameness ( $\delta$ aủंòs) of Christ is reaffirmed in 13:8 with a more emphatic and detailed language, ${ }^{271}$ where the

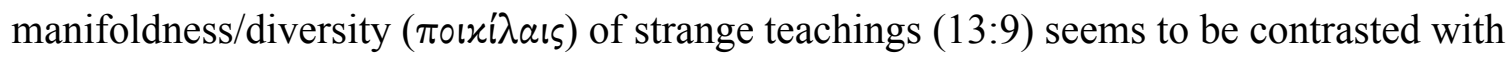
the sameness (ó aủò̀s) of Christ (13:8). ${ }^{272}$ While manifoldness/diversity (13:9) denotes ambiguity and deceit, ${ }^{273}$ Christ's sameness entails consistency and trustworthiness, which is based on the reality that His sameness is temporally described as existing in the past

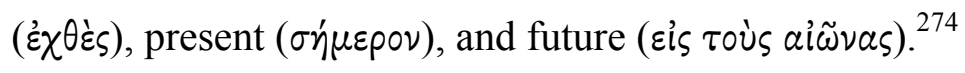

${ }^{270}$ Hebrews 1:11-12 seems to point to an eschatological destruction of the earth and heavens (as we know them) by the action of the Lord, and not simply because of a natural process of getting old. This eschatological divine action seems to be indicated by the use of the verb $\dot{\varepsilon} \lambda i \sigma \sigma \omega$ with reference to the world in Heb 1:12 and Rev 6:14, the only two occurrences of the verb in the NT.

${ }^{271}$ For a connection between 13:8 and 1:12, see Johnson, Hebrews, 346; Attridge, The Epistle to the Hebrews, 392; Ellingworth, The Epistle to the Hebrews, 705.

${ }^{272}$ After the exhortation to remember the leaders of the church who teach the word of Godwhich is associated to the consideration of their conduct and the imitation of their faith (13:7), and before

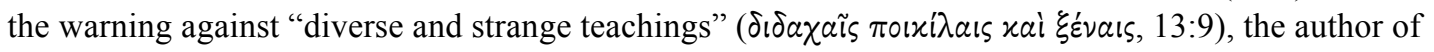

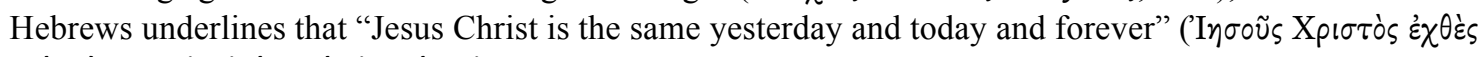

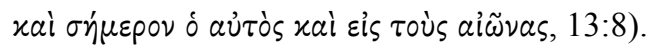

${ }^{273}$ Toเxỉ aı has two basic meanings: (1) "existence in various kinds or modes, diversified, manifold," and (2) "existence in various aspects." The second meaning may describe (a) things (manycolored, variegated) and (b) persons with "devious ways of thinking," which is a figurative extension of

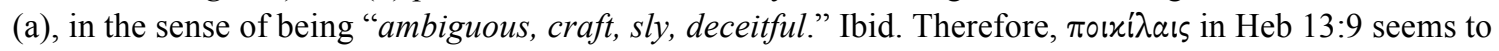
convey the meaning $2 \mathrm{~b}$.

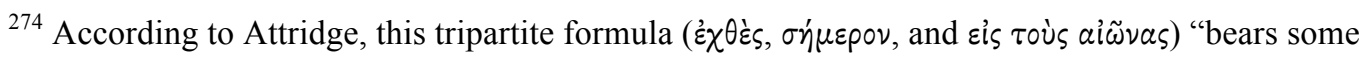
superficial resemblance to divine self-predications of the Old Testament," but "it is not a cryptic way of identifying Jesus and Yahweh. Some commentators have been tempted to correlate the three temporal elements with moments in the history of Jesus in his humanity and exalted state, where he functions as intercessor. The formula would then parallel the traditional christological perspective of the catena in chap. 1. Since the patristic period, other commentators have read the formula as a summary of a three-stage christology, like that explicit in the exordium and implied elsewhere in Hebrews. Nothing in the immediate context makes either christological scheme explicit. The latter interpretation is probably closer to the mark, 
Divine temporal becoming

It must be pointed out, however, that the temporal description of the divine sameness is not a spatio-temporal language that anthropomorphically depicts a timeless-

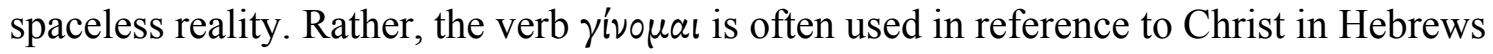
(see $1: 4 ; 2: 17 ; 5: 5,9 ; 6: 20 ; 7: 16,26$ ), conveying the idea that He became something, which implies temporal sequence. ${ }^{275}$ More precisely, He became "much superior to angels" (1:4) and "exalted above the heavens" (7:26); He became a high priest $(2: 17 ; 5: 5$; $6: 20 ; 7: 16)$ and "the source of eternal salvation" (5:9). To be sure, this becoming of exaltation and salvific priesthood presupposes His previous earthly experience of suffering and death as a human being (see 2:9-10, 14, 17-18; 5:7-10). But Hebrews does not ascribe the becoming to a human nature of Christ that functions as a spatio-temporal instrument of His timeless-spaceless divine nature. It is not merely the human Christ who becomes exalted and becomes a high priest for salvation, instrumentally making the divine Christ also exalted and high priest. As a matter of fact, if the Jesus of 2:9 is the Son of 1:2-3 and 10, namely, the creator and sustainer God, then the idea of Jesus being

although it is not a systematic affirmation but a foundation for exhortation that is here offered. The emphasis is clearly on the eternal 'sameness' of Christ. Because Jesus Christ is an integral part of the eternal divine realm that is unchanging, he is now, for the Christian addressees, a sure foundation for their communal life (v. 7) and doctrine (v. 9)." Attridge, The Epistle to the Hebrews, 393.

${ }^{275}$ I agree with Kibbe that while the verb y'voual can have a stative or a progressive sense, these passages seem to imply some kind of progression. Taking the the whole argument of Hebrews into account, Kibbe points out that "in order for us to fix our eyes on the one who walked the path ahead of us as the model of faith and perseverance and obedience, his own 'becoming' must bear some correspondence to ours.” Kibbe, “Is it Finished?" 48n99. Kibbe's position is clearly different from Webster's idea that becoming in this context is "not to be taken to mean the realization or acquisition of some wholly new, additional reality," but "a perfect movement in the being of God. This movement is not a coming-to-be." Rather, it is "the repetition in time of his eternal being." John Webster, "The One Who Is Son: Theological Reflections on the Exordium to the Epistle to the Hebrews" in The Epistle to the Hebrews and Christian Theology, ed. Richard Bauckham, Daniel R. Driver, Trevor A. Hart, and Nathan MacDonald (Grand Rapids, MI: Eerdmans, 2009), 92-93. 


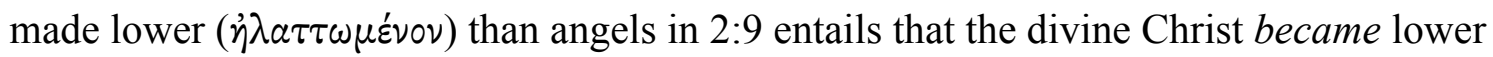
in His incarnation, ${ }^{276}$ a temporal sequence in the divinity of Christ's being of being higher (before the incarnation) and then lower (after the incarnation).

Likewise, 5:8 depicts the earthly suffering of the incarnate Christ with a significant remark: "though being a Son" (YLT), ${ }^{277}$ "he learned obedience through what he suffered." This learned obedience qualified Him to become the source of salvation (5:9) and high priest (5:10). The Son here is not yet the exalted Son (king, see 1:3-6, 8-9) and the ascended high priest (see 4:14; 8:1-2; 9:11-12, 24-25). Rather, this is the suffering Son who is becoming qualified for His salvific priesthood. If the note "though being a Son" suggests an attitude of surprise in face of this process of qualification involving the Son, the surprise is not based on the fact that the Son who was learning obedience was the king of 1:3-6, 8-9, since these passages point to a future ${ }^{278}$ enthronement after the purification of sins (1:3) performed when He ascended to heaven. ${ }^{279}$ Rather, in light of the description of the Son before the incarnation as the

\footnotetext{
${ }^{276}$ In the quotation of Ps 8:5 (8:6 LXX) in Heb 2:7, to be made a lower than the angels ( $\eta^{\lambda} \alpha \dot{\tau} \tau \omega \sigma a \varsigma$

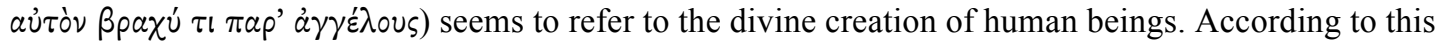

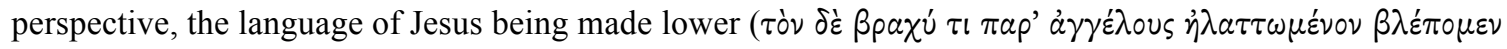

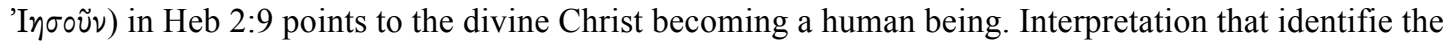
suffering and death of the incarnate Christ as the point when he was made lower, perhaps in terms of humiliation, disregards that in 2:9 Jesus is made lower than angels so that (ö $\pi \omega \varsigma)$ He might taste ( $\gamma \varepsilon v i \sigma \eta \tau a l)$ death. See Attridge, The Epistle to the Hebrews, 76. In other words, it is because Christ is made lower (incarnation) that $\mathrm{He}$ is able to taste death (see 2:14), and not that He was made lower precisely when $\mathrm{He}$ tasted death. On the other hand, this is not merely a reference to the incarnation by itself, but an incarnation that has mortality in view. See Lane, Hebrews 1-8, 49. In this sense, Christ's suffering and death are part of the picture of being made lower than angels. For interpretations that focus on suffering/death, see Ellingworth, The Epistle to the Hebrews, 154; Johnson, Hebrews, 91; Koester, Hebrews, 217. For a position that emphasizes the incarnation, see Cockerill, The Epistle to the Hebrews, 132-133.

${ }^{277}$ I use the YLT for this expression because it better captures the participle $\ddot{\omega} \nu$ in $\varkappa a i \pi \varepsilon \rho ~ \grave{\omega} \nu$ viós.

${ }^{278}$ Taking the moment when the Son learned obedience on earth as a reference.

${ }^{279}$ Based on the understanding that 1:5-6 refer to the enthronement of the ascended Son (see also
} 
creator and sustainer God $(1: 2-3,10)$, the surprise is that it was the same divine person

who underwent a process of becoming qualified for His salvific priesthood. In short,

Christ did that as incarnate God. Obviously, to do this as incarnate God is different from

merely doing it through a human nature, since the former implies a divine temporality

that, by definition, is able to really experience sequential events.

\section{Summary}

In summary, God is really able to experience sequential events, and in this sense

divinity is temporal. A number of examples can be enumerated:

$1: 3-4,8-9,13)$ that follows the purification of sins in $1: 3$, the language of begetting ( $\gamma \varepsilon \nu \nu \alpha \dot{\alpha})$, Father and

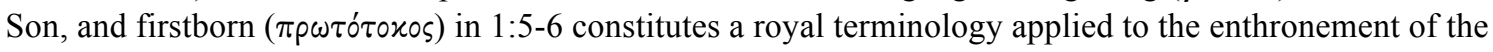
ascended Christ. Notice the royal context of Ps 2:7 (see vv. 6-8) and 2 Sam 7:14 (see vv. 12-16), which are the quotations used in Heb 1:5. Likewise, the language of firstborn ( $\pi \rho \omega \tau$ ó $\tau \circ$ xos) is used in Ps 88:28 LXX (89:27 ESV) in reference to the Davidic king (see also 89:3-4, 20-29, 35-36 ESV). It is interesting to note that in the OT both Levites (Num 3:45; 8:18) and the Davidic king (Ps 88:28 LXX) are God's firstborn. In Hebrews, Christ, God's firstborn, is both king and priest. It is significant that Acts 13:13 quotes Ps 2:7 in light of Christ's resurrection. In regards to $\pi \rho \omega \tau$ ó $\tau$ oxos in the NT, Col 1:18 uses the language to emphasize

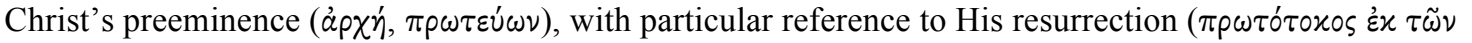

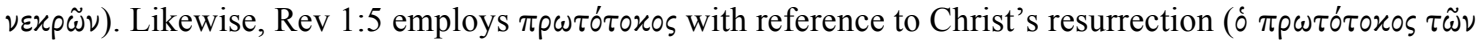

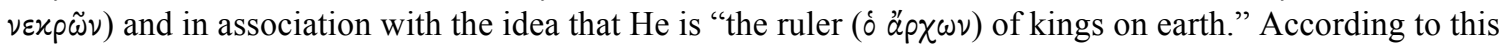
perspective, in Hebrews, Christ is the firstborn of God as the resurrected and ascended Son who is enthroned in heaven. To be sure, a potential objection to this view is the interpretation that in Heb 1:6 God

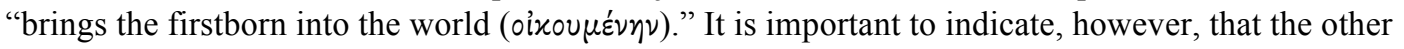

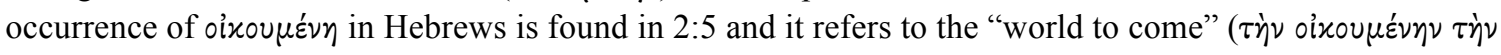
$\left.\mu \varepsilon \lambda_{\lambda}{ } v \sigma \alpha \nu\right)$, and not to this present world. Furthermore, when the author of Hebrews mentions Christ

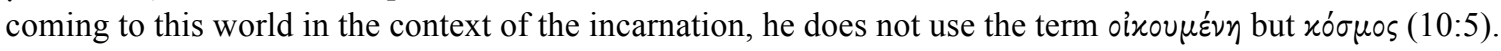
Associated with these terminological considerations, the context of Heb 1:3-13 seems to indicate that

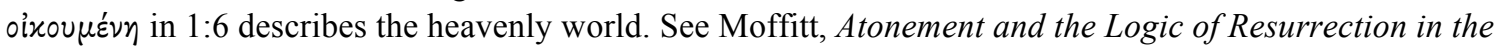
Epistle to the Hebrews, 53-68; Ardel B. Caneday, "The Eschatological World Already Subjected to the Son: The Oikoumevn of Hebrews 1.6 and the Son's Enthronement," in A Cloud of Witnesses: The Theology of Hebrews in Its Ancient Contexts, ed. Richard Bauckham, Daniel Driver, Trevor Hart, and Nathan MacDonald (London: T\&T Clark, 2008), 28-39; Cortez, "'The Anchor of the Soul that Enters Within the Veil'," 213-224. Hence, the language of begetting in Heb 1:5 is not an ontological explanation of Christ's divine nature. In other words, this passage is not related to an idea of eternal (timeless) generation of the Son. See Attridge, The Epistle to the Hebrews, 53-57; Cockerill, The Epistle to the Hebrews, 103-105; Ellingworth, The Epistle to the Hebrews, 111-114, 118; Johnson, Hebrews, 77-79; Koester, Hebrews, 191193, 197-199; Lane, Hebrews 1-8, 24-27. For references to other interpretations that understand the begetting of the Son in 1:5 as Christ's eternal generation, incarnation, baptism, or second coming, see Cockerill, The Epistle to the Hebrews, 103; Ellingworth, The Epistle to the Hebrews, 112; Koester, Hebrews, 191. Despite such references, these commentators affirm Christ's exaltation as His begetting as 
(1) God speaks discursively and in multiple ways, meaning that His speech may be mediated or immediate. Divine speech necessarily implies temporal sequence and, therefore, divine temporality.

(2) God reacts (positively or negatively) to human actions. For instance, He can be provoked by them for a certain period of time, and then judge or condemn those who performed those actions. In a positive way, He can be pleased by human actions. The spatio-temporal dynamics of the sacrificial offering is a fitting framework for the understanding of the notion of divine pleasure. Temporally, the offering of the sacrifice implies a sequence of death of the victim and a movement toward God, which takes place spatially as the smoke goes up to heaven (burnt offerings) or the blood is carried into the sanctuary (purification offerings). This spatio-temporal movement is seen as Christ appears before God in the heavenly sanctuary (God's place). Thus, these direct historical relationships of God with human beings and Christ necessarily implies divine spatiotemporality.

(3) For God the Father, there was a time (temporality) when Christ was not in His presence in the heavenly sanctuary (spatiality). In addition, the notion of divine omnipresence does not invalidate the significance of the spatial idea of God being met in His most holy place. He can rest at a specific time after a sequence of activities. God's Trinitarian relationships necessarily imply divine temporality.

(4) The divinity of Christ has a temporal sameness (in the past, present, and future), meaning that He does not become old and His years have no end. Divine

the Son in 1:5. 
temporality is identical but infinite and analogical to the temporality of creation.

(5) At the same time, the divine Christ experiences becoming. The incarnation implied a sequence where the creator and sustainer God was made lower than the angels. As a human being, the divine Christ underwent a process of becoming qualified to be a salvific high priest that involved suffering and learned obedience. Then, at His ascension, the resurrected Christ became the exalted king and the salvific high priest. In light of these examples, divinity is spatio-temporal, as it is able to really experience sequential events in specific places. Christ's divinity is necessarily temporal in an inifinite analogical sense.

Having discussed divinity in Hebrews as the first principle of reality, I move to the description of humanity in this epistle.

\section{Humanity: Christ and the Concept of Human Nature}

There are a few passages in Hebrews that reveal assumptions about the reality of human beings in general, and several passages that offer hints about the human nature of Christ. I will start this section with the discussion of the conception of human beings in general. The main idea of this general anthropology is that human nature is necessarily grounded in the body and its functions. Associated with this idea, the discussion on the human incarnation of Christ's divine being will emphasize that His humanity is not necessary to provide a spatio-temporal instrument for His divinity. I will start this discussion with the anthropology of Hebrews and then move to Christological anthropology. ${ }^{280}$

\footnotetext{
${ }^{280}$ Those following a Barthian view of anthropology (see Humanity under the Ontological Model
} 


\section{General Anthropology: Human Nature Grounded in the Body}

The author of Hebrews clearly emphasizes that God has access to the deepest

parts of a human person, which includes "soul/life ${ }^{281}$ and spirit" and "both joints and marrow"282 (4:12). The point of this language is that He is able to discern or judge (xpıтเxos) "the thoughts and intentions of the heart." In this passage, the inner human nature consists of physical (joints and marrow) and abstract aspects (soul/life and spirit), ${ }^{283}$ which implies that the deepest internal part of human beings is not described as an immaterial soul that constitutes the essence of a person, being secondarily and externally accompanied by a body. ${ }^{284}$ Rather, physical language is included in the

in the previous chapter) may question the methodological approach of studying human beings in general and then connecting general anthropology to the humanity of Christ, instead of going the other way around. While I appreciate the idea of using Christ's humanity as the starting point for a general anthropology, I do not think that the methodological move that I make here is unsound. First, the Barthian position may fear that the move from general anthropology to Christ's humanity implies some kind of natural theology (epistemologically staring with humanity and moving to God/Christ). This charge, however, is unfair. My study about human beings does not use data from scientific anthropological studies. Rather, the source of information for my general anthropological conclusions is the same that Barthian theologians would use to construe their accounts of a Christological anthropology, namely, the biblical material. Second, the notion of incarnation in Hebrews stipulates that Christ "had to be made like his brothers in every respect" (2:17), except for $\sin (4: 15)$. Therefore, in some sense, what we study about human beings in general does apply to Christ's humanity.

${ }^{281}$ These are the two basic related meanings of $\psi v \chi \eta \dot{\eta}$. See BDAG, 1098. Cockerill seems to prefer the term life in Heb 4:12. See Cockerill, The Epistle to the Hebrews, 216. $\psi v \chi \dot{\eta}$ and $\pi \nu \varepsilon \cup \tilde{\mu} \mu$ appear together also in 1 Thess 5:23 in the NT.

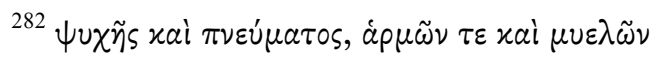

${ }^{283}$ My argument here is similar to the notion that these psychological/abstract and physical aspects summarize the whole of human nature or existence, as advanced by Attridge, The Epistle to the Hebrews, 134; Koester, Hebrews, 274; Peter T. O’Brien, The Letter to the Hebrews, PNTC (Grand Rapids, MI; Nottingham, England: Eerdmans; Apollos, 2010), 176-177. However, my argument has a significant nuance: in Heb 4:12, these aspects summarize the inner human nature or existence.

284 There are unconvincing attempts to interpret Heb 4:12 according to an anthropological framework of Greek (following a platonic orientation) ontology. As Attridge indicates, "P. Proulx and L. Alonso-Schökel ("Hebr. IV, 12-13: componentes y estructura," Bib 54 [1973] 331-39) attempt to fit all the elements of this verse into a Platonic framework provided by Tim. 43-45, 69-74, 81, 85, 90, but such a scheme as a whole is artificial and unconvincing." Attridge, The Epistle to the Hebrews, $135 \mathrm{n} 38$. 
reference to inner human nature, and the last part of 4:12 confirms this understanding, as thoughts and intentions (psychological language) are directly associated with the heart (bodily language) in the deepest internal part of a human person. Elaborating on this anthropological perspective, one cannot talk about the essence of human beings without reference to the body. The discussion on to what extent anthropological language of 4:12 should be taken as literal or figurative ${ }^{285}$ does not impact the point that I emphasize here.

Furthermore, Spicq sees in Heb 4:12 a Philonic dichotomy between $\psi v \chi \eta^{\prime}$ (animal soul, life) and $\pi \nu \varepsilon \tilde{u} \mu \alpha$ (voũs, the rational nature, the connection with the divine, the real essence of human beings), namely, a dichotomy between the natural and spiritual natures of human beings. Spicq, L'Épitre aux Hébreux, 1:5253. Attridge explains that "the theoretical distinction between $\psi v \chi \eta$ ' and voṽ s is made by Aristotle $A n .2 .2$ (413b 24-27); 3.4 (429a 10 -429b 9); 3.5 (430a 18-25). It becomes commonplace in later Greek philosophy and religion, where $\pi \nu \varepsilon \tilde{\mu} \mu \alpha$ and voũ s are often equated. ... Philo's psychology is complex and his language fluid, reflecting the various philosophical theories on which he has drawn. See Dillon, Middle Platonists, 174-78. At times he simply distinguishes between soul or pneuma and body (Op. mund. 135; Leg. all. 3.161). Within the soul $\left(\psi \cup \chi \eta^{\prime}\right)$ he can isolate the rational element ( $\left.\nu 0 \tilde{\varsigma} \varsigma\right)$ as the superior part $(O p$. mund. 69; Leg. all. 1.37-40), a distinction parallel to that of irrational and rational components of the soul (Rer. div. her. 232). The spirit can be seen as the essence of the soul (Rer. div. her. 55-57; Det. pot. ins. 80-86; Quaest. in Gen. 259), which is infused into the soul by God (Leg. all. 3.37). The distinction of matter, soul, and spirit will be more fully developed in Gnostic sources." Attridge, The Epistle to the Hebrews, 135n39. More recently, Johnson stipulated that Heb 4:12 reflects "the tripartite psychology familiar in Platonism (see Timaeus 43A-45E, 69A-90E).” Johnson, Hebrews, 134. However, a Philonic distinction of soul and spirit, and a Platonic tripartite psychology are not convincing conceptual backgrounds for the understanding of Heb 4:12. First, as Attridge has indicated, a Philonic distinction of soul and spirit presupposes that the human spirit is the superior to the soul $\left(\psi v \chi^{\prime}\right)$. Nevertheless, there is no hierarchy between human $\psi \cup \chi \tilde{\eta} \varsigma$ the $\pi \nu \varepsilon \dot{u} \mu a \tau o s$ in Hebrews. Koester correctly indicates that "there is little difference in meaning, of the salvation of one's 'soul' (10:39) and the completion of one's 'spirit' in the heavenly city of God (12:23)." Koester, Hebrews, 274. See Herbert Braun, An Die Hebräer (Tübingen: Mohr Siebeck, 1984), 119; O'Brien, The Letter to the Hebrews, 177n137. Moreover, Smillie properly observes that $\psi v \times \eta$ in Hebrews is used "for the spiritual nature of the human ... person" (see Heb 6:19;

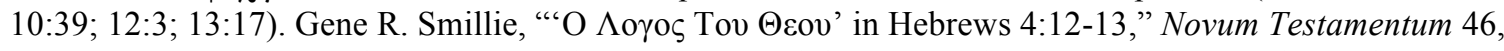
no. 4 (2004): 343. Second, a tripartite (Platonic) proposal does not make justice to the fact that Heb 4:12 use two pairs, $\psi v \chi \tilde{\eta} \varsigma$ xaì $\pi \nu \varepsilon \dot{\mu} \mu a \tau o \varsigma$ and $\dot{\alpha} \rho \mu \tilde{\omega} \nu \tau \varepsilon$ xal $\mu v \varepsilon \lambda \tilde{\omega} \nu$. From a logical standpoint, it is difficult to see how two pairs form a tripartite divison. Such attempt seems to impose an alien framework into the text.

${ }^{285}$ Some scholars interpret joints and marrow in Heb 4:12 as metaphorical equivalents of soul and

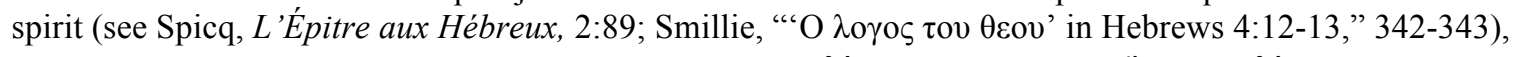

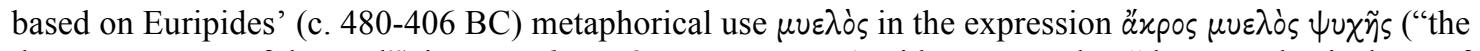
deepest marrow of the soul") in Hippolytus, 255. However, Attridge argues that "the metaphysical use of $\mu \cup \varepsilon \lambda o^{\circ}$ in that passage hardly implies it is regularly used in such a metaphorical way," and suggests that "it is probably better to understand the phrase" in Heb 4:12 "as a complex summary of the whole of human nature." Attridge, The Epistle to the Hebrews, 135. While conceding that it is uncertain whether joints and marrow in Heb 4:12 "are to be understood literally or figuratively," Ellingworth points out that "literal and figurative associations of parts of the body are not separated in biblical anthropology, which does not 
As Ellingworth correctly indicates in his remarks on this passage, "literal and figurative associations of parts of the body are not separated in biblical anthropology, which does not sharply distinguish between physical and psychological functions. ${ }^{286}$ To put it more pointedly, a literal and figurative association regarding parts of the body in biblical language is possible because there is in the biblical anthropological mindset an ontological holistic combination of physical and psychological aspects and functions. ${ }^{287}$ According to this anthropological view that the inner nature of human beings includes bodily parts, 10:22 mentions a complete purification of the human person. Externally, the body is washed with pure water. Internally, the heart is sprinkled from an evil conscience. Therefore, the inner human nature is portrayed with a psychological

sharply distinguish between physical and psychological functions." Ellingworth, The Epistle to the Hebrews, 263.

${ }^{286}$ Ellingworth, The Epistle to the Hebrews, 263.

${ }^{287}$ The distinction aspective/partitive employed by James Dunn (drawn from D. H. Whiteley, Theology of St. Paul [Philadelphia: Fortress Press, 1966], 36) is helpful on this point. While the partitive conception regards "the human being as made up of distinct parts," the aspective view sees the human being "as a whole person existing on different dimensions" or aspects. Whereas Dunn acknowledges the value of this distinction when used in broad terms, he warns against the simple application of this distinction to Hebrew and Greek forms of thought, in which the former is considered aspective and the latter partitive. He argues that "the complexity and diversity of the evolving debate within Greek philosophy on physics can hardly be adequately grasped by such distinctions. And the influence of Hellenistic thought particularly on diaspora Judaism diminishes the distinction anyway - as Philo always demonstrate." James D. G. Dunn, The Theology of Paul the Apostle (Grand Rapids, MI: Eerdmans, 1998), 54. While aware of this complexity, I find the aspective/partitive distinction conceptually helpful for the realization that biblical anthropology (and not necessarily all Hebrew forms of thought) has an aspective, and not partitive, view of human beings. A recent example of a holistic (monistic) interpretation of biblical anthropology, which implies an aspective view of human beings, is Joel B. Green, Body, Soul, and Human Life: The Nature of Humanity in the Bible, Studies in Theological Interpretation (Grand Rapids, MI: Baker Academic, 2008). Green is aware of the danger of simplistic differentiations between generalized accounts of Hebrew and Greek thinking (see ibid., 51-54), but he argues that the Bible does not hold a partitive or dualist notion of the human being. Green offers a survey of biblical anthropology in NT and OT studies in the twentieth and twentieth-first century, with an emphasis on a holistic (monistic) interpretation. See ibid., pp. 4-16. At the end of his study, he denies the idea of an intermediate state between death and resurrection, and defends the absolute need of resurrection for life after death. He writes, "There is no part of us, no aspect of our personhood, that survives death." In the NT, "life-after-death requires . . re-embodiment" (resurrection). Ibid., 179. 
(conscience) and bodily language (heart). In this way, psychological terms such as $\psi v \chi \eta \dot{~}$

$(4: 12 ; 6: 19 ; 10: 39 ; 12: 3 ; 13: 17)$ and $\pi \nu \varepsilon \tilde{u} \mu \alpha(4: 12 ; 12: 23),{ }^{288}$ used in an anthropological

sense, should not be interpreted as referring to an immaterial entity or noncorporeal being

that constitutes the real essence of human beings. ${ }^{289}$ In fact, the occurrences of $\psi v \chi \eta$ in

$6: 19 ; 10: 39 ; 12: 3$ and $13: 17$ do not point to this interpretation. ${ }^{290}$ Likewise, the reference

to "the spirits of the righteous made perfect" in the heavenly Jerusalem (12:23) does not

${ }^{288}$ Attridge speculates that, perhaps, the use of $\pi \nu \varepsilon \tilde{u} \mu \alpha$ in 9:14 and 12:9 is also anthropological. Attridge, The Epistle to the Hebrews, 376n81. In my judgment, these passages do not indicate a specific anthropological use of $\pi \nu \varepsilon \tilde{u} \mu \alpha$.

${ }^{289}$ To use the categories mentioned by Green, I am basically suggesting that the anthropology of Hebrews implies a form of monism, meaning that human beings have "no second, metaphysical entity, such as a soul or spirit," as defended by forms of radical dualism ("the soul [or mind] is separable from the body, having no necessary relation to the body") and wholistic dualism (the human person is "composed of discrete elements" that constitute "a functional unity"). Green indicates that the monism he has in mind assumes that what "we label "soul"" is "neither reducible to brain activity" (against reductive materialism) "nor evidence of a substantial, ontological entity such as a "soul"" (against radical dualism and wholistic dualism), "but rather represent essential aspects or capacities of the self." Green, Body, Soul, and Human Life, 31.

${ }^{290}$ In $6: 19, \psi \cup \chi \eta^{\prime}$ is related to the hope ( $\dot{\varepsilon} \lambda \pi \dot{\delta} \delta \circ$, v. 18) of the believer. In 10:39, those who have faith will preserve $(\pi \varepsilon \rho ı \pi \operatorname{in} \sigma \nu) \psi \nu \chi \eta^{\prime}$ (in other words, these persons will be preserved), but those who

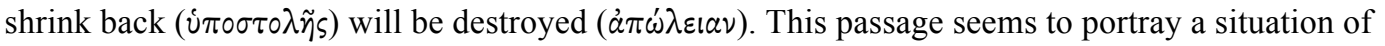
judgment, when there will be either salvation or damnation (which implies the destruction of the $\psi v \chi \eta^{\prime}$ ) of

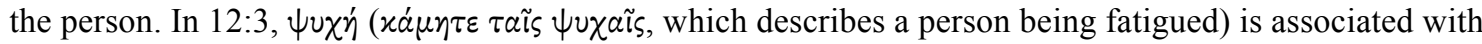
the situation when a person gives up ( $\left.\varepsilon \chi \lambda \cup \sigma^{\prime} \mu \varepsilon \nu \circ \iota\right)$. As Eduard Schweizer indicates, $\psi v \chi \eta^{\prime}$ is related to the

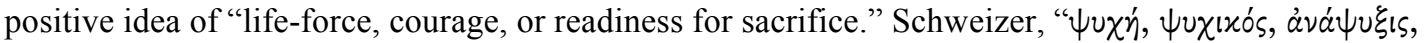

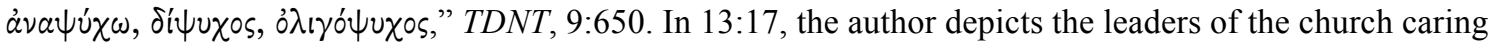

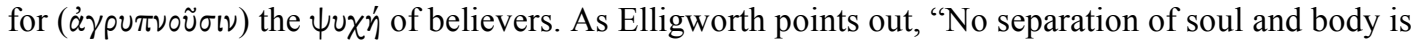
implied, but the author's concern is clearly the spiritual good of the community." Ellingworth, The Epistle to the Hebrews, 723. Schweizer even wonders if the meaning of $\psi v \chi \eta^{\prime}$ in 13:17 emphasizes the human

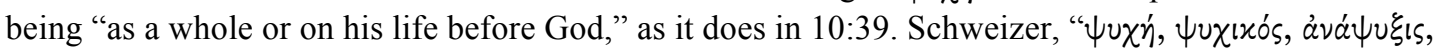

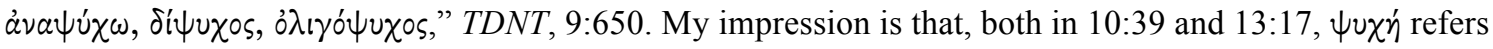
to the human being as a whole (or as a person, see this definition in BDAG, 1099), with a particular emphasis on his/her life before God. Therefore, having all these passages in view, $\psi v \chi \eta^{\prime}$ is not anthropologically conceptualized in Hebrews as an immaterial entity (soul) or noncorporeal being that constitutes the real essence of human beings. Rather, it is related to human desire/hope (6:19) and vitality/courage (12:3), and refers to the human being as a whole with an emphasis on his/her life before God (10:39; 13:17). 
indicate that the human spirit is an immaterial entity or noncorporeal being. ${ }^{291}$

\begin{abstract}
${ }^{291}$ My suggestion in this footnote is that the reference to Zion in 12:22-24 is not an ontological or temporal description, but a mental possibility for living believers (pointing to the final salvation), just as Sinai in this context is a possibility for them in terms of judgment. If this congregation or group of righteous people (spirits) includes deceased believers, the inclusion is rhetorical or proleptical, as this is not a present ontological description. With this summary and keeping in mind what I explain in this footnote, the reading that interprets the spirits in 12:23 in terms of a noncorporeal presence of deceased believers in heaven assumes that what constitutes the essence of a person is an immaterial entity that is secondarily accompanied by a body. Furthermore, this interpretation presupposes that it is precisely this immaterial entity that is made perfect in human beings. However, it is important to note that the audience (living believers) hearing the words of 12:22-23 is described as having "come to Mount Zion and to the city ( $\pi \delta^{\prime} \lambda \varepsilon \iota$ ) of the living God, the heavenly Jerusalem." Obviously, these believers do not come literally or ontologically to God's heavenly city, because they still seek ( $\dot{\varepsilon} \pi\llcorner\eta \eta \tau \sim \tilde{v} \mu \varepsilon v)$ this city $(\pi \dot{o} \lambda \iota v)$ that is to come (13:14). The reference to the hope ( $\dot{\varepsilon} \lambda \pi^{\prime} \dot{\delta} \delta \varsigma$ ) of believers entering in the heavenly presence of God (inside the curtain where Christ has gone on our behalf) in 6:18-20 may be helpful for the understanding of a nonliteral entrance of believers in the heavenly city of God in 12:22-23. But how about deceased believers? Have they come literally or ontologically to God's heavenly city, as perfected disembodied spirits? This does not seem to be the picture of deceased believers in chap. 11. They all died in faith, "not having received the things promised, but having seen them and greeted them from afar" (11:13). Similar to the audience of Heb 13:14, the believers who died in faith are described as those who seek ( $\dot{\varepsilon} \pi\llcorner\eta \eta \tau 0 \tilde{v} \sigma \nu, 11: 14)$ a heavenly country, the city ( $\left.\pi \delta^{\prime} \lambda \iota v, 11: 16\right)$ that God has prepared for them (11:14-16). When the hope of life after death is mentioned, there is a reference to the eschatological resurrection ( $\dot{\alpha} \alpha \sigma \tau \tau \dot{\alpha} \sigma \varepsilon \omega \varsigma, 11: 35)$. At the end of the chapter, the author reiterates that they did not receive the promise (11:39) and emphasizes that "God had provided something better for us, that apart from us they should not be made perfect" (11:40). If the essence of the human being is an immaterial entity (soul or spirit), these ideas about deceased believers in chapter 11 could receive the following interpretation: (1) the better provision that God has for "us" (living believers) is the work of Christ, which makes us perfect in the sense that it allows us to have access to God (this understanding of perfection was explored above in the discussion of the Goal of the Priesthood. See also Cockerill, The Epistle to the Hebrews, 597-599; Johnson, Hebrews, 309-310; Koester, Hebrews, 520) (2) the believers of chapter 11 died without receiving the promise and without being made perfect because their death preceded the salvific work of Christ (see Cockerill, The Epistle to the Hebrews, 598), which the audience of Hebrews can benefiting from; and (3) the believers of chapter 11 did not benefit from Christ's work when they died, but when Christ started His salvific work, as disembodied spirits after death they started benefiting from His work just as living believers did (See ibid., $599,656,657 \mathrm{n} 71$ ). It is in this way that, apart from living believers (the audience of Hebrews), deceased believers should not be made perfect (11:40) (ibid., 599). It is also in this sense that they are spirits made perfect in the heavenly Jerusalem (12:22-23) (ibid., 656, 657n71). Whereas points 1 and 2 are consistent with the message of Hebrews, point 3 stretches the ideas of the epistle to accommodate the anthropological presupposition that the essence of the human being is an immaterial entity secondarily accompanied by a body. In his remarks on 12:23, Ellingworth argues that it is "misleading to suggest that the righteous are thought of here as having been made perfect in spirit, but not yet in body: this dichotomy does not appear significant in Hebrews." Ellingworth, The Epistle to the Hebrews, 681. For Koester, "Hebrews provides no clarity about a person's state between death and final judgment." Koester, Hebrews, 546. Even Cockerill acknowledges that the author of Hebrews "makes no statement about what the faithful of old experienced after their deaths." Cockerill, The Epistle to the Hebrews, 598. In my estimation, point 3 stretches the anthropology of Hebrews in two ways. First, it extrapolates the natural reading of chapter 11, which expresses the possibility of going beyond death in a bodily way, either by being taken by God without seeing death (Enoch, 11:5) or by living again in terms of resurrection $(11: 19 ; 35)$. Second, in contrast to 11:40, deceased believers would precede the audience of Hebrews in terms of perfection and fulfillment of the promise. More specifically, they would have access to God in the promised city "apart from" the audience of Hebrews (believers alive, described as "us" in 11:40) in a chronological and qualitative way.
\end{abstract}


Keeping in mind this conception that human nature is grounded in the body and

This argument is opposed to Cockerill's point that deceased believers "have been 'made perfect' in the same way that contemporary believers 'have been made perfect."' Ibid., 657. Chronologically, the deceased believers of chapter 11 would have benefited from the work of Christ and would have access to God at least since His ascension. Presumably, they would have been experiencing this benefit before many believers among the audience of Hebrews who may have become Christian years after the ascension of Christ. Qualitatively, their access to God would be distinct from the one of living believers. Different from their situation in 11:13-16, and assuming that the immaterial soul or spirit would be the essence of their humanity, these deceased believers would be ontologically present in the promised heavenly city and have literal access to God there, while living believers would still long to be ontologically there (13:14), having only a mental access probably through hope and prayer (see $4: 16 ; 6: 19-20 ; 9: 19 ; 12: 22-24)$. This argument is different from Scholer's artificial distinction between deceased believers being made perfect now, and receiving only at the end the eschatological promise of rest with living believers. See Scholer, Proleptic Priests, 200-201. In his remarks on 12:22-24, Cortez suggests that, "by referring to and using Scripture as God's own speech in his exposition, the author of Hebrews has constructed a world in which the audience stands at Mount Zion where they hear God speak and, hence, witness the enthronement of the Son, his appointment as high priest, and the inauguration of the new covenant." Cortez, "“The Anchor of the Soul That Enters Within the Veil'," 444. If this suggestion is sound, my point here is that believers have mental (through hope and prayer) access to this world. Therefore, taking into account these implications of point 3 , I suggest this point misreads the anthropological picture of Hebrews. According to these implications, I suspect that if the author and the audience of Hebrews shared the presupposition that an immaterial entity (soul or spirit) is the essence of the human being, the author would have framed chapter 11 (especially 11:13-16, 35, 39-40) in a different way. In my view, a more natural reading of Hebrews suggests the following elaboration of point 3: The believers of chap. 11 did not benefit from Christ's work as living believers do and they did not receive the promises (11:13-16; 39-40). Deceased believers are not disembodied spirits after death, but wait for a future resurrection (11:35, Koester seems to interpret 11:3940 in terms of resurrection. See Koester, Hebrews, 520-521) to live again and have access to God (attain perfection) in the promised heavenly city along with living believers, who already experience on earth this access non-ontologically on the basis of Christ's ascension. Accordingly, the spirits made perfect in 12:2224 are probably another description of the church or congregation ( $\left.\varepsilon x \lambda \lambda \eta \sigma^{\prime} \alpha\right)$ of "the firstborn who are enrolled in heaven" (12:23). These parallel descriptions refer to believers (as persons) in general, who benefit from the work of Christ. However, the expression "you have come" ( $\pi \rho \circ \sigma \varepsilon \lambda \eta \lambda u$ $\theta a \tau \varepsilon, 12: 22)$ depicts a non-ontological access and presence of believers in the heavenly city. This point is compatible with Cockerill's idea that the contrast between Sinai (12:18-21) and Zion (12:22-24) in 12:18-24 is not "a simple contrast between the old and the new religious orders, or between the times before and after Christ." Rather, the contrast is between "belief and unbelief, with apostasy and faithfulness, with judgment and blessing." Cockerill, The Epistle to the Hebrews, 643. Following this interpretation, my suggestion is that Zion in 12:22-24 is not an ontological or temporal description, but a mental possibility for living believers (pointing to the final salvation), just as Sinai (in the way it is described in this context) is also a possibility for them in the sense of judgment. Does this congregation or group of righteous people (spirits) include deceased believers? As far as this is not an ontological description in the present, it is rhetorically, and perhaps proleptically, possible. In terms of rhetoric, notice how the author of Hebrews, as he deals with past and present realities, employs figurative language for situations somehow related to death in chapters 11-12: (1) although dead, Abel still speaks through the faith expressed by the sacrifice he offered (11:4) (see ibid., 527n35, 37); (2) the blood of Christ speaks something better than Abel (12:24) (see ibid., 659); (3) Isaac was resurrected figuratively or as a parable ( $\pi a p a \beta 0 \lambda \tilde{\eta})$ when Abraham offered up him (11:19); (4) the believers of chap. 11 are portrayed as a great cloud of witnesses that surround the audience of Hebrews, as this audience runs the race of the Christian life (12:1). In terms of proleptic language, the rhetorical portrayal of a present reality can use images of a future reality. Lane seems to interpret the assembly in 12:23 as an eschatological reality. Lane, Hebrews 9-13, 649. 
its functions, ${ }^{292}$ I will move to the discussion of Christological anthropology in Hebrews. $^{293}$

\section{Christological Anthropology}

The notion that human nature is grounded in the body and its functions indicates that Christ's human nature should not be conceptualized in terms of His body being instrumental to an alleged immaterial being (soul or spirit). Likewise, the presupposition that God is not a timeless-spaceless being implies that the humanity of Christ was not needed as a spatio-temporal instrument of His divinity. In this way, Christ did/does not experience spatio-temporal events through His human nature, but as a divine-human being. Therefore, the concept that human nature is grounded in the body and its functions implies that Christ's human nature is essential (not instrumental) to (1) His incarnate life and death and to (2) His incarnate life and the heavenly priesthood. My next step is to articulate this implication from the Christological anthropology of Hebrews.

Incarnate life and death

As a matter of fact, in its more explicit Christological anthropology, Hebrews emphasizes Christ's mortal humanity ${ }^{294}\left(2: 9^{295}\right)$, more precisely, a humanity for

\footnotetext{
${ }^{292}$ This reflection is clearly different from Schenk's view that Hebrews assumes a dichotomous understanding of the human person, where the body (transitory hindrance) is innately inferior to the spirit (potentially eternal). See Schenck, Cosmology and Eschatology in Hebrews, 133-139, 143.

${ }^{293}$ For a recent study on the humanity of Christ in Hebrews, which focuses on His resurrected humanity, see Moffitt, Atonement and the Logic of Resurrection in the Epistle to the Hebrews. Moffitt is particularly critical of a dualistic (body, spirit) interpretation of the ontology of Christ's glorified humanity. See ibid., 178-179, 302.

${ }^{294}$ Assuming a simple (not composite) ontological singularity of Christ as a divine-human being, the incarnate God experienced death at the cross. Christ's divinity did not die, as it did not cease to exist (cf. Heb 1:10-12; John 10:17-18). In a mysterious way, His divinity experienced death, but not in the sense of ceasing to exist.
} 
${ }^{295}$ The Christological anthropology of Heb 2 seems to indicate that Christ's incarnation made Him lower than angels (2:9). This passage elaborates on the quotation of Ps 8:5-7 LXX (8:4-6 ESV) in vv. 6-8. According to 2:7, man ( $\ddot{\alpha} \nu \rho \omega \pi \circ \varsigma, 2: 6)$ was made a little lower or for a little while lower than the angels

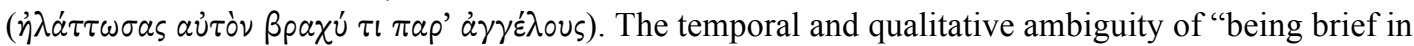
duration" (little while) or "being low in quality" (little) expressed by the adjective $\beta$ paxú (see BDAG, 183) seems to play a role in the Christological reading of 2:9, which points out that Jesus was made a little lower

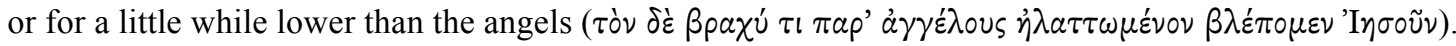
While NIV prefers the rendition "a little lower," other translations opt for "a little while lower" (NASB, NRSV, NET, ESV). Overall, the language of being lower does not seem to allude to an ontological hierarchy of being, where the human being is in itself ontologically lower than the angelic being. The point is not primarily ontology, but honor. This idea is incompatible with Cockerill's position, who implicitly maintains an ontological distinction for the language of lower and higher. Cockerill, The Epistle to the Hebrews, 132-133. In contrast to Cockerill, Ellingworth and Johnson interpret the lowering of 2:9 in terms of mortality rather than incarnation. See Ellingworth, The Epistle to the Hebrews, 154; Johnson, Hebrews, 91. As it will become evident below, my point about honor is consistent with lowering in terms of mortality, assuming that the death and suffering of Christ describe His humiliation. As a matter of fact, the incarnate Christ was for a little while lower than angels changed because He was "crowned with glory and honor" after His death (2:9). This coronation made Christ "much better than the angels" (1:4 NASB). Assuming that the coronation implies His resurrection, it was Christ as a human being that became lower than angels, and it was also Christ as a (resurrected) human being that became higher than angels. Being God, Christ was always superior to the angels from an ontological standpoint. "He is the radiance of the glory of God and the exact imprint of his nature, and he upholds the universe by the word of his power" (1:3). He is the creator $(1: 10,2)$ and eternal (1:11-12) God. However, as a human being, Christ was lower (incarnation) and then higher (ascension) to the angels, not from an ontological standpoint, but from the perspective of a position of honor. Thus, it is not the possession of human nature by itself that determines whether someone is lower or higher than angels. Rather, Christ became superior because of a higher kingly position of honor. Conversely, He was previosuly made lower than the angels in the incarnation presumably because, in God's creation, human beings occupy a lower position of honor in comparison with the angels (2:7). I am reading 2:7 anthropologically and then Christologically (in light of 2:9). If 2:7 is read only Christologically, then perhaps it could be said that Christ was made lower than angels in terms of His mortal humanity (see the comments on 2:14 below). In an anthropological reading, it would make no sense to interpret that God made human beings lower than angels in terms of their mortal humanity, since God did not create human beings for mortality (see Gen 1-2). In any case, if 2:7 is read anthropologically and Christologically or read only Christologically, the reason for making Christ higher than angels (in light of chap. 1) is not related to a glorified state of His body, but to His crowning with glory and honor because of His death (2:9). Again, the point here is the position of honor, and not an ontological status of the human body. While the changes of becoming lower and higher take place in the realm of honor rather than of ontology, theses changes do result from ontological events, namely, lowering incarnation, suffering death, and exalted ascension. In fact, His suffering death could be seen as the center of these ontological events, as Christ became incarnate in order to "taste death" and became higher than angels in the coronation "because of the suffering of death" (2:9). In context, the passage reads, "But we see him who for a little while was made lower than the angels, namely Jesus, crowned with glory and honor because of the suffering of death

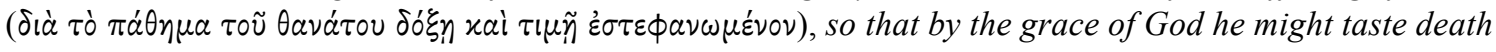

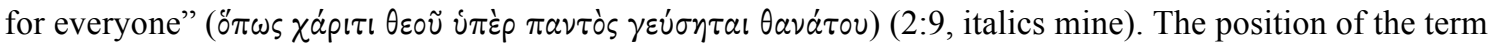
ö $\pi \omega \varsigma$, which associated with the subjunctive verb $\gamma \varepsilon \dot{\sigma} \sigma \eta \tau \alpha$ ( to taste or come to know, BDAG, 195) indicates

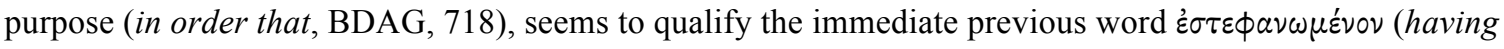

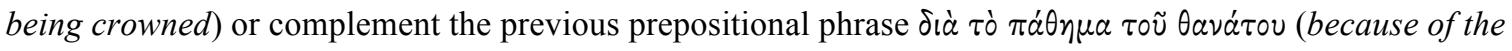
suffering of death). See Attridge, The Epistle to the Hebrews, 76. See also Cockerill, The Epistle to the Hebrews, 134n46; Ellingworth, The Epistle to the Hebrews, 155. Considering these possibilities, Attridge suggests that the clause initiated by " $\pi \omega$ s "relates to the whole of what precedes and indicates the basic purpose of the savior's mission that culminates in his death and exaltation." Attridge, The Epistle to the Hebrews, 76. In short, all these remarks point to the idea that Christ's suffering death was the main goal of 
(sacrificial) death $\left(2: 14^{296} ; 10: 5-9^{297}\right) .{ }^{298}$ In His humanity for death, test/temptation and

the incarnation, as the incarnation was the ontological ground for His suffering death.

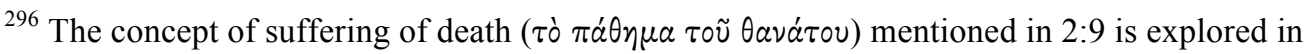

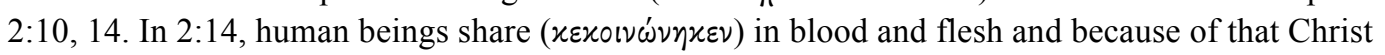
"likewise partook ( $\mu \varepsilon \tau \varepsilon \dot{\varepsilon} \sigma \chi \varepsilon \nu)$ of the same things." The difference between human beings in general and

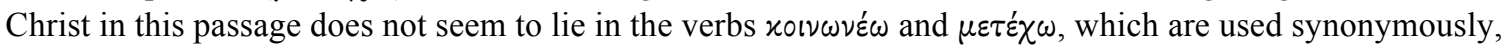

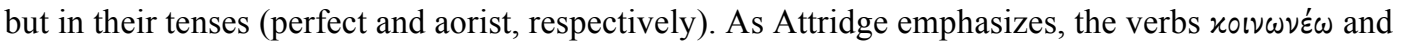
$\mu \varepsilon \tau \dot{\varepsilon} \chi \omega$, which respectively describe human beings sharing in flesh and blood and Christ partaking in flesh and blood, are used synonymously. See the parallel use of these Greek terms in Prov 1:11, 18 (LXX); 1 Cor 10:17-21; 2 Cor 6:14. Attridge, The Epistle to the Hebrews, 91. Furthermore, the adverb $\pi \alpha \rho a \pi \lambda \eta \sigma^{\prime} \omega \varsigma$ (meaning likewise) that immediately precedes $\mu \varepsilon \tau \varepsilon \dot{\sigma} \chi \varepsilon \nu$ "itself does not show clearly just how far the similarity goes. But it is used in contexts where no differentiation is intended, in the sense in just the same way." BDAG, 770. Cockerill classifies the aorist $\mu \varepsilon \tau \varepsilon \dot{\sigma} \chi \varepsilon \nu$ as ingressive (began to partake), minimizing its

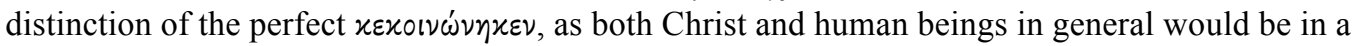
continuous state of partaking/sharing of blood and flesh. Cockerill, The Epistle to the Hebrews, 147n105. The argumentation that follows indicates that I do not subscribe to Cockerill's position. Rather, my suggestion is that the expressions "blood and flesh" (2:14) and "in the days of his flesh" (5:7) do not merely describe the incarnation. Rather, they emphasize His passion, as they are used in direct relationship to His

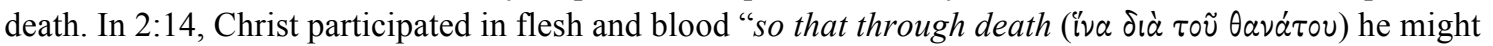
destroy him having the power of death" (NRSV, italics mine). In 5:7, "the days of His flesh" refer particularly to when His "prayers and supplications, with loud cries and tears," addressed the "one who was able to save him from death" (italics mine). In other words, these passages do not simply highlight His humanity, but His mortal humanity. As Attridge indicates regarding 5:7, "the 'days of his flesh' or 'his fleshly (i.e., mortal) days." Attridge, The Epistle to the Hebrews, 149; italics mine. From a canonical perspective, this interpretation is similar to the idea of perishable body that is contrasted to a resurrected imperishable body in 1 Cor 15:50-54 (see footnotes below). The language of partaking of blood and flesh (Heb 2:14) and of the "days of His flesh" (Heb 5:7) seem to point to Christ's mortal or perishable humanity (focus on His death). Therefore, from this perspective, the use of the aorist (partook of blood and flesh) in 2:14 and the temporal qualification (in the days of His flesh) in 5:7 is better understood in the context of Christ's mortal or perishable humanity.

${ }^{297}$ This passage qualifies Christ's human nature as a humanity for sacrificial death by quoting Ps 40:6-8 (39:6-8 LXX). The most important difference between the psalm and Hebrews is that the latter uses

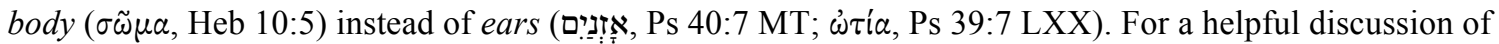
the difference with the LXX, see Cockerill, The Epistle to the Hebrews, 435-436. Cockerill stipulates that " "ears you prepared for me' fits the context well. However, it is probable that another [LXX] translator took 'ears' as a metaphor in which the part stood for the whole, 'ears' for the entire 'body,' which God 'prepared as a vehicle of obedience." The author of Hebrews "could have built his case on the more literal translation which would have been in full agreement with the obedience of the Son. However, 'body' allowed him to tie this obedience more readily to the incarnation and final offering of Christ's 'body' on the cross." Ibid., 436. In Heb 10:5, Christ spoke the words of the psalm "when He came into the world (xó $\mu$ rov)." According to Cockerill, "'as he was coming into the world,' or, perhaps, 'as he was about to come into the world,' pinpoints the eve of the incarnation as the occasion when Christ spoke these words." This expression echoes the "Behold, I have come" from v. 7 of the psalm quoted in 10:5." Ibid., 434. Likewise, Lane stipulates that the expression "“when he comes into the world,' is distinctly 'incarnational' language." Lane, Hebrews 9-13, 262. This Christological speech contrasts the body prepared for Him and the sacrifices and offerings $(10: 5-6,8)$ of the Aaronic priesthood (implied in 10:1-4). In this contrast, Christ came to do God's will $(10: 7,9)$. Cockerill emphasizes that "the obedience of Christ described in Ps 40:68," as used in Heb 10:5-9, "is the means by which the old, ineffective system is removed (Heb 10:8) and 
the new system of heart obedience is established (Heb 10:9). Thus this psalm is the turning point that enables the pastor to move from his initial explanation of Jer 31:31-34 in 8:7-13 to his final reiteration of this prophecy in 10:15-18." Cockerill, The Epistle to the Hebrews, 441. Indeed, the incarnation is an act for obedience, as Christ came to the world to do God's will, and the offering of Christ's body (His sacrificial death) defines His obedience (10:10). In 13:11-12, the body of Christ is implied in His bloody suffering outside the gate (the word $\sigma \omega \mu \alpha \tau \alpha$ appears in 13:11). Similar to 10:10, the language of sanctification through this sacrifice $(\dot{\alpha} \gamma / \dot{\alpha} \sigma \eta \delta \dot{\alpha})$ is used. The linkage between these two passages is important because they are the two instances where $\sigma \tilde{\omega} \mu \alpha$ is used for Christ in Hebrews, explicitly $(10: 5,10)$ and implicitly

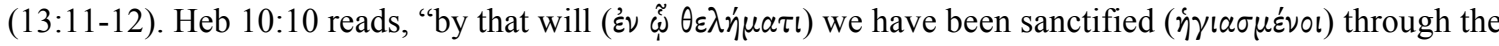

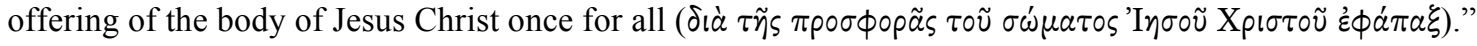
As Cockerill maintains, this offering gives specificity to the will of God in this verse. Ibid., 443. All these remarks point to the idea that Christ's obedience and humanity/body are conceptualized in the context of

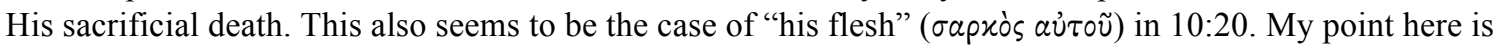
that His flesh is seen in the context of His sacrificial death. For a helpful discussion of the possibilities

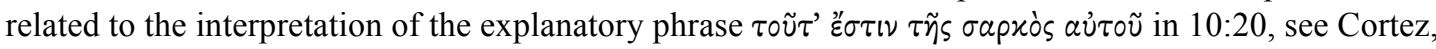
"The Anchor of the Soul That Enters Within the Veil'," 415-419. In short, he firstly indicates that the

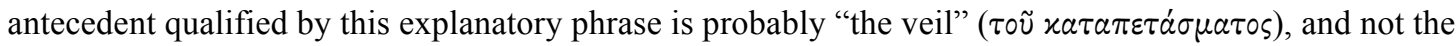

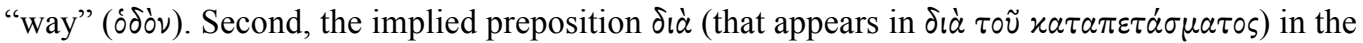
explanatory phrase is both locative ("through the veil, that is, through His flesh") and instrumental ("through the veil, that is, by means of His flesh"). In his words, "The locative sense of $\delta i \dot{\alpha}$, identifies the 'veil' as the point of access to the presence of God; a meaning that is, in fact, because of the image, analogous to the instrumental. The veil as a point of access (locative) is in an analogous sense a means of access as well (instrumental). Admittedly, there is a progression in the meaning of the preposition, but this is something that we should expect from the use of metaphorical images. Thus, we should understand this expression in the following way: "by the new and living way that he opened for us through the curtain, that is, [by means] of his flesh.” Ibid., 419. In agreement with my discussion of the macro-hermeneutical principles of reality regarding the notion of Christ's flesh and blood, the instrumentality of the blood of Christ in 10:19 paralells the instrumentality of the flesh in 10:20, and the instrumentality of His flesh and blood refer to His sacrificial death as the means by which believers enter the heavenly sanctuary.

${ }^{298}$ Compare the footnote above on 2:14 with the contrast between perishable and imperishable body in 1 Cor 15:50-54. The contrast indicated here assumes a synonymous parallelism in the passage. More specifically, "Paul is not using synthetic parallelism that introduces a further thought ('flesh and blood' = the living; 'corruptible' = the dead), but synonymous parallelism ('flesh and blood' = 'corruptible') to refer to the condition of physical human existence. The first assertion, that flesh and blood cannot inherit the kingdom of God, is explained by the second in ways that any Greek reader could understand. 'Flesh and blood' represents what is corruptible, and what is corruptible cannot stake a claim on what is incorruptible." David E. Garland, 1 Corinthians, Baker Exegetical Commentary on the New Testament (Grand Rapids, MI: Baker Academic, 2003), 741. Garland indicates (see ibid., 741n1) that this synonymous parallelism is affirmed by R. Morissette, "La chair et le sang ne peuvent hériter du Règne de Dieu' (1 Cor. xv,50)," Science et esprit 26 (1974): 46-48 (article pages 39-67); H. Conzelmann, 1 Corinthians, translated by J. W. Leitch, Hermeneia (Philadelphia: Fortress, 1975), 290n10; G. D. Fee, The First Epistle to the Corinthians, New International Commentary on the New Testament (Grand Rapids, MI: Eerdmans. 1987), 798; B. Witherington III, Conflict and Community in Corinth: A Socio-Rhetorical Commentary on 1 and 2 Corinthians (Grand Rapids: Eerdmans, 1995), 310; C. Wolff, Der erste Brief des Paulus an die Korinther, Theologischer Handkommentar zum Neuen Testament 7 (Berlin: Evangelische Verlagsanstalt. 1996), 414; R. F. Collins, First Corinthians, Sacra Pagina 7 (Collegeville, MN: Liturgical Press, 1999), 579; J. R. Asher, Polarity and Change in 1 Corinthians 15: A Study of Metaphysics, Rhetoric, and Resurrection, Hermeneutische Untersuchungen zur Theologie 42 (Tübingen: Mohr, 2000), 153-54; W. Schrage, Der erste Brief an die Korinther (1 Kor 15, 1-16, 24), Evangelisch-katholischer Kommentar zum Neuen Testament 7/4 (Zurich: Benziger/Neukirchen-Vluyn: Neukirchener Verlag, 2001), 366. On the other hand, the synthetic parallelism is defended by F. L. Godet, Commentary on the First Epistle of St. Paul to 
suffering were part of His life, but these experiences reached their climax in His death. ${ }^{299}$ In the context of test/temptation and suffering, ${ }^{300}$ the incarnate Christ developed

the Corinthian, vol. 2: Chapters 9-16, translated by A. Cusin (Edinburgh: Clark, 1887), 434; J. Jeremias, "Flesh and Blood Cannot Inherit the Kingdom of God," New Testament Studies 2 (1995-1956), 152. With regard to the ideas of perishable and imperishable body in 1 Cor 15:50-54, Paul introduces his argument in 1 Cor 15 by emphasizing Christ's death, burial, and resurrection (vv. 3-4). Then, he explains how the resurrection of Christ is related to the future resurrection of deceased believers (vv. 12-23). Before he moves to the discussion of the resurrected body, Paul's remarks about the reign of Christ and His campaign against enemies, especially against death as the last enemy (vv. 24-28), are similar to the ideas presented in Hebrews about Christ as king subjugating enemies (Heb 1:13, 2:8; 10:12-13) and defeating the power of death (Heb 2:14-15). Regarding the resurrected body of deceased believers (vv. 35-49), Paul contrasts the present human body (before or at death-Paul employs here the language of sowing [verb $\sigma \pi \varepsilon i p \omega]$. While this language emphasizes the dead [see 15:35-36], the concluding statements of this discussion indicate that the bodies of living believers are also included [see 15:52-53]) and the resurrected body by employing the

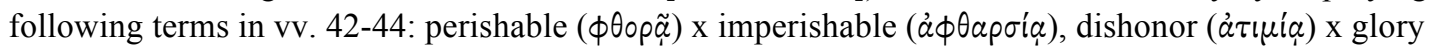

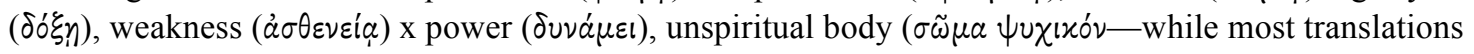
render $\psi u \chi$ ¿xóv as natural [ESV, NASB, NIV, YLT, NET], the term in 1 Cor 14:44 conveys more precisely the idea of unspiritual [BDAG, 1100]. See the use of $\psi$ uxixós in 1 Cor 2:14 [reference to someone who "does not accept the things of the Spirit of God"], James 3:15 [described as something that does not come from above and associated with the idea of earthly and demoniac], and Jude 19 [describes someone "devoid of the Spirit"]) x spiritual body ( $\left.\sigma \tilde{\omega} \mu \alpha \pi \nu \varepsilon v \mu \alpha \tau \iota x^{\prime} \nu\right)$. Toward the conclusion of this discussion, Paul points out that "flesh and blood ( $\sigma \dot{\alpha} \rho \xi$ xai aĩ $\mu \alpha)$ cannot inherit the kingdom of God, nor does the perishable

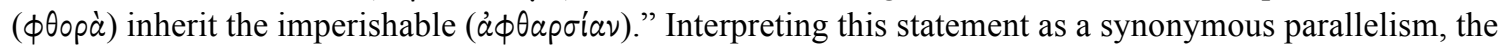
language of flesh and blood is used in the sense of a perishable body, that is, it relates to death. This idea is confirmed by the eschatological event when "the dead will be raised imperishable" and living believers "shall be changed" (15:52). For both living and deceased believers, the perishable will put on the imperishable, meaning that the mortal will put on immortality (15:53-54). Therefore, the language of flesh and body in 1 Cor 15:50 conveys the idea of a perishable or mortal body, as it relates to death. It is also plausible, in light of 1 Cor 11:23-26, that the language of eating Christ's flesh and blood in John 6:51-56 refers not merely to His humanity, but to His mortal humanity, with special reference to His death (in the

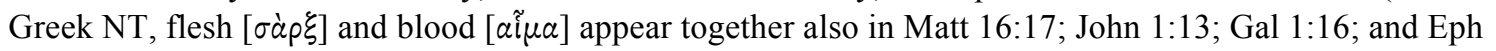
6:12). Hence, in these contexts, blood and flesh are not merely elements of the human body, but they portray a body that faces death.

${ }^{299}$ It is possible to discern in Hebrews both a more focused and a broader perspective of Christ's experience of temptation. Since the notion of His suffering $(\pi \dot{\alpha} \sigma \chi \omega)$ in Hebrews is related to His death (see $2: 9-10 ; 5: 7-8 ; 9: 26 ; 13: 12$ ), His suffering death is the event of His test/temptation. On the other hand, 4:15 provides a broader perspective in which Christ has been tested/tempted "in all things as we are, yet without

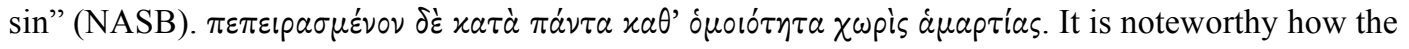
language of a broader perspective of His humanity in 2:17 is similar to the language of a broader perspective of His test/temptation in 4:15. The expression xatà $\pi \dot{\alpha} \nu \tau \alpha$ appears in both passages, and same

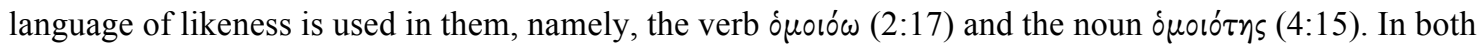
perspectives, the test/temptation of Christ enabled Him to be merciful (2:17) or sympathetic (4:15) toward human beings.

${ }^{300}$ In 2:18, His test/temptation is qualified in terms of suffering. "For because he himself has

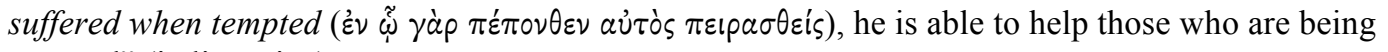
tempted" (italics mine). 
something new both in relation to human beings, namely, mercy $(2: 17)$ and sympathy $(4: 15),{ }^{301}$ and in relation to God the Father, in terms of learned obedience $(5: 8){ }^{302}$ This is not to say that Christ could not have been already merciful and sympathetic toward human beings before the incarnation. The point here is that the incarnate Christ developed these attitudes on a new level because He experienced test/temptation and suffering now as a divine-human being (not through a human nature).

One of the main ideas highlighted by the Christological concept of humanity for (sacrificial) death in Hebrews is the identity of the incarnate Christ with human beings, particularly in His death. Because of the incarnation, Christ was able to "taste death for everyone" (2:9). Due to His anthropological participation in mortal humanity $(2: 14)$, He is a brother of believers $(2: 11-12,17)$. Therefore, Christ's humanity was essential for His sacrifice on the cross, in the sense that this was a real human ${ }^{303}$ sacrifice on behalf of the human family. In other words, His humanity is crucial for the identification of His sacrifice with human beings.

The next point to be described is Christ's incarnate life and His heavenly priesthood.

${ }^{301}$ The test/temptation of Christ enabled Him to be merciful $(2: 17)$ or sympathetic $(4: 15)$ toward

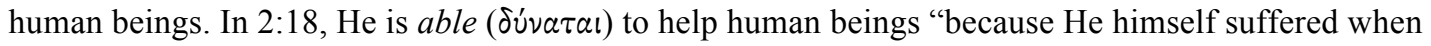

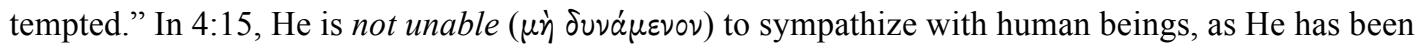
tempted in all things.

302 The concepts of temptation and learned obedience are two related notions in the Christological anthropology of Hebrews. Similar to the idea of becoming enabled in temptation and suffering, the notion of learned obedience from what He suffered indicates that Christ developed something new (learned obedience) in relation to God Father. Although the language of test/temptation is not employed in 5:7-8, the notion of suffering (5:8) and death (5:7) is present there. In Christ's incarnate experience, He had to show

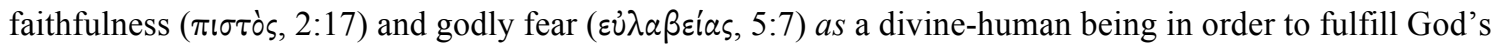
will. This was a new experience for Him, in comparison with His divine life before the incarnation.

${ }^{303}$ To be sure, Christ's sacrifice was a divine-human sacrifice. But I am just emphasizing here that 


\section{Incarnate life and heavenly priesthood}

Just as the humanity of Christ was an essential ontological ground for His earthly

life, especially characterized by temptation, suffering, and death; His resurrected

humanity ${ }^{304}$ is also a crucial ontological ground for His heavenly life and priesthood.

The language of "the power of an indestructible life" (7:16) appears to point to His

resurrection ${ }^{305}$ (cf. 13:20) in a glorified or imperishable human body. ${ }^{306}$ This resurrected

the sacrifice was truly human.

${ }^{304}$ Although I affirm the glorification of Christ's resurrected humanity (as it will become evident below), I do not subscribe to Vanhoye's idea of Christ's teleoisis (His priestly consecration/perfection) as the transformation of His humanity in His sacrifice and manifested in His resurrection. In Vanhoye's perspective, the idea of perfection in Hebrews is described as the recreation of a human being according to the plan of God. According to Vanhoye's explanation of Christ's teleoisis, there was "a real transformation of his flesh and blood nature. ... a sacrifice which took over his whole being so as to open it up to the recreative action of God, and which introduced his renewed humanity into eternal intimacy with God." Vanhoye, Old Testament Priests and the New Priest, 166-167. This conception is consistent with Vanhoye's notion of sacrifice as transformation, more specifically a transformation of the creature "by imparting to it the divine holiness." Ibid., 198. According to this understanding, the primary idea conveyed by the concept of sacrifice is not an action that offers something to God (God as the recipient of the action, perhaps in terms of the propitiation of His wrath), but rather an action performed by God (God as the subject of the action, His transformation of the human being). For further explanation about Vanhoye's understanding of the transformation of Christ's humanity as the key point of His sacrifice and priestly consecration (teleiosis), see ibid., 83, 157, 194, 197, 167-168, 180, 187, 197-198, 205, 219.

${ }^{305}$ This idea is different from Cockerill's interpretation of Christ's indestructible life as a reference to His eternal divinity, and not as pointing to His resurrection. Cockerill, The Epistle to the Hebrews, 323324. Other scholars, however, interpret this language of imperishable life in the context of Christ's resurrection, as the emphasis of Hebrews is on His exaltion. See Koester, Hebrews, 355; Lane, Hebrews 1 8, 184; Moffitt, Atonement and the Logic of Resurrection in the Epistle to the Hebrews, 42, 148; Vanhoye, Old Testament Priests and the New Priest, 162. In his survery of Christ's resurrection in Hebrews in the secondary literature, Moffitt outlines the following views: (1) the resurrection is not central for the author, who focuses on the death and exaltation (e.g., F.F. Bruce, P. Ellingworth, B. Westcott, W. Lane, A.

Vanhoye); (2) the resurrection as spiritual ascension (Christ ascended immediately to heaven after His death) (e.g., H. Windisch, O. Hofius, J. Jeremias); (3) the relationship between resurrection and exaltation is unclear (e.g., W. Loader, C. Koester, H. Weiss); (4) the resurrection is completely conflated with the exaltation (e.g., E. Grässer, D. Hay, U. Kellermann, R. Nelson, K. Schenck, J. Thompson); (5) there is no resurrection in Hebrews (e.g., H. Attridge, G. Bertram, H. Braun, E. Käsemann). See Moffitt, Atonement and the Logic of Resurrection in the Epistle to the Hebrews, 4-41. Moffitt considers that these views are insufficient treatments of Christ's resurrection in Hebrews, and suggests that they all wrongly assume that the cross is "the act of sacrifice," implying that the heavenly exaltation is only a clarification of "the spiritual significance of the cross." Ibid., 41.

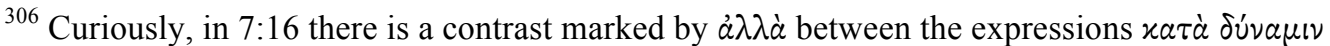

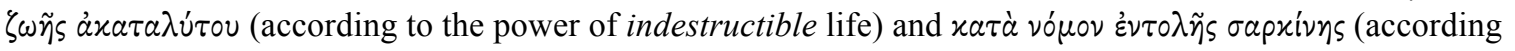


and everlasting life constitutes the ground for Christ's ongoing heavenly intercession on behalf of believers $(7: 24-25)$.

Once again, the notion of identification with human beings is central to the humanity of Christ. The earhly life of the incarnate Christ was essential for His heavenly priestly mercy and sympathy toward human beings (2:17; 4:15; cf. 5:1-2), as He intercedes for them before the Father in heaven $(2: 17 ; 7: 25 ; 9: 24)$. In fact, His identification with human beings is not only significant for His attitude toward them, but also for His mediation before the Father. To be more specific, He presented in heaven His sacrificial offering before the Father and continuously intercedes for human beings as the representative of the human family. As the human representative of His brothers (cf. 2:17), the incarnate Christ is worthy (cf. 3:3) to be heard by the Father, since He is described as faithful to the Father $(2: 17 ; 3: 2)$. This faithfulness was probably developed in His learned obedience in the context of suffering (5:7-8; cf. 10:7, 9). Hence, this conception of human representation seems to be essential for the Father's acceptance of Christ's heavenly offering and intercession on behalf of human beings.

\section{Summary}

In summary, the general anthropology of Hebrews assumes that the inner human nature is not defined by an immaterial entity (soul/spirit) secondarily accompanied by a body. Rather, the essence of human nature is necessarily grounded in the body and its

to the law of the fleshly ordinance). As I have emphasized the words in italics, the adjectives $\alpha x a \tau a \lambda u^{\prime} \tau o v$ (indestructible) and $\sigma a p x i v \eta s$ (fleshly) form a contrastive parallel in this sentence. See Cockerill, The Epistle to the Hebrews, 323. In the context of Heb 7:11-28, in contrast to the sequential Aaronic priests who were prevented from continuing their office because of their mortality $(7: 23)$, that is, their perishable humanity, Christ's indestructible life means that He holds a permanent priesthood (7:24). 
functions. By implication, Christ's human nature is not conceived as an immaterial being with a spatial instrumental body. Likewise, because the divine nature is not timelessspaceless, Christ's humanity is not a spatio-temporal instrument of His divinity.

Accordingly, He does/did not experience spatio-temporal events through His human nature, but as a divine-human being.

Instead of being defined in terms of spatio-temporal instrumentality for Christ's

divinity, His humanity is essential for the sacrifice on the cross and for Christ's heavenly priesthood. This essentiality focuses on the identification of the incarnate Christ with the human family. In other words, His mediation on behalf of human beings is real because He is able sympathize with them as one of them. Furthermore, His sacrifice is truly a human sacrifice and, therefore, it is really on behalf of human beings. Likewise, the heavenly presentation of His sacrifice before the Father and His oingoing intercession is truly performed in favor of human beings, as the incarnate Christ is one of them in terms of His humanity.

The remarks above reveal that Christ's humanity is crucial for the interpretation of His priesthood, as His earthly sacrifice and heavenly priesthood revolve around and assume the incarnation. The idea of human nature as essential, not instrumental, to Christ's priesthood is consistent with a spatio-temporal sequence of the priestly work that involves earth and heaven, as described by the historical model. My next step is to describe the cosmology of Hebrews, which is the last principle of reality to be depicted in the present research.

Cosmology: Christ, Heaven, and Earth As mentioned above, the priesthood of Christ in Hebrews implies a spatio- 
temporal sequence that involves earth and heaven. In this section on cosmology, I will focus on the ontological reality of earth and heaven from the perspective of spatiotemporality.

Hebrews assumes a dynamic relationship of Christ with heaven ${ }^{307}$ and earth: ${ }^{308}$ (1) He is their creator $(1: 10) ;^{309}$ (2) He came to this earthly world ${ }^{310}$ in His incarnation $(10: 5) ;(3)$ after His resurrection $(13: 20 ; 7: 16)$, He ascended to heaven $\left(1: 6^{311} ; 4: 14\right.$; 9:24); (4) while He is in heaven (8:1-2), He has influence on believers on earth (see, e.g., 13:21), and because of Him they have a spiritual non-ontological access to God in heaven $(4: 16 ; 6: 19-20 ; 10: 19-21 ; 12: 22)$; and $(5)$ He will come from heaven to appear a second time on earth to save believers $(9: 28) .^{312}$

${ }^{307}$ The terminology for heaven in Hebrews includes the singular $(9: 24 ; 11: 12 ; 12: 26)$ and plural $(1: 10 ; 4: 14 ; 7: 26 ; 8: 1 ; 9: 23 ; 12: 25)$ forms of the noun oủpavós, and is related to the adjective émoupávios (heavenly) $(3: 1 ; 6: 4 ; 8: 5 ; 9: 23 ; 11: 16 ; 12: 22)$. Among its lexical meanings, the noun oúpavós conveys the idea of sky or transcendent heaven. BDAG, 738. For the lexical meanings of દ̇moupávios, see BDAG, 388.

${ }^{308}$ Not all of the eleven occurrences of the noun $\gamma \tilde{\eta}$ (earth) in Hebrews have a cosmological connotation. Some of its occurrences describe land (land that receives rain, 6:7; the land of Egypt, 8:9; the land of promise, 11:9; dry land, 11:29). But when this noun appears along with the terms oúpavós (heaven)

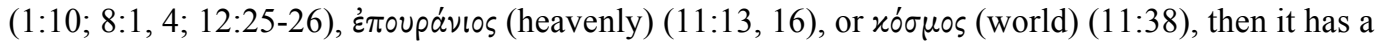
cosmological connotation and is properly translated as earth. For the possible lexical meanings of $\gamma \tilde{\eta}$, see BDAG, 196.

${ }^{309}$ See also $\tau \dot{\alpha} \pi \alpha ́ v \tau \alpha$ in $1: 2$.

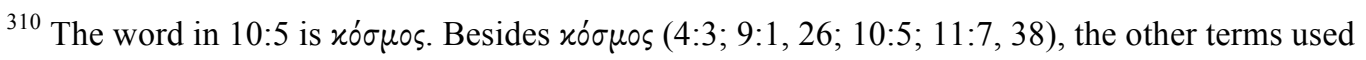

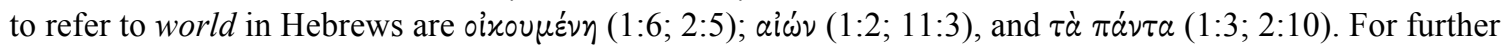
information about their lexical meanings, see BDAG, 32, 561, 699, 782.

${ }^{311}$ For the interpretation of this passage as a reference to Christ's ascension, see the last part of footnote 274 above.

${ }^{312}$ For studies on the cosmology of Hebrews, see Schenck, Cosmology and Eschatology in Hebrews; Edward Adams, "The Cosmology of Hebrews " in The Epistle to the Hebrews and Christian Theology, ed. Richard Bauckham, Daniel R. Driver, Trevor A. Hart, and Nathan MacDonald (Grand Rapids, MI: Eerdmans, 2009), 122-139; Jon C. Laansma, "The Cosmology of Hebrews," in Cosmology and New Testament Theology, ed. Sean M. McDonough and Jonathan T. Pennington (London: T\&T Clark, 2008), 125-143; Jon C. Laansma, "Hidden Stories in Hebrews: Cosmology and Theology," in Cosmology and New Testament Theology, ed. Richard Bauckham, Daniel Driver, Trevor Hart, and Nathan MacDonald 
In the present account of cosmology in Hebrews, this dynamic relationship of Christ with heaven and earth will be informed by three concepts: (1) the framework of eschatology, (2) the notion of heaven, and (3) the conception of heavenly sanctuary. I will start with the framework of eschatology.

\section{Framework: A Cosmological Eschatology}

As I have indicated in the discussion on Divinity above, 1:10-12 seems to point to an eschatological destruction of the earth and heavens (as we know them) by the action of the Lord. ${ }^{313}$ According to 1:11-12, "they will perish," and the Lord "will roll them up."314 The author mentions the Lord's eschatological shaking of heaven and earth (12:26), and explains that created things are shaken or removed ${ }^{315}$ "in order that (iva) the things that cannot be shaken may remain ( $\mu \varepsilon^{\prime}(\nu)$ )" (12:27), namely, the divine kingdom that believers are receiving (12:28). ${ }^{316}$ Therefore, the distinction between created things being removed and the kingdom remaining is eschatological, as the context emphasizes the future divine judgment that has cosmological proportions (12:25-29). In other words, this distinction is

(London: T\&T Clark, 2008), 9-18; Ellingworth, "Jesus and the Universe in Hebrews," 337-350. See also Cockerill, The Epistle to the Hebrews, 24-34; Koester, Hebrews, 97-104.

${ }^{313}$ Cockerill and Adams interpret the reference to earth and heavens in this passage as encompassing the whole created order. Cockerill, The Epistle to the Hebrews, 112; Adams, "The Cosmology of Hebrews," 130.

${ }^{314}$ Elsewhere in the NT, the verb $\dot{\varepsilon} \lambda \dot{i} \sigma \sigma \omega$ (to roll up) is used in Rev 6:14 to describe an cosmological destruction in the context of the eschatological day of the divine wrath (see Rev 6:16).

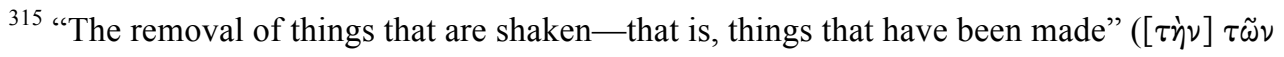

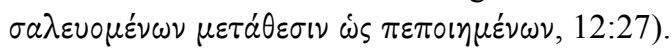

${ }^{316}$ The author quotes Hag 2:6 in 12:26. Then, he indicates that believers are "receiving a kingdom

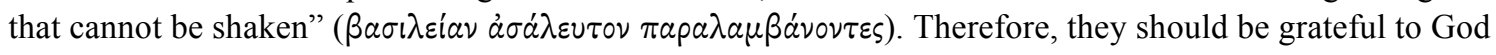
$(12: 28)$. 
not ontologically static but historically dynamic. ${ }^{317}$ In this eschatological or historical dynamics, what remains is what it is to come. ${ }^{318}$ In the context of God's future judgment, the present creation will give place to the enduring divine kingdom (12:26-28).

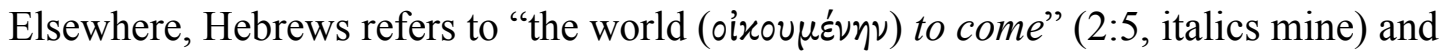
"the age (ai $\tilde{\nu} \circ)$ ) to come" (6:5, italics mine). While the epistle does not use the language of new creation to refer to the replacement of the present creation by the enduring divine kingdom, ${ }^{319}$ God is the one who prepared ${ }^{320}$ the city $(11: 16)$ expected by the believers in Heb $11{ }^{321}$ In this sense, God makes a new creation to replace the old creation. ${ }^{322}$

${ }^{317}$ This dynamism is evident in the telic sequence implied by the use of the conjunction iva in 12:27: the created things being shaken are removed so that (iva) what is not shaken may remain.

${ }^{318}$ The verb $\mu \varepsilon^{\prime} v \omega$ (remain) appears elsewhere in Hebrews in a similar context in 13:14. In that passage, the author highlights that "here we have no lasting ( $\left.\mu \varepsilon^{\prime} v 0 v \sigma \alpha \nu\right)$ city, but we seek the city that is to come ( $\left.\mu \varepsilon^{\prime} \lambda \lambda_{0} \sigma \sigma \alpha \nu\right)$." According to the logic of this statement, there is a parallel between the verbs $\mu \varepsilon^{\prime} \nu \omega$ and $\mu \varepsilon \dot{\prime} \lambda \lambda \omega$.

${ }^{319}$ Some scholars believe that Hebrews stipulates a permanent removal of material creation. See Attridge, The Epistle to the Hebrews, 381; Marie E. Isaacs, Sacred Space: An Approach to the Theology of the Epistle to the Hebrews (Sheffield: Sheffield Academic Press, 1992), 65, 67, 82, 86; Schenck, Cosmology and Eschatology in Hebrews, 126-144. Others reject the interpretation of annihilation of creation and emphasize the idea of its judgment (Koester), cleansing (Laansma), and re-creation (Adams). See Koester, Hebrews, 103; Adams, "The Cosmology of Hebrews," 137-138; Laansma, "Hidden Stories in Hebrews," 13-14. Laansma sees Christ's bodily resurrection as a theological decisive indication that the created world will not be annihilated. Laansma, "The Cosmology of Hebrews," 129. Adams enumerates the following indirect evidence for a re-creation of the world in Hebrews: The Son is the heir of (1) all things (1:2), which means that there will be a cosmos in the eschaton to be inherited; Christ has/will have a future (2) universal reign (2:6-8); and the references to (3) the coming world (2:5) and (4) the city that is to come $(13: 14 ; 11: 10)$, which he relates to the New Jerusalem descending on the new earth in Rev 21:9-22:5. Adams, "The Cosmology of Hebrews," 138.

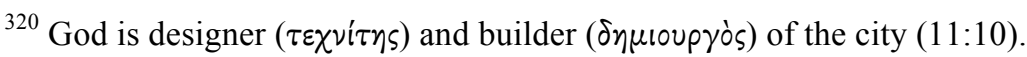

${ }^{321}$ The believers of Heb 11 "were strangers and foreigners on the earth" (11:13, NET). Noah even "condemned the world" ( $\tau \dot{\nu} \nu$ xó $\mu^{\circ} \nu$ ) by his reverent fear (11:7). The enduring divine kingdom seems to be alluded in the affirmation that these believers were seeking a heavenly country $(11: 14,16)$, the city prepared by God (11:16).

${ }^{322}$ It is possible to see a parallel between Hebrews and Rev 21:1-2, as the former has the concept of heaven and earth passing away (cf. with Rev 21:1) and the coming of a heavenly city (cf. with Rev 21:2) in the eschatological context of divine judgment (cf., e.g., with Rev 20:11-15). Rev 21:1 indicates that the heaven and earth that pass way $(\dot{\alpha} \pi \tilde{\eta} \lambda \theta a \nu)$ are the "first heaven and the first earth" ( $\dot{\delta} \gamma \dot{\alpha} \rho \pi \rho \tilde{\omega} \tau o s$ oujpavòs 
For the purposes of the present research, the most significant aspect of the cosmological eschatology of Hebrews is that the relationship between Christ and heaven and earth does not entail a vertical movement only, as the eschatological framework implies also a historical dynamics or a horizontal movement. ${ }^{323}$ The idea of a historical dynamics of the world is compatible with a historical sequence in Christology, since there was on earth a Christological historical dynamics of incarnation, life, death, resurrection, and ascension. ${ }^{324}$

In order to support a historical dynamics of events in heaven (especially after the ascension), I will explore below the concept of heaven in Hebrews, as this exploration prepares the ground for the ontological understanding of Christ in the heavenly sanctuary.

\section{Heaven in Hebrews}

A distinction seems to emerge when the occurrences of the terminology for heaven are examined in Hebrews. As mentioned above, for example, the removal of

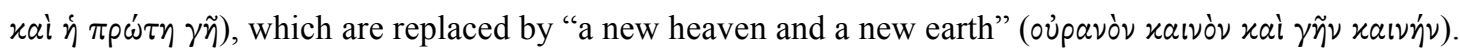
Moreover, Rev 21:2 adds that the holy city (New Jerusalem) comes down out of heaven presumably to the new created world (the new heaven and the new earth). From a canonical reading, Rev 21:1-2 seem to complete the sketchy eschatological picture provided by Hebrews. In my estimation, the cosmological eschatology of Hebrews is compatible with the eschatology of Revelation.

${ }^{323}$ It is noteworthy that biblical typology is characterized by horizontal and vertical structures. See Davidson, "Typological Structures in the Old and New Testaments," 191-408.

${ }^{324}$ Hebrews does not elaborate on the time elapsed between death, resurrection, and ascension. A more precise elaboration would require a canonical reading of the NT. I have mentioned in the beginning of this section on Cosmology that Christ ascended to heaven after His resurrection. Considering that Hebrews does not emphasize much on the resurrection, some scholars have maintained that Christ ascended to heaven at His death (see footnotes 85 and 330 above). However, this position is problematic. First, Hebrews does affirm Christ's resurrection. The explicit passage about this event is 13:20, which indicates that God brought up Christ from the death ( $\delta$ áva $\gamma a \gamma \dot{\omega} \nu \dot{\varepsilon} \varkappa \nu \varepsilon \varkappa p \tilde{\omega} \nu)$. A less explicit passage emphasizes His "indestructible life" in 7:16 that contrasts with Christ's mortal humanity before the resurrection. To be sure, these two passages do not use the explicit language of bodily resurrection. But to assume some kind of immaterial resurrection means that the essence of human nature is not grounded in the body, a position I have rejected in my reading of the anthropology of Hebrews in Humanity above. Therefore, I suggest that Christ ascended to heaven after His bodily resurrection, and not at His death on the cross. 
heaven and earth (the present creation) in the context of God's eschatological judgment (12:26). While this heaven is shaken/removed, the hope is on the heavenly country or city (11:16), the kingdom that cannot be shaken. Thus, the same terminology (heaven) is used for the reality that will pass away and the reality of the new order coming from God.

Considering the singular and plural forms of oủpavós (heaven) and the adjective

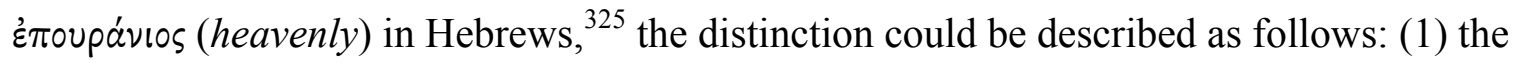
heaven(s) or sky in the realm of human beings $(1: 10 ; 11: 12 ; 12: 25-26)$ and $(2)$ as the heaven(s) of God's realm $(8: 5 ; 9: 23 ; 11: 16 ; 12: 22) .{ }^{326}$ In effect, this would establish a basic difference between a reality that can be shaken/removed (e.g., our earth and heaven, that is, our world) and a reality that cannot be shaken/that endures (e.g., God's heavenly city).

Nevertheless, I have not mentioned yet four occurrences related to Christ's ascension: He passed through ( $\delta \varepsilon \varepsilon \lambda \eta \lambda \nu \theta o ́ \tau \alpha^{327}$ ) the heavens (4:14); He was exalted above

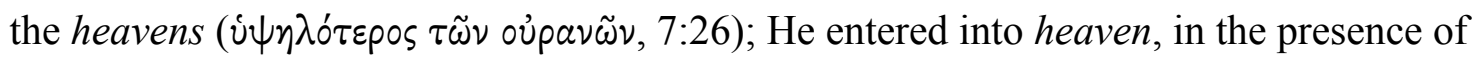
God (9:24); and $\mathrm{He}$ "is seated at the right hand of the throne of the majesty in the heavens" (8:1, NASB; italics mine). In the first two occurrences, Christ is beyond the heavens. In the other two, He is in (the) heaven(s). Perhaps, following the basic

\footnotetext{
${ }^{325}$ The occurrences of these terms in Hebrews refer to the following realities: the stars of heaven (11:12), the heaven that is shaken/removed along with the earth (singular: 12:26; plural: 1:10; 12:25), things in the heavens as types for copies on earth (9:23), heavenly things having shadows on earth (8:5), heavenly things purified (9:23), heavenly country (11:16); heavenly Jerusalem (12:22), heavenly calling (3:1), and heavenly gift (6:4).

${ }^{326}$ See Adams, "The Cosmology of Hebrews," 132; Schenck, Cosmology and Eschatology in Hebrews, 145.

${ }^{327}$ See BDAG, 244.
} 
distinction of the human and the divine realms, Christ is beyond the heaven(s) of the human realm, but is in the heaven(s) of the divine realm. ${ }^{328}$ In distinguishing human realm and divine realm, I simply mean the atmospheric heavens (human realm) and the created universe beyond the atmosphere where God rules the world (divine realm).

Taking into account that the ascension of Christ is the ascension of the (bodily) resurrected Christ, the heaven(s) of the divine realm seems to be spatial. ${ }^{329}$ Furthermore, as indicated in my discussion on Divinity above, the idea of ascension and the notion of the resurrected Christ appearing in the presence of God imply a temporal sequence of past, present, and future (that is, a sequentiality of before and after) in heaven.

Therefore, the heavenly divine realm where Christ ministers as high priest is ontologically consistent with a spatio-temporal (historical) dynamics initiated with His ascension. His continual intercession (7:25), then, should be understood as part of this historical dynamics, as it relates to human beings in the spatio-temporal (historical) reality of their earthly lives, especially considering that, when they sin on earth, the intercession of Christ is effective in heaven, particularly as they pray. In this sense, there is a synchronic correspondence between the spatio-temporal (historical) realities of the divine heavenly realm and the realities of the human earthly realm.

An important aspect of the divine heavenly realm that seems to entail its spatio-

\footnotetext{
${ }^{328}$ I agree with Ellingworht that Hebrews "does not develop a cosmology including several heavens." Ellingworth, The Epistle to the Hebrews, 127. See also Koester, Hebrews, 99; MacRae, "Heavenly Temple and Eschatology in the Letter to the Hebrews," 187. My distinction here is a minimal distinction of God's realm and human realm.

${ }^{329}$ For Adams, "The heavenly abode of God is not necessarily, for the author, a 'spiritual,' in the sense of non-substantial, dimension, especially if he assumes that the risen and ascending Christ entered into it bodily. The author seems to conceive of it as a 'place' and describes it, albeit analogously, in materialist terms." Adams, "The Cosmology of Hebrews," 131.
} 
temporal (historical) reality is the notion of the sanctuary in heaven. ${ }^{330}$

\section{The Heavenly Sanctuary}

In Hebrews, the noun $\sigma x \eta \nu \eta^{331}$ and the expression $\tau \dot{\alpha} \alpha \alpha^{\prime} \gamma(\alpha$ (and its variants)

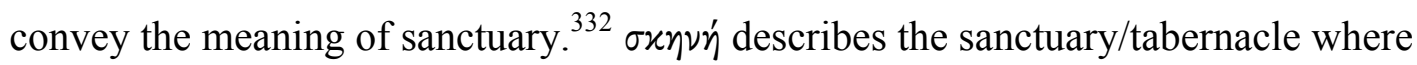
Christ ministers in 8:2 and 9:11. With regard to $\tau \dot{\alpha} \alpha ّ \gamma l \alpha$ and its variant forms, 10 occurrences are found in Hebrews: 8:2; 9:1 (singular form), 2 (anarthrous form), 3 (anarthrous and compound form-“'A $\gamma ı \alpha$ 'A $\gamma^{\prime}(\omega \nu), 8,12,24$ (anarthrous form), 25; 10:19; 13:11. Among these occurrences, three of them $(8: 2 ; 9: 12,24)$ describe this sanctuary

${ }^{330}$ The heavenly sanctuary in Hebrews is the main topic of the debate over the conceptual background of the epistle. Schenck, Cosmology and Eschatology in Hebrews, 8; Laansma, "The Cosmology of Hebrews," 140. According to Schenck, there are three basic ontological interpretations of the heavenly sanctuary in Hebrews: (1) Platonic, (2) Apocalyptic, and (3) Cosmological. The Platonic position focuses on 8:5, interpreting $i \pi \circ \delta \varepsilon i \gamma \mu a \tau \iota$ and $\sigma x \iota \tilde{a}$ in a Platonic fashion, and stipulates that the heavenly sanctuary is a platonic model. The Apocalyptic view interprets the heavenly sanctuary as a free standing structure in heaven. Finally, the cosmological interpretation views the sanctuary as a representation of the universe, where the earth is the outer court (Holy Place) and heaven is the inner court (Most Holy Place). This cosmological understanding derives from readings of Philo and Josephus. See Schenck, Cosmology and Eschatology in Hebrews, 8, 151-154. For further information regarding the Platonic interpretation, see ibid., 117-122. Schenck seems to adopt the cosmological interpretation, at least metaphorically, as he views God's heaven metaphorically as the Most Holy Place. See ibid., 145, 168. This line of interpretation seems to be also adopted by McKelvey, Pioneer and Priest, 72-87, 169; Laansma, "Hidden Stories in Hebrews," $14,16-17$. As it will be evident from my arguments in this section, I follow the interpretation of a free standing structure in heaven.

${ }^{331}$ Out of the 31 occurrences of $\sigma x \eta \nu \eta \dot{~ i n ~ t h e ~ N T, ~} 10$ are found in Hebrews $(8: 2,5 ; 9: 2-3,6,8,11$, $21 ; 11: 9 ; 13: 10)$. Considering that its basic meaning is tent, $\sigma \times \eta \nu \eta$ is used to refer to the tabernacle or the cultic tent (the tent of the testimony). See BDAG, 928.

${ }^{332}$ I do not follow Vanhoye's idea that "Hebrews distinguishes $\sigma x \eta \nu \eta '$ (tent) and $\tau \alpha \dot{\alpha} \ddot{\alpha} \gamma ı$ (sanctuary)." Vanhoye stipulates a metaphorical interpretation where the "true sanctuary" is actually "God's own holiness." In this way, the language of a sanctuary in heaven is merely the attempt to describe in limited human words the transcendent divine holiness. On the other hand, his reading of Heb 9:11 seems to indicates that $\sigma x \eta \nu \eta$ refers to Christ's glorified humanity, which as a house reunites into Himself "all persons who are faithful to Him." Vanhoye, Old Testament Priests and the New Priest, 194, 197. In my estimation, this interpretation and distinction is quite speculative. Furthermore, I do not subscribe to Schenck's notion that in Hebrews $\sigma x \eta \nu \eta$ refers to the sanctuary as a whole (with the exception of 9:1-10) while $\tau \dot{\alpha} a ́ \gamma \iota \alpha$ refers to the Most Holy Place, which substantiates his idea that the heavenly sanctuary does not have an outer court (Holy Place) but only an inner court (Most Holy Place). See Schenck, Cosmology and Eschatology in Hebrews, 145-146, 159. As it will become evident in my discussion, I find convincing 
explicitly as the place where Christ is the high priest (see also 10:19-21 in comparison with $\left.6: 19-20^{333}\right)$. It is noteworthy that only in 9:2-3 there is a clear distinction between the holy place and the most holy place. All other occurrences of $\tau \dot{\alpha} \alpha \ddot{\gamma} \gamma \alpha$ (and its variants) in Hebrews appear to refer to the sanctuary as a whole, ${ }^{334}$ and this conclusion seems to be supported by its use in the $\mathrm{LXX}^{335}$

With these terminologies and occurrences in view, I will concentrate on passages that relate to Christ and the heavenly sanctuary $(6: 19-20 ; 8: 2 ; 9: 11-12,24 ; 10: 19-20)$, with a particular focus on how the reality of this sanctuary is portrayed in its connection

the interpretation of $\tau \dot{\alpha} \alpha \ddot{\gamma} \gamma \alpha$ as referring to the whole sanctuary, and not only to the Most Holy Place.

${ }^{333}$ For a proposal of chiastic correspondence between 6:19-20 and 10:19-20 and an elaboration of its implications for the priesthood of Christ, see Davidson, "Christ's Entry 'within the Veil' in Hebrews 6:19-20," 178.

334 A. P. Salom, "Ta Hagia in the Epistle to the Hebrews," AUSS 5, no. 1 (1967): 65. See also O. Kuss, Der Brief an Die Hebräer Und Die Katholischen Briefe, 2 ed. (Regensburg: Pustet, 1966), 125; O. Michel, Der Brief an Die Hebräer, 14 ed. (Göttingen: Vandenhoeck \& Ruprecht, 1984), 323; E. Riggenbach, Der Brief an Die Hebräer (Leipzig: Deichert, 1922), 284; H-F. Weiss, Der Brief an Die Hebräer (Göttingen: Vandenhoeck \& Ruprecht, 1991), 486n46; Rissi, Die Theologie des Hebräerbriefs, 38. In English versions, ESV seems to be one of the most consistent translations, as it renders the plural form as holy places $(8: 2 ; 9: 8,12,24,25 ; 10: 19 ; 13: 11)$, and the singular form as place of holiness (9:1). Other versions have more variation. Among the versions compared below, NIV opts for "most holy place" in several instances, whereas ESV, NASB, and NRSV never employ this rendition in these passages.

\begin{tabular}{|l|l|l|l|l|l|l|}
\hline Hebrews Passage & ESV & NASB & NRSV & NET & NIV & KJV \\
\hline $8: 2$ & holy places & sanctuary & sanctuary & sanctuary & sanctuary & sanctuary \\
\hline $9: 1$ (singular) & place of holiness & sanctuary & sanctuary & sanctuary & sanctuary & sanctuary \\
\hline $9: 8$ & holy places & holy place & sanctuary & holy place & most holy place & the holiest of all \\
\hline $9: 12$ & holy places & holy place & holy place & most holy place & most holy place & holy place \\
\hline $9: 24$ (anarthrous) & holy places & holy place & sanctuary & sanctuary & sanctuary & holy places \\
\hline $9: 25$ & holy places & holy place & holy place & sanctuary & most holy place & holy place \\
\hline $10: 19$ & holy places & holy place & sanctuary & sanctuary & most holy place & the holiest \\
\hline $13: 11$ & holy places & holy place & sanctuary & sanctuary & most holy place & sanctuary \\
\hline
\end{tabular}

335 According to Carl Coesart, from the 109 occurrences of $\tau \alpha \dot{\alpha} \not \alpha l \alpha$ in the LXX that refer to the sanctuary, in 106 times the term refers to the whole sanctuary. In three verses it describes the Holy Place (1 Kgs 8:8; 2 Chr 5:9, 11). There is no reference to the Most Holy Place alone. See Carl Coesart, "A Study of Ta Hagia in the LXX, Pseudepigrapha, Philo, and Josephus, and Its Implications in Hebrews," (MA Thesis, Nazarene Theological Seminary, 2000). For a summary of Coesart's study on extra-biblical literature, see Carl Coesart, "The Use of Hagios for the Sanctuary in the Old Testament Pseudepigrapha, Philo, and Josephus," AUSS 42 (2004): 91-103. 
with Christ. Most of these passages emphasize that Christ entered the heavenly sanctuary

$(6: 20 ; 9: 12,24)$. However, where exactly did He enter? According to $6: 19$, He entered

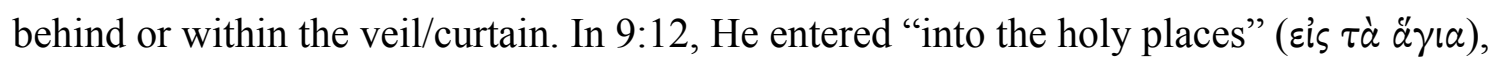

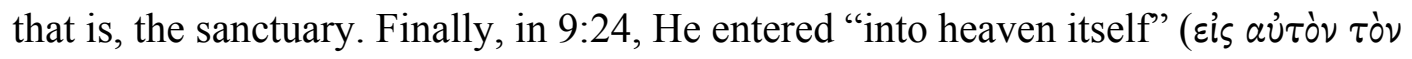

oúpavóv). The reading of these three passages in conjunction, raises the following

question: Does heaven contain a sanctuary or heaven is itself a sanctuary, as apparently

suggested by 9:24 (see also $4: 14^{336}$ ) ${ }^{337}$ In short, the answer provided below indicates

\begin{abstract}
336 The idea that heaven is itself a sanctuary seems to be assumed not only in 9:24, but also in 4:14, where Christ passes through the heavens as a high priest. This passage evokes the image of the high priest Christ entering the heavenly sanctuary in His ascension, as if the heavens of the human realm were a curtain through which He enters the heaven of the divine realm, that is, the heavenly sanctuary. This idea is highlighted in commentaries about 4:14. For example, see Cockerill, The Epistle to the Hebrews, 224;

Koester, Hebrews, 282. The difference is that Cockerill and Koester highlight Christ's entrance into heaven as the Most Holy Place, while I emphasize His entrance into heaven as the sanctuary as a whole (according to the understanding of $\tau \dot{\alpha} \alpha \ddot{\gamma} ı \alpha$ as I have indicated above).

337 Taking into consideration the relationship between sanctuary and heaven, Schenck outlines "three major suggestions for the nature of the heavenly tent in Heb. 8-10," namely, (1) "a literal structure in heaven," (2) "a reference to multilayered heavens," and (3) "a metaphor for the highest heaven itself." Schenck, Cosmology and Eschatology in Hebrews, 145. Overall, he observes these suggestions in different interpretations of the heavenly sanctuary in 9:24: (1) "the interpretation which believes there to be a literal structure within heaven" understands 9:24 as "a synecdoche," where "the whole (heaven) is substituted for its part (the tabernacle in heaven)"; (2) "the view which identifies the parts of the tent with a multilayered heaven" interprets the "holy of holies" as "the highest heaven" - this is "a more literal cosmological reading" of 9:24; (3) the position that conceives heaven as a "metaphor for whole tent" identifies the "holy of holies with heaven as a whole" - this is a "metaphorical-cosmological reading" of 9:24. Ibid., 165. For bibliographic information regarding these positions, see ibid., 165n69. Schenck argues that while it is difficult to classify those who read 9:24 platonically, he tends to place them in the interpretation of (a modified) synecdoche. Ibid., 165n69. The view of synecdoche (literal sanctuary) aligns with my idea of heaven containing a sanctuary, whereas the cosmological views of a multilayered heaven (literal cosmological reading) and of heaven as a whole (metaphorical cosmological reading) align with heaven being a sanctuary. While Schenck considers all these interpretations as "theoretically possible," he dismisses the idea of a literal sanctuary in heaven and a synecdoche in 9:24 on the basis of the following

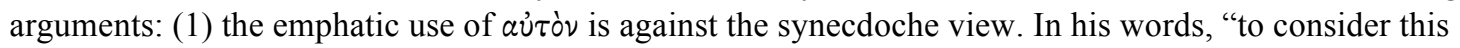
phrase only a figurative equivalent to 'the sanctuary in the heavens' arguably loses some of the meaning: Christ did not enter the sanctuary symbolizing the realities of heaven; he entered heaven itself'; (2) a literal reading of the cleansing of the heavenly sanctuary in 9:23 is "an absurd image for a literal structure in the purest heaven." Ibid., 165, 174, 181. In my estimation, the second argument is unconvincing. Shenck's assumption that a heavenly sanctuary does not need purification is not derived from his reading of Hebrews, but it is essentially his own presupposition. The second argument is textual and well articulated, but not strong enough. To my understanding, the emphatic form is not necessarily against the synecdoche

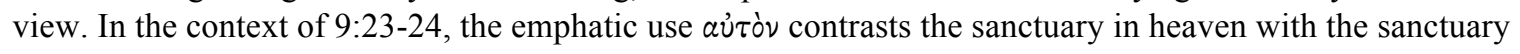


that, in a more specific view, heaven contains a sanctuary. In a more general way, however, heaven is a sanctuary. This answer can be unpacked in two points. First, the reading of 9:24 does not deny that heaven contains a sanctuary. This argument is supported by two lines of argument: (a) 9:24 assumes a typological relationship between the heavenly and the earthly sanctuaries, and (b) 9:24 is consistent with parallel references to heaven that seem to assume a sanctuary in heaven. Second, heaven is a sanctuary as a synecdoche, where the whole (the heavenly realm) is used for the part (the heavenly sanctuary).

First, the reading of 9:24 does not deny that heaven contains a sanctuary, as this passage assumes a typological relationship between the heavenly and the earthly sanctuaries. The idea of Christ entering heaven is contrasted with a priestly entrance into the earthly sanctuary in 9:24. ${ }^{338}$ This comparison implies a contrast between two sanctuaries on the basis of a connection between them: The earthly sanctuary was an antitype of the true ( $\dot{\alpha} \nu \tau i \tau v \pi \alpha \tau \tilde{\omega} \nu \dot{\alpha} \lambda \eta \theta \iota \nu \tilde{\omega} \nu)$ heavenly sanctuary. A typological language also appears in 8:5, where the heavenly sanctuary is the type ( $\tau \dot{\prime} \pi \circ \nu)^{339}$ of the earthly

on earth. The emphasis is on a heavenly reality. The synecdoche view still emphasizes a heavenly reality, even though Schenck expects a more emphatic interpretation that views heaven itself as the heavenly sanctuary. In the text below I explain why I find the synecdoche view a viable interpretation. For a defense of synecdoche, see Hurst, The Epistle to the Hebrews, 28.

${ }^{338}$ The earthly sanctuary is referred as the sanctuary made by (human) hands ( $\chi \varepsilon ı \rho \circ$ oin $\left.\eta \alpha \alpha \ddot{\alpha} \gamma l \alpha\right)$. Temples "made by hands" ( $\chi \varepsilon ı \rho \circ \pi \circ i \eta \tau \alpha)$, that is, earthly sanctuaries are mentioned in Acts 7:48 and 17:24.

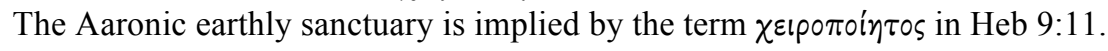

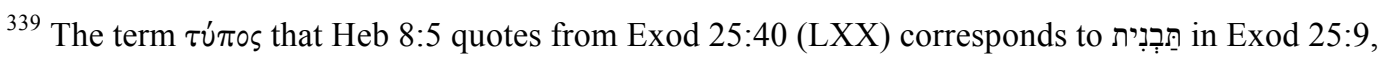
40 (MT). In his study of this Hebrew expression in relationship with the typology of Hebrews, Davidson argues that תִּבְנִית may signify a "solid construction or an architect's blueprint." The context of Exod 25:9, 40 suggests that Moses had not "been shown merely architect's plans," but "was provided in vision with a view of something constructed, relating in vivid reality to how the sanctuary was going to look." In this way, there are four possibilities for the interpretation of sַבְבְנית as something constructed in Exod 25:9, 40: (1) "a miniature model by which to construct the earthly sanctuary," (2) "a miniature model of the heavenly 
sanctuary (implicitly referred as sketch and shadow). ${ }^{340}$ The typological connection

between the earthly and heavenly sanctuaries assumes an analogy between antitype and

type. Whereas the qualification of the antitype as sketch and shadow indicates that the

type (heavenly sanctuary) cannot be described with precision on the basis of an

observation of the antitype (earthly sanctuary), they must be similar enough for the type

to serve as the pattern for the construction of the antitype (see 8:5). ${ }^{341}$ This idea of

sanctuary for the building of the earhly (that is, both a copy of and a model/pattern for), or (3) "the heavenly sanctuary itself (that is, the original)," (4) Moses first saw "the heavenly sanctuary itself and then a three-dimensional model of the heavenly, according to which he was to pattern the construction of the earthly." Davidson stipulates that "the teophanic context of Exodus 24 implies that Moses saw the heavenly sanctuary." Nevertheless, "if the heavenly sanctuary itself (unmediated by some miniature model presentation) were solely in view, this would not seem to coincide with other OT portrayals of the heavenly sanctuary," which "is described as a vast, majestic temple, accommodating countless angels" (see, e.g., Isa 6:1; Ps 11:4; Dan 7:9-14 — these passages are suggested by de Souza referenced below). "If Moses had been able to take in such a display of majesty (unmediated by some kind of miniature model), it would not be necessary for God to tell him repeatedly to build it according to what he was shown (Exod 25:9, 40; 26:30; 27:8; Num 8:4). The emphasis of these latter passages rule out the view that Moses saw only the heavenly reality and then was left to translate it into earthly proportions." Therefore, Davidson concludes, "It seems more probable that Moses was first given a vision of the heavenly sanctuary and then was provided with a miniature model of it by which to construct the earthly." Davidson, "Typology in the Book

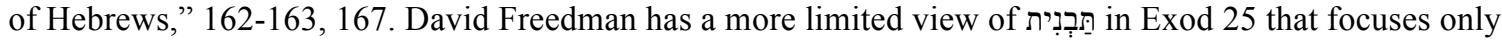
on the heavenly sanctuary itself, and does not include the miniature model as Davidson's more elaborated interpretation suggests. See David N. Freedman, Pottery, Poetry, and Prophecy: Studies in Early Hebrew Poetry (Winona Lake, IN: Eisenbrauns, 1980), 138n20; David N. Freedman, "Temple without Hands," in Temples and High Places in Biblical Times (Jerusalem: The Nelson Glueck School of Biblical Archaeology of Hebrew Union College, 1977), 28. For a more recent treatment of הַבְנִית in Exod 25 that follows Davidson's perspective, see de Souza, "The Heavenly Sanctuary/Temple Motif in the Hebrew Bible," 164173. As I agree with Davidson's suggestion, for the purposes of the present study, my remarks on the typological relationship of the heavenly and earthly sanctuaries implicitly include the idea of a miniature model that mediated the construction of the earthly sanctuary. At the same time, the inclusion of a miniature model does not deny the fact that the heavenly sanctuary is ultimately the type of the earthly sanctuary.

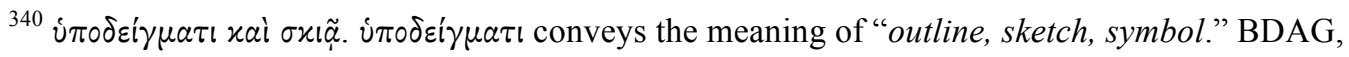
1037. NET and NRSV render it as sketch in 9:23. This term also occurs in 4:11 and 8:5, while $\sigma x i \alpha ́$

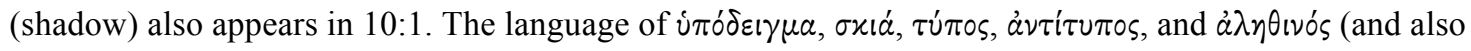

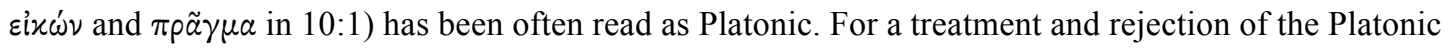
reading, see Hurst, The Epistle to the Hebrews, 13-21.

${ }^{341}$ Several scholars believe that Hebrews assumes a real sanctuary in heaven. See Weiss, Der Brief an die Hebräer, 486; David M. Allen, Deuteronomy and Exhortation in Hebrews: A Study in Narrative RePresentation (Tübingen: Mohr Siebeck, 2008), 219; Hurst, The Epistle to the Hebrews, 28; R. McL. Wilson, Hebrews (Grand Rapids, MI: Eerdmans, 1987), 166; Barrett, "The Eschatology of the Epistle to the Hebrews," 386. Some scholars even stipulate that Hebrews assumes a bipartite sanctuary (Holy Place 
similarity is appropriate not only for the understanding of the reality of the sanctuaries but also for their service. ${ }^{342}$ The use of 'Avá $\gamma \varkappa \eta$ (necessity) ${ }^{343}$ in 9:23 emphasizes that just as the sketches (antitype: the earthly sanctuary) of the heavenly things ${ }^{344}$ needed to be purified ( $\varkappa a \theta a p i \zeta \varepsilon \sigma \theta a \iota)$ with their correspondent sacrifices, it was necessary by implication that the heavenly things themselves ${ }^{345}$ (type: the heavenly sanctuary) should be purified with "better sacrifices." Hence, the notion of correspondence in terms of necessity highlights the resemblance between type and antitype, while acknowledging that the type has superior characteristics, not being merely identical to the antitype. ${ }^{346}$ According to this perspective, heaven contains a sanctuary. Taking into account the Aaronic earthly sanctuary (see, e.g., 9:1-5), the features of this antitype follow the pattern provided by the heavenly type (8:5). The type is certainly superior and not precisely the same as the antitype, but its features resemble, although not precisely, the earthly

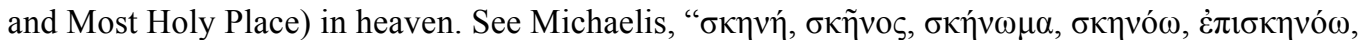

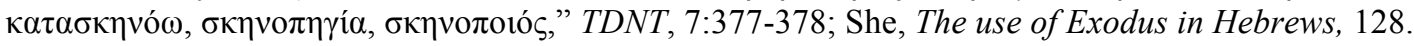
While Michaelis seems to suggest this view, She clearly indicates that the heavenly sanctuary is a spatiotemporal reality. Conversely, while Schenck acknowledges that 8:5 constitutes a strong argument for a real sanctuary in heaven, he argues that "the author does not mean to say that all the parts of the earthly tabernacle correspond to 'parts' of the heavenly tabernacle. The author would be saying somewhat loosely that everything in the earthly tabernacle corresponded in general to the $\tau \dot{\pi} \pi \circ \varsigma$ Moses saw on the mountain." Schenck, Cosmology and Eschatology in Hebrews, 172. In my judgment, even though the idea of a general correspondence could be acceptable, the expression "somewhat loosely" is unclear, especially considering that Schenck does not interpret the heavenly sanctuary in Hebrews as a real sanctuary. It is not clear to me how it is possible to establish a general correspondence if there is no correspondence in reality, but only in meaning. As I argue in this section, it seems to me that 8:5 and 9:24 point to a correspondence of reality.

${ }^{342}$ As Davidson indicates in his remarks on 9:24, "the antitupos 'corresponds' to the preceding tupos but also points forward to the eschatological inauguration of its services." Davidson, "Typology in the Book of Hebrews," 153.

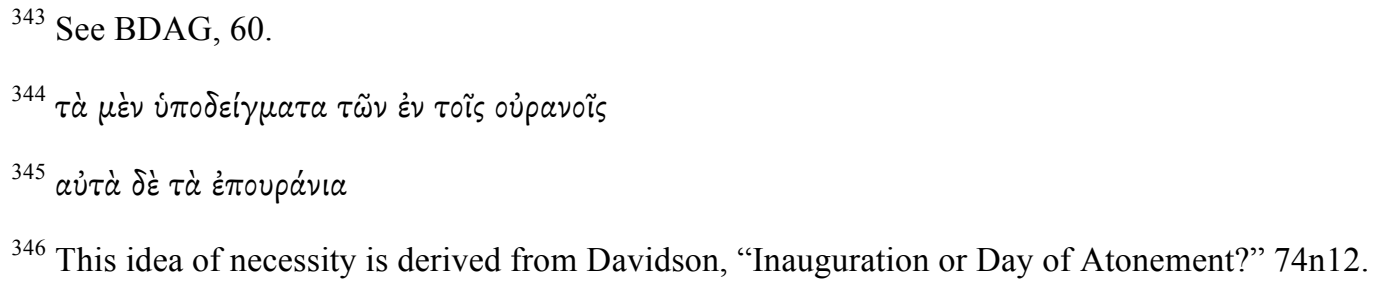


sanctuary. Yet, just as the earthly sanctuary was a spatio-temporal reality, the heavenly

sanctuary is also a spatio-temporal reality. ${ }^{347}$ In other words, this sanctuary exists in another part of the universe that is heaven.

\section{Moreover, 9:24 is consistent with parallel references to heaven that seem to}

assume a sanctuary in heaven. Gathering the references to the heavenly sanctuary in 9:23-

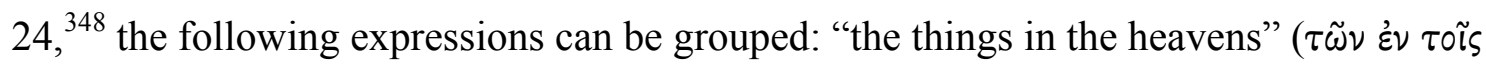

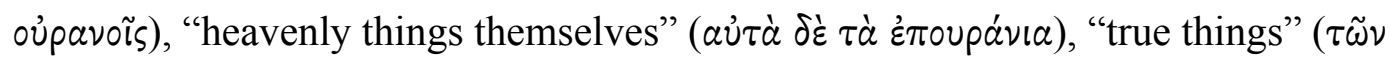

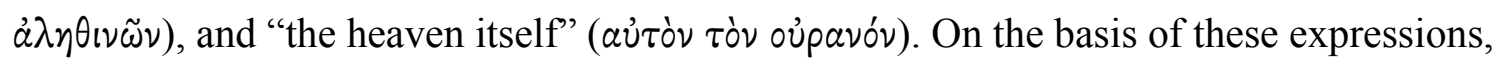
the plural forms ${ }^{349}$ with the implied word things seem to support the interpretation that

${ }^{347}$ See Johnsson, “The Heavenly Sanctuary: Figurative or Real?” 35-51.

${ }^{348}$ The affirmation that Christ entered into heaven ( $\tau \dot{v} v$ oủpavóv), and not into the earthly antitype (9:24), should be read from the perspective of how the sanctuaries are mentioned in their comparison in 9:23. In 9:23a, the earthly and the heavenly sanctuary are referred to as $\tau \dot{\alpha} \mu \dot{\varepsilon} \nu \dot{v} \pi \circ \delta \varepsilon i \gamma \mu \alpha \tau \alpha$ (earthly

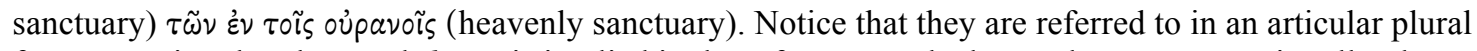
form, meaning that the word things is implied in the reference to the heavenly sanctuary. Literally, the

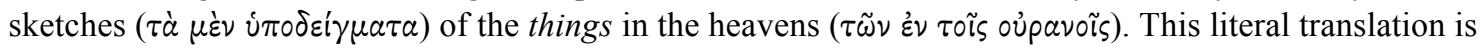
adopted by NASB (see also YLT). Other versions opt for "heavenly things" (see ESV, NIV, NRSV). In

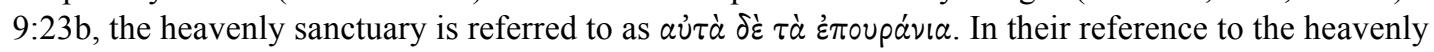
sanctuary, the parallel between this expression and $\tau \tilde{\omega} \nu \dot{\varepsilon} \nu \tau 0 \tilde{\varsigma}$ oujpavoĩs is clear. Obviously, the adjective

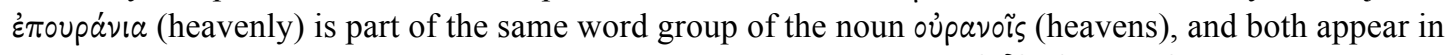

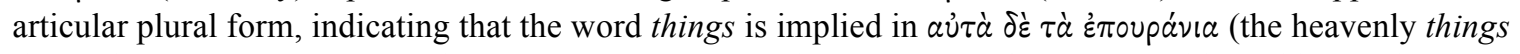
themselves). Turning to 9:24, there is a continuation of the comparison between earthly and heavenly sanctuaries. In 9:23 they are similar because both need to be purified, but they are different in the sense that they are purified with different types of sacrifice. In 9:24, the similarity is that both sanctuaries are entered by a priest (see also 9:25), but the basic ontological difference is that the earthly sanctuary is described

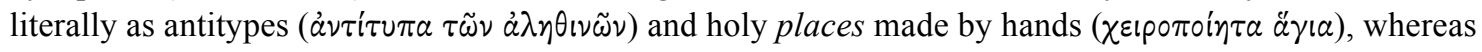

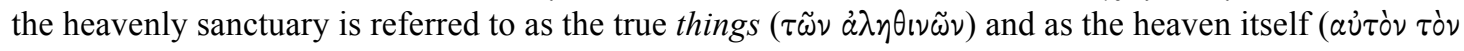
oúpavóv). The literal rendition "holy places" and "true things" is adopted by ESV.

${ }^{349}$ In the reading of 9:23-24 there is an important continuation in the language employed to refer to the earthly and heavenly sanctuaries. First, the plural forms dominate 9:23 and are also found in 9:24, leading to the inclusion of places and things in a literal translation. $\dot{\alpha} \lambda \eta \theta$

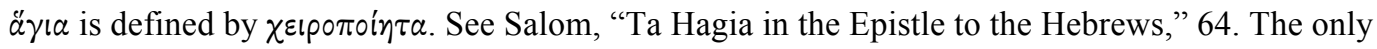

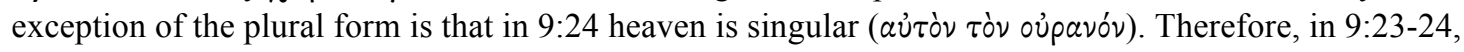
the earthly sanctuary is always referred to in the plural form and the heavenly sanctuary is referred to in the plural form as well, with the exception of "the heaven" in 9:24. 
there is a real sanctuary in heaven, that is, heaven contains a sanctuary. ${ }^{350}$

Second, I suggest that heaven is a sanctuary as a synecdoche, where the whole (the heavenly realm) is used for the part (the heavenly sanctuary). This suggestion derives from the comparison between the realities of the earthly and heavenly sanctuaries pointed out in 9:24. The earthly sanctuary is described literally as holy places made by hands

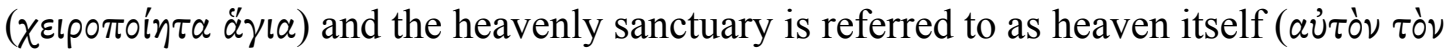
oúpavóv). Assuming that the use of $\chi \varepsilon เ p \circ \pi \circ i \eta \tau \alpha$ indicates that the earthly sanctuary belongs to the realm of this creation, ${ }^{351}$ then the emphasis on heaven itself probably underlines that the heavenly sanctuary does not belong to the realm of this creation, but to the heavenly realm of God's presence (as indicated in the continuation of the verse). In this sense, Christ's entrance into the heavenly realm is not different from His entrance in the reality of heavenly sanctuary there. In fact, His entrance in the heavenly realm seems to be a general way of describing His entrance into the sanctuary in heaven.

The interpretation of the idea of heaven itself literally being a sanctuary would exclude the notion of Christ entering into a real sanctuary in heaven, especially if this

\footnotetext{
${ }^{350}$ The difference in meaning between singular and plural forms of oủpavós and ä $\gamma 10 \varsigma$ (for sanctuary) should not be exaggerated. To mention two examples, in 8:1 Christ is in the heavens (plural

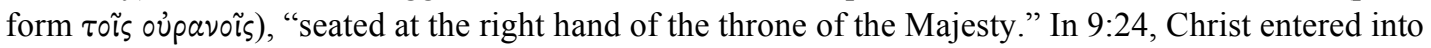
heaven (singular form $\tau \dot{v} v$ oúpavóv) "to appear in the presence of God." Comparing 8:1 and 9:24, the use of the singular or the plural form does not seem to make a difference in terms of meaning. In a second example, the earthly sanctuary is referred to by singular $\tau \sigma^{\prime} a ́ \gamma 10 \nu$ in $9: 1$, while this sanctuary is referred to by the plural $\tau \dot{\alpha} \ddot{\alpha} \gamma ı \alpha$ in 9:25. Again, the use of the singular or the plural form does not seem to make a

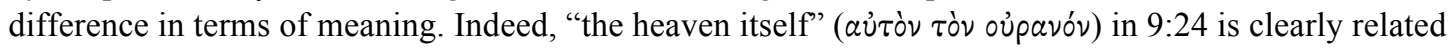

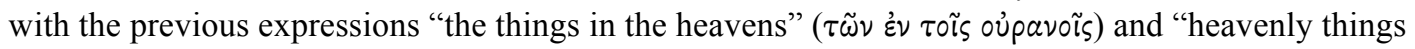

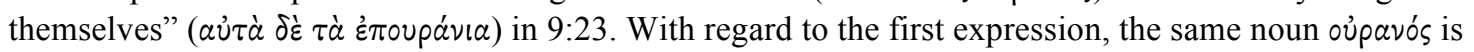
used. In the case of the second expression, the same emphatic aũós is employed.

${ }^{351}$ The other occurrence of $\chi \varepsilon ı \rho \circ \pi$ in $\tau$ os in Hebews spells out what the author means by the use of

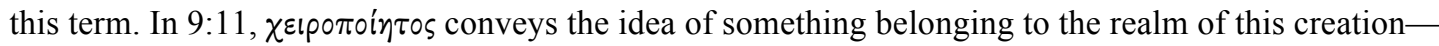

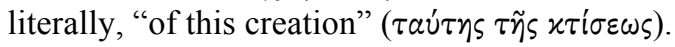


interpretation assumes that God's heaven is a timeless-spaceless environment. According to this assumption, the sanctuary in heaven cannot be a reality, but it is only a metaphorical language that portrays a timeless-spaceless environment by means of a nonontological spatio-temporal image. ${ }^{352}$ Nevertheless, since this timeless-spaceless assumption does not find support in Hebrews, ${ }^{353}$ instead of perceiving an incongruity between the idea of a real sanctuary in heaven and the reference to the heavenly sanctuary as heaven itself (9:24), this reference could be taken as a synecdoche, where the whole (the heavenly realm) is used for the part (the heavenly sanctuary). ${ }^{354}$

To conclude, I will briefly comment on the idea of God's presence in the heavenly sanctuary. As a matter of fact, the ontological entrance of Christ in the heavenly sanctuary is used in Hebrews to ground exhortations encouraging a spiritual nonontological entrance of believers (presumably through hope ${ }^{355}$ and prayer) into this sanctuary $(6: 19-20 ; 10: 19-20) .{ }^{356}$ Both these ontological and non-ontological entrances convey the idea of going into the presence of God. ${ }^{357}$ The logical implication would be

\footnotetext{
${ }^{352}$ For a discussion regarding the idea of temporality or timelessness in relationship with the the heavenly sanctuary, see Fernando Luis Canale, "Philosophical Foundations and the Biblical Sanctuary," AUSS 36, no. 2 (1998): 183-206.

353 See, for example, my remarks on eschatological (historical) or spatio-temporal dynamics and the ontological typological relationship between earthly and heavenly sanctuaries above.

${ }^{354}$ See footnote 333 above.

${ }^{355}$ See 6:19.

${ }^{356}$ In 6:20, the high priest Jesus is called a forerunner ( $\left.\pi \rho o ́ \delta \rho \circ \mu \circ \varsigma\right)$.

${ }^{357}$ In 9:24, Christ's ontological entered the heavenly sanctuary to appear in the presence of God. In 10:19, the exhortation to a non-ontological entrance of believers into the heavenly sanctuary parallels the

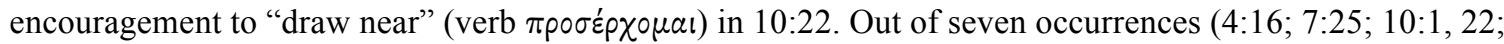

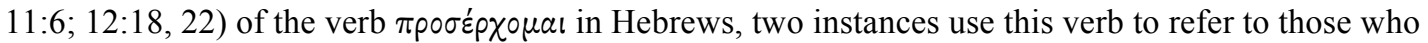
"draw near to God" $(7: 25 ; 11: 6)$. In this context, it seems plausible to assume that the non-ontological entrance of believers into the heavenly sanctuary conveys the idea of drawing near to the presence of God.
} 
that God the Father is present in the heavenly sanctuary. While Hebrews does not explore further this idea of God being present in the heavenly sanctuary, when the term

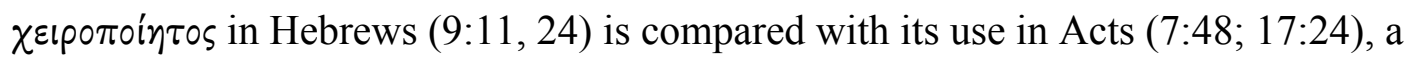
significant question may be raised regarding God's presence in a real sanctuary in heaven. The emphasis of Acts 7:48 and 17:24 is that God does not dwell in temples made by (human) hands. In light of this statement, can God dwell in a heavenly sanctuary? This question echoes Solomon's prayer at the inauguration ceremony of the temple in $1 \mathrm{Kgs} 8$ (see also $2 \mathrm{Chr} 6) .{ }^{358}$ According to this prayer, God does not dwell on earth or in an

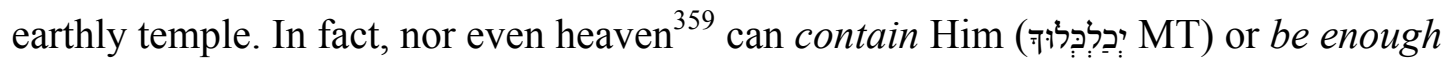

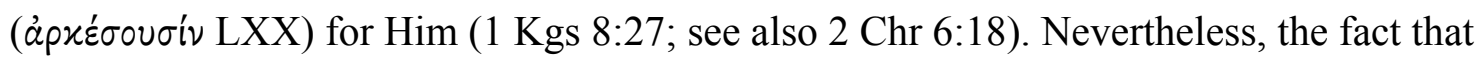
heaven cannot contain or be enough for God should not be simply equated with the idea that He cannot be really there. In other words, His real presence in the heavenly sanctuary does not mean that this sanctuary contains His transcendent being. Indeed, despite the fact that heaven does not contain God, He is not unable to dwell in heaven (heaven is His dwelling place-1 Kgs 8:30; see also $2 \mathrm{Chr} 6: 21) .{ }^{360}$ Moreover, even though God's dwelling place is in heaven, He was able to dwell in the earthly temple in some sense. ${ }^{361}$

\footnotetext{
${ }^{358}$ In fact, the statement of Acts 7:48, while supported by a quotation from Isa 66:1-2 in Acts 7:49-50, is preceded by a reference to the fact that Solomon built a house for God (7:47).

${ }^{359}$ The verse indicates that the highest form of heaven is in view: literally, "the heavens and the

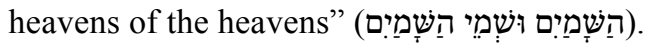

${ }^{360}$ In the prayer, when the people of Israel would offer supplications toward the earthly temple,

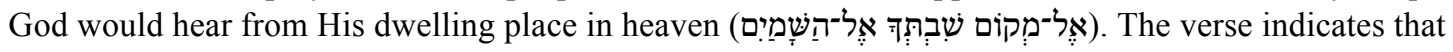
God dwells in heaven, not on earth.

${ }^{361}$ The glory of the Lord filled the temple, and Solomon declared that it was built as place for the Lord to dwell forever (1 Kgs 8:10-13; see also $2 \mathrm{Chr} 5: 14-6: 2$ ). Literally, "a place for you to dwell in

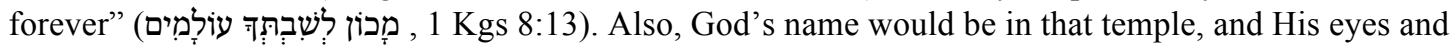
heart would be there (1 Kgs 9:3; see also $2 \mathrm{Chr} 7: 16$ ).
} 
Using a typological relationship of sanctuaries in Hebrews, and considering Solomon's temple an antitype, the dwelling of God in the true sanctuary in heaven must be even more remarkable than His dwelling in the earthly sanctuary. In light of these comments, can God dwell in a heavenly sanctuary? Yes, as long as this dwelling does not imply the the notion of containing Him. This point implies, then, that God relates to creatures, not only on earth (earthly sanctuary) but also in heaven (heavenly sanctuary), through His immanence and not through His transcendence. To put it more sharply, even in the heavenly sanctuary, God relates to creatures in heaven (humans and angels) in divine immanence, and not in divine transcendence.

\section{Summary}

In summary, the relationship between Christ and earth/heaven takes place in the context of a cosmological eschatology, which entails a historical dynamics of horizontal (sequence of events) and vertical (from heaven to earth, from earth to heaven) movements that involve time and space on earth and in heaven. More specifically, the incarnation, a vertical movement of the divine Christ from heaven to earth, marks the beginning of the horizontal movement or the history of the earthly divine-human Christ. The earthly horizontal movement is characterized by His life, death, resurrection, and ascension, which is a vertical movement from earth to heaven. Because of this vertical movement, Christ is beyond the heaven(s) of the human realm (the atmospheric heaven), but is in the heaven(s) of the divine realm (the created universe beyond the atmosphere where God rules the world).

Moreover, the vertical movement of the ascension initiates the horizontal movement of the work of the incarnate Christ as high priest in the heavenly sanctuary, a 
movement that synchronically relates to the horizontal movement of the history of earthly human beings (for instance, Christ enables them to enter non-ontologically the heavenly sanctuary presumably through their hope and prayer). This horizontal movement continues until His second coming, a vertical movement from heaven to earth.

Regarding the spatio-temporal reality of the divine (created) heaven implied in this historical dynamics, the ascension of the (bodily) resurrected Christ indicates that heaven is spatial, and His appearing in the presence of God the Father entails temporality (a sequentiality of before and after). According to this perspective, then, the ascended Christ performs His priesthood in a real spatio-temporal sanctuary in heaven, which typologically resembles the real spatio-temporal earthly sanctuary. Although the spatiotemporal heavenly sanctuary is characterized by the presence of God, this does not mean that it contains the divine reality, just as the earthly sanctuary did not.

\section{Implications for Christ's Priesthood}

Taking into account the principles of reality described above, it is necessary to draw their main implications for the understanding of Christ's priesthood. To accomplish this task, I will review the key ideas indicated above in the discussion of the principles of reality and, then, draw implications for each component of the priesthood of Christ in the historical model.

First, I have pointed out that God is really able to experience sequential events, as Hebrews assumes that He is temporal and not timeless. This presupposition about God's reality is necessary to understand the spatio-temporal dynamics of Christ's priesthood, inasmuch as the spatio-temporal nature of God's and Christ's reality ontologically informs the language of Christ appearing before God the Father in the heavenly 
sanctuary. For the Father, there was a time (temporality) when Christ was not in His presence in the heavenly sanctuary (spatiality). Moreover, the everlasting temporal sameness and eternity of the divine Christ is compatible with His experience of becoming (the incarnation, the process of qualification to the official priesthood through suffering and learned obedience, the ascension, the exaltation as a royal high priest).

Second, regarding the humanity of Christ, human nature is grounded in the body, that is, this nature is spatio-temporal. Since the divine nature is not timeless-spaceless, Christ's humanity is not a spatio-temporal instrument of His divinity. In His earthly mortal humanity, Christ developed something new in relation to human beings (mercy, sympathy) and toward the Father (obedience), as He developed these attitudes on a new level, in the context of test/temptation and suffering as a divine-human being. Instead of an instrument of divinity, Christ's humanity is crucial for His identification and mediatorial representation as a real human being on behalf of the human family.

Third, in the context of cosmology, the ascension of Christ entails a historical dynamics of horizontal (sequence of events) and vertical (earth-heaven) movements that involve time and space on earth and in heaven. The ascension initiates the horizontal movement of the work of the incarnate Christ as high priest officially in the heavenly sanctuary, a movement that synchronically relates to the horizontal movement of the history of earthly human beings. The spatio-temporal reality of the divine realm of (created) heaven implied in this historical dynamics is supported by the ascension of the spatial (bodily) resurrected Christ and His appearing in the presence of God (a temporal sequentiality of before and after). Christ performs His priesthood in a spatio-temporal sanctuary in heaven characterized by the presence of God, which is not contained in the 
sanctuary, as this created heavenly environment is related to divine immance, not to His transcendence.

The spatio-temporal or historical interpretation of the principles of reality (divinity, humanity, and cosmology) assumed in Hebrews has direct implications for the understanding of each component (need, agent, actions, and goal) of the historical model of Christ's priesthood outlined in the first part of this chapter. I will start with the first component, namely, the need of Christ's priesthood.

Need

In the historical model, Christ's priesthood is needed to solve the sin problem, which means that His priestly work is necessary to restore the covenantal relationship between human beings and God by mediating divine forgiveness, to purify/eliminate the guilty conscience of human beings and help them endure temptation, and purify the heavenly sanctuary, which has been defiled by human sin and reveals that the sin problem impacts creation at a cosmic level.

Even though Hebrews does not elaborate on the origin of sin, the historical dynamics of the principles of reality seem to indicate that the sin problem began at some point in the past history of God and human beings. Hence, the sin problem was not eternally constituted in God's being or by His will that later became actualized in the history of human beings. Another implication of this historical interpretation of the principles of reality is that the sinful weakness of human beings is not the human ontological condition that initiated sin. Presumably, it was the initial historical attitude of rebellion against God (cf. Gen 3) that led to this ontological condition of weakeness, that in turn, led to sin. 
From the vantage point of the notion of covenant, the sin problem implies a breaking of the covenantal relationship between God and human beings, which is regulated by divine laws. In this context, sin is narrowly the historical breaking of the law, and broadly the historical breaking of a covenantal relationship with God. From this covenantal perspective, the sin problem describes the emergence of a spiritual distance that separates God and human beings. But this distance is not only characterized by the fact that human beings sinfully depart from God, but also by the fact that in His temporality God reacts to this sinful departure. The more conspicuous reaction is the negative attitude of judgment. In this context, the priesthood of Christ is necessary for the redemption of the transgressions by which human beings broke their covenantal relationship with God, thereby restoring the original created unity between God and human beings. However, the fact that He is the one who appointed Christ as high priest indicates that God also reacts positively to the sinful departure of human beings, in the sense that He provides a way to reestablish His covenantal relationship with them.

\section{Agent}

Regarding the agent of the priesthood in the historical model, Christ was prepared/perfected for the official priestly office through His incarnation and deadly suffering, to learn obedience to God and be merciful toward human beings. Thus, His official priesthood was initiated at His exalted ascension.

According to the historical framework of the principles of reality, Christ's preparation/perfection as the priestly agent through His incarnation and deadly suffering, learning obedience to God and being merciful toward human beings, was a real historical process for the divine-human Christ, and not something relegated to an instrumental 
(spatio-temporal) humanity of Christ. Similarly, the official initiation of His priesthood at the ascension is a historical (temporal) event that took place in a specific place (spatial divine real sanctuary in heaven).

\section{Actions}

The priestly actions of Christ in the historical model officially initiated with His presentation before the Father of His earthly sacrifice. On the basis of the Father's acceptance of that sacrifice, Christ performs an ongoing salvific mediation that includes intercession for forgiveness before the Father and empowerment of believers through the Holy Spirit. This ongoing mediation is finished by the eschatological judgment and salvation, as Christ will bring complete salvation to believers in His second coming.

Considering the spatio-temporal interpretation of the principles of reality, the presentation of Christ's sacrifice to the Father at the ascension was a historical (spatiotemporal) event that was subsequently followed by His ongoing mediation before the Father in heaven and by the Spirit on earth. The spatio-temporal continual action in heaven synchronically relates to the history of human beings on earth, particularly considering their actions and prayers. This means that God's forgiveness is a real divine action that historically responds to the priestly activity of Christ. Likewise, the purification of the heavenly things is somehow a spatio-temporal activity in the heavenly sanctuary in terms of forgiveness and judgment. Moreover, Christ's empowerment of believers through the Spirit really happens historically. This is not an eternally constituted reality in the being or will of God that is actualized in spatio-temporal realities on earth.

\section{Goal}


The goal of Christ's priesthood in the historical model is to establish a covenantal relationship between God and human beings, and this takes place in three phases: (1) the inauguration of the new/better covenant at the ascension of Christ and the official initiation of His priesthood in the heavenly sanctuary, (2) the daily mediation that provides divine forgiveness and the internalization of the divine laws in God's covenantal people, and (3) the final purification in the context of eschatological judgment and salvation leading to the consummation of the new/better covenant.

Taking into account the historical interpretation of the principles of reality, the goal of Christ's priesthood is not fulfilled as an earthly actualization of a reality already constituted in God's heaven. Rather, there is a divine work done in heaven to achieve human salvation in the official inauguration, daily mediation, and final purification. Christ's daily mediation in the heavenly sanctuary synchronically relates to the history of human beings on earth, implying that God's forgiveness temporally follows their prayers and Christ's intercession. Thus, there is a temporal synchronism between heaven and earth, as Christ empowers believers to remain and grow in the new covenantal relationship with God, in the context of their struggle against sin, until the judgment and salvation leading to the historical (spatio-temporal) achievement of the redemptive goal of the covenant.

\section{Potential Challenges to These Implications}

This spatio-temporal interpretation of the principles of reality behind Christ's priesthood in Hebrews, suggested in this research, could be challenged in two main ways. One challenge could be the charge of literalism in the interpretation of Hebrews. This critique would assume that Hebrews is not to be read ontologically, but as a theological 
exhortation (13:22). The first problem I see in this criticism is that literalism is not an accurate description of the interpretation of Hebrews suggested in the present study, as I have proposed that God's spatio-temporality is not exactly the same as human spatiotemporality and the heavenly sanctuary is not precisely identical to the earthly sanctuary, but a reality is assumed. The second problem with this challenge is that while the primary purpose of Hebrews is not to provide a theological ontology, the theological exhortation does not exclude ontological notions but rather assumes them. ${ }^{362}$ In other words, the exhortation to believers assumes that Christ is really a high priest in heaven on their behalf. Another important point relates to Hebrews' use of Psalms. The author of Hebrews could be charged of literalism as He uses the poetical language of Psalms in order to scripturally ground the events of Christ's kingship and priesthood. ${ }^{363}$ However, the Christological use of Psalms in Hebrews seems to indicate that their poetry is not merely metaphorical language with no reference to reality, but it points to the fulfilment of historical realities in a poetic way. In short, the problem of not allowing the biblical text to have a say about the reality it assumes or implies is that we leave the door open to explicitly or implicitly speculate about the meaning of the reality assumed by the text outside Scripture. When the theologian brings this alien speculation to guide and shape scriptural interpretation, he or she acts as if there was an absconditus God behind the God

\footnotetext{
${ }^{362}$ Adams makes a similar point in his discussion of the cosmology of Hebrews. In his words, "Hebrews is not a treatise on cosmology," but the author does "make serious statements that relate to" cosmological "questions." Hence, "cosmological assertions are intertwined with his Christological claims, so that one could not jettison his cosmology without doing serious damage to his Christology." Adams, "The Cosmology of Hebrews," 122, 138. See also Laansma, "The Cosmology of Hebrews," 125. Following the logic of Adams' argument, the implied ontology of Hebrews is foundational for its theology and exhortation.

${ }^{363}$ See, e.g., Heb 1:5 and 5:5 (Ps 2:7); 1:6 (Ps 97:7); 1:8-9 (Ps 45:6-7); 1:10-12 (102:25-27); 1:13 (Ps 110:1); 2:6-8 (Ps 8:5-7); 5:6 and 7:17, 21 (Ps 110:4).
} 
of Scripture, or an absconditus Christ behind the Christ of Scripture, or an absconditus divine heaven behind the heaven of Scripture. ${ }^{364}$ Their realities are obviously more complex than their portrayal in Scripture, but not contrary to or necessarily less than this portrayal.

The second type of charge would not necessarily challenge my ontological reading of Hebrews, but question whether the ontological assumptions of Hebrews should be taken into account in modern theology. According to this type of challenge, the assumptions of Hebrews would be part of a first century (pre-scientific) view of reality. ${ }^{365}$ Without entering into the discussion of biblical inspiration, ${ }^{366}$ it is importance to notice that Hebrews was not merely following ancient cosmological views. ${ }^{367}$ In principle, the interpretation suggested in this study does not seem to be incompatible with the scientific data used in modern cosmology research. ${ }^{368}$ Furthermore, the holistic account of human

364 This is an extension of Barth's criticism to the notion of God absconditus that I have described in the previous chapter (see Ontological Model, Divinity).

365 This challenge follows Bultmann's notion that the cosmology of the NT is mythical and obsolete. See Rudolf Bultmann, Kerygma and Myth: A Theological Debate, trans. Hans Werner Bartsch (New York: Harper and Row, 1961), 1-8.

${ }^{366}$ This is an important topic to be addressed in this type of debate. One aspect to be discussed, for example, is that God, the supreme creator, would not communicate to the inspired author a mistaken cosmology. According to this view, if there is an outdated cosmology, this would be related with the human prophet (who lived in a pre-scientific age), and not with God. However, I would suggest that while the biblical inspired material is not a treatise on cosmology, it remains to be shown that the Bible contains cosmological statements or assumptions that go against modern scientific research, even though this has been the view promoted by many theologians. An example of this situation is the myth of a solid heavenly dome the correction offered by Randall W. Younker and Richard M. Davidson, "The Myth of the Solid Heavenly Dome: Another Look at the Hebrew Rāqîa“,” AUSS 49, no. 1 (2011): 125-147.

${ }^{367}$ While a research on ancient cosmologies was beyond the scope of the present study, I have indicated in the section on cosmology that Hebrews does not assume, for example, an outdated Platonic cosmology or an outdated cosmological view of several heavens.

${ }^{368}$ My study suggests that there is an atmospheric heaven or sky and a part of the created universe (the heaven where God governs the world) that is beyond our scientific knowledge of the universe. The existence of this heaven where God governs the universe cannot be either proved or disproved by modern 
nature, for example, is consistent with theological anthropological modern views. ${ }^{369}$ With regard to a spatio-temporal God and His spatio-temporal heaven, they go beyond the scope of scientific enquiry, as these are realities existing beyond our world, even though these topics may raise interesting questions for philosophical theology. Therefore, this second challenge is not a problem for the results suggested in this research.

My answers to these potential challenges, however, do not preclude the need of further research on the way biblical materials present assumptions about realities and also how modern science can dialogue with the ontological theology found implicitly or explicitly in Scripture.

Having discussed the implications of the principles of reality assumed in Hebrews for the understanding of Christ's priesthood, I will outline in the next chapter a brief comparison of my findings about the priesthood of Christ in Hebrews and its principles of reality in this chapter (the historical model) with the models described and compared in the previous chapters.

scientific cosmology. Since modern science does not offer us an exhaustive knowledge of the universe, the notion of a divine heaven is not incompatible with the scientific data used in modern cosmology.

${ }^{369}$ See, e.g., Nancey C. Murphy, Bodies and Souls, or Spirited Bodies? (Cambridge; New York: Cambridge University Press, 2006); John C. Polkinghorne, Theology in the Context of Science (New Haven: Yale University Press, 2009), 74. 


\section{CHAPTER 5}

\section{A BRIEF COMPARISON OF THE MODELS}

\section{Introduction}

In this short chapter, I will compare the priesthood of Christ and its principles of reality in the historical model (depicted in chapter 4), with the sacramental, functional, and ontological models (described in chapters 2 and 3). The comparisons at the end of chapters 2 and 3 will serve as a basis for this last comparison. Thus, I will follow the same structure/style and I do not need to repeat here all the explanations outlined earlier.

\section{The Priesthood of Christ}

The Need for Christ's Priesthood

The comparison of the models regarding the need for CP in chapter 2 was organized according to two basic questions: (1) What is the problem of $\sin$ ? (2) Why is CP necessary? The answers to the first question (see Table 9) in the three first models were initially two: an ontological disorder that hinders the teleological movement from human beings to God (sacramental model), and a moral rebellion of human beings against God (functional and ontological models). Both answers assume that original creation is incomplete and in need of fulfillment. In this way, sin either describes (theistic evolution: ontological and sacramental [O’Collins] models) or deepens (historical fall: sacramental [Aquinas] and functional models) this incompleteness. In this context, how does the historical model answer this question and how does it relate to the answers 
provided by the other models? First of all, the book of Hebrews does not offer the details that the models provide. More specifically, it is not possible to determine categorically in the context of Hebrews that the sin problem is primarily human rebellion. Likewise, the affirmation of a complete original creation is not explicitly stated in Hebrews.

\section{Table 9. The need for $\mathrm{CP}$}

\begin{tabular}{|c|c|c|c|}
\hline SACRAMENTAL MODEL & FUNCTIONAL MODEL & ONTOLOGICAL MODEL & HISTORICAL MODEL \\
\hline $\begin{array}{l}\text { The Problem of Sin } \\
\circ \text { ontological disorder } \\
\circ \quad \text { background: original } \\
\text { creation is incomplete }\end{array}$ & $\begin{array}{l}\text { The Problem of Sin } \\
\circ \text { moral rebellion } \\
\circ \quad \text { background: original } \\
\text { creation is incomplete }\end{array}$ & $\begin{array}{l}\text { - The Problem of Sin } \\
\circ \text { moral rebellion } \\
\circ \text { background: original } \\
\text { creation is incomplete }\end{array}$ & $\begin{array}{l}\text { - The Problem of Sin } \\
\text { moral rebellion } \\
\text { (transgression of the } \\
\text { divine law) } \\
\text { background: original } \\
\text { creation complete }\end{array}$ \\
\hline $\begin{array}{l}\text { Why CP is necessary } \\
\circ \text { human healing } \\
\circ \text { improvement of } \\
\text { original creation: } \\
\text { qualified by a } \\
\text { historical fall } \\
\text { (Aquinas) or theistic } \\
\text { evolution (O'Collins) }\end{array}$ & $\begin{array}{l}\text { Why CP is necessary } \\
\text { ○ divine propitiation } \\
\circ \text { improvement of } \\
\text { original creation: } \\
\text { qualified by a } \\
\text { historical fall }\end{array}$ & $\begin{array}{l}\text { Why CP is necessary } \\
\text { O divine propitiation } \\
\circ \quad \text { improvement of } \\
\text { original creation: } \\
\text { qualified by theistic } \\
\text { evolution }\end{array}$ & 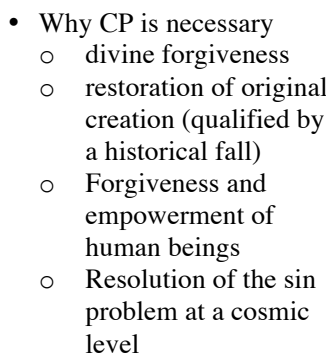 \\
\hline
\end{tabular}

However, we should not read Hebrews in isolation from other canonical books.

While a canonical study of the priesthood of Christ lies beyond the scope of this study, I suggest that Hebrews seems to assume the picture of creation delineated in Genesis (Heb 4:4 quotes Gen 2:2): The good/complete creation (Gen 1-2) is marred by human sin, which was initiated as a rebellion/disobedience against God (Gen 3). ${ }^{1}$

Furthermore, the scope of the sin problem in Hebrews is not limited to human

\footnotetext{
${ }^{1}$ Arguably, this was not only the case at the beginning of human sin. Rather, rebellion seems to be the main definition of the sin problem in every age, as this is the reason for the strongest warnings of Hebrews (see my discussion on the need for $\mathrm{CP}$ in the previous chapter).
} 
beings, but comprises a defilement of heaven and the action of the devil leading to death. ${ }^{2}$ This larger scope appears to imply that these elements, not emphasized in the three models, were not part of a supposedly original incomplete creation (Why would heaven be defiled in original creation? Why would the devil lead people to death in original creation?), but they have been added after the disruption of a complete original creation.

Regarding the second question (Why is CP necessary?), two answers were provided by the three models: $\mathrm{CP}$ is needed primordially to heal human beings from the imperfection of their creation (sacramental model) or it is necessary chiefly for the propitiation of God (functional and ontological models). From the broader perspective of the incompleteness of original creation, $\mathrm{CP}$ is ultimately needed to improve original creation, either directly (theistic evolution) through the activities of ontological healing (O'Collins) and divine propitiation (ontological model), or indirectly (historical fall, the incompleteness of original creation is now addressed under the new conditions of sin) through these same activities (Aquinas and Calvin respectively). Because the historical model defines the sin problem primordially in terms of rebellion, it agrees with the functional and ontological models that the principal need for $\mathrm{CP}$ is divine forgiveness. This is exemplified by the fact that CP in Hebrews begins with the ascension of Christ, who goes before the presence of God the Father. Only after that the empowerment of human beings is possible. Furthermore, since the historical model views original creation as complete, $\mathrm{CP}$ is needed for restoration of original creation, and not its improvement or

\footnotetext{
${ }^{2}$ The action of the devil producing death in Hebrews (2:14) could be understood as another pointer that Hebrews assumes the Genesis account of the Fall, as the serpent leads human beings to sin and death in chapter 3 (see Rev 12:9). In this view, the action of the devil in Heb 2:14 would be a continuation of what was initiated in Gen 3.
} 
fulfillment. The notions that $\mathrm{CP}$ is not effective when it is rejected by human beings and that $\mathrm{CP}$ does not eliminate the need of personal endurance emphasize the idea of human responsibility, and not a fulfillment of original creation. Rather, the idea of fulfillment is related to the redemptive plans of God outlined in the Aaronic priesthood.

\section{The Agent of Priesthood}

The following questions guided the comparison of the three models regarding the agent of CP: (1) How is Christ's divinity involved in His priesthood? (2) How is Christ's humanity involved in His priesthood? Taking into account the first question, in the sacramental model the divine agent focuses His priestly activity upon human beings (see Table 10), while in the functional and ontological models this agent focuses on God. Second, while the functional model seems to see the agency of the divine Son (second person) working to propitiate God the Father (first person), the ontological model tends to draw a more general picture of God acting upon Himself. In this way, the divinity of Christ seems to be the main agent of the priesthood in the ontological model. In comparison with these views, the historical model seems to focus on God the Father as the object of the priestly action in terms of forgiveness. Like in the functional and ontological models, this statement derives from the notion that rebellion is the main feature of the sin problem. While the historical model would agree with the ontological model that Christ's priesthood could be interpreted as God acting upon Himself (subject/object), the historical model would describe this conception along the lines of the functional model, where the God the Son (incarnate) works for the forgiveness ${ }^{3}$ of God

\footnotetext{
${ }^{3}$ While the functional model speaks of propitiation, the historical model prefers the concept of
} 
the Father (provided this work was already planned by the Father).

Table 10. The agent of CP

\begin{tabular}{|c|c|c|c|}
\hline SACRAMENTAL MODEL & FUNCTIONAL MODEL & ONTOLOGICAL MODEL & HISTORICAL MODEL \\
\hline $\begin{array}{l}\text { - Agency: Christ's divinity } \\
\circ \quad \text { Main agent } \\
\circ \underline{\text { Focus: acts toward }} \\
\\
\text { human beings }\end{array}$ & $\begin{array}{l}\text { - Agency: Christ's divinity } \\
\text { ○ Guarantees: eternity } \\
\text { and power of the } \\
\text { priesthood } \\
\circ \quad \begin{array}{l}\text { Focus: God (second } \\
\text { person propitiates } \\
\text { the first person) }\end{array}\end{array}$ & 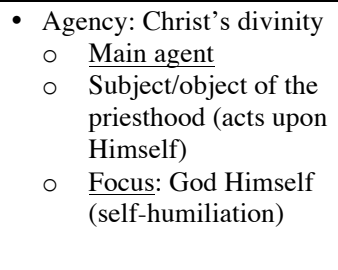 & $\begin{array}{l}\text { - Agency: Christ's Divinity } \\
\text { Main agent: divine- } \\
\text { human } \\
\circ \text { Learned obedience } \\
\circ \quad \text { Focus: God the Son } \\
\text { intercedes for the } \\
\text { forgiveness of God } \\
\text { the Father }\end{array}$ \\
\hline $\begin{array}{l}\text { - Agency: Christ's } \\
\text { humanity }\end{array}$ & $\begin{array}{l}\text { - Agency: Christ's } \\
\text { humanity }\end{array}$ & $\begin{array}{l}\text { - Agency: Christ's } \\
\text { humanity }\end{array}$ & $\begin{array}{l}\text { - Agency: Christ's } \\
\text { Humanity }\end{array}$ \\
\hline $\begin{array}{l}\text { His human life as } \\
\text { the scope of the } \\
\text { priesthood } \\
\text { Human nature as the } \\
\text { instrument of the } \\
\text { divine agency (point } \\
\text { of contact with the } \\
\text { physical world) }\end{array}$ & $\begin{array}{ll}\circ & \text { Main agent } \\
\circ & \text { Performs priestly } \\
& \text { functions/actions } \\
& \text { (obedience, } \\
& \text { teaching, sacrifice) }\end{array}$ & $\begin{array}{ll}\text { Earthly form of } \\
\text { God's self- } \\
\text { humiliation } \\
\text { Recipient of the } \\
\text { benefits of the } \\
\text { priesthood }\end{array}$ & $\begin{array}{ll}\circ & \text { Main agent: divine- } \\
\text { human } & \\
\circ & \text { Enabled divinity to } \\
\text { experience suffering, } & \text { test/temptation, death } \\
\text { (pre-requisite) in a } \\
\text { divine-human level } \\
\circ \quad \text { Priest-king, God's } \\
\text { appointment } \\
\text { (officially at the } \\
\text { ascension) } \\
\end{array}$ \\
\hline
\end{tabular}

Regarding the agency, the historical model conceptualizes Christ as agent of the priesthood acting as divine-human being, and not through a human nature. ${ }^{4}$ While the sacramental and ontological models consider the divinity of Christ as the main agent of His priesthood, and the functional model attempts to focus on His humanity as the main agent, the historical model seeks to highlight the unity of a divine-human agency.

The main emphasis of the historical model regarding Christ's humanity is that the human nature enabled His divinity to experience suffering, test/temptation, and death as a

forgiveness.

${ }^{4}$ As already indicated, the divine Christ was able to perform mediation before His incarnation in terms of creation. Furthermore, the divine Christ in the incarnate state was able to learn obedience and to become merciful on a new level (the level of a divine-human being). 
human being. However, a key difference between the historical model and the other models is that this experience ${ }^{5}$ is not a constitutive part of His priesthood, but a prerequisite. The priestly agency officially starts at His ascension into heaven. This official beginning is not sufficiently emphasized in the other models, which affirm in different ways the priestly agency in the incarnate earthly life with its climax on the cross.

\section{The Actions of the Priest}

The comparison of the priestly actions of Christ was organized according to the following questions: (1) How are His actions seen as a whole? (2) What are the priestly actions of the earthly Christ? (3) What are the priestly actions of the ascended Christ?

Priestly action as a whole: Regarding the first question, the sacramental and ontological models tend to view Christ's priestly action as one (see Table 11). The unifying principle in the sacramental model is the notion of Christ's invisible sacrifice (with different forms of material expression and effective communication to human beings - sacraments). Whereas in the ontological model the unifying principle in this model is the one person of Christ, who is the object of His own priestly actions. On the other hand, the functional model emphasizes distinct and subsequent actions in Christ's priesthood (teaching, sacrifice on the cross, and heavenly intercession). In comparison with these models, the historical model is similar to the functional model in the emphasis of distinct and subsequent actions, although the sequence of actions is different. This difference leads to the next question.

\footnotetext{
${ }^{5}$ Another important difference is that a timeless-spaceless divinity, as assumed in the other
} 


\section{Table 11. The actions of $\mathrm{CP}$}

\begin{tabular}{|c|c|c|c|}
\hline SACRAMENTAL MODEL & FUNCTIONAL MODEL & ONTOLOGICAL MODEL & HISTORICAL MODEL \\
\hline $\begin{array}{l}\text { Action: one (invisible } \\
\text { sacrifice) - multiple } \\
\text { material expressions }\end{array}$ & $\begin{array}{l}\text { Actions: multiple } \\
\text { (teaching, sacrifice, } \\
\text { intercession) and } \\
\text { subsequent }\end{array}$ & $\begin{array}{l}\text { Action: one (Christ's one } \\
\text { person and action - } \\
\text { subject/object the action) }\end{array}$ & $\begin{array}{l}\text { Action: multiple } \\
\text { (sacrificial offering, } \\
\text { ongoing salvific } \\
\text { mediation, eschatological } \\
\text { judgment and final } \\
\text { salvation) }\end{array}$ \\
\hline - Earthly Christ & - Earthly Christ & - Earthly Christ & - Earthly Christ \\
\hline $\begin{array}{ll}\text { Entire life (devotion } \\
\text { to God - invisible } \\
\text { sacrifice) } \\
\text { Material expression } \\
\text { (cross) } \\
\text { - Powerful influence } \\
\text { on material human } \\
\text { beings }\end{array}$ & $\begin{array}{ll}\circ \quad \text { Teachings } \\
\circ \quad \text { Penal } \\
\text { substitutionary } \\
\text { sacrifice (cross) } \\
\text { - Christ punished in } \\
\text { the place of sinners }\end{array}$ & $\begin{array}{ll}\circ & \text { Intercessory } \\
& \text { life/death } \\
\circ \quad \text { Substitutionary } \\
\text { sacrifice (cross) } \\
\text { - Sinners destructed } \\
\quad \text { in Christ }\end{array}$ & $\begin{array}{l}\text { Life/death as } \\
\text { preparatory and } \\
\text { even proleptic or } \\
\text { part) for His official } \\
\text { heavenly priesthood }\end{array}$ \\
\hline $\begin{array}{l}\text { - Ascended Christ } \\
\text { Ministers the } \\
\text { sacraments } \\
\text { (eucharist - } \\
\text { material/sacramenta } \\
1 \text { form of the } \\
\text { sacrifice): heals } \\
\text { human beings on } \\
\text { earth (application of } \\
\text { salvation) }\end{array}$ & $\begin{array}{l}\text { - Ascended Christ } \\
\text { Intercession in } \\
\text { heaven: subsequent } \\
\text { propitiation of the } \\
\text { Father } \\
\text { Teaching } \\
\text { (word/sacrament): } \\
\text { application of } \\
\text { salvation to } \\
\text { believers on earth } \\
\text { (Lord's Supper) }\end{array}$ & $\begin{array}{l}\text { - Ascended Christ } \\
\text { Reveals the reality } \\
\text { of complete } \\
\text { reconciliation to } \\
\text { human beings on } \\
\text { earth } \\
\text { (contemporaneous } \\
\text { to all times, taste of } \\
\text { the new reality in } \\
\text { the eucharist) }\end{array}$ & $\begin{array}{l}\text { - Ascended Christ } \\
\circ \quad \text { Presentation of His } \\
\text { sacrifice to the Father } \\
\text { at the ascension } \\
\circ \quad \text { Ongoing salvific } \\
\text { mediation } \\
\text { (intercession for } \\
\text { forgiveness, } \\
\text { empowerment of } \\
\text { believers) } \\
\text { Eschatological } \\
\text { judgment and final } \\
\text { salvation at the } \\
\text { second coming }\end{array}$ \\
\hline
\end{tabular}

Priestly actions of the earthly Christ: In the three models, the main emphasis regarding the priestly actions of the earthly Christ lies on the interpretations of His sacrifice. According to the principle of invisible sacrifice in the sacramental model, His entire earthly life of devotion to God is a sacrifice that assumes a particular visibile/material expression on the cross. Since CP is needed for the healing of human beings and the divine Christ is the main agent of the priesthood that acts through the instrumentality of His humanity, the material expression of Christ's sacrifice on the cross

models, does not really have this experience. The experience is merely instrumental via human nature. 
is a powerful influence on material human beings. ${ }^{6}$

For the functional model, Christ's earthly teachings are priestly activities, but the main emphasis centers on His penal substitutionary sacrifice on the cross. Because CP is needed for divine propitiation and His humanity is its main agent, the sacrifice of the cross describes the human Christ receiving the wrath of God in the place of elected human beings (propitiation by punishing Christ in the place of sinful human beings).

In the ontological model, while Christ's life (especially when in prayer) and death are intercessory, the focus is on His substitutionary sacrifice on the cross, which means the destruction of $\sin /$ evil. In contrast to these models, the historical model interprets Christ's life and particularly His sacrifice as pre-requisites (that may involve proleptic priestly language) for the fulfillment of the priestly role officially initiated at the ascension. This point leads us to the next question.

Priestly actions of the ascended Christ: As far as the priestly actions of the ascended Christ, the sacramental model emphasizes the sacraments of the church (particularly the eucharist), which are ultimately ministered by the ascended Christ. Following the principle of invisible sacrifice, the eucharist is a material/sacramental form of Christ's sacrifice that effectively heals human beings. For the functional model, the emphasis is on Christ's ongoing heavenly intercession, which is a subsequent salvific activity that propitiates God the Father on the basis of the earthly sacrifice on the cross. This model also assumes that the priestly teaching of Christ continues after His ascension in the form of word and sacrament, which effectively applies (especially through the

\footnotetext{
${ }^{6}$ In contrast to the functional model, there is no penal substitutionary atonement in this model.
} 
Lord's Supper) salvific grace to human beings. In the ontological model, the ascended Christ reveals the reality of complete reconciliation in His contemporaneity to all times, offering a taste of this new reality in the eucharist. In contrast to the sacramental and functional models, the ontological model attempts to avoid the notion of subjective salvific application of the priestly actions in Christ (the reality of salvation) to concrete human beings.

However, only the functional model focuses on a concrete salvific activity in heaven. In the sacramental and ontological models, the emphasis is on the activity of the ascended Christ on earth, either sacramentally healing human beings (sacramental model) or revealing to them the complete reality of human reconciliation already effected by God in Christ (ontological model). In comparison with these models, the historical model intensifies the focus of the functional model on Christ's priestly activity in heaven, as it emphasizes the official priestly actions of His ascended state. The historical model stipulates a sequence of official priestly activities performed by the ascended Christ in heaven. At the ascension, He presented the sacrifice on the cross to the Father, entering into the heavenly sanctuary, for the forgiveness of human sins. In his ongoing salvific mediation, He intercedes for forgiveness before the Father and empower believers through the Holy Spirit (see Heb 6:4; 10:29). ${ }^{7}$ In contrast to the other models, the historical model does not regard the Lord's Supper/Eucharist part of Christ's priestly action, even though from a canonical perspective this crucial earthly celebration can be

\footnotetext{
${ }^{7}$ Even though the focus of these passages is not on the elaboration of the role of the Holy Spirit in this process, 6:4 seems to describe the earthly experience of salvation as sharing in the Holy Spirit, which is also depicted as tasting the heavenly gift, the word of God, and the powers of the coming age. In 10:29, the one who rejects Christ and the blood of the covenant that has sanctified him/her also outrages the Spirit of grace.
} 
understood as a remembrance and proclamation of the new convenant (see 1 Cor 11:25268 ; Matt 26:28; Mark 14:24; Luke 22:20) mediated by Christ's priesthood. Finally, Christ's priestly activity is associated with the eschatological judgment and then the second coming that will bring complete salvation to believers.

\section{The Goal of the Priesthood}

Considering that all models propose that the goal of $\mathrm{CP}$ is the reconciliation of human beings with God, the following questions guided their comparison: (1) What is the nature of the reconciliatory goal? (2) How does CP achieve this goal?

Regarding the first question, the sacramental model emphasizes an ontological reconciliation, described in terms of a teleological union, a participation of human beings in God, which is ultimately the goal of original creation (see Table 12). The emphasis of the functional model is on a moral reconciliation characterized by the grace of God's forgiveness, who justifies and then sanctifies human beings. The ontological model pushes the functional model a little further by assuming that creation is in need of moral reconciliation since the beginning, and emphasizes that the locus of the reality of reconciliation is Christ. In His divine-human person, God and humanity are reconciled, which means that the goal of $\mathrm{CP}$ is already an ontological reality. In comparison with these models, the historical model conceptualizes the goal of covenantal/moral reconciliation according to the framework of the better/new covenant. The first covenant (Aaronic priesthood) was a pointer to the reality of Christ's priesthood. Only this reality

\footnotetext{
${ }^{8}$ I have taken the language of remembrance (ává $\left.\mu \nu \eta \sigma \varsigma\right)$ and proclamation (related to the verb $\left.\varkappa \alpha \tau \alpha \gamma \gamma \varepsilon^{\prime} \lambda \lambda \omega\right)$ from this passage.
} 
could achieve the goal of the removal of sin, bringing about a close relationship between God and human beings.

Table 12. The goal of $\mathrm{CP}$

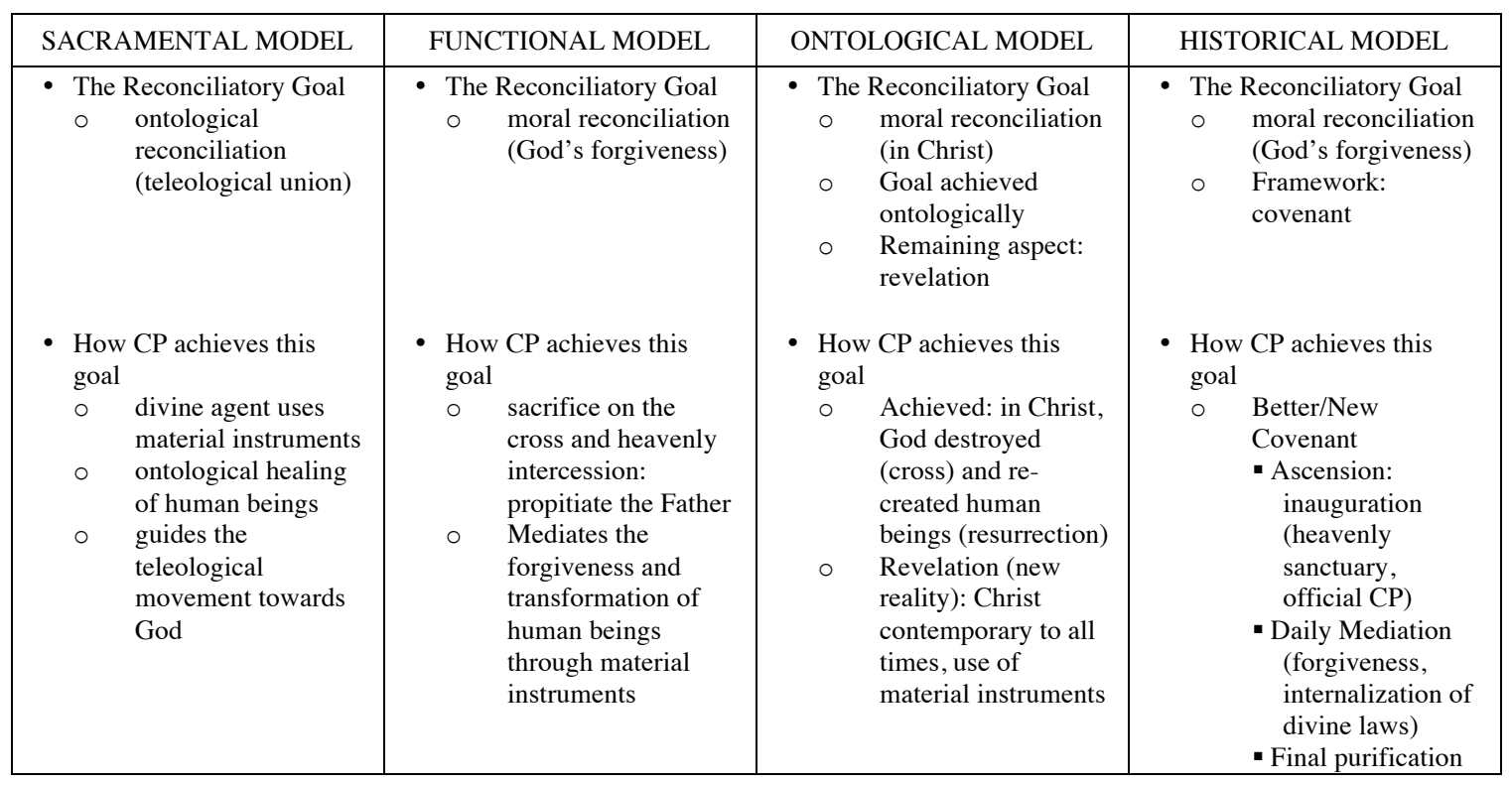

In this context, how does CP lead to the reconciliatory goal? In the sacramental model, the ontological reconciliation is reached through the healing of human beings. By means of material instruments (Christ's humanity, sacraments), the divine agent in CP produces this healing, leading human beings in their teleological movement towards God. For the functional model, the moral reconciliation is reached primordially through the propitiation of the Father. The transformation of human beings, also mediated by material instruments (word/sacrament), is dependent and subsequent to His forgiveness. In this case, CP leads to the reconciliatory goal by primordially propitiating the Father (in His earthly sacrifice on the cross and in His heavenly intercession), and then by mediating 
forgiveness and transformation to human beings through material instruments. In the ontological model, the reconciliatory goal is already a complete reality in (in Christ), but it still needs to be revealed to human beings. Christ is revealing the new reality of reconciliation by means of His contemporaneity to all times, using material instruments to provide a taste of this new reality. In comparison with these models, the historical model stipulates that the goal of moral reconciliation is achieved on the basis of the establishment of the better/new covenant that took place at the official inauguration of Christ's priesthood at His ascension. With this, He initiated a daily mediation that provides forgiveness of sins and the internalization of divine laws by which human beings achieve spiritual union with God. Christ helps believers remain and grow in the covenantal relationship with God, as they struggle against sin, until the judgment and salvation leading to the consummation of the covenant.

Having provided this brief comparison of the models of Christ's priesthood, I will compare the interpretation of the macro-hermeneutical principles of reality assumed by the historical model with the interpretations assumed by the other three models.

\section{The Priesthood of Christ}

\section{Divinity: Christ and the Concept of Divine Nature}

The sacramental, functional, and ontological models seem to affirm or are logically close to the idea that God, in His perfection, is timeless/spaceless in His being (for instance, immutable, simple, impassible, non-discursive knowledge), and consequently His eternal (timeless/spaceless) action is described by His will (predestination). This notion is nuanced in different ways (see Table 13). According to this general perspective, the "historical" action of God takes place through the use of 
earthly spatio-temporal instruments that repeat the simultaneous divine action into the sequentiality of earthly time. What is already a timeless or simultaneous reality in God is actualized or repeated into sequential time.

\section{Table 13. Divinity}

\begin{tabular}{|c|c|c|c|}
\hline SACRAMENTAL MODEL & FUNCTIONAL MODEL & ONTOLOGICAL MODEL & HISTORICAL MODEL \\
\hline $\begin{array}{l}\text { - God's nature: } \\
\text { timeless/spaceless }\end{array}$ & $\begin{array}{l}\text { - God's nature: timeless/ } \\
\text { spaceless (emphasis on } \\
\text { knowledge) }\end{array}$ & $\begin{array}{l}\text { God's nature: simultaneous } \\
\text { temporality (logically close to } \\
\text { timelessness) and } \\
\text { incomprehensible spatiality } \\
\text { (logically close to } \\
\text { spacelessness) }\end{array}$ & $\begin{array}{l}\text { - God's nature: spatio- } \\
\text { temporal (able to } \\
\text { sequentially experience } \\
\text { spatio-temporality) }\end{array}$ \\
\hline $\begin{array}{l}\text { - God's eternal action: } \\
\text { timeless predestination } \\
\text { (primary cause) }\end{array}$ & $\begin{array}{l}\text { - God's eternal action: } \\
\text { timeless predestination }\end{array}$ & $\begin{array}{l}\text { - God's eternal action: } \\
\text { simultaneous (timeless) } \\
\text { action/predestination }\end{array}$ & $\begin{array}{l}\text { - God's eternal plan: } \\
\text { predestination }\end{array}$ \\
\hline $\begin{array}{l}\text { - God's historical action: } \\
\text { historical/chronological } \\
\text { actualization through } \\
\text { spatio-temporal } \\
\text { instruments (secondary } \\
\text { causes) }\end{array}$ & $\begin{array}{l}\text { - God's historical action: } \\
\text { historical/chronologica } \\
1 \text { actualization through } \\
\text { spatio-temporal } \\
\text { instruments (secondary } \\
\text { causes implied) }\end{array}$ & $\begin{array}{l}\text { - God's historical action: divine } \\
\text { historical/chronological self- } \\
\text { repetition through spatio- } \\
\text { temporal instruments } \\
\text { (secondary causes implied) }\end{array}$ & $\begin{array}{l}\text { - God's historical action: } \\
\text { historical/chronologica } \\
1 \text { action }\end{array}$ \\
\hline $\begin{array}{l}\text { The object of God's } \\
\text { salvific action: spatio- } \\
\text { temporal human beings }\end{array}$ & $\begin{array}{l}\text { The object of God's } \\
\text { salvific action: spatio- } \\
\text { temporal human beings }\end{array}$ & $\begin{array}{l}\text { The object of God's salvific } \\
\text { action: He Himself (spatio- } \\
\text { temporal human beings are } \\
\text { benefited in Him/Christ) }\end{array}$ & $\begin{array}{l}\text { - The object of God's } \\
\text { salvific action: spatio- } \\
\text { temporal human beings } \\
\text { compatible with His } \\
\text { spatio-temporal actions }\end{array}$ \\
\hline
\end{tabular}

In contrast to these models, the historical model holds that God is spatio-temporal, meaning that He is able to really experience sequential events in specific places. This position implies that there is no divine eternal/timeless action (predestination) and, therefore, there is no need to conceptualize an actualization of eternal action in spatiotemporal reality. In other words, God's actions really take place in history (in the sense of a sequence of events) instead of being merely duplicated in the temporality of our world. In this context, there is no distinction between eternal and historical action, since all action is historical. In this case, divine predestination would be an eternal divine plan, 
instead of a real eternal "action." Furthermore, if there is a need some kind of instrumentality for the fulfillment of the salvific divine plan, this need is not caused by a discontinuity between God as timeless-spaceless reality and spatio-temporal human beings, but motivated by other factors.

\section{Humanity: Christ and the Concept of Human Nature}

The sacramental, functional, and ontological models agree that Christ's humanity is spatio-temporal (see Table 14), while they stipulate different levels of relationships between Christ's humanity and divinity, from the perspective of space-time. Essentially, Christ's humanity is a spatio-temporal instrument of His non-spatial/timeless divinity. The historical model concurs with the idea that Christ's humanity is spatio-temporal, but it disagrees with the other models regarding the understanding of the instrumentality of His humanity.

In short, in the historical model, Christ's humanity is not a spatio-temporal instrument of His non-spatial/timeless divinity, since divinity is spatio-temporal in an analogical infinite sense. Christ's humanity is a pre-requisite that enables Him as God to be a human being by ontological accommodation. In this sense, Christ experiences reality on a new level, namely, on the divine-human level. This new experience qualifies Him to be more symphatetic toward human beings and obedient toward God. Christ's humanity enables Him as God to experience something altogether new, that is, obedience and death. 


\section{Table 14. Humanity}

\begin{tabular}{|c|c|c|c|}
\hline SACRAMENTAL MODEL & FUNCTIONAL MODEL & ONTOLOGICAL MODEL & HISTORICAL MODEL \\
\hline $\begin{array}{l}\text { Christ's human nature: } \\
\text { spatio-temporal }\end{array}$ & $\begin{array}{l}\text { - Christ's human nature: } \\
\text { spatio-temporal }\end{array}$ & $\begin{array}{l}\text { - Christ's human nature: } \\
\text { spatio-temporal }\end{array}$ & $\begin{array}{l}\text { - Christ's human nature: } \\
\text { spatio-temporal }\end{array}$ \\
\hline $\begin{array}{l}\text { - Instrumentality: secondary } \\
\text { cause (spatio-temporal) of } \\
\text { divine } \\
\text { timelessness/spacelessness }\end{array}$ & $\begin{array}{l}\text { Instrumentality: } \\
\text { secondary cause (spatio- } \\
\text { temporal) of divine } \\
\text { timelessness/spacelessn } \\
\text { ess }\end{array}$ & $\begin{array}{l}\text { Instrumentality: secondary } \\
\text { cause (spatio-temporal) of } \\
\text { divine simultaneity } \\
\text { (logically close to } \\
\text { timelessness/spacelessness) }\end{array}$ & $\begin{array}{l}\text { - God becomes a human } \\
\text { being ontologically } \\
\text { (mystery of the } \\
\text { incarnation) }\end{array}$ \\
\hline $\begin{array}{l}\text { - Goal of the instrumentality: } \\
\text { historical actualization }\end{array}$ & $\begin{array}{l}\text { - Goal of the } \\
\text { instrumentality: } \\
\text { historical actualization }\end{array}$ & $\begin{array}{l}\text { - Goal of the instrumentality: } \\
\text { historical revelation }\end{array}$ & $\begin{array}{l}\text { - Goal of the } \\
\text { incarnation: } \\
\text { qualification (more } \\
\text { sympathy, obedience) }\end{array}$ \\
\hline $\begin{array}{l}\text { - Central instrumental role: } \\
\text { passibility (impassible } \\
\text { divinity) }\end{array}$ & $\begin{array}{l}\text { - Central instrumental } \\
\text { role: passibility } \\
\text { (impassible divinity) }\end{array}$ & $\begin{array}{l}\text { - Central instrumental role: } \\
\text { historical revelation of } \\
\text { simultaneous (logically } \\
\text { timeless) passibility }\end{array}$ & $\begin{array}{l}\text { Central ontological } \\
\text { role: death (God } \\
\text { experiences death) } \\
\end{array}$ \\
\hline
\end{tabular}

Cosmology: Christ, Heaven, and Earth

The sacramental, functional, and ontological models seem to assume that God's heaven is a timeless/spaceless environment while the earth is obviously spatio-temporal (see Table 15). The bridge from heaven to earth, which are two different ontological types of environment, consists on spatio-temporal instruments, particularly the sacraments. In the sacramental and functional models, the role of these instruments is the actualization of the heavenly reality on earth, whereas in the ontological model its role is the revelation of the heavenly reality on earth. In contrast to these models, there is no ontological gap between God's heaven and earth, in the sense that both are spatiotemporal environments. Hence, the historical events in heaven synchronically relate to historical events on earth. Furthermore, in contrast to the other models that basically restrict the actions of the earthly Christ to the earthly realm (because of the obvious reason that heaven is a timeless-spaceless environment), the historical model stipulates that Christ acts historically in heaven. In principle, if the ascended Christ needs to act on earth through instruments or secondary causes, the use of these instruments is not 
motivated by a distinction of timeless-spaceless and spatio-temporal realities. However, the historical model does not emphasize the use of secondary causes in its understanding of CP.

\section{Table 15. Cosmology}

\begin{tabular}{|c|c|c|c|}
\hline SACRAMENTAL MODEL & FUNCTIONAL MODEL & ONTOLOGICAL MODEL & HISTORICAL MODEL \\
\hline $\begin{array}{l}\text { - God's heaven: } \\
\text { timeless/spaceless }\end{array}$ & $\begin{array}{l}\text { - God's heaven: } \\
\text { timeless/spaceless }\end{array}$ & $\begin{array}{l}\text { God's heaven: temporal } \\
\text { simultaneity (logically } \\
\text { timeless)/spatially } \\
\text { incomprehensible (logically } \\
\text { spaceless) }\end{array}$ & $\begin{array}{l}\text { - God's heaven: spatio- } \\
\text { temporal }\end{array}$ \\
\hline - Earth: spatio-temporal & - Earth: spatio-temporal & - Earth: spatio-temporal & - Earth: spatio-temporal \\
\hline $\begin{array}{l}\text { The ascended Christ acts } \\
\text { on earth through spatio- } \\
\text { temporal } \\
\text { instruments/secondary } \\
\text { causes (sacraments) }\end{array}$ & $\begin{array}{l}\text { The ascended Christ } \\
\text { acts on earth through } \\
\text { spatio-temporal } \\
\text { instruments/secondary } \\
\text { causes (proclamation } \\
\text { and sacraments) }\end{array}$ & $\begin{array}{l}\text { The ascended Christ acts on } \\
\text { earth through spatio-temporal } \\
\text { instruments/secondary causes } \\
\text { (proclamation and sacraments) }\end{array}$ & $\begin{array}{l}\text { The ascended Christ } \\
\text { acts in heaven } \\
\text { historically, which } \\
\text { synchronically relates } \\
\text { to earthly history }\end{array}$ \\
\hline $\begin{array}{l}\text { - Goal of His action on } \\
\text { earth: partially actualize } \\
\text { the reality of new } \\
\text { creation on earth }\end{array}$ & $\begin{array}{l}\text { - Goal of His action on } \\
\text { earth: partially } \\
\text { actualize the reality of } \\
\text { new creation on earth }\end{array}$ & $\begin{array}{l}\text { - Goal of His action on earth: } \\
\text { partially reveal the reality of } \\
\text { new creation on earth }\end{array}$ & $\begin{array}{l}\text { - Goal of His action in } \\
\text { heaven: historically } \\
\text { fulfill the reality of the } \\
\text { new covenant }\end{array}$ \\
\hline $\begin{array}{l}\text { - Christ: effects new } \\
\text { timeless creation in the } \\
\text { cosmos }\end{array}$ & $\begin{array}{l}\text { - Christ: effects new } \\
\text { timeless creation in the } \\
\text { cosmos }\end{array}$ & $\begin{array}{l}\text { - Christ: is the locus of non- } \\
\text { sequential (logically timeless) } \\
\text { new creation (micro/macro- } \\
\text { cosmos) }\end{array}$ & $\begin{array}{l}\text { - Christ: historically } \\
\text { effects the new } \\
\text { covenant (new creation } \\
\text { in the cosmos implied) }\end{array}$ \\
\hline
\end{tabular}

\section{Implications for Christ's Priesthood}

\section{Need}

With regard to the need for the priesthood, the sacramental, functional, and ontological models assume that original creation is incomplete (see Table 16). The presupposition that God is timeless/spaceless, shared by the three models, implies that this incompleteness is intended by the timeless will of God. The ontological model, for example, seems to indicate that the original incompleteness is ontologically characterized by sequential time. On the other hand, the historical model does not assume that original 
creation is incomplete nor is sequential time a problem to be overcome.

Table 16. Implications for CP

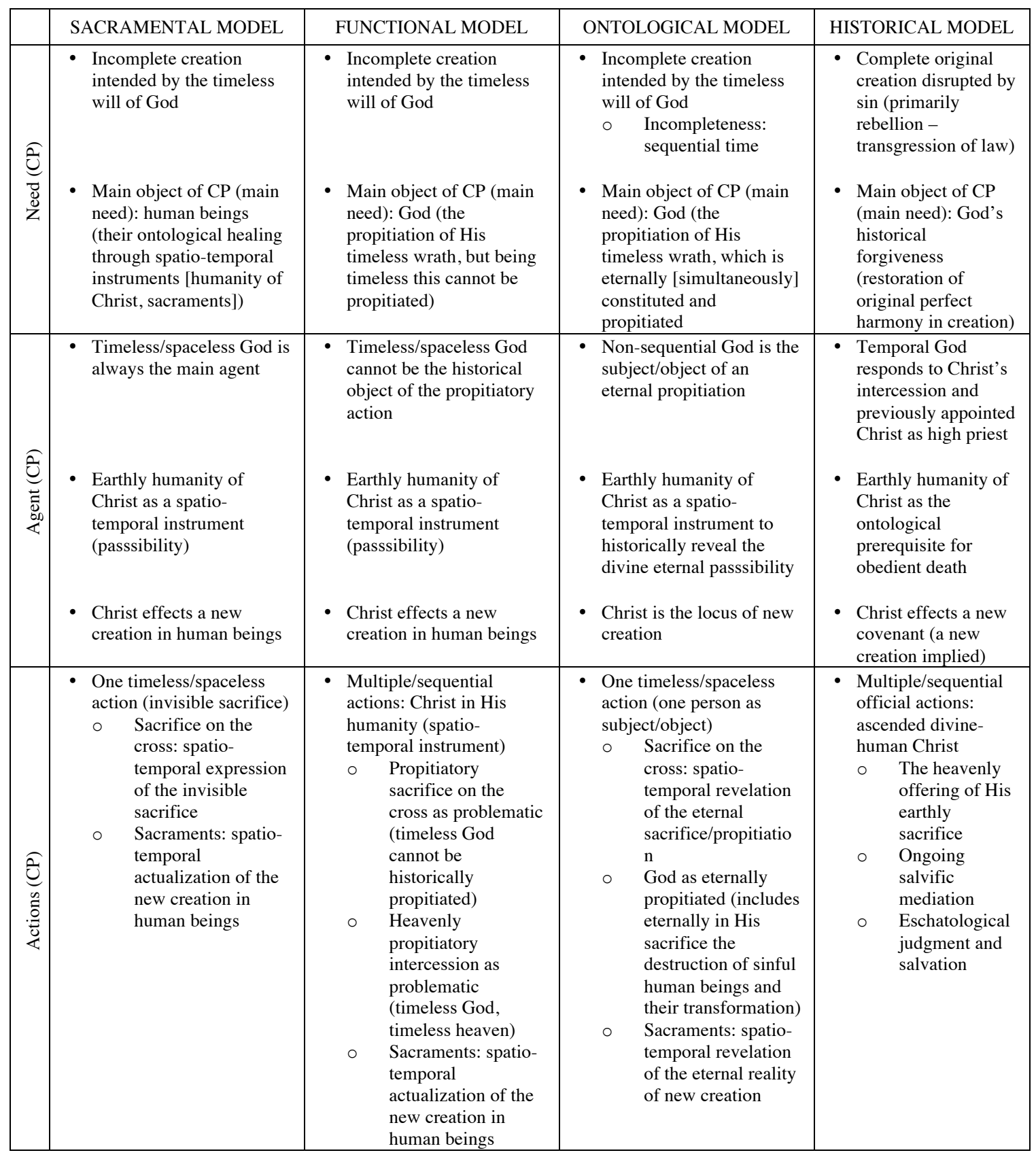


Table 16-Continued

\begin{tabular}{|c|c|c|c|c|}
\hline & SACRAMENTAL MODEL & FUNCTIONAL MODEL & ONTOLOGICAL MODEL & HISTORICAL MODEL \\
\hline 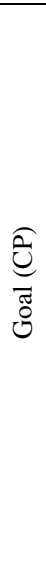 & $\begin{array}{l}\text { Reconciliation: } \\
\text { ontologically performed } \\
\text { by the divine Christ } \\
\text { through spatio-temporal } \\
\text { instruments } \\
\text { O Ontological healing } \\
\text { of human beings } \\
\text { Guides them in their } \\
\text { teleological } \\
\text { movement toward } \\
\text { God } \\
\text { Moral reconciliation } \\
\text { as part of the } \\
\text { ontological } \\
\text { reconciliation } \\
\text { (teleology) }\end{array}$ & $\begin{array}{l}\text { - Reconciliation: morally } \\
\text { performed in terms of } \\
\text { forgiveness } \\
\circ \quad \text { Historical } \\
\text { forgiveness as } \\
\text { problematic (real } \\
\text { propitiation on the } \\
\text { cross and in } \\
\text { heavenly } \\
\text { intercession as } \\
\text { problematic) } \\
\text { Mediation of divine } \\
\text { forgiveness and } \\
\text { human (ontological) } \\
\text { transformation } \\
\text { through spatio- } \\
\text { temporal } \\
\text { instruments }\end{array}$ & $\begin{array}{ll}\text { - } & \text { Moral reconciliation } \\
\circ & \text { Eternal forgiveness } \\
\circ & \text { Already } \\
\text { (ontological) } & \\
\text { achieved } \\
\text { - Eternal } \\
\text { forgiveness } \\
\text { - Already } \\
\text { - } \text { achieved } \\
\text { Revelation of } \\
\text { the achieved } \\
\text { reconciliation } \\
\text { through spatio- } \\
\text { temporal } \\
\text { instruments }\end{array}$ & $\begin{array}{l}\text { - Reconciliation: } \\
\text { morally performed } \\
\text { in terms of } \\
\text { forgiveness } \\
\text { Historical } \\
\text { forgiveness: } \\
\text { real heavenly } \\
\text { intercession } \\
\text { - Human } \\
\text { transformation: } \\
\text { empowerment of } \\
\text { believers, } \\
\text { internalization of the } \\
\text { divine law }\end{array}$ \\
\hline
\end{tabular}

Taking into account in what sense Christ's priesthood is necessary, the idea of ontological healing in human beings advanced by the sacramental model is qualified by the instrumentality of spatio-temporal agencies that includes Christ's humanity and the sacraments. On the other hand, the emphasis on divine wrath that requires Christ's priestly propitiation in the functional model seems ontologically problematic when one considers the presupposition of divine timelessness. The wrath of a timeless God is eternally constituted, and not caused by something external to Himself in chronological history. By claiming that God is eternally the agent and the subject of propitiation, the ontological model appears to be more coherent with the presupposition of a timeless God, because His wrath and propitiation are found in His simultaneous being, and not in chronological history. But that would seem to imply that the conflict between good and evil observed in history is ontologically found and grounded in the essential being of God. Conversely, the historical model avoids the conclusion that the conflict between good and evil exists ontologically in God's eternal being by stipulating that the ultimate reality of this conflict exists in history. In this way, the sin problem began at some point 
in the history between God and human beings. Moreover, the historical model is more ontologically consistent than the functional model with regard to the notion of divine forgiveness. Different from a timeless God, whose wrath is eternally constituted, a temporal God reacts to human actions that take place in history.

\section{Agent}

As far as the agent of the priesthood is concerned, a timeless/spaceless presupposition of God's being and action favors the idea that He is the subject of the priesthood, as He cannot be the object of a chronological action performed outside of Himself. In this sense, the sacramental model is consistent with this ontological presupposition, as the model sees the movement of Christ's priestly activity moving from God to human beings for their healing through the spatio-temporal instrumentality of His humanity. On the other hand, it is difficult for the functional model to ontologically sustain the view that the actions of Christ are directed toward the Father, as a timeless God cannot be the object of the historical actions of the incarnate Christ (nor a divine Christ can be the subject of a historical propitiation, unless instrumentally through a human nature). The ontological model seems to solve this Protestant dilemma by making the timeless God the eternal subject and object of His action. He is eternally selfpropitiated, and the benefits of this propitiation are enjoyed by a transformed humanity in the eternal Christ. An ontological consequence of this decision is that Christ is the timeless locus of new creation (and transformed human beings), while the sacramental and functional models have Christ historically and partially actualizing new creation in human beings. In contrast to these models, the historical model holds that a spatiotemporal God can respond in terms of historical legal forgiveness. In this way, the 
humanity of Christ does need to be interpreted as a spatio-temporal instrument of the divinity, through which He interacts with the spatio-temporal world. Rather, through the ontological incarnation of his divine being, His humanity allows Him to interact with human beings directly and experience death. Furthermore, Christ effects a new covenant historically, which also implies a new creation, in the sense that He is not replicating an eternal (timeless-spaceless) reality in our spatio-temporal world, but this new reality is really new as it takes place in history.

\section{Actions}

In the context of the actions of the priest, the emphasis of the sacramental (one invisible sacrifice) and ontological (one person as eternally subject/object) models on one action is compatible with the presupposition of a timeless divine action. On the other hand, the notion of the functional model that the actions are multiple and sequential is incompatible with this presupposition, which means that these actions would be performed by Christ in His humanity (as a spatio-temporal instrument), and not in His divinity. This interpretation would partially ${ }^{9}$ fit the earthly actions of Christ, but it seems ontologically problematic for a heavenly propitiatory intercession before a timeless/spaceless Father in a timeless/spaceless heaven. On the other hand, by assuming a spatio-temporal interpretation of divine spatio-temporal action, the historical model is able to stipulate a multiple and sequential view of the official actions of the ascended Christ (heavenly offering of the earthly sacrifice, ongoing salvific mediation, and eschatological judgment and final salvation) and postulate that God can really respond

\footnotetext{
${ }^{9}$ The idea of Christ's sacrifice on the cross as propitiatory seems ontologically problematic when
} 
(historically) to the priestly activity, as He forgives human beings as a response to Christ's priestly work. In fact, this spatio-temporal ongoing action in heaven parallels the history of human beings on earth, their actions and prayers. Hence, Christ's action to empower human beings really happens historically. This is not an eternally constituted reality in the being or will of God that is actualized in the spatio-temporal realities of earth. Likewise, the purification of the heavenly things is somehow a spatio-temporal activity in the heavenly sanctuary in terms of forgiveness and judgment.

\section{Goal}

Regarding the goal of the priesthood, the sacramental model is ontologically consistent with the presuppositions about Divinity, Humanity, and Cosmology. In order to achieve the goal of ontological reconciliation, the divine Christ priesthood uses spatiotemporal instruments to ontologically heal human beings and guide their teleological movement toward God. The functional model, on the other hand, seems to lack ontological coherence between the idea of moral reconciliation, characterized by the divine forgiveness that is based on the propitiatory work of Christ (earthly sacrifice and heavenly intercession), and the presupposition of a timeless God. This God cannot forgive human beings historically (as an action that responds to another action). The ontological model seems to solve the ontological inconsistency related to the divine forgiveness of a timeless God by ultimately locating this forgiveness in (timeless/simultaneous) eternity, and not by understanding it historically. The ontological model is also compatible with its own interpretation of the macro-hermeneutical

\footnotetext{
interpreted from the perspective of a timeless/spaceless God, who cannot be historically propitiated.
} 
principles of reality when it assumes that the goal of Christ's priesthood is already ontologically achieved, if this is seen eternally and not historically (not through the work of the earthly Christ), and that the spatio-temporal instruments mediate a revelation of this timeless reality.

Conversely, in the historical model the goal of Christ's priesthood is not fulfilled as an earthly actualization of a reality already constituted in God. Rather, there is a divine engagement for human salvation in human history. Christ's daily mediation in the heavenly sanctuary synchronically relates to the history of human beings on earth, which implies that God's forgiveness temporally follows their prayers and Christ's intercession. Thus, there is a temporal synchronism between heaven and earth, as Christ empowers believers to remain and grow in a covenantal relationship with God, in the context of their struggle against sin, until the eschatological judgment and salvation leading to the historical (spatio-temporal) consummation of the covenant.

\section{Conclusion}

In my concluding remarks of chapter 4 , I indicated that the sacramental and the ontological models of Christ's priesthood tend to be more ontologically consistent with their respective interpretations of the principles of reality. From a historical perspective of Catholic and Protestant theologies, it is possible that the functional model (classical Protestantism) formulated an account of Christ's priesthood that represents an alternative to the sacramental model (in the Thomistic form), without paying special attention to the interpretation of the principles of reality. This would explain the reason why the sacramental and functional models have different accounts of Christ's priesthood, while maintaining a similar interpretation of the principles of reality. For instance, the problem 
of ontological coherence regarding the idea of propitiation describes both the sacramental model (Thomistic form) and the functional model, as this idea is ontologically incompatible with a non-spatial/timeless interpretation of the principles of reality. In modern theology, for the sake of ontological consistency, either the notion of propitiation has been dropped (sacramental model: O'Collins' form) or reinterpreted (the ontological model). The principles of reality of the sacramental model seem to be built for a notion of God as the subject of Christ's priesthood, but not its object. As a result, the idea of divine propitiation is unnecessary. Human beings are the object and, thus, the earth is the main realm of this priesthood, not heaven.

The situation is different for the functional model, as the notion of divine propitiation is perhaps the chief idea for the understanding of Christ's priesthood. To affirm that God is the primary object of this priesthood requires a different ontological interpretation of God, the role of Christ's humanity, and a focus on God's heaven. The ideas that the divine Christ became able to experience passibility in His earthly life (Luther) and that the human Christ is physically/spatially present in heaven (Calvin) call for a more active role of Christ's humanity and have ontological implications that should be further elaborated toward an alternative (spatio-temporal) interpretation of the principles of reality. But this was not the route adopted by the ontological model, which reinterpreted divine propitiation as an eternal (simultaneous) reality, presumably giving no room for a real historical propitiatory intercession of the ascended Christ in heaven.

As I conclude the present chapter, my suggestion is that the historical model provides an alternative that makes the interests of the functional model more viable than the route adopted by the ontological model. To be sure, the historical model does not 
reject the general idea of human (ontological) transformation advanced by the sacramental model. However, the historical model does not believe that this is the first role of Christ's priesthood. Rather, God's forgiveness is the first target. At the same time, the view of a capricious God that needs to be appeased by the suffering of an innocent man is avoided on the grounds that $\mathrm{He}$ is the one who appoints Christ for the priesthood (an idea advanced by the functional model) and that Christ is also God (in this sense God is also the subject of the priestly action—an insight advanced by the ontological model). Furthermore, the most fundamental difference between the historical model and the sacramental model is that the former operates with a spatio-temporal view of divine reality while the latter assumes a timeless-spaceless view, which also implies differences regarding the nature and process of human transformation suggested by each model. As far as these two views of divine reality are concerned, these two models are ontologically consistent. Nevertheless, my study of Hebrews leads to the spatio-temporal reading of the historical model, which produces a distinct picture of Christ's priesthood. With regard to the functional and ontological models, I have noticed in this study that the functional model has interesting insights about Christ's priesthood that push toward a reinterpretation of the principles of reality (in my view, a spatio-temporal reinterpretation) that would sustain these insights. Likewise, I have noted that the ontological model contains important remarks about the principles of reality (in the direction of a spatio-temporal understanding) that would push toward a reinterpretation of the priesthood of Christ. In this sense, the functional and ontological models are close to the historical model, as the historical model could be seen as an expansion of Christ's priesthood, as delineated by the functional model, and of the principles of reality, as 
problematized by the ontological model. A basic difference, however, between the historical model and these other models is the strong emphasis on a heavenly priesthood and the intentional interpretation of this priesthood as spatio-temporal. 


\title{
CHAPTER 6
}

\section{SUMMARY, CONCLUSION, AND RECOMMENDATIONS}

\begin{abstract}
Summary
The purpose of the present study has been to deconstruct hermeneutically conflicting models of the doctrine of $\mathrm{CP}$ in order to articulate a constructive proposal of an alternative model as a suggestion for the resolution of the conflict of interpretations regarding this doctrine. To contextualize this purpose, chapter 1 introduced different interpretations of the doctrine of Christ's priesthood (background of the problem) in systematic theology and highlighted that there is disagreement betweem them on this regard (the problem). Then, the chapter briefly indicated the goal, the value, and the parameters of the research to be pursued (purpose, justification, scope, conceptual framework, and methodology).

In chapter 2 (The Priesthood of Christ), I described the three models of interpretation of the doctrine of Christ's priesthood that have been selected in this study, namely, the sacramental, the functional, and the ontological models. This description provided a general overview of the discussion from a systematic perspective, and also prepared the ground for the study of the macro-hermeneutical presuppositions that undergird each model. Considering that the description of the models was organized according to the topics need, agent, actions, and goal, this chapter outlined each model as indicated in the first three content columns of Table 17.
\end{abstract}


Table 17. The priesthood of Christ

\begin{tabular}{|c|c|c|c|c|}
\hline & SACRAMENTAL MODEL & FUNCTIONAL MODEL & ONTOLOGICAL MODEL & HISTORICAL MODEL \\
\hline 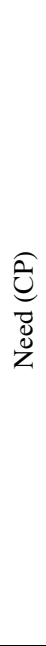 & $\begin{array}{l}\text { Why CP is necessary } \\
\circ \text { human healing } \\
\text { improvement of } \\
\text { original creation: } \\
\text { qualified by a } \\
\text { historical fall } \\
\text { (Aquinas) or theistic } \\
\text { evolution (O'Collins) }\end{array}$ & $\begin{array}{l}\text { - The Problem of Sin } \\
\circ \quad \text { moral rebellion } \\
\text { background: original } \\
\text { creation is incomplete }\end{array}$ & $\begin{array}{l}\text { - The Problem of Sin } \\
\circ \text { moral rebellion } \\
\circ \text { background: } \\
\text { original creation is } \\
\text { incomplete }\end{array}$ & $\begin{array}{l}\text { The Problem of Sin } \\
\text { moral rebellion } \\
\text { (transgression of } \\
\text { the divine law) } \\
\text { background: } \\
\text { original creation } \\
\text { complete }\end{array}$ \\
\hline 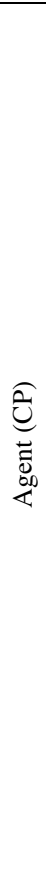 & $\begin{array}{l}\text { - Agency: Christ's divinity } \\
\text { Main agent } \\
\text { Focus: acts toward } \\
\text { human beings } \\
\text { - Agency: Christ's } \\
\text { humanity } \\
\text { His human life as } \\
\text { the scope of the } \\
\text { priesthood } \\
\text { Human nature as the } \\
\text { instrument of the } \\
\text { divine agency (point } \\
\text { of contact with the } \\
\text { physical world) }\end{array}$ & $\begin{array}{l}\text { - Agency: Christ's divinity } \\
\text { Guarantees: eternity } \\
\text { and power of the } \\
\text { priesthood } \\
\text { Focus: God (second } \\
\text { person propitiates } \\
\text { the first person) } \\
\\
\text { - Agency: Christ's } \\
\text { humanity } \\
\text { Main agent } \\
\text { Performs priestly } \\
\text { functions/actions } \\
\text { (obedience, } \\
\text { teaching, sacrifice) }\end{array}$ & 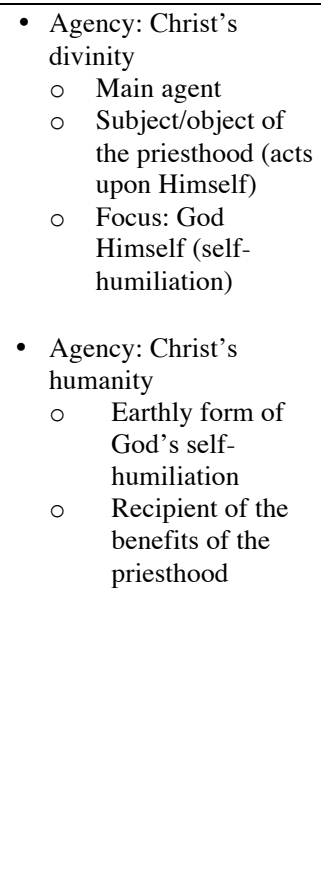 & $\begin{array}{l}\text { - Agency: Christ's } \\
\text { Divinity } \\
\text { Main agent: } \\
\text { divine-human } \\
\circ \quad \text { Learned obedience } \\
\text { Focus: God the } \\
\text { Son intercedes for } \\
\text { the forgiveness of } \\
\text { God the Father } \\
\text { Agency: Christ's } \\
\text { Humanity } \\
\text { Main agent: } \\
\text { divine-human } \\
\text { Enabled divinity to } \\
\text { experience } \\
\text { suffering, } \\
\text { test/temptation, } \\
\text { death (pre- } \\
\text { requisite and } \\
\text { proleptic } \\
\text { priesthood) in a } \\
\text { divine-human level } \\
\text { Priest-king, God's } \\
\text { appointment } \\
\text { (officially at the } \\
\text { ascension) }\end{array}$ \\
\hline
\end{tabular}


Table 17-Continued

\begin{tabular}{|c|c|c|c|c|}
\hline & SACRAMENTAL MODEL & FUNCTIONAL MODEL & ONTOLOGICAL MODEL & HISTORICAL MODEL \\
\hline 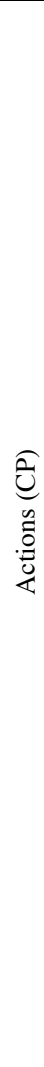 & $\begin{array}{l}\text { - Earthly Christ } \\
\text { Entire life (devotion } \\
\text { to God - invisible } \\
\text { sacrifice) } \\
\text { Material expression } \\
\text { (cross) } \\
\text { - Powerful influence } \\
\text { on material human } \\
\text { beings } \\
\\
\text { Ascended Christ } \\
\text { Ministers the } \\
\text { sacraments } \\
\text { (eucharist - } \\
\text { material/sacramenta } \\
1 \text { form of the } \\
\text { sacrifice): heals } \\
\text { human beings on } \\
\text { earth (application of } \\
\text { salvation) }\end{array}$ & $\begin{array}{ll}\text { - } & \\
\text { Earthly Christ } \\
\circ \quad \text { Teachings } \\
& \text { Penal } \\
\text { substitutionary } \\
\text { sacrifice (cross) } \\
\text { - Christ punished in } \\
\text { the place of sinners } \\
\\
\\
\text { - Ascended Christ } \\
\text { Intercession in } \\
\text { heaven: subsequent } \\
\text { propitiation of the } \\
\text { Father } \\
\text { Teaching } \\
\text { (word/sacrament): } \\
\text { application of } \\
\text { salvation to } \\
\text { believers on earth } \\
\text { (Lord's Supper) }\end{array}$ & 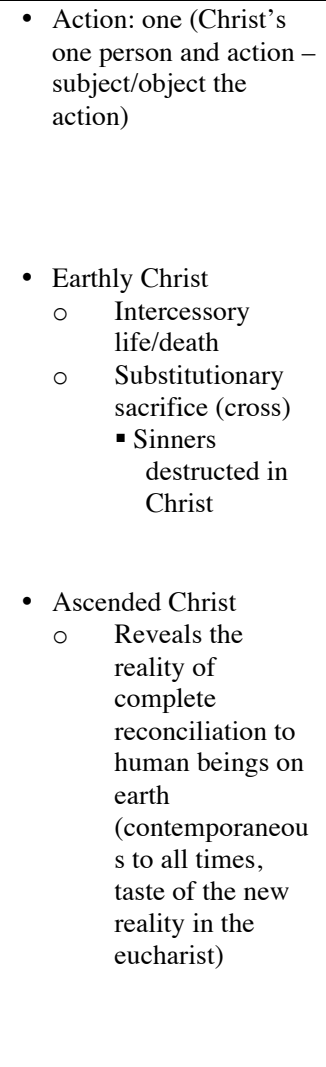 & 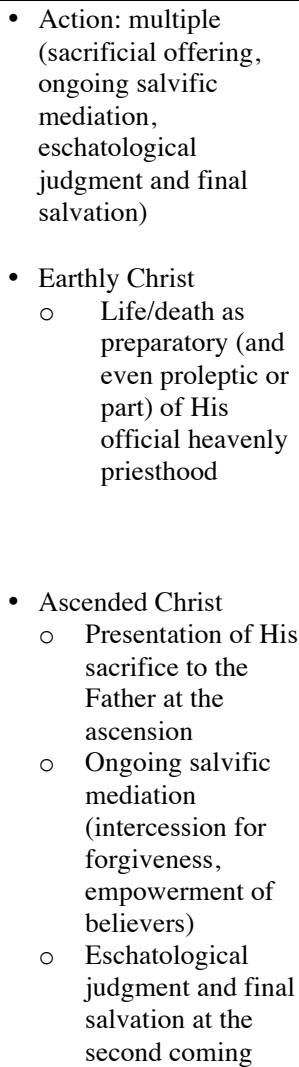 \\
\hline 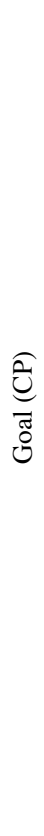 & $\begin{array}{l}\text { - How CP achieves this } \\
\text { goal } \\
\circ \quad \begin{array}{l}\text { divine agent uses } \\
\text { material instruments }\end{array} \\
\circ \quad \begin{array}{l}\text { ontological healing } \\
\text { of human beings }\end{array} \\
\text { guides the } \\
\text { teleological } \\
\text { movement towards } \\
\text { God }\end{array}$ & $\begin{array}{l}\text { - How CP achieves this } \\
\text { goal } \\
0 \quad \text { sacrifice on the } \\
\text { cross and heavenly } \\
\text { intercession: } \\
\text { propitiate the Father } \\
\text { Mediates the } \\
\text { forgiveness and } \\
\text { transformation of } \\
\text { human beings } \\
\text { through material } \\
\text { instruments }\end{array}$ & $\begin{array}{l}\text { - The Reconciliatory } \\
\text { Goal } \\
\begin{array}{l}\text { moral } \\
\text { reconciliation (in }\end{array} \\
\text { Christ) } \\
\text { Goal achieved } \\
\text { ontologically } \\
\text { Remaining } \\
\text { aspect: revelation } \\
\text { How CP achieves this } \\
\text { goal } \\
\text { Achieved: in } \\
\text { Christ, God } \\
\text { destroyed (cross) } \\
\text { and re-created } \\
\text { human beings } \\
\text { (resurrection) } \\
\text { Revelation (new } \\
\text { reality): Christ } \\
\text { contemporary to } \\
\text { all times, use of } \\
\text { material } \\
\text { instruments }\end{array}$ & $\begin{array}{l}\text { - The Reconciliatory } \\
\text { Goal } \\
\text { moral } \\
\text { reconciliation } \\
\text { (God's } \\
\text { forgiveness) } \\
\text { Framework: } \\
\text { covenant } \\
\text { - How CP achieves this } \\
\text { goal } \\
\text { Better/New } \\
\text { Covenant } \\
\text { - Ascension: } \\
\text { inauguration } \\
\text { (heavenly } \\
\text { sanctuary, } \\
\text { official CP) } \\
\text { - Daily } \\
\text { Mediation } \\
\text { (forgiveness, } \\
\text { internalization } \\
\text { of divine laws) } \\
\text { - Final } \\
\text { purification }\end{array}$ \\
\hline
\end{tabular}


After this general depiction, chapter 3 (The Priesthood of Christ) initiated the hermeneutical analysis of each model, focusing on macro-hermeneutical principles of reality, namely, the interpretations of each model regarding divinity, humanity, and cosmology as far as the reality of Christ is concerned. The chapter showed how ontological assumptions about Christ inform the interpretation of His priesthood in the sacramental, functional, and ontological models. In short, I delineated the interpretations of the macro-hermeneutical principles as outlined in the first three content columns of Table 18.

\section{Table 18. The priesthood of Christ}

\begin{tabular}{|c|c|c|c|c|}
\hline & SACRAMENTAL MODEL & FUNCTIONAL MODEL & ONTOLOGICAL MODEL & HISTORICAL MODEL \\
\hline \multirow{4}{*}{ 吝 } & $\begin{array}{l}\text { - God's nature: } \\
\text { timeless/spaceless }\end{array}$ & $\begin{array}{l}\text { - God's nature: timeless/ } \\
\text { spaceless (emphasis on } \\
\text { knowledge) }\end{array}$ & $\begin{array}{l}\text { God's nature: } \\
\text { simultaneous temporality } \\
\text { (logically close to } \\
\text { timelessness) and } \\
\text { incomprehensible } \\
\text { spatiality (logically close } \\
\text { to spacelessness) }\end{array}$ & $\begin{array}{l}\text { - God's nature: spatio- } \\
\text { temporal (able to } \\
\text { sequentially } \\
\text { experience spatio- } \\
\text { temporality) }\end{array}$ \\
\hline & $\begin{array}{l}\text { - God's eternal action: } \\
\text { timeless predestination } \\
\text { (primary cause) }\end{array}$ & $\begin{array}{l}\text { - God's eternal action: } \\
\text { timeless predestination }\end{array}$ & $\begin{array}{l}\text { - God's eternal action: } \\
\text { simultaneous (timeless) } \\
\text { action/predestination }\end{array}$ & $\begin{array}{l}\text { - God's eternal plan } \\
\text { (predestination) }\end{array}$ \\
\hline & $\begin{array}{l}\text { - God's historical action: } \\
\text { historical/chronological } \\
\text { actualization through } \\
\text { spatio-temporal } \\
\text { instruments (secondary } \\
\text { causes) }\end{array}$ & $\begin{array}{l}\text { - God's historical action: } \\
\text { historical/chronological } \\
\text { actualization through } \\
\text { spatio-temporal } \\
\text { instruments (secondary } \\
\text { causes implied) }\end{array}$ & $\begin{array}{l}\text { God's historical action: } \\
\text { divine } \\
\text { historical/chronological } \\
\text { self-repetition through } \\
\text { spatio-temporal } \\
\text { instruments (secondary } \\
\text { causes implied) }\end{array}$ & $\begin{array}{l}\text { - God's historical } \\
\text { action: } \\
\text { historical/chronologi } \\
\text { cal action }\end{array}$ \\
\hline & $\begin{array}{l}\text { The object of God's } \\
\text { salvific action: spatio- } \\
\text { temporal human beings }\end{array}$ & $\begin{array}{l}\text { The object of God's } \\
\text { salvific action: spatio- } \\
\text { temporal human beings }\end{array}$ & $\begin{array}{l}\text { - The object of God's } \\
\text { salvific action: He } \\
\text { Himself (spatio-temporal } \\
\text { human beings are } \\
\text { benefited in Him/Christ) }\end{array}$ & $\begin{array}{l}\text { - The object of God's } \\
\text { salvific action: } \\
\text { spatio-temporal } \\
\text { human beings } \\
\text { compatible with His } \\
\text { spatio-temporal } \\
\text { actions }\end{array}$ \\
\hline
\end{tabular}


Table 18-Continued

\begin{tabular}{|c|c|c|c|c|}
\hline & SACRAMENTAL MODEL & FUNCTIONAL MODEL & ONTOLOGICAL MODEL & HISTORICAL MODEL \\
\hline \multirow{4}{*}{ 馵 } & $\begin{array}{l}\text { - Christ's human nature: } \\
\text { spatio-temporal }\end{array}$ & $\begin{array}{l}\text { - Christ's human nature: } \\
\text { spatio-temporal }\end{array}$ & $\begin{array}{l}\text { - Christ's human nature: } \\
\text { spatio-temporal }\end{array}$ & $\begin{array}{l}\text { - Christ's human } \\
\text { nature: spatio- } \\
\text { temporal }\end{array}$ \\
\hline & $\begin{array}{l}\text { Instrumentality: } \\
\text { secondary cause (spatio- } \\
\text { temporal) of divine } \\
\text { timelessness/spacelessnes } \\
\text { s }\end{array}$ & $\begin{array}{l}\text { - Instrumentality: } \\
\text { secondary cause (spatio- } \\
\text { temporal) of divine } \\
\text { timelessness/spacelessnes } \\
\text { s }\end{array}$ & $\begin{array}{l}\text { Instrumentality: } \\
\text { secondary cause (spatio- } \\
\text { temporal) of divine } \\
\text { simultaneity (logically } \\
\text { timelessness/spacelessnes } \\
\text { s) }\end{array}$ & $\begin{array}{l}\text { - God becomes a } \\
\text { human being } \\
\text { ontologically } \\
\text { (mystery of the } \\
\text { incarnation) }\end{array}$ \\
\hline & $\begin{array}{l}\text { - Goal of the } \\
\text { instrumentality: historical } \\
\text { actualization }\end{array}$ & $\begin{array}{l}\text { - Goal of the } \\
\text { instrumentality: historical } \\
\text { actualization }\end{array}$ & $\begin{array}{l}\text { - Goal of the } \\
\text { instrumentality: historical } \\
\text { revelation }\end{array}$ & $\begin{array}{l}\text { - Goal of the } \\
\text { incarnation: } \\
\text { qualification (more } \\
\text { sympathy, } \\
\text { obedience) }\end{array}$ \\
\hline & $\begin{array}{l}\text { - Central instrumental role: } \\
\text { passibility (impassible } \\
\text { divinity) }\end{array}$ & $\begin{array}{l}\text { - Central instrumental role: } \\
\text { passibility (impassible } \\
\text { divinity) }\end{array}$ & $\begin{array}{l}\text { - Central instrumental role: } \\
\text { historical revelation of } \\
\text { simultaneous (logically } \\
\text { timeless) passibility }\end{array}$ & $\begin{array}{l}\text { - Central ontological } \\
\text { role: death (God } \\
\text { experiences death) }\end{array}$ \\
\hline \multirow{5}{*}{$\begin{array}{l}\text { को } \\
0 \\
0 \\
0 \\
0 \\
0 \\
0\end{array}$} & $\begin{array}{l}\text { - God's heaven: } \\
\text { timeless/spaceless }\end{array}$ & $\begin{array}{l}\text { - God's heaven: } \\
\text { timeless/spaceless }\end{array}$ & $\begin{array}{l}\text { God's heaven: temporal } \\
\text { simultaneity (logically } \\
\text { timeless)/spatially } \\
\text { incomprehensible } \\
\text { (logically spaceless) }\end{array}$ & $\begin{array}{l}\text { - God's heaven: } \\
\text { spatio-temporal }\end{array}$ \\
\hline & - Earth: spatio-temporal & - Earth: spatio-temporal & - Earth: spatio-temporal & $\begin{array}{l}\text { - Earth: spatio- } \\
\text { temporal }\end{array}$ \\
\hline & $\begin{array}{l}\text { The ascended Christ acts } \\
\text { on earth through spatio- } \\
\text { temporal } \\
\text { instruments/secondary } \\
\text { causes (sacraments) }\end{array}$ & $\begin{array}{l}\text { The ascended Christ acts } \\
\text { on earth through spatio- } \\
\text { temporal } \\
\text { instruments/secondary } \\
\text { causes (proclamation and } \\
\text { sacraments) }\end{array}$ & $\begin{array}{l}\text { The ascended Christ acts } \\
\text { on earth through spatio- } \\
\text { temporal } \\
\text { instruments/secondary } \\
\text { causes (proclamation and } \\
\text { sacraments) }\end{array}$ & $\begin{array}{l}\text { - The ascended Christ } \\
\text { acts in heaven } \\
\text { historically, and this } \\
\text { action } \\
\text { synchronically } \\
\text { relates to the history } \\
\text { that takes place on } \\
\text { earth }\end{array}$ \\
\hline & $\begin{array}{l}\text { - Goal of His action on } \\
\text { earth: partially actualize } \\
\text { the reality of new creation } \\
\text { on earth }\end{array}$ & $\begin{array}{l}\text { - Goal of His action on } \\
\text { earth: partially actualize } \\
\text { the reality of new creation } \\
\text { on earth }\end{array}$ & $\begin{array}{l}\text { - Goal of His action on } \\
\text { earth: partially reveal the } \\
\text { reality of new creation on } \\
\text { earth }\end{array}$ & $\begin{array}{l}\text { - Goal of His action in } \\
\text { heaven: historically } \\
\text { fulfill the reality of } \\
\text { the new covenant }\end{array}$ \\
\hline & $\begin{array}{l}\text { - Christ: effects new } \\
\text { timeless creation in the } \\
\text { cosmos }\end{array}$ & $\begin{array}{l}\text { Christ: effects new } \\
\text { timeless creation in the } \\
\text { cosmos }\end{array}$ & $\begin{array}{l}\text { Christ: is the locus of } \\
\text { non-sequential (logically } \\
\text { timeless) new creation } \\
\text { (micro/macro-cosmos) }\end{array}$ & $\begin{array}{l}\text { Christ: historically } \\
\text { effects the new } \\
\text { covenant (new } \\
\text { creation in the } \\
\text { cosmos implied) }\end{array}$ \\
\hline
\end{tabular}

From the perspective of this interpretation of the macro-hermeneutical principles,

I concluded the chapter with a reflection on the implications of such principles for the

understanding of Christ's priesthood, as summarized in the first three content columns of 
Table 16.

In chapter 4, I took the last step in this hermeneutical analysis, in which I attempted to read systematically the general picture of Christ's priesthood (need, agent, actions, and goal) and its macro-hermeneutical principles of reality (divinity, humanity, and cosmology) in Hebrews - the main source for a theological understanding of Christ's priesthood. This study is a constructive proposal that seeks to offer a viable alternative to the conflicting interpretations of the priesthood of Christ in the sacramental, functional, and ontological models. In fact, I label this alternative as historical model. But this is not a full blown model yet. What I propose in this research are the initial contours of this alternative model, which are the result of my study of Hebrews.

The basic contours of the historical model become more evident when compared with the other models discussed in this dissertation. A short comparison was provided in chapter 5, which began with the the priesthood of Christ, as Table 17 indicates. Furthermore, Table 18 outlines the priesthood of Christ sketched by the historical model in comparison with the other models. As indicated in chapter 3, the interpretation of macro-hermeneutical principles of reality has crucial implications for the understanding of Christ's priesthood. Comparatively, the implications of the interpretation of these principles in the historical model are highlighted on Table 16.

Concisely, the basic difference between the historical and the other models is the strong emphasis on an official heavenly priesthood and the intentional interpretation of it as spatio-temporal. In this sense, the model is historical because it assumes a sequence of events in the heaven. In short, each one of the models could be depicted as follows:

The priesthood of Christ in the sacramental model basically refers to a 
Christological picture that is soteriologically concrete in spatio-temporal instruments that convey and actualize the timeless-spaceless reality of the new creation in human beings.

In the functional model, the priesthood of Christ is essentially described in a Christological language that involves sequentiality of functions (earthly cross and heavenly intercession), but it is soteriologically concrete in spatio-temporal instruments that convey/actualize the timeless-spaceless reality of the new creation in human beings.

The priesthood of Christ in the ontological model mainly portrays a Christology that reveals, by means of spatio-temporal instruments, in our spatio-temporal world the soteriological reality of new creation that is already concrete in God.

Finally, in the historical model, the priesthood of Christ emphasizes a real spatiotemporal official activity in heaven in which God is involved in the soteriological process of forgiving and transforming human beings (new creation).

\section{Conclusion}

The main contention of the present study is that the historical model constitutes a viable alternative that points to a way out of the conflicting systematic interpretations of the doctrine of Christ's priesthood. This conclusion is unpacked in the following arguments.

First, from the perspective of the historical model, the basic problem of the sacramental model lies on the interpretation of the macro-hermeneutical principles of reality, as it conceptualizes the divine reality and realm in terms of timelessnessspacelessness. At the same time, the principal virtue of the sacramental model is the overall logical coherence between the understanding of Christ's priesthood and the ontological presupposition of the divine reality and realm as timeless-spaceless. 
Therefore, while the historical model reads from the overall picture of Christ's priesthood in the Epistle to the Hebrews that the macro-hermeneutical principles of reality are spatio-temporal, this model also learns from the sacramental model the importance of keeping a logical consistency between the interpretation of Christ's priesthood and the understanding of principles of reality. Accordingly, by assuming a spatio-temporal view of divine reality, the historical model will necessarily (in terms of internal consistency) outline a different conception of the priesthood of Christ in comparison with the sacramental model.

Second, in contrast to the sacramental model, the chief weakness of the functional model (when evaluated from the perspective of the historical model) is the lack of consistency between its notion of the priesthood of Christ and its interpretation or assumptions regarding the macro-hermeneutical principles of reality. While the picture of Christ's priesthood in this model seems to imply a spatio-temporal view of reality, its interpretation of the principles of reality is more aligned with a timeless-spaceless perspective of divine reality. In its reading of Christ's priesthood in Hebrews, the historical model recognizes that the functional model provides a more adequate picture of Christ's priesthood than the sacramental and ontological models, and this is its significant virtue. However, the important idea of sequential actions and events in the functional model is obscured by a timeless-spaceless understanding of divine reality. In this sense, the historical model learns by observing the functional model that a consistent understanding of Christ's priesthood characterized by sequential actions and events requires an interpretation of the macro-hermeneutical principles of reality that presupposes spatio-temporality in the notion of divine reality. 
Third, the major problem of the ontological model (when evaluated from the perspective of the historical model) is that it did not modify in a substantial way the timeless-spaceless view of reality assumed by the sacramental and functional models. To be sure, the historical model learns from the ontological model the criticism of several inadequacies of the classical paradigm of a divine timeless-spaceless reality. Also, the historical model acknowledges that the notion of Christ's priesthood and the interpretation of the macro-hermeneutical principles of reality are more systematically coherent in the ontological model than in the functional model. These two points describe the most important virtues of the ontological model. However, the more systematically coherent interpretation of the ontological model means that the priesthood of Christ in the model does not seem consistent with the picture of this priesthood in Hebrews, as read by the historical model. While the sacramental model interprets Christ's priesthood in terms of a spatio-temporal (instrumental) application of a timeless-spaceless reality to spatiotemporal human beings, the ontological model speaks of Christ's priesthood in the sense of a non-sequential (logically timeless-spaceless) reality that is revealed to spatiotemporal human beings (that is, they experience sequentiality).

Fourth, the consistency of the historical model is basically described by a focus on an official heavenly priesthood described in Hebrews that implies, for instance, a real appearance before God the Father and a real activity of salvific mediation in the heavenly sanctuary that is supported by a spatio-temporal view of God and heaven. These activities allow an actual interaction between what takes place on earth (e.g., human prayer) and what happens in heaven (e.g., Christ's intercession). 


\section{Recommendations for Further Research}

The consistency of the historical model delineated in this dissertation and the proposal that the model is a viable alternative to the disagreements between the sacramental, functional, and ontological models does not mean that the historical model does not have limitations. First of all, it needs to be emphasized that the historical model is a working hypothesis, and not a full blown model. In my view, the consolidation of the model depends on further examination of its arguments and the systematic expansion of its ideas.

First, by suggesting a further examination of the arguments of the historical model, I acknowledge that the present study was a systematic description and analysis of the basic ideas that produce a general understanding of Christ's priesthood. For instance, this study explored the sacramental, functional, and ontological models as heuristic tools for a systematic and conceptual comprehension of the priesthood of Christ, and not with the primary interest of deepening the understanding of what Aquinas, O'Collins, Calvin, Luther, Barth, and Torrance think about this issue, which probably would be the interest of a research in the field of historical theology. However, studies with this interest could be helpful to correct, adjust, or refine what the present research affirms about these models and theologians. Furthermore, this dissertation outlined the historical model by spending only one chapter on a systematic interpretation of Christ's priesthood in Hebrews. Nevertheless, entire dissertations could be written on this topic, deepening the exegetical discussion of key passages and covering other aspects of the exegetical work in Hebrews, such as the historical and conceptual background of the epistle. In this way, biblical studies would be useful to correct, adjust, or refine what the present research speaks about the priesthood of Christ in Hebrews (the historical model). 
Second, a systematic expansion of the ideas of the historical model suggested in this dissertation implies further research on biblical, doctrinal, historical, and philosophical theology. In my view, a systematic expansion in biblical theology is the most urgent need. In the present research, the historical model derives its ideas from the epistle to the Hebrews. Even though I argue that Hebrews is the normative starting point for a study on Christ's priesthood in systematic theology, ${ }^{1}$ as this is the only place in Scripture where Christ is called (high) priest, I recognize that the historical model cannot be restricted to a reading of Hebrews. Rather, the model must be informed by a canonical reading that observes how the picture of Christ's priesthood is enriched by the study of the canon as a whole (tota Scriptura). Such enrichment may include correction, adjustment, or refinement of the historical model presented in this dissertation.

For instance, in his study of Prov 8, Richard Davidson suggests that the meaning of the verb נסך in Prov 8:23 is illuminated by the occurrence of this term in Ps 2:6, which describes the installment of a king in using the language of birth in Ps 2:7. ${ }^{2}$ Davidson stipulates that in the context of Prov 8:22-31 this royal installment "refers to the time of Christ's installment into a new office at the commencement of creation and the particular

\footnotetext{
${ }^{1}$ The idea of a normative starting point does not mean that any study of Christ's priesthood must start with Hebrews. The present dissertation, for example, begins with theological models and then moves to the study of Hebrews. However, the study of Hebrews in this dissertation assumes that this epistle is the normative starting point for the study of Christ's priesthood. In other words, the theological models described in chapters 2 and 3 could be properly evaluated only after a study of Christ's priesthood in Hebrews. Thus, Hebrews is the normative source for an evaluation of theological interpretations of Christ's priesthood.

${ }^{2}$ Richard M. Davidson, "Proverbs 8 and the Place of Christ in the Trinity," Journal of the Adventist Theological Society 17, no. 1 (2006): 49. For the meaning of III as installment, see F. Brown, S. R. Driver, and C. A. Briggs, A Hebrew and English Lexicon of the Old Testament (Oxford: Oxford, 1907), 651. Davidson indicates that the birth language is associated with royal installment in Prov 8:22-24 and Ps 2. In this way, 'birth' is a "technical language to describe the formal installation of royalty into a new office." Davidson, "Proverbs 8 and the Place of Christ in the Trinity," 50.
} 
role to which He is installed as the 'Mediator' between an infinite [transcendent ${ }^{3}$ ] God and His finite creatures." ${ }^{4}$ Taking this interpretation of Prov 8 into account, it is possible that a mediatorial priesthood of Christ also associated with His enthronement as king took place in the context of creation. In this case, Prov 8:22-31 could be related to Ps 2:67 in terms of a mediation of creation, while Hebrews (see 1:5; 5:5) would relate to this psalm refering to a mediation of redemption in the context of the ascension and enthronement of the resurrected Christ. This scenario seems to suggest that the royal priestly mediation of Hebrews constitutes not only the salvation of human beings but also the recovery of Christ's royal mediation at the beginning of creation. If this canonical reading is correct, the scope of Christ's mediation would include actions in a world without sin, before and after the existence of the sin problem. ${ }^{5}$ In fact, the notion of mediation and even priesthood seems to be present in the Bible in a world before and after $\sin ^{6}$ However, in order to substantiate and unfold this idea, future studies would

${ }^{3}$ Davidson, "Proverbs 8 and the Place of Christ in the Trinity," 53.

${ }^{4}$ Ibid., 52. Davidson suggests that "perhaps in a council between the members of the Godhead before creation, it was decided that the One we now call the Second Person of the Godhead would at the commencement of creation condescend to partially empty himself (cf. the kenosis of Phil 2), to step down (perhaps taking the form of an angel?) to become the Mediator between the infinite God and finite creatures? And that Prov 8 is referring to this installation - this 'begetting' of the Son of God-into the office of Mediator between the transcendent God and finite created beings? And that Prov 8 describes the mediatorial role of Wisdom-the pre-incarnate Christ?” Ibid., 53.

${ }^{5}$ The difference between this idea of mediation in creation and the notion of mediation in creation before sin implied or elaborated in the sacramental, functional, and ontological models is that in these models "original" creation was incomplete. On the other hand, the canonical expansion of the historical model on this point would mean that the conditions of complete original creation are recovered at the end. While those models conceptualize that Christ's mediation is needed because of the incompleteness of creation, the historical model would stipulate that this mediation is part of the reality of complete creation and, therefore, eschatologically recovered with the events initiated at Christ's ascension.

${ }^{6}$ Regarding the world before sin, Davidson argues that "the Garden of Eden was the first sanctuary on earth" and that the man was a priest in the garden. The arguments that support these statements include the idea that there are numerous parallels "between the accounts of creation as a whole and the construction of the mosaic sanctuary" and that terminology for work assigned to man with regard to 
need to show (1) whether the language of mediation and priesthood could be used interchangeably and, if so, (2) what would be the need, actions, and goal of a priesthood without reference to sin. In fact, this is only one example of the possibilities of the study of the canon as a whole (tota Scriptura) for a potential enrichment of the historical model presented in this dissertation. Another example could be a typological reading of the sanctuary in the Hebrew Bible that would draw connections with the priesthood of Christ.

After a canonical (tota Scriptura) systematic expansion, doctrinal and philosophical studies could be undertaken for a further systematic expansion of the historical model. Doctrinal studies could explore how the priesthood of Christ, as explained by the historical model (now as a canonical model, and not merely a model derived from Hebrews), are systematically related to Christology in general, soteriology, ecclesiology, the doctrine of God, pneumatology, hamartiology, anthropology, and eschatology. The connections and implications provided by this exploration may lead also to correction, adjustment, or refinement of the historical model presented in this dissertation. Moreover, philosophical studies could deepen the discussion on time and space, relating or comparing this discussion with traditions in philosophical theology that deal with this issue (e.g., classical theism, process theology, etc.). Likewise, historical studies could relate or compare the historical model with significant theologians who

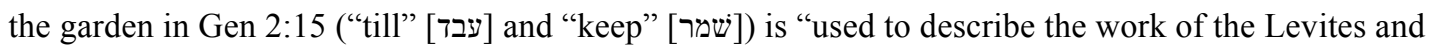
priests in the Sanctuary (Num 3:7-8; 18:3-7)." Richard M. Davidson, "Back to the Beginning: Genesis 1-3 and the Theological Center of Scripture," in Christ, Salvation, and the Eschaton: Essays in Honor of Hans K. LaRondelle, ed. Jiri Moskala (Berrien Springs, MI: Seventh-day Adventist Theological Seminary, 2009), 16-17. See also Richard M. Davidson, "Earth's First Sanctuary: Genesis 1-3 and Parallel Creation Accounts," AUSS 53, no. 1 (2015): 65-89. In terms of the world after sin, Rev 20:6 (see also 1:6; 5:10) indicates that the saved (those who share in the first resurrection) "will be priests of God and of Christ." According to this perspective, the language of priesthood goes beyond the sin problem and salvation, which is the focus of Hebrews. 
were not included in the sacramental, functional, and ontological models. For instance, some features of the historical model could be shown to be at least partially compatible with the soteriology of Jacobus Arminius, ${ }^{7}$ who attempted to overcome the traditional idea of predestination described in chapter 3 of this dissertation. ${ }^{8}$ However, it is not clear to me that his theology would support the ideas highlighted in the historical model, as the doctrine of God in Arminius is similar to classical theism (Aquinas). ${ }^{9}$ Nevertheless, this is a topic for another study. My point here is that, by way of comparison with other philosophical and theological traditions, studies on philosophical and historical theology could offer heuristic tools that may lead to correction and adjustment of the language used in the historical model, and/or to the refinement and sophistication of the concepts and language employed in the model.

${ }^{7}$ For Arminius' understanding of Christ's priesthood, see, e.g., Orations of Arminius 1.

${ }^{8}$ As Keith Stanglin indicates, for Arminius, "predestination is conditional on a person's free acceptance or rejection of God's saving grace.” Keith D. Stanglin, Arminius on the Assurance of Salvation: The Context, Roots, and Shape of the Leiden Debate, 1603-1609, Brill's Series in Church History (Leiden; Boston: Brill, 2007), 84. According to Arminius, in his act of predestination God primarily establishes the condition for salvation, namely, human repentance and faith. See Arminius A Declaration of the Sentiments of Arminius. Translation taken from James Arminius, The Works of James Arminius, 3 vols., The Master Christian Library Ver. 5.0 [CD Rom] (Albany, OR: AGES Software, 1997), 1:222-223. For helpful information on Arminius' conception of divine predestination, see William den Boer, God's Twofold Love: The Theology of Jacob Arminius (1559-1609), Reformed Historical Theology (Göttingen; Oakville, CT: Vandenhoeck and Ruprecht, 2010), 178-179; William den Boer, "Jacobus Arminius: Theologian of God's Twofold Love," in Arminius, Arminianism, and Europe Jacobus Arminius (1559/60-1609), ed. Theodoor Leeuwen (Leiden; Boston: Brill, 2009), 47-48.

${ }^{9}$ Arminius argues that God does not know realities in the world as they appear or develop in history, since "the understanding of God is derived from no external cause, not even from an object." Public Disputations 4.37. Translation taken from Arminius, 1:413. Rather, "the act of understanding in God is his own being and essence." It means that God knows all things "as they are in Himself and in his understanding." Public Disputations 4.32. Translation taken from ibid., 1:410-411. Hence, "by a single and undivided act . . . He knows all things." Public Disputations 4.33. Translation taken from ibid., 1:411. "The mode by which God understands, is not that which is successive . . but it is simple." Ibid. Following this perspective, the decree of Predestination is a timeless/eternal act "because God does nothing in time, which He has not decreed to do from all eternity." And this is based on God's immutability, since "if it were otherwise, God might be charged with mutability." Arminius Public Disputations 15.6. Translation taken from ibid., 1:532-533. Likewise, regarding divine knowledge, "God knows all things from eternity; nothing 
In short, the present dissertation provides a working hypothesis of a priestly Christology outlined in the historical model. This hypothesis invites further research in the fields of biblical theology and exegesis, doctrinal studies, historical theology, and philosophical theology.

recently." Arminius Public Disputations 4.33. Translation taken from ibid., 1:411. 


\title{
APPENDIX A
}

\section{References and Allusions to Christ's Priesthood in the Context of the Structure of Hebrews}

\author{
Introduction
}

For a proper reflection about the components of Christ's priesthood (need, agent, actions, goal) based on Hebrews, it is necessary to provide some preliminary remarks regarding references and allusions to His priesthood, especially in the context of the terminology for the priesthood and of the structure of the epistle. ${ }^{1}$

\section{The Terminology for the Priesthood}

The terminology ${ }^{2}$ adopted by the author of Hebrews to refer explicitly to the idea

\footnotetext{
${ }^{1}$ While I comment on the literary structure of Hebrews, I do not deal with introductory matters of the study of the epistle, such as authorship, immediate audience, place of origin, date of composition, and historical background. Even though I recognize that a discussion of these topics sheds light on the understanding of Hebrews, there is no sufficient space in this study to explore these matters. In a recent introduction to Hebrews, Mason indicates that "most contemporary scholars . . concede that we cannot know the author's personal identity but that we can discern several things about him from the text." Regarding the immediate audience, "modern interprets" increasingly "argue that nothing in Hebrews demands a reading so dependent on Jewish ethnicity," but "scholarly reconstructions of the precise setting continue to vary. Regardless, almost all interpreters now agree," with reference to 13:24, "that the text was sent to friends still in Rome." Mason and McCruden, Reading the Epistle to the Hebrews, 3. For a detailed discussion of the introductory matters of Hebrews, see Attridge, The Epistle to the Hebrews, 1-32; Cockerill, The Epistle to the Hebrews, 1-78; David A. DeSilva, Perseverance in Gratitude: A SocioRhetorical Commentary on the Epistle "to the Hebrews" (Grand Rapids, MI: Eerdmans, 2000), 1-82; Ellingworth, The Epistle to the Hebrews, 1-85; Johnson, Hebrews, 1-62; Koester, Hebrews, 19-132; O'Brien, The Letter to the Hebrews, 1-43; Lane, Hebrews 1-8, xlvii-clv.

${ }^{2}$ A short introduction to priestly terminology in the NT is found in Vanhoye, Old Testament Priests and the New Priest, 63-66.
} 


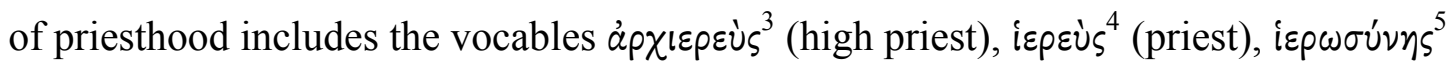

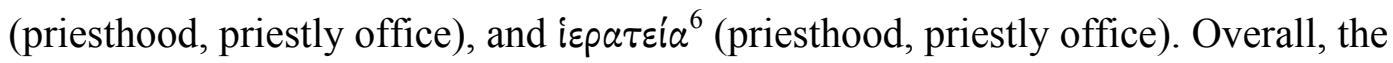

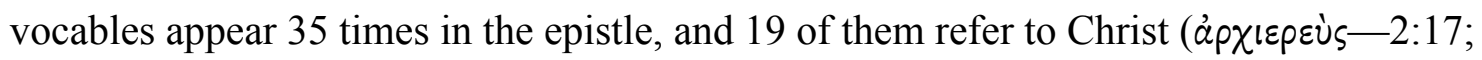

$3: 1 ; 4: 14,15 ; 5: 5,10 ; 6: 20 ; 7: 26 ; 8: 1 ; 9: 11 ;$ iعpeùs— $5: 6 ; 7: 11,15,17,21 ; 8: 4 ; 10: 21$;

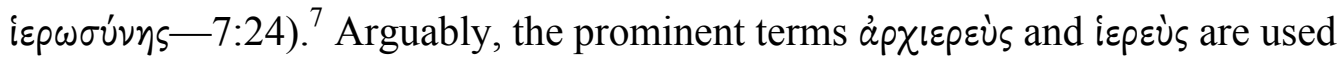

interchangeably with reference to the (high) priesthood of Christ, as they do not seem to carry a particular distinction or emphasis. ${ }^{8}$ Initially, Jesus $(2: 9 ; 3: 1 ; 4: 14)$ Christ $(5: 5)$, the

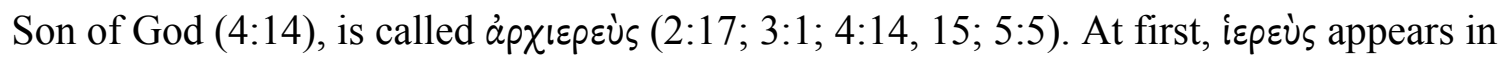
the first (5:6) of three quotations of Ps 110:4 (LXX 109:4) in the epistle-the other two are 7:17 and $21^{9}$ — which identify Christ as a priest according to the order of Melchizedek. It is noteworthy that the author comments on this connection with

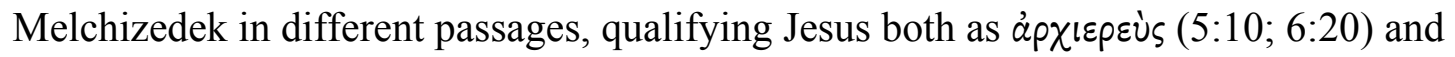

${ }^{3}$ This vocable appears 17 times in Hebrews $(2: 17 ; 3: 1 ; 4: 14,15 ; 5: 1,5,10 ; 6: 20 ; 7: 26,27,28 ; 8: 1$,

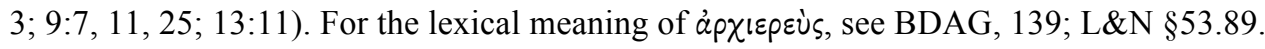

${ }^{4}$ This vocable appears 14 times in Hebrews $(5: 6 ; 7: 1,3,11,14,15,17,20,21,23 ; 8: 4 ; 9: 6 ; 10: 11$,

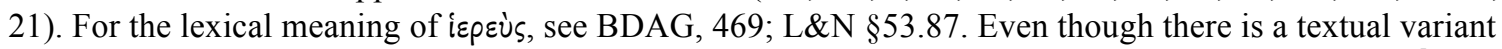

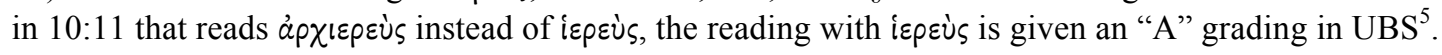

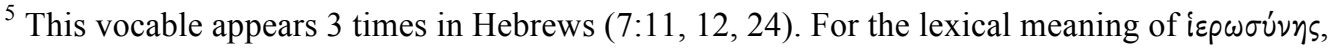
see BDAG, 471; L\&N §53.86.

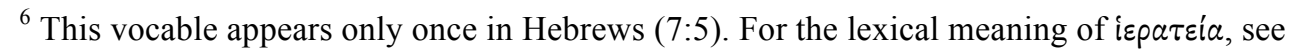
BDAG, 469; L\&N §53.86.

${ }^{7}$ The Greek NT text used in this study is the $\mathrm{UBS}^{5}$.

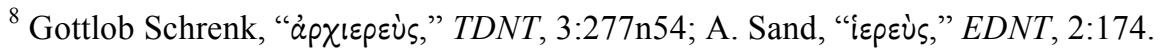

${ }^{9}$ The quotation in 7:21 has a textual variant. The longer reading includes the latter part of Ps 109:4 LXX ( $\varkappa \tau \dot{\alpha} \tau \dot{\eta} \nu \tau \dot{\xi} \xi\llcorner\nu \mathrm{M} \varepsilon \lambda \chi เ \sigma \varepsilon \delta \varepsilon \chi)$, likewise the other two quotations in 5:6 and 7:17. However, the "A" grading in $\mathrm{UBS}^{5}$ is given to the shorter reading, which does not contain that part. Even though the shorter reading does not mention Melchizedek, his name seems to be implied in this quotation on the basis of two related arguments: (1) this is a clear quotation from Ps 119:4 LXX, a passage that emphasizes Melchizedek; 


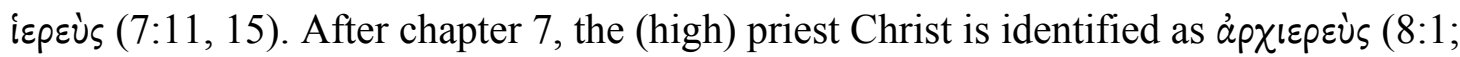

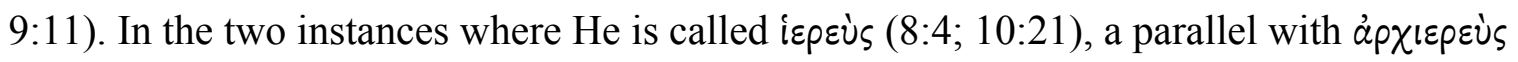

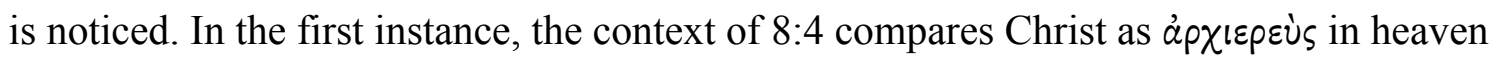

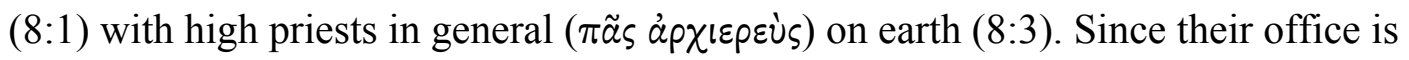

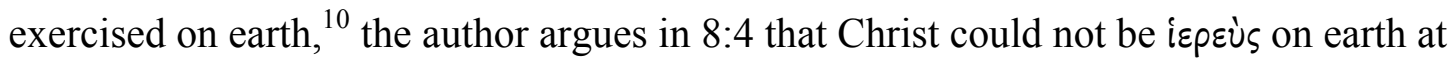

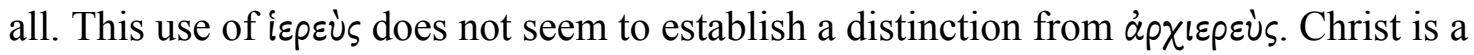

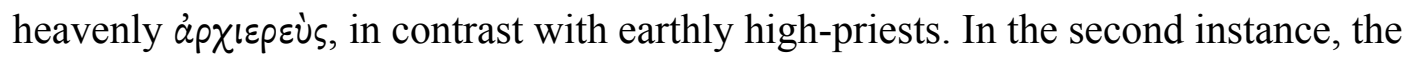

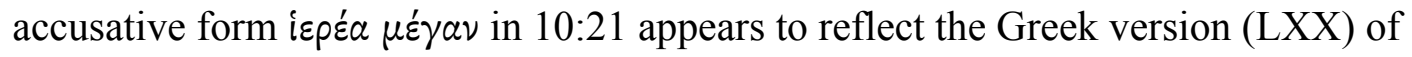
references to high-priest in the Hebrew Bible. The LXX does not employ the term

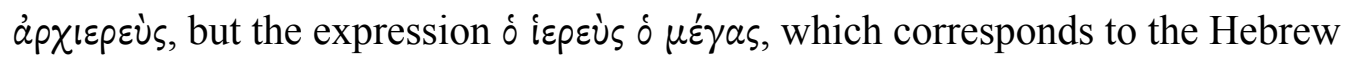

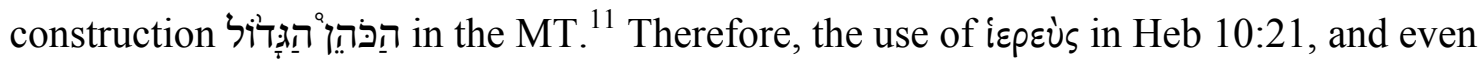

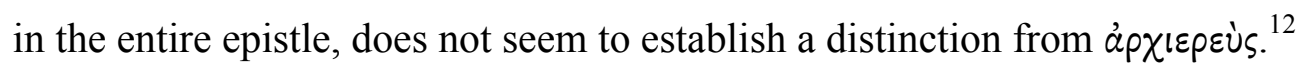

Besides the use of specific terms to refer explicitly to the idea of priesthood, the author of Hebrews seems to allude to Christ's priesthood with the cultic/ritual language

(2) this is the third quotation of that psalm in Hebrews, and the first two do mention Melchizedek.

${ }^{10}$ The repetition of the verb $\pi \rho \circ \sigma \phi \varepsilon ́ p \omega$ and the noun $\delta \tilde{\omega} \rho \circ \nu$ in 8:4 suggests that the participial

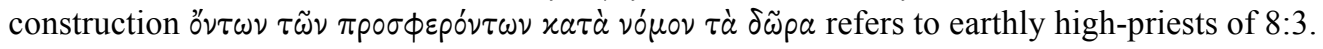

${ }^{11}$ Compare the following passages in the MT and the LXX, Lev 21:10; Num 35:25, 28; 2 Kgs $12: 11 ; 22: 4,8 ; 23: 4 ; 2$ Chr 34:9; Neh 3:1, 20; 13:38; Hag 1:1, 12, 14; 2:2, 4; Zech 3:1, 8; 6:11. The LXX

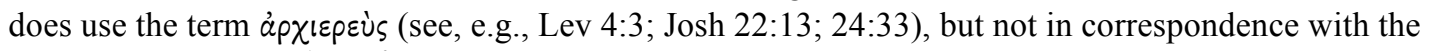

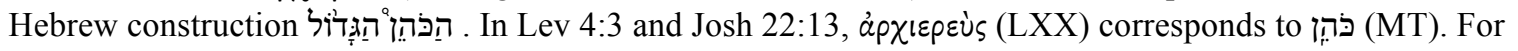

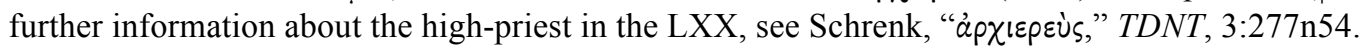

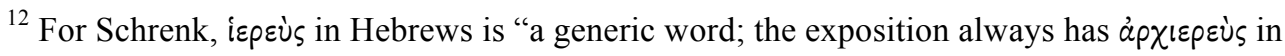

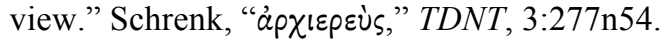


of purification $(1: 3 ; 9: 14,22-23),{ }^{13} \operatorname{blood}(9: 12,14 ; 10: 19,29 ; 12: 24 ; 13: 12,20),{ }^{14}$

sacrifice $(5: 1 ; 7: 27 ; 8: 3 ; 9: 23,26 ; 10: 12,10,14,26),{ }^{15}$ ministry/service $(8: 2,6),{ }^{16}$

sanctuary $(8: 2 ; 9: 11,12,24),{ }^{17}$ and mediation $(7: 25 ; 8: 6 ; 9: 15 ; 12: 24 ; 13: 15,21) .{ }^{18}$ When

${ }^{13}$ The language of purification is explicitly expressed in Hebrews through the nouns xatapıruós

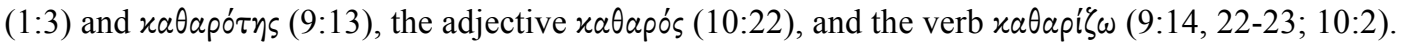
Overall, these terms respectively mean purification, purity, pure or clean, and to purify or cleanse. Such meanings may have ritual/cultic and moral connotations. See BDAG, 488-490; L\&N §53.28-29. In Hebrews, the language of purification is associated with $\sin (1: 3 ; 10: 2)$, blood $(9: 13-14,22)$, sacrifice $(9: 23$; 10:2), and evil conscience (10:22). In the LXX, there is a concentration of the occurrences of these Greek terms in Leviticus, which highlights their cultic/ritual connotation. In the context of the priestly consecration of Aaron and his sons, the altar is purified with sacrificial blood (Lev 8:15; see also Exod 29:36-37), and this purification is also a priestly practice in other contexts (Lev 16:19; Exod 30:10; Ezek 43:26). The Day of Atonement, for instance, includes not only the purification of the altar (Lev 16:19), but also the atonement ( $\dot{\xi} \xi \lambda \dot{\alpha} \sigma x \circ \mu \alpha \iota)$ of the sanctuary as a whole and the cleansing ( $\kappa a \theta \alpha \rho i \xi \omega)$ of the priests (v. 20 - the priests are mentioned only in the LXX, not in the MT; see also v. 24 LXX. The MT includes atonement for the priests in v. 33). In Lev 16:30, atonement ( $\dot{\xi} \xi 1 \lambda a ́ \sigma x o \mu a l)$ is defined in terms of cleansing ( $\varkappa a \theta a p i \zeta \omega)$ from sin, and the chapter indicates that this atoning purification is a priestly activity.

${ }^{14}$ The majority of the NT occurrences of the noun aĩ $\mu \alpha$ are in Hebrews $(2: 14 ; 9: 7,12-14,18-22$, $25 ; 10: 4,19,29 ; 11: 28 ; 12: 4,24 ; 13: 11-12,20)$. This noun occurs 97 times in the NT, and 21 are in Hebrews. In fact, aĩua appears 11 times in Heb 9, which is the NT chapter with more references to this noun. From the 21 occurrences, 7 seem to refer cultically/ritually to Jesus' blood, as this is a sacrificial blood $(9: 14 ; 12: 24 ; 13: 12)$ of the covenant $(10: 29 ; 13: 20)$, the blood that gives access to the heavenly sanctuary or the holy places $(9: 12 ; 10: 19)$.

${ }^{15}$ Most of the NT occurrences of the noun Avoía are in Hebrews $(5: 1 ; 7: 27 ; 8: 3 ; 9: 9,23,26 ; 10: 1$,

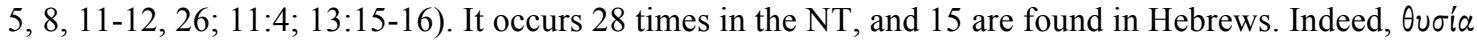
appears 10 times in Heb 10, which is the NT chapter with more references to this noun. From the 15 occurrences, 7 seem to refer to Christ's sacrifice, 2 explicitly $(9: 26 ; 10: 12)$ and 3 implicitly $(5: 1 ; 7: 27 ; 8: 3$; $9: 23 ; 10: 26)$. The occurrences of Uvoía in Heb 10:5, 8 indicate a parallel meaning of sacrifice and offering

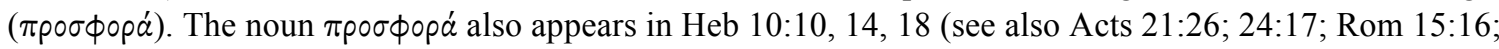
Eph 5:2). In vv. 10 and 14, it depicts Christ's sacrificial offering.

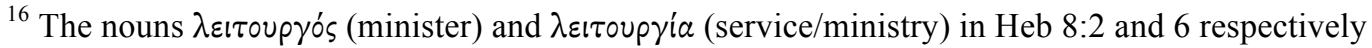
refer to Christ as priest in the heavenly sanctuary (see vv. 1-6). In 9:21, $\lambda \varepsilon$ eq oup pía describes the service/ministry of the earthly tabernacle, and in 10:11 the participial form of the verb $\lambda \varepsilon i \tau o u p \gamma \varepsilon \dot{\varepsilon} \omega$ depicts

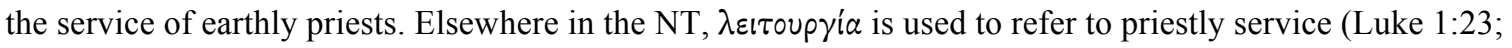

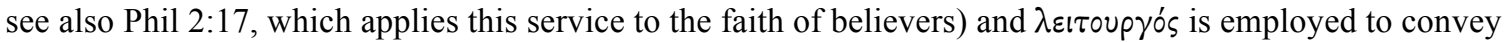
the idea of a priestly minister of the gospel (Rom 15:16). This terminology, especially in the verbal form, is profusely used in the LXX to describe the priestly service (see, e.g., Exod 28:35, 43; 29:30; 30:20; 31:10; 35:19; 36:33 [39:26 MT]; 37:19 [38:21 MT]; 38:27 [40:30 MT]; 39:11-12 [39:32 MT]).

${ }^{17}$ In Hebrews, the noun $\sigma x \eta \nu \eta \dot{~ a n d ~ t h e ~ e x p r e s s i o n ~} \tau \dot{\alpha} a ̈ \gamma ı \alpha$ (and its variants) convey the meaning of sanctuary. Most of the 31 occurrences of $\sigma \times \eta \nu \eta$ in the NT are found in Hebrews $(8: 2,5 ; 9: 2-3,6,8,11,21$; $11: 9 ; 13: 10)$. Considering that its basic meaning is tent, $\sigma \times \eta \nu \eta$ is used to refer to the tabernacle or the cultic tent (the tent of the testimony). See BDAG, 928. This noun describes the sanctuary/tabernacle where Christ ministers in Heb 8:2; 9:11. With regard to the plural expression $\tau \dot{\alpha}$ ä $\gamma ı \alpha$ (and its variant forms), 10 
the explicit references to Christ's priesthood indicated in the previous paragraph are taken together with the allusions mentioned in the present paragraph, the main passages related to Christ's priesthood in Hebrews are: 1:3; 2:17; 3:1; 4:14-15; 5:1, 5-6, 10; 6:20; 7:11, $15,17,21,24,25-27 ; 8: 1-4,6 ; 9: 11-12,14-15,22-24,26 ; 10: 10,12,14,19,21,26,29$; $12: 24 ; 13: 12,15,20-21$.

After these preliminary remarks on the terminology of the priesthood I will briefly describe the priesthood of Christ in the context of the structure of Hebrews.

\section{The Priesthood and the Sctructure of Hebrews}

\section{Using George Guthrie's proposal as a frame of reference of the structure of}

Hebrews, ${ }^{19}$ in which there is a complex interplay between the genres of exposition and

occurrences are found in Hebrews (8:2; 9:1 [singular form], 2 [anarthrous form], 3 [anarthrous and

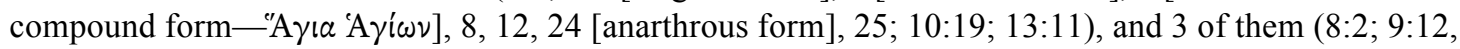
24) point to the sanctuary where Christ is the high priest. It is noteworthy that, with the exception of the contrast between the holy place and the most holy place in Heb 9:2-3, all other occurrences of $\tau \dot{\alpha} a$ á $\gamma\llcorner\alpha$ (and its variants) in Hebrews appear to refer to the sanctuary as a whole. See Salom, "Ta Hagia in the Epistle to the Hebrews," 59-70. This point will be further elaborated in the section below on Cosmology.

${ }^{18}$ The idea of Christ's priestly mediation in Hebrews seems to be highlighted by the noun $\mu \varepsilon \sigma^{\prime} i \eta s$

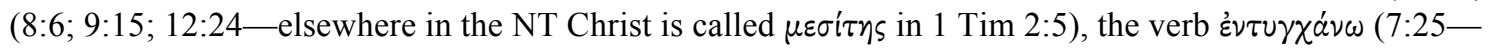

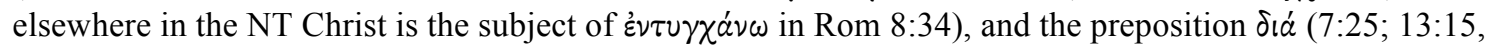
21). With the meaning of mediator (see BDAG, 634; L\&N \$31.22), $\mu \varepsilon \sigma i \tau \eta \varsigma$ depicts Christ as the mediator of a better $(8: 6)$ and new $(9: 15 ; 12: 24)$ covenant. This mediation is associated with Christ's priestly

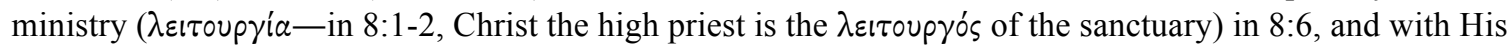
sacrificial death and blood in 9:15 and 12:24 respectively. Describing the action of intercession or appeal

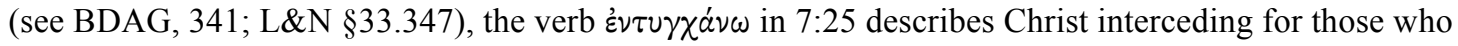
come to God, and this intercession appears in the context of His permanent priesthood (v. 24) as a High Priest (v. 26). The preposition $\delta ı \alpha$ in the genitive form (through) coveys the idea of agency or means, among other senses (see Daniel B. Wallace, Greek Grammar Beyond the Basics: An Exegetical Syntax of the New Testament [Grand Rapids, MI: Zondervan, 1996], 368-369). In 7:25, a passage that I have already indicated its priestly context, believers come to God through Christ. In 13:15, using a priestly language, believers are exhorted to offer a sacrifice of praise to God through Christ. In 13:21, the author of Hebrews prays that God may work in believers through Christ. This mediatorial activity seems to be associated with His sacrifical blood in 13:20.

${ }^{19}$ See George H. Guthrie, The Structure of Hebrews: A Text-Linguistic Analysis (Leiden; New York: Brill, 1994), 144; George H. Guthrie, Hebrews, The NIV Application Commentary (Grand Rapids, MI: Zondervan, 1998), 39-40. In this dissertation, I use Guthrie's more recent unpublished outline of 
exhortation $^{20}$ - the exposition serving the overall purpose of exhortation in the book, ${ }^{21}$ the main passages about Christ's priesthood are found in different sections and genres of the epistle, as it can be observed in the general structure of Hebrews outlined below. ${ }^{22}$ Introduction (1:1-4)*

Exposition I: The Son as Our Messenger (1:5-2:18)*

Exhortation $(2: 1-4)$

Exhortation (3:1-4:13)

Transition from exposition to exhortation (3:1-6)*

Exposition II: The Son as Our High Priest (4:14-10:25)*

Transition/overlap: exhortation, exposition (4:14-16)*

Hebrews, which includes minor adjustments to his two previous publications, found in Guthrie, "The Structure of Hebrews Revisited," https://hebrews.unibas.ch/documents/2006GuthrieH.pdf (accessed 28 December, 2016), 2 (Figure 2: the Structure of the Book of Hebrews). He adopts the method of textlinguistics analysis or discourse analysis, which attempts to track cohesion shifts in the discourse. See Guthrie, The Structure of Hebrews, 36-37, 45-58. To some extent, his analysis builds on the literary analysis of Albert Vanhoye, La Structure Littéraire De L'Épitre Aux Hébreux (Paris: Desclée de Brouwer, 1962). See Guthrie, The Structure of Hebrews, 45; Cynthia Long Westfall, A Discourse Analysis of the Letter to the Hebrews: The Relationship between Form and Meaning, Library of New Testament Studies (London; New York: T\&T Clark, 2005), 19. Supporters of Guthrie's proposal include, Lane, Hebrews 1-8, xc-xcviii; O'Brien, The Letter to the Hebrews, 31-34; Barry C. Joslin, "Can Hebrews Be Structured? An Assessment of Eight Approaches," Currents in Biblical Research 6, no. 1 (2007): 115-122. The main critic of Guthrie is probably Westfall, who considers "his proposal of two independent but interrelated backbones [exposition and exhortation] that run side by side but eventually converge" as incoherent and confusing. Westfall, A Discourse Analysis of the Letter to the Hebrews, 20. For a defense of Guthrie's proposal in face of Westfall's criticism, see Joslin, "Can Hebrews be Structured?," 99-129; O'Brien, The Letter to the Hebrews, 33-34.

${ }^{20}$ Guthrie affirms "a brilliant interplay between expositional spans and more overtly hortatory spans in the book, and that these subgenres, while dynamically interweaving both rhetorically and semantically, have distinct features and functions, which must be taken into account in structural assessments of the book. These subgenres neither should be held apart, as if they were two parallel but separate rivers flowing side-by-side, nor should they be mingled to the point that their distinctiveness and unique contributions to the discourse become obscured." Guthrie, "The Structure of Hebrews Revisited," https://hebrews.unibas.ch/documents/2006Guthrie.pdf (accessed 28 December, 2016), 6; Guthrie, The Structure of Hebrews, 50, 115.

${ }^{21}$ In agreement with the idea that Hebrews is a "word of exhortation [ $\left.\pi \alpha \rho \alpha \dot{x} \lambda \lambda \sigma_{1 \zeta}\right]$ " (Heb 13:22), Guthrie argues that "the expositional material serves the hortatory purpose of the whole work," assuming that "the purpose of the book of Hebrews is to exhort the hearers to endure in their pursuit of the promised reward." He explains, "In the expositional units the discourse deals with information about the Son. In the hortatory units the author turns to his hearers and exhorts them to take action." The Christological exposition "offers a powerful motivation for an active obedience and endurance" of believers. Guthrie, The Structure of Hebrews, 143, 145.

${ }^{22}$ Adapted from Guthrie, "The Structure of Hebrews Revisited," https://hebrews.unibas.ch/documents/2006GuthrieH.pdf (accessed 28 December, 2016), 2 (Figure 2: the Structure of the Book of Hebrews). The symbol (*) indicates that the section contains at least one main passage about Christ's priesthood. 


\section{Exhortation (5:11-6:20)}

Transition from exhortation to exposition $(6: 13-20)^{*}$

Transition/overlap: exposition, exhortation (10:19-25)*

Exhortation (10:26-13:19)*

Benediction/Conclusion (13:20-25)*

Generally speaking, besides the introduction (1:1-4) and benediction/conclusion (13:20-25), ${ }^{23}$ Hebrews has two sections of exposition, namely, the Son as our messenger (1:5-2:18) and the Son as our high priest (4:14-10:25), ${ }^{24}$ and ends with exhortation (10:26-13:19). ${ }^{25}$ The first expositional section includes hortatory material or exhortation (2:1-4), and the first and second sections are connected by exhortation (3:1-4:13), which has a transition ${ }^{26}(3: 1-6)$ between the first section of exposition and the hortatory material and moves to an overlap of exposition and exhortation (4:14-16) in the transition from the hortatory material and the second section of exposition. Besides this overlap, the second section includes exhortation (5:11-6:20), which has a transition (6:13-20) that brings the discourse back to exposition. In the transition (10:19-25) from the second section to the final hortatory material there is again an overlap of exposition and exhortation.

\section{Almost all explicit references to Christ as (high) priest appear in exposition II}

\footnotetext{
${ }^{23}$ For Guthrie, the benediction includes vv. 20-21 and the conclusion comprises vv. 22-25. Guthrie, "The Structure of Hebrews Revisited," https://hebrews.unibas.ch/documents/2006GuthrieH.pdf (accessed 28 December, 2016), 2 (Figure 2: the Structure of the Book of Hebrews).

${ }^{24}$ These are short titles of the sections. According to Guthrie, the first section is entitled "The Position of the Son, Our Messenger, in Relation to the Angels" and the second section is labeled "The Position of the Son, Our High Priest, in Relation to the Earthly Sacrificial System.” Ibid.

${ }^{25}$ Guthrie speaks of "three general movements in the discourse," the two Christological expositions in their logical development, and the final hortatory material that draws "force from the expositional material and by reiteration of key themes and forms found in other blocks of exhortation, ... using especially encouragement, warnings, promises, and positive and negative examples." Ibid., https://hebrews.unibas.ch/documents/2006Guthrie.pdf (accessed 28 December, 2016), 5, 8-9.

${ }^{26}$ For a helpful treatment of transition devices and techniques in Hebrews, see Guthrie, The Structure of Hebrews, 94-111.
} 
$(4: 14-15 ; 5: 5,6,10 ; 7: 11,15,17,21,24,26 ; 8: 1,4 ; 9: 11 ; 10: 21)$. Occurrences of these

references are found in exposition I (2:17), and in transitions from expositon to

exhortation $(3: 1 ; 10: 21)$ and vice-versa $(4: 14-15 ; 6: 20) .{ }^{27}$ Therefore, explicit references to

Christ's priesthood tend to be found in hortatory material only when there is a transition

from or to exposition. On the other hand, allusions to Christ's priesthood, while largely

present in exposition II $(5: 1 ; 7: 25,27 ; 8: 2-3,6 ; 9: 11,12,14-15,22-24,26 ; 10: 12,10,14$,

$19)$, occur in the final hortatory material $(10: 26,29 ; 12: 24 ; 13: 12,15)$, and also in the

introduction (1:3) and the benediction (13:20-21).

Not surprisingly, most references and allusions to Christ's priesthood appear in

exposition II, which is a section that deals specifically with this priesthood. I briefly

outline this section on Christ's priesthood below. ${ }^{28}$

The Position of the Son, Our High Priest, in Relation to the Earthly Sacrificial System (4:14-10:25)

Opening: Having a Great High Priest-Hold Fast and Draw Near (4:14-16)

A. The Apointment of the Son as a Superior High Priest (5:1-10; 7:1-28)

1. Introduction: The Son Taken from Among Humans and Appointed According to the Order

\begin{abstract}
${ }^{27}$ In his treatment of transition devices in Hebrews, Guthrie suggests the existence of "hook words" that are used for lexical stitching. To put it differently, "two parts of the discourse are stitched together in the book's structural development" through the use of "common words." In this sense, "the end of one unit and the beginning of the next" are "stitched together by the use of a repeated term or terms." Taking into account the shift between genres (exposition and exhortation) in Hebrews, hook words are used not only to build continuity between "adjacent units," such as the immediate shift from exposition to exhortation, but also to effect a long "stitching of the expository unit to the next expository unit." An

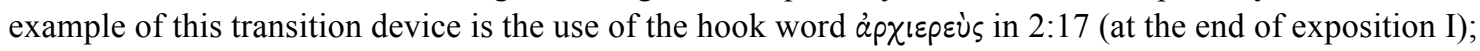
3:1 (shift to exhortation); 4:14 (the beginning of exposition II). The use of this word in 2:17 constitutes the first reference to Christ's priesthood in the book. "As the author shifts to exhortation at 3:1 the high priest theme is reiterated and then deactivated until 4:14," which is the beginning of the next exposition section. Ibid., 13-16. Therefore, there is an immediate transition from exposition to exhortation in 2:17 and 3:1, but also a "dynamic transition" from exposition I and exposition II in 2:17 and 4:14, as "the author resumes his Christological exposition at 4:14 and following." Ibid., https://hebrews.unibas.ch/documents/2006Guthrie.pdf (accessed 28 December, 2016), 18. It must be noted

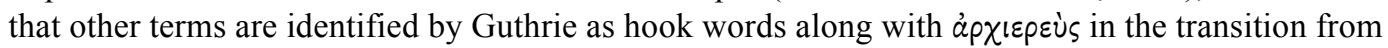
exposition to exhortation in 2:17-18 and 3:1-2, and in the transition from exposition I to exposition II in 2:17-18 and 4:14-5:3. See ibid., 16-18.
\end{abstract}

${ }^{28}$ Adapted from ibid., https://hebrews.unibas.ch/documents/2006GuthrieH.pdf (accessed 28 December, 2016), 2 (Figure 2: the Structure of the Book of Hebrews). 
of Melchizedek (5:1-10)

Exhortation (5:11-6:20)

The Difficulty in Giving Advanced Teaching on the Subject: Their Immaturity (5:11-6:3)

Warning: The Danger of Falling Away From Christian Faith (6:4-8)

The Author's Confidence in and Desire for the Hearers (6:9-12)

Transition to Exposition: God's Oath-Our Basis for Hope (6:13-20)

2. The Superiority of Melchizedek (5:1-10)

ab (transition). We Have Such a High Priest Who is a Minister in Heaven (8:1-2)

B. The Superior Offering of the Appointed High Priest (8:3-10:18)

1. Introduction: The More Excellent Ministry of the Heavenly High Priest (8:3-6)

2. The Superiority of the New Covenant (8:7-13)

3. The Superior New Covenant Offering (9:1-10:18)

a. The Place and Practice of Old Covenant Offering (9:1-10)

b. The New Covenant Offering Superior as to Blood, Place, and Eternality (9:11-10:18)

Closing: Since We Have a Great Priest-Draw Near, Hold Fast, Consider (10:19-25)

According to Guthrie, exposition II forms a great inclusio in the book, evidenced

by at least nine lexical parallels between the opening at 4:14-16 and the closing at 10:19-

$25 .^{29}$ This inclusio is constituted by two primary themes regarding Christ's priesthood-

(a) His superior appointment $(5: 1-10 ; 7: 1-28)$ and (b) His superior offering (8:3-

$10: 18)^{30}$ - and the transition between them (8:1-2) is arguably the center of the inclusio. ${ }^{31}$

This preliminary overview of the terminology related to Christ's priesthood in the

context of the literary structure of Hebrews provided the initial background information

for my conceptual articulation of the components of Christ's priesthood in chapter 4.

${ }^{29}$ See ibid., https://hebrews.unibas.ch/documents/2006Guthrie.pdf (accessed 28 December, 2016), $20-21$.

${ }^{30}$ In his treatment of transition devices in Hebrews, Guthrie suggests the existence of two significant parallel introductions in the book. The first one is the parallel between the beginning of expositions I (1:5-2:18) and II (4:14-10:25). Both expositions are introduced by the quotation of Ps $2: 7$ (see 1:5 and 5:5). Guthrie argues that "this parallel introduction facilitates a fluid transition from the first major expositional span of material, to the second." Ibid., 23. While this first parallel relates to the transition between expositions I and II, the second parallel concerns the transition between the two main parts of exposition II. In fact, the themes of (a) Christ's superior appointment $(5: 1-10 ; 7: 1-28)$ and (b) Christ's superior offering (8:3-10:18) present a similar introduction (see 5:1 and 8:3), one with the focus on the idea of appointment (5:1) and the other focusing on the offering (8:3). Ibid., 24-25.

${ }^{31}$ According to Guthrie, "The intermediary transition at Heb. 8:1-2 could be considered the center point for the great central exposition on the high priestly ministry of Christ." Guthrie, The Structure of Hebrews, 146. 


\section{BIBLIOGRAPHY}

Adams, Edward. "The Cosmology of Hebrews" In The Epistle to the Hebrews and Christian Theology, edited by Richard Bauckham, Daniel R. Driver, Trevor A. Hart and Nathan MacDonald, 122-139. Grand Rapids, MI: Eerdmans, 2009.

Ahn, Ho-Jin. "The Humanity of Christ: John Calvin's Understanding of Christ's Vicarious Humanity." Scottish Journal of Theology 65, no. 2 (2012): 145-158.

Akin, Daniel L. 1, 2, 3 John. New American Commentary. Nashville: Broadman \& Holman, 2001.

Allen, David M. Deuteronomy and Exhortation in Hebrews: A Study in Narrative RePresentation. Tübingen: Mohr Siebeck, 2008.

Allen, Leslie C. Ezekiel 20-48. Word Biblical Commentary. Dallas: Thomas Nelson, 1998.

Allen, R. Michael. “Calvin's Christ: A Dogmatic Matrix for Discussion of Christ's Human Nature.” International Journal of Systematic Theology 9, no. 4 (2007): 328-397.

Allman, James E. "I $\Lambda \alpha ́ \sigma \kappa \varepsilon \sigma \theta \alpha 1$ : To Propitiate or to Expiate?” Bibliotheca sacra 172, no. 687 (2015): 335-355.

Althaus, Paul. The Theology of Martin Luther. Translated by R. C. Schultz. Philadelphia: Fortress, 1966.

Anderson, David R. The King-Priest of Psalm 110 in Hebrews. Studies in Biblical Literature. New York: Peter Lang, 2001.

Anderson, Gary A., and Saul M. Olyan. Priesthood and Cult in Ancient Israel. Journal for the Study of the Old Testament Supplement Series. Sheffield, England: Sheffield Academic Press, 1991.

Anderson, Mary Elizabeth. Gustaf Wingren and the Swedish Luther Renaissance. American University Studies 243. New York: Peter Lang, 2006.

Angel, Joseph L. Otherworldly and Eschatological Priesthood in the Dead Sea Scrolls. Studies on the Texts of the Desert of Judah. Leiden; Boston: Brill, 2010. 
Anthony, Neal J. Cross Narratives: Martin Luther's Christology and the Location of Redemption. Princeton Theological Monograph Series. Eugene, OR: Pickwick, 2010.

Aquinas, Thomas. On Evil. Translated by Richard J. Regan. Oxford; New York: Oxford University Press, 2003.

. Selected Philosophical Writings. Translated by Timothy S. McDermott. Oxford World's Classics. Oxford; New York: Oxford University Press, 2008.

. Summa Contra Gentiles. Translated by James F. Anderson Anton C. Pegis, Vernon J. Bourke, and Charles J. O’Neil, Edited by Joseph Kenny. New York: Hanover House, 1955-1957.

Summa Theologica. Translated by Fathers of the English Dominican Province. 5 vols. The Master Christian Library. CD-ROM, version 5.0. Albany, OR: AGES Software, 1997.

Aquinas, Thomas, and Colman E. O'Neill. The One Mediator (3a.15-26): Latin Text, English Translation, Introduction, Notes, Appendices and Glossary. Summa Theologiae. London: Blackfriars, 1965.

Arminius, James. The Works of James Arminius. 3 vols. The Master Christian Library. CD-ROM, version 5.0. Albany, OR: AGES Software, 1997.

Attridge, Harold W. The Epistle to the Hebrews: A Commentary on the Epistle to the Hebrews. Hermeneia. Philadelphia: Fortress, 1989.

. "God in Hebrews." In The Epistle to the Hebrews and Christian Theology, edited by Richard Bauckham, Daniel R. Driver, Trevor A. Hart and Nathan MacDonald, 95-110. Grand Rapids, MI: Eerdmans, 2009.

Balserak, Jon. Divinity Compromised: A Study of Divine Accommodation in the Thought of John Calvin. Studies in Early Modern Religious Reforms. Dordrecht: Springer, 2006.

Barrett, Charles K. "The Eschatology of the Epistle to the Hebrews." In The Background of the New Testament and Its Eschatology: C. H. Dodd Festschrift, edited by W. D. Davies and D. Daube, 363-393. Cambridge: Cambridge University Press, 1956.

Barth, Karl. Church Dogmatics. 14 vols. Edited by G. W. Bromiley and T. F. Torrance. Peabody, MA: Hendrickson, 2010.

Basinger, David. "Divine Control and Human Freedom: Is Middle Knowledge the Answer?" Journal of the Evangelical Theological Society 36, no. 1 (1993): 55-64. 
Bateman, Herbert W. Four Views on the Warning Passages in Hebrews. Grand Rapids, MI: Kregel, 2007.

Batka, L'ubmoír. "Luther's Teaching on Sin and Evil." In The Oxford Handbook of Martin Luther's Theology, edited by Robert Kolb, Irene Dingel and L'ubmoír Batka, 233-253. Oxford; New York: Oxford University Press, 2014.

Bauckham, Richard. "The Divinity of Jesus Christ in the Epistle to the Hebrews." In The Epistle to the Hebrews and Christian Theology, edited by Richard Bauckham, Daniel R. Driver, Trevor A. Hart and Nathan MacDonald, 15-36. Grand Rapids, MI: Eerdmans, 2009.

Bauer, Walter, F. W. Danker, W. F. Arndt, and F. W. Gingrich. Greek-English Lexicon of the New Testament and Other Early Christian Literature. 3rd ed. Chicago: University of Chicago Press, 2000.

Bavinck, Herman. “Calvin's Doctrine of the Lord's Supper.” Mid-America Journal of Theology 19 (2008): 127-142.

Bayer, Oswald. Martin Luther's Theology: A Contemporary Interpretation. Grand Rapids, MI: Eerdmans, 2008.

. Theology the Lutheran Way. Translated by Jeffrey G. Silcock and Mark C. Mattes. Lutheran Quarterly Books. Grand Rapids, MI: Eerdmans, 2007.

Behr, John. The Way to Nicaea. The Formation of Christian Theology. Crestwood, NY: St. Vladimir's Seminary Press, 2001.

Bell, M. Charles. Calvin and Scottish Theology: The Doctrine of Assurance. Edinburgh: Handsel, 1985.

Bell, Theo. "Man Is a Microcosmos: Adam and Eve in Luther's Lectures on Genesis (1535-1545)." Concordia Theological Quarterly 69, no. 2 (2005): 159-184.

Berkhof, Louis. Systematic Theology. Grand Rapids, MI: Eerdmans, 1976.

Berkouwer, G. C. Sin. Studies in Dogmatics. Grand Rapids, MI: Eerdmans, 1971. . The Triumph of Grace in the Theology of Karl Barth. American ed. Grand Rapids, MI: Eerdmans, 1956.

Bertoluci, Jose M. "The Son of the Morning and the Guardian Cherub in the Context of the Controversy between Good and Evil." Th.D. Dissertation, Andrews University, 1985. 
Billings, J. Todd. "John Calvin's Soteriology: On the Multifaceted 'Sum' of the Gospel." International Journal of Systematic Theology 11, no. 4 (2009): 428-447.

. Union with Christ: Reframing Theology and Ministry for the Church. Grand Rapids, MI: Baker Academic, 2011.

Blanchette, Oliva. The Perfection of the Universe According to Aquinas: A Teleological Cosmology. University Park: Pennsylvania State University, 1992.

Blanco, Marcos. "Atemporalidad, Omnisciencia Y Providence Divinas: Podemos Adelantar La Segunda Venida?” DavarLogos 2, no. 2 (2003): 153-165.

Blankenhorn, Bernhard. "The Instrumental Causality of the Sacraments: Thomas Aquinas and Louis-Marie Chauvet." Nova et Vetera 4, no. 2 (2006): 255-294.

Blenkinsopp, Joseph. Sage, Priest, Prophet: Religious and Intellectual Leadership in Ancient Israel. Library of Ancient Israel. Louisville, KY: Westminster John Knox Press, 1995.

Blocher, Henry. "Karl Barth's Christocentric Method." In Engaging with Barth: Contemporary Evangelical Critiques, edited by David Gibson and Daniel Strange, 21-54. New York: T\&T Clark, 2008.

Bloesch, Donald G. Jesus Is Victor!: Karl Barth's Doctrine of Salvation. Eugene, OR: Wipf and Stock, 2001.

Blomberg, Craig L. "Matthew." In Commentary on the New Testament Use of the Old Testament, edited by G. K. Beale and D. A. Carson, 1-109. Grand Rapids, MI; Nottingham: Baker Academic; Apollos, 2007.

Blount, Douglas K. “On the Incarnation of a Timeless God." In God and Time: Essays on the Divine Nature, edited by Gregory E. Ganssle and David M. Woodruff, 236248. Oxford; New York: Oxford University Press, 2002.

Boer, William den. God's Twofold Love: The Theology of Jacob Arminius (1559-1609). Reformed Historical Theology. Göttingen; Oakville, CT: Vandenhoeck and Ruprecht, 2010.

. "Jacobus Arminius: Theologian of God's Twofold Love." In Arminius, Arminianism, and Europe Jacobus Arminius (1559/60-1609), edited by Theodoor Leeuwen. Leiden; Boston: Brill, 2009.

Boersma, Hans. Heavenly Participation: The Weaving of a Sacramental Tapestry. Grand Rapids, MI: Eerdmans, 2011. 
. Nouvelle Théologie and Sacramental Ontology: A Return to Mystery. Oxford: Oxford University Press, 2012.

. "Sacramental Ontology: Nature and the Supernatural in the Ecclesiology of Henri De Lubac.” New Blackfriars 88, no. 1015 (2007): 242-273.

Bowers, Erin Kesterson. "In Opposition to God: The Doctrine of Sin in the Theologies of Friedrich Schleieramcher and Karl Barth.” Ph.D. Dissertation, Princeton Theological Seminary, 2013.

Boyd, Gregory A. God of the Possible: A Biblical Introduction to the Open View of God. Grand Rapids, MI: Baker, 2000.

Braun, Herbert. An Die Hebräer. Tübingen: Mohr Siebeck, 1984.

Brent, James. "God's Knowledge and Will.” In The Oxford Handbook of Aquinas, edited by Brian Davies and Eleonore Stump, 158-172. Oxford; New York: Oxford University Press, 2011.

Brewbaker III, William S. "Thomas Aquinas and the Metaphysics of Law." Alabama Law Review 58, no. 3 (2007): 575-614.

Brock, Stephen L. "St. Thomas and the Eucharistic Conversion." The Thomist 65, no. 4 (2001): 529-565.

Brooks, Walter Edward. "Perpetuity of Christ's Sacrifice in the Epistle to the Hebrews." Journal of Biblical Literature 89, no. 2 (1970): 205-214.

Brosché, Fredrik. Luther on Predestination: The Antinomy and the Unity between Love and Wrath in Luther's Concept of God. Acta Universitatis Upsaliensis, Studiae Doctrinae Christianae Upsaliensia 18. Stockholm: Almqvist \& Wiksell, 1978.

Brown, F., S. R. Driver, and C. A. Briggs. A Hebrew and English Lexicon of the Old Testament. Oxford: Oxford, 1907.

Brown, Raymond E. An Introduction to New Testament Christology. New York: Paulist, 1994.

Bruce, F. F. The Epistle to the Hebrews. New International Commentary on the New Testament. Grand Rapids, MI: Eerdmans, 1964.

Brun, Rudolf B. "Cosmology, Cosmic Evolution, and Sacramental Reality: A Christian Contribution." Zygon: Journal of Religion \& Science 37, no. 1 (2002): 175.

Büchsel, Friedrich. Die Christologie Des Hebräerbriefs. Gütersloh: C. Bertelsmann, 1922. 
Buckley, James J. "Christian Community, Baptism, and Lord's Supper." In The Cambridge Companion to Karl Barth, edited by John Webster, 195-211. Cambridge: Cambridge University Press, 2000.

Bultmann, Rudolf. Kerygma and Myth: A Theological Debate. Translated by Hans Werner Bartsch. New York: Harper and Row, 1961.

Burgess, Andrew. The Ascension in Karl Barth. Hampshire, England; Burlington, VT: Ashgate, 2004.

Callender, Elizabeth Jarrell. "A Theology of Spatiality: The Divine Perfection of Omnipresence in the Theology of Karl Barth." Ph.D. Dissertation, University of Otago, 2011.

Calvin, John. Calvin's Bible Commentaries. The John Calvin Collection. Albany, OR: AGES Software, 1998.

. Institutes of the Christian Religion. Translated by Ford Lewis Battles. 2 vols. Edited by John T. McNeill. Philadelphia: Westminster Press, 1960.

Canale, Fernando Luis. Back to Revelation-Inspiration: Searching for the Cognitive Foundation of Christian Theology in a Postmodern World. Lanham, MD; Oxford: University Press of America, 2001.

. Basic Elements of Christian Theology: Scripture Replacing Tradition. Berrien Springs, MI: Andrews University Lithothec, 2005.

. The Cognitive Principle of Christian Theology: A Hermeneutical Study of the Revelation and Inspiration of the Bible. Berrien Springs, MI: Andrews University Lithothec, 2005.

. A Criticism of Theological Reason: Time and Timelessness as Primordial Presuppositions. Andrews University Seminary Doctoral Dissertation Series 10. Berrien Springs, MI: Andrews University Press, 1987.

. "Deconstructing Evangelical Theology?" Andrews University Seminary Studies 44, no. 1 (2006): 95-130.

. "Evolution, Theology, and Method: Part 3 Evolution and Adventist Theology." Andrews University Seminary Studies 42, no. 1 (2004): 5-48.

. "Is There Room for Systematics in Adventism?" Journal of the Adventist Theological Society 12, no. 2 (2001): 110-131.

. "Philosophical Foundations and the Biblical Sanctuary." AUSS 36, no. 2 (1998): 183-206. 
Caneday, Ardel B. "The Eschatological World Already Subjected to the Son: The Oikoumevn of Hebrews 1.6 and the Son's Enthronement." In A Cloud of Witnesses: The Theology of Hebrews in Its Ancient Contexts, edited by Richard Bauckham, Daniel Driver, Trevor Hart, and Nathan MacDonald, 28-39. London: T\&T Clark, 2008.

Canlis, Julie. "Calvin, Osiander, and Participation in God." International Journal of Systematic Theology 6, no. 2 (2004): 169-184.

. Calvin's Ladder: A Spiritual Theology of Ascent and Ascension. Grand Rapids, MI: Eerdmans, 2010.

Cary, Phillip. "Why Luther Is Not Quite Protestant: The Logic of Faith in a Sacramental Promise." Pro Ecclesia 14, no. 4 (Fall 2005): 447-486.

Cassidy, James J. “T. F. Torrance’s Realistic Soteriological Objectivism and the Elimination of Dualisms: Union with Christ in Current Perspective." MidAmerica Journal of Theology 19 (2008): 165-194.

Catão, Bernard. Salut Et Rédemption Chez Saint S. Thomas d'Aquin: L'acte Sauveur Du Christ. Paris: Aubier, 1965.

Cessario, Romanus. “Aquinas on Christian Salvation.” In Aquinas on Doctrine: A Critical Introduction, edited by Thomas G. Weinandy, Daniel A. Keating and John Yocum, 117-137. London; New York: T\&T Clark International, 2004.

Chalamet, Christophe. "No Timelessness in God: On Differing Interpretations of Karl Barth's Theology of Eternity, Time and Election.” Zeitschrift für Dialektische Theologie 4 (2010): 21-37.

Chardonnens, Denis. "Eternité Du Sacerdoce Du Christ Et Effet Eschatologique De L'eucharistie." Revue Thomiste 107, no. 1 (1999): 159-180.

Chauvet, Louis Marie. Symbol and Sacrament: A Sacramental Reinterpretation of Christian Existence. Collegeville, MN: Liturgical Press, 1995.

Christ-Von Wedel, Christine. Erasmus of Rotterdam Advocate of a New Christianity. Erasmus Studies. Toronto; Buffalo; London: University of Toronto Press, 2013.

Clark, John Christian. "The Priestly Office of Jesus Christ in the Thought of John Calvin." Ph.D. Dissertation, The University of Toronto, 2013.

Cockerill, Gareth Lee. The Epistle to the Hebrews. New International Commentary on the New Testament. Grand Rapids, MI; Cambridge, U.K.: Eerdmans, 2012. 
Cody, Aelred. Heavenly Sanctuary and Liturgy in the Epistle to the Hebrews: The Achievement of Salvation in the Epistle's Perspectives. St. Meinrad, IN: Grail Publications, 1960.

. A History of the Old Testament Priesthood. Rome: Pontifical Biblical Institute, 1969.

Coesart, Carl. "A Study of Ta Hagia in the LXX, Pseudepigrapha, Philo, and Josephus, and Its Implications in Hebrews." MA Thesis, Nazarene Theological Seminary, 2000 .

. "The Use of Hagios for the Sanctuary in the Old Testament Pseudepigrapha, Philo, and Josephus." AUSS 42 (2004): 91-103.

Collins, Paul M. Trinitarian Theology, West and East: Karl Barth, the Cappadocian Fathers, and John Zizioulas. Oxford; New York: Oxford University Press, 2001.

Colyer, Elmer M. How to Read T.F. Torrance: Understanding His Trinitarian \& Scientific Theology. Downers Grove, IL; Eugene, OR: InterVarsity; Wipf and Stock, 2007.

Compton, Jared. Psalm 110 and the Logic of Hebrews. Library of New Testament Studies. New York: Bloomsbury T\&T Clark, 2015.

Cooper, Lamar Eugene. Ezekiel. New American Commentary. Nashville: Broadman \& Holman, 1998.

Cortez, Felix H. "'The Anchor of the Soul That Enters within the Veil': The Ascension of the 'Son' in the Letter to the Hebrews." Ph.D. Dissertation, Andrews University, 2008 .

. "From the Holy to the Most Holy Place: The Period of Hebrews 9:6-10 and the Day of Atonement as a Metaphor of Transition." Journal of Biblical Literature 125, no. 3 (2006): 527-547.

Cortez, Marc. "Body, Soul and (Holy) Spirit: Karl Barth's Theological Framework for Understanding Human Ontology.” International Journal of Systematic Theology 10, no. 3 (2008): 328-345.

Couenhoven, Jesse. "Grace as Pardon and Power: Pictures of the Christian Life in Luther, Calvin, and Barth." Journal of Religious Ethics 28, no. 1 (2000): 63-88.

The Council of Trent: The Canons and Decrees of the Sacred and Ecumenical Council of Trent. Edited by J. Waterworth. London: Dolman, 1848. 
Craig, Willian Lane. "The Middle-Knowledge View." In Divine Foreknowledge: Four Views, edited by James K. Beilby, Paul R. Eddy and Gregory A. Boyd, 119-143. Downers Grove, IL: InterVarsity Press, 2001. . Time and Eternity: Exploring God's Relationship to Time. Wheaton, IL: Crossway, 2001.

Crawford, John Richard. "Calvin and the Priesthood of All Believers." Scottish Journal of Theology 21, no. 2 (1968): 145-156.

Crisp, Oliver D. "Calvin on Creation and Providence." In John Calvin and Evangelical Theology: Legacy and Prospect, edited by Sung Wook Chung, 43-65. Louisville, KY: Westminster John Knox Press, 2009.

. “On Barth's Denial of Universalism.” Themelios 29, no. 1 (2003): 18-29.

Cullmann, Oscar. The Christology of the New Testament. Translated by Shirley C. Guthrie and Charles A. M. Hall. Philadelphia: Westminster, 1959.

D'Angelo, Mary Rose. Moses in the Letter to the Hebrews. Society of Biblical Literature Dissertation Series. Missoula, MT: Scholars Press, 1979.

Dahl, Nils Alstrup. "A New and Living Way: The Approach to God According to Heb 10:19-25." Interpretation 5, no. 4 (1951): 401-412.

Davidson, Richard M. "Back to the Beginning: Genesis 1-3 and the Theological Center of Scripture." In Christ, Salvation, and the Eschaton: Essays in Honor of Hans $K$. LaRondelle, edited by Jiri Moskala, 5-29. Berrien Springs, MI: Seventh-day Adventist Theological Seminary, 2009.

. "The Chiastic Literary Structure of the Book of Ezekiel." In To Understand the Scriptures: Essays in Honor of William H. Shea, edited by David Merling, 7193. Berrien Springs, MI: Siegfried H. Horn Archaeological Museum, 1997.

. "Christ's Entry 'within the Veil' in Hebrews 6:19-20: The Old Testament Background.” Andrews University Seminary Studies 39, no. 2 (2001): 175-190.

. "Earth's First Sanctuary: Genesis 1-3 and Parallel Creation Accounts." Andrews University Seminary Studies 53, no. 1 (2015): 65-89.

. "Ezekiel 28:11-19 and the Rise of the Cosmic Conflict." In The Great Controversy and the End of Evil: Biblical and Theological Studies in Honor of Ángel Manuel Rodriguez in Celebration of His Seventieth Birthday, edited by Gerhard Pfandl, 57-69 Silver Spring, MD; Nampa, ID: Review and Herald, Biblical Research Institute; Pacific Press, 2015. 
. "Inauguration or Day of Atonement?: A Response to Norman Young's 'Old Testament Background to Hebrews 6:19-20 Revisited'.' Andrews University Seminary Studies 40, no. 1 (2002): 69-88.

."Proverbs 8 and the Place of Christ in the Trinity." Journal of the Adventist Theological Society 17, no. 1 (2006): 33-54.

. Song for the Sanctuary: A Graduate Textbook on the Biblical Doctrine of the Sanctuary. Berrien Springs, MI: Andrews University Press, Forthcoming.

. "Typological Structures in the Old and New Testaments." Th.D. Dissertation, Andrews University, 1981.

. "Typology in the Book of Hebrews." In Issues in the Book of Hebrews, edited by Frank B. Holbrook, 121-186. Silver Spring, MD: Biblical Research Institute, 1989.

Davies, Brian. "Prayer." In The Oxford Handbook of Aquinas, edited by Brian Davies and Eleonore Stump, 467-474. Oxford; New York: Oxford University Press, 2011.

. The Thought of Thomas Aquinas. New York: Oxford University Press, 1993.

Davies, John H. "The Heavenly Work of Christ in Hebrews." In Studia Evangelica IV, edited by F. L. Cross, 384-389. Berlin: Akademie-Verlag, 1968.

. A Letter to Hebrews. Cambridge Bible Commentary: New English Bible. London: Cambridge University Press, 1967.

Dawson, R. Dale. The Resurrection in Karl Barth. Aldershot, England; Burlington, VT: Ashgate, 2007.

Dekker, Eef. Middle Knowledge. Studies in Philosophical Theology. Leuven, Belgium: Peeters, 2000.

Demarest, Bruce A. A History of Interpretation of Hebrews VII. 1-10 from the Reformation to the Present. Tübingen: Mohr Siebeck, 1976.

. The Cross and Salvation: The Doctrine of Salvation. Foundations of Evangelical Theology. Wheaton, IL: Crossway, 2006.

DeSilva, David A. Perseverance in Gratitude: A Socio-Rhetorical Commentary on the Epistle "to the Hebrews." Grand Rapids, MI: Eerdmans, 2000. 
de Souza, Elias Brasil. "The Heavenly Sanctuary/Temple Motif in the Hebrew Bible: Function and Relationship to the Earthly Counterparts." Ph.D. Dissertation, Andrews University, 2005.

DeVries, Dawn. Jesus Christ in the Preaching of Calvin and Schleiermacher. Columbia Series in Reformed Theology. Louisville, KY: Westminster John Knox Press, 1996.

DeWeese, Garrett J. God and the Nature of Time. Ashgate Philosophy of Religion Series. Aldershot, UK; Burlington, VT: Ashgate, 2004.

Dey, Lala K. K. The Intermediary World and Patterns of Perfection in Philo and Hebrews. Cambridge, MA: Society of Biblical Literature, 1975.

Dominice, M. L’humanité De Jésus d'après Calvin. Paris: Je Sers, 1933.

Domning, Daryl P., and Monika Hellwig. Original Selfishness: Original Sin and Evil in the Light of Evolution. Aldershot, England; Burlington, VT: Ashgate, 2006.

Doolan, Gregory T. Aquinas on the Divine Ideas as Exemplar Causes. Washington: Catholic University of America Press, 2008.

Doukhan, Jacques. Daniel: The Vision of the End. Berrien Springs, MI: Andrews University Press, 1987.

Dowey, Edward A. "Law in Luther and Calvin." Theology Today 41, no. 2 (1984): 146153.

Drury, John L., “The Priest Sacrificed in Our Place: Karl Barth's Use of the Cultic Imagery of Hebrews in Church Dogmatics IV/1, §59.2.” Paper presented at the 1st Annual Barth Conference, "Thy Word is Truth: Reading Scripture Theologically with Karl Barth.” Princeton Theological Seminary, May 21-24, 2006.http://www.drurywriting.com/john/The Priest Sacrificed in Our Place.pdf (accessed 30 December, 2016).

. The Resurrected God: Karl Barth's Trinitarian Theology of Easter. Minneapolis: Fortress, 2014.

Dunn, James D. G. The Theology of Paul the Apostle. Grand Rapids, MI: Eerdmans, 1998.

Dunnill, John. Covenant and Sacrifice in the Letter to the Hebrews. Society for New Testament Studies. Cambridge: Cambridge University Press, 1992.

Ebeling, Gerhard, and Scott A. Celsor. "Luther's Understanding of Reality." Lutheran Quarterly 27, no. 1 (2013): 56-75. 
Edmondson, Stephen. Calvin's Christology. Cambridge; New York: Cambridge University Press, 2004.

Edwards, Mark James. "The Divine Moment: Eternity, Time, and Triune Temporality in Karl Barth's Church Dogmatics.” Princeton: Princeton Theological Seminary, 2013.

Eisenbaum, Pamela Michelle. The Jewish Heroes of Christian History: Hebrews 11 in Literary Context. Atlanta, GA: Scholars Press, 1997.

Eitel, Adam. "The Resurrection of Jesus Christ: Karl Barth and the Historicization of God's Being." International Journal of Systematic Theology 10, no. 1 (2008): 3653.

Elert, Werner. The Structure of Lutheranism. Translated by Walter Hansen. Vol. 1. St. Louis: Concordia, 1962.

Ellington, William David. "Karl Barth's Doctrine of Sin in the Church Dogmatics, Vol. I/1-IV/3.” Ph.D. Dissertation, Boston University, 1965.

Ellingworth, Paul. The Epistle to the Hebrews: A Commentary on the Greek Text. New International Greek Testament Commentary. Grand Rapids, MI; Carlisle, England: Eerdmans; Paternoster, 1993.

. "Jesus and the Universe in Hebrews." Evangelical Quarterly 58, no. 4 (1986): 337-350.

Ellis, Brannon. Calvin, Classical Trinitarianism, and the Aseity of the Son. Oxford: Oxford University Press, 2012.

Emerson, Jan Swango, and Hugh Feiss, eds. Imagining Heaven in the Middle Ages: A Book of Essays. Garland Reference Library of the Humanities. New York: Garland, 2000.

Enns, Peter. The Evolution of Adam: What the Bible Does and Doesn't Say About Human Origins. Grand Rapids, MI: Brazos Press, 2012.

Erickson, Millard J. Truth or Consequences: The Promise and Perils of Postmodernism. Downers Grove, IL: InterVarsity, 2001.

Evans, Efion E. "The Puritan Concept of Divine Intercession.” In Puritan Papers, Volume Two: 1960-1962, edited by J.I. Packer, 187-205. Phillipsburg, NJ; Kingsburg, CA: Presbyterian and Reformed; The den Dulk Christian Foundation, 2001. 
Exegetical Dictionary of the New Testament. 3 vols. Edited by Horst Robert Balz and Gerhard Schneider. Grand Rapids, MI: Eerdmans, 1990-1993.

Faricy, Robert L. All Things in Christ: Teilhard De Chardin's Spirituality. London: Collins, 1981.

Farrow, Douglas. "Ascension and Atonement." In The Theology of Reconciliation, edited by Colin E. Gunton, 67-92. London; New York: T\&T Clark, 2003.

. Ascension and Ecclesia: On the Significance of the Doctrine of the Ascension for Ecclesiology and Christian Cosmology. Edinburgh: T\&T Clark, 1999.

. "Karl Barth on the Ascension: An Appreciation and Critique." International Journal of Systematic Theology 2, no. 2 (2000): 127-150.

Feld, Helmut. Der Hebräerbrief. Darmstadt: Wissenschaftliche Buchgesellschaft, 1985.

Fergusson, David. "The Ascension of Christ: Its Significance in the Theology of T. F. Torrance." Participatio 3 (2012): 92-107.

Flint, Thomas P. Divine Providence: The Molinist Account. Cornell Studies in the Philosophy of Religion. Ithaca, NY: Cornell University Press, 2006.

Floor, Lambertus. "The General Priesthood of Believers in the Epistle to the Hebrews." In Ad Hebraeos: Essays on the Epistle to the Hebrews, 72-82. Pretoria: Die Nuwe-Testamentiese Werkgemeenskap van Suid-Afrika, 1971.

Ford, David. Barth and God's Story: Biblical Narrative and the Theological Method of Karl Barth in the Church Dogmatics. Frankfurt am Main: Peter Lang, 1981.

Freedman, David N. Pottery, Poetry, and Prophecy: Studies in Early Hebrew Poetry. Winona Lake, IN: Eisenbrauns, 1980.

. "Temple without Hands." In Temples and High Places in Biblical Times, 2130. Jerusalem: The Nelson Glueck School of BIblical Archaeology of Hebrew Union College, 1977.

Gadamer, Hans-Georg. Truth and Method. Translated by Joel Weinsheimer and Donald G. Marshall. London; New York: Continuum, 2004.

Gane, Roy. Cult and Character: Purification Offerings, Day of Atonement, and Theodicy. Winona Lake, IN: Eisenbrauns, 2005. . Leviticus, Numbers. The NIV Application Commentary. Grand Rapids, MI: Zondervan, 2004. 
. "Re-Opening Katapetasma ('Veil') in Hebrews 6:19." Andrews University Seminary Studies 38, no. 1 (2000): 5-8.

Ganssle, Gregory E., ed. God and Time: Four Views. Cumbria, UK: Paternoster, 2001.

Ganssle, Gregory E., and David M. Woodruff, eds. God and Time: Essays on the Divine Nature. Oxford; New York: Oxford University Press, 2002.

Garland, David E. 1 Corinthians. Baker Exegetical Commentary on the New Testament. Grand Rapids, MI: Baker Academic, 2003.

Gassmann, Günthern, and Scott H. Hendrix. Fortress Introduction to the Lutheran Confessions. Minneapolis: Fortress, 1999.

Gennrich, Paul Wilhelm. Die Christologie Luthers Im Abendmahlsstreit. Königsberg: Vandenhoeck \& Rupprecht, 1929.

Gerrish, Brian A. Grace and Gratitude: The Eucharistic Theology of John Calvin. Minneapolis, MN: Fortress, 1993.

. "Priesthood and Ministry in the Theology of Luther." Church History 34, no. 4 (1965): 404-422.

. "To the Unknown God : Luther and Calvin on the Hiddenness of God." The Journal of Religion 53, no. 3 (1973): 263-292.

Gibson, David. Reading the Decree: Exegesis, Election and Christology in Calvin and Barth. London; New York: T\&T Clark, 2009.

Gondreau, Paul. "The Humanity of Christ, the Incarnate Word." In The Theology of Thomas Aquinas, edited by Rik Van Nieuwenhove and Joseph Wawrykow, 252276. Notre Dame, IN: University of Notre Dame Press, 2005.

. The Passions of Christ's Soul in the Theology of St. Thomas Aquinas. Scranton, PA: University of Scranton Press, 2009.

Goris, Harm. "Divine Foreknowledge, Providence, Predestination, and Human Freedom." In The Theology of Thomas Aquinas, edited by Rik Van Nieuwenhove and Joseph Wawrykow, 99-122. Notre Dame, IN: University of Notre Dame Press, 2005.

Gorman, Michael. "Incarnation.” In The Oxford Handbook of Aquinas, edited by Brian Davies and Eleonore Stump, 428-435. Oxford; New York: Oxford University Press, 2011. 
Gorman, Frank H., Jr. The Ideology of Ritual: Space, Time, and Status in the Priestly Theology. Vol. 91. Journal for the Study of the Old Testament Supplement Series. Sheffield, England: Sheffield Academic Press, 1990.

Gräbe, Peter. "The New Covenant and Christian Identity in Hebrews.” In Cosmology and New Testament Theology, edited by Richard Bauckham, Daniel Driver, Trevor Hart, and Nathan MacDonald, 118-127. London: T\&T Clark, 2008.

Grässer, Erich. "Der Hebräerbrief 1938-1963.” Theologische Rundschau 30, no. 2-3 (1964): 138-236.

Gray, Patrick. "Hebrews among Greek and Romans." In Reading the Epistle to the Hebrews: A Resource for Students, edited by Eric F. Mason and Kevin B. McCruden, 13-30. Atlanta: Society of Biblical Literature, 2011.

Grayston, Kenneth. "The Meaning of Parakletos." Journal for the Study of the New Testament 13 (1981): 67-82.

Grebe, Matthias. Election, Atonement, and the Holy Spirit: Through and Beyond Barth's Theological Interpretation of Scripture. Princeton Theological Monograph Series. Eugene, OR: Wipf and Stock, 2014.

Greek-English Lexicon of the New Testament: Based on Semantic Domains. 2nd ed. Edited by J. P. Louw and E. A. Nida. New York: United Bible Societies, 1989.

A Greek-English Lexicon of the Septuagint. Rev. ed. Edited by Johan Lust, Erik Eynikel and Katrin Hauspie. Stuttgart: Deutsche Bibelgesellschaft, 2003.

Green, Joel B. Body, Soul, and Human Life: The Nature of Humanity in the Bible. Studies in Theological Interpretation. Grand Rapids, MI: Baker Academic, 2008.

Greer, Rowan A. The Captain of Our Salvation: A Study in the Patristic Exegesis of Hebrews. Tübingen: Mohr, 1973.

Greggs, Tom. “'Jesus Is Victor': Passing the Impasse of Barth on Universalism.” Scottish Journal of Theology 60, no. 2 (2007): 196-212.

Grenz, Stanley J. The Named God and the Question of Being: A Trinitarian TheoOntology. Louisville: Westminster John Knox Press, 2005.

Griffin, David R. "Introduction to Suny Series in Constructive Postmodern Thought." In Founders of Constructive Postmodern Philosophy: Peirce, James, Bergson, Whitehead, and Hartshorne, edited by David Ray Griffin, vii-X. Albany, NY: State University of New York Press, 1993. 
. "Reconstructive Theology." In The Cambridge Companion to Postmodern Theology, edited by Kevin J. Vanhoozer, 92-108. Cambridge; New York: Cambridge University Press, 2003.

Griffith, Howard. "High Priest in Heaven: The Intercession of the Exalted Christ in Reformed Theology; Analysis and Critique." Ph.D. dissertation, Westminster Theological Seminary, 2004.

Gritsch, Eric W., and Robert W. Jenson. Lutheranism: The Theological Movement and Its Confessional Writings. Philadelphia: Fortress, 1976.

Grudem, Wayne. Systematic Theology: An Introduction to Biblical Doctrine. Leicester, England; Grand Rapids, MI: InterVarsity; Zondervan, 1994.

Gulley, Norman R. Systematic Theology: God as Trinity. Berrien Springs, MI: Andrews University Press, 2011.

Gunton, Colin E. Becoming and Being: The Doctrine of God in Charles Hartshorne and Karl Barth. Oxford; New York: Oxford University Press, 1978.

. "Historical and Systematic Theology." In The Cambridge Companion to Christian Doctrine, edited by Colin E. Gunton, 3-20. Cambridge: Cambridge University Press, 2004.

. "Salvation." In The Cambridge Companion to Karl Barth, edited by John B. Webster, 143-158. Cambridge, UK; New York: Cambridge University Press, 2000.

Guthrie, George H. Hebrews. The NIV Application Commentary. Grand Rapids, MI: Zondervan, 1998. . The Structure of Hebrews: A Text-Linguistic Analysis. Leiden; New York: Brill, 1994.

. "The Structure of Hebrews Revisited" Paper presented at the Annual Meeting of the Society of Biblical Literature. Washington, DC, 2006. https://hebrews.unibas.ch/documents/2006GuthrieH.pdf (accessed 28 December, 2016).

Gutwenger, Engelbert. "Transubstantiation." Encyclopedia of Theology: The Concise Sacramentum Mundi. Edited by Karl Rahner. New York: Crossroad, 1982. 17511755.

Gyllenberg, Rafael. "Die Christologie Des Hebräerbriefes." Zeitschrift für systematische Theologie 11 (1934): 662-690. 
Haanes, Vidar L. "Christological Themes in Luther's Theology." Studia Theologica 61, no. 1 (2007): 21-46.

Habets, Myk. "The Doctrine of Election in Evangelical Calvinism: T. F. Torrance as a Case Study." Irish Theological Quarterly 73, nos. 3-4 (2008): 334-354.

. Theosis in the Theology of Thomas Torrance. Farnham, UK; Burlington, VT: Ashgate, 2009.

Haga, Joar. Was There a Lutheran Metaphysics? The Interpretation of Communicatio Idiomatum in Early Modern Lutheranism. Refo500 Academic Studies. Göttingen: Vandenhoeck \& Ruprecht, 2012.

Hagner, Donald A. "The Son of God as Unique High Priest: The Christology of the Epistle to the Hebrews." In Contours of Christology in the New Testament, edited by Richard N. Longenecker, 247-267. Grand Rapids, MI: Eerdmans, 2005.

Hahn, Scott W. "A Broken Covenant and the Curse of Death: A Study of Hebrews 9:1522." The Catholic Biblical Quarterly 66, no. 3 (2004): 416-436.

. "Covenant, Cult, and the Curse-of-Death: $\Delta 1 \alpha \theta \dot{K} \mathrm{K \eta}$ in Heb 9:15-22." In Hebrews: Contemporary Methods, New Insights, edited by Gabriella Gelardini, 75-88. Leiden; Boston: Brill, 2005.

Hall, Douglas John. Professing the Faith: Christian Theology in a North American Context. Minneapolis: Fortress, 1996.

Hanson, Paul D. "A New Challenge to Biblical Theology." Journal of the American Academy of Religion 67, no. 2 (1999): 447-460.

Hasker, William. God, Time, and Knowledge. Cornell Studies in the Philosophy of Religion. Ithaca, NY; London: Cornell University Press, 1998.

Hay, Andrew R. "The Heart of Wrath: Calvin, Barth, and Reformed Theories of Atonement." Neue Zeitschrift für systematische Theologie und Religionsphilosophie 55, no. 3 (2013): 361-378.

Hay, David. Glory and the Right Hand: Psalm 110 in Early Christianity. Nashville, TN: Abingdon Press, 1973.

Hays, Richard B. “'Here We Have No Lasting City': New Covenantalism in Hebrews.” In The Epistle to the Hebrews and Christian Theology, edited by Richard Bauckham, Daniel R. Driver, Trevor A. Hart, and Nathan MacDonald, 151-173. Grand Rapids, MI: Eerdmans, 2009. 
Hector, Kevin W. "God's Triunity and Self-Determination: A Conversation with Karl Barth, Bruce McCormack and Paul Molnar." International Journal of Systematic Theology 7, no. 3 (2005): 246-261.

Heidegger, Martin. "The onto-Theo-Logical Constitution of Metaphysics." In Identity and Difference, 42-74. Chicago: University of Chicago Press, 2002.

Helm, Paul. Calvin and the Calvinists. Edinburgh: Banner of Truth Trust, 1982. . "Calvin, English Calvinism and the Logic of Doctrinal Development." Scottish Journal of Theology 34, no. 2 (1981): 179-186.

. "Divine Timeless Eternity." In God and Time: Four Views, edited by Gregory E. Ganssle, 28-60. Cumbria, UK: Paternoster, 2001.

. Eternal God: A Study of God without Time. Oxford; New York: Oxford University Press, 2010.

Helmer, Christine. "God from Eternity to Eternity: Luther's Trinitarian Understanding." Harvard Theological Review 96, no. 2 (2003): 127-146.

Highfield, Ron. Barth and Rahner in Dialogue: Toward an Ecumenical Understanding of Sin and Evil. American University Studies Series VII. New York: Peter Lang, 1989.

Hill, William J. Search for the Absent God: Tradition and Modernity in Religious Understanding. New York: Crossroad, 1992.

Himmelfarb, Martha. A Kingdom of Priests: Ancestry and Merit in Ancient Judaism. Jewish Culture and Contexts. Philadelphia: University of Pennsylvania Press, 2006.

Holmes, Christopher R. J. "The Person and Work of Christ Revisited: In Conversation with Karl Barth.” Anglican Theological Review 95, no. 1 (2013): 37-55.

. Revisiting the Doctrine of the Divine Attributes: In Dialogue with Karl Barth, Eberhard Jüngel and Wolf Krötke. New York: Peter Lang, 2007.

Holz, Dominic. "Sacraments." In The Oxford Handbook of Aquinas, edited by Brian Davies and Eleonore Stump, 448-457. Oxford; New York: Oxford University Press, 2011.

Horton, Michael S. "Covenant, Election, and Incarnation: Evaluating Barth's Actualist Christology." In Karl Barth and American Evangelicalism, 112-147. Grand Rapids, MI; Cambridge, UK: Eerdmans, 2011. 
Huijgen, Arnold. "Divine Accommodation and Divine Transcendence in Calvin's Theology." In Calvinus Sacrarum Literarum Interpres: Papers of the International Congress on Calvin Research, edited by Herman J. Selderhuis, 119130. Göttingen: Vandenhoeck \& Ruprecht, 2008.

Hunsinger, George. Conversational Theology: Essays on Ecumenical, Postliberal, and Political Themes, with Special Reference to Karl Barth. New York: T\&T Clark, 2015.

. "The Dimension of Depth: Thomas F. Torrance on the Sacraments of Baptism and the Lord's Supper." Scottish Journal of Theology 54, no. 2 (2001): 155-176.

. Disruptive Grace: Studies in the Theology of Karl Barth. Grand Rapids, MI: Eerdmans, 2000.

. The Eucharist and Ecumenism: Let Us Keep the Feast. New York: Cambridge University Press, 2008.

. Evangelical, Catholic, and Reformed: Doctrinal Essays on Barth and Related Themes. Grand Rapids, MI: Eerdmans, 2015.

. "Jesus as the Lord of Time According to Karl Barth." Zeitschrift für Dialektische Theologie 4 (2010): 113-127.

. "Karl Barth's Christology: Its Basic Chalcedonian Character.” In The Cambridge Companion to Karl Barth, edited by John Webster, 127-142. Cambridge: Cambridge University Press, 2000.

. Reading Barth with Charity: A Hermeneutical Proposal. Grand Rapids, MI: Baker Academic, 2015.

Hunter, A. M. The Teaching of Calvin: A Modern Interpretation. 2nd ed. London: James Clarke, 1950.

Hurst, Lincoln D. The Epistle to the Hebrews: Its Background of Thought. Society for New Testament Studies Monograph Series. Cambridge; New York: Cambridge University Press, 2005.

Ickert, Scott S. "Luther on the Timelessness of God." Lutheran Quarterly 7, no. 1 (1993): 45-66.

Ingraffia, Brian D. Postmodern Theory and Biblical Theology: Vanquishing God's Shadow. Cambridge; New York: Cambridge University Press, 1995.

Isaacs, Marie E. Sacred Space: An Approach to the Theology of the Epistle to the Hebrews. Sheffield: Sheffield Academic Press, 1992. 
Jacobs, Paul. Prädestination Und Verantwortlichkeit Bei Calvin. Darmstadt: Wissenschaftliche Buchgesellschaft, 1968.

James, E. O. The Nature and Function of Priesthood: A Comparative and Anthropological Study. London: Thames and Hudson, 1955.

Jansen, John Frederick. Calvin's Doctrine of the Work of Christ. James Clarke \& Co.: London, 1956.

Janz, Denis. Luther and Late Medieval Thomism: A Study in Theological Anthropology. Waterloo, ON, Canada: Wilfrid Laurier University Press, 1983.

Jeffcoat, James R., Jr. "Martin Luther's Doctrine of Ministry.” Ph.D. dissertation, Drew University, 1989.

Jenson, Matt. Gravity of Sin: Augustine, Luther, and Barth on Homo Incurvatus in Se. London; New York: T\&T Clark, 2006.

Jenson, Philip Peter. Graded Holiness: A Key to the Priestly Conception of the World. Vol. 106. Journal for the Study of the Old Testament Supplement Series. Sheffield, England: Sheffield Academic Press, 1992.

Jenson, Robert W. God after God: The God of the Past and the God of the Future, Seen in the Work of Karl Barth. Indianapolis: Bobbs-Merrill, 1969.

The Jewish Study Bible. 2nd ed. Jewish Publication Society. New York: Oxford University Press, 2014.

Joest, Wilfried. Ontologie Der Person Bei Luther. Göttingen, Germany: Vandenhoeck \& Ruprecht, 1967.

Johnson, Adam J. "A Fuller Account: The Role of 'Fittingness' in Thomas Aquinas' Development of the Doctrine of the Atonement." International Journal of Systematic Theology 12, no. 3 (2010): 302-318.

Johnson, Dale Arthur. "Luther's Understanding of God." Lutheran Quarterly 16, no. 1 (1964): 59-69.

Johnson, Luke Timothy. Hebrews: A Commentary. The New Testament Library. Louisville, KY: Westminster John Knox Press, 2006. . "The Scriptural World of Hebrews." Interpretation 57, no. 3 (2003): 237-250.

Johnsson, William G. "Day of Atonement Allusions." In Issues in the Book of Hebrews, edited by Frank B. Holbrook, 105-120. Silver Spring, MD: Biblical Research Institute, 1989. 
. "Defilement and Purgation in the Book of Hebrews." Ph.D. Dissertation, Vanderbilt University, 1973.

. "The Heavenly Sanctuary: Figurative or Real?" In Issues in the Book of Hebrews, edited by Frank B. Holbrook, 35-51. Silver Spring, MD: Biblical Research Institute, 1989.

. "Hebrews: An Overview." In Issues in the Book of Hebrews, edited by Frank B. Holbrook, 13-34. Silver Spring, MD: Biblical Research Institute, 1989.

Jones, Michael Keenan. Toward a Christology of Christ the High Priest. Rome: Gregorian University Press, 2006.

Jones, Paul Dafydd. The Humanity of Christ: Christology in Karl Barth's Church Dogmatics. London; New York: T\&T Clark, 2008.

Jorgenson, Allen. "Karl Barth's Christological Treatment of Sin." Scottish Journal of Theology 54, no. 4 (2001): 439-462.

Joslin, Barry C. "Can Hebrews Be Structured? An Assessment of Eight Approaches." Currents in Biblical Research 6, no. 1 (2007): 99-129.

Jüngel, Eberhard. God's Being Is in Becoming: The Trinitarian Being of God in the Theology of Karl Barth. London: Bloomsbury, 2014.

Kaiser, Christopher B. "Climbing Jacob's Ladder: John Calvin and the Early Church on Our Eucharistic Ascent to Heaven." Scottish Journal of Theology 56, no. 3 (2003): 247-267.

Kärkkäinen, Veli-Matti. "Deification View." In Justification: Five Views, edited by James K. Beilby and Paul R. Eddy, 219-264. Downers Grove, IL: InterVarsity, 2011.

. "Justification." In Global Dictionary of Theology: A Resource for the Worldwide Church, edited by Veli-Matti Kärkkäinen William A. Dyrness, Juan F. Martinez, Simon Chan, 447-452. Downers Grove, IL; Nottingham, UK: InterVarsity, 2008.

Käsemann, Ernst. The Wandering People of God: An Investigation of the Letter to the Hebrews. Translated by Roy A. Harrisville and Irving L. Sandberg. Minneapolis: Augsburg, 1984.

Kasper, Walter. Jesus the Christ. New ed. London; New York: T\&T Clark, 2011.

Kendall, R. T. Calvin and English Calvinism to 1649. Oxford Theological Monographs. Oxford: Oxford University Press, 1979. 
Kibbe, Michael. "Is It Finished? When Did It Start? Hebrews, Priesthood, and Atonement in Biblical, Systematic, and Historical Perspective." The Journal of Theological Studies 65, no. 1 (2014): 25-61.

Kilmartin, Edward. "Theology of the Sacraments: Toward a New Understanding of the Chief Rites of the Church of Jesus Christ." In Alternative Futures for Worship: General Introduction, edited by Regis A. Duffy, 123-175. Collegeville, MN: Liturgical Press, 1987.

Kim, Eunsoo. Time, Eternity, and the Trinity: A Trinitarian Analogical Understanding of Time and Eternity. Eugene, OR: Wipf and Stock, 2010.

Koehler, Ludwig, Walter Baumgartner, and J. J. Stamm. The Hebrew and Aramaic Lexicon of the Old Testament. Translated by M. E. J. Richardson. 4 vols. Leiden: Brill, 1994-2000.

Koester, Craig R. Hebrews: A New Translation with Introduction and Commentary. Anchor Bible 36. New Haven, CT: Yale University Press, 2001.

Kowalski, Dean Allan. "Conditionals of Freedom as Bivalent: A Defense of Middle Knowledge.” Ph.D. dissertation, The University of Wisconsin, 2000.

Krötke, Wolf. Sin and Nothingness in the Theology of Karl Barth. Translated by Philip G. Ziegler and Christina-Maria Bammel. Princeton: Princeton Theological Seminary, 2005.

Kruse, Colin G. The Letters of John. Pillar New Testament Commentary. Grand Rapids, MI; Nottingham, England: Eerdmans; Apollos, 2000.

Kubicki, Judith Marie. The Presence of Christ in the Gathered Assembly. New York: Continuum, 2006.

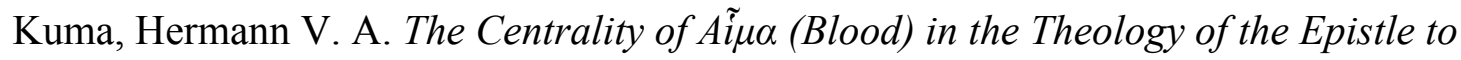
the Hebrews: An Exegetical and Philological Study. Lewiston, NY: Edwin Mellen Press, 2013.

Kurianal, James. Jesus Our High Priest: Ps 110,4 and the Substructure of Heb 5,1-7,28. Frankfort am Main: Peter Lang, 2000.

Kuss, O. Der Brief an Die Hebräer Und Die Katholischen Briefe. 2nd ed. Regensburg: Pustet, 1966.

Laansma, Jon C. “The Cosmology of Hebrews." In Cosmology and New Testament Theology, edited by Sean M. McDonough and Jonathan T. Pennington, 125-143. London: T\&T Clark, 2008. 
. "Hidden Stories in Hebrews: Cosmology and Theology." In Cosmology and New Testament Theology, edited by Richard Bauckham, Daniel Driver, Trevor Hart and Nathan MacDonald, 9-18. London: T\&T Clark, 2008.

Laansma, Jon C., and Daniel J. Treier, eds. Christology, Hermeneutics and Hebrews: Profiles from the History of Interpretation. London: Bloomsbury T\&T Clark, 2012.

Ladd, George Eldon. A Theology of the New Testament. Rev. ed. Grand Rapids, MI: Eerdmans, 1993.

Lane, William L. Hebrews 1-8. Word Biblical Commentary. Dallas: Thomas Nelson, 1991.

. Hebrews 9-13. Word Biblical Commentary. Dallas: Thomas Nelson, 1991.

Langdon, Adrian. God the Eternal Contemporary: Trinity, Eternity, and Time in Karl Barth. Eugene, OR: Wipf \& Stock, 2012.

Langdon, B. Gilkey. "Cosmology, Ontology, and the Travail of Biblical Language." The Journal of Religion 41, no. 3 (1961): 194-205.

Laub, Franz. Bekenntnis Und Auslegung: Die Paränetische Funktion Der Christologie Im Hebräerbrief. Regensburg: Pustet, 1980.

Law, David R. "Descent into Hell, Ascension, and Luther's Doctrine of Ubiquitarianism.” Theology 107, no. 838 (2004): 250-256.

Lee, Kye Won. Living in Union with Christ: The Practical Theology of Thomas F. Torrance. New York: Peter Lang, 2003.

Lee, Sang Hyun. “Jonathan Edwards's Dispositional Conception of the Trinity: A Resource for Contemporary Reformed Theology." In Toward the Future of Reformed Theology: Tasks, Topics, Traditions, edited by David Willis-Watkins, Michael Welker, and Matthias Gockel, 444-455. Grand Rapids, MI: Eerdmans, 1999.

Leftow, Brian. "God's Impassibility, Immutability, and Eternity.” In The Oxford Handbook of Aquinas, edited by Brian Davies and Eleonore Stump, 173-186. Oxford; New York: Oxford University Press, 2011.

. "God's Omnipotence." In The Oxford Handbook of Aquinas, edited by Brian Davies and Eleonore Stump, 187-195. Oxford; New York: Oxford University Press, 2011. 
. Time and Eternity. Cornell Studies in the Philosophy of Religion. Ithaca, NY: Cornell University Press, 1991.

. "A Timeless God Incarnate." In The Incarnation: An Interdisciplinary Symposium on the Incarnation of the Son of God, edited by Daniel Kendall, Stephen T. Davis and Gerald O'Collins, 273-299. Oxford: Oxford University Press, 2002.

Lehne, Susanne. The New Covenant in Hebrews. Library of New Testament Studies. Sheffield: Sheffield Academic Press, 1997.

Leuchter, Mark. Levites and Priests in History and Tradition. Ancient Israel and Its Literature. Atlanta: Society of Biblical Literature, 2011.

Levering, Matthew. "Aquinas on the Liturgy of the Eucharist." In Aquinas on Doctrine: A Critical Introduction, edited by Thomas G. Weinandy, Daniel A. Keating and John Yocum, 183-197. London; New York: T \& T Clark International, 2004.

. Christ and the Catholic Priesthood: Ecclesial Hierarchy and the Pattern of the Trinity. Mundelein, IL: Hillenbrand, 2010.

. "Christ the Priest: An Exploration of Summa Theologiae III, Question 22." The Thomist 71, no. 3 (2007): 379-417.

. Christ's Fulfillment of Torah and Temple: Salvation According to Thomas Aquinas. Notre Dame, IN: University of Notre Dame Press, 2002.

Lienhard, Marc. Luther, Witness to Jesus Christ: Stages and Themes of the Reformer's Christology. Minneapolis: Augsburg, 1982.

Loader, William R. G. Sohn Und Hoherpriester: Eine Traditionsgeschichtliche Untersuchung Zur Christologie Des Hebräerbriefes. Neukirchen-Vluyn: Neukirchener, 1981.

Löhr, Hermut. Umkehr Und Sünde Im Hebräerbrief. Beihefte Zur Zeitschrift Für Die Neutestamentliche Wissenschaft Und Die Kunde Der Älteren Kirche. Berlin: de Gruyter, 1994.

Lohse, Bernhard. Martin Luther: An Introduction to His Life and Work. Translated by Robert C. Schultz. Philadelphia: Fortress, 1986.

. Martin Luther's Theology: Its Historical and Systematic Development. Translated by Roy A. Harrisville. Minneapolis: Fortress, 2011.

Lonergan, Bernard J. F. Method in Theology. Toronto: University of Toronto Press, 1990. 
Luck, Ulrich. "Himmlisches Und Irdisches Geschehen Im Hebräerbrief: Ein Beitrag Zum Problem Des Historischen Jesus Im Urchristentum.” Novum Testamentum 6, no. 2-3 (1963): 192-215.

Luther, Martin. D. Martin Luthers Werke: Kritische Gesamtausgabe. 73 vols. Weimar: Herman Böhlaus Nachfolger, 1883-2009.

. Luther's Works. 55 vols. American ed., Edited by J. Pelikan, H. Lehmann and Hilton C. Oswald. Saint Louis, MO; Philadelphia: Concordia; Fortress, 19551986.

Luther, Martin, and Mitchell Tolpingrud. "Luther's Disputation Concerning the Divinity and Humanity of Christ." Lutheran Quarterly 10, no. 2 (1996): 151-178.

MacNeill, Harris L. The Christology of the Epistle to the Hebrews. Chicago: University of Chicago Press, 1914.

MacRae, G. W. "Heavenly Temple and Eschatology in the Letter to the Hebrews." Semeia 12 (1978): 179-199.

Mahoney, Edward P. "Metaphysical Foundations of the Hierarchy of Being According to Some Late-Medieval and Renaissance Philosophers." In Philosophies of Existence: Ancient and Medieval, edited by Parviz Morewedge, 165-257. New York: Fordham University Press, 1982.

Mannermaa, Tuomo. Christ Present in Faith: Luther's View of Justification. Minneapolis: Fortress, 2005.

. "Justification and Theosis in Lutheran-Orthodox Perspective." In Union with Christ: The New Finnish Interpretation of Luther, edited by Carl E. Braaten and Robert W. Jenson, 25-41. Grand Rapids, MI: Eerdmans, 1998.

Marion, Jean-Luc. God without Being: Hors-Texte. Translated by Thomas A. Carlson. Chicago: University of Chicago Press, 1995.

Marschler, Thomas. "Das Hohepriestertum Jesu Christi Nach Dem Hl. Thomas Von Aquin.” Doctor Angelicus 3 (2003): 143-163.

Mason, Eric F. "Cosmology, Messianism, and Melchizedek: Apocalyptic Jewish Traditions and Hebrews." In Reading the Epistle to the Hebrews: A Resource for Students, edited by Eric F. Mason and Kevin B. McCruden, 53-76. Atlanta: Society of Biblical Literature, 2011. . 'You Are a Priest Forever': Second Temple Jewish Messianism and the Priestly Christology of the Epistle to the Hebrews. Studies on the Texts of the Desert of Judah. Leiden; Boston: Brill, 2008. 
Mason, Eric F., and Kevin B. McCruden, eds. Reading the Epistle to the Hebrews: A Resource for Students. Atlanta: Society of Biblical Literature, 2011.

Mastroserio, D. "La Natura Del Sacerdocio Di Cristo Nel Pensiero Dei Tomisti." Sapienza 16 (1963): 337-372.

Mazaheri, J. H. "Calvin and Augustine's Interpretations of 'the Father in Heaven'." Revue d'histoire ecclésiastique 106, nos. 3-4 (2011): 440-451.

McCormack, Bruce L. "Christonomie.” In Barth Handbuch, edited by Michael Beintker, 226-231. Tübingen: Mohr Siebeck, 2016.

. "Divine Impassibility or Simply Divine Constancy? Implications of Karl Barth's Later Christology for Debates over Impassibility." In Divine Impassibility and the Mystery of Human Suffering, edited by James Keating and Thomas Joseph White, 150-186. Grand Rapids, MI: Eerdmans, 2009.

. For Us and Our Salvation: Incarnation and Atonement in the Reformed Tradition. Studies in Reformed Theology and History. Princeton: Princeton Theological Seminary, 1993.

. "Grace and Being: The Role of God's Gracious Election in Karl Barth's Theological Ontology." In The Cambridge Companion to Karl Barth, edited by John Webster, 92-110. Cambridge: Cambridge University Press, 2000.

. Karl Barth's Critically Realistic Dialectical Theology: Its Genesis and Development, 1909-1936. Oxford; New York: Clarendon Press; Oxford University Press, 1995.

. Orthodox and Modern: Studies in the Theology of Karl Barth. Grand Rapids, MI: Baker Academic, 2008.

. "The Person of Christ." In Mapping Modern Theology: A Thematic and Historical Introduction, edited by Kelly M. Kapic and Bruce L. McCormack, 169-171. Grand Rapids, MI: Baker Academic, 2012.

. "So That He May Be Merciful to All: Karl Barth and the Problem of Universalism." In Karl Barth and American Evangelicalism, 227-249. Grand Rapids, MI; Cambridge, UK: Eerdmans, 2011.

. "What's at Stake in Current Debates over Justification?: The Crisis of Protestantism in the West." In Justification: What's at Stake in the Current Debates, edited by Mark Husbands and Daniel J. Treier, 81-117. Downers Grove, IL; Leicester, England: InterVarsity Press; Apollos, 2004. 
. "With Loud Cries and Tears': The Humanity of the Son in the Epistle to the Hebrews." In The Epistle to the Hebrews and Christian Theology, edited by Richard Bauckham, Daniel R. Driver, Trevor A. Hart and Nathan MacDonald, 3768. Grand Rapids, MI: Eerdmans, 2009.

McCruden, Kevin B. Solidarity Perfected: Beneficent Christology in the Epistle to the Hebrews. Berlin: De Gruyter, 2008.

McDonnell, Kilian. John Calvin, the Church and the Eucharist. Princeton: Princeton University Press, 1967.

McGoldrick, James Edward. "Luther's Doctrine of Predestination.” Reformation \& Revival 8, no. 1 (1999): 81-103.

McGowan, A. T. B. "Justification and the Ordo Salutis." In Justification in Perspective: Historical Developments and Contemporary Challenges, edited by Bruce L. McCormack, 147-166. Grand Rapids, MI: Baker Academic, 2006.

McGrath, Alister E. The Genesis of Doctrine: A Study in the Foundations of Doctrinal Criticism. Oxford, UK; Cambridge, MA: Blackwell, 1990. . Iustitia Dei: A History of the Christian Doctrine of Justification. 3rd ed. Cambridge; New York: Cambridge University Press, 2005.

McKelvey, R. J. Pioneer and Priest: Jesus Christ in the Epistle to the Hebrews. Eugene, OR: Pickwick Publications, 2013.

McLean, Stuart D. Humanity in the Thought of Karl Barth. Edinburgh: T\&T Clark, 1981.

Meeter, Harm H. The Heavenly High Priesthood of Christ: An Exegetico-Dogmatic Study. Grand Rapids, MI: Eerdmans-Sevensma, 1916.

Metzger, Bruce M. A Textual Commentary on the Greek New Testament. 2nd ed. A Companion Volume to the United Bible Societies' Greek New Testament (4th Rev. ed.). London; New York: United Bible Societies, 1994.

Meyer, Boniface. “Calvin's Eucharistic Doctrine, 1536-39.” Journal of Ecumenical Studies 4, no. 1 (1967): 47-65.

Michel, O. Der Brief an Die Hebräer. 14th ed. Göttingen: Vandenhoeck \& Ruprecht, 1984.

Miller, Stephen R. Daniel. New American Commentary. Nashville, TN: Broadman \& Holman, 1994. 
Milne, Bruce A. "The Idea of Sin in Twentieth-Century Theology." Tyndale Bulletin 26 (1975): 3-33.

Moffitt, David M. Atonement and the Logic of Resurrection in the Epistle to the Hebrews. Supplements to Novum Testamentum. Leiden; Boston: Brill, 2011.

Molnar, Paul D. Incarnation and Resurrection: Toward a Contemporary Understanding. Grand Rapids, MI: Eerdmans, 2007.

. Thomas F. Torrance: Theologian of the Trinity. Farnham, England;

Burlington, VT: Ashgate, 2009.

Mooney, Christopher F. Teilhard De Chardin and the Mystery of Christ. London: Collins, 1966.

Morard, Martin. "Sacerdoce Du Christ Et Sacerdoce Des Chrétiens Dans Le Commentaire Des Psaumes De Saint Thomas d'Aquin." Revue Thomiste 107, no. 1 (1999): 119-142.

Morris, Leon. The Apostolic Preaching of the Cross. 3rd ed. Grand Rapids, MI: Eerdmans, 1965.

Mueller, John T. "Notes on Luther's Conception of the Word of God as the Means of Grace." Concordia Theological Monthly 20, no. 8 (1949): 580-600.

Müller, Ekkehardt. "Jesus and the Covenant in Hebrews." In 'For You Have Strengthened Me': Biblical and Theological Studies in Honor of Gerhard Pfandl in Celebration of His Sixty-Fifth Birthday, 189-208. St. Peter am Hart, Austria: Seminar Schloss Bogenhofen, 2007.

Muller, Richard A. Calvin and the Reformed Tradition: On the Work of Christ and the Order of Salvation. Grand Rapids, MI: Baker Academic, 2012. . Christ and the Decree: Christology and Predestination in Reformed Theology from Calvin to Perkins. Durham, NC: The Labyrinth Press, 1986.

Murphy, Nancey C. Bodies and Souls, or Spirited Bodies? Cambridge; New York: Cambridge University Press, 2006.

Murray, Scott R. "The Concept of $\Delta 1 \alpha \theta \dot{K} \mathrm{~K} \eta$ in the Letter to the Hebrews." Concordia Theological Quarterly 66, no. 1 (2002): 41-60.

Nagel, Norman E. "Luther and the Priesthood of All Believers." Concordia Theological Quarterly 61, no. 4 (1997): 277-298. 
Nairne, Alexander. The Epistle of Priesthood: Studies in the Epistle to the Hebrews. 2nd ed. Edinburgh: T\&T Clark, 1915.

Neder, Adam. "History in Harmony: Karl Barth on the Hypostatic Union." In Karl Barth and American Evangelicalism, 148-176. Grand Rapids, MI; Cambridge, UK: Eerdmans, 2011.

Nelson, Richard D. Raising up a Faithful Priest: Community and Priesthood in Biblical Theology. Louisville, KY: Westminster John Knox Press, 1993.

Ngien, Dennis. "Chalcedonian Christology and Beyond: Luther's Understanding of the Communicatio Idiomatum." The Heythrop Journal 45, no. 1 (2004): 54-68.

. The Suffering of God According to Martin Luther's 'Theologia Crucis'. New York: Peter Lang, 1995.

Niesel, Wilhelm. The Theology of Calvin. Translated by Harold Knight. Philadelphia: Westminster Press, 1956.

Nilsson, Kjell Ove. Simul: Das Miteinander Von Göttlichem Und Menschlichem in Luthers Theologie. Forschungen Zur Kirchen Und Dogmengeschichte 17. Göttingen: Vandenhoeck \& Ruprecht, 1966.

Nissilä, Keijo. Das Hohepriestermotiv Im Hebräerbrief: Eine Exegetische Untersuchung. Helsinki: Oy Liiton Kirjapaino, 1979.

Nomoto, S. "Herkunft Und Struktur Der Hohenpriestervorstellung Im Hebräerbrief." Novum Testamentum 10 (1968): 10-25.

Norman, R. Stanton. "Human Sinfulness." In A Theology for the Church, edited by Daniel L. Akin, 409-479. Nashville, TN: B\&H Publishing Group, 2007.

Oberman, Heiko Augustinus. "The 'Extra' Dimension in the Theology of Calvin." Journal of Ecclesiastical History 21, no. 1 (1970): 43-64.

O'Brien, Peter T. The Letter to the Hebrews. Pillar New Testament Commentary. Grand Rapids, MI; Nottingham, England: Eerdmans; Apollos, 2010.

O'Callaghan, Paul. Christ Our Hope: An Introduction to Eschatology. Washington, DC: Catholic University of America Press, 2011.

O'Collins, Gerald. Believing in the Resurrection: The Meaning and Promise of the Risen Jesus. New York: Paulist Press, 2012.

. Catholicism: A Very Short Introduction. Very Short Introductions. Oxford; New York: Oxford University Press, 2008. 
. “Christ's Resurrection and Ascension." America 160, no. 11 (1989): 262-263.

. Christology: A Biblical, Historical, and Systematic Study of Jesus. 2nd ed.

Oxford; New York: Oxford Univesity Press, 2009.

. Incarnation. New Century Theology. London: Continuum, 2002.

. Jesus Our Redeemer: A Christian Approach to Salvation. Oxford; New York: Oxford University Press, 2007.

. "Our Risen Selves: What Does Resurrection Mean for Us?" America, 9 April, 2012, 11-14.

. Rethinking Fundamental Theology: Toward a New Fundamental Theology.

Oxford; New York: Oxford University Press, 2011.

."Vatican II on the Liturgical Presence of Christ." Irish Theological Quarterly 77, no. 1 (2012): 3-17.

O'Collins, Gerald, and E. G. Farrugia. A Concise Dictionary of Theology. 3rd ed. New York; Mahwah, NJ: Paulist Press, 2013.

O'Collins, Gerald, and Michael Keenan Jones. Jesus Our Priest: A Christian Approach to the Priesthood of Christ. Oxford; New York: Oxford University Press, 2010.

O'Donnell, John J. Trinity and Temporality: The Christian Doctrine of God in the Light of Process Theology and the Theology of Hope. Oxford Theological Monographs. Oxford; New York: Oxford University Press, 1983.

Oropeza, B. J. "The Warning Passages in Hebrews: Revised Theologies and New Methods of Interpretation." Currents in Biblical Research 10, no. 1 (2011): 81100.

Osborne, Grant R. The Hermeneutical Spiral: A Comprehensive Introduction to Biblical Interpretation. Downers Grove, IL: InterVarsity, 1991.

Osborne, Kenan B. Christian Sacraments in a Postmodern World: A Theology for the Third Millennium. New York: Paulist Press, 1999. 1988.

. Sacramental Theology: A General Introduction. New York: Paulist Press,

Osler, Margaret J. Divine Will and the Mechanical Philosophy: Gassendi and Descartes on Contingency and Necessity in the Created World. Cambridge; New York: Cambridge University Press, 2004. 
Osterhaven, M. Eugene. "Calvin on Word and Sacrament, and Man." Reformed Journal 8, no. 5 (1958): 21-24.

Ott, Ludwig. Fundamentals of Catholic Dogma. Rockford, IL: Tan Books, 1974.

Padgett, Alan G. God, Eternity, and the Nature of Time. New York: St. Martin's Press, 1992.

Pannenberg, Wolfhart. An Introduction to Systematic Theology. Grand Rapids, MI: Eerdmans, 1991.

Park, Chan Ho. Transcendence and Spatiality of the Triune Creator. European University Studies Series XXIII, Theology. Bern; New York: Peter Lang, 2005.

Partee, Charles. "Predestination in Aquinas and Calvin." Reformed Review 32, no. 1 (1978): 14-22.

Partee, Charles. The Theology of John Calvin. Louisville; London: Westminster John Knox Press, 2008.

Parunak, Henry van Dyke. "Structural Studies in Ezekiel.” Ph.D. Dissertation, Harvard University, 1978.

Pasnau, Robert. Thomas Aquinas on Human Nature: A Philosophical Study of Summa Theologiae 1a, 75-89. Cambridge, UK; New York: Cambridge University Press, 2002.

Paulson, Steven D. “Luther on the Hidden God." Word \& World 19, no. 4 (1999): 363371.

Pelikan, Jaroslav. The Emergence of the Catholic Tradition (100-600). The Christian Tradition: A History of the Development of Doctrine. Chicago: University of Chicago Press, 1971.

Persaud, W.D. "Lutheran Theology." In Global Dictionary of Theology: A Resource for the Worldwide Church, edited by Veli-Matti Kärkkäinen William A. Dyrness, Juan F. Martinez, Simon Chan, 510-514. Downers Grove, IL; Nottingham, UK: InterVarsity, 2008.

Peterson, Brandon. "Paving the Way? Penalty and Atonement in Thomas Aquinas's Soteriology." International Journal of Systematic Theology 15, no. 3 (2013): 265 283.

Peterson, David. Hebrews and Perfection: An Examination of the Concept of Perfection in the "Epistle to the Hebrews." Society for New Testament Studies Monograph Series. Cambridge; New York: Cambridge University Press, 2005. 
Peterson, Robert A. Calvin's Doctrine of the Atonement. Phillipsburg, NJ: Presbyterian and Reformed Publishing, 1983.

. Salvation Accomplished by the Son: The Work of Christ. Wheaton, IL: Crossway, 2012.

. Salvation Applied by the Spirit: Union with Christ. Wheaton, IL: Crossway, 2015.

Peura, Simo. "Christ as Favor and Gift: The Challenge of Luther's Understanding of Justification." In Union with Christ: The New Finnish Interpretation of Luther, edited by Carl E. Braaten and Robert W. Jenson, 42-48. Grand Rapids, MI: Eerdmans, 1998.

Pickstock, Catherine. "Thomas Aquinas and the Quest for the Eucharist." Modern Theology 15, no. 2 (1999): 159-180.

Pierce, C. A. Conscience in the New Testament. London: SCM Press, 1955.

Pike, Nelson. God and Timelessness. Studies in Ethics and the Philosophy of Religion. London: Routledge and K. Paul, 1970.

Pinnock, Clark H. Most Moved Mover: A Theology of God's Openness. Didsbury Lectures. Carlisle, UK; Grand Rapids, MI: Paternoster Press; Baker Academic, 2001.

Pohle, Joseph. "The Real Presence of Christ in the Eucharist." The Catholic Encyclopedia. New York: Robert Aplleton, 1909.

http://www.newadvent.org/cathen/05573a.htm (accessed November 6, 2011).

Pohle, Joseph, and Arthur Preuss. The Sacraments: A Dogmatic Treatise. 4 vols. St. Louis, MO: B. Herder, 1917.

Pojman, Louis P., and Michael Rea. Philosophy of Religion: An Anthology. 7th ed. Stanford, CT: Cengage Learning, 2013.

Polkinghorne, John C. Theology in the Context of Science. New Haven: Yale University Press, 2009.

Popa, Klaus. "Method, Data and Hermeneutical Presuppositions: A Limited Analysis of the Relation between Method, Data and Hermeneutical Presuppositions in Rhetorical Criticism, Rhetorical Critical School, Narrative Criticism and Text Linguistics." MA thesis, Vrije Universiteit, Amsterdam, 2007. 
Power, David N. “Sacraments in General.” In Systematic Theology: Roman Catholic Perspectives, edited by Francis Schüssler Fiorenza and John P. Galvin, 461-496. Minneapolis: Fortress Press, 2011.

Pratz, Gunther. "The Relationship between Incarnation and Atonement in the Theology of Thomas F. Torrance." Journal for Christian Theological Research 3 (1998).

Preus, Herman A. "Luther on the Universal Priesthood and the Office of the Ministry." Concordia Journal 5, no. 2 (1979): 55-62.

Price, Daniel J. Karl Barth's Anthropology in Light of Modern Thought. Grand Rapids, MI: Eerdmans, 2002.

Pruett, Gordon E. “A Protestant Doctrine of the Eucharistic Presence.” Calvin Theological Journal 10, no. 2 (1975): 142-174.

Qu, Li. Concrete Time and Concrete Eternity: Karl Barth's Doctrine of Time and Eternity and Its Trinitarian Background. Carlisle, United Kingdom: Langham Monographs, 2014.

. "Newton, Einstein and Barth on Time and Eternity." Scottish Journal of Theology 67, no. 04 (2014): 436-449.

Rahner, Karl. Theology, Anthropology, Christology. Translated by David Bourke. Theological Investigations 13. New York: Seabury, 1975.

. The Theology of the Spiritual Life. Theological Investigations. Baltimore: Helicon Press, 1967.

Raitt, Jill. “Calvin's Use of Persona." In Calvinus Ecclesiae Genevensis Custos: International Congress for Calvin Research, 273-287. New York: Peter Lang, 1984.

. "St. Thomas Aquinas on Free Will and Predestination." Duke Divinity School Review 43, no. 3 (1978): 188-195.

Rascher, Angela. Schriftauslegung Und Christologie Im Hebräerbrief. Berlin: Walter de Gruyter, 2007.

Raunio, Antti. “The Human Being." In Engaging Luther: A (New) Theological Assessment, edited by Olli-Pekka Vainio, 27-58. Eugene, OR: Wipf and Stock, 2010 .

Redding, Graham. Prayer and the Priesthood of Christ in the Reformed Tradition. Edinburgh; New York: T\&T Clark, 2005. 
Remy, Gérard. "Sacerdoce Et Médiation Chez Saint Thomas." Revue Thomiste 99, no. 1 (1999): 101-118.

Rice, George E. "Apostasy as a Motif and Its Effect on the Structure of Hebrews." Andrews University Seminary Studies 23, no. 1 (1985): 29-35.

Riggenbach, E. Der Brief an Die Hebräer. Leipzig: Deichert, 1922.

Rissi, Mathias. Die Theologie Des Hebräerbriefs: Ihre Verankerung in Der Situation Des Verfassers Und Seiner Leser. Tübingen: Mohr Siebeck, 1987.

Roberts, Richard Henry. "Barth's Doctrine of Time: Its Nature and Implications." In Karl Barth: Studies of His Theological Method, edited by Stephen Sykes, 88-146. Oxford; New York: Clarendon Press; Oxford University Press, 1979.

Robertson, A. T. A Grammar of the Greek New Testament in the Light of Historical Research. Bellingham, WA: Logos Bible Software, 2006.

Robertson, Jon M. Christ as Mediator: A Study of the Theologies of Eusebius of Caesarea, Marcellus of Ancrya, and Athanasius of Alexandria. Oxford; New York: Oxford University Press, 2007.

Rodríguez, Angel M. “Transfer of Sin in Leviticus.” In The Seventy Weeks, Leviticus, and the Nature of Prophecy, edited by Frank B. Holbrook, 169-197. Silver Spring, MD: Biblical Research Institute, 1986.

Rogers, Mark. "A Dangerous Idea? Martin Luther, E. Y. Mullins, and the Priesthood of All Believers.” Westminster Theological Journal 72, no. 1 (2010): 119-134.

Rooke, Deborah W. Zadok's Heirs: The Role and Development of the High Priesthood in Ancient Israel. Oxford Theological Monographs. Oxford: Oxford University Press, 2012.

Russell, Robert John, and Kirk Wegter-McNelly. "Science.” In The Blackwell Companion to Modern Theology, edited by Gareth Jones, 512-556. Malden, MA; Oxord, UK: Blackwell, 2004.

Sabourin, Leopold. Priesthood: A Comparative Study. Leinden: Brill, 1973.

Saia, Michael R. Does God Know the Future? A Biblical Investigation of Foreknowledge and Free Will. Fairfax, VA: Xulon Press, 2002.

Salom, A. P. "Ta Hagia in the Epistle to the Hebrews.” AUSS 5, no. 1 (1967): 59-70.

Sarna, Nahum M. Exodus: The Traditional Hebrew Text with the New JPS Translation. The JPS Torah Commentary. Philadelphia: The Jewish Publication Society, 1991. 
Scheller, Emil Justus. Das Priestertum Christi Im Anschluss an Den Hl. Thomas Von Aquin: Vom Mysterium Des Mittlers in Seinem Opfer Und Unsere Anteilnahme. Paderborn: Schöningh, 1934.

Schenck, Kenneth L. "The Celebration of the Enthroned Son: The Catena of Hebrews 1:5-14." Journal of Biblical Literature 120 (2006): 469-485.

. Cosmology and Eschatology in Hebrews: The Setting of the Sacrifice. Society for New Testament Studies, Edited by John M. Court. Cambridge: Cambridge University Press, 2007.

. "God Has Spoken: Hebrews' Theology of the Scriptures." In The Epistle to the Hebrews and Christian Theology, edited by Richard Bauckham, Daniel R. Driver, Trevor A. Hart and Nathan MacDonald, 321-336. Grand Rapids, MI: Eerdmans, 2009.

. "Philo and the Epistle to the Hebrews: Ronald Williamson's Study after Thirdy Years." In The Studia Philonica Annual: Studies in Hellenistic Judaism, edited by D. T. Runia and G. E. Stirling, 112-135. Atlanta: Scholars, 2002.

Schnackenburg, Rudolf. The Johannine Epistles: A Commentary. Translated by Reginald and Ilse Fuller. New York: Crossroad, 1992.

Schnelle, Udo. Theology of the New Testament. Translated by M. Eugene Boring. Grand Rapids, MI: Baker Academic, 2009.

Scholer, John M. Proleptic Priests: Priesthood in the Epistle to the Hebrews. Vol. 49. Journal for the Study of the New Testament Supplement Series. Sheffield: Sheffield Academic Press, 1991.

Schwarz, Hans. "Luther's Understanding of Heaven and Hell." In Interpreting Luther's Legacy: Essays in Honor of Edward C Fendt, edited by Fred W. Meuser and Stanley D. Schneider, 83-94. Minneapolis: Augsburg, 1969.

Schwobel, Christoph. "Recovering Human Dignity." In God and Human Dignity, edited by R. Kendall Soulen and Linda Woodhead. Grand Rapids, MI: Eerdmans, 2006.

Senor, Thomas D. "Incarnation and Timelessness." Faith and Philosophy 7, no. 2 (1990): 149-164.

. "Incarnation, Timelessness, and Leibniz's Law Problems." In God and Time: Essays on the Divine Nature, edited by Gregory E. Ganssle and David M. Woodruff, 220-235. Oxford; New York: Oxford University Press, 2002.

She, King L. The Use of Exodus in Hebrews. New York: Peter Lang, 2011. 
Shepherd, Michael B. "Daniel 7:13 and the New Testament Son of Man.” Westminster Theological Journal 68, no. 1 (2006): 99-111.

Short, Howard Prather. “On Middle Knowledge." Ph.D. dissertation, The University of Oklahoma, 2007.

Siggins, Ian D. Kingston. Martin Luther's Doctrine of Christ. Yale Publications in Religion. Eugene, OR: Wipf and Stock, 2003.

Silva, Moises. "Perfection and Eschatology in Hebrews." Westminster Theological Journal 39, no. 1 (1976): 60-71.

Simon, Wolfgang. "Worship and the Eucharist in Luther Studies." Dialog: A Journal of Theology 47, no. 2 (2008): 143-156.

Small, Brian C. The Characterization of Jesus in the Book of Hebrews. Biblical Interpretation Series. Leiden; Boston: Brill, 2014.

Smalley, Stephen S. 1, 2, 3 John. Word Biblical Commentary. Dallas: Thomas Nelson, 1984.

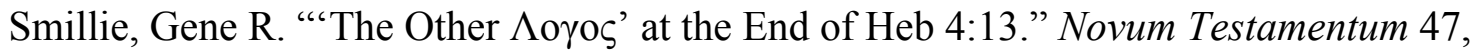
no. 1 (2005): 19-25.

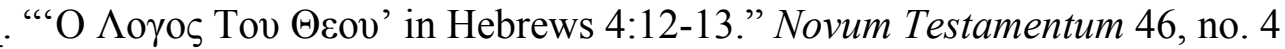
(2004): 338-359.

Smith, Aaron T. A Theology of the Third Article: Karl Barth and the Spirit of the Word. Minneapolis: Fortress, 2014.

Smith, Jerome. A Priest Forever: A Study of Typology and Eschatology in Hebrews. London; Sydney: Sheed \& Ward, 1969.

Socinus, F. De Jesu Christi Filii Dei Natura Sive Essentia Adversus Volarum. Amsterdam: Bibliotheca Fratrum Putanorum, 1656.

Sonderegger, Katherine. "Sanctification as Impartation in the Doctrine of Karl Barth." Zeitschrift für Dialektische Theologie 18, no. 3 (2002): 308-315.

Southgate, Christopher. The Groaning of Creation: God, Evolution, and the Problem of Evil. Louisville: Westminster John Knox, 2008.

Spicq, Ceslas. L'Épitre Aux Hébreux. 2 vols. Paris: Libraire Lecoffre, 1952-1953. 
Stadelmann, Andreas. "Zur Christologie Des Hebräerbriefes in Der Neueren Diskussion." In Theologische Berichte 2: Zur Neueren Christologischen Diskussion, 135-221. Zürich: Benziger Verlag, 1973.

Stanglin, Keith D. Arminius on the Assurance of Salvation: The Context, Roots, and Shape of the Leiden Debate, 1603-1609. Brill's Series in Church History. Leiden; Boston: Brill, 2007.

Steiger, Johann Anselm, and Carolyn Schneider. "The Communicatio Idiomatum as the Axle and Motor of Luther's Theology." Lutheran Quarterly 14, no. 2 (2000): $125-158$.

Steinbronn, Anthony J. "Luther's Use of Larvae Dei." Concordia Journal 19, no. 2 (1993): 135-147.

Steinmetz, David C. "Scripture and the Lord's Supper in Luther's Theology." Interpretation 37, no. 3 (1983): 253-265.

Stelzenberger, J. Syneidesis Im Neuen Testament. Paderbron: Schoningh, 1961.

Sterling, Geoffrey E. "Ontology Versus Eschatology: Tensions between Author and Community in Hebrews." The Studia Philonica Annual 13 (2001): 190-211.

Stoevesandt, Hinrich, and Jurgen Fangmeier, eds. Karl Barth: Letters, 1961-1968. Translated by Geoffrey W. Bromiley. Edinburgh: T\&T Clark, 1981.

Stump, Eleonore. Aquinas. Arguments of the Philosophers. London; New York: Routledge, 2003.

."Aquinas' Metaphysics of the Incarnation." In The Incarnation: An Interdisciplinary Symposium on the Incarnation of the Son of God, edited by Stephen T. Davis, Daniel Kendall and Gerald O'Collins, 197-218. Oxford; New York: Oxford University Press, 2002.

Stump, Eleonore, and Norman Kretzmann. "Eternity." The Journal of Philosophy 78, no. 8 (1981): 429-458.

Sumner, Darren O. Karl Barth and the Incarnation: Christology and the Humility of God. London: Bloomsbury, 2014.

Swain, Scott R. The God of the Gospel: Robert Jenson's Trinitarian Theology. Downers Grove, IL: InterVarsity, 2013.

Swinburnson, Benjamin W. "John Calvin, Eternal Generation, a Communication of Essence: A Reexamination of His Views." Kerux 25, no. 1 (2010): 26-49. 
Tait, Arthur J. The Heavenly Session of Our Lord: An Introduction to the History of the Doctrine. London: R. Scott, 1912.

Tanner, Kathryn. God and Creation in Christian Theology: Tyranny or Empowerment. Minneapolis, MN: Fortress Press, 2005.

Teilhard de Chardin, Pierre. Science and Christ. New York: Harper \& Row, 1968.

Tetley, Joy D. "The Priesthood of Christ as the Controlling Theme of the Epistle to the Hebrews." Ph.D. dissertation, University of Durham, UK, 2008.

Theological Dictionary of the New Testament. Translated by G. W. Bromiley. 10 vols., Edited by G. Kittel and G. Friedrich. Grand Rapids, MI: Eerdmans, 1964-1976.

Thiselton, Anthony C. Hermeneutics: An Introduction. Grand Rapids, MI: Eerdmans, 2009.

. The Hermeneutics of Doctrine. Grand Rapids, MI: Eerdmans, 2007.

. The Two Horizons: New Testament Hermeneutics and Philosophical

Description. Carlisle, UK; Grands Rapids, MI: Paternoster; Eerdmans, 1993.

Thomas, C. Adrian. A Case for Mixed-Audience with Reference to the Warning Passages in the Book of Hebrews. New York: Peter Lang, 2008.

Thompson, James W. The Beginnings of Christian Philosophy: The Epistle to the Hebrews. Washington, DC: Catholic Biblical Association of America, 1982.

. "What Has Middle Platonism to Do with Hebrews." In Reading the Epistle to the Hebrews: A Resource for Students, edited by Eric F. Mason and Kevin B. McCruden, 31-52. Atlanta: Society of Biblical Literature, 2011.

Thomson, Iain D. Heidegger on Ontotheology: Technology and the Politics of Education. Cambridge; New York: Cambridge University Press, 2005.

Thuesen, Peter Johannes. Predestination: The American Career of a Contentious Doctrine. Oxford; New York: Oxford University Press, 2009.

Timm, Alberto R. "The Priesthood of Christ According to Martin Luther." In Christ, Salvation, and the Eschaton: Essays in Honor of Hans K. LaRondelle, edited by Daniel Heinz, Jiri Moskala and Peter M. van Bemmelen, 171-187. Berrien Springs, MI: Seventh-day Adventist Theological Seminary, 2009.

. "El Sacerdocio De Cristo Y De Todos Los Creyentes Según Martín Lutero." Theologika 10, no. 1 (1995): 2-47. 
Torrance, Alan. "The Trinity.” In The Cambridge Companion to Karl Barth, edited by John B. Webster, 72-91. Cambridge, UK; New York: Cambridge University Press, 2000.

Torrance, James B. "The Vicarious Humanity and Priesthood of Christ in the Theology of John Calvin." In Calvinus Ecclesiae Doctor, edited by W. H. Neuser, 69-84. Kampen, Netherlands: J. H. Kok, 1978.

Torrance, Thomas F. Atonement: The Person and Work of Christ. Milton Keynes, UK; Colorado Springs, CO; Downers Grove, IL: Paternoster; IVP Academic, 2009.

. "Calvin's Doctrine of the Trinity." Calvin Theological Journal 25, no. 2 (1990): 165-193.

. The Christian Doctrine of God: One Being Three Persons. Edinburgh; New York: T\&T Clark, 2001.

. Conflict and Agreement in the Church. 2 vols. London: Lutterworth Press, 1960.

. Divine and Contingent Order. Edinburgh: T\&T Clark, 1998.

. The Ground and Grammar of Theology: Consonance between Theology and Science. Edinburgh: T\&T Clark, 2001.

. Incarnation: The Person and Life of Christ. Downers Grove, IL: IVP Academic, 2008.

. "Karl Barth and the Latin Heresy." Scottish Journal of Theology 39, no. 4 (1986): 461-482.

. Karl Barth: Biblical and Evangelical Theologian. Edinburgh: T\&T Clark, 1990.

. The Mediation of Christ. Grand Rapids, MI: Eerdmans, 1984.

."My Interaction with Karl Barth." In How Karl Barth Changed My Mind, edited by Donald K. McKim, 52-64. Grand Rapids, MI: Eerdmans, 1986.

. Preaching Christ Today: The Gospel and Scientific Thinking. Grand Rapids, MI: Eerdmans, 1994.

. "Predestination in Christ." Evangelical Quarterly 13 (1941): 108-141. 2003.

Royal Priesthood: A Theology of Ordained Ministry. Edinburgh: T\&T Clark, 
. Space, Time, and Incarnation. Edinburgh: T\&T Clark, 1997.

. Space, Time and Resurrection. Edinburgh: Handsel Press, 1976.

. Theology in Reconciliation: Essays Towards Evangelical and Catholic Unity in East and West. London: G. Chapman, 1975.

. Theology in Reconstruction. London: SCM Press, 1965.

Torrell, Jean-Pierre. Christ and Spirituality in St. Thomas Aquinas. Thomistic Ressourcement Series. Washington: Catholic University of America Press, 2011.

Tracy, David. Blessed Rage for Order: The New Pluralism in Theology. Chicago: University of Chicago Press, 1996.

Treiyer, Alberto R. "Antithetical or Correspondence Typology?" In Issues in the Book of Hebrews, edited by Frank B. Holbrook, 187-198. Silver Spring, MD: Biblical Research Institute, 1989.

. "The Day of Atonement as Related to the Contamination and Purification of the Sanctuary." In The Seventy Weeks, Leviticus, and the Nature of Prophecy, edited by Frank B. Holbrook, 198-256. Silver Spring, MD: Biblical Research Institute, 1986.

Trook, Douglas Alan. "The Unified Christocentric Field: Toward a Time-Eternity Relativity Model for Theological Hermeneutics in the onto-Relational Theology of Thomas F. Torrance." Ph.D. Dissertation, Drew University, 1986.

Tylenda, Joseph N. "Calvin's Understanding of the Communication of Properties." Westminster Theological Journal 38, no. 1 (1975): 54-65.

. "Christ the Mediator: Calvin Versus Stancaro." Calvin Theological Journal 7 (1972): 5-16.

. "The Controversy on Christ the Mediator: Calvin's Second Reply to Stancaro." Calvin Theological Journal 8 (1972): 131-157.

. "Eucharistic Sacrifice in Calvin's Theology." Theological Studies 37, no. 3 (1976): 456-466.

Ungeheuer, von Joseph. Der Grosse Priester Über Dem Hause Gottes, Die Christologie Des Hebräerbriefes. Würzburg: H. Stürtz, 1939.

Van Buren, Paul. Christ in Our Place: The Substitutionary Character of Calvin's Doctrine of Reconciliation. Edinburgh: Oliver \& Boyd, 1957. 
Van den Brom, Luco Johan. "Time and Eternity in Christian God-Talk." Zeitschrift für Dialektische Theologie 4 (2010): 38-66.

Van Nieuwenhove, Rik. "'Bearing the Marks of Christ's Passion': Aquinas' Soteriology." In The Theology of Thomas Aquinas, edited by Rik Van Nieuwenhove and Joseph Wawrykow, 277-302. Notre Dame, IN: University of Notre Dame Press, 2005.

. "The Saving Work of Christ." In The Oxford Handbook of Aquinas, edited by Brian Davies and Eleonore Stump, 436-447. Oxford; New York: Oxford University Press, 2011.

. "St. Anselm and St. Thomas Aquinas on 'Satisfaction': Or How Catholic and Protestant Understandings of the Cross Differ." Angelicum 80 (2003): 159-176.

Van Til, Cornelius. Barth's Christology. Philadelphia: Presbyterian and Reformed Publishing Company, 1962.

VanderKam, James C. From Joshua to Caiaphas: High Priests after the Exile. Minneapolis: Fortress Press, 2004.

Vanhoozer, Kevin J. “Atonement.” In Mapping Modern Theology: A Thematic and Historical Introduction, edited by Kelly M. Kapic and Bruce L. McCormack, 175-202. Grand Rapids, MI: Baker Academic, 2012.

. First Theology: God, Scripture and Hermeneutics. Downers Grove, IL; Leicester, England: InterVarsity; Apollos, 2002.

. Remythologizing Theology: Divine Action, Passion, and Authorship.

Cambridge: Cambridge University Press, 2010.

Vanhoye, Albert. A Different Priest: The Letter to the Hebrews. Series Rhetorica Semitica. Miami, FL: Convivium Press, 2011.

. La Structure Littéraire De L'Épitre Aux Hébreux. Paris: Desclée de Brouwer, 1962.

. Old Testament Priests and the New Priest: According to the New Testament. Translated by J. Bernard Orchard. Studies in Scripture. Petersham, MA: St. Bede's Publications, 1986.

. Our Priest Is Christ: The Doctrine of the Epistle to the Hebrews. Rome: Pontifical Biblical Institute, 1977. 
Velde, Rudi te. Aquinas on God: The 'Divine Science' of the Summa Theologiae. Ashgate Studies in the History of Philosophical Theology. Aldershot, Hants, England; Burlington, VT: Ashgate, 2006.

. „Deelgenoot Van De Goddelijke Natuur”: Genade En Participatie Bij Thomas Van Aquino." Tijdschrift voor Filosofie 55, no. 4 (1993): 607-633.

Walker, Robert T. "Incarnation and Atonement: Their Relation and Inter-Relation in the Theology of T. F. Torrance." Participatio 3 (2012): 1-63.

Wallace, Daniel B. The Basics of New Testament Syntax: An Intermediate Greek Grammar. Grand Rapids, MI: Zondervan, 2000.

. Greek Grammar Beyond the Basics: An Exegetical Syntax of the New Testament. Grand Rapids, MI: Zondervan, 1996.

Walsh, Liam G. "Liturgy in the Theology of St. Thomas." The Thomist 38, no. 3 (1974): 557-583.

. "Sacraments." In The Theology of Thomas Aquinas, edited by Rik Van Nieuwenhove and Joseph Wawrykow, 326-364. Notre Dame, IN: University of Notre Dame Press, 2005.

Wawrykow, Joseph. “Grace.” In The Theology of Thomas Aquinas, edited by Rik Van Nieuwenhove and Joseph Wawrykow, 192-221. Notre Dame, IN: University of Notre Dame Press, 2005.

. "Hypostatic Union.” In The Theology of Thomas Aquinas, edited by Rik Van Nieuwenhove and Joseph Wawrykow, 222-251. Notre Dame, IN: University of Notre Dame Press, 2005.

Webb, Stephen H. Jesus Christ, Eternal God: Heavenly Flesh and the Metaphysics of Matter. Oxford; New York: Oxford University Press, 2011.

Wéber, Édouard-Henri. Le Christ Selon Saint Thomas d'Aquin. Jésus Et Jésus-Christ. Paris: Desclée, 1988.

Webster, John. "The Firmest Grasp of the Real: Barth on Original Sin." Toronto Journal of Theology 4, no. 1 (1988): 19-29.

. "The One Who Is Son: Theological Reflections on the Exordium to the Epistle to the Hebrews" In The Epistle to the Hebrews and Christian Theology, edited by Richard Bauckham, Daniel R. Driver, Trevor A. Hart, and Nathan MacDonald, 69-94. Grand Rapids, MI: Eerdmans, 2009. 
. The Oxford Handbook of Systematic Theology. Oxford: Oxford University Press, 2009.

Weigel, Peter. Aquinas on Simplicity: An Investigation into the Foundations of His Philosophical Theology. Oxford; New York: Peter Lang, 2008.

Weinandy, Thomas G. "Aquinas: God Is Man: The Marvel of the Incarnation.” In Aquinas on Doctrine: A Critical Introduction, edited by Thomas G. Weinandy, Daniel A. Keating, and John Yocum, 67-89. London; New York: T\&T Clark International, 2004.

Weiss, H. F. Der Brief an Die Hebräer. Göttingen: Vandenhoeck \& Ruprecht, 1991.

Wendel, François. Calvin: Origins and Development of His Religious Thought. Translated by Philip Mairet. New York: Harper and Row, 1963.

West, Jim. "Divine Wrath." Lexham Theological Wordbook. Edited by Douglas Mangum et al. Bellingham, WA: Lexham Press, 2014.

Westcott, Brooke Foss. The Epistle to the Hebrews the Greek Text with Notes and Essays. Classic Commentaries on the Greek New Testament. London: Macmillan, 1903.

Westfall, Cynthia Long. A Discourse Analysis of the Letter to the Hebrews: The Relationship between Form and Meaning. Library of New Testament Studies. London; New York: T\&T Clark, 2005.

Wierenga, Edward R. "Timelessness Out of Mind: On the Alleged Incoherence of Divine Timelessness." In God and Time: Essays on the Divine Nature, edited by Gregory E. Ganssle and David M. Woodruff, 153-164. Oxford; New York: Oxford University Press, 2002.

Wilkinson, David. Christian Eschatology and the Physical Universe. London; New York: T\&T Clark, 2010.

Williams, A. N. The Ground of Union: Deification in Aquinas and Palamas. New York: Oxford University Press, 1999.

Williams, Garry J. "Barth's Doctrine of the Atonement." In Engaging with Barth: Contemporary Evangelical Critiques, edited by David Gibson and Daniel Strange, 232-272. New York: T\&T Clark, 2008.

Williamson, Ronald. Philo and the Epistle to the Hebrews. Leiden: Brill, 1970. 
Willis, E. David. Calvin's Catholic Christology: The Function of the So-Called "Extra Calvinisticum”. Studies in Medieval and Reformation Thought. Leiden: Brill, 1966.

Wilson, R. McL. The New Century Commentary: Hebrews. Grand Rapids, MI: Eerdmans, 1987.

Witte, Von Johannes L. "Die Christologie Calvins." In Daskonzil Von Chalkedon: Geschichte Und Gegenwart, edited by Aloys Grillmeier and Heinrich Bacht, 3: 487-529. Wurzburg: Echter-Verlag, 1954.

Wolterstorff, Nicholas. "Unqualified Divine Temporality." In God and Time: Four Views, edited by Gregory E. Ganssle, 187-213. Cumbria, UK: Paternoster, 2001.

Wriedt, Markus. "Luther on Call and Ordination: A Look at Luther and the Ministry." Concordia Journal 28, no. 3 (2002): 254-269.

Wright, David F. “Calvin's Accommodating God.” In Calvinus Sincerioris Religionis Vindex: Calvin as Protector of the Purer Religion, edited by Wilhelm H. Neuser and Brian G. Armstrong, 3-20. Kirksville, MO: Sixteenth Century Journal Publishers, 1997.

Wyatt, Peter. Jesus Christ and Creation in the Theology of John Calvin. Princeton Theological Monograph Series. Allison Park, PA: Pickwick Publications, 1996.

Yeago, David S. "Lutheran-Roman Catholic Consensus on Justification: The Theological Achievement of the Joint Declaration." Pro Ecclesia 7, no. 4 (1998): 449-470.

Yearley, Lee H. "St. Thomas Aquinas on Providence and Predestination." Anglican Theological Review 49, no. 4 (1967): 409-423.

Yocum, John P. "Sacraments in Aquinas." In Aquinas on Doctrine: A Critical Introduction, edited by Thomas G. Weinandy, Daniel A. Keating, and John Yocum, 159-181. London; New York: T\&T Clark International, 2004.

Young, Norman H. "The Day of Dedication or the Day of Atonement? The Old Testament Background to Hebrews 6:19-20 Revisited." Andrews University Seminary Studies 40, no. 1 (2002): 61-68.

Younker, Randall W., and Richard M. Davidson. "The Myth of the Solid Heavenly Dome: Another Look at the Hebrew Rāqîa". Andrews University Seminary Studies 49, no. 1 (2011): 125-147.

Zachman, Randall C. The Assurance of Faith: Conscience in the Theology of Martin Luther and John Calvin. Minneapolis: Fortress Press, 1993. 
Zahl, Paul F. M. The First Christian: Universal Truth in the Teachings of Jesus. Grand Rapids, MI: Eerdmans, 2003.

Ziegler, Roland F. "Luther and Calvin on God: Origins of Lutheran and Reformed Differences." Concordia Theological Quarterly 75, no. 1-2 (2011): 63-90.

Zimmermann, Heinrich. Die Hohepriester: Christologie Des Hebräerbriefes. Paderborn: Ferdinand Schöningh, 1964.

Zywietz, Valentin. "Representing the Government of God: Christ as the hilasterion in Romans 3:25.” M.A. thesis, Andrews University, 2016. 